\title{
DIMENSIONAMENTO DE USINAS \\ HIDROELÉTRICAS ATRAVÉS DE TÉCNICAS DE OTIMIZAÇÃO EVOLUTIVA
}

\section{Donato da Silva Filho}

Tese apresentada à Escola de Engenharia de São Carlos da Universidade de São Paulo, como parte dos requisitos para obtenção do título de Doutor em Engenharia Elétrica.

Orientador: Prof. Dr. Adriano Alber de França Mendes Carneiro

São Carlos

Dezembro - 2003 
Ficha catalográfica preparada pela Seção de Tratamento da Informação do Serviço de Biblioteca - EESC/USP

Silva Filho, Donato

Dimensionamento de usinas hidroelétricas através de técnicas de otimização evolutiva / Donato da Silva Filho. -- São Carlos, 2003.

Tese (Doutorado) -- Escola de Engenharia de São Carlos-Universidade de São Paulo, 2003.

Área: Engenharia Elétrica.

Orientador: Prof. Dr. Adriano Alber de França Mendes Carneiro.

1. Dimensionamento de usinas hidroelétricas.

2. Otimização evolutiva. 3. Modelo de simulação.

4. Regras de operação. 5. Análises de sensibilidade.

6. Regulamentação e planejamento. I. Título. 


\section{FOLHA DE JULGAMENTO}

Candidato: Engenheiro DONATO DA SILVA FILHO

Tese defendida e julgada em 18-12-2003 perante a Comissão Julgadora:

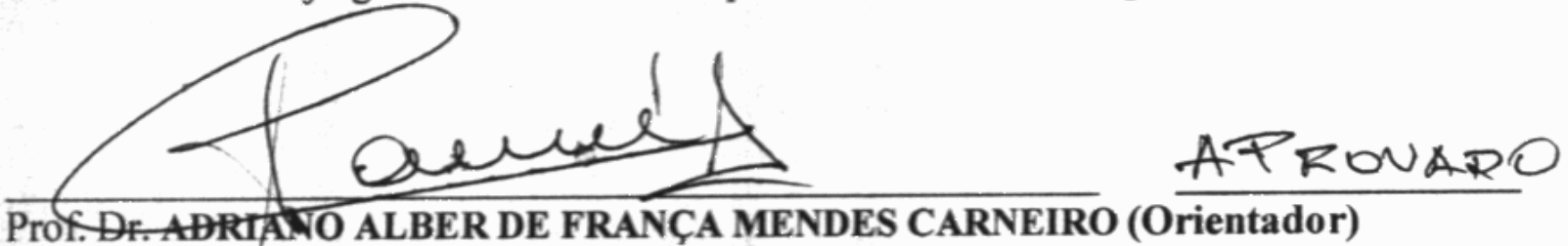

(Escola de Engenharia de São Carlos/USP)

Secundino bares t.

APRONADO

Prof. Tit. SECUND,NO SOARES FILHO

(Universidade Estadual de Gampinas/UNICAMP)

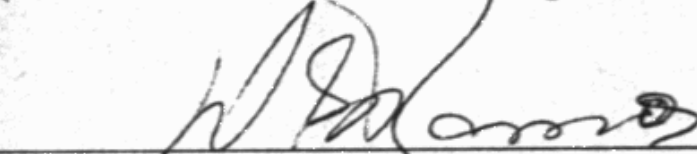

ABROVADO

Prof. Dr. DOREL SOARES RAMOS

(Escola Politécnica /USP)

Mlequ
Dr. JEAN CESARE NEGRI
(Companhia de Energia de São Paulo/CESP)

APROUADO

Dr. MARCELO PRAIS

(Qperador Nacional do Sistema Elétrico/ONS)

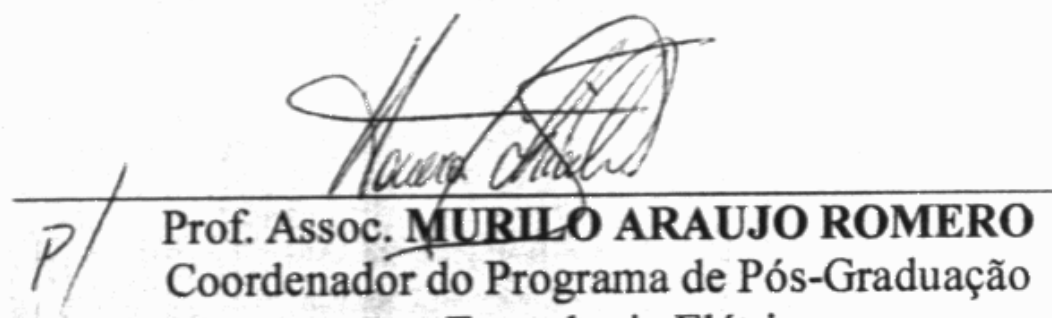

em Engenharia Elétrica

APRONADO

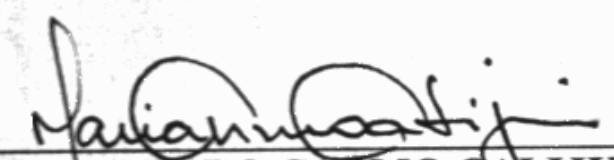

Profa. Assoc. MARIA DO CARMO CALIJURI

Presidente da Comissão de Pós-Graduação 

Aos meus pais, pelo apoio incondicional, pelo amor, pelo carinho e pela atenção.

À minha amada esposa Suzanne, pelo amor intenso, pela liberdade de viajar em seu sorriso sincero, pela sua companhia sempre agradável, pela sua simpatia espontânea, pelo nosso filho que está chegando, e pela paciência de ler e reler todo o texto desta tese. 



\section{Agradecimentos}

Ao Prof. Adriano Alber de França Mendes Carneiro, pelos ensinamentos, pela orientação, pela confiança, pelas críticas construtivas, pela amizade e pela liberdade a mim confiada.

Ao Prof. Daniel Pete Loucks, pela excelente receptividade, pelos ensinamentos, pela orientação e pela amizade durante meu estágio na Cornell University, Ithaca, Nova Iorque, Estados Unidos.

Ao Prof. Dorel Soares Ramos, da Escola Politécnica da Universidade de São Paulo e da Bandeirante Energia S/A, pela participação na banca do exame de qualificação e pelas tantas sugestões e ensinamentos que muito contribuíram para o aprimoramento do trabalho.

Ao Prof. Denis Vinicius Coury, principalmente pela sugestão de transformar o trabalho de Mestrado em trabalho de Doutorado Direto, finalizado com a presente tese.

Ao Engenheiro José Roberto Chaves, da Duke Energy International, pela participação na banca do exame de qualificação e pelas suas críticas e sugestões.

Ao Engenheiro Roberto Castro, da CPFL Energia, pela participação na banca de qualificação e pelas sugestões.

Ao assessor anônimo da FAPESP, pelos valiosos comentários e pelas críticas que em muito contribuíram para a confecção desta tese.

Aos meus pais, Donato e Ângela, pelo imenso esforço para fornecer-me a oportunidade de ter uma sólida formação moral e educacional.

À minha esposa Suzanne, pelo companheirismo, pelo carinho, pelo amor, pela paciência e pela compreensão das tantas horas que me fiz ausente para poder completar este trabalho.

Às minhas irmãs Roseli e Rosangela, pelo amor, carinho, suporte e incentivo. Ao meu cunhado Osmir, pela amizade fraterna.

À minha tia Neusa e ao meu tio Alfredo, pelo acompanhamento constante da minha formação e pela participação cada vez mais freqüente em minha vida.

Ao amigo Renato Tinós (méééé), pela revisão minuciosa do texto, e também à amiga Lúcia Tinós, pelo incentivo incessante na fase final do trabalho.

Aos amigos da Duke Energy International, da Companhia Energética de São Paulo - CESP, da Agência Nacional de Energia Elétrica - ANEEL e da Companhia Energética de Minas Gerais - CEMIG, pela pronta ajuda no fornecimento de dados e na 
explicação de técnicas e procedimentos normalmente adotados pelas empresas do Setor Elétrico Brasileiro.

Aos funcionários e professores do Departamento de Engenharia Elétrica da Escola de Engenharia de São Carlos, pela colaboração durante a realização dos trabalhos.

Aos amigos do LSEE da ESSC/USP, que pela excelente convivência fizeram com que o trabalho fosse sempre mais agradável e divertido.

Aos amigos do Laboratório de Sistemas Hidrotérmicos - LSH da Universidade Estadual de Campinas - UNICAMP, pela receptividade e pela ajuda durante o semestre acadêmico que cursei naquela instituição.

Aos amigos mais próximos, que mesmo não contribuindo de forma direta ao desenvolvimento do trabalho, foram sempre um importante ponto de apoio pessoal.

Aos novos amigos da Bandeirante Energia S/A, pela companhia e pelo incentivo na fase final do trabalho.

Aos vários amigos de "corrida", pela participação nos momentos de descontração, tão necessários para a renovação das forças e idéias.

Aos amigos da Associação Luso-Brasileira da Cornell University - Lubrasa, pela amizade e pelo apoio durante minha estada nos Estados Unidos.

À Fundação de Amparo à Pesquisa do Estado de São Paulo - FAPESP, pelo fornecimento da bolsa de doutorado e por todo o suporte financeiro para que a pesquisa pudesse ser executada.

À Comissão Fulbright e à Coordenação de Formação de Pessoal de Nível Superior - CAPES, pela bolsa de estudos no exterior que permitiu a realização do estágio de um ano acadêmico na Cornell University, Ithaca, Nova Iorque. 
"Não sei de que modo o mundo me vê; mas a mim mesmo pareço ter sido apenas um menino brincando na praia, entretendo-me em encontrar de quando em quando um seixo mais liso ou uma concha mais bela do que o ordinário enquanto todo o vasto oceano da verdade jazia inexplorado diante de mim”. 



\section{Resumo}

SILVA FILHO, DONATO (2003). Dimensionamento de usinas hidroelétricas através de técnicas de otimização evolutiva. Tese (Doutorado) - Escola de Engenharia de São Carlos, Universidade de São Paulo, 2003.

As metodologias normalmente utilizadas para otimizar as dimensões de uma usina hidroelétrica, incluindo os métodos empregados pelo Setor Elétrico Brasileiro, baseiam-se em análises do tipo custo/benefício. Os custos provêm de gastos diretos com a construção da usina e os benefícios correspondem a receitas proporcionadas pela venda de energia. Para avaliar os benefícios, são realizadas simulações da operação da usina e a energia produzida é valorizada economicamente. Esta necessidade das simulações da operação faz com que o problema de dimensionamento não possua uma função analítica explícita para determinar os benefícios energéticos, o que dificulta a implementação de métodos tradicionais de otimização. O objetivo deste trabalho é justamente desenvolver e implementar uma metodologia de dimensionamento que permita que o processo de busca pelas dimensões ótimas seja automático. Para tanto, acoplam-se um modelo de otimização evolutiva e um modelo de simulação da operação de sistemas hidroelétricos. Adicionalmente, o modelo proposto também deve ser flexível, permitindo que as regras de operação do sistema hidroelétrico, o conjunto de vazões afluentes, a forma de valorização da energia gerada e uma série de outros fatores sejam tratados como parâmetros do modelo. Os resultados encontrados indicam que, sob o ponto de vista computacional, o modelo proposto é automático, flexível e eficiente. Além disso, as várias análises de sensibilidade realizadas atestam a consistência da metodologia proposta e permitem avaliar a forma como os diferentes parâmetros do modelo influenciam as próprias dimensões da usina sob dimensionamento. A partir destas análises, sugerem-se algumas medidas de regulamentação e planejamento para que as dimensões de novas usinas não sejam determinadas a partir de sinalizações imprecisas de parâmetros que influenciam de forma decisiva suas dimensões ótimas.

Palavras-chaves: dimensionamento de usinas hidroelétricas, otimização evolutiva, modelo de simulação, regras de operação, análises de sensibilidade, regulamentação e planejamento. 



\begin{abstract}
SILVA FILHO, DONATO (2003). Sizing hydropower plants via evolutionary optimization techniques. Thesis (Doctorade) - Escola de Engenharia de São Carlos, Universidade de São Paulo, 2003.

The methods normally applied to optimally size a hydropower plant, including the ones used by the Brazilian Power Industry, are based on cost/benefit analysis. The costs are due to direct expenses with the hydropower plant construction and the benefits correspond to incomes from selling energy. The benefits are evaluated throughout computing simulations of the hydropower plant operation, followed by the assignment of an economical value to the energy produced by it. The need for computing simulations turns out a non-analytical objective function for the sizing problem, what makes the use of traditional optimization tools very hard. The objective of this work is just to develop and implement a sizing method that automatically performs the search for the optimal sizes of a hydropower plant. The proposed method combines an evolutionary optimization technique and a simulation model for the operation of hydropower systems. Additionally, the proposed model is also flexible in the sense that the operation rules for the hydroelectric system simulation, the set of water inflows, the way the energy is valued and some other factors that may influence the results are treated as parameters. The results show that, from the computing point of view, the proposed method is automatic, flexible and efficient. Furthermore, the sensitivity analyses performed validate the method consistency and establish relationships among the different parameters and the way they affect the optimal features of the new hydropower plant. Based on the results of such analyses, some regulation and planning measures are suggested in order to avoid sizing hydropower plants with mistaken parameters that can substantially change its optimal features.
\end{abstract}

Keywords: sizing hydropower plants, evolutionary optimization, simulation model, operation policies, sensitivity analysis, regulamentation and planning. 



\section{Lista de Figuras}

\section{Capítulo II - Energia Elétrica: Benefícios, Impactos e o Sistema Interligado Nacional}

Figura 2.1 - Estágios de desenvolvimento do ser humano e consumo de energia....................... 8 Figura 2.2 - Consumo mundial de energia entre 1980 e 2000................................................. 10

Figura 2.3 - Relação entre PIB e consumo de energia per capita ............................................ 11

Figura 2.4 - Relação entre indicadores sociais e consumo de energia per capita. .................... 13

Figura 2.5 - Relação entre IDH e consumo de energia per capita ......................................... 14

Figura 2.6 - Participação das fontes primárias de energia na produção mundial total. .......... 19

Figura 2.7 - Vistas atuais externa e interna da primeira usina hidroelétrica construída por

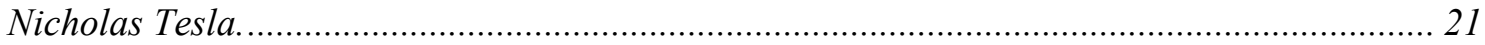

Figura 2.8-Quatro primeiras lâmpadas alimentadas com energia nuclear.......................... 22

Figura 2.9 - Consumo de energia elétrica relativo às fontes de geração durante o ano de 2000.

Figura 2.10 - Parte interna da Estação de Força e Luz de Campos, em 1890.................. 25

Figura 2.11 - Casa de força da usina Marmelos-Zero, em 1989, após sua restauração e

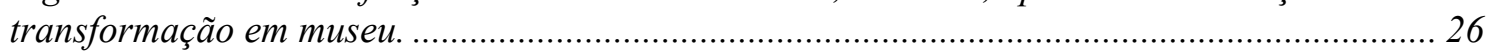

Figura 2.12 - Casa de força original da usina hidroelétrica Monjolinho. ................................ 26

Figura 2.13 - Viagem inaugural do bonde elétrico em São Paulo, em 21/02/1900................... 27

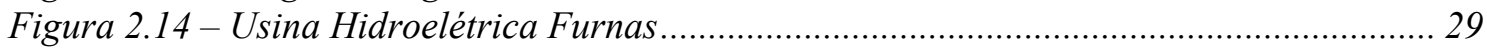

Figura 2.15 - Capacidade instalada no SIN em agosto de 2001. .......................................... 34

Figura 2.16 - Fontes de energia utilizadas na geração de eletricidade no Brasil e no mundo. 35

Figura 2.17 - Produção de energia elétrica para cada uma das fontes disponíveis em 2001... 37

Figura 2.18 - Intercâmbios regionais de energia durante o ano de 2001, em GWh................. 38

Figura 2.19 - Balanço energético do SIN em 2001................................................................ 40

Figura 2.20 - Esvaziamento do Sistema Sudeste/Centro-Oeste. .............................................. 40

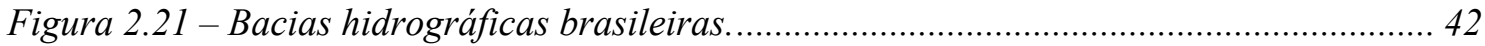

\section{Capítulo III - Dimensionamento de Usinas Hidroelétricas}

Figura 3.1 - Etapas que antecedem a entrada em operação de uma usina hidroelétrica.......... 47 Figura 3.2 - Comparação entre as Energias Firme e Assegurada para alguns aproveitamentos.

Figura 3.3 - Ilustração dos níveis de armazenagem máximo e mínimo........................................56

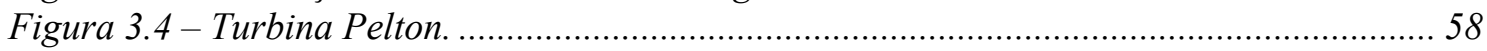

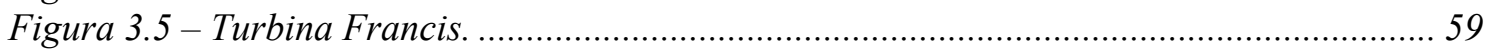

Figura 3.6 - Curva de rendimento de uma turbina Francis..................................................... 59

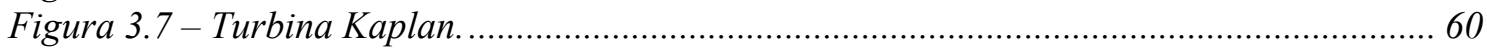

Figura 3.8 - Relação entre altura de queda efetiva,engolimento máximo e máxima potência

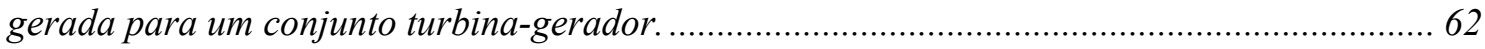

Figura 3.9 - Impactos energéticos da escolha da queda de referência da turbina .................... 64

Figura 3.10 - Impactos da escolha da queda de referência da turbina sobre sua eficiência. ... 65

Figura 3.11 - Cálculo dos beneficios energéticos globais de uma usina hidroelétrica............. 69

Figura 3.12 - Cálculo dos beneficios energéticos locais de uma usina hidroelétrica. ............... 69

\section{Capítulo IV - Modelo Proposto}

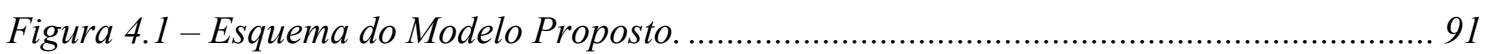

Figura 4.2 - Despacho de Energia Firme em dois patamares. ................................................. 98

Figura 4.3 - Fluxo de caixa do investimento....................................................................... 101 
Figura 4.4 - Exemplo de cálculo do valor presente do investimento total. .............................. 103

Figura 4.5 - Representação esquemática de um AG com representação binária..................... 110

Figura 4.6 - Gráfico tridimensional da função de avaliação................................................ 111

Figura 4.7 - Representação binária das variáveis $x_{1}$ e $x_{2}$.......................................................111

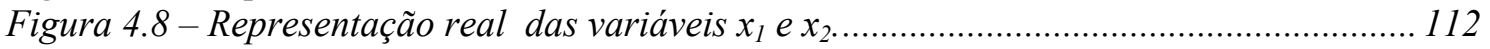

Figura 4.9 - Resultado do operador de cruzamento binário de um ponto. ............................. 118

Figura 4.10 - Resultado do operador de cruzamento binário de dois pontos......................... 119

Figura 4.11 - Resultado do operador de cruzamento binário uniforme ................................. 119

Figura 4.12 - Resultado do operador de cruzamento real média aritmética. ........................... 120

Figura 4.13 - Resultado do operador de cruzamento real média geométrica......................... 121

Figura 4.14 - Resultado do operador de cruzamento real $B L X$ - $\alpha$......................................... 122

Figura 4.15 - Resultado do operador de cruzamento real heurístico. .................................. 122

Figura 4.16 - Resultado do operador de mutação binária ..................................................... 123

Figura 4.17 - Energia Firme do sistema para diferentes volumes mínimos de Emborcação. . 129

Figura 4.18 - Geração Média do sistema para diferentes volumes mínimos de Emborcação. 130

Figura 4.19 - Energia Secundária do sistema para diferentes volumes mínimos de Emborcação.

130

Figura 4.20 - Energia Firme do sistema para diferentes volumes máximos de Emborcação.. 131

Figura 4.21 - Geração Média do sistema para diferentes volumes máximos de Emborcação. 132

Figura 4.22 - Energia Secundária do sistema para diferentes volumes máximos de

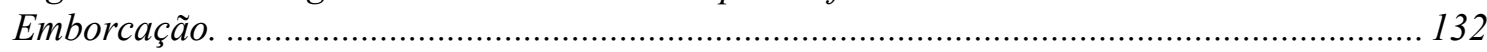

Figura 4.23 - Energia Firme do sistema para diferentes vazões de referência de Emborcação.

Figura 4.24 - Geração Média do sistema para diferentes vazões de referência de Emborcação.

Figura 4.25 - Energia Secundária do sistema para diferentes vazóes de referência de

Emborcação.

Figura 4.26 - Energia Firme do sistema para diferentes quedas de referência de Emborcação.

136

Figura 4.27 - Geração Média do sistema para diferentes quedas de referência de Emborcação.

Figura 4.28 - Energia Secundária do sistema para diferentes quedas de referência de

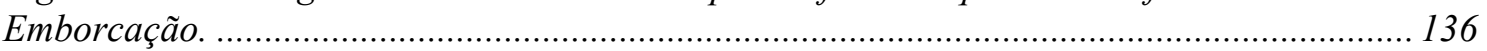

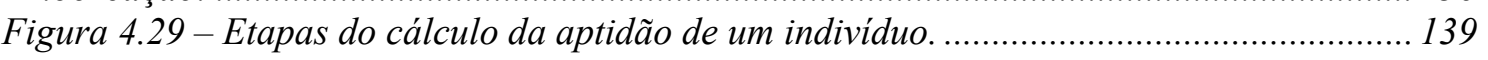

Figura 4.30 - Primeira etapa do processo cálculo da aptidão de um indivíduo...................... 140

Figura 4.31 - Segunda etapa do processo de cálculo da aptidão de um indivíduo................... 143

Figura 4.32 - Conjunto de pacotes que compõem o modelo. .................................................. 151

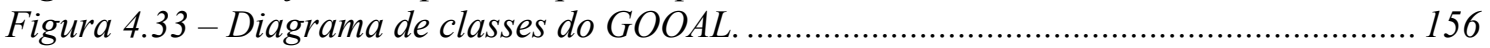

Figura 4.34 - Diagrama de classes do pacote Dimensionamento............................................ 157

\section{Capítulo V-Modelagem de Usinas Hidroelétricas}

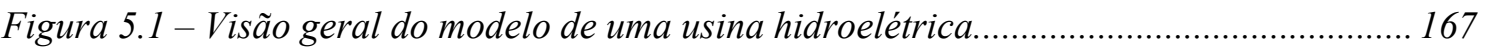

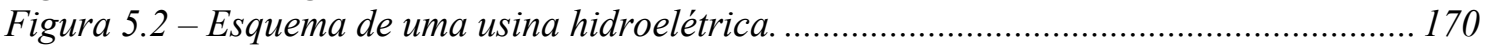

Figura 5.3 - Queda bruta de uma usina hidroelétrica. ........................................................ 173

Figura 5.4 - Nivel de montante para a usina de Emborcação................................................. 174

Figura 5.5 - Nivel de jusante para a usina de Emborcação.................................................... 174

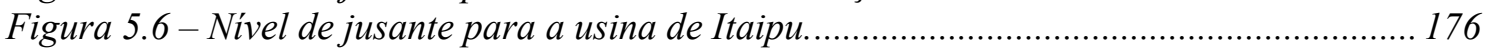

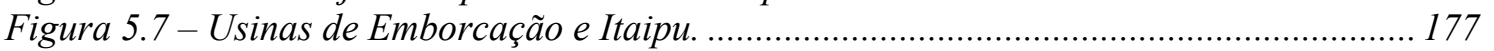

Figura 5.8 - Efeito de remanso em São Simão................................................................. 177

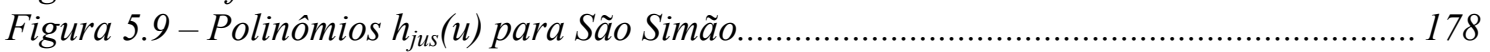

Figura 5.10 - Efeito de remanso na usina de Rosana. ............................................................ 180

Figura 5.11 - Efeito de remanso na usina de Itaipu............................................................. 180

Figura 5.12 - Perdas hidráulicas em uma usina hidroelétrica. ............................................ 181 
Figura 5.13 - Fluxo através de uma tubulação. 181

Figura 5.14 - Esquema de uma usina hidroelétrica para aplicação da Equação de Bernoulli.

Figura 5.15 - Perda de carga para usina de Emborcação.

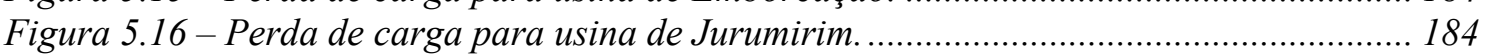

Figura 5.17 - Altura de queda líquida para a usina de Emborcação. .................................... 185

Figura 5.18 - Curvas de desempenho de uma turbina tipo Francis........................................ 188

Figura 5.19 - Potência gerada pela turbina para diferentes quedas líquidas. ......................... 189

Figura 5.20 - Rendimento da turbina para diferentes quedas líquidas. ................................. 190

Figura 5.21 - Engolimento máximo e potência máxima de um conjunto turbina/gerador em

função da altura de queda líquida.

Figura 5.22 - Engolimento máximo e potência máxima para uma máquina da usina de

Emborcação.

Figura 5.23 - Função de Geração de Emborcação................................................................... 202

Figura 5.24 - Polinômio cota x área para a usina de Emborcação.......................................... 204

Figura 5.25 - Obtenção de séries históricas de vazões afluentes............................................. 206

Figura 5.26 - Vazão natural afluente à usina de Emborcação. .............................................. 206

Figura 5.27 - Valores mínimo, médio e máximo da vazão natural afluente de Emborcação. . 207

Figura 5.28 - Valores médios e desvio padrão da vazão natural afluente de Emborcação. ... 207

Figura 5.29 - Conjunto de usinas para cálculo da vazão incremental. ................................... 208

Figura 5.30 - Interpretação das variáveis utilizadas nos estudos. ........................................ 211

\section{Capítulo VI-Modelos de Otimização e Simulação}

Figura 6.1 - Esquema de um sistema hidrotérmico de potência ............................................ 217

Figura 6.2 - Custo de operação do sistema não-hidráulico complementar .............................. 218

Figura 6.3 - Sistema teste para o exemplo de operação ótima .............................................. 220

Figura 6.4 - Operação ótima para vazões afluentes iguais à MLT........................................ 222

Figura 6.5 - Ilustração da metodologia de simulação. ............................................................ 225

Figura 6.6 - Condições de operação e resultados do modelo de simulação.............................. 226

Figura 6.7 - Visualização da regra de operação em paralelo.............................................. 228

Figura 6.8 - Nuvem de pontos da usina de Jurumirim......................................................... 230

Figura 6.9 - Nuvem de pontos da usina de Chavantes............................................................. 230

Figura 6.10 - Nuvem de pontos da usina de Capivara.......................................................... 230

Figura 6.11 - Política de operação para as três usinas a reservatório do rio Paranapanema.

Figura 6.12 - Algoritmo Simplificado do Processo Iterativo

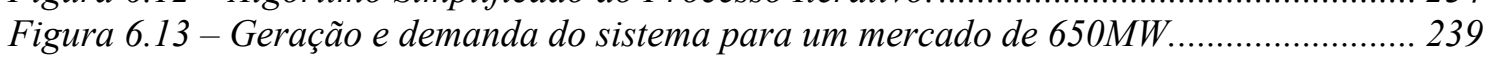

Figura 6.14 - Trajetórias de volume para um mercado de 650MW......................................... 239

Figura 6.15 - Vazão afluente natural e vazão afluente simulada para a usina de Capivara... 240

Figura 6.16 - Energia armazenada no sistema para diferentes mercados. ............................ 241

Figura 6.17 - Volume armazenado em Jurumirim para diferentes mercados. ........................ 241

Figura 6.18 - Volume armazenado em Capivara para diferentes mercados. ........................... 241

Figura 6.19-Energia armazenada no sistema para mesmo mercado e diferentes políticas de

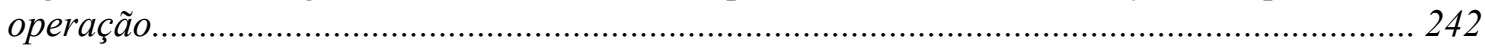

Figura 6.20 - Geração do sistema para mesmo mercado e diferentes políticas de operação. 243

Figura 6.21 - Sistema para cálculo da Energia Firme. ......................................................... 244

Figura 6.22 - Algoritmo para cálculo da Energia Firme...................................................... 245

\section{Capítulo VII - Estudos de Casos}

Figura 7.1 - Principais usinas hidroelétricas do Sistema Sudeste/Centro-Oeste .................... 251

Figura 7.2 - Curva de custo de construção para Emborcação. ............................................. 257 
Figura 7.3 - Curva de custo de aquisição de terras para Emborcação. ..................................2258

Figura 7.4 - Curva de custo da turbina/gerador de base para Emborcação. ........................... 259

Figura 7.5 - Curva de custo da turbina/gerador de ponta para Emborcação. .........................259

Figura 7.6 - Curva de custo de construção para Porto Primavera........................................... 260

Figura 7.7 - Curva de custo de aquisição de terras para Porto Primavera. ............................ 261

Figura 7.8 - Curva de custo da turbina/gerador de base para Porto Primavera. ................... 261

Figura 7.9 - Curva de custo da turbina/gerador de ponta para Porto Primavera................... 262

Figura 7.10 - Resultados do AG para os testes do grupo EF. ...............................................2. 266

Figura 7.11 - Resultados do AG para os testes do grupo EFES..............................................2.267

Figura 7.12 - Resultados do AG para os testes do grupo EFESPG ........................................267

Figura 7.13 - Convenção de nomenclatura dos testes.......................................................... 272

Figura 7.14 - Visualização dos custos e beneficios anuais em função do volume máximo de

Emborcação, mantendo-se o volume mínimo e a capacidade instalada de ponta nulos. ......... 279

Figura 7.15 - Volumes mínimo e máximo em função do preço médio da Energia Firme......... 286

Figura 7.16 - Custos e receitas em função do preço médio da Energia Firme......................... 286

Figura 7.17 - Custos marginais de operação para todo o histórico de vazões......................... 289

Figura 7.18 - Custos marginais de operação para os anos secos do histórico de vazões. ...... 289

Figura 7.19 - Custos marginais de operação para os anos úmidos do histórico de vazões. ... 289

Figura 7.20 - Receita Líquida Anual em função da capacidade de ponta para $r=2 \ldots \ldots \ldots \ldots . .294$

Figura 7.21 - Receita Líquida Anual em função da capacidade de ponta para $r=3 \ldots \ldots \ldots \ldots . .296$

Figura 7.22 - Comparação das características físicas da usina sob dimensionamento em

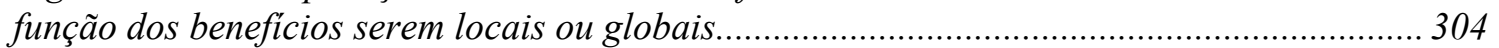

Figura 7.23 - Comparação da Receita Líquida Anual da usina sob dimensionamento em

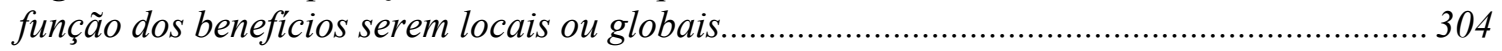

Figura 7.24 - Seqüências de vazões naturais afluentes para os Períodos Críticos dos dois

históricos de vazão ...................................................................................................... 310

Figura 7.25 - Comparação das vazões naturais afluentes mínima, média e máxima durante os

Periodos Críticos dos dois históricos de vazão.................................................................. 310

Figura 7.26 - Comparação das vazões defluentes mínima, média e máxima durante os Períodos

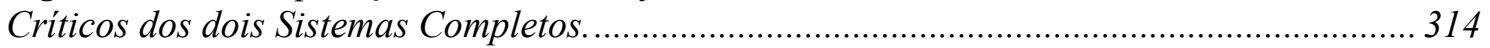

\section{Anexos $A, B$ e $C$}

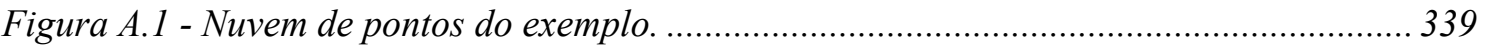

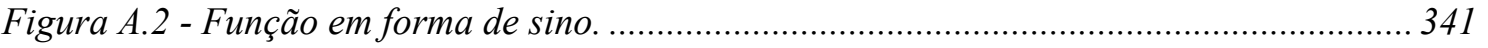

Figura A.3 - Função montanha para a nuvem de pontos da Figura A.1 ............................... 342

Figura A.4 - Função montanha revisada para a nuvem de pontos da Figura A.1 - $\beta=3$...... 343

Figura A.5 - Função montanha revisada para a nuvem de pontos da Figura A.1 - $\beta=8$....... 343

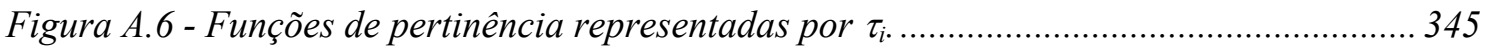

Figura A.7 - Curva ajustada para os pontos do exemplo. …….................................................... 347

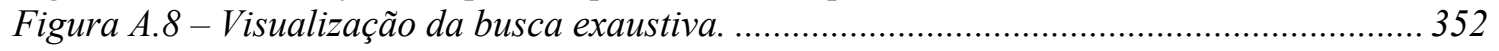




\section{Lista de Tabelas}

\section{Capítulo II - Energia Elétrica: Beneficios, Impactos e o Sistema Interligado Nacional}

Tabela 2.1 - Cronologia da potência desenvolvida por algumas máquinas. .............................. 9

Tabela 2.2 - População e consumo de energia em alguns países em 2000............................... 12

Tabela 2.3 - Alguns problemas ambientais, suas causas e grupos sociais afetados.................. 16

Tabela 2.4 - Emissão de $\mathrm{CO}_{2}$ a partir da queima de combustíveis fósseis durante o ano de

2000 ......

Tabela 2.5 - Capacidades instaladas em alguns países em janeiro de 2000.

Tabela 2.6 - Potencial hidroelétrico e capacidade instalada nas bacias hidrográficas

brasileiras em janeiro de 2001.

\section{Capítulo IV - Modelo Proposto}

Tabela 4.1 - Valores de aptidão de indivíduos da população inicial..................................... 113

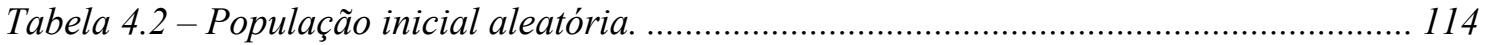

Tabela 4.3 - População inicial metade aleatória e metade complementar (binária e real). ... 115

Tabela 4.4 - Probabilidades de seleção e acumulada ......................................................... 117

Tabela 4.5 - Resumo da forma como os parâmetros de dimensionamento influenciam os

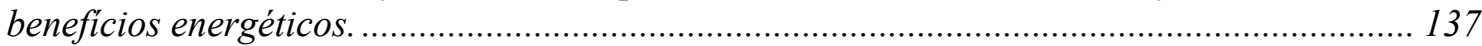

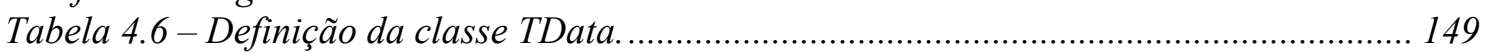

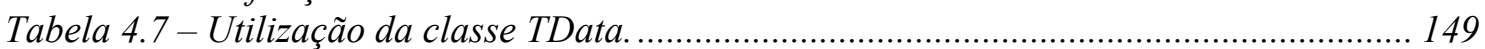

Tabela 4.8 - Implementação de uma operação da classe TData. ........................................... 150

Tabela 4.9 - Dados do estudo de dimensionamento .............................................................. 159

Tabela 4.10 - Dados do estudo de simulação do sistema de referência .................................... 160

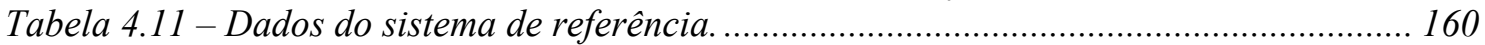

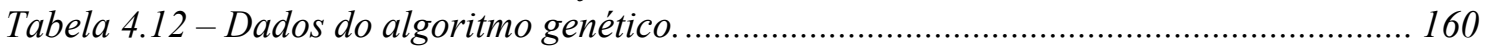

Tabela 4.13 - Dados do mecanismo de valorização da energia............................................... 162

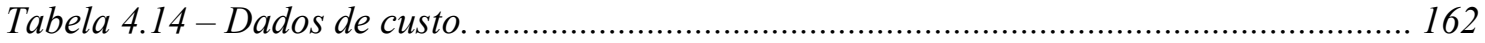

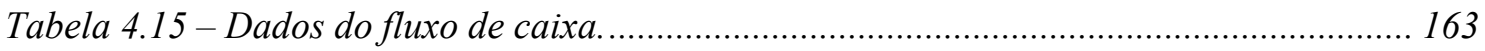

Tabela 4.16 - Resultados do modelo de dimensionamento. .................................................. 164

\section{Capítulo V-Modelagem de Usinas Hidroelétricas}

Tabela 5.1 - Polinômios $h_{\text {jus }}(u)$ para São Simão.

\section{Capítulo VI - Modelos de Otimização e Simulação}

Tabela 6.1 - Principais dados das usinas do sistema teste.

Tabela 6.2 - Caracterização do Período Crítico das usinas com reservatório de acumulação.

Tabela 6.3 - Valores de Energia Firme das usinas a reservatório do rio Paranapanema...... 248

Tabela 6.4 - Valores de Energia Secundária das usinas a reservatório do rio Paranapanema.

\section{Capítulo VII - Estudos de Casos}

Tabela 7.1 - Principais características de algumas usinas utilizadas nos testes. 
Tabela 7.2 - Aproveitamentos catalogados com características físicas principais e custos... 255

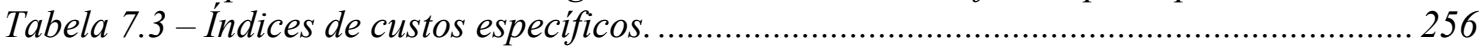

Tabela 7.4 - Classificação dos índices de custos específicos................................................ 256

Tabela 7.5 - Dados da curva de custo de construção para Emborcação.................................. 258

Tabela 7.6 - Dados da curva de custo de aquisição de terras para Emborcação...................... 258

Tabela 7.7 - Dados da curva de custo da turbina/gerador de base para Emborcação............ 258

Tabela 7.8 - Dados da curva de custo da turbina/gerador de ponta para Emborcação...........259

Tabela 7.9 - Dados da curva de custo de construção para Porto Primavera ............................ 260

Tabela 7.10 - Dados da curva de custo de aquisição de terras para Porto Primavera........... 260

Tabela 7.11 - Dados da curva de custo da turbina/gerador de base para Porto Primavera... 261

Tabela 7.12 - Dados da curva de custo da turbina/gerador de ponta para Porto Primavera. 262

Tabela 7.13 - Conjuntos de parâmetros dos Algoritmos Genéticos. ........................................2.264

Tabela 7.14 - Testes utilizados para balizar a escolha dos parâmetros do AG. ......................2.265

Tabela 7.15 - Testes para determinação do tempo de processamento do Dime. ...................... 269

Tabela 7.16 - Resultado completo do estudo Emb37ParEF40M1BGHT ................................ 278

Tabela 7.17 - Volume mínimo e máximo, custos e receitas em função do preço médio da

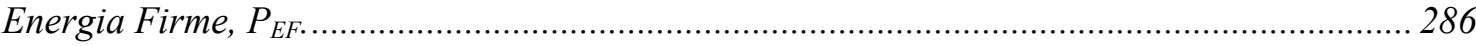

Tabela 7.18 - Resultado completo do estudo Emb37ParEF40M2BGHT............................... 293

Tabela 7.19 - Análise incremental da expansão da casa de força para $r=2 \ldots \ldots \ldots \ldots \ldots \ldots \ldots \ldots . . . . . . . . . . .293$

Tabela 7.20 - Resultado completo do estudo Emb37ParEF40M3BGHT................................. 295

Tabela 7.21 - Análise incremental da expansão da casa de força para $r=3 \ldots \ldots \ldots \ldots \ldots \ldots \ldots \ldots . . . . .296$

Tabela 7.22 - Resultado completo do estudo Emb37ParEF40M1ESBGHT.............................. 298

Tabela 7.23 - Resultado completo do estudo Emb37ParEF40M2ESBGHT............................ 299

Tabela 7.24 - Principais características fisicas da usina sob dimensionamento em função da

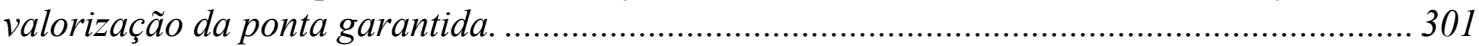

Tabela 7.25 - Custos e receitas em função da valorização da ponta garantida........................ 301

Tabela 7.26 - Definição dos testes utilizados na comparação dos beneficios local e global... 302

Tabela 7.27 - Comparação das características físicas da usina sob dimensionamento em

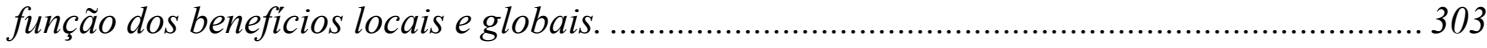

Tabela 7.28 - Comparação das Receitas Líquidas Anuais em função dos beneficios locais e

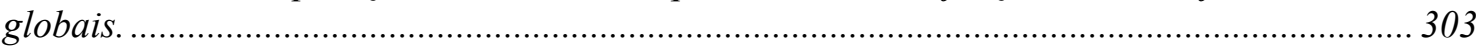

Tabela 7.29 - Comparação dos benefícios energéticos sistêmicos em função da consideração de

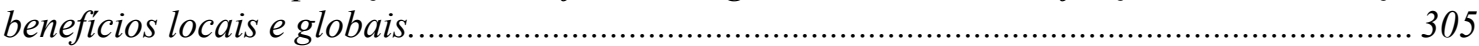

Tabela 7.30 - Definição dos testes utilizados na comparação das regras de operação............ 306

Tabela 7.31 - Comparação das características físicas da usina sob dimensionamento em

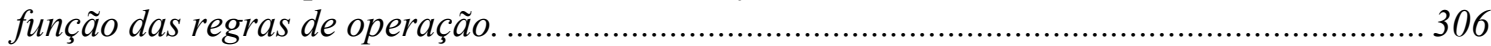

Tabela 7.32 - Comparação das Receitas Líquidas Anuais em função das regras de operação.

Tabela 7.33 - Comparação dos benefícios energéticos sistêmicos em função das regras de

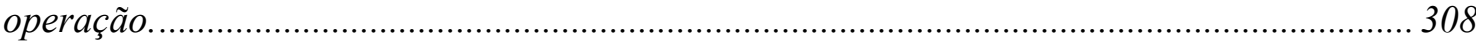

Tabela 7.34 - Definição dos testes utilizados na comparação dos históricos de vazão. ........... 309

Tabela 7.35 - Comparação das características físicas da usina sob dimensionamento em

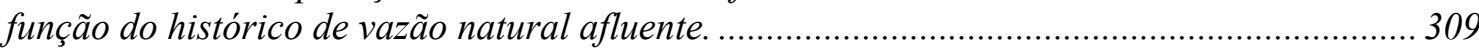

Tabela 7.36 - Comparação dos benefícios energéticos sistêmicos em função dos históricos de

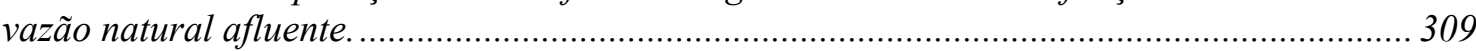
Tabela 7.37 - Comparação das Receitas Líquidas Anuais em função do histórico de vazão

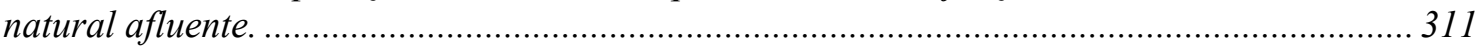

Tabela 7.38 - Definição dos testes utilizados na comparação do Sistema de Referência......... 313 Tabela 7.39 - Comparação das características físicas da usina sob dimensionamento em

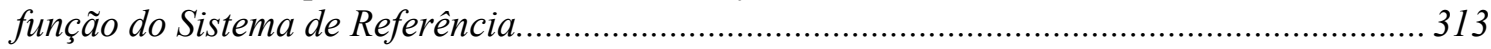

Tabela 7.40 - Comparação das Receitas Líquidas Anuais em função do Sistema de Referência.

Tabela 7.41 - Comparação dos beneficios energéticos sistêmicos em função do Sistema de Referência. 
Tabela 7.42 - Definição dos testes utilizados na comparação das usinas sob dimensionamento. 316

Tabela 7.43 - Comparação das características físicas da usina sob dimensionamento em função do Sistema de Referência. 316 Tabela 7.44 - Comparação dos benefícios energéticos sistêmicos em função da usina sob dimensionamento.

\section{Anexos $A, B$ e $C$}

Tabela A.1 - Centróides determinados pelo método da montanha.

Tabela A.2 - Valores das funções $\tau_{i}$ para $x=0,5$.

Tabela A.3 - Conjunto de pontos característicos obtido para a nuvem de pontos do exemplo. 



\section{Lista de Símbolos}

- $\Delta \boldsymbol{E F}_{\boldsymbol{a}}$ : acréscimo de energia firme do sistema de referência proporcionado pela alternativa $a$, em $\overline{\mathrm{MW}}$.

- $\eta$ : rendimento do conjunto turbina-gerador.

- $\alpha$ : coeficiente utilizado no cálculo do engolimento máximo.

- $\lambda$ : fator de acoplamento dos reservatórios, $0 \leq \lambda \leq 1$.

- $\rho$ : massa específica da água, igual a $10^{3} \mathrm{~kg} / \mathrm{m}^{3}$.

- $\Delta \boldsymbol{E F}^{*}$ : acréscimo de Energia Firme do sistema de referência proporcionado pela alternativa com maior Energia Firme, em $\overline{\mathrm{MW}}$.

- $\Omega_{i}$ : conjunto das usinas situadas imediatamente a montante da usina hidroelétrica $i$.

- $\eta_{\text {méd }}$ : rendimento médio do conjunto turbina-gerador.

- $\Delta t$ : duração de um intervalo de simulação/otimização, em segundos.

- $\left[\boldsymbol{a}_{\boldsymbol{i}}, \boldsymbol{b}_{\boldsymbol{i}}\right]$ : intervalo de pertinência da $i$-ézima variável do Algoritmo Genético.

- $\boldsymbol{a}_{\boldsymbol{e}}\left(\boldsymbol{h}_{\boldsymbol{m} o n}\right)$ : área do espelho d'água, em $\mathrm{km}^{2}$, em função de $h_{m o n}$.

- $\boldsymbol{a p}\left(x_{i}\right)$ : aptidão do i-ézimo indivíduo do Algoritmo Genético.

- $\boldsymbol{B}_{\boldsymbol{E} F}$ : benefício de Energia Firme, em $\overline{\mathrm{MW}}$.

- $\boldsymbol{B}_{\boldsymbol{E}}$ : benefício de Energia Secundária, em $\overline{\mathrm{MW}}$.

- $\boldsymbol{B}_{P G}$ : benefício de Ponta Garantida, em $M W$.

- $\boldsymbol{C}(\boldsymbol{t})$ : custo de operação ao longo do intervalo $t$, definido em alguma unidade monetária, genericamente denotada por $\$$.

- $\boldsymbol{c}_{a t}\left(\boldsymbol{a}_{\boldsymbol{m} \dot{x} \boldsymbol{x}}\right)$ : custo de aquisição de terras, em US\$.

- $\boldsymbol{c}_{c r}\left(\boldsymbol{x}_{\boldsymbol{m} \dot{x} \boldsymbol{x}}\right)$ : custo de construção do reservatório, em US\$.

- $\boldsymbol{c e}_{\boldsymbol{m} \hat{s}}$ : coeficientes de evaporação, um para cada mês, em $m m$.

- $\quad \boldsymbol{c}_{\text {med }}$ : nível médio do canal de fuga, em $m$. 
- $\boldsymbol{c f}_{\text {med,i }}$ : cota média do canal de fuga da usina $i$, em $m$.

- $\boldsymbol{c}_{g t, b}\left(\boldsymbol{p}_{\text {nom,b }}\right)$ : custo dos geradores e das turbinas de base, em US\$.

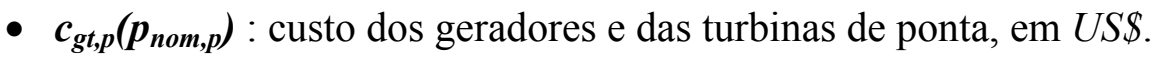

- $\boldsymbol{C I}$ : custo de instalação, em $U S \$ / \mathrm{kW}$.

- $\boldsymbol{C}_{I T}$ : custo anual de investimento, em US\$.

- $\boldsymbol{C O M}_{\boldsymbol{i}}$ : custo anual de operação e manutenção da usina $i$, em $10^{3}$ US\$/ano.

- $C_{T}$ : custo anual total da usina, em US\$/ano.

- $\boldsymbol{C} \boldsymbol{T}_{\boldsymbol{a}}$ : custo total anual da alternativa de divisão de quedas $a$, em US\$, contendo apenas os aproveitamentos economicamente viáveis.

- $\boldsymbol{D}(\boldsymbol{t})$ : carga média durante o intervalo $t$, em $\overline{M W}$.

- $\boldsymbol{D}_{\boldsymbol{j}}$ : cronograma de desembolso, definido como uma fração do investimento total $I_{T}$.

- $\boldsymbol{E}(\boldsymbol{t})$ : geração média das fontes não-hidráulicas durante o intervalo $t$, em $\overline{M W}$.

- $\boldsymbol{E} \boldsymbol{A}$ : efeito de afogamento do canal de fuga, em $\%$.

- $\boldsymbol{E}_{\boldsymbol{B}}$ : energia diária despachada na base, em $M W h$.

- $\boldsymbol{E} \boldsymbol{C}$ : efeito cota, em \%.

- $\boldsymbol{E F}_{\boldsymbol{C}}$ : Energia Firme do Sistema Completo, em $\overline{\mathrm{MW}}$.

- $\boldsymbol{E F}_{\boldsymbol{R}}$ : Energia Firme do Sistema de Referência, em $\overline{\mathrm{MW}}$.

- $\boldsymbol{E}_{\boldsymbol{P}}$ : energia diária despachada na ponta, em $M W h$.

- $\boldsymbol{E S}_{\boldsymbol{C}}$ : Energia Secundária do Sistema Completo, em $\overline{\mathrm{MW}}$.

- $\boldsymbol{E S}_{\boldsymbol{R}}$ : Energia Secundária do Sistema de Referência, em $\overline{\mathrm{MW}}$.

- $\boldsymbol{F}$ : aptidão total da população do Algoritmo Genético.

- $\boldsymbol{f}_{\text {cap }}$ : fator de capacidade, adimensional.

- fcap $_{\text {ref }}$ : fator de capacidade de referência, adimensional.

- $\boldsymbol{f c}_{\boldsymbol{m} \boldsymbol{x} \boldsymbol{x}}$ : fator de capacidade máxima, adimensional. 
- $\boldsymbol{f}_{i}(\lambda)$ : regra baseda em otimização para cada usina $i$.

- $\boldsymbol{F R C}\left(\boldsymbol{t}_{\boldsymbol{d}}, \boldsymbol{T}_{\boldsymbol{U}}\right)$ : fator de recuperação de capital a uma taxa de desconto anual $t_{d}$, ao longo da vida útil do aproveitamento $T_{U}$, em anos.

- $\boldsymbol{g}$ : aceleração da gravidade, igual a $9,81 \mathrm{~m} / \mathrm{s}^{2}$.

- $\boldsymbol{g}_{\text {máx,pc }}$ : máxima geração verificada ao longo do Período Crítico, em $\overline{\mathrm{MW}}$.

- $\boldsymbol{H}(\boldsymbol{t})$ : geração média total das hidroelétricas durante o intervalo $t$, em $\overline{M W}$.

- $\boldsymbol{h}_{\boldsymbol{b}}(\boldsymbol{x}, \boldsymbol{u})$ : a altura de queda bruta, em $m$.

- $\boldsymbol{h}_{\boldsymbol{e}}$ : queda de referência efetiva, em $m$.

- HIST - conjunto de meses pertencentes ao histórico.

- $\boldsymbol{h}_{j u s}(\boldsymbol{u})$ : nível d'água de jusante, em $m$ e em relação ao nível do mar.

- $\boldsymbol{h}_{l}$ : altura de queda líquida, em $m$.

- $\boldsymbol{h}_{l}(t)$ : altura de queda líquida da usina no intervalo $t$, em $m$.

- $\boldsymbol{h}_{\boldsymbol{m o n}}(\boldsymbol{x})$ : nível d'água de montante da usina, em $m$ e em relação ao nível do mar.

- $\boldsymbol{h}_{\text {nom }}$ : queda de referência nominal, em $m$.

- $\boldsymbol{h}_{p}$ : perdas hidráulicas, em $m$.

- $\boldsymbol{I}_{C B, a}$ : índice custo/benefício da alternativa de divisão de quedas $a$, em $U S \$ / M W h$.

- IM : índice de mérito, em $U S \$ / M W h$.

- $\boldsymbol{I}_{T}$ : investimento total da usina, em US\$.

- $\boldsymbol{I}_{T, V P}$ : valor presente do investimento total, em US\$.

- $\boldsymbol{n}_{\text {conj }}$ : número de conjuntos de máquinas de uma usina.

- nha : número de horas em um ano, igual a 8760.

- $\boldsymbol{n}_{h p}$ : número de horas diárias do período de ponta.

- $\boldsymbol{n}_{\text {ind }}$ : número de indivíduos da população do Algoritmo Genético. 
- $\quad N_{P C}$ - número de meses do Período Crítico.

- $\boldsymbol{n} \boldsymbol{r}$ : níveis de referência para cálculo do remanso, em $m$.

- $\boldsymbol{P}(t)$ : população do Algoritmo Genético existente na geração $t$.

- $\boldsymbol{p}(\boldsymbol{t})$ : geração média da usina no intervalo $t$, em $\overline{\mathrm{MW}}$.

- $\boldsymbol{P}_{\boldsymbol{E F}}$ : preço médio da Energia Firme, em $U S \$ / M W h$.

- $\boldsymbol{p}_{\text {ef,máq }}$ : potência efetiva de um gerador da usina, em $M W$.

- $\boldsymbol{P}_{\boldsymbol{E F B}}$ : preço da energia gerada no horário de base, em US\$/MWh.

- $\boldsymbol{P}_{E F P}$ : preço da energia gerada no horário de ponta, em $U S \$ / M W h$.

- $\boldsymbol{p} \boldsymbol{e}_{\boldsymbol{i}}:$ produtibilidade específica da usina $i$, em $M W /\left(m^{3} / s\right) \cdot m$.

- $\boldsymbol{p} \boldsymbol{e}_{\boldsymbol{m} \dot{x} \boldsymbol{x}, \boldsymbol{i}}$ : geração máxima da usina $i$, em $\overline{\mathrm{MW}}$, fornecida como restrição elétrica.

- $\boldsymbol{p}_{\boldsymbol{m}} \boldsymbol{m}_{n, i}$ : geração mínima da usina $i$, em $\overline{\mathrm{MW}}$, fornecida como restrição elétrica.

- $\boldsymbol{P}_{E S}$ : preço da Energia Secundária, em $U S \$ / M W h$.

- $P \boldsymbol{G}_{\boldsymbol{C}}$ : Ponta Garantida do Sistema Completo, em $M W$.

- $\quad \boldsymbol{P G}_{\boldsymbol{R}}$ : Ponta Garantida do Sistema de Referência, em $M W$.

- $\boldsymbol{p}_{\boldsymbol{i}}$ : probabilidade de seleção do indivíduo $i$ do Algoritmo Genético.

- $\boldsymbol{p}_{\boldsymbol{m a ́ x}}$ : máxima potência que pode ser gerada pela usina, em $M W$.

- $\boldsymbol{p}_{\text {máx }, \text { com,i } i}$ : geração hidráulica máxima contínua da usina $i$, em $\overline{\mathrm{MW}}$.

- $\boldsymbol{p}_{\text {máx,tur }}$ : expressa a máxima potência do conjunto para alturas de queda menores que a altura de queda efetiva.

- $\boldsymbol{p}_{\text {nom }}$ : capacidade instalada total da usina, em $M W$.

- $\boldsymbol{p}_{\text {nom, } \boldsymbol{b}}$ : capacidade instalada de base, em $M W$.

- $\boldsymbol{p}_{\text {nom,p }}$ : capacidade instalada de ponta, em $M W$.

- $\boldsymbol{P}_{\boldsymbol{P G}}$ : preço atribuído à capacidade disponível, em US\$/(MW.ano). 
- $\boldsymbol{q}_{e f}$ : vazão de referência efetiva, em $\mathrm{m}^{3} / \mathrm{s}$.

- $\boldsymbol{q} \boldsymbol{f}_{\boldsymbol{m a ́ x}}$ : vazão máxima da usina, em $\mathrm{m}^{3} / \mathrm{s}$, estimada a partir do histórico.

- $\boldsymbol{q}_{i}$ : probabilidade acumulada de seleção do indivíduo i.

- $\boldsymbol{q}_{i}(\boldsymbol{t})$ : vazão turbinada média da usina hidroelétrica $i$ durante o intervalo $t$, em $\mathrm{m}^{3} / \mathrm{s}$.

- $\boldsymbol{q}_{\text {máx } \boldsymbol{x} \text { ger }}$ : expressa o engolimento máximo da turbina para alturas de queda maiores que a altura de queda efetiva.

- $\boldsymbol{q}_{\text {máx,i }}(\boldsymbol{t})$ : engolimento máximo da usina hidroelétrica $i$ durante o intervalo $t$, em $\mathrm{m}^{3} / \mathrm{s}$.

- $\boldsymbol{q}_{\text {máx,máq }}$ : engolimento máximo de um conjunto turbina/gerador, em $\mathrm{m}^{3} / \mathrm{s}$.

- $\boldsymbol{q}_{\text {máx,tur }}$ : expressa o engolimento máximo da turbina para alturas de queda menores que a altura de queda efetiva.

- $\boldsymbol{q}_{\text {nom }}$ : vazão de referência nominal, em $\mathrm{m}^{3} / \mathrm{s}$.

- $\boldsymbol{r}$ : razão entre $P_{E F P}$ e $P_{E F B}$, adimensional.

- $\boldsymbol{R}_{\boldsymbol{E} F}$ : receita anual obtida com o benefício de Energia Firme, em US\$/ano.

- $\boldsymbol{R}_{E S}$ : receita anual obtida com o benefício de Energia Secundária, em US\$/ano.

- $\boldsymbol{R}_{L Q}$ : receita líquida anual da usina, em US\$/ano.

- $\boldsymbol{R}_{\boldsymbol{P G}}$ : receita anual obtida com o benefício de Ponta Garantida, em US\$/ano.

- $\boldsymbol{R}_{T}$ : receita anual total, em US\$/ano.

- $\boldsymbol{T}$ : número de intervalos do histórico.

- $\boldsymbol{T}_{\boldsymbol{0}}$ e $\boldsymbol{T}_{1}$ : intervalos para realização da simulação simplificada.

- $\boldsymbol{t}_{\boldsymbol{c}}$ : taxa de cruzamento do Algoritmo Genético, adimensional.

- $\boldsymbol{T}_{\boldsymbol{C}}$ : tempo de construção da obra, em anos.

- $\boldsymbol{t}_{\boldsymbol{d}}$ : taxa de desconto, adimensional.

- $\boldsymbol{t}_{i f}$ : taxa de indisponibilidade forçada, adimensional.

- $\boldsymbol{t}_{\boldsymbol{j} d \boldsymbol{c}}$ : taxa anual de juros durante a construção, adimensional. 
- $\boldsymbol{t}_{\boldsymbol{m}}$ : taxa de mutação do Algoritmo Genético, adimensional.

- $\boldsymbol{t}_{\boldsymbol{m a n}}$ : taxa de manutenção programada, adimensional.

- $\boldsymbol{T}_{\boldsymbol{U}}$ : vida útil da usina, em anos.

- $\boldsymbol{u}_{\boldsymbol{m a x} x \boldsymbol{i}, \text { }}$ : vazão defluente máxima, fornecida pelo usuário, em $\mathrm{m}^{3} / \mathrm{s}$.

- $\boldsymbol{u e}_{\boldsymbol{m} \boldsymbol{m}, \boldsymbol{i}}$ : vazão defluente mínima, fornecida pelo usuário, $\mathrm{em} \mathrm{m}^{3} / \mathrm{s}$.

- $\boldsymbol{u g}_{\boldsymbol{r}}$ : vazão defluente média garantida com nível de confiabilidade $r$, em $\mathrm{m}^{3} / \mathrm{s}$.

- $\boldsymbol{u}_{\boldsymbol{i}}(\boldsymbol{t})$ : vazão defluente média da usina hidroelétrica $i$ durante o intervalo $t$, em $\mathrm{m}^{3} / \mathrm{s}$.

- $\boldsymbol{u}_{\text {min }}(t)$ e $\boldsymbol{u}_{\text {máx }}(t)$ : limites mínimo e máximo de vazão defluente média durante o intervalo $t$, em $\mathrm{m}^{3} / \mathrm{s}$

- $\boldsymbol{v}_{i}(\boldsymbol{t})$ : vazão vertida média da usina hidroelétrica $i$ durante o intervalo $t$, em $\mathrm{m}^{3} / \mathrm{s}$.

- $\boldsymbol{x}_{\boldsymbol{e v}}(\boldsymbol{t})$ : volume de água evaporado, em $\mathrm{hm}^{3}$, durante o intervalo $t$.

- $x f_{\text {min }}$ e $x f_{\text {máx }}$ : limites mínimo e máximo para a capacidade do reservatório da usina sob dimensionamento, ambos em $\mathrm{hm}^{3}$.

- $\boldsymbol{x}_{\text {máx }}$ : volume máximo do reservatório, em $\mathrm{hm}^{3}$.

- $\boldsymbol{x}_{\text {máx, } \max }$ : volume máximo maximorum, em $\mathrm{hm}^{3}$.

- $\boldsymbol{x}_{\text {méd,i }}(\boldsymbol{t})$ : volume médio armazenado no reservatório da usina hidroelétrica $i$ durante o intervalo $t$, em $\mathrm{hm}^{3}$.

- $\boldsymbol{x}_{\text {min }}$ : volume mínimo do reservatório, em $\mathrm{hm}^{3}$.

- $\boldsymbol{x}_{\boldsymbol{m} \boldsymbol{r}}$ : volume morto do reservatório, em $\mathrm{hm}^{3}$.

- $\boldsymbol{x}_{\boldsymbol{s e g}}$ : volume de segurança, em $\mathrm{hm}^{3}$.

- $\boldsymbol{x}_{\text {útil }}$ : volume útil do reservatório, em $\mathrm{hm}^{3}$.

- $y(t)$ : vazão afluente média ao reservatório durante o intervalo $t$, em $\mathrm{m}^{3} / \mathrm{s}$.

- $y_{\text {inc,i } i}(t)$ : vazão afluente incremental à usina $i$ durante o intervalo $t, \mathrm{em} \mathrm{m}^{3} / \mathrm{s}$. 


\section{Lista de Abreviaturas e Siglas}

- AG: Algoritmo Genético.

- AMFORP: American \& Foreign Power Company.

- ANEEL: Agência Nacional de Energia Elétrica.

- BEX: Método de Busca Exaustiva.

- CAPES: Coordenação de Formação de Pessoal de Nível Superior.

- CCPE: Comitê Coordenador do Planejamento da Expansão dos Sistemas Elétricos.

- CEEE: Comissão Estadual de Energia Elétrica.

- CELUSA: Centrais Elétricas Urubupungá.

- CEMIG: Centrais Elétricas de Minas Gerais.

- CEMIG: Companhia Energética de Minas Gerais.

- CESP: Companhia Energética de São Paulo.

- CGE: Câmara de Gestão da Crise.

- CHESF: Companhia Hidro Elétrica do São Francisco.

- CIP: Custo Unitário de Referência de Ponta.

- CME: Companhia Mineira de Eletricidade.

- COPEL: Companhia Paranaense de Energia.

- CPFL: Companhia Paulista de Força e Luz.

- CRE: Custo Unitário de Referência de Energia.

- CUR: Custo Unitário de Referência.

- DET: Despacho Econômico Térmico.

- EE: Modelo Estocástico Explícito.

- EESC: Escola de Engenharia de São Carlos. 
- EFE: Empresa Fluminense de Energia Elétrica.

- $\quad$ EI: Modelo Estocástico Implícito.

- EIA: Estudo de Impacto Ambiental.

- ELETROBRÁS: Centrais Elétricas Brasileiras S.A.

- ESCELSA: Espírito Santo Centrais Elétricas S. A.

- FAO: Organização para Agricultura e Alimentação (Food and Agriculture Organization).

- FAPESP: Fundação de Amparo à Pesquisa do Estado de São Paulo.

- $\quad$ FFE: Fundo Federal de Eletrificação.

- GOOAL: Genetic Object Oriented Algorithm.

- IBGE: Instituto Brasileiro de Geografia e Estatística.

- IDH: Índice de Desenvolvimento Humano.

- LI: Licença de Instalação.

- Light: Brazilian Traction, Light and Power.

- Light: Rio de Janeiro Tramway, Light and Power.

- Light: São Paulo Railway, Light and Power Empresa Cliente Ltda - SP RAILWAY

- LO: Licença de Operação.

- LP: Licença Prévia.

- LSEE: Laboratório de Sistemas de Energia Elétrica - SEL/ESSC/USP.

- LSH: Laboratório de Sistemas Hidrotérmicos.

- MAE: Mercado Atacadista de Energia.

- MLT: Média de Longo Termo.

- MM: Método da Montanha.

- MME: Ministério de Minas e Energia. 
- MRE: Mecanismo de Realocação de Energia.

- MVE: Mecanismo de Valorização da Energia.

- N.A.Máx: Nível Máximo de Armazenagem.

- N.A.Mín: Nível Mínimo de Armazenagem.

- ONS: Operador Nacional do Sistema Elétrico.

- $\quad$ Par: Regra Paralela de Operação.

- $\quad$ PEG: Planejamento da Expansão da Geração.

- PET: Planejamento da Expansão da Transmissão.

- PIB: Produto Interno Bruto.

- PNB: Produto Nacional Bruto.

- PPC\$: Dólar da Paridade do Poder de Compra.

- REVISE: Revisão Institucional do Setor de Energia Elétrica.

- RE-SEB: Projeto de Reestruturação do Setor Elétrico Brasileiro.

- RIMA: Relatório de Impacto Ambiental.

- RO: Regra de Operação.

- Roo: Regra de Operação Baseada em Otimização.

- SC: Sistema Completo.

- SEL: Departamento de Engenharia Elétrica da EESC/USP.

- SI: Sistemas Isolados.

- SIN: Sistema Interligado Nacional.

- SINV: Sistema de Inventário Hidroelétrico de Bacias Hidrográficas.

- SR: Sistema de Referência.

- $\quad$ TEP: Tonelada Equivalente de Petróleo.

- UNICAMP: Universidade Estadual de Campinas. 
- USD: Usina Sob Dimensionamento.

- USELPA: Usinas Elétricas do Paranapanema S. A.

- USP: Universidade de São Paulo.

- VA: Conjunto de Vazões Afluentes.

- VMM: Modelo Linear Baseado em Vazões Médias Mensais.

- VPC: Modelo Linear Baseado Somente nas Vazões do Período Crítico. 


\section{Sumá rio}

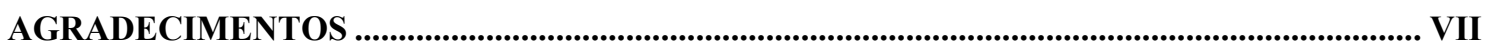

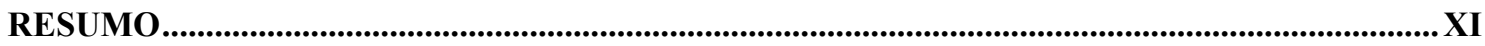

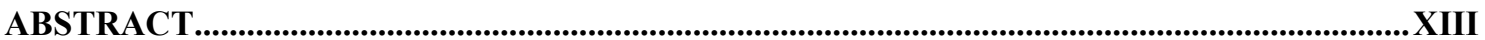

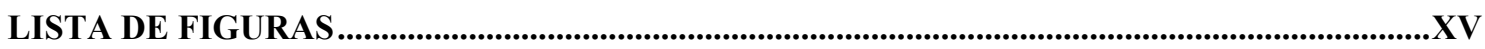

LISTA DE TABELAS ............................................................................................................................... XIX

LISTA DE SÍMBOLOS...................................................................................................................XXIII

LISTA DE ABREVIATURAS E SIGLAS........................................................................................ XXIX

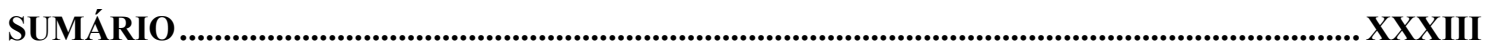

\section{CAPÍTULO I - INTRODUÇÃO ......................................................1}

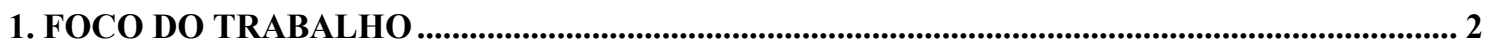

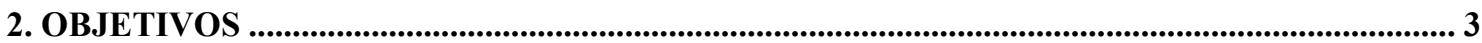

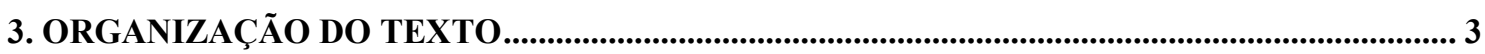

\section{CAPÍTULO II - ENERGIA ELÉTRICA: BENEFÍCIOS, IMPACTOS E O SISTEMA INTERLIGADO NACIONAL ..5}

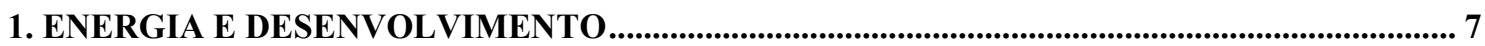

2. ENERGIA E MEIO AMBIENTE ...................................................................................................... 15

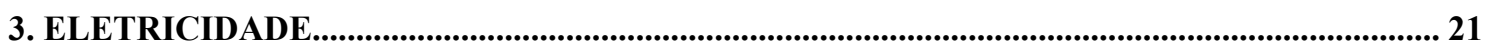

4. SISTEMA INTERLIGADO NACIONAL - SIN …….......................................................................... 25

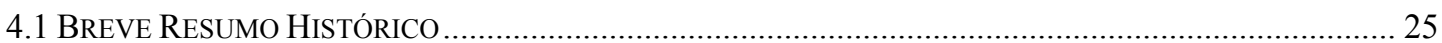

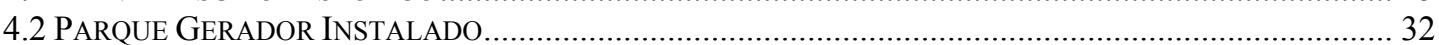

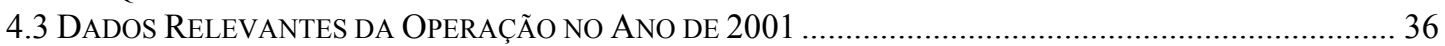

4.4 O POTENCIAL HIDROELÉTRICO BRASILEIRO ............................................................................. 41

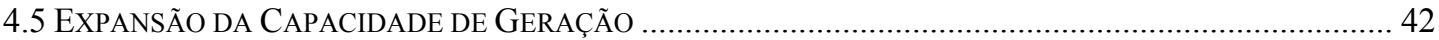

\section{CAPÍTULO III - DIMENSIONAMENTO DE USINAS}

HIDROELÉTRICAS ......................................................45

1. REQUISITOS PARA IMPLANTAÇÃO DE USINAS HIDROELÉTRICAS................................... 47

2. BREVE DESCRIÇÃO DOS BENEFÍCIOS ENERGÉTICOS ........................................................... 51

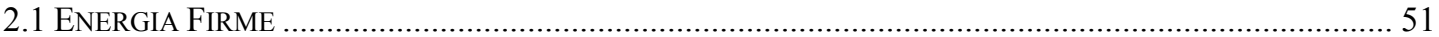

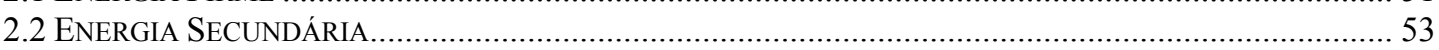

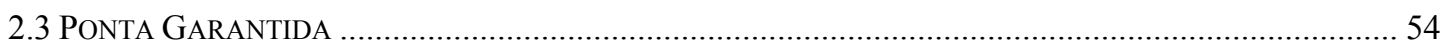


3. PARÂMETROS DE DIMENSIONAMENTO ENERGÉTICO....................................................55

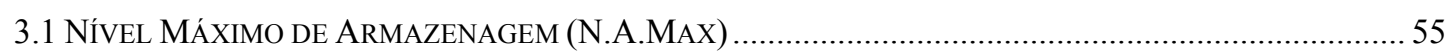

3.2 Nível MíNIMO de ARMAZENAGEM (N.A.MiN) …………...................................................... 55

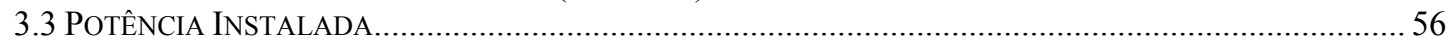

3.4 QUEDAS DE REFERÊNCIA E DE PROJETO DAS TURBINAS................................................................. 57

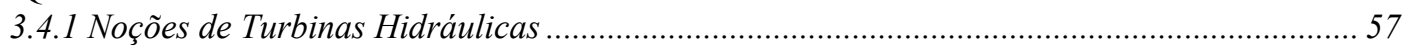

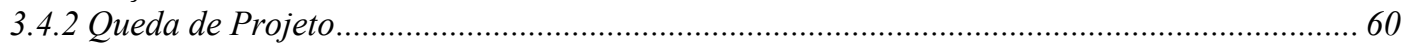

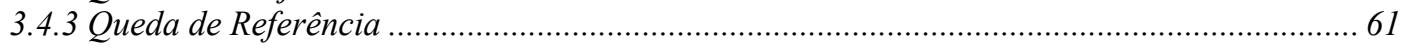

4. DETERMINAÇÃO DOS PARÂMETROS DE DIMENSIONAMENTO ENERGÉTICO............. 67

4.1 Modelo Adotado Pelo Setor ElÉTRICO BRASILEIRo ............................................................... 71

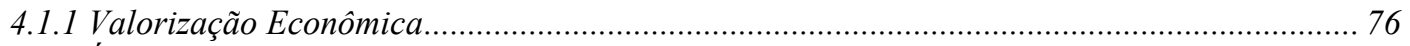

4.1.2 Índice Custo/Beneficio de um Aproveitamento..................................................................... 78

4.1.3 Índice Custo/Beneficio de uma Alternativa ………............................................................... 79

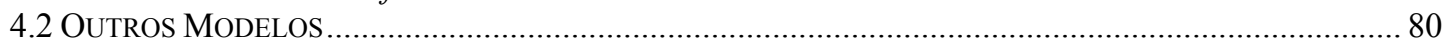

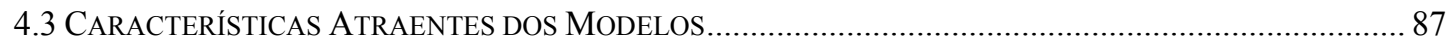

\section{CAPÍTULO IV - MODELO PROPOSTO ..........................91}

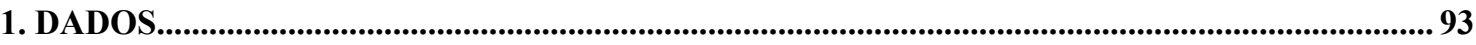

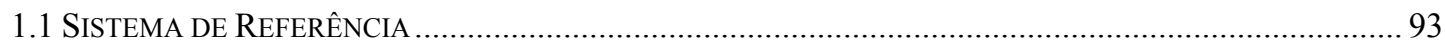

1.2 INFORMAÇÕES DO LOCAL DA NOVA USINA HIDROELÉTRICA ............................................................. 93

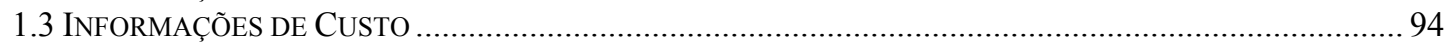

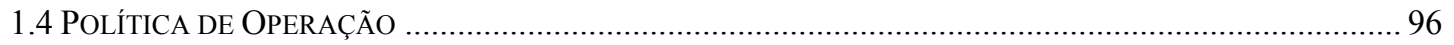

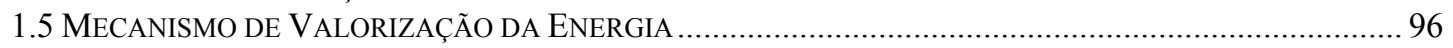

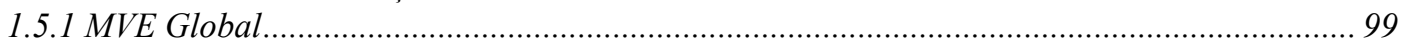

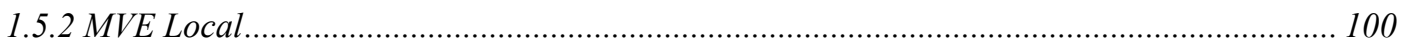

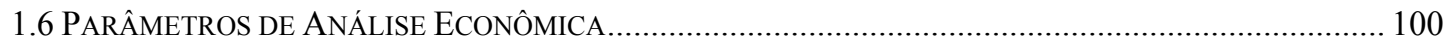

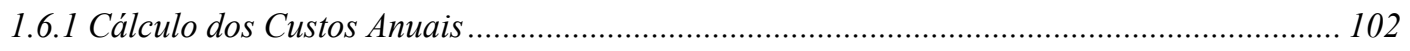

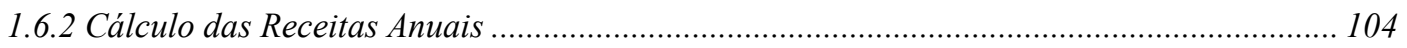

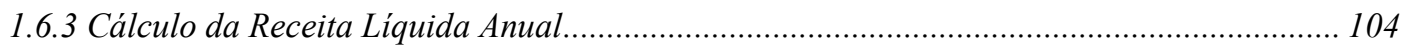

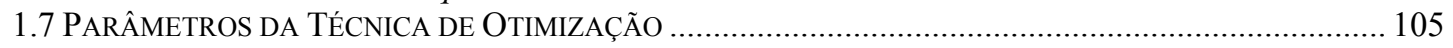

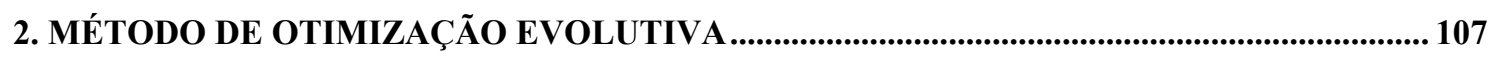

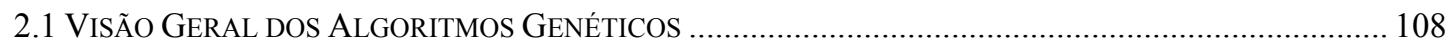

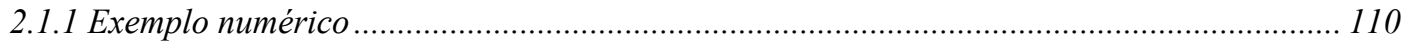

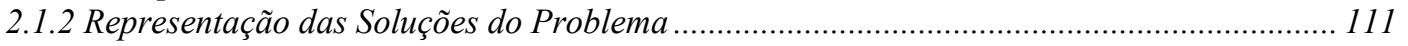

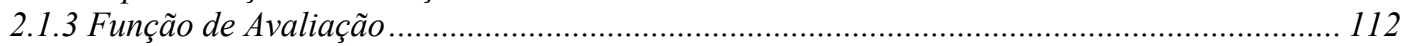

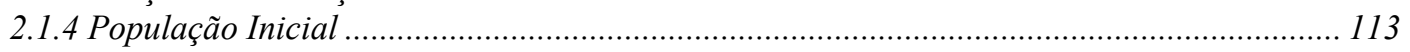

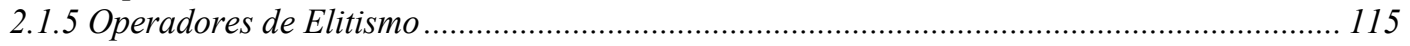

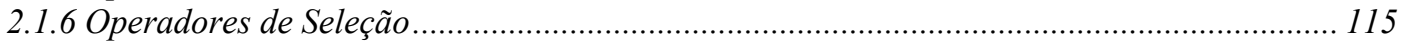

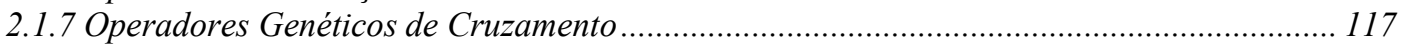

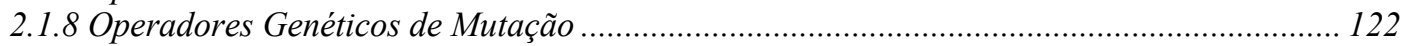

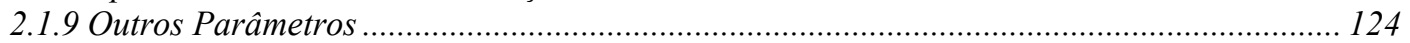

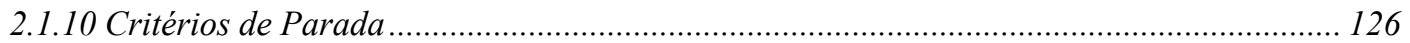

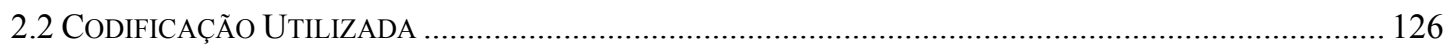

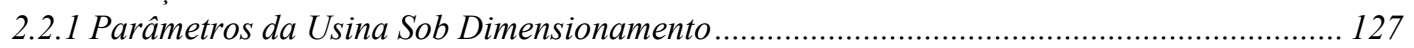

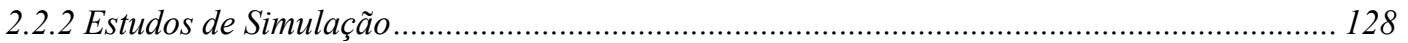

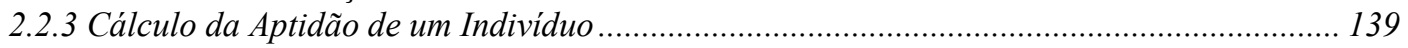

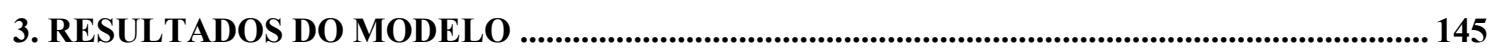

3.1 DimENSÕES ÓTIMAS DA NOVA USINA HIDROELÉTRICA ……………………………………...... 145

3.2 ALTERAÇÕES NAS OUTRAS USINAS HIDROELÉTRICAS ................................................................. 146

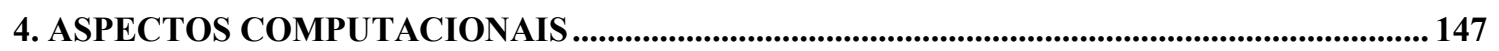

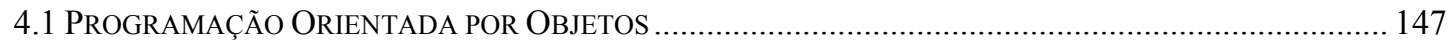

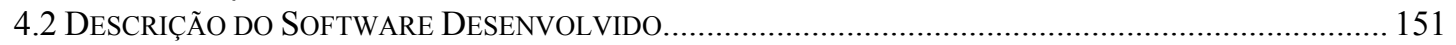




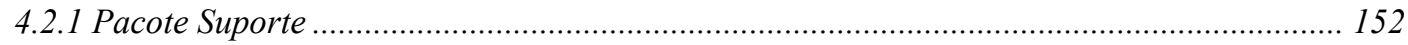

4.2.2 Pacote Sistema Hidroelétrico........................................................................................... 153

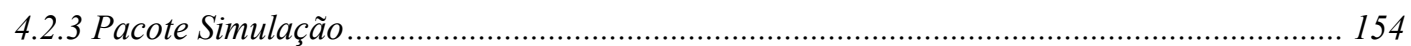

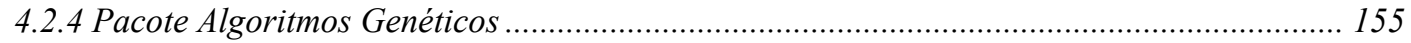

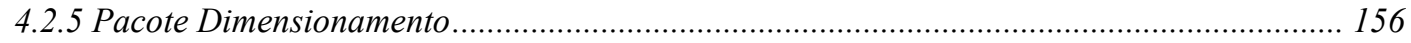

5. EXEMPLO DE ESTUDO DE DIMENSIONAMENTO_........................................................... 159

\section{CAPÍTULO V - MODELAGEM DE USINAS}

HIDROELÉTRICAS .............................................................167

1. FUNÇÃO DE GERAÇÃO DE USINAS HIDROELÉTRICAS .................................................. 169

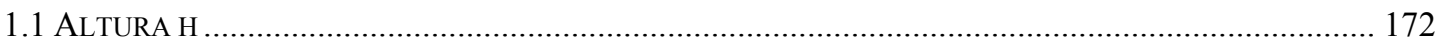

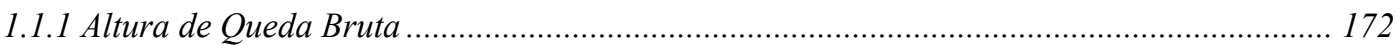

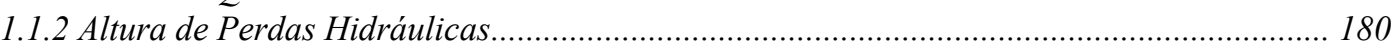

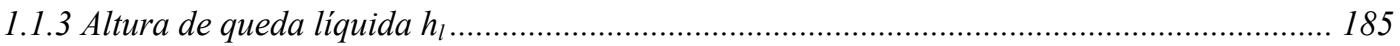

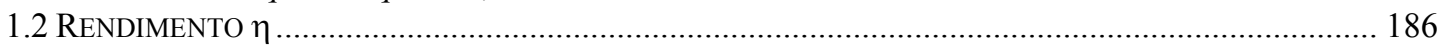

1.3 ENGOLIMENTO MÁXIMO Q

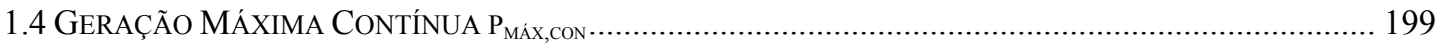

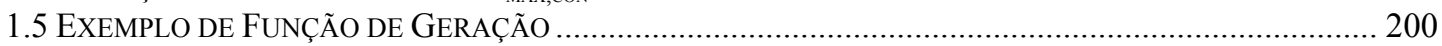

2. PERDAS POR EVAPORAÇÃO .......................................................................................................... 203

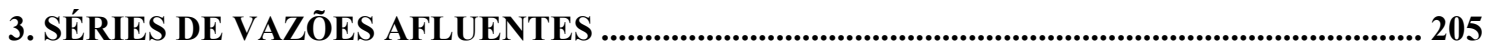

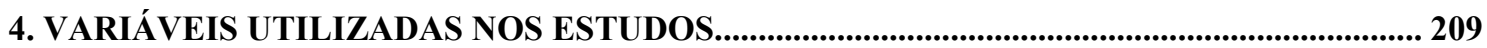

\section{CAPÍTULO VI - MODELOS DE OTIMIZAÇÃO E

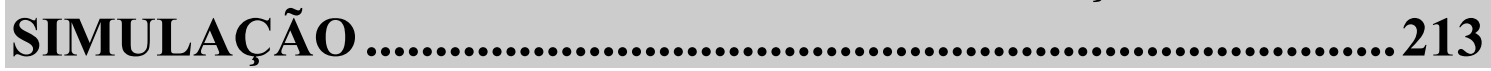

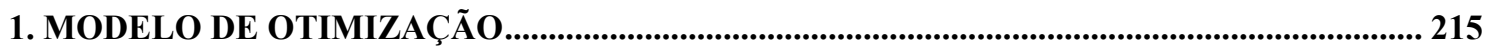

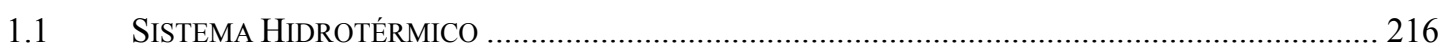

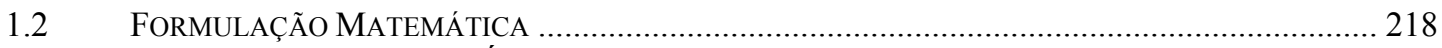

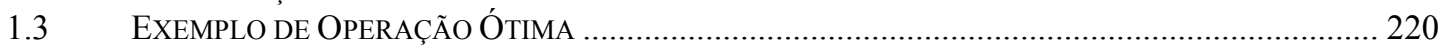

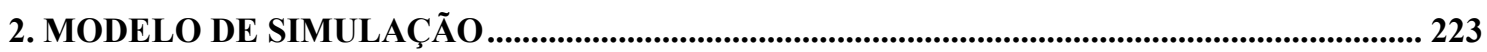

2.1 Simulação de um Período do Histórico ou com Vazões Médias .................................. 225

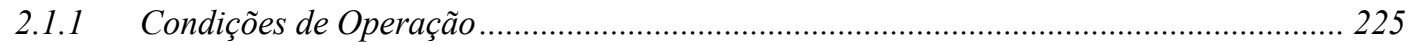

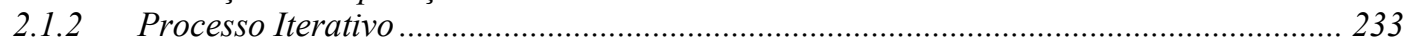

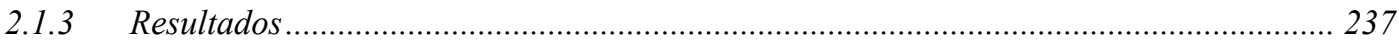

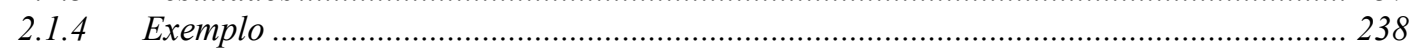

2.2 SimulaÇão Para CÁlCUlo da ENERGia FIRME................................................................ 243

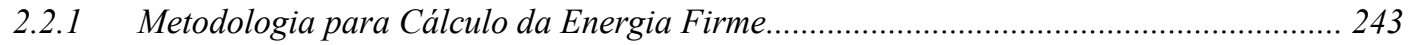

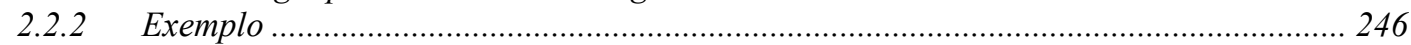

\section{CAPÍTULO VII - ESTUDOS DE CASOS .............................249}

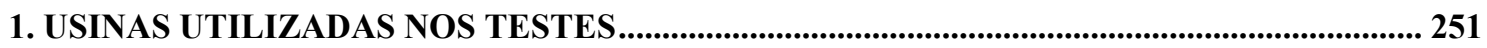

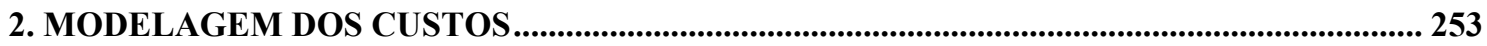

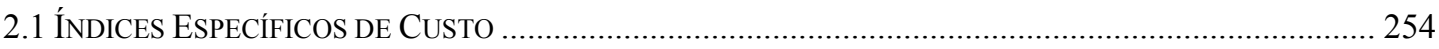

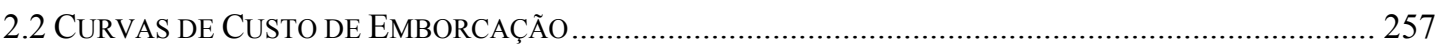




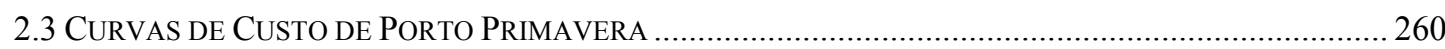

3. AJUSTES DOS PARÂMETROS DO ALGORITMO GENÉTICO................................................. 263

4. DEFINIÇÃO DOS ESTUDOS DE DIMENSIONAMENTO ............................................................ 271

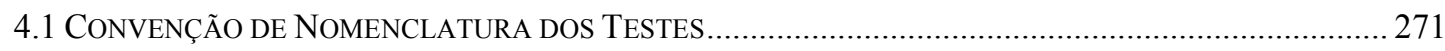

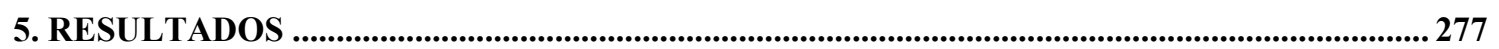

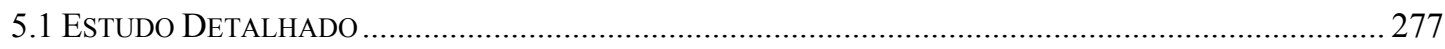

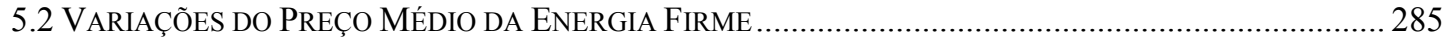

5.3 INSERÇÃO DO FATOR DE MODULAÇÃO...................................................................................... 287

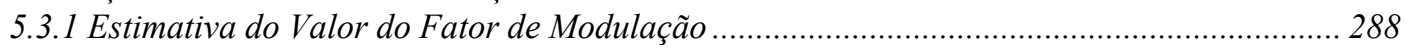

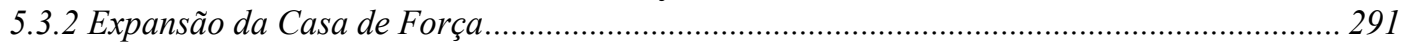

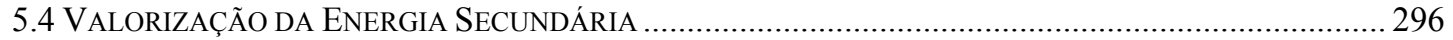

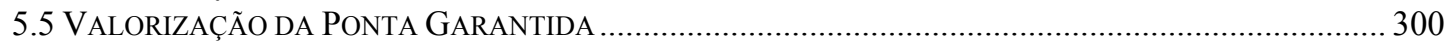

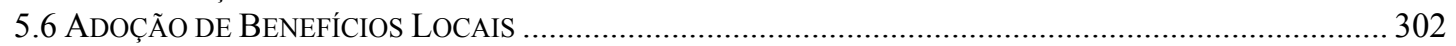

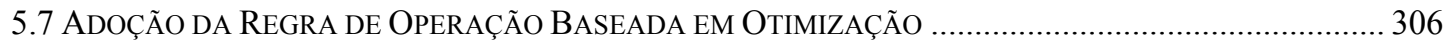

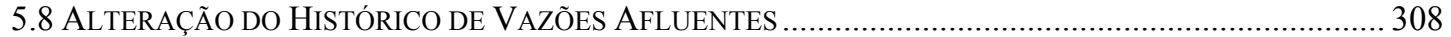

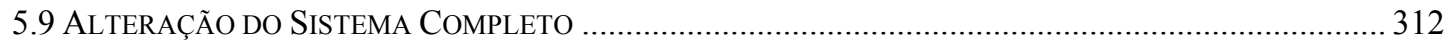

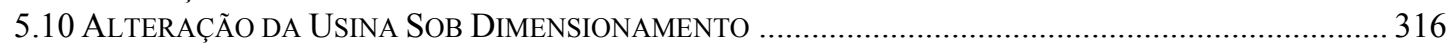

CAPÍTULO VIII - CONCLUSÕES............................................319

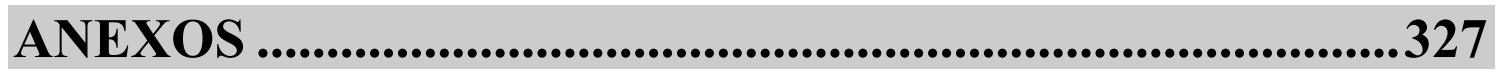

ANEXO A - DADOS COMPLETOS DE ALGUMAS USINAS HIDROELÉTRICAS ..................... 329

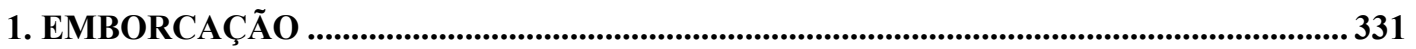

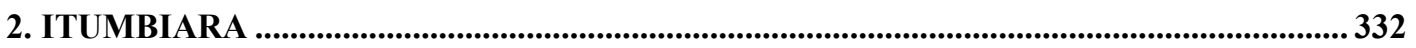

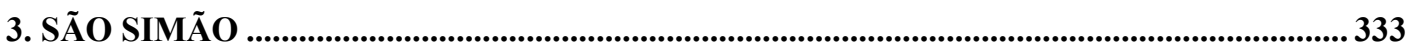

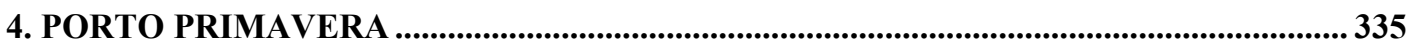

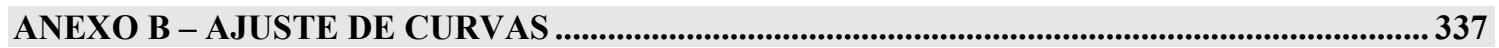

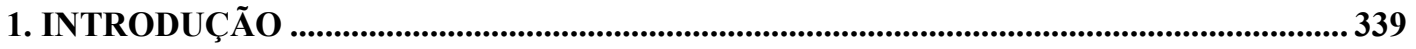

2. DETERMINAÇÃO DOS CENTRÓIDES ..............................................................................339

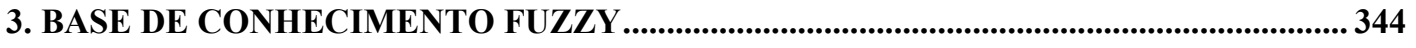

ANEXO C - BUSCA EXAUSTIVA _......................................................................................................... 349

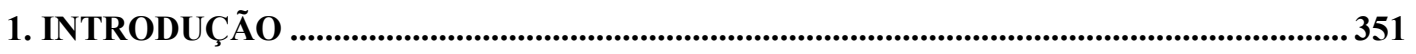

REFERÊNCIAS BIBLIOGRÁFICAS ...................................353 


\section{Capítulo I}

\section{Introdução}

A Energia Elétrica tem se caracterizado como uma fonte de energia altamente versátil, capaz de ser utilizada nos mais diferentes meios e para as mais diferentes finalidades, suprindo desde grandes fornos de siderúrgicas, até simples aparelhos eletrodomésticos. Esta versatilidade fez com que sua utilização aumentasse sensivelmente ao longo das últimas décadas, apresentando ainda hoje taxas elevadíssimas de crescimento. Conseqüentemente, os Sistemas de Energia Elétrica, ou Sistemas Elétricos de Potência, responsáveis pelo fornecimento de grande parte de toda a energia consumida nos dias atuais, passaram a ocupar uma posição de fundamental importância em vários países.

Os Sistemas Elétricos de Potência apresentam portes gigantescos, possuindo um número elevado de usinas, centenas ou milhares de quilômetros de linhas de transmissão, além de uma infinidade de subestações e centros de controle. A complexidade e os elevados custos envolvidos no gerenciamento de todos estes equipamentos têm sido responsáveis por significativos esforços de empresas, centros de pesquisa e universidades de várias partes do mundo, cujos objetivos são encontrar técnicas seguras e eficientes para operar e expandir os Sistemas de Energia Elétrica.

Tanto a operação quanto a expansão dos Sistemas Elétricos de Potência visam garantir que o mercado consumidor de energia seja atendido dentro de critérios de qualidade de suprimento e a baixos custos. Enquanto a operação trata da utilização do sistema existente, a expansão preocupa-se com o crescimento do mesmo. A operação enfoca a identificação de como o mercado será atendido a partir dos recursos disponíveis, isto é, quanto cada usina vai gerar, quais linhas de transmissão serão utilizadas, como serão ajustados os taps dos transformadores, etc. A expansão objetiva determinar quando, onde e como as usinas, as linhas de transmissão, os sistemas de distribuição, e todos os demais equipamentos de controle devem ser adicionados ao sistema existente. 


\section{Foco do Trabalho}

Este trabalho concentra-se em uma das etapas do Planejamento da Expansão da Geração dos Sistemas Elétricos de Potência: o Dimensionamento de Usinas Hidroelétricas. Embora o processo de dimensionamento seja complexo, o princípio básico que norteia sua execução é bastante simples: desejam-se encontrar os parâmetros de projeto de forma que a diferença entre os benefícios e os custos da usina hidroelétrica seja máxima ${ }^{1}$. É justamente no cálculo dos custos e dos benefícios que surgem as grandes dificuldades encontradas no dimensionamento de um novo aproveitamento.

Os custos de um projeto envolvem aquisição de terras, eventuais remoções e relocações de pequenas cidades ou vilas, construção das estruturas físicas (barragem, casa de máquinas, vertedouro, etc.), juros durante a construção, compra de equipamentos elétricos, operação e manutenção, medidas mitigadoras de impactos ambientais, etc. Por mais detalhado que possa ser, o levantamento de custos sempre deixa margem a variações, dado o porte do empreendimento e uma série de adversidades econômicas, políticas e naturais que podem alterar o seu cronograma.

Os benefícios de uma usina hidroelétrica equivalem aos ganhos energéticos que a obra trará ao sistema ao qual ela vai integrar-se, medidos pelos acréscimos de Energia Firme $^{2}$, Energia Secundária e Ponta Garantida. Estes ganhos dependem da evolução da demanda de energia, da disponibilidade hidrológica, das regras de operação que determinam o rateio da carga entre as diversas usinas hidroelétricas, do critério de suprimento de energia entre as empresas, das restrições de intercâmbio, do custo de combustível das usinas termoelétricas, do sistema tarifário, da valorização do suprimento de ponta, etc.

Além das dificuldades encontradas nos cálculos dos custos e dos benefícios de uma usina hidroelétrica, o método de busca pelas dimensões ótimas constitui uma complicação adicional. Há a necessidade de serem medidos os benefícios e os custos associados a cada conjunto possível de parâmetros, estabelecendo ainda alguma "regra" para que novos parâmetros sejam determinados a partir dos atuais, visando o aumento da diferença entre os benefícios e os custos.

\footnotetext{
${ }^{1}$ Assume-se que os benefícios são maiores que os custos, o que torna o empreendimento viável.

2 A denominação Energia Firme, conceito determinístico atribuído à geração média de uma usina ao longo do Período Crítico do histórico de vazões observado, é utilizada genericamente em todo o texto. Ressalta-se que este conceito tem sido substituído pelos conceitos de Energia Garantida ou Assegurada, onde o critério de suprimento é probabilístico.
} 


\section{Objetivos}

O objetivo deste trabalho é desenvolver um modelo que realize de forma automática a busca pelos valores ótimos dos parâmetros de dimensionamento de uma usina hidroelétrica. Para tanto, desenvolveu-se e implementou-se uma metodologia que combina técnicas de otimização evolutiva (Algoritmos Genéticos) com um algoritmo de simulação da operação de sistemas hidroelétricos. A escolha de tal combinação de ferramentas justifica-se pelo casamento das características do problema com as exigências da técnica de otimização.

Por um lado, não há uma função analítica explícita para o problema, já que os benefícios energéticos são medidos através de simulações da operação, o que praticamente inviabiliza o uso de técnicas tradicionais de otimização, normalmente baseadas em derivadas. Por outro lado, os Algoritmos Genéticos, além de serem uma técnica relativamente eficiente e robusta de otimização, possuem a vantagem de guiarem a busca pela solução ótima somente pelo valor da função objetivo.

Adicionalmente, o modelo desenvolvido deve ser suficientemente flexível para permitir que sejam realizadas análises de sensibilidade para determinar como os diversos fatores que alteram o processo de dimensionamento influenciam as características ótimas da usina em questão. Dentre estes fatores destacam-se o modo como a energia gerada é valorizada, considerações sobre as capacidades instaladas de base e de ponta, o conjunto de vazões afluentes e as políticas de operação empregadas nas simulações, o entendimento dos benefícios serem "sistêmicos" ou "locais", o sistema existente em que a nova usina será inserida e a própria posição relativa que esta usina vai ocupar no sistema (usina de montante ou de jusante, por exemplo).

\section{Organização do Texto}

Inicialmente, no Capítulo II mostra-se uma breve visão da evolução do consumo de energia pelo Homem, atentando ao papel desempenhado pela energia elétrica e à particular posição do Brasil na utilização de fontes primárias de geração. Em seguida, o panorama energético brasileiro é traçado com base nos dados disponíveis no Plano Decenal de Geração 2001-2010, elaborado pela ELETROBRÁS - Centrais Elétricas Brasileiras S.A.. Esse capítulo é então encerrado com uma descrição geral do Planejamento da Expansão da Geração utilizado no Brasil. 
No Capítulo III descreve-se como o dimensionamento de usinas hidroelétricas é realizado no Brasil, mostrando os requisitos legais para instalação de uma usina e os parâmetros de dimensionamento envolvidos na análise energética de um aproveitamento. Nesse capítulo apresentam-se vários métodos de dimensionamento e elabora-se uma lista de características atraentes destes métodos.

No Capítulo IV apresenta-se o modelo proposto neste trabalho, delineando-se sua concepção geral e detalhando cada parte que o compõe. A técnica de otimização é apresentada, bem como a forma de avaliação de uma alternativa de dimensionamento. Também apresentam-se os aspectos computacionais de implementação do método proposto e um exemplo de sua execução.

No Capítulo V descreve-se a modelagem matemática adotada para representar as usinas hidroelétricas, apresentando-se todas as equações responsáveis pela determinação da quantidade de energia produzida por uma usina, bem como aspectos relacionados à modelagem das perdas por evaporação, vazões afluentes e as interpretações das próprias variáveis utilizadas no modelo.

No Capítulo VI apresentam-se os modelos de otimização e simulação da operação de sistemas hidrotérmicos de potência. São mostrados também exemplos de operação ótima e de regras de operação obtidas para diferentes usinas.

No Capítulo VII apresentam-se vários estudos de caso, nos quais são analisados os resultados do cálculo dos parâmetros de dimensionamento para algumas usinas, em diversas condições de aplicação, envolvendo diferentes formas de valorizar a energia gerada, consideração de benefícios locais ou globais, regras diferentes para operação do sistema hidroelétrico, etc.

Finalmente, no Capítulo VIII concluem-se os estudos realizados e delineiam-se algumas pesquisas que podem ser derivadas aproveitando-se o que foi feito neste trabalho. 


\section{Capítulo II}

\section{Energia Elétrica: Beneficios, Impactos e o Sistema Interligado Nacional}

No ano 400 a.C., Platão lamentava as florestas perdidas que haviam coberto as montanhas estéreis da Grécia. Tratava-se da conseqüência do uso da madeira para a construção de navios e para o aquecimento de fornalhas utilizadas para construção de armas. O fato isolado que Platão lamentava faz parte de um processo abrangente, comumente atrelado e confundido com o próprio desenvolvimento da humanidade: a utilização de recursos naturais para gerar bem-estar e conforto ao Homem.

À medida que a espécie humana foi se multiplicando e se apropriando do espaço terrestre, a necessidade de energia foi aumentando, principalmente pela exigência de sobrevivência em condições adversas e à sofisticação do modo de vida.

De forma geral, quanto melhor a qualidade de vida, maior o consumo de energia $^{3}$. Esta afirmação traduz-se em uma relação entre o consumo de energia e o grau de desenvolvimento dos diferentes países, constatando-se que os habitantes de países desenvolvidos, desfrutando vidas mais confortáveis e usufruindo mais intensamente dos avanços tecnológicos, consomem mais energia.

Obviamente, o fato de viver em um país rico ou pobre não determina completamente o consumo de energia de uma pessoa. Deve-se ainda atentar às desigualdades sociais, uma vez que ricos e pobres de uma mesma nação consomem quantidades desiguais de energia e muito provavelmente utilizam diferentes fontes para obtê-la. Por exemplo, em uma residência brasileira de classe média, as pessoas não utilizam lenha para cozinhar, ao passo que isso é comum em casas humildes, principalmente na zona rural.

Uma outra relação que pode ser estabelecida trata justamente dos impactos ambientais resultantes do processo de obtenção de energia. Por exemplo, países que 
queimam grandes quantidades de combustíveis fósseis para gerar energia elétrica emitem mais gases responsáveis pelo efeito estufa que países que possuem sistemas elétricos baseados em usinas hidroelétricas. Da mesma forma que no consumo de energia, o impacto ambiental também varia em função das desigualdades sociais. Retornando ao exemplo do método de cocção dos alimentos, a pessoa que utiliza lenha provocará um impacto ambiental completamente diferente da que possui um fogão a gás ou elétrico [62].

As duas próximas seções deste capítulo dedicam-se a explicar e ilustrar os benefícios e os impactos decorrentes da utilização de energia. Na seqüência, a composição dos vários tipos de energia no consumo total dos diversos países é utilizada para salientar a importância da energia elétrica. Na terceira seção analisam-se as fontes primárias de energia utilizadas para gerar eletricidade nos diferentes países, incluindo o Brasil.

$\mathrm{Na}$ quarta seção apresentam-se e discutem-se as principais características do sistema elétrico brasileiro, chamado de Sistema Interligado Nacional - SIN, e na quinta seção finaliza-se o capítulo analisando alguns aspectos da expansão da capacidade de geração do Brasil.

\footnotetext{
${ }^{3}$ Este consumo energético não se limita às necessidades alimentares; trata-se do consumo total de uma pessoa, considerando gastos com alimentação, vestuário, residência, transporte, trabalho, etc.
} 


\section{Energia e Desenvolvimento}

O crescente domínio dos recursos naturais pelo ser humano, desde o tempo em que vivia praticamente da caça e da pesca e nem sequer utilizava o fogo para preparar seus alimentos, até o seu estágio tecnológico atual, pode ser estreitamente relacionado com o consumo total de energia, tal como ilustrado na Figura 2.1 [62]. Os seis estágios de desenvolvimento do ser humano mostrados na figura podem ser resumidos da seguinte forma:

- Homem Primitivo: habitou o Leste da África há aproximadamente 1.000 .000 de anos, não utilizava o fogo e consumia somente a energia de seus alimentos, algo em torno de $2.000 \mathrm{kcal} / \mathrm{dia}$.

- Homem Caçador: habitou a Europa há aproximadamente 100.000 anos, cozinhava seus alimentos e também queimava a madeira para aquecerse.

- Homem Agrícola Primitivo: habitou a Mesopotâmia em 5.000 a.C., já semeava seus alimentos e utilizava a energia dos animais para auxiliá-lo no desenvolvimento de suas tarefas.

- Homem Agrícola Avançado: habitou o noroeste da Europa em 1.400, utilizava o carvão para o aquecimento, também conseguia fazer uso das forças da água e do vento, além de utilizar o transporte animal.

- Homem Industrial: surgiu na Inglaterra por volta de 1875, caracterizado principalmente pela invenção da máquina a vapor, no início da Revolução Industrial.

- Homem Tecnológico: a partir de 1970 nos Estados Unidos, caracterizado pelo crescente uso dos computadores e da automação industrial,

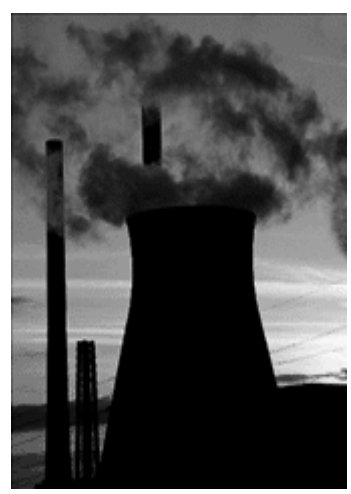
consumindo cerca de $250.000 \mathrm{kcal} / \mathrm{dia}$. 


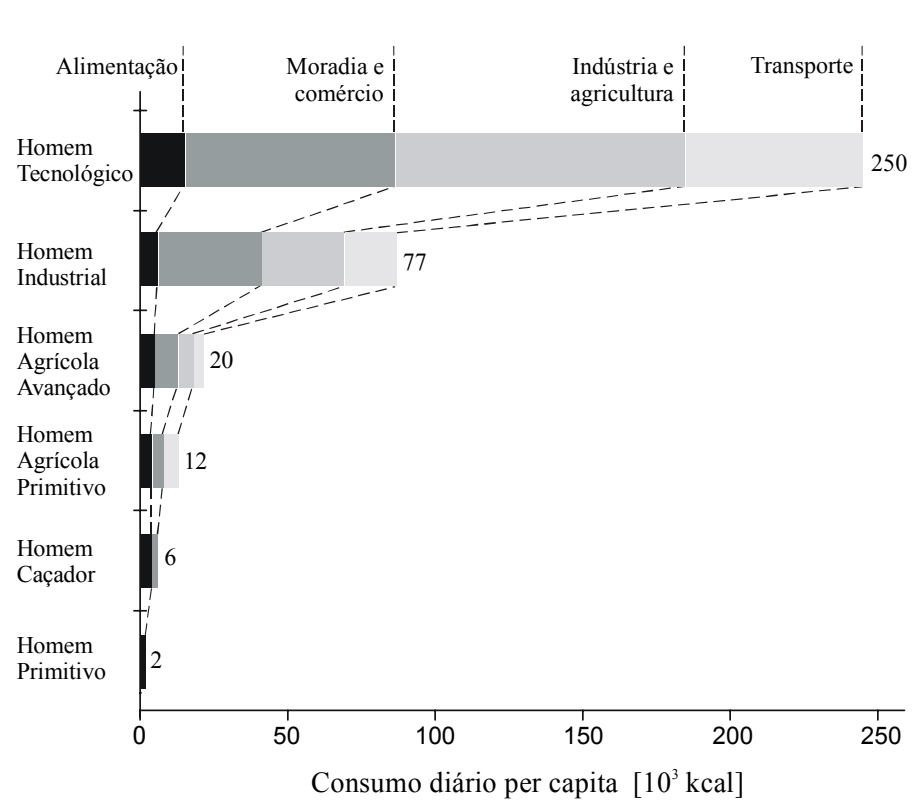

Fonte:[36].

Figura 2.1 - Estágios de desenvolvimento do ser humano e consumo de energia.

Assim, em um milhão de anos, o Homem evoluiu de um estágio primitivo, no qual não conhecia o fogo, até o atual estágio tecnológico. Durante esta evolução, o consumo diário de energia per capita cresceu de $2.000 \mathrm{kcal}$ para quase $250.000 \mathrm{kcal}$. De forma geral, quanto maior o consumo de energia, mais confortável a vida. Graças aos motores de combustão, derivados de petróleo podem ser utilizados para mover carros, ônibus, aviões e navios, permitindo que mercadorias e pessoas sejam transportadas através de longas distâncias. Graças à queima de gás e madeira, sistemas de aquecimento interno permitem que pessoas tenham uma vida confortável mesmo em lugares extremamente frios, com temperaturas que freqüentemente atingem $-40^{\circ} \mathrm{C}$. De forma oposta, sistemas de refrigeração tornam ambientes de trabalho agradáveis e evitam o apodrecimento rápido de alimentos perecíveis mesmo em regiões quentes, onde a temperatura facilmente supera a marca dos $35^{\circ} \mathrm{C}$.

Além destas comodidades atreladas à habitação, os processos de manufatura também se aprimoraram ao longo dos anos, utilizando máquinas e equipamentos que, além de serem capazes de realizar trabalhos pesados, permitiram a automatização da produção, com sensíveis ganhos de produtividade.

Uma boa maneira de situar temporalmente os avanços tecnológicos que viabilizaram o estágio de desenvolvimento atual é a cronologia da potência desempenhada pelos diversos equipamentos inventados ao longo da história. Na Tabela 2.1 apresentam-se as datas e as potências de algumas máquinas responsáveis pela transformação de recursos naturais em energia. 
Nota-se que o uso da energia da água fluindo em rios, mesmo princípio utilizado em modernas usinas hidroelétricas, tem sido feito há cerca de 3000 anos; já os moinhos de vento, cuja utilização como fonte renovável para geração de eletricidade atualmente tem sido intensamente discutida, foram inventados há cerca de 400 anos; por outro lado, usinas termoelétricas movidas a carvão ou a combustível nuclear, tecnologias largamente utilizadas em países europeus e nos Estados Unidos, são bem recentes. Observa-se também o grande marco que viabilizou a Revolução Industrial, a invenção da máquina a vapor, ocorrida durante o século XVIII.

Tabela 2.1 - Cronologia da potência desenvolvida por algumas máquinas.

\begin{tabular}{lcr}
\hline \multicolumn{1}{c}{ Equipamento } & Data & Potência Desenvolvida (kW) \\
\hline Homem usando uma alavanca & 3000 a.C. & 0,037 \\
\hline Boi puxando uma carga & 3000 a.C. & 0,372 \\
\hline Turbina de água & 1000 a.C. & 0,298 \\
\hline Roda d'água vertical & 350 a.C. & 2,24 \\
\hline Moinho de vento Turret & 1600 d.C. & 10,4 \\
\hline Máquina a vapor de Newcommen & 1712 d.C. & 4,1 \\
\hline Máquina a vapor de Watt (terrestre) & 1800 d.C. & 29,8 \\
\hline Máquina a vapor (naval) & 1837 d.C. & 559,3 \\
\hline Máquina a vapor (naval) & 1843 d.C. & $1.118,6$ \\
\hline Turbina de água & 1854 d.C. & 596,6 \\
\hline Turbina a vapor & 1906 d.C. & 13.050 \\
\hline Turbina a vapor & 1921 d.C. & 29.828 \\
\hline Usina termoelétrica a carvão & 1973 d.C. & 1.092 .450 \\
\hline Usina termonuclear & 1974 d.C. & 1.133 .464 \\
\hline Usina hidroelétrica de Itaipu & 1983 d.C. & 12.600 .000 \\
\hline & & Fonte: $[36]$.
\end{tabular}

A utilização das invenções mencionadas e de uma infinidade de outras máquinas tem feito o consumo de energia pela humanidade crescer de forma sensível ao longo dos anos. Para ilustrar este fato, na Figura 2.2 mostra-se o crescimento do consumo de energia entre os anos de 1980 e 2000 [46]. De acordo com os dados apresentados, o consumo mundial de energia cresceu $39,5 \%$ neste período, o que poderia ser justificado pelo simultâneo aumento populacional de 37,03\% [44]. No entanto, a idéia de que cada novo habitante do planeta tenha consumido a mesma cota de energia é, infelizmente, irreal. 


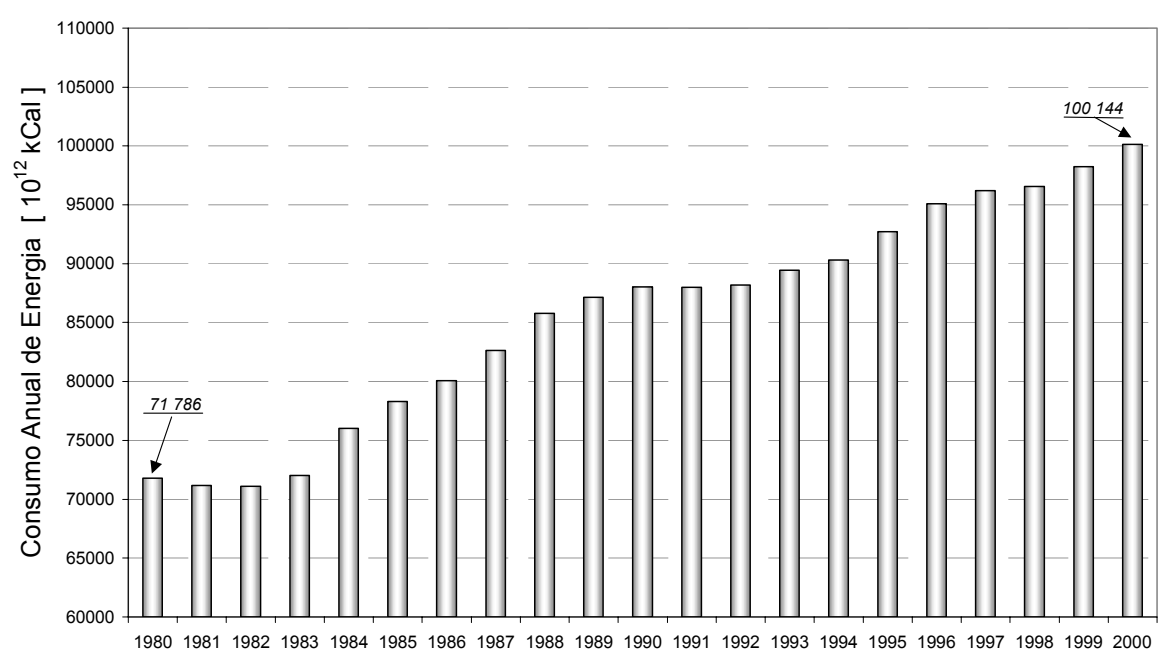

Figura 2.2 - Consumo mundial de energia entre 1980 e 2000.

Grandes diferenças existem entre o consumo de energia dos países pobres e dos países ricos. Para ilustrar estas diferenças de forma bem simples, a relação entre riqueza e consumo de energia pode ser estabelecida analisando-se a relação entre o "tamanho da economia" de um país e seu respectivo consumo de energia, tal como ilustrado na Figura 2.3 (PPC US\$ é o dólar da Paridade do Poder de Compra). O "tamanho da economia" foi medido pelo Produto Interno Bruto - PIB, mas ele também poderia ter sido medido pelo Produto Nacional Bruto $-\mathrm{PNB}^{4}$.

É importante salientar que a curva ajustada presta-se somente a uma análise qualitativa superficial, indicando uma tendência e não uma relação rígida entre as variáveis.

\footnotetext{
${ }^{4}$ Confusões são comumente geradas devido ao mau entendimento dos significados destes indicadores. O PIB é o valor de toda a produção de bens e serviços ocorrida dentro das fronteiras do país, sem considerar a nacionalidade dos que se apropriaram dessas rendas, sem descontar rendas eventualmente enviadas ao exterior e sem considerar as recebidas do exterior, justificando o qualificativo de interno. O PNB considera as rendas recebidas do exterior por cidadãos do país e desconta as que foram apropriadas por cidadãos estrangeiros, justificando o qualificativo nacional [68]. No caso do Brasil, o PNB é menor do que o PIB porque uma parcela da ordem de 3\% do PIB brasileiro não é usufruída por brasileiros e sim enviada ao exterior na forma de lucros, dividendos e juros do capital estrangeiro. Assim, a renda interna bruta é de fato menor do que PIB. Nos Estados Unidos, ao contrário, o PNB é maior do que PIB porque as rendas obtidas pelas empresas americanas no exterior e enviadas aos Estados Unidos na forma de remessas de lucros e dividendos, são consideradas parte do PNB americano. Portanto: o PIB descontado da renda enviada ao exterior e somado à renda recebida do exterior é chamado PNB. O conceito de PNB, por esse motivo, está mais próximo ao conceito de Renda Nacional. O Produto Nacional Bruto, descontadas as perdas por depreciação, é exatamente igual à Renda Nacional Líquida. Assim:

$\rightarrow$ PIB - Renda enviada ao exterior + Renda recebida do exterior $=$ PNB.

$\rightarrow$ PNB - Depreciação = Produto Nacional Líquido = Renda Nacional Liquida

$\rightarrow$ Renda Nacional Líquida / População = renda per capita
} 


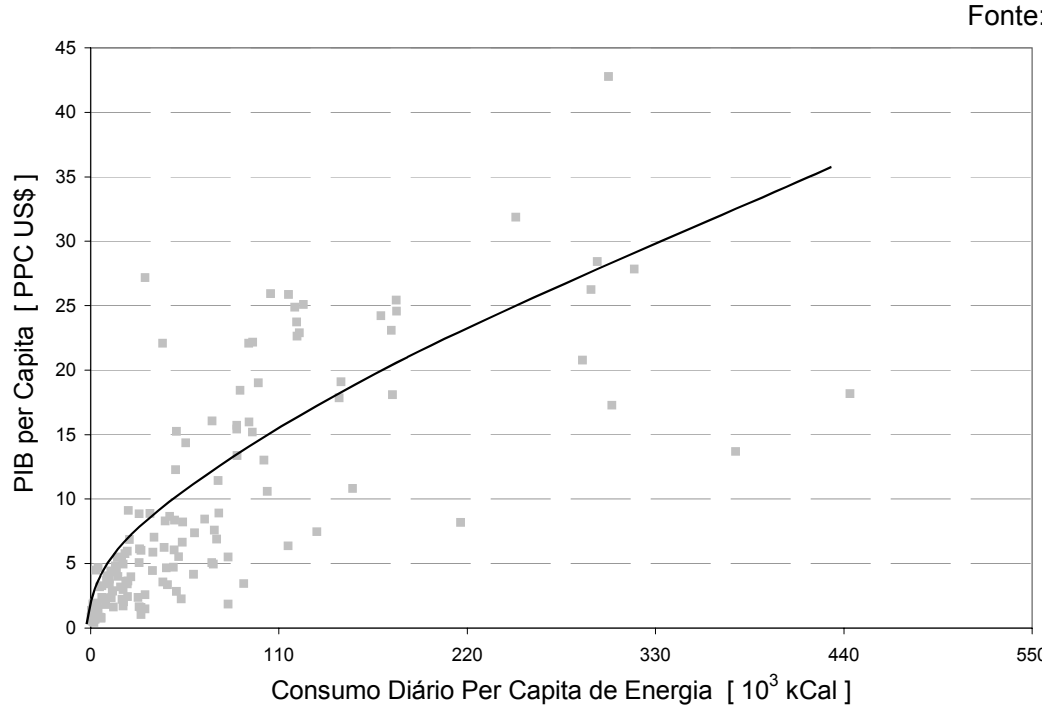

Figura 2.3 - Relação entre PIB e consumo de energia per capita.

As diferenças entre o consumo de energia dos países ricos e pobres ocorrem principalmente porque países desenvolvidos normalmente possuem grandes parques industriais, centros urbanos e residências mais sofisticadas, onde o consumo de energia é intenso. Além disso, em países subdesenvolvidos e em desenvolvimento, boa parte da energia para a agricultura, transporte e atividades domésticas provém de seres humanos e animais; em países desenvolvidos utilizam-se máquinas para a agricultura, veículos motorizados para o transporte e eletrodomésticos nas atividades domésticas, todos consumidores ávidos de energia [62].

Ainda para ilustrar as diferenças de consumo de energia entre os diferentes povos, na Tabela 2.2 são comparados os consumos de energia de alguns países ao longo do ano de 2000. Constata-se que nesse ano, 4,6\% da população mundial habitava os Estados Unidos, porém este país era responsável por $24,9 \%$ do consumo energético mundial, apresentando um consumo per capita de $245,7.10^{3}$ kcal por dia [43]. Observase que o consumo energético per capita americano é bastante elevado mesmo quando comparado a outros países desenvolvidos como Japão, França e Inglaterra. Este fato é explicado pelo modo de vida americano, baseado no alto consumo de bens, incentivando o uso intenso de energia em todas as etapas da cadeia produtiva. Além disso, destaca-se a influência do clima de algumas regiões americanas, uma vez que no norte do país se gasta muito com aquecimento durante o inverno, enquanto no sul o uso de equipamentos de refrigeração é elevado no verão.

É interessante notar que $21,0 \%$ da população mundial vive na China; sob o ponto de vista energético, para que este país alcançasse níveis de consumo per capita semelhantes aos de países desenvolvidos, grandes investimentos em infra-estrutura deveriam ser feitos. 
Observa-se ainda a posição da Somália, onde o consumo per capita é de apenas $500 \mathrm{kcal}$ por dia, valor inferior às necessidades de alimentação, mostrando que em pleno século XX existem países cujas médias de consumo de energia per capita são menores que as necessidades do homem em seu estágio primitivo, há um milhão de anos.

Tabela 2.2 - População e consumo de energia em alguns países em 2000.

\begin{tabular}{lrrc}
\hline \multicolumn{1}{c}{ País } & $\begin{array}{c}\text { População } \\
\%\end{array}$ & $\begin{array}{c}\text { Consumo } \\
\%\end{array}$ & $\begin{array}{c}\text { Consumo Diário } \\
\text { Per Capita } 10^{3} . k c a l\end{array}$ \\
\hline Brasil & 2,8 & 2,2 & 38,0 \\
\hline China & 21,0 & 9,5 & 20,2 \\
\hline Estados Unidos & 4,6 & 24,8 & 245,7 \\
\hline França & 1,0 & 2,6 & 123,8 \\
\hline Inglaterra & 1,0 & 2,6 & 117,6 \\
\hline Japão & 2,1 & 5,5 & 120,1 \\
\hline Somália & 0,2 & 0,0022 & 0,5 \\
\hline & & & Fontes: $[43,44,46]$.
\end{tabular}

Analisando as quantidades de energia consumidas pelos diferentes países e comparando-as às respectivas qualidades de vida de seus povos, pode-se estabelecer, ainda que simples e superficialmente, uma relação direta entre qualidade de vida e consumo de energia ${ }^{5}$. Para quantificar tal relação, na Figura 2.4 apresentam-se alguns gráficos construídos com dados disponíveis para 162 países [117]. Nestas figuras são apresentados quatro indicadores sociais - taxa de analfabetismo, mortalidade infantil, expectativa de vida e fertilidade total - como funções do consumo diário per capita de energia.

Os gráficos mostram que nos países onde o consumo diário per capita de energia é menor que $110.10^{3} \mathrm{kcal}$, as taxas de mortalidade infantil, analfabetismo e fertilidade são relativamente elevadas, enquanto a expectativa de vida é baixa. Os gráficos também indicam que consumos diários per capita de energia maiores que $110.10^{3} \mathrm{kcal}$ estão diretamente relacionados a bons valores de indicadores sociais. Estes dois fatos sugerem que superar o consumo diário de $110.10^{3} \mathrm{kcal}$ per capita pode garantir melhores condições de vida a uma nação [62].

Na realidade, o que eleva a qualidade de vida não é o alto consumo de energia em si, mas sim os serviços que são oferecidos através do sistema energético, tais como

\footnotetext{
5 A curva ajustada presta-se apenas a uma análise qualitativa, indicando uma tendência e não uma relação rígida entre as variáveis.
} 
iluminação, aquecimento, refrigeração, transporte, capacidade de produção industrial, etc. De forma análoga, o baixo consumo de energia não é a causa do subdesenvolvimento; ele apenas traduz as condições em que a população vive, com infra-estrutura deficiente, sistema de saúde impróprio, utilização de trabalho animal e humano em atividades pesadas, etc. [62].

Fonte:[117] [43].
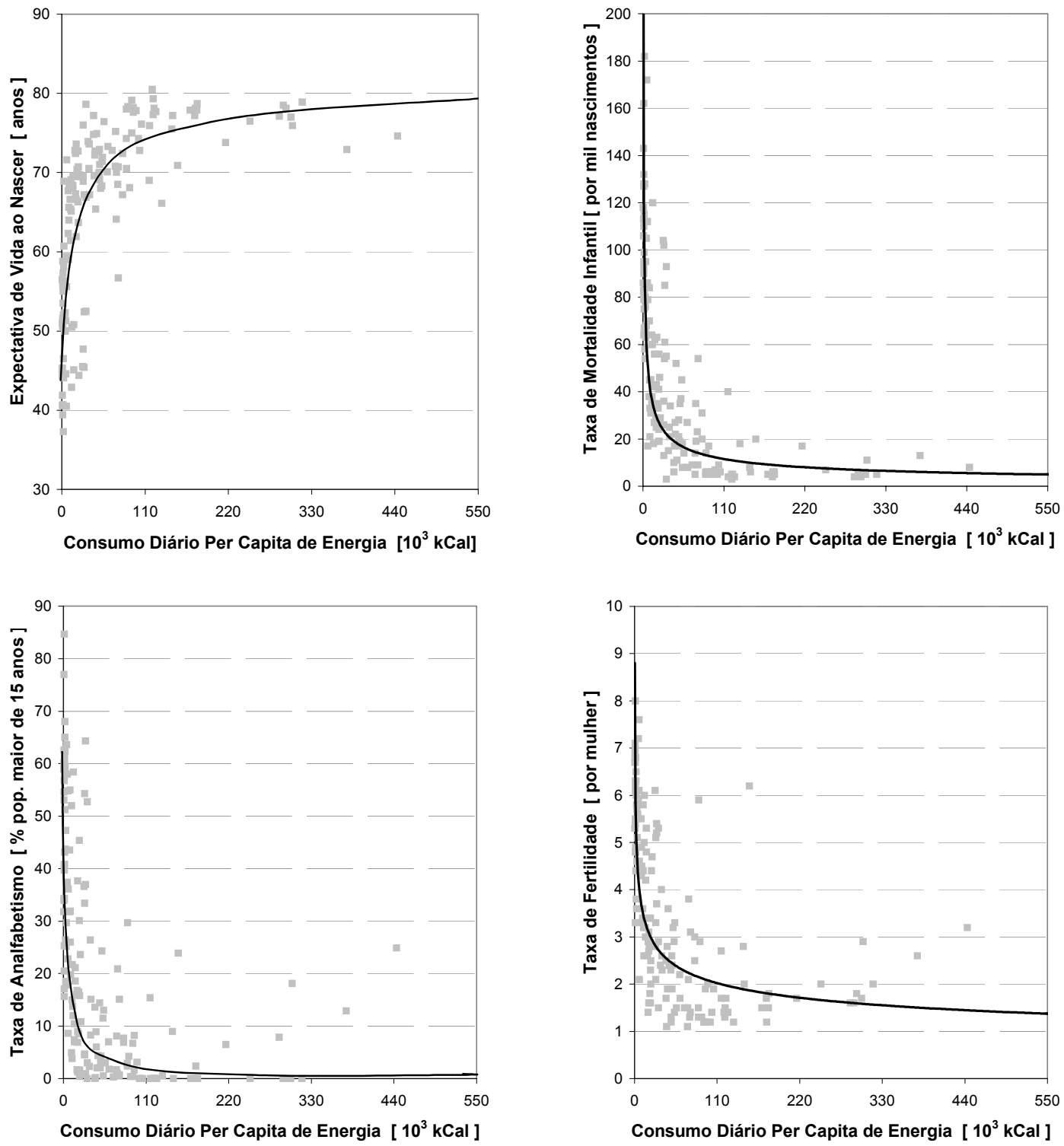

Figura 2.4 - Relação entre indicadores sociais e consumo de energia per capita.

Os dados mostrados até agora sugerem uma forte relação entre consumo de energia per capita e qualidade de vida. Para finalizar esta discussão, na Figura 2.5 estabelece-se a relação entre um indicador social mais apurado, o Índice de Desenvolvimento Humano (IDH), e o consumo de energia per capita. O IDH reflete melhor a qualidade de vida de um povo porque seu cálculo é feito utilizando-se três 
indicadores sociais: (i) o primeiro refere-se à saúde, medido por meio da esperança de vida ao nascer; (ii) o segundo trata da educação, medido com base na taxa de alfabetização de adultos, juntamente com a taxa de matrícula combinada nos três níveis de ensino; (iii) o terceiro visa aferir a renda das pessoas em seus próprios países, medido pelo PIB per capita ajustado para diferenças no custo de vida de cada país, sendo o resultado expresso em PPC\$ (dólar da Paridade do Poder de Compra). O IDH é o parâmetro utilizado para classificar os países no Relatório do Desenvolvimento Humano (RDH) produzido pelas Nações Unidas [117].

Fonte:[117].

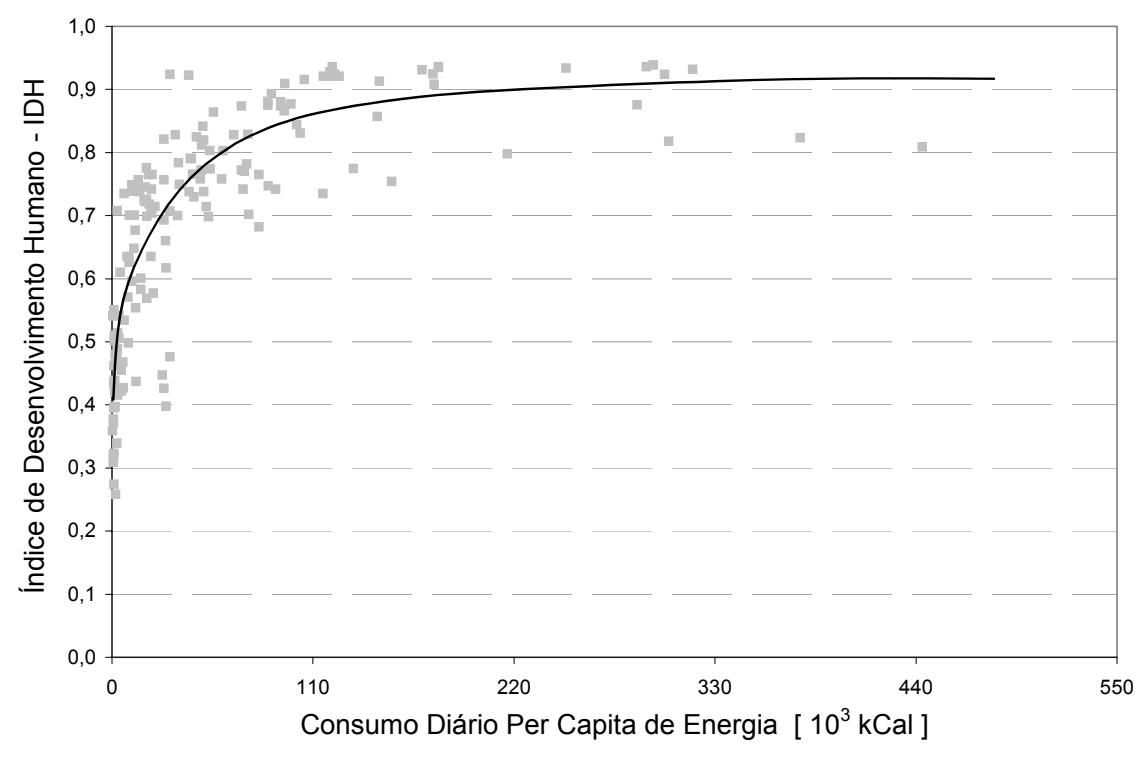

Figura 2.5 - Relação entre IDH e consumo de energia per capita.

De forma semelhante ao observado através dos outros indicadores sociais, o limite mínimo de $110.10^{3} \mathrm{kcal}$ para o consumo diário per capita de energia parece garantir um nível de vida classificado como bom pelo IDH. Pela figura, observa-se que para consumos de energia superiores a este valor, o IDH é quase sempre maior que 0,8 . Vale apenas observar que valores idênticos de IDH podem estar associados a padrões de vida distintos, uma vez que os três índices sociais utilizados nos cálculos podem se compensar. Por exemplo, uma longevidade menor pode ser compensada por uma renda maior, e vice-versa. 


\section{Energia e Meio Ambiente}

As condições nas quais a vida se estabelece sobre a superfície terrestre possuem uma dinâmica determinada tanto por alterações naturais quanto por alterações induzidas pelo Homem. As causas naturais são aquelas sobre as quais não é possível que seja exercida nenhuma espécie de controle. As próprias diferenças das condições climáticas no inverno e no verão são exemplos de alterações naturais. Métodos de previsão podem ajudar na prevenção contra os impactos das variações climáticas, mas nada pode ser feito para evitar um inverno rigoroso ou um verão escaldante. Outros exemplos de alterações naturais nas condições de vida do planeta são os desastres naturais, tais como erupções vulcânicas, terremotos, maremotos, furacões, períodos anormais de seca ou de cheia, etc [62].

As alterações induzidas referem-se a processos que são desencadeados na natureza devido à ação humana. Até a Revolução Industrial, os impactos ocasionados pelo uso de recursos naturais pelo Homem eram bem pequenos. A partir das invenções de máquinas potentes que podiam desempenhar, a uma velocidade elevada, o trabalho de várias pessoas, o ser humano passou a apropriar-se da natureza de forma mais intensa, gerando bens de consumo e também intensificando mudanças no meio ambiente.

Conforme mostrado na seção anterior, os crescimentos populacional e industrial, o desenvolvimento dos meios de transporte, a evolução na forma de praticar a agricultura e uma infinidade de outros fatores fizeram com que o crescimento do consumo de energia fosse elevado ao longo dos séculos XIX e XX. A causa de muitos problemas ambientais é justamente o modo como a energia é produzida e utilizada. Para ilustrar esta relação de causa e efeito, na Tabela 2.3 são listados alguns problemas ambientais, suas principais causas e os principais grupos sociais afetados.

A poluição urbana, por exemplo, pode ser sentida praticamente em todas as grandes cidades do mundo. Além dos aglomerados fabris emitirem gases para a atmosfera como resultado dos processos de manufatura, para movimentar as fábricas é necessário gerar energia. Se esta energia é gerada à custa da queima de combustíveis fósseis, aos gases emitidos pelas fábricas adicionam-se os gases das usinas termoelétricas. Não bastante, nos centros urbanos a movimentação de automóveis e caminhões é intensa e as fontes de energia para estes veículos são os combustíveis fósseis, gerando ainda mais poluentes. Ao final de tanta emissão de gases, a atmosfera 
apresenta-se carregada de óxidos de enxofre e nitrogênio, monóxido de carbono, ozônio e matéria particulada suspensa, incluindo o chumbo. As conseqüências para a saúde das pessoas são as mais variadas possíveis: irritação dos olhos, irritação respiratória, falta de ar, doenças crônicas do pulmão, asfixia, doenças nos rins, enfisema, etc. [116].

Outro problema ambiental, a poluição em ambientes fechados, atinge mais intensamente as famílias pobres de zonas rurais devido à queima de lenha ou de outros materiais para produzir a energia necessária à cocção dos alimentos. A Organização para Agricultura e Alimentação (FAO - http://www.fao.org) estima que entre 30 e 40\% da população mundial utiliza lenha para cozinhar. As crianças e as mulheres, por ficarem mais dentro de casa, ficam mais expostas à fumaça e são as que mais sofrem com infecções respiratórias e pneumonia.

Tabela 2.3 - Alguns problemas ambientais, suas causas e grupos sociais afetados.

\begin{tabular}{llc}
\hline Problema Ambiental & \multicolumn{1}{c}{$\begin{array}{c}\text { Principal Causa do } \\
\text { Problema }\end{array}$} & $\begin{array}{c}\text { Principal Grupo Social } \\
\text { Afetado }\end{array}$ \\
\hline Poluição urbana do ar & Energia (indústria e transportes) & População urbana \\
\hline $\begin{array}{l}\text { Poluição do ar em ambientes } \\
\text { fechados }\end{array}$ & Energia (cozinhar) & Pobres nas zonas rurais \\
\hline Chuva ácida & $\begin{array}{l}\text { Energia (queima de } \\
\text { combustível fóssil) }\end{array}$ & Todos \\
\hline $\begin{array}{l}\text { Diminuição da camada de } \\
\text { ozônio }\end{array}$ & Indústria & Todos \\
\hline $\begin{array}{l}\text { Aquecimento por efeito estufa } \\
\text { e mudança de clima }\end{array}$ & $\begin{array}{l}\text { Energia (queima de } \\
\text { combustível fóssil) }\end{array}$ & Todos \\
\hline $\begin{array}{l}\text { Disponibilidade e qualidade } \\
\text { de água doce }\end{array}$ & $\begin{array}{l}\text { Aumento populacional, } \\
\text { agricultura }\end{array}$ & Todos \\
\hline $\begin{array}{l}\text { Degradação costeira e } \\
\text { marinha }\end{array}$ & Transporte e energia & Todos \\
\hline $\begin{array}{l}\text { Desmatamento e } \\
\text { desertificação }\end{array}$ & $\begin{array}{l}\text { Aumento populacional, } \\
\text { agricultura, energia }\end{array}$ & Pobres nas zonas rurais \\
\hline $\begin{array}{l}\text { Resíduos tóxicos, químicos e } \\
\text { perigosos }\end{array}$ & Indústria e energia nuclear & Todos \\
\hline
\end{tabular}

Na maioria dos problemas ambientais listados, a relação entre energia e impacto ambiental é evidente. Por exemplo, a chuva ácida é ocasionada principalmente pela reação entre o vapor d'água presente na atmosfera com óxidos de enxofre e nitrogênio, produzidos pela queima de combustíveis fósseis utilizados como fonte de energia para acionar automóveis e usinas termoelétricas. Em alguns casos, a relação entre energia e meio ambiente não é tão direta. Por exemplo, à primeira vista, a degradação costeira e marinha não parece ser causada pelo consumo energia. No entanto, uma análise mais 
cuidadosa faz com que o transporte de petróleo e os vários derramamentos ocorridos com navios petroleiros estabeleçam uma relação direta entre a energia utilizada nos meios de transporte e a deterioração ambiental.

Um dos gases cuja concentração excessiva na atmosfera seria responsável pelo aquecimento do planeta através do efeito estufa é o dióxido de carbono ou gás carbônico, $\mathrm{CO}_{2}$, resultante de reações de combustão. Países que utilizam grandes quantidades de combustíveis fósseis são grandes emissores de $\mathrm{CO}_{2}$. Conforme mostrado na Tabela 2.4, durante o ano de 2000, os Estados Unidos foram responsáveis por quase $25 \%$ de todo o $\mathrm{CO}_{2}$ lançado na atmosfera devido ao uso ou à queima de combustíveis fósseis ${ }^{6}$. Este fato deve-se principalmente ao alto número de usinas termoelétricas americanas e à grande frota de automóveis deste país.

Tabela 2.4-Emissão de $\mathrm{CO}_{2}$ a partir da queima de combustíveis fósseis durante o ano de 2000.

\begin{tabular}{|c|c|c|}
\hline País & $\begin{array}{c}\text { Emissão de } \mathrm{CO}_{2} \text { em } 10^{6} \text { tons. } \\
\text { Equivalentes de Carbono }\end{array}$ & $\begin{array}{l}\text { Porcentagem da Emissão } \\
\text { Mundial Total - \% }\end{array}$ \\
\hline Brasil & 95 & 1,5 \\
\hline Canadá & 158 & 2,5 \\
\hline China & 775 & 12,0 \\
\hline EUA & 1.571 & 24,4 \\
\hline França & 109 & 1,7 \\
\hline Índia & 253 & 3,9 \\
\hline Japão & 314 & 4,9 \\
\hline Noruega & 10 & 0,2 \\
\hline Rússia & 451 & 7,0 \\
\hline Suécia & 13 & 0,2 \\
\hline Mundo & 6.443 & 100,0 \\
\hline
\end{tabular}

Outro impacto que o meio ambiente sofre para viabilizar a geração de energia é a construção de usinas hidroelétricas. Embora este tipo de empreendimento, quando bem concebido e planejado, praticamente não emita poluentes para gerar energia, as alterações do meio ambiente devido à construção da usina são sensíveis. O curso natural do rio é interrompido, grandes áreas são alagadas e todo o clima da região do reservatório se altera.

Como conseqüência da barragem, a circulação de peixes fica praticamente interrompida, alterando a fauna do rio. Em alguns casos criam-se estruturas para

\footnotetext{
${ }^{6}$ Apesar da emissão de $\mathrm{CO}_{2}$ estar longe de ser um indicador completo da poluição do ar, normalmente sua emissão através da queima de combustíveis ocorre em conjunto com a de outros poluentes, como óxidos de enxofre e de nitrogênio, por exemplo.
} 
permitir a passagem de peixes através das barragens, mas nem todas as espécies respondem positivamente a estes artifícios.

Como contra-exemplo da não emissão de poluentes por usinas hidroelétricas pode-se citar a usina hidroelétrica de Balbina, localizada na região amazônica. $O$ enchimento do reservatório foi realizado sem haver a necessária remoção da vegetação existente. Sob a água, a matéria orgânica começou a apodrecer, emitindo grandes quantidades de gases à atmosfera, principalmente metano. Além deste efeito, a água do lago tornou-se ácida, prejudicando as turbinas e as estruturas da própria usina.

Dependendo do local do empreendimento, cidades ou vilarejos têm que ser relocados, o que afeta o estilo de vida das pessoas e muitas vezes cria graves problemas sociais. Áreas produtivas também podem ser perdidas, ou mesmo áreas de valor histórico e arqueológico, tais como cavernas habitadas por povos primitivos. Por exemplo, o lago da usina hidroelétrica de Itaipu inundou o Parque Nacional das Sete Quedas, provocando além de severos impactos ambientais, a perda de uma área de elevada beleza cênica e potencial turístico.

Comparando esta seção à anterior, nota-se que ao mesmo tempo em que elevadas taxas de consumo de energia representam desenvolvimento e conforto, elas também podem representar degradação do meio ambiente e aumento da incidência de sérias doenças. A questão natural que surge é justamente como conciliar desenvolvimento e meio ambiente, de forma a usufruir o conforto do progresso sem sofrer os indesejáveis impactos ambientais.

A resposta desta questão passa justamente pela forma como a energia é gerada e consumida. Diferentes fontes de geração e diferentes usos finais produzem diferentes impactos ambientais.

A evolução das participações das diferentes fontes primárias de energia na produção mundial total de energia entre 1970 e 2000 é mostrada na Figura 2.6. Entendese como fonte primária de energia os produtos energéticos fornecidos diretamente pela natureza, como petróleo, gás natural, carvão mineral, urânio, lenha e outros. Voltando ao gráfico, a altura total da coluna de cada ano equivale a $100 \%$, indicando a produção total de energia no mundo no respectivo ano. A altura da coluna de cada tipo de fonte primária em um ano indica a participação dessa fonte na produção total. Assim, nota-se que o petróleo é atualmente utilizado para gerar cerca de $40 \%$ de toda a energia produzida; o carvão e o gás natural possuem praticamente a mesma significância, gerando de 20 a $25 \%$ da energia mundial; na seqüência tem-se a energia hidráulica, a 
energia nuclear e algumas fontes renováveis como geotérmica, solar e eólica, além do uso da madeira e das perdas ôhmicas.

Estes dados mostram que mais de $85 \%$ da energia produzida mundialmente provém de combustíveis fósseis, gerando a emissão de vários poluentes, como já mencionado anteriormente.

Pela Figura 2.6 notam-se reduções sensíveis das participações relativas do petróleo e do carvão como fontes primárias de energia, ao contrário do que ocorreu com as outras fontes.

Fonte: [45].

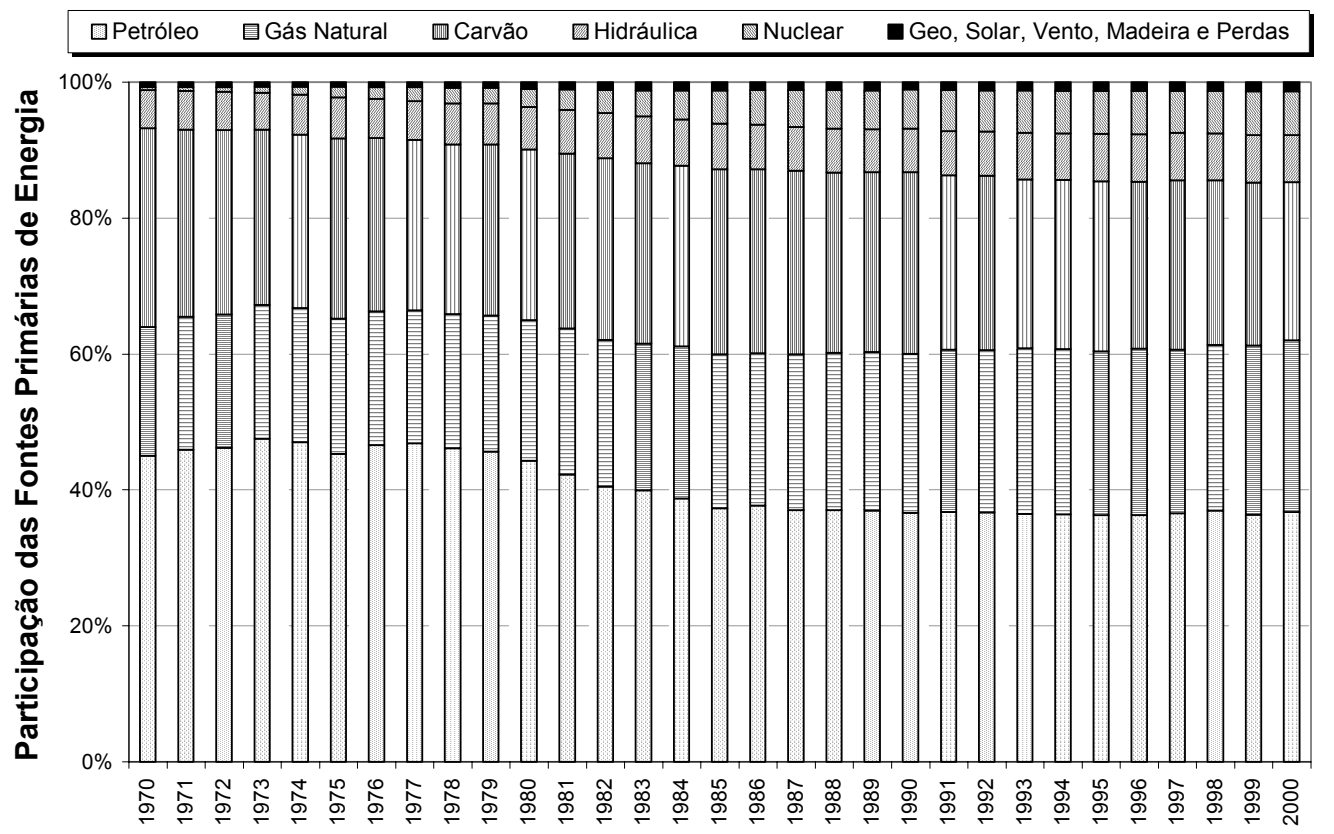

Figura 2.6 - Participação das fontes primárias de energia na produção mundial total.

Grande parte da energia produzida pelas fontes primárias não é consumida diretamente na forma primária. O petróleo, por exemplo, passa por um processo de transformação que o converte em formas mais apropriadas para o uso, como gasolina, óleo diesel, querosene e gás liquefeito, classificados como energia secundária. Esta energia pode ser diretamente consumida ou ainda pode passar por outro processo de transformação e gerar energia elétrica, uma energia terciária neste caso. Isto não significa que a energia elétrica seja uma energia terciária. Quando ela é obtida a partir da hidroeletricidade, do carvão, do gás natural, da energia nuclear, ou das energias geotérmica e eólica, ela é uma energia secundária. 
As últimas sentenças do parágrafo anterior revelam algo interessante: praticamente todas as fontes primárias de energia podem ser transformadas em eletricidade! Tal transformação realmente ocorre e uma parcela significativa da energia mundial é consumida sob a forma de energia elétrica. A eletricidade caracteriza-se por sua versatilidade, estando disponível na maioria dos lares e indústrias, podendo ser facilmente convertida em outras formas de energia, tais como energias luminosa, mecânica e térmica.

Na próxima seção analisa-se a utilização da energia elétrica no mundo e no Brasil, mostrando a situação peculiar que este país apresenta no cenário mundial. 


\section{Eletricidade}

O cientista inglês Michael Faraday é reconhecido como o descobridor do dispositivo capaz de gerar energia elétrica em uma escala que permitia sua utilização. Os estudos de Faraday foram incentivados pelo seguinte raciocínio lógico: se a eletricidade podia produzir magnetismo, fato conhecido na época, por que o magnetismo não podia produzir eletricidade?

Em 1831, ele descobriu a solução e produziu eletricidade através do movimento. Faraday mostrou que para haver corrente elétrica, a mera existência de um campo magnético não era suficiente; o campo deveria estar em movimento. A primeira usina termoelétrica surgiu quarenta anos mais tarde, quando um gerador inventado por Thomas Edson foi acoplado a uma máquina a vapor, invenção de James Watt.

O primeiro uso da energia hidráulica para produzir eletricidade ocorreu em 1882, no rio Fox, Estado de Wisconsin, Estados Unidos, instalando-se uma roda d'água acoplada a um gerador. Logo após, em maio de 1896, o croata Nicholas Tesla inaugurou as três primeiras unidades da primeira usina da bacia do rio Niágara, Figura 2.7, na divisa entre os Estados Unidos e o Canadá. Em novembro deste mesmo ano, Tesla inaugurou a primeira linha de transmissão em corrente alternada, ligando os geradores à cidade de Buffalo, a $35 \mathrm{~km}$ de distância [40].
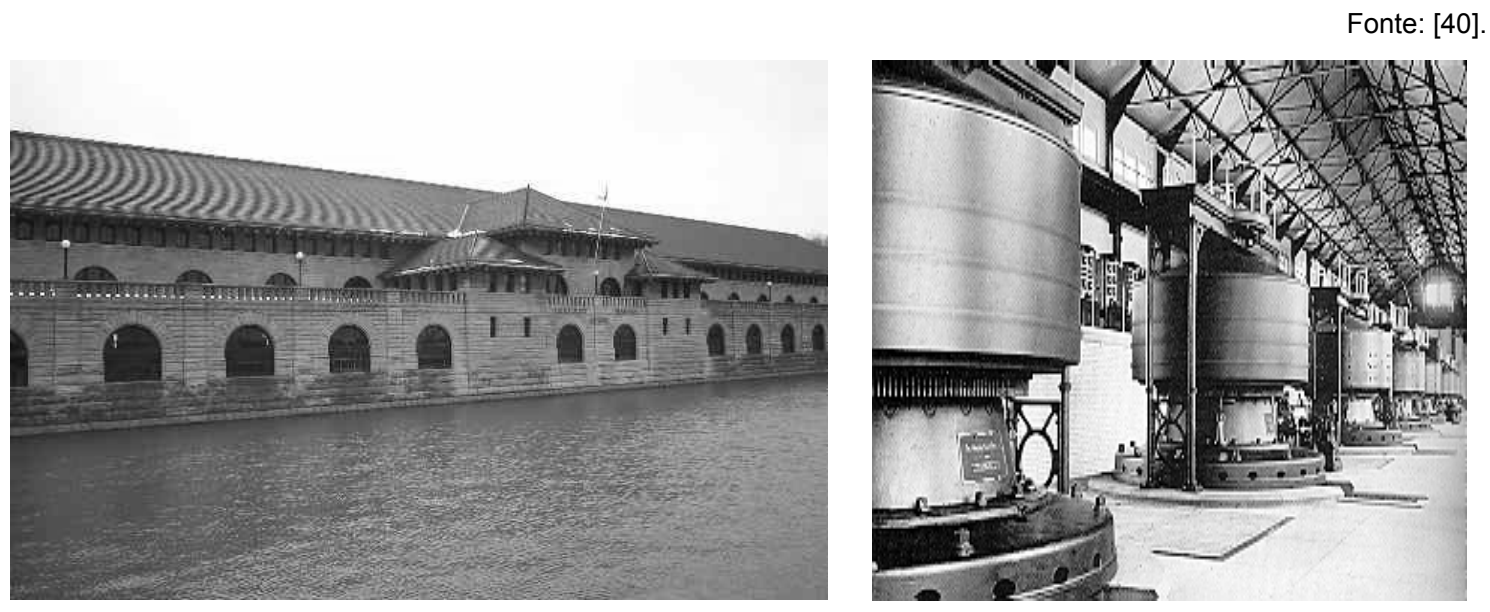

Figura 2.7 - Vistas atuais externa e interna da primeira usina hidroelétrica construida por Nicholas Tesla. 
A utilização de energia nuclear para gerar eletricidade só ocorreu pela primeira vez no dia vinte de dezembro de 1951, através do reator experimental produzido pelo Laboratório Nacional de Argonne, Califórnia, Estados Unidos. As quatro primeiras lâmpadas alimentadas por energia elétrica gerada a partir de reações nucleares são mostradas na Figura 2.8 [4].

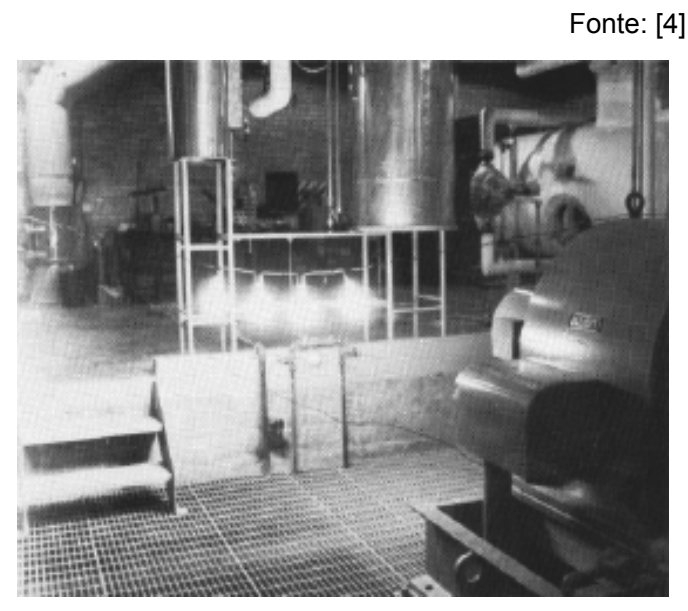

Figura 2.8-Quatro primeiras lâmpadas alimentadas com energia nuclear.

À medida que a utilização de energia elétrica foi sendo intensificada, sistemas de geração, transmissão e distribuição foram sendo construídos a fim de atender à crescente demanda. Este crescimento foi tão intenso que gerou sistemas gigantescos, compostos por várias usinas de energia elétrica, milhares de quilômetros de linhas de transmissão e de redes de distribuição, todos conectados através de subestações de transformação, controlados e operados, na maior parte das vezes, de forma integrada.

A geração de energia elétrica é feita preferencialmente de acordo com as fontes disponíveis em cada local. Na Tabela 2.5 são apresentadas as capacidades instaladas de alguns países segundo os tipos de usinas. A designação Outras se refere a usinas geotérmicas, eólicas, solares e à base de madeira. Comparando as capacidades instaladas dos países listados, nota-se o parque gerador colossal dos Estados Unidos, o maior do mundo, quase três vezes maior que o da China, detentora da segunda maior capacidade instalada. Analisando a capacidade instalada por tipo de fonte, nota-se que o sistema de geração americano possui as maiores potências instaladas em cada uma das modalidades. Atenção especial deve ser dada ao parque térmico, no qual a queima de combustíveis fósseis é responsável por altas taxas de emissão de gases poluentes.

Observando os outros países, nota-se que alguns são "especialistas" em determinados tipos de usina, tais como a Noruega e o Brasil em usinas hidroelétricas, a Índia em usinas termoelétricas e a França em usinas nucleares. O consumo de energia ao longo do ano 2000 relativo a cada fonte pode ser observado na Figura 2.9. Observase que o consumo praticamente segue a proporção das potências instaladas. No caso da Noruega, o pequeno consumo de energia termoelétrica deve-se à importação de energia. 
Tabela 2.5 - Capacidades instaladas em alguns paises em janeiro de 2000.

\begin{tabular}{|c|c|c|c|c|c|}
\hline \multirow{2}{*}{ País } & \multicolumn{4}{|c|}{ Capacidade Instalada por Tipo de Usina - GW } & \multirow{2}{*}{ Total } \\
\hline & Térmica & Hidráulica & Nuclear & Outras & \\
\hline EUA & 581 & 99 & 98 & 17 & 795 \\
\hline China & 222 & 70 & 2 & 0 & 294 \\
\hline Japão & 162 & 22 & 45 & 1 & 229 \\
\hline Rússia & 138 & 43 & 21 & 0 & 203 \\
\hline Canadá & 33 & 67 & 11 & 0 & 111 \\
\hline França & 26 & 21 & 63 & 0 & 110 \\
\hline Índia & 80 & 25 & 2 & 1 & 108 \\
\hline Brasil & 6 & 59 & 1 & 3 & 69 \\
\hline Suécia & 7 & 16 & 10 & 0 & 34 \\
\hline Noruega & 0 & 27 & 0 & 0 & 27 \\
\hline Mundo & 2.175 & 694 & 358 & 36 & 3262 \\
\hline
\end{tabular}

Fonte: [42]

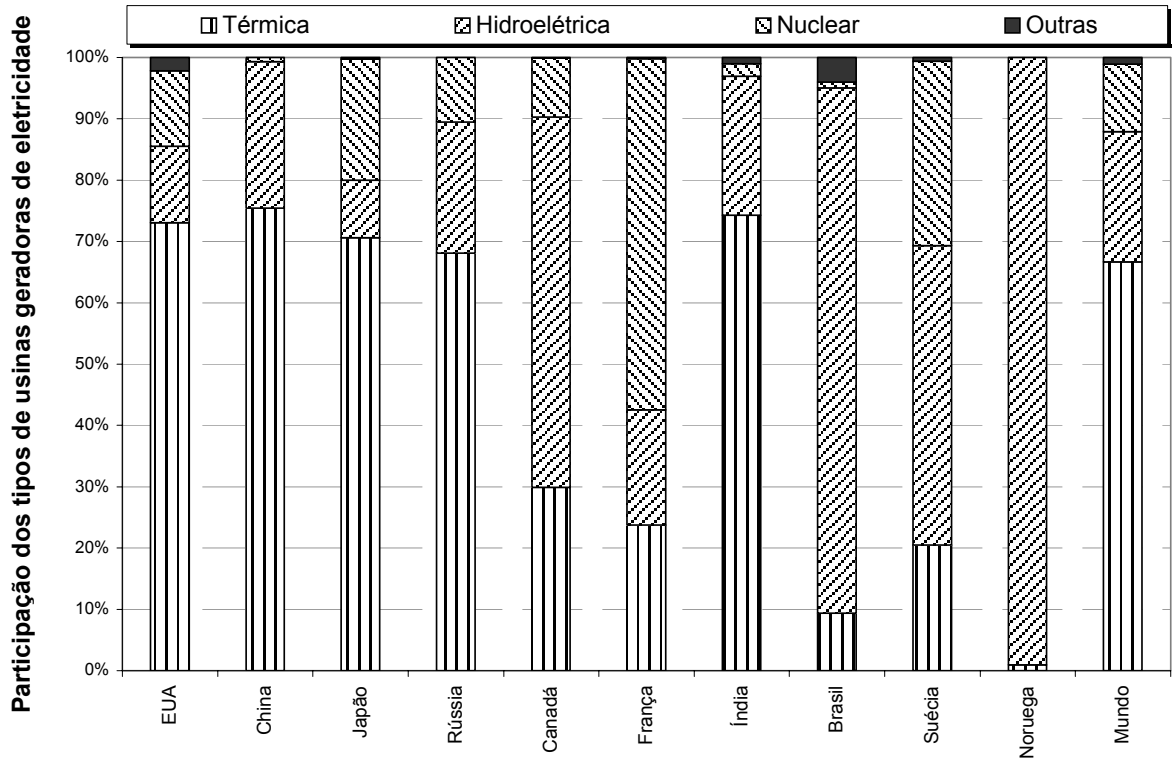

Figura 2.9-Consumo de energia elétrica relativo às fontes de geração durante o ano de 2000.

Cada uma das diferentes fontes utilizadas na geração de eletricidade possui suas vantagens e desvantagens. As usinas térmicas possuem tempos de construção relativamente curtos, custos de investimento relativamente baixos e podem ser instaladas próximas aos centros consumidores. No entanto, a operação destas usinas é 
cara por causa da compra de combustível, além de serem fontes poluidoras e nãorenováveis.

As usinas hidroelétricas possuem custos de operação baixíssimos, são fontes renováveis e praticamente não emitem gases tóxicos. No entanto, os investimentos iniciais são elevados, bem como o tempo de construção e os impactos ambientais decorrentes da criação do reservatório.

As usinas nucleares não emitem gases poluentes, possuem custo de operação baixo, porém os custos com a construção e os gastos com segurança são altos. Os acidentes, embora sejam raros, quando ocorrem proporcionam danos catastróficos, e ainda há o problema de armazenagem dos resíduos radioativos que até o momento não foi resolvido.

Outras fontes, tais como a eólica e a solar (bem abundantes), e a geotérmica (disponibilidade mais restrita), destacam-se principalmente por serem renováveis e limpas. Embora estas características tendam a determinar seus usos no futuro, o atual desenvolvimento tecnológico faz com que estas fontes produzam energia a preços nãocompetitivos, além de limitar seus empregos em grande escala.

Atenção deve ser dada à energia eólica, cuja exploração é estimulada no Brasil pela Agência Nacional de Energia Elétrica - ANEEL. O primeiro produtor mundial de energia desta natureza é a Alemanha, onde já funcionam geradores com três a cinco MW de potência instalada. Em segundo lugar segue a Espanha, com uma capacidade instalada de geração eólica de mais de $3.000 \mathrm{MW}$, superando com folga o terceiro colocado, os Estados Unidos.

A ANEEL concedeu, em dezembro de 2001, 43 autorizações para construção de usinas eólicas, correspondentes a 3.680 MW de capacidade instalada. Essas usinas deverão entrar em operação até 2005.

Resta agora uma análise mais detalhada do sistema elétrico brasileiro, realizada na próxima seção. 


\section{Sistema Interligado Nacional - SIN}

\subsection{Breve Resumo Histórico}

A inserção da energia elétrica no Brasil ocorreu quase que concomitantemente à própria invenção dos aparelhos que viabilizaram seu uso. Em 1879, o Imperador D. Pedro II introduziu no país aparelhos construídos por Thomas Edson para a utilização de eletricidade na iluminação pública. Como conseqüência, foi inaugurada na Estação Central da Estrada de Ferro D. Pedro II, atual Estrada de Ferro Central do Brasil, a primeira iluminação elétrica permanente do país.

Entre 1881 e 1883, tornaram-se reais as possibilidades práticas da utilização industrial da energia elétrica e da lâmpada de Thomas Alva Edson, graças inicialmente às experiências do francês Marcel Deprez. Em 1881, Deprez utilizou um sistema de corrente contínua para transportar energia entre as cidades de Grenoble e Vizille (14 $\mathrm{km})$ e posteriormente entre Paris e Creil (50km).

Em 1883, Thomas Edson Fonte: [49]. inaugurou em Nova Iorque a primeira usina de força elétrica do mundo, fornecendo iluminação para casas e escritórios na ilha de Manhattam. Em junho deste mesmo ano, entrou em operação na cidade de Campos, Estado do Rio de Janeiro, o primeiro serviço público municipal de eletricidade do Brasil e da América do Sul, com a inau-

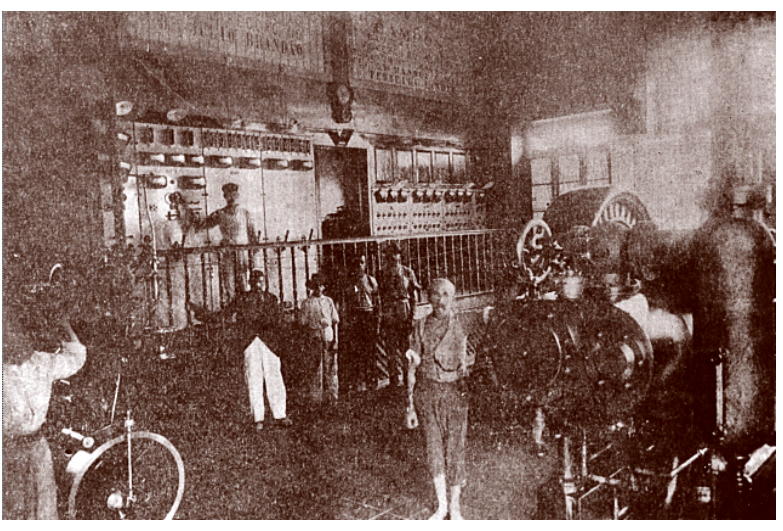

Figura 2.10 - Parte interna da Estação de Força e Luz de Campos, em 1890.

guração de uma usina termelétrica de $52 \mathrm{~kW}$, chamada de Estação de Força e Luz, Figura 2.10, alimentando 39 lâmpadas. Neste mesmo ano, começou a funcionar a primeira usina hidroelétrica no país, localizada no Ribeirão do Inferno, afluente do rio Jequitinhonha, na cidade de Diamantina, Minas Gerais. Graças a esta usina, a energia elétrica foi utilizada pela primeira vez para a indústria, no processo de lavagem da terra para extração de diamantes [49].

Em 1887, Porto Alegre passou a ser a primeira capital a usufruir um serviço permanente de fornecimento de luz a particulares com a implantação da termelétrica da Cia. Fiat Lux, com capacidade de 160kW. 
Um ano depois, Nikola Tesla conseguiu produzir a corrente alternada. Graças à utilização de corrente alternada e à transformação de tensão, ao final da década de 1890 tornou-se possível a transmissão da energia elétrica por distâncias mais longas e seu emprego em maior escala.

Em 1889, ano da Proclamação da República, a Companhia Mineira de Eletricidade - CME, fundada em 1888, inaugurou a usina hidrelétrica MarmelosZero, Figura 2.11, pertencente ao industrial Bernardo Mascarenhas, com $252 \mathrm{~kW}$, em Juiz de Fora, MG.

No ano seguinte foi assinado um contrato entre a Prefeitura de São Carlos, interior do Estado de São Paulo, e a empresa Malfatti \& Huggins, para fornecimento de

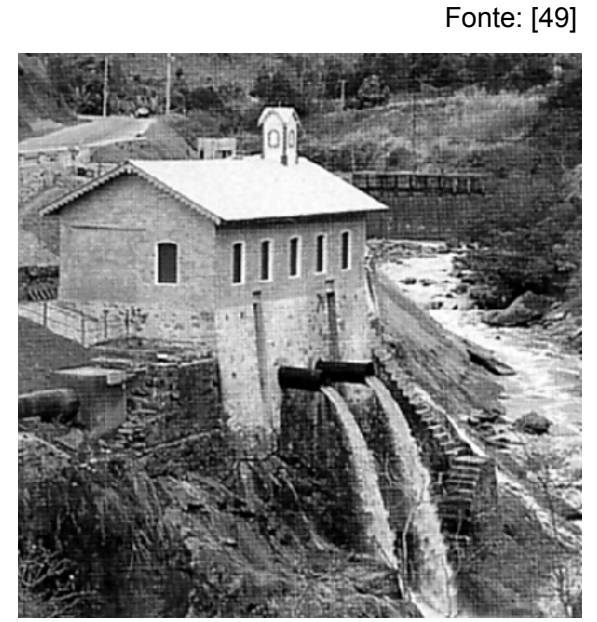

Figura 2.11 - Casa de força da usina Marmelos-Zero, em 1989, após sua restauração e transformação em museu. energia elétrica ao município. Graças a este contrato, iniciou-se a construção de uma usina hidroelétrica no rio Monjolinho, em um local denominado Salto Grande. A usina, denominada usina hidroelétrica Monjolinho, Figura 2.12, entrou em operação em 2 de julho de 1893 e foi a primeira hidrelétrica do estado de São Paulo e a segunda do país, contando com duas turbinas que acionavam dois geradores monofásicos de $50 \mathrm{~kW}$ cada.

A usina começou a ser Fonte: [49] reconstruída em 1907, sendo reinaugurada em 1909, a 300m a jusante da localização original, totalizando potência de $600 \mathrm{~kW}$ e fornecendo energia aos municípios de São Carlos e Araraquara.

Em 1912, foi implantado o serviço de bondes elétricos em São Carlos e, no final da década, o

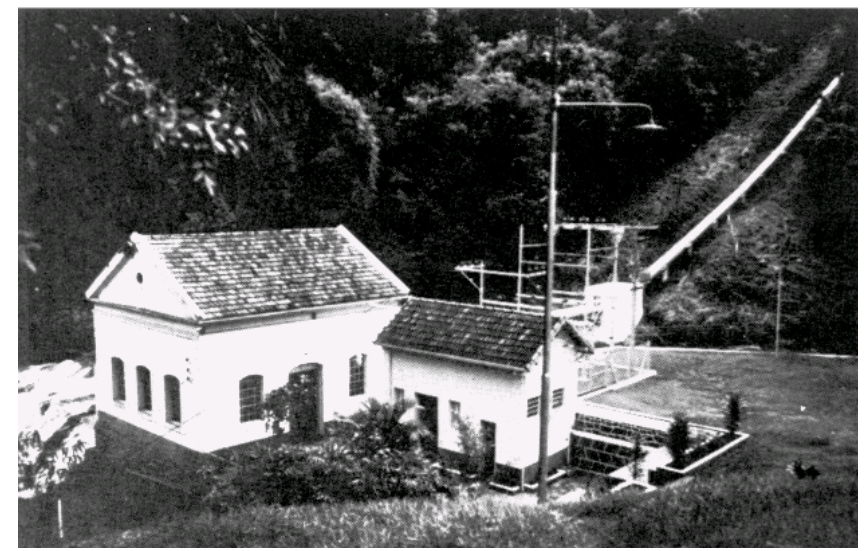

Figura 2.12 - Casa de força original da usina hidroelétrica Monjolinho. município já era um dos mais industrializados do Estado de São Paulo. 
Tão logo a energia elétrica foi se tornando disponível, suas aplicações foram sendo diversificadas. Em 1892 foi inaugurada pela Companhia Ferro-Carril do Jardim Botânico, no Rio de Janeiro, a primeira linha de bondes elétricos instalada em caráter permanente no Brasil.

Naquela época, o desenvolvimento da indústria da energia elétrica no Brasil deuse principalmente através de empresas privadas estrangeiras. Em 1889, foi criada em Toronto, Canadá, a empresa São Paulo Railway, Light and Power Empresa Cliente Ltda - SP RAILWAY, apelidada de Light. A companhia tinha como objetivo o estabelecimento e operação de centrais para a produção, utilização e venda de eletricidade, além da implantação de linhas Fonte: [49]. férreas, telegráficas e telefônicas. Por meio de decreto do Presidente Campos Sales, a Light recebeu autorização para instalar-se no Brasil, com garantia do monopólio dos serviços de bondes elétricos e do fornecimento de energia elétrica na cidade de São Paulo.

Em 1900, havia 17 localidades

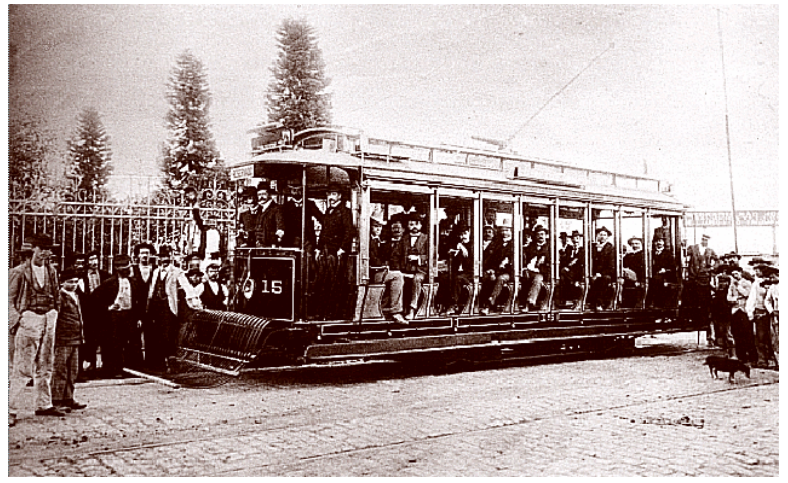

Figura 2.13 - Viagem inaugural do bonde elétrico em São Paulo, em 21/02/1900.

servidas pela eletricidade no país. Onze empresas fornecedoras operavam ao todo 6 termelétricas e 5 hidrelétricas, com uma capacidade instalada total de $12085 \mathrm{~kW}$. Neste mesmo ano a Light colocou em funcionamento, na cidade de São Paulo, uma linha de bondes movidos a eletricidade, Figura 2.13, e recebeu concessão para disponibilizar energia elétrica para iluminação. Para suprir estes novos serviços, inaugurou-se a usina hidroelétrica de Parnaíba, com 2000 kW [31].

Em 1904, também em Toronto, Canadá, criou-se a empresa Rio de Janeiro Tramway, Light and Power e, em 1912, mais uma vez em Toronto, foi criada a empresa Brazilian Traction, Light and Power, que unificou as empresas do grupo Light. Em 1927, outra empresa estrangeira, a norte-americana American \& Foreign Power Company, conhecida como Amforp, iniciou suas atividades no Brasil.

Até meados do século XX, o desenvolvimento da indústria de energia elétrica brasileira deu-se basicamente através de sistemas isolados, com usinas localizadas próximas às cidades do Rio de Janeiro e São Paulo. As interligações começaram a ocorrer na década de 20, visando apenas transferências de energia em épocas de crise. Embora alguns sistemas fossem interligados, a operação das usinas continuava sendo 
feita de forma descentralizada, sem tirar proveito das diferenças regionais de carga e de disponibilidade de água [18].

$\mathrm{O}$ pioneirismo das interligações coube à Amforp, adquirindo o controle de numerosas concessionárias que atuavam no interior paulista e em várias capitais estaduais. A Amforp promoveu, por intermédio da Companhia Paulista de Força e Luz (CPFL), a interligação dos sistemas de vinte e duas empresas que atendiam a municípios de grande importância econômica no interior paulista, como Campinas, Araraquara, Ribeirão Preto e São José do Rio Preto. Um dos obstáculos a ser superado era a falta de padrão de freqüência. Para tanto, foram eliminadas as freqüências diferentes de $60 \mathrm{~Hz}$ e modernizadas as linhas de transmissão, com a construção de uma rede em 66 kV. Em meados da década de 1930, este trabalho resultou na interligação de vinte pequenas usinas que somavam $50 \mathrm{MW}$ de capacidade instalada. Pela primeira vez no Brasil, um sistema elétrico interligado funcionou com despacho centralizado.

Em 1934, foi aprovado o Código de Águas que estabeleceu regras para o uso da água e para o fornecimento de energia elétrica. Este código estipulou que os rios deixavam de ser propriedade dos donos das terras por onde eles corriam e passavam a ser propriedade do município, do Estado ou da União, dependendo do caso. Por propriedade do rio entendia-se não somente a água, mas também as quedas d'água, ou seja, o Estado passava a ser o proprietário dos potenciais hidroelétricos e seus usos poderiam ser delegados a terceiros através de autorizações ou concessões.

Além do mais, as tarifas passavam a ser fixadas segundo os custos de operação e o valor dos investimentos, abandonando o modelo no qual as tarifas sofriam correção automática conforme a variação cambial.

A nova legislação desestimulou fortemente a participação das empresas privadas, o que acabou gerando sérias crises de abastecimento. Para centralizar as atividades do Setor Elétrico ${ }^{7}$ e promover o desenvolvimento necessário das fontes energéticas, o Estado iniciou sua intervenção na área de energia. A primeira intervenção direta do governo federal aconteceu em 1945, com a criação da CHESF - Companhia Hidro Elétrica do São Francisco, com a tarefa de construir e operar a usina de Paulo Afonso, inaugurada em 1955 com potência instalada de 180 MW. 
Os Estados também iniciaram suas atividades no Setor Elétrico, originando a CEEE - Comissão Estadual de Energia Elétrica, no Rio Grande do Sul, a CEMIG Centrais Elétricas de Minas Gerais, em Minas Gerais, e a Uselpa - Usinas Elétricas do Paranapanema S. A., em São Paulo. A criação destas empresas não evitou a crise no final da década de 50, com cortes de energia e racionamento sistemático.

Em 1953 criou-se o FFE - Fundo Federal de Eletrificação, com o objetivo de financiar o desenvolvimento do Setor Elétrico através da cobrança de impostos sobre a energia elétrica. Em 1954, foram elaborados projetos de lei que previam o Plano Nacional de Eletrificação e a criação da empresa Centrais Elétricas Brasileiras S.A. (Eletrobrás). O Plano Nacional de Eletrificação previa a expansão da geração de energia elétrica através da exploração do potencial hidroelétrico nacional, além de prever maciça intervenção do Estado nas áreas de geração e transmissão. A Eletrobrás só foi definitivamente constituída em 1962 [18].

O Plano de Metas que delineou o Fonte: [47]. desenvolvimento do país durante $\mathrm{o}$ governo de Juscelino Kubitschek (19561961) definiu como prioritária a expansão da oferta de energia elétrica, determinando a construção de novas usinas hidroelétricas. Em 1957, foi criada a empresa Central Elétrica de Furnas S. A., com o objetivo inicial de construir a usina de mesmo nome, Figura 2.14.

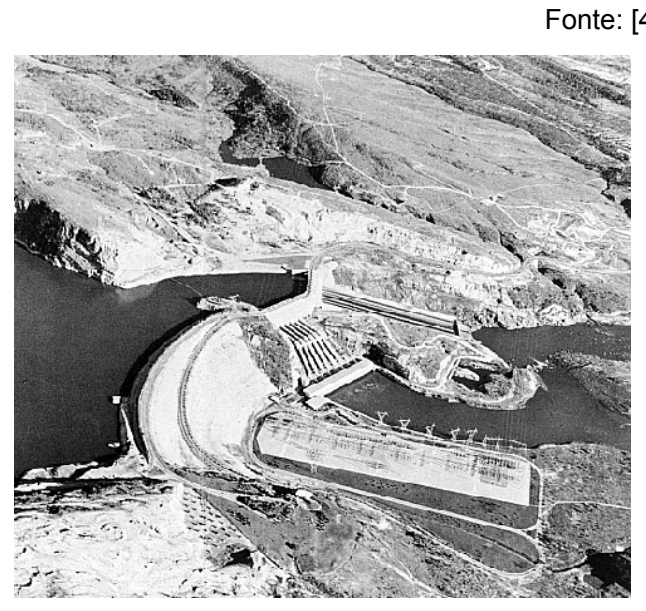

Figura 2.14 - Usina Hidroelétrica Furnas

A usina de Furnas entrou em operação em 1963, regularizando o suprimento de energia em São Paulo. Com a inauguração de Furnas, foram interligados os sistemas elétricos do Rio de Janeiro, São Paulo e Minas Gerais, dando início ao que viria a ser o Sistema Interligado Nacional - SIN.

A CEMIG implementou o Plano de Eletrificação de Minas Gerais, construindo usinas de porte maior, desde $8 \mathrm{MW}$ (Usina Hidroelétrica Tronqueiras) até quase

\footnotetext{
${ }^{7}$ Para ilustrar a falta de padronização da época, no pós-guerra a Light promoveu a interligação entre as usinas de Cubatão-SP e Fontes-RJ com o objetivo de possibilitar o intercâmbio de energia entre os sistemas de São Paulo e do Rio de Janeiro. Além de uma linha de transmissão com mais de $300 \mathrm{~km}$ de extensão, foi necessário instalar uma estação conversora de freqüência, com capacidade de $50 \mathrm{MW}$, em Aparecida (norte do Estado de São Paulo), pois as duas principais cidades do país operavam sistemas elétricos com freqüências distintas: $50 \mathrm{~Hz}$ no Rio de Janeiro e $60 \mathrm{~Hz}$ em São Paulo.
} 
400 MW (Usina Hidroelétrica Três Marias). No Estado de São Paulo, também se elaborou um plano semelhante, implementado pela Uselpa, construindo inicialmente usinas no rio Paranapanema (Usina Salto Grande, com 68MW e Usina Hidroelétrica Jurumirim, com 98MW). Outra empresa paulista, a Celusa - Centrais Elétricas Urubupungá, construiu as usinas de Jupiá e Ilha Solteira.

Outras empresas estaduais criadas foram a Copel - Companhia Paranaense de Energia, a Escelsa - Espírito Santo Centrais Elétricas S. A., a EFE - Empresa Fluminense de Energia Elétrica, dentre outras. Desta forma, entre 1952 e 1962, a participação das usinas estaduais e federais no cenário nacional evoluiu de $6,8 \%$ a $31,3 \%$ da potência instalada total.

Em 1964, já com o governo militar, os ativos do Grupo Amforp foram adquiridos pelo governo federal. Em 1979, o mesmo aconteceu com as empresas do Grupo Light, originando as empresas Light Serviços de Eletricidade S. A., subsidiária da Eletrobrás no Rio de Janeiro, e ELETROPAULO Eletricidade de São Paulo S.A., controlada pelo governo paulista.

A expansão e a operação do setor passaram a ser executadas principalmente pela Eletrobrás, atuando como holding das empresas estatais e federais. Uma das ações que marcaram o setor foi o projeto Canambra, um conjunto de estudos desenvolvido em 1962 por um consórcio de empresas canadenses e americanas, coordenado pelo Comitê Coordenador dos Estudos Energéticos da Região Centro-Sul.

Entre os anos de 1970 e 1980 foram observadas taxas de crescimento do consumo de energia elétrica da ordem de $10 \%$ ao ano. Grandes obras foram implementadas neste período, destacando-se as obras da CHESF no rio São Francisco, as usinas de Furnas no rio Grande e no rio Paranaíba, as usinas da CESP nos rios Tietê e Paranapanema, as usinas construídas pela CEMIG, as usinas construídas pela Copel, a Usina Hidroelétrica Itaipu, a Usina Hidroelétrica Tucuruí, a Usina Nuclear Angra I, dentre outras.

A filosofia de controle do Estado permaneceu até 1988, quando foi concebida a Revisão Institucional de Energia Elétrica - REVISE, de onde se originaram as alterações do setor elétrico durante a década de 1990.

Estas alterações previam a desverticalização do setor, separando as atividades de geração, transmissão e distribuição. As privatizações das empresas estatais e federais deveriam ocorrer para fomentar a concorrência nos setores de geração e distribuição, enquanto a transmissão continuaria sob o domínio do Estado, para garantir o livre 
acesso dos compradores e vendedores à via de transporte da energia. Também foram previstos órgãos responsáveis pela regulamentação do setor, pela expansão, pela operação e pela liquidação das operações comerciais.

Como marco inicial da implantação do novo modelo pode-se definir o leilão de privatização da Escelsa em 1995. Como forma de retirar efetivar a implementação do mercado de energia elétrica, entre agosto de 1996 e novembro de 1998 foi concebido o projeto de Reestruturação do Setor Elétrico Brasileiro - RE-SEB. Neste projeto foram instituídas várias mudanças, tais como a competição na geração de energia elétrica, a independência dos serviços de transmissão, o livre acesso dos consumidores livres, bem como os órgãos de regulação/fiscalização, de mercado e de operação do sistema.

Como resultado, em 1997 foi constituído o órgão regulador do setor de energia elétrica, denominado Agência Nacional de Energia Elétrica - ANEEL. No ano seguinte regulamentou-se o Mercado Atacadista de Energia - MAE, ambiente no qual deveriam ocorrer as ações de compra e venda entre os agentes interessados. Neste mesmo ano organizou-se o Operador Nacional do Sistema Elétrico - ONS, entidade privada responsável pela coordenação da operação do SIN [50].

Infelizmente, as privatizações ocorreram sem ao menos estarem definidas todas as regras e leis que levariam à tão aclamada "competição" no setor elétrico brasileiro, com ganhos de produtividade e redução de custos. Em meio a um cenário institucional incerto, investimentos praticamente não foram realizados, gerando uma crise de suprimento no país, com racionamento de energia e perspectivas de cortes de fornecimento (popularmente conhecidos como "apagões"). O consumidor, aclamado como o grande beneficiário do processo de privatização, viu a qualidade do abastecimento decair ao mesmo tempo que as tarifas aumentavam de valor [66].

Atualmente, vive-se um clima de insatisfação geral no Setor Elétrico Brasileiro, manifestada por consumidores, distribuidores e geradores. Neste contexto, tem sido discutida uma nova reforma no modelo de negócios da energia elétrica. Indicações iniciais apontam para a criação de um pool para comercialização da energia, mas ainda é cedo para afirmar o que de fato será implantado. 


\subsection{Parque Gerador Instalado}

O Brasil possuía, em agosto de 2001, uma capacidade instalada total de 69.069MW, dividida em duas partes: Sistema Interligado Nacional (SIN) e Sistemas Isolados (SI). O Sistema Interligado Nacional, por sua vez, pode ser dividido em quatro grandes subsistemas: Subsistema Sudeste/Centro-Oeste, Subsistema Sul, Subsistema Nordeste e Subsistema Norte. De acordo com dados extraídos de [57], em agosto de 2001, cada um destes subsistemas apresentava as seguintes características:

\section{- Subsistemas Sul e Sudeste/Centro-Oeste}

O Subsistema Sudeste/Centro-Oeste possuía uma capacidade instalada total de $39.875 \mathrm{MW}^{8}$, com $36.152 \mathrm{MW}$ em usinas hidroelétricas (91\% do total), $1.757 \mathrm{MW}$ em usinas termoelétricas a óleo combustível e gás natural, e $1.996 \mathrm{MW}$ em usinas termonucleares. A capacidade hidroelétrica instalada representava $60 \%$ da capacidade hidroelétrica instalada nacional em operação, havendo ainda um potencial inventariado da ordem de 45GW para ser aproveitado.

O Subsistema Sul possuía uma capacidade instalada total de $12.103 \mathrm{MW}$, com 9.918MW em usinas hidroelétricas $(82 \%$ do total) e $2.185 \mathrm{MW}$ em usinas termoelétricas. Na região sul localizavam-se as usinas a carvão de Jorge Lacerda, Presidente Médici, São Jerônimo, Charqueadas e Figueira, totalizando 1.415MW instalados, algumas a óleo combustível, com 170MW de capacidade, e a usina termoelétrica a gás natural Uruguaiana, com 600MW.

\section{- Subsistemas Norte e Nordeste}

O Subsistema Nordeste possuía uma capacidade instalada de $10.435 \mathrm{MW}$, com 10.145MW em usinas hidroelétricas (97\% do total) e 290MW em usinas termoelétricas.

O Subsistema Norte possuía 4.281MW instalados exclusivamente em usinas hidroelétricas.

A capacidade hidroelétrica instalada nestes dois subsistemas equivalia a $36 \%$ da capacidade hidroelétrica instalada nacional em operação, dispondo ainda de um potencial já inventariado de cerca de $61 \mathrm{GW}$, considerando, na Região Norte, apenas as bacias do Tocantins/Araguaia, Xingu e Tapajós.

\footnotetext{
${ }^{8}$ Considerando apenas a "parte brasileira" da usina hidroelétrica de Itaipu, $6300 \mathrm{MW}$, corresponde à metade da potência instalada total desta usina.
} 


\section{- Conexão dos Subsistemas Sul e Sudeste/Centro-Oeste}

A capacidade de transferência do sistema de transmissão que interconectava as regiões sul/sudeste/centro-oeste era da ordem de $3.600 \overline{\mathrm{MW}}$ no sentido sul $\rightarrow$ sudeste/centrooeste, e $3.900 \overline{\mathrm{MW}}$ no sentido inverso. O intercâmbio de energia era marcadamente sazonal, com fluxos no sentido sul $\rightarrow$ sudeste/centro-oeste durante o período de maio a novembro, e no sentido sudeste/centro-oeste $\rightarrow$ sul durante o período de dezembro a abril.

\section{- Conexão dos Subsistemas Norte e Nordeste}

A capacidade de transferência do sistema de transmissão que interconectava as regiões norte e nordeste era da ordem de $600 \overline{\mathrm{MW}}$ no sentido norte $\rightarrow$ nordeste e $700 \overline{\mathrm{MW}}$ no sentido oposto. Esta interligação também possuía característica sazonal, com fluxos de energia no sentido norte $\rightarrow$ nordeste no primeiro semestre do ano, quando existe abundância de água na bacia do rio Tocantins, devido à geração da usina hidroelétrica de Tucuruí, e no sentido inverso no segundo semestre.

\section{- Conexão dos Subsistemas Norte e Sudeste/Centro-Oeste}

Em dezembro de 1998, os Sistemas Interligados Sul/Sudeste/Centro-Oeste e Norte/Nordeste foram interconectados através da interligação Norte/Sul, um circuito de $500 \mathrm{kV}$ com $1.000 \mathrm{~km}$ de extensão e intercâmbio máximo de $1.000 \overline{\mathrm{MW}}$. A entrada desta linha de transmissão em operação aumentou a confiabilidade do Sistema Interligado Nacional e seus benefícios devem aumentar ainda mais a partir de sua expansão que deve ocorrer após a entrada em operação da segunda etapa da usina hidroelétrica de Tucuruí, prevista para 2004.

\section{- Sistemas Isolados}

Estes sistemas correspondiam a mais de 330 localidades eletricamente isoladas uma das outras, a maioria na Região Norte. Dentre elas destacavam-se os sistemas de Manaus, Porto Velho, Rio Branco, Macapá e Boa Vista. Os Estados do Maranhão, Pernambuco, Bahia, Tocantins, Mato Grosso e Mato Grosso do Sul também apresentam Sistemas Isolados, porém de pequeno porte e com crescimento reduzido, não exigindo ações de planejamento da expansão por parte das concessionárias.

Em Manaus, havia cerca de $1.062 \mathrm{MW}$ de potência instalada, sendo $250 \mathrm{MW}$ da usina hidroelétrica Balbina e $812 \mathrm{MW}$ em usinas termoelétricas. No interior do Estado do Amazonas havia ainda aproximadamente 200MW instalados em usinas termoelétricas a diesel. Em Porto Velho, havia 414MW instalados, sendo 216MW na 
usina hidroelétrica Samuel e 198MW em usinas termoelétricas. Em Rio Branco, o sistema era puramente termoelétrico, com capacidade instalada de 155MW. Em Macapá, havia 197MW de potência instalada, com 70MW na usina hidroelétrica Coaracy Nunes e 127MW na usina termoelétrica a diesel Santana. Em Boa Vista havia três usinas termoelétricas, totalizando 127MW. No interior do Pará também havia sistemas isolados, totalizando cerca de 60MW de potência instalada. Os sistemas isolados do interior do Mato Grosso totalizavam cerca de 130MW.

Assim, os sistemas isolados totalizavam 2.345MW, dos quais $1.809 \mathrm{MW}$ correspondiam a usinas termoelétricas $(77 \%$ do total) e $536 \mathrm{MW}$ a usinas hidroelétricas.

Para permitir uma melhor visualização dos dados descritos acima, na Figura 2.15 são ilustradas as capacidades instaladas para os sistemas que compõem o SIN.

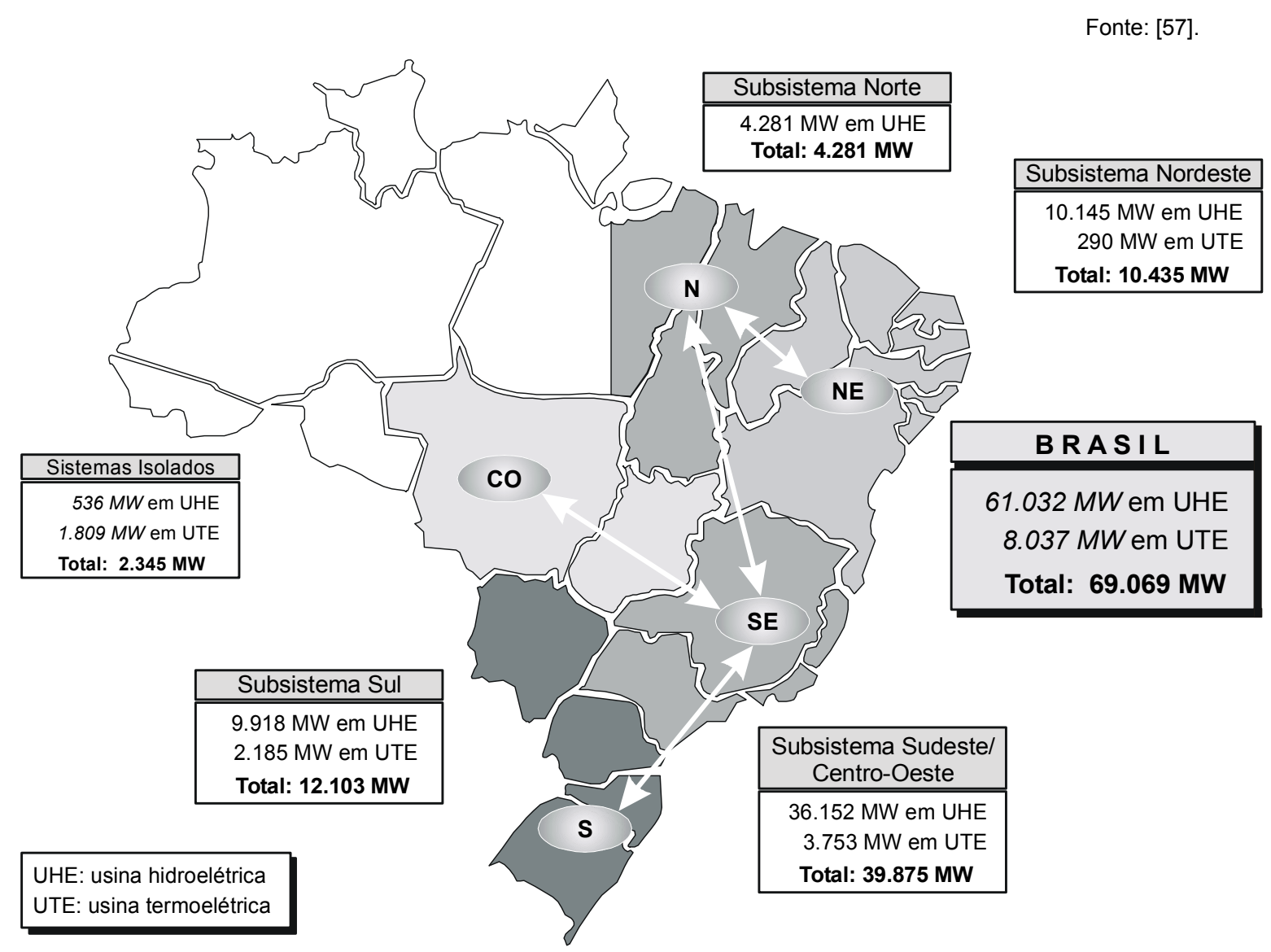

Figura 2.15 - Capacidade instalada no SIN em agosto de $2001^{9}$.

Analisando as características do Sistema Elétrico Brasileiro, nota-se que os 61.032MW instalados em usinas hidroelétricas representavam $88 \%$ da capacidade 
instalada do sistema, caracterizando o Sistema Elétrico Brasileiro como predominantemente hidroelétrico. Esta propriedade distingue o país da maior parte dos países, porque suas potências instaladas concentram-se em usinas termoelétricas. Para enfatizar esta diferença, na Figura 2.16 são comparadas as capacidades instaladas do Brasil e do mundo no dia primeiro de janeiro de 2000.

A predominância hidroelétrica faz com que o sistema brasileiro possua características peculiares. Por exemplo, a predominância de usinas hidroelétricas, quase que invariavelmente implica grandes distâncias entre os centros consumidores e as unidades geradoras de energia, traduzindo-se em sistemas de transmissão abrangentes.

Outra característica interessante é a necessidade de coordenação da operação energética das usinas, ou operação de médio/longo prazo, uma vez que a quantidade de água disponível em uma usina depende de como as outras usinas são operadas. Esta interdependência espacial não existe, por exemplo, em sistemas termoelétricos.

Fonte: [42]

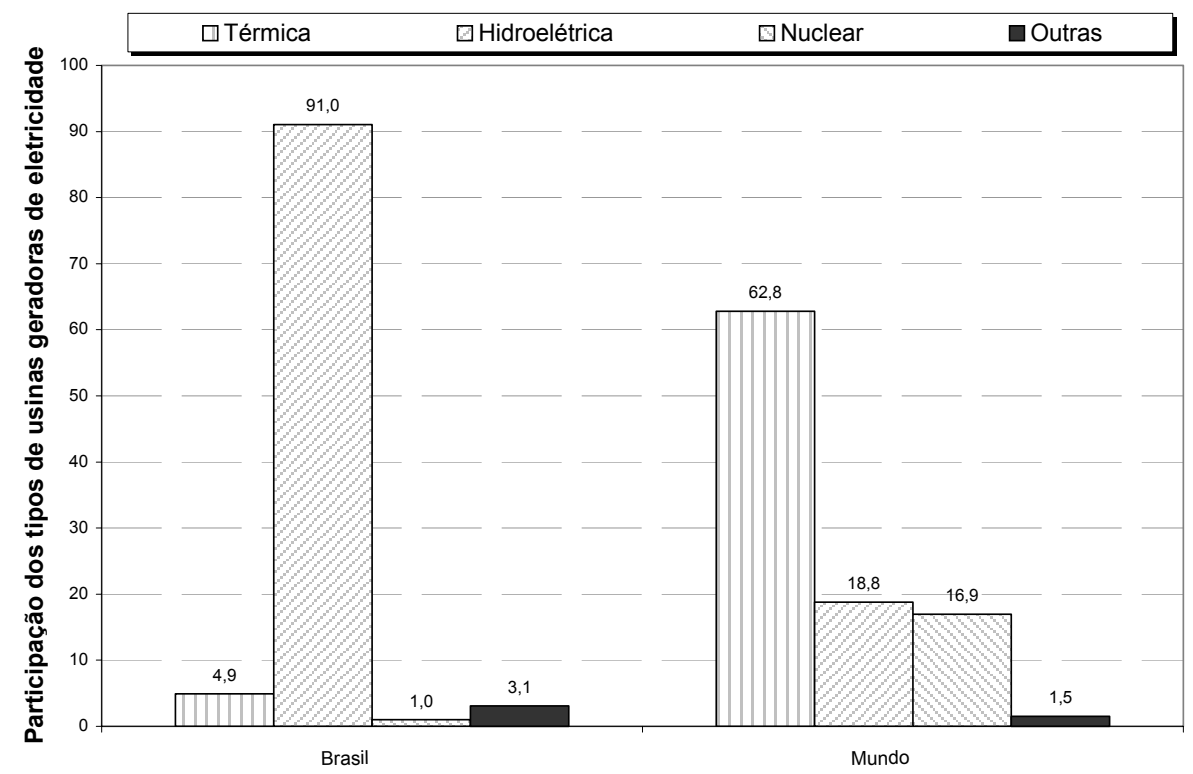

Figura 2.16 - Fontes de energia utilizadas na geração de eletricidade no Brasil e no mundo.

Além disso, a operação integrada do sistema ocasiona ganhos sinérgicos para os subsistemas, pois se pode tirar proveito das diferenças entre as estações climáticas e entre as cargas relacionadas às diversas partes do país.

\footnotetext{
${ }^{9}$ Nota-se que os Estados de Mato Grosso do Sul e Maranhão, para efeitos de suprimento de energia elétrica, são considerados como pertencentes à Região Sul e à Região Norte, respectivamente.
} 


\subsection{Dados Relevantes da Operação no Ano de 2001}

De acordo com [87], os recursos energéticos disponíveis no SIN ao final do ano de 1999 indicavam uma situação de duvidoso equilíbrio entre a oferta e a demanda de energia elétrica ao longo de 2000, mesmo considerando as expansões previstas nos sistemas de geração e transmissão. A falta de expansão do sistema nos anos anteriores havia forçado a utilização da energia armazenada nos reservatórios e, em janeiro de 2000, a energia armazenada no SIN era de cerca de $38.000 \mathrm{GWh}$, correspondendo a apenas $22 \%$ da capacidade total de armazenagem.

Graças às elevadas vazões afluentes ao longo do ano de 2000, a crise de abastecimento foi postergada, configurando-se de fato ao longo de 2001 [88]. Foi organizada a Câmara de Gestão da Crise (GCE), desenvolvendo estudos e simulações para avaliação da situação do sistema e das medidas que seriam tomadas para contornar o problema. Toda a sociedade foi chamada para cooperar com a redução do consumo de energia e foram estabelecidas metas de consumo para cada residência, impondo-se reduções de até $20 \%$ em relação ao consumo médio. Este "Programa de Racionamento de Energia" teve resultados excelentes sob o ponto de vista de ter alcançado as metas desejadas de redução de consumo. Entretanto, sob o ponto de vista econômico, a crise do Sistema Elétrico Brasileiro provocou um grande desaquecimento econômico, reduzindo sensivelmente a atividade industrial, aumentando ainda mais o desemprego e provocando perdas estimadas de até $2,5 \%$ do PIB.

Durante o ano de 2001, a produção total de energia pelo SIN foi de 326.137GWh, ou $37.265 \overline{\mathrm{MW}}$, contra $356.588 \mathrm{GWh}$, ou $40.595 \overline{\mathrm{MW}}$ verificados em 2000 , configurando uma redução de $8,54 \%$ na produção total de energia. Devido à situação das usinas hidroelétricas, houve uma redução, em relação ao ano de 2000, de 13\% na produção de energia hidroelétrica, e um aumento de $60 \%$ na produção de energia termoelétrica. A utilização de cada uma das fontes disponíveis pode ser visualizada na Figura 2.17.

Observa-se que as usinas hidroelétricas, mesmo em época de crise de abastecimento, foram responsáveis pela produção de $93,2 \%$ de toda a energia produzida no país e importada, o que reforça a predominância da hidroeletricidade no Brasil. Também é notável a participação da usina hidroelétrica de Itaipu, cuja produção é quase igual a um quarto da produção nacional.

Mudanças na matriz energética brasileira podem ser sentidas pela maior 
participação da energia nuclear, graças à entrada em operação da usina de Angra II, e da energia termoelétrica convencional, com usinas a gás natural importado da Bolívia. Além disso, a integração do SIN à Argentina introduziu a parcela de energia importada.

Fonte: [88].

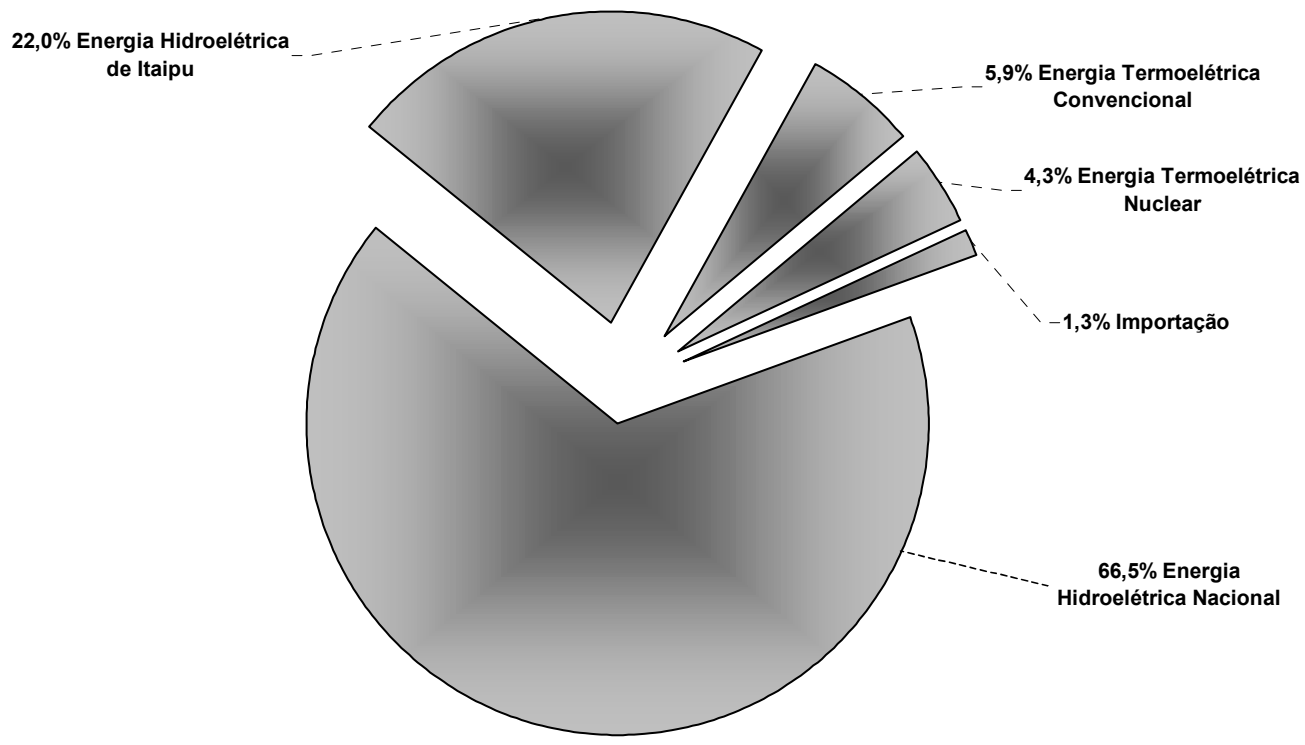

Figura 2.17 - Produção de energia elétrica para cada uma das fontes disponíveis em 2001.

Além da produção nacional total, é interessante observar a produção dos sistemas regionais e os intercâmbios de energia, ilustrados na Figura 2.18. Os intercâmbios da região Norte para as regiões Nordeste e Sudeste/Centro-Oeste são marcantes, como também são as diferenças regionais do país no que se refere ao consumo de energia: a região Sudeste/Centro-Oeste representava $61,4 \%$ da carga do SIN; a Sul, 18,4\%; a Norte, $6,2 \%$; e a Nordeste, $14,0 \%$.

Quanto à expansão, no ano de 2001 a capacidade instalada no SIN cresceu apenas 3,4\%, contra os 5,9\% no ano de 2000 e 4,4\% no ano de 1999 . Obviamente, a preocupação maior neste ano foi resolver o impasse da crise, ainda que temporariamente. 


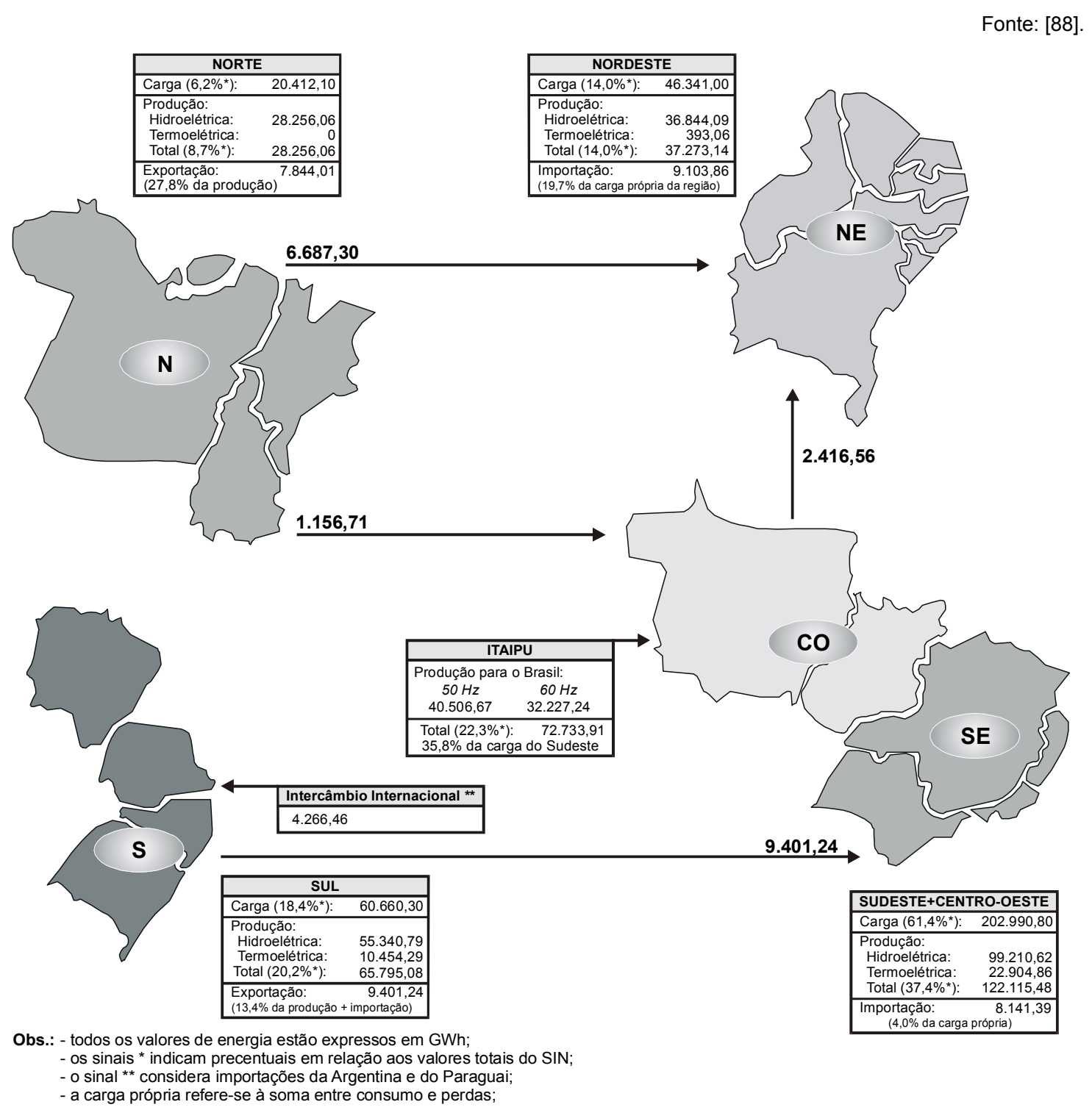

Figura 2.18 - Intercâmbios regionais de energia durante o ano de 2001, em GWh.

Finalmente, após analisar o estado inicial e a produção de energia ao longo de 2001, apresenta-se na Figura 2.19 um balanço energético do SIN através do uso de um reservatório equivalente de energia para cada região do país [10, 90]. Analisando inicialmente os estoques iniciais de energia, observam-se os níveis alarmantes da Região Nordeste ao final de 2000, e os estoques razoáveis de energia das Regiões Sudeste/Centro-Oeste e Norte, ainda que considerados baixos para o mês de dezembro.

$\mathrm{Na}$ realidade, o sistema vinha passando por um processo de esvaziamento ao longo dos últimos anos, tal como ilustrado na Figura 2.20. Ao final de 1998, os reservatórios da Região Sudeste/Centro-Oeste possuíam 45\% da energia armazenada máxima que eles poderiam estocar. Embora essa já era uma situação considerada desconfortável, ao final 1999 o nível desta região chegou a 18\%, um nível crítico por 
dois motivos principais: (i) com volumes reduzidos, os reservatórios perdem seus papéis de reguladores das vazões naturais e o sistema passa a depender da variabilidade de distribuição das chuvas; (ii) volumes reduzidos implicam em baixas alturas de queda, reduzindo a produtividade e a disponibilidade de potência das usinas.

O processo de esvaziamento deu-se principalmente devido à utilização da água armazenada nos reservatórios para equilibrar a oferta de energia à demanda, já que novas unidades geradoras não foram construídas em número suficiente durante o período. Em 1999 o esvaziamento acentuou-se, de forma que a situação do sistema no início do ano 2000 indicava problemas de abastecimento. Felizmente, por puro acaso, as vazões afluentes no início de 2000 foram favoráveis e aliviaram o problema imediato de suprimento naquele ano. Porém, a situação ao final de 2000 estava longe da normalidade. A ocorrência de vazões reduzidas em 2001 levou os sistema a níveis absolutamente críticos e, finalmente, à necessidade de racionar a energia. Embora a causa do racionamento tenha sido inicialmente atribuída às baixas vazões afluentes do início de 2001, um estudo encomendado pelo próprio governo federal concluiu que a hidrologia desfavorável apenas precipitou uma crise que só poderia ocorrer devido à soma de outros fatores [2].

A razão determinativa da crise foi a falta de investimentos no setor. Por um lado, o governo estava mais preocupado em “enxugar” as empresas e prepará-las para venda durante a transição para o modelo descentralizado do setor elétrico, a investir na expansão do sistema e garantir o fornecimento de energia. Por outro lado, as empresas privadas já atuantes no sistema não promoveram a expansão, em parte por não serem obrigadas a isto e em parte por não terem recebido sinalizações de preço adequadas à situação. 
Fonte: [88]

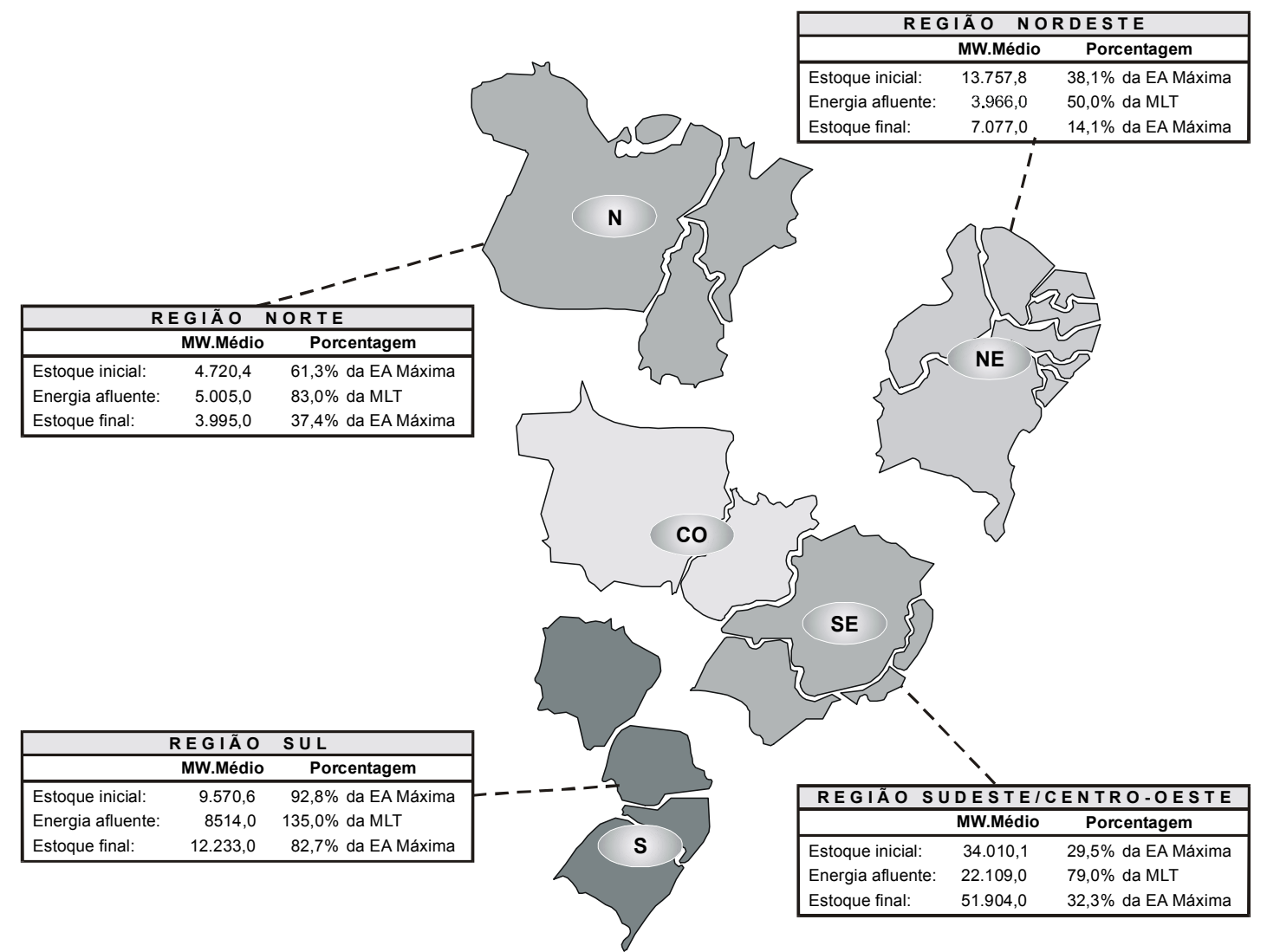

Obs.: - EA significa Energia Armazenada;

- MLT significa Média de Longo Termo;

- o estoque inicial refere-se à energia armazenada no dia 01/01/2001;

- o estoque final refere-se à energia armazenada no dia 31/12/2001;

Figura 2.19 - Balanço energético do SIN em 2001.

Fonte: [2].

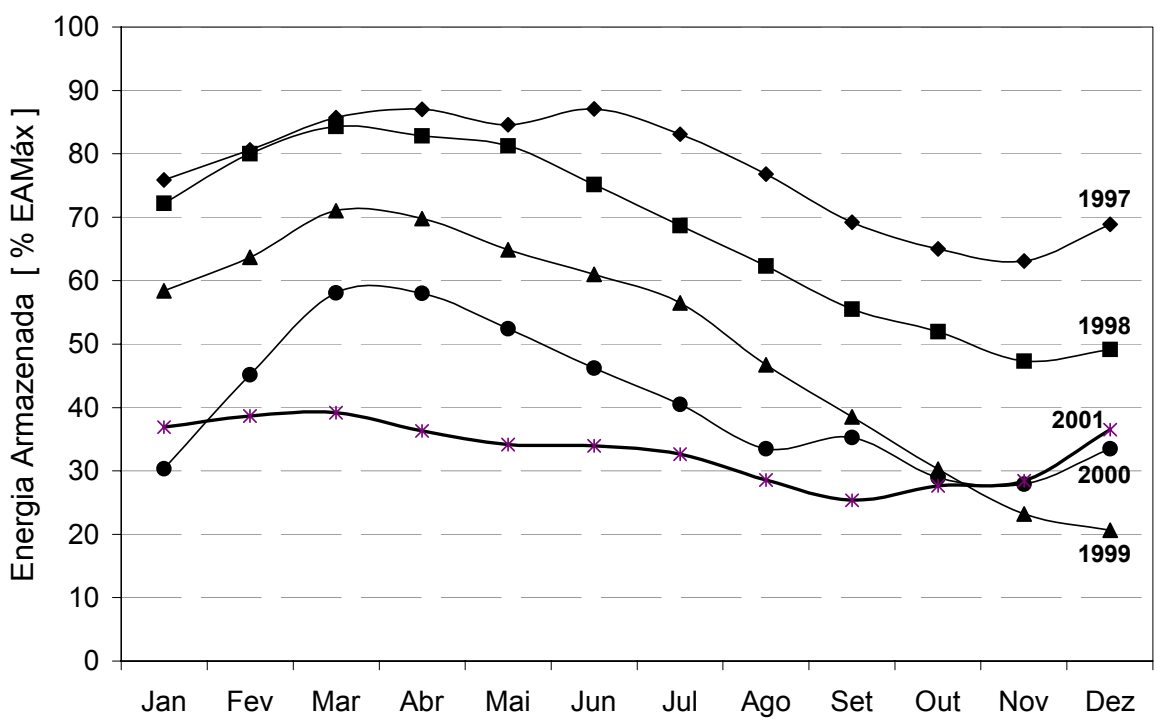

Figura 2.20 - Esvaziamento do Sistema Sudeste/Centro-Oeste. 


\subsection{O Potencial Hidroelétrico Brasileiro}

O potencial hidroelétrico brasileiro, estimado em $260 \mathrm{GW}$, está distribuído em oito bacias hidrográficas, ilustradas na Figura 2.21. Dentre estas bacias, destacam-se as do Rio Amazonas e do Rio Paraná, com 40\% e 23\% do potencial nacional, respectivamente. Apesar destas bacias apresentarem os maiores potenciais do país, suas explorações são sensivelmente diferenciadas. Enquanto na bacia do Rio Paraná já não há espaço para construção de grandes usinas hidroelétricas, a bacia do Rio Amazonas encontra-se praticamente intocada.

Para ilustrar estes fatos e mostrar a situação das outras bacias, seus potenciais e suas potências instaladas são mostradas na tabela abaixo. Também foi definido um índice de aproveitamento, indicando a porcentagem explorada do potencial de cada bacia.

Observando os dados relativos ao Brasil como um todo, constata-se que somente um quarto do potencial nacional está sendo efetivamente utilizado. Este cenário indica que a predominância hidráulica do sistema elétrico brasileiro deve manter-se nas próximas décadas, mesmo considerando-se a inserção de usinas térmicas a gás e o desenvolvimento de outras fontes renováveis, como a energia eólica e a solar.

Entretanto, a continuidade da expansão da hidroeletricidade no Brasil enfrentará sérios obstáculos, já que as bacias hidrográficas mais próximas aos centros de carga encontram-se saturadas (bacias do Rio Paraná e São Francisco, por exemplo), e o aproveitamento das bacias do Rio Amazonas e Tocantins depende da construção de imensos sistemas de transmissão para trazer grande parte da energia gerada ao sul e ao sudeste do país.

Tabela 2.6 - Potencial hidroelétrico e capacidade instalada nas bacias hidrográficas brasileiras em janeiro de 2001.

\begin{tabular}{lrrr}
\hline \multicolumn{1}{c}{ Bacia Hidrográfica } & $\begin{array}{c}\text { Potencial } \\
{[\mathrm{MW}]}\end{array}$ & $\begin{array}{c}\text { Instalado } \\
{[\mathrm{MW}]}\end{array}$ & $\begin{array}{c}\text { Índice de } \\
\text { Aproveitamento }\end{array}$ \\
\hline 1. Bacia do Rio Amazonas & 105.410 & 592 & $0,56 \%$ \\
\hline 2. Bacia do Rio Tocantins & 27.540 & 5.394 & $19,59 \%$ \\
\hline 3. Bacia do Atlântico Norte/Nordeste & 3.402 & 303 & $8,91 \%$ \\
\hline 4. Bacia do Rio São Francisco & 26.319 & 10.473 & $39,79 \%$ \\
\hline 5. Bacia do Atlântico Leste & 14.092 & 2.367 & $16,8 \%$ \\
\hline 6+7. Bacia do Rio Paraná + Paraguai & 60.378 & 38.580 & $63,9 \%$ \\
\hline 8. Bacia do Rio Uruguai & 13.337 & 294 & $2,2 \%$ \\
\hline 9. Bacia do Atlântico Sudeste & 9.617 & 2.508 & $26,08 \%$ \\
\hline Brasil & 260.095 & 60.511 & $23,26 \%$ \\
\hline
\end{tabular}


Fonte: [8].

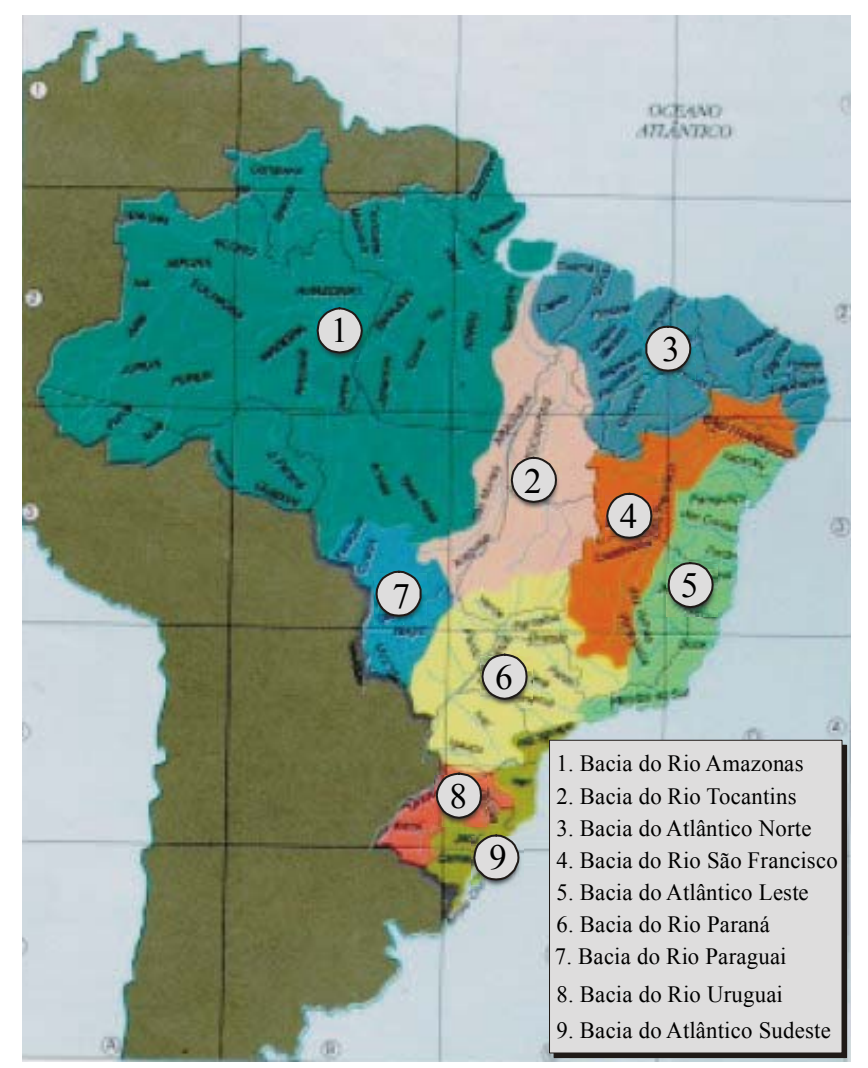

Figura 2.21 - Bacias hidrográficas brasileiras.

Para que o potencial existente possa ser explorado de forma eficiente, segundo critérios técnicos que garantam a lucratividade dos empreendimentos e a não mutilação dos recursos naturais, vários estudos de planejamento são realizados. Estes estudos são tratados na próxima seção.

\subsection{Expansão da Capacidade de Geração}

Ao longo das últimas décadas, a expansão do Sistema Elétrico Brasileiro vinha sendo planejada de forma centralizada, através de um processo de análise que subsidiava a tomada de decisões referentes a onde, quando e como deveriam ser construídas novas unidades geradoras de energia. Segundo as abordagens adotadas, as decisões deveriam ser tomadas tendo como objetivo principal a garantia do suprimento de energia segundo padrões de qualidade e confiabilidade, visando sempre optar pelos empreendimentos que apresentavam menores custos frente a seus benefícios [6, 12, 13, 32-34, 56, 59].

Com as atuais reformas institucionais do Setor Elétrico Brasileiro, introduziu-se a competição nos segmentos de geração e comercialização de energia elétrica, a determinação do livre acesso aos sistemas de transmissão e distribuição, e um novo 
panorama institucional com os já citados Mercado Atacadista de Energia - MAE, Agência Nacional de Energia Elétrica - ANEEL e Operador Nacional do Sistema Elétrico - ONS [3].

No novo contexto do Setor Elétrico, a instauração do ambiente competitivo alterou as premissas e os principais objetivos do planejamento da expansão das fontes de energia e dos sistemas de transmissão. O Planejamento da Expansão da Geração (PEG) deixou de ser determinativo e passou a ser "indicativo", enquanto o Planejamento da Expansão da Transmissão (PET) continua sendo determinativo e passa a possuir o objetivo principal de garantir a concorrência entre os agentes de mercado.

De acordo com [1], os principais objetivos do planejamento passam a ser os seguintes:

- Orientar ações de governo para assegurar o fornecimento de energia de qualidade e nas quantidades demandadas pela sociedade;

- Oferecer aos agentes do mercado de energia elétrica um quadro de referência para elaboração de seus planos de investimento;

- Estabelecer, de acordo com os aspectos operacionais do sistema, a expansão mais adequada da rede elétrica de transmissão.

Para alcançar tais objetivos, o planejamento da expansão deve disponibilizar informações que traduzam as soluções de expansão dos sistemas elétricos, de forma a fomentar a competição e a melhoria da qualidade do serviço.

A organização destas informações e a realização dos estudos de planejamento passam a ser realizadas pelo Comitê Coordenador do Planejamento da Expansão dos Sistemas Elétricos - CCPE, monitorado pela Secretaria de Energia e pelo Ministério de Minas e Energia, de acordo a Portaria MME n $150 / 99$.

Os "produtos" gerados pela atividade do CCPE devem permitir que os agentes identifiquem os sinais econômicos para seus posicionamentos estratégico, tático e operacional, requerendo estudos de longo, médio e curto prazos. Além disso, o CCPE deve acompanhar as condições de atendimento à demanda de expansão da oferta. Os principais produtos do CCPE são os seguintes:

- Planejamento de Longo Prazo: consolidação de um conjunto de informações tomando como premissas a política econômica, as diretrizes de políticas energética, ambiental e industrial, e os avanços tecnológicos.

- Planejamento Indicativo de Expansão: conjunto amplo de informações 
que inclui desde o suporte fornecido pelo Planejamento de Longo Prazo, até as premissas utilizadas na realização dos estudos. O plano indicativo também conterá relações dos empreendimentos hidroelétricos, termoelétricos, troncos de transmissão, etc., indicando seus respectivos estágios de desenvolvimento. Com as informações desta etapa do planejamento serão elaborados os programas de licitação das concessões de usinas e os programas de estudos de inventário e viabilidade.

- Planejamento Determinativo de Expansão da Transmissão: conjunto de obras consideradas inadiáveis para garantir boas condições de atendimento ao mercado. Estas obras vão compor os programas de licitação ou autorização conduzidos pela ANEEL.

- Acompanhamento Pró-Ativo das Decisões do Planejamento: as recomendações indicadas pelo planejamento deverão ser avaliadas periodicamente, identificando-se ações necessárias para solucionar dificuldades de suprimento decorrentes da não ocorrência das premissas utilizadas nos estudos iniciais ou alterações de outras naturezas.

De forma resumida, o Plano Indicativo para Expansão da Geração conterá uma lista com as usinas candidatas a serem construídas, podendo estar incluídas nesta lista, além das que apresentam menor custo frente aos benefícios, usinas que interessem especificamente a algum agente de mercado. A partir destas listas, os agentes concorrerão para obtenção das concessões através de licitações.

Dependendo do interesse dos agentes, obras de transmissão podem ser consideradas inadiáveis e podem passar a ser determinativas. Embora isso não seja citado nos documentos de estruturação do CCPE, o mesmo princípio de urgência pode ser aplicado em obras de geração. Assim, o planejamento teria caráter indicativo para os agentes de mercado, mas teria como prioridade maior a garantia de suprimento.

Paralelamente ao planejamento, o CCPE deveria funcionar como um fiscal dos acordos firmados para expansão do sistema, comparando os estágios de desenvolvimento dos projetos e os cronogramas firmados durante a concessão dos empreendimentos. 


\section{Capítulo III}

\section{Dimensionamento de Usinas Hidroelétricas}

A construção de uma usina hidroelétrica traduz-se na realização de um investimento financeiro. A partir do capital utilizado para custear a construção da usina, deseja-se que as receitas operacionais, obtidas com a venda da energia gerada ao longo da vida útil do empreendimento, proporcionem lucros aos investidores.

Dependendo da concepção do aproveitamento hidroelétrico, o montante necessário para sua construção será diferente, bem como os benefícios provenientes da venda de energia. Uma vez definida a localização da usina, várias características do empreendimento devem ser determinadas, tais como a disposição física da barragem, vertedouro e casa de máquinas, o tipo de material utilizado na barragem, o volume do reservatório, o tipo e a potência das turbinas e dos geradores, as subestações transformadoras, o sistema elétrico ao qual a usina será interconectada, etc. São várias decisões tomadas à medida que estudos vão sendo realizados e o projeto vai sendo mais bem definido e detalhado.

Embora o processo de dimensionamento seja complexo, o princípio básico que norteia sua execução é bastante simples: desejam-se encontrar os parâmetros de projeto de forma que a diferença entre os benefícios e os custos da usina hidroelétrica seja máxima. É justamente no cálculo dos custos e dos benefícios que surgem as grandes dificuldades encontradas no dimensionamento de um aproveitamento hidroelétrico.

Os custos de um projeto envolvem aquisição de terras, eventuais remoções e relocações de pequenas cidades ou vilas, construção das estruturas físicas (barragem, casa de máquinas, vertedouro, etc.), juros durante a construção, compra de equipamentos elétricos, operação e manutenção, medidas mitigadoras de impactos ambientais, etc. Por mais detalhado que possa ser, o levantamento de custos sempre deixa margem a variações, dado o porte do empreendimento e uma série de adversidades econômicas, políticas e naturais que podem alterar o seu cronograma. 
Os benefícios de uma usina hidroelétrica equivalem aos ganhos energéticos que a obra trará ao sistema ao qual ela vai integrar-se, medidos pelos acréscimos de Energia Firme, Energia Secundária e Ponta Garantida. Estes ganhos dependem da evolução da demanda de energia, da disponibilidade hidrológica, das regras de operação que condicionam o despacho entre as diversas usinas hidroelétricas, do critério de suprimento de energia entre as empresas, das restrições de intercâmbio, do custo de combustível das usinas termoelétricas, do sistema tarifário, da valorização do suprimento de ponta, etc.

Além das dificuldades encontradas nos cálculos dos custos e dos benefícios de uma usina hidroelétrica, o método de busca pelas dimensões ótimas constitui uma complicação adicional. Há a necessidade de serem medidos os benefícios e os custos associados a cada conjunto possível de parâmetros, estabelecendo ainda alguma "regra" para que novos parâmetros sejam determinados a partir dos atuais, visando o aumento da diferença entre os benefícios e os custos.

Todos estes fatores são explicados com mais detalhes ao longo deste capítulo. Para iniciar, descreve-se a seqüência de etapas necessárias para sistematizar o processo de dimensionamento. Em seguida são apresentados os benefícios energéticos de uma usina hidroelétrica, os parâmetros de dimensionamento e suas implicações sobre o funcionamento da usina, o modelo adotado pelo Setor Elétrico Brasileiro para estudos de inventário e alguns modelos publicados na literatura especializada. 


\section{Requisitos para Implantação de Usinas Hidroelétricas}

$\mathrm{Na}$ elaboração do projeto de uma usina hidroelétrica, vários aspectos devem ser contemplados, desde a escolha de um local apropriado para a construção da barragem, até a definição de seu projeto final, do cronograma de obras e de sua entrada em operação. Na Figura 3.1 são ilustradas as etapas que antecedem a entrada em operação de uma usina hidroelétrica, considerando aspectos legais referentes a Engenharia, Meio Ambiente e Licitação da Concessão. A duração de cada uma das etapas depende do porte do empreendimento e do tempo de tramitação dos processos de aprovação junto à Agência Nacional de Energia Elétrica e aos órgãos ambientais [57].

Fonte: [57].

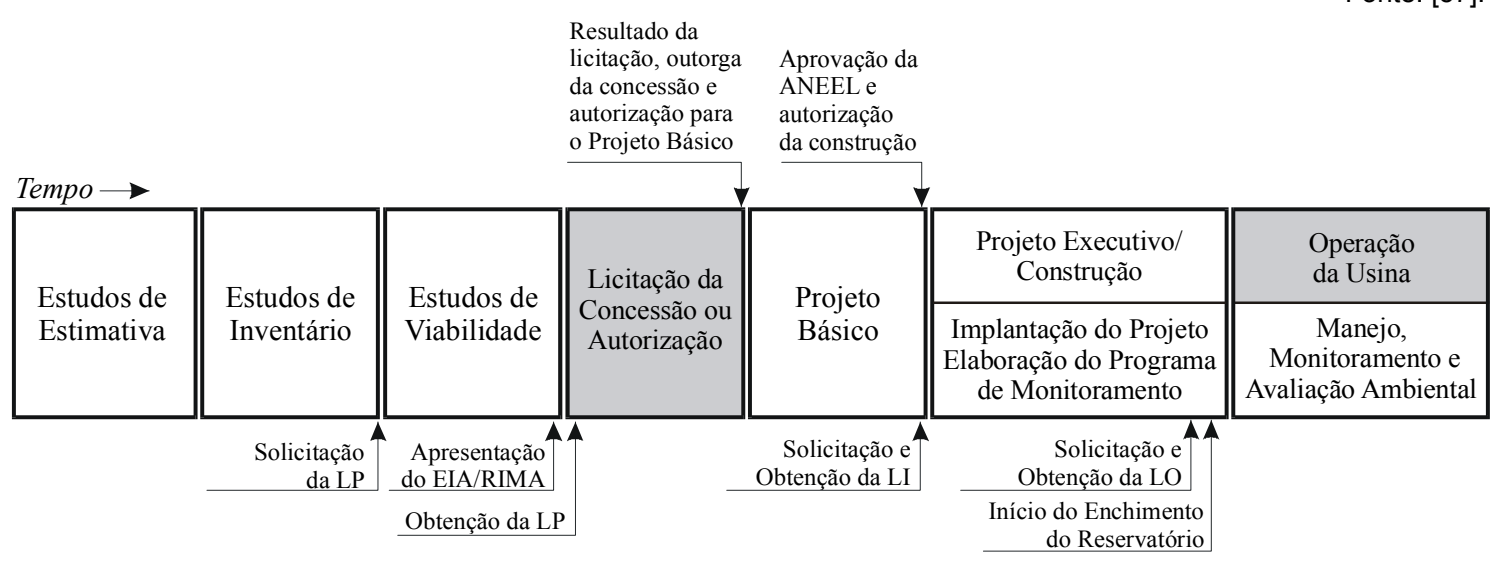

Figura 3.1 - Etapas que antecedem a entrada em operação de uma usina hidroelétrica.

Os Estudos de Estimativa tratam da primeira avaliação do recurso energético disponível. A estimativa representa uma análise preliminar das características topográficas, geográficas e geológicas das bacias hidrográficas. Estas análises resultam em valores preliminares do potencial hidroelétrico, do número de locais barráveis, dos custos dos empreendimentos e da definição dos estudos de inventário e de seus respectivos prazos de execução [56].

Os Estudos de Inventário definem o potencial hidroelétrico da bacia hidrográfica, o estudo de divisão de quedas e a estimativa de custo de cada aproveitamento, segundo um orçamento padrão. Este procedimento permite classificar as usinas de acordo com seus índices custo/benefício.

Os Estudos de Viabilidade visam definir a concepção global de um aproveitamento, realizando seu dimensionamento final, definindo-se o melhor eixo da barragem, o arranjo geral das estruturas, os níveis de armazenagem, as quedas das 
turbinas, o volume útil do reservatório, a potência instalada, o número e o tipo de unidades geradoras, além dos benefícios e custos associados.

As características concebidas durante os Estudos de Viabilidade são detalhadas na elaboração do Projeto Básico, quando são efetuados os orçamentos finais e a definição das obras civis e dos equipamentos permanentes. O Projeto Básico é detalhado em nível construtivo, com a elaboração dos projetos das obras civis e dos equipamentos eletromecânicos, originando o Projeto Executivo para a obra.

É interessante notar que na Figura 3.1 o Projeto Básico é realizado após a Licitação da Concessão, quando já está definido o empreendedor que vai implantar a usina. Este fator faz com que o próprio empreendedor seja responsável pelo Projeto Básico, com liberdade para melhorar a solução encontrada durante a viabilidade de forma a tornar o seu empreendimento mais competitivo.

Alternativamente, o Projeto Básico também poderia ser realizado antes da Licitação, de forma que o empreendedor conheceria melhor os detalhes do aproveitamento e poderia calibrar melhor sua proposta.

Sob o ponto de vista de determinação das características da usina, atenção especial deve ser dada às etapas de Inventário e Viabilidade. Nestas fases é realizado o chamado dimensionamento energético-econômico, no qual são determinados os principais parâmetros que influenciam o desempenho energético da usina hidroelétrica. Embora estas duas fases tenham objetivos semelhantes, em cada uma delas são utilizadas informações e metodologias com diferentes profundidade e precisão. Conforme já mencionado, o Inventário possui uma conotação de avaliação do potencial, enquanto a Viabilidade pretende justificar o empreendimento [6, 51, 55, 58].

Paralelamente à análise econômico-energética, são realizados estudos ambientais, destacando-se o Estudo de Impacto Ambiental (EIA) e o Relatório de Impacto Ambiental (RIMA) ${ }^{10}$. Também há o licenciamento ambiental, que define o acompanhamento sistemático das conseqüências ambientais da usina. Este processo desenvolve-se desde as etapas iniciais do planejamento e consiste de três licenças [81]:

\footnotetext{
${ }^{10} \mathrm{O}$ nome RIMA não retrata o conteúdo deste relatório, pois não se trata apenas de uma "análise ambiental", mas também de análises sócio-econômicas. Além disso, nem sempre o "impacto" de um projeto é negativo, como a denominação "impacto" parece sugerir. Um projeto de geração pode, por exemplo, desenvolver a economia da região de sua instalação e até mesmo melhorar a qualidade da água de um rio devido às necessidades de tratamento da usina.
} 
- Licença Prévia (LP): deve ser solicitada pelo empreendedor na fase preliminar do planejamento da atividade, tão logo seja definida a localização da usina;

- Licença de Instalação (LI): deve ser requerida antes da implantação do aproveitamento. Sua solicitação deve ser acompanhada do projeto detalhado do empreendimento e sua concessão implica o compromisso de manter as características finais compatíveis com as do projeto;

- Licença de Operação (LO): permite a entrada em operação da usina, sendo precedida por vistoria detalhada e uma série de testes dos equipamentos. A concessão da LO implica o compromisso da manutenção do bom funcionamento dos equipamentos e do programa de manutenção ambiental.

A próxima seção apresenta uma breve descrição dos benefícios energéticos proporcionados por uma usina hidroelétrica. 



\section{Breve Descrição dos Benefícios Energéticos}

Os benefícios energéticos relacionados a uma usina hidroelétrica resumem-se aos valores de Energia Firme, Energia Secundária e Ponta Garantida. Esta seção visa apresentar e descrever de forma bem genérica estes conceitos. Os procedimentos detalhados de cálculo dos benefícios energéticos são mostrados no Capítulo VI.

\subsection{Energia Firme}

Em uma usina hidroelétrica, o "combustível" utilizado para gerar energia resume-se basicamente à água que flui pelo rio. Como este recurso apresenta uma disponibilidade natural irregular, reservatórios são construídos para regularizar as vazões, garantindo a geração de energia elétrica de forma mais uniforme.

No entanto, como os reservatórios possuem capacidade limitada, em longos períodos de estiagem (seqüência de três ou quatro anos secos, por exemplo), a manutenção de níveis de geração acima dos proporcionados pelas vazões afluentes pode levar ao esvaziamento do sistema. Define-se a Energia Firme como sendo a geração média capaz de ser produzida por esse sistema durante a ocorrência do período mais severo de vazões afluentes observado no histórico, o Período Crítico.

Assim, o conceito de Energia Firme está diretamente relacionado à garantia de suprimento de um sistema hidroelétrico. Este conceito pode ser estendido às usinas, estabelecendo-se uma forma de rateio da Energia Firme do Sistema entre elas. Neste trabalho, adota-se como Energia Firme de uma usina, sua geração média ao longo do Período Crítico do sistema no qual ela se insere.

Normalmente, o valor de Energia Firme é expresso em $\overline{\mathrm{MW}}$. Por exemplo, a usina hidroelétrica de Emborcação possui uma Energia Firme de $485 \overline{\mathrm{MW}}$ [82], ou seja, ela pode gerar energia ininterruptamente, em média, a uma potência de $485 \mathrm{MW}$ mesmo nas condições mais severas de vazão afluente já verificadas no histórico. Como em condições mais favoráveis sua geração poderá ser maior que sua Energia Firme, pode-se contar com alta confiabilidade, com garantia de suprimento, que a usina de Emborcação gerará $485 \overline{\mathrm{MW}}$. Este é o valor que a empresa detentora da usina poderá contratar a longo prazo com seus clientes, já que ela pode garantir esta geração.

Embora a Energia Firme seja utilizada neste trabalho como critério de garantia de suprimento, ela já não vem mais desenvolvendo este papel no Setor Elétrico 
Brasileiro, sendo substituída pelo conceito probabilístico de Energia Assegurada. A Energia Assegurada é calculada utilizando-se várias séries sintéticas de energias afluentes (duas mil seqüências, por exemplo) e normalmente está vinculada a um índice explícito de confiabilidade. Por exemplo, dizer que a Energia Assegurada de Emborcação é $559 \overline{\mathrm{MW}}$ [82], com confiabilidade de 95\%, significa dizer que esta usina consegue atender a uma carga deste valor em $95 \%$ do tempo das simulações realizadas com as séries sintéticas.

Neste trabalho, utiliza-se o conceito de Energia Firme como energia garantida pela usina. A utilização deste conceito deve-se ao seu cálculo ser mais simples e bem mais rápido que o cálculo da Energia Assegurada, facilitando assim os estudos de dimensionamento. Além disso, o próprio cálculo da Energia Assegurada necessita dos valores de Energia Firme, fazendo com que os modelos de cálculo de Energia Firme ainda possuam uma importância elevada [82]. Finalmente, comparando os valores de Energia Firme e Energia Assegurada de alguns aproveitamentos, Figura 3.2, nota-se que as diferenças são relativamente pequenas, mostrando que a simplicidade do cálculo da Energia Firme não compromete os valores de garantia de suprimento das usinas hidroelétricas.

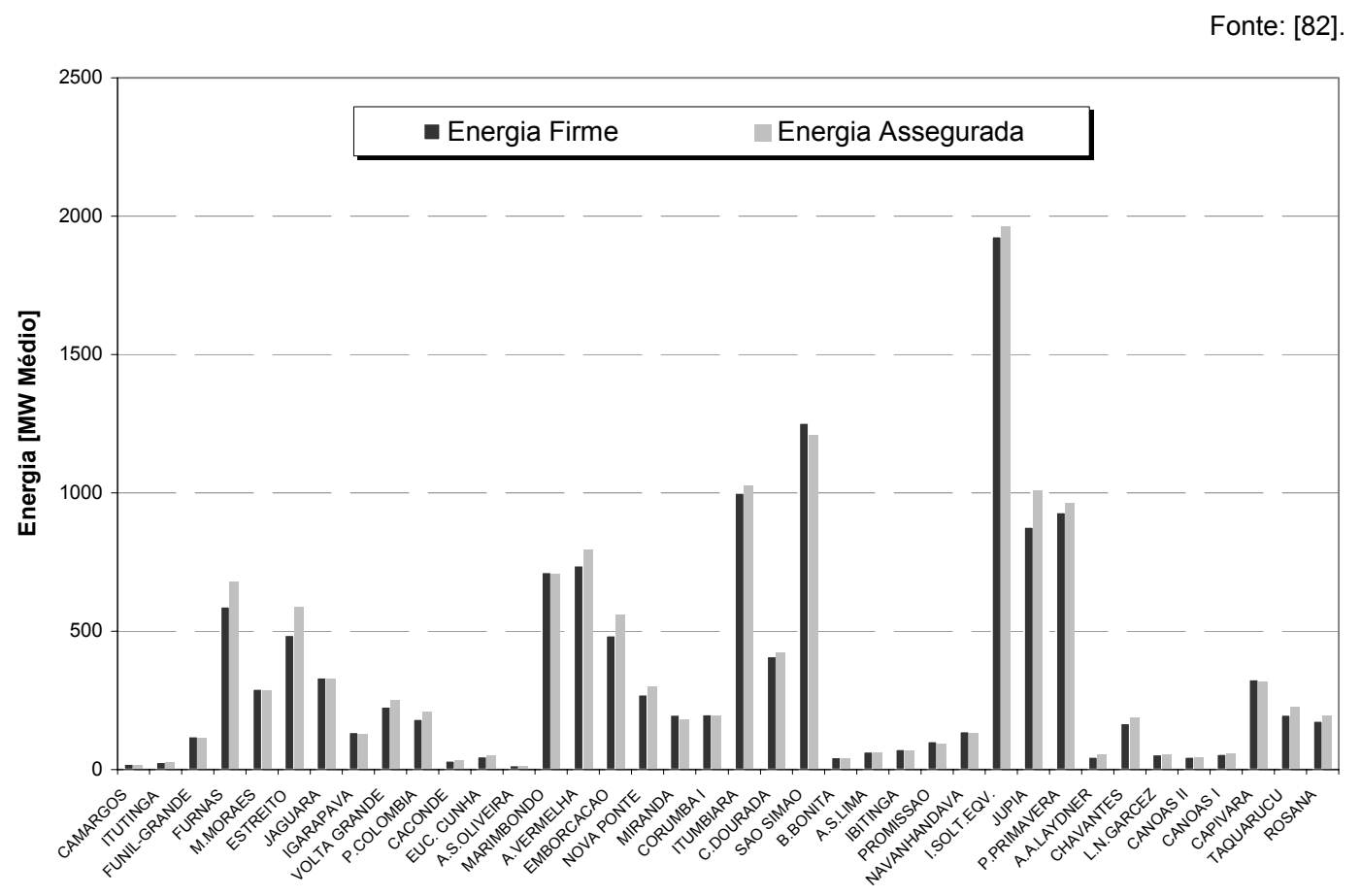

Figura 3.2 - Comparação entre as Energias Firme e Assegurada para alguns aproveitamentos. 


\subsection{Energia Secundária}

O conceito de Energia Secundária refere-se a uma energia que não possui mesmas garantias de suprimento da Energia Firme. Conforme observado, a Energia Firme refere-se à geração média que a usina pode proporcionar no período mais severo de vazões afluentes, o Período Crítico. No entanto, como na maioria do tempo as vazões afluentes são superiores às vazões do Período Crítico, a Geração Média ao longo de todo o histórico de vazões afluentes é maior que a Energia Firme. Por definição, a Energia Secundária é a diferença entre a Geração Média e a Energia Firme.

Assim, a Energia Secundária seria a energia disponível, em média, além da Energia Firme. Este valor médio deve ser analisado com cautela, uma vez que a disponibilidade de Energia Secundária varia sensivelmente ao longo do tempo. Nos períodos secos praticamente não há sobras de energia e, portanto, a Energia Secundária é nula. Nos períodos chuvosos há excesso de água e os valores de Energia Secundária são grandes. Além dessas variações sazonais, a intensidade anual de chuvas apresenta uma distribuição irregular, fazendo com os valores anuais de Energia Secundária sejam diferentes.

Devido a estas incertezas de disponibilidade, a Energia Secundária normalmente apresenta um valor econômico bem inferior ao da Energia Firme, caracterizando um benefício econômico marginal.

Para viabilizar a utilização da Energia Secundária, devem ser incentivados contratos entre geradores e grandes consumidores, de forma que seja oferecida uma energia a preço inferior ao da Energia Firme, porém com baixa garantia de suprimento, conhecida como energia interruptível.

Outra forma de utilizar a Energia Secundária é a implantação de um parque termoelétrico complementar. Por exemplo, supõe-se uma empresa de geração detentora de uma usina hidroelétrica com Energia Firme de $500 \overline{\mathrm{MW}}$ e Energia Secundária de $100 \overline{\mathrm{MW}}$. Para estabelecer contratos de longo prazo com seus clientes, o máximo valor contratável é $500 \overline{\mathrm{MW}}$ (Energia Firme). No entanto, se esta mesma empresa adquirisse um usina termoelétrica de $50 \mathrm{MW}$, sua energia contratável passaria a $550 \overline{\mathrm{MW}}$. Nos períodos de cheia, a empresa poderia utilizar a Energia Secundária para gerar a parte que caberia à usina termoelétrica, deixando-a desligada. Neste caso, diz-se que a usina termoelétrica "firmou" parte da Energia Secundária da usina hidroelétrica. 


\subsection{Ponta Garantida}

A operação de um sistema elétrico de potência pressupõe a existência de potência instalada suficiente para atender aos vários patamares de carga, bem como a situações operacionais especiais, como falhas de equipamentos ou restrições diversas. Isso implica que, durante os horários de pico de abastecimento, determinadas unidades geradores serão obrigadas a gerar energia a potências elevadas.

Esta geração a potências elevadas nem sempre é possível em uma usina hidroelétrica. A potência máxima que uma usina hidroelétrica pode gerar depende de sua queda líquida. Se o reservatório estiver cheio, a queda líquida é elevada e a potência máxima da usina também. No entanto, conforme o reservatório esvazia-se, a queda líquida reduz-se, e com ela a potência máxima que pode ser gerada. Estas variações da potência disponível fazem com que seja necessário o cálculo de um parâmetro que expresse o quanto de potência determinada usina pode fornecer na maior parte do tempo, ou ao menos nas piores situações operativas, com baixos níveis de armazenagem no reservatório. Este parâmetro da usina é chamado de Ponta ou Potência Garantida.

Para calcular a Ponta Garantida, utilizam-se estudos de simulação. Quando se realiza um estudo de simulação da operação da usina e determinam-se suas Energias Firme e Secundária, têm-se como resultados adicionais a queda líquida e a potência máxima ao longo de cada intervalo do estudo. Estes valores de potência máxima podem ser utilizados para calcular uma curva de permanência ao longo do Período Crítico, definindo-se a Ponta Garantida da usina como a potência máxima que pode ser garantida durante $95 \%$ deste período.

Uma das formas da Ponta Garantida traduzir-se em benefício econômico é o estabelecimento de um preço ("capacity fee") ao MW garantido das unidades geradoras [7]. As receitas oriundas desta taxa sobre a capacidade de ponta deveriam servir de incentivo para aumentar a capacidade disponível do sistema, evitando problemas futuros com o suprimento da demanda nos horários de carga máxima. Além disso, existem os ganhos decorrentes da modulação, onde as usinas podem alocar mais energia à ponta $\mathrm{e}$ valorizar seus contratos de acordo com estas características, resultando em um ganho financeiro. 


\section{Parâmetros de Dimensionamento Energético}

De forma geral, uma vez especificado o eixo da barragem de uma usina hidroelétrica, existem cinco parâmetros que definem seu dimensionamento energético [56, 59]: níveis máximo e mínimo de armazenagem (N.A.Max e N.A.Min, respectivamente), potência instalada e alturas de queda de referência e de projeto das turbinas. Estes parâmetros são detalhados a seguir.

\subsection{Nível Máximo de Armazenagem (N.A.Max)}

O N.A.Max corresponde ao nível máximo do espelho d'água do reservatório. Conforme pode ser observado na Figura 3.3, determinar o N.A.Max traduz-se em definir o volume máximo da usina, $x_{m a ́ x}$, pois quanto maior o volume armazenado, mais elevado o nível do espelho d'água.

A elevação do N.A.Max aumenta a capacidade de armazenagem do reservatório e a queda líquida da usina, proporcionando ganhos de Energia Firme, Energia Secundária e Potência Garantida. Por outro lado, elevam-se os custos de construção da barragem, vertedouro e estruturas principais, além de aumentar a área inundada pelo reservatório e, conseqüentemente, os gastos com aquisição de terras e relocações.

\subsection{Nível Mínimo de Armazenagem (N.A.Min)}

O N.A.Min é o nível mínimo do espelho d'água do reservatório para o qual a usina pode ser operada. Determinar o nível N.A.Min traduz-se em determinar o volume mínimo operativo da usina, $x_{\min }$.

De acordo com a Figura 3.3, dado um valor de N.A.Max, a redução do N.A.Min proporciona aumento de volume útil, $x_{\text {útil }}$, com conseqüente aumento da capacidade de regularização e Energia Firme. Em contrapartida, ao reduzir o N.A.Min, reduz-se a queda líquida média da usina e, conseqüentemente, a Ponta Garantida. Além disso, a redução do N.A.Min faz com que as turbinas passem a operar em faixas maiores de queda líquida, dificultando a operação com rendimento máximo.

$\mathrm{O}$ volume correspondente à diferença entre os níveis N.A.Max e N.A.Min, o volume útil da usina, determina a capacidade de regularização das vazões afluentes. Volumes úteis pequenos podem ser utilizados para regularizar vazões afluentes diárias ou semanais, enquanto volumes úteis grandes podem ser capazes de regularizar vazões mensais, anuais ou plurianuais. 
Em alguns casos, adota-se N.A.Min igual a N.A.Max e a usina passa a ser denominada usina a fio d'água. Isto pode ocorrer, por exemplo, quando a usina possui várias outras a sua montante; neste caso, a vazão afluente já se encontra regularizada, dispensando a utilização do próprio volume na regularização. Outros fatores podem fazer com que uma usina seja a fio d'água, tais como restrições ambientais, tamanho muito reduzido do reservatório e uso do lago para navegação ou recreação [69].

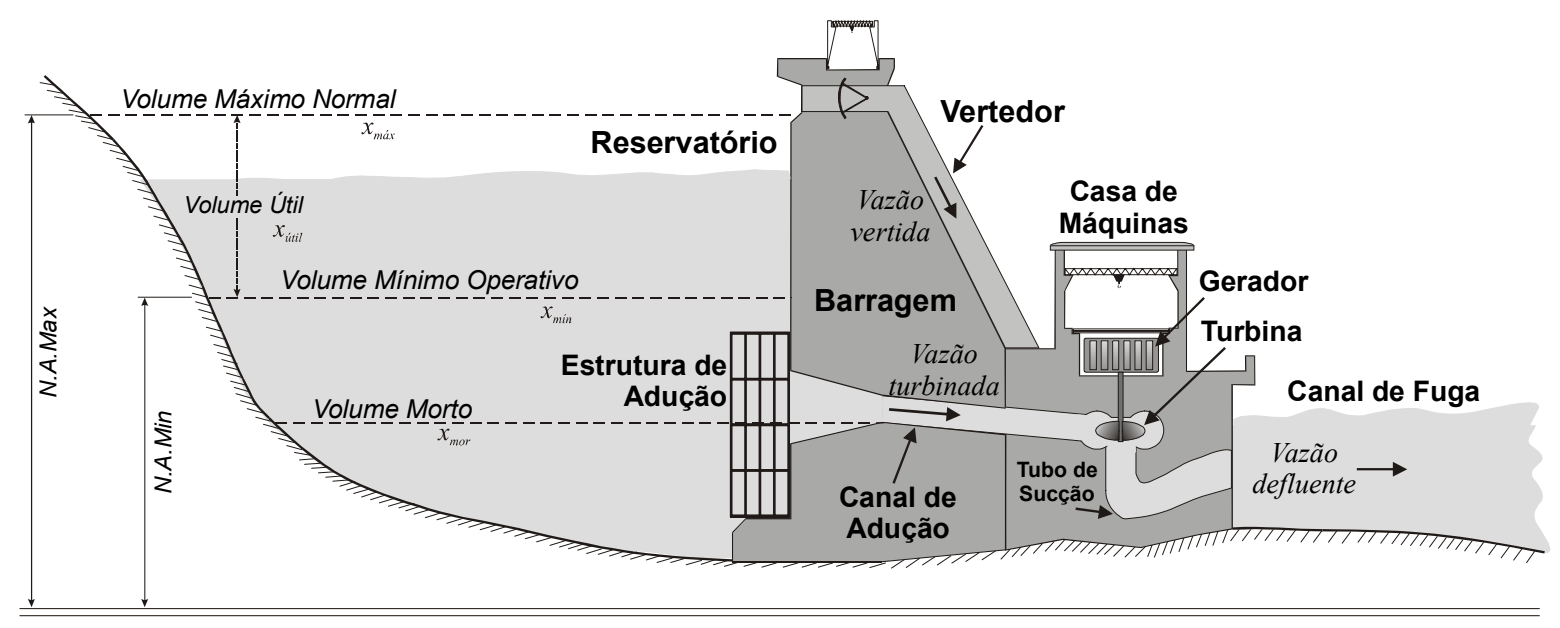

Figura 3.3 - Ilustração dos níveis de armazenagem máximo e mínimo.

\subsection{Potência Instalada}

A potência instalada é o nível de motorização da usina e, portanto, estabelece o limite superior para a quantidade de energia que pode ser gerada. A capacidade instalada total da usina, $p_{\text {nom }}$ em $M W$, é dividida em duas partes: capacidade instalada de base, $p_{\text {nom, }}$ em $M W$, e capacidade instalada de ponta, $p_{n o m, p}$ também em $M W$.

A capacidade instalada de base é definida como a mínima capacidade necessária para que a usina não apresente vazões vertidas ao longo do Período Crítico do sistema no qual ela vai ser inserida. Já a capacidade instalada de ponta traz somente benefícios de Energia Secundária e Ponta Garantida à usina. Estas grandezas relacionam-se através da seguinte equação:

$$
p_{\text {nom }}=p_{\text {nom }, b}+p_{\text {nom }, p}
$$

Aumentos de potência instalada alteram os benefícios da seguinte forma:

- Se durante o Período Crítico do sistema estiverem sendo observadas vazões vertidas na usina, ao elevar a potência instalada de base estas vazões poderão ser turbinadas, proporcionando ganhos de Energia Firme. O nível de motorização de 
base é definido como aquele que garante a inexistência de vazões vertidas ao longo do Período Crítico. A partir deste nível de motorização, a instalação de mais máquinas não aumentará a Energia Firme.

- Níveis de motorização superiores à de base são denotados por motorização de ponta. Incrementos da motorização de ponta fazem com que vazões históricas mais elevadas que as do Período Crítico, que seriam vertidas, possam ser turbinadas, proporcionando ganhos de Energia Secundária. Se o nível de motorização da usina já for suficiente para turbinar as vazões afluentes de todo o histórico, o que é praticamente impossível, a instalação de mais máquinas não alterará a Energia Secundária.

- A elevação do nível de motorização permite que a usina gere mais energia nos horários de pico, elevando sua Ponta Garantida.

Em contrapartida, aumentos de potência instalada implicam maiores gastos com a casa de força, estrutura de adução, turbinas, geradores, equipamentos auxiliares, transformadores e sistema de transmissão [54].

\subsection{Quedas de Referência e de Projeto das Turbinas}

As quedas da turbina determinadas durante o dimensionamento energético são as quedas de projeto e de referência. Para melhor entender estes parâmetros e suas implicações nos benefícios energéticos proporcionados por uma usina hidroelétrica, primeiro é feita uma breve descrição dos principais tipos de turbina e, na seqüência, explicam-se as conseqüências da escolha de diferentes valores de queda de projeto e queda de referência.

\subsubsection{Noções de Turbinas Hidráulicas}

As turbinas de uma usina hidroelétrica são responsáveis pela transformação da energia potencial da água em energia mecânica. Esta energia mecânica é então transferida, através de um eixo, a um gerador, onde é finalmente transformada em eletricidade.

Apesar da grande variedade de modelos disponível atualmente, a maioria das turbinas pode ser classificada em dois grupos principais: turbinas de reação e turbinas de ação. Em uma turbina de ação, o rotor é instalado em uma câmara que não é 
totalmente preenchida com água, onde jatos de água são direcionados contra palhetas ou conchas localizadas na periferia do rotor. A soma da ação dos jatos d'água sobre as palhetas gera o torque responsável pelo movimento rotativo do rotor. Sob o ponto de vista energético, a energia cinética da água é utilizada para produzir a energia mecânica que a turbina transfere ao gerador elétrico.

A mais clássica turbina de ação é a turbina Pelton, Figura 3.4, desenvolvida em 1880 por Lester Pelton, um engenheiro de minas do Estado de Ohio, Estados Unidos. Turbinas Pelton são utilizadas em usinas hidroelétricas com quedas variando de $200 \mathrm{~m}$ a $1.500 \mathrm{~m}$.

Uma turbina de reação converte ambas as energias potencial e cinética da água em energia mecânica. O rotor de uma turbina de reação fica alojado em uma câmara completamente preenchida com água. Na entrada desta câmara existem pás ajustáveis que aceleram e conduzem, em direções apropriadas, o fluxo de água até o rotor. $\mathrm{Na}$ Figura 3.5 e na Figura 3.7 são mostradas duas das mais famosas turbinas de reação.

A turbina Francis foi projetada e desenvolvida pelo inglês James Francis. Nesta turbina, a água do distribuidor é direcionada para a parte lateral e sai pela parte inferior; por causa desta característica, estas turbinas são chamadas de turbinas de reação de fluxo radial. As turbinas Francis trabalham com quedas variando de $20 \mathrm{~m}$ a $750 \mathrm{~m}$ e são as mais usadas em grandes usinas hidroelétricas.

A turbina Kaplan foi projetada na antiga Universidade Técnica Alemã de Brno, pelo professor Viktor Kaplan. Neste modelo, ao passar pelo distribuidor, a água é direcionada para fluir paralelamente ao eixo da turbina; por causa desta característica, turbinas Kaplan são também chamadas de turbinas de reação de fluxo axial. Este tipo de turbina trabalha com quedas inferiores a $70 \mathrm{~m}$.
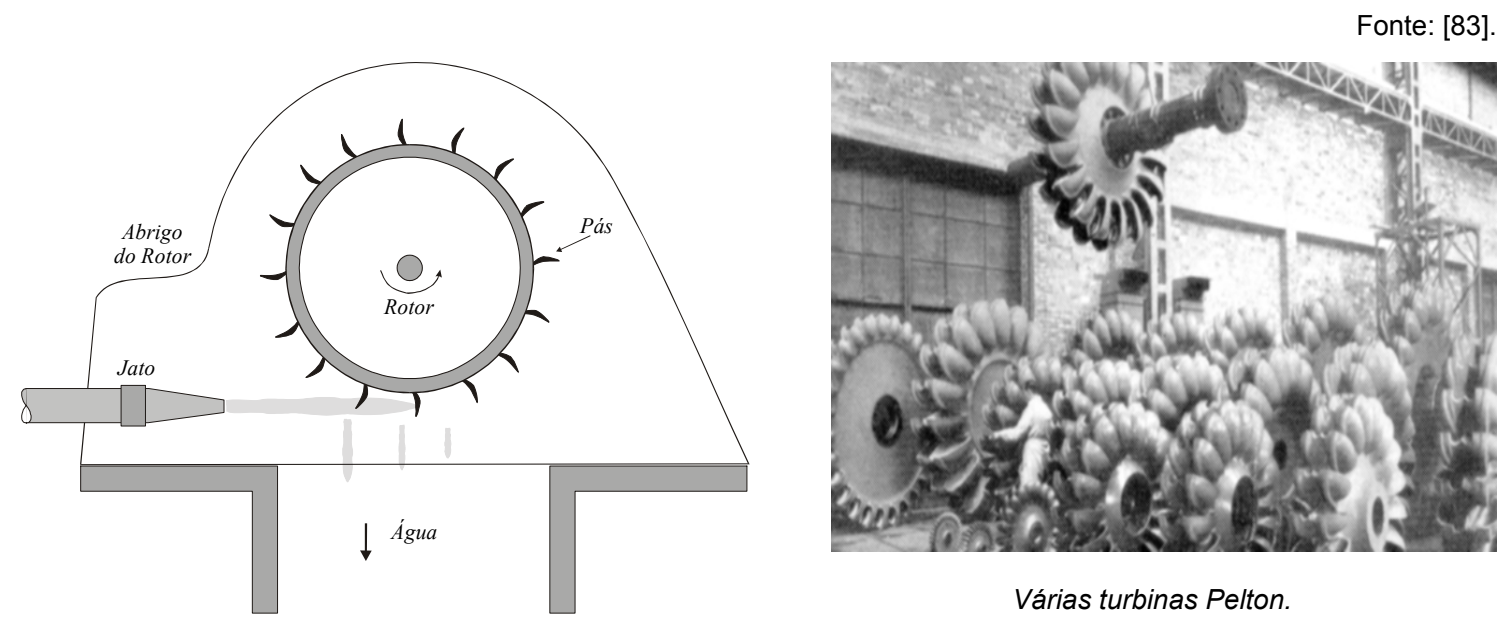

Figura 3.4 - Turbina Pelton. 


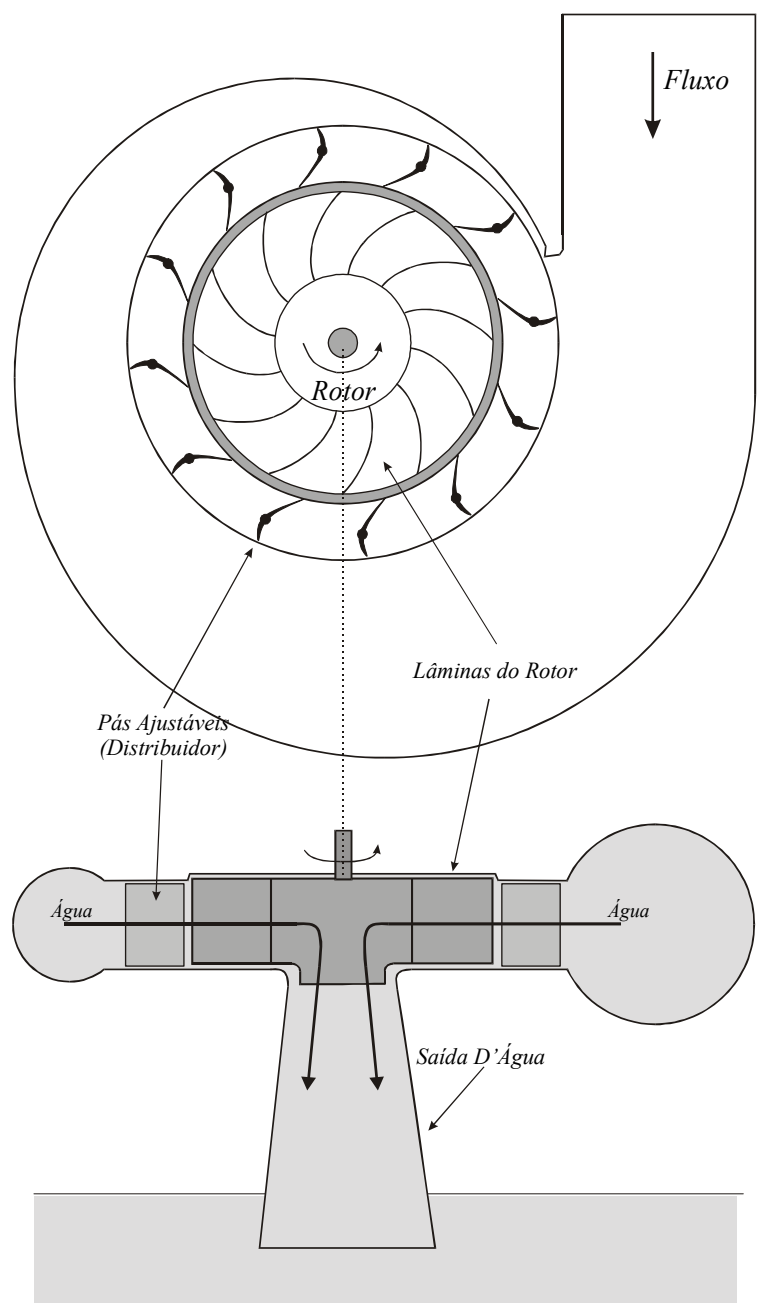

Fonte: [83].

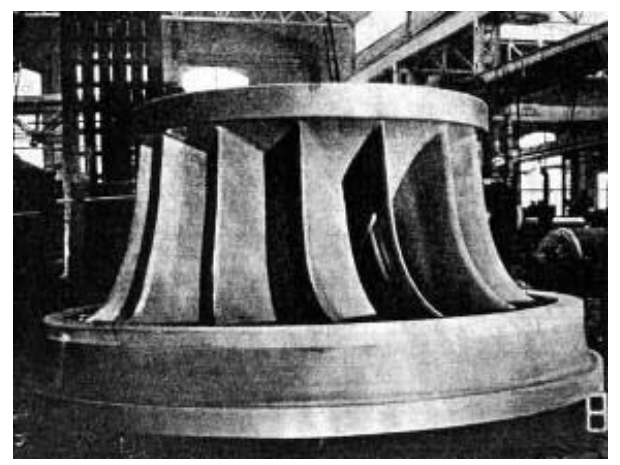

Turbina Francis.

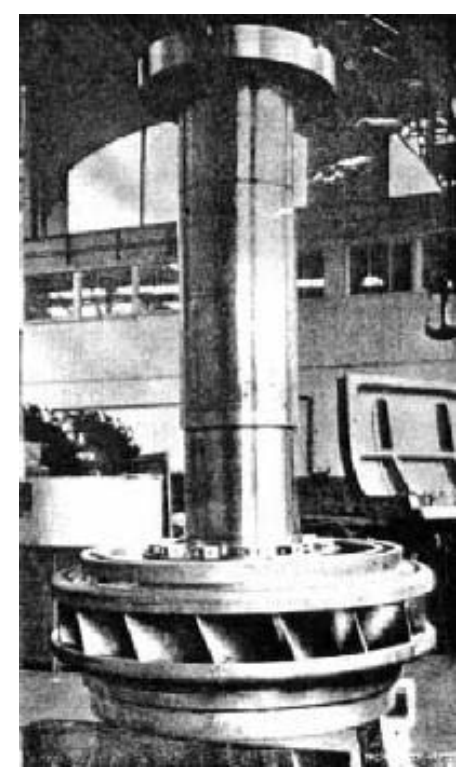

Turbina Francis com eixo de conexão ao gerador.

Figura 3.5 - Turbina Francis.

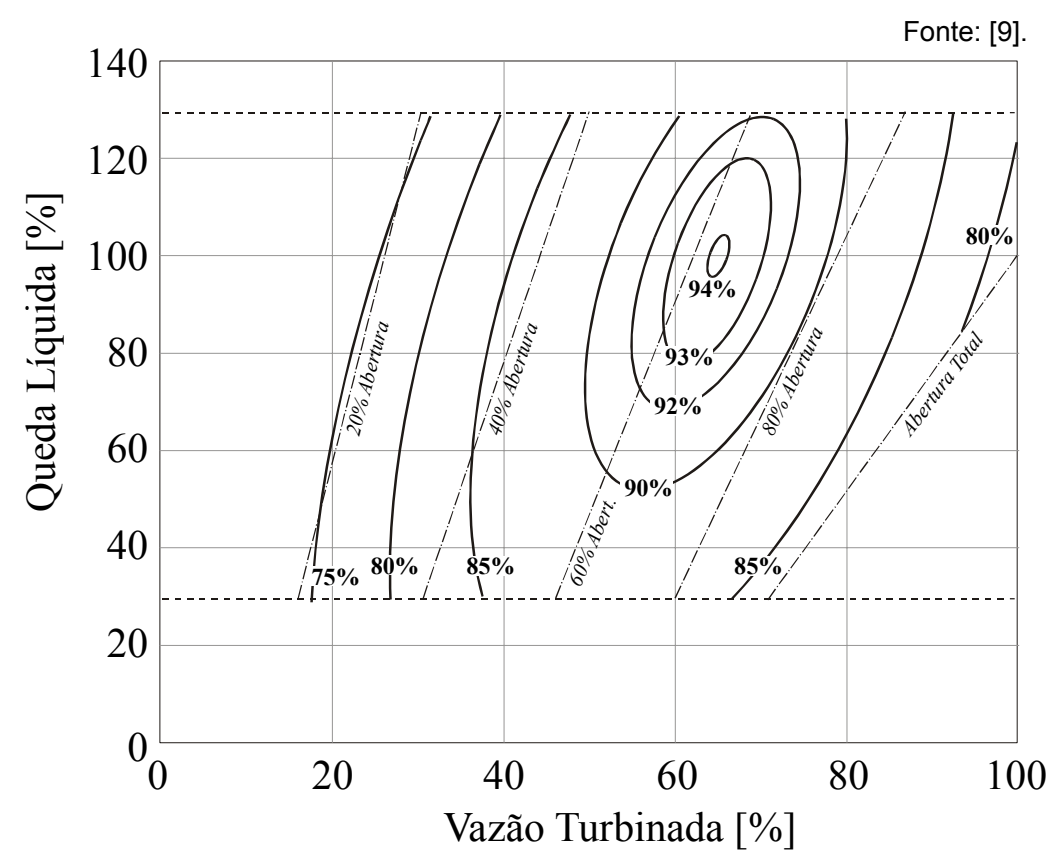

Figura 3.6 - Curva de rendimento de uma turbina Francis. 

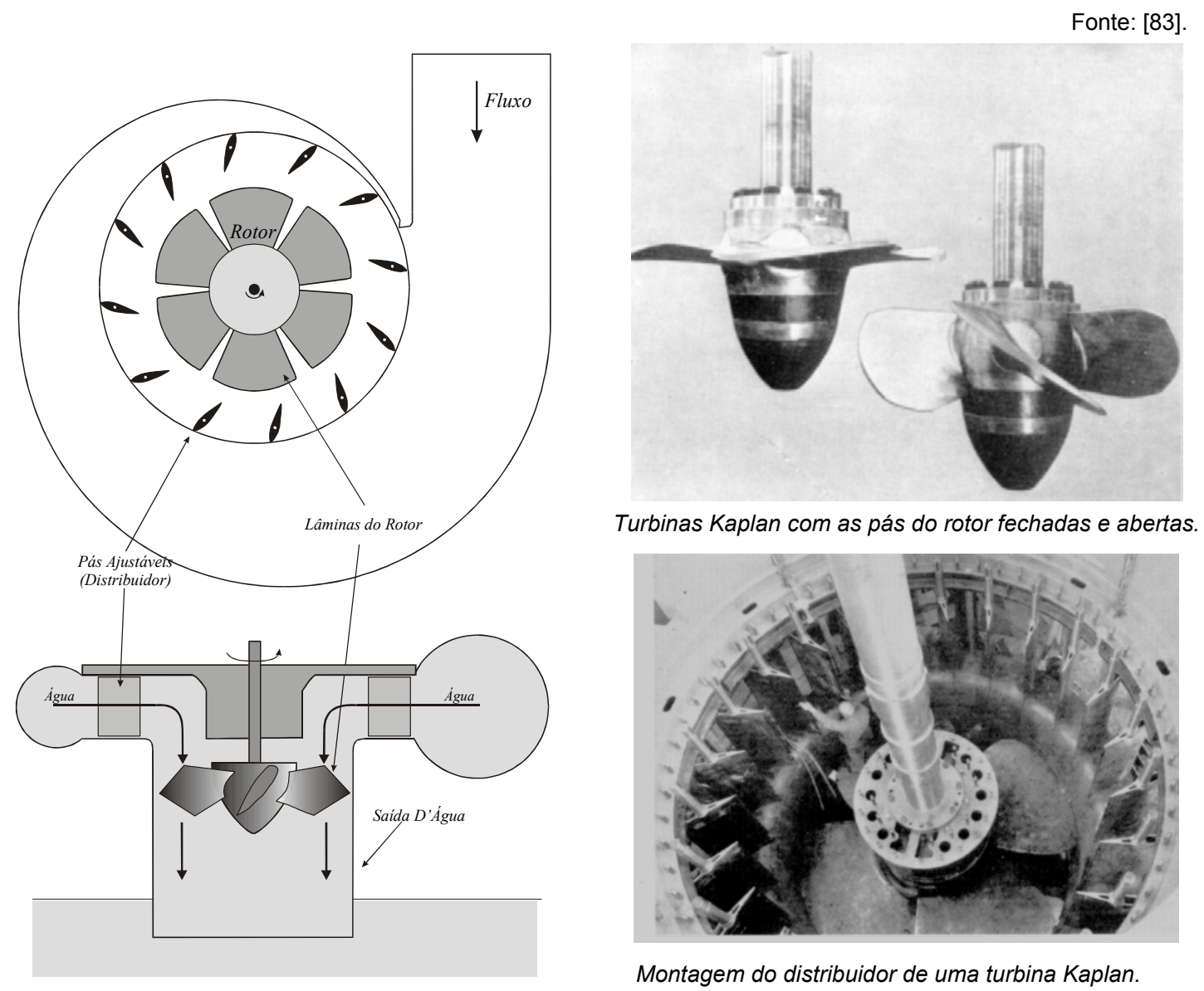

Montagem do distribuidor de uma turbina Kaplan.

Figura 3.7 - Turbina Kaplan.

\subsubsection{Queda de Projeto}

A eficiência de todos os tipos de turbina muda de acordo com as condições de operação, dependendo da vazão turbinada e da queda líquida. A relação entre estas grandezas normalmente pode ser expressa através de uma curva de rendimento, tal como a exemplificada na Figura 3.6. Os valores percentuais de queda e vazão são utilizados para facilitar a análise, as "aberturas" referem-se às pás do distribuidor e as curvas indicam situações de mesmo rendimento.

A queda de projeto é definida como a queda na qual a turbina apresenta eficiência máxima. Usualmente, deseja-se que a turbina apresente máxima eficiência, ou máximo rendimento, na altura de queda líquida na qual ela vai operar durante a maior parte do tempo. Para tanto, utilizam-se resultados de estudos de simulação e determinase o valor modal da distribuição dos valores de altura de queda líquida. Este valor corresponde à altura de queda mais freqüente e é utilizado como queda de projeto. 
Opcionalmente, pode-se calcular a queda de projeto através de uma média ponderada, multiplicando a queda líquida de cada intervalo de simulação pela respectiva geração no período:

$$
\text { Queda de projeto }=\frac{\sum(\text { Queda líquida } \cdot \text { Energia gerada })}{\sum \text { Energia gerada }}
$$

\subsubsection{Queda de Referência}

Quando a queda líquida de uma usina hidroelétrica é pequena, normalmente porque o reservatório está com reduzido volume de água armazenado, mesmo com o distribuidor completamente aberto, o fluxo de água não é suficiente para fazer a turbina suprir o gerador com uma potência igual à sua capacidade instalada. Neste caso, diz-se que a turbina está limitando a operação do conjunto turbina-gerador.

A mínima queda líquida para a qual a turbina, com o distribuidor totalmente aberto, consegue suprir o gerador com sua potência instalada é a chamada queda de referência. Durante a fase de projeto, a queda de referência é conhecida como queda nominal, $h_{n o m}$; após construção da usina, este parâmetro é aferido e o valor encontrado é chamado de queda efetiva, $h_{e f}$. A vazão que passa pela turbina quando ela está submetida à queda de referência e o distribuidor está totalmente aberto é chamada de vazão de referência; trata-se da máxima vazão que pode passar pela turbina. De forma semelhante à altura de queda, durante a fase de projeto a vazão de referência é chamada de engolimento nominal, $q_{\text {nom }}$, e após a usina ser construída é chamada de engolimento efetivo, $q_{e f}$.

Para quedas líquidas superiores à queda de referência, o distribuidor deve ser fechado para que a potência fornecida ao gerador não seja superior à potência instalada do mesmo, o que provocaria danos ${ }^{11}$. Nesta situação diz-se que o gerador limita a operação do conjunto turbina-gerador.

As relações entre altura de queda líquida, máxima vazão turbinada (ou engolimento máximo) e máxima potência gerada são ilustradas na Figura 3.8. Como este trecho do texto refere-se a estudos de dimensionamento, utilizam-se os valores nominais de queda e de engolimento.

\footnotetext{
11 A potência instalada do gerador é chamada de potência nominal, $p_{n o m}$, ou potência efetiva, $p_{e f}$, dependendo se a usina está em projeto ou já foi construída.
} 

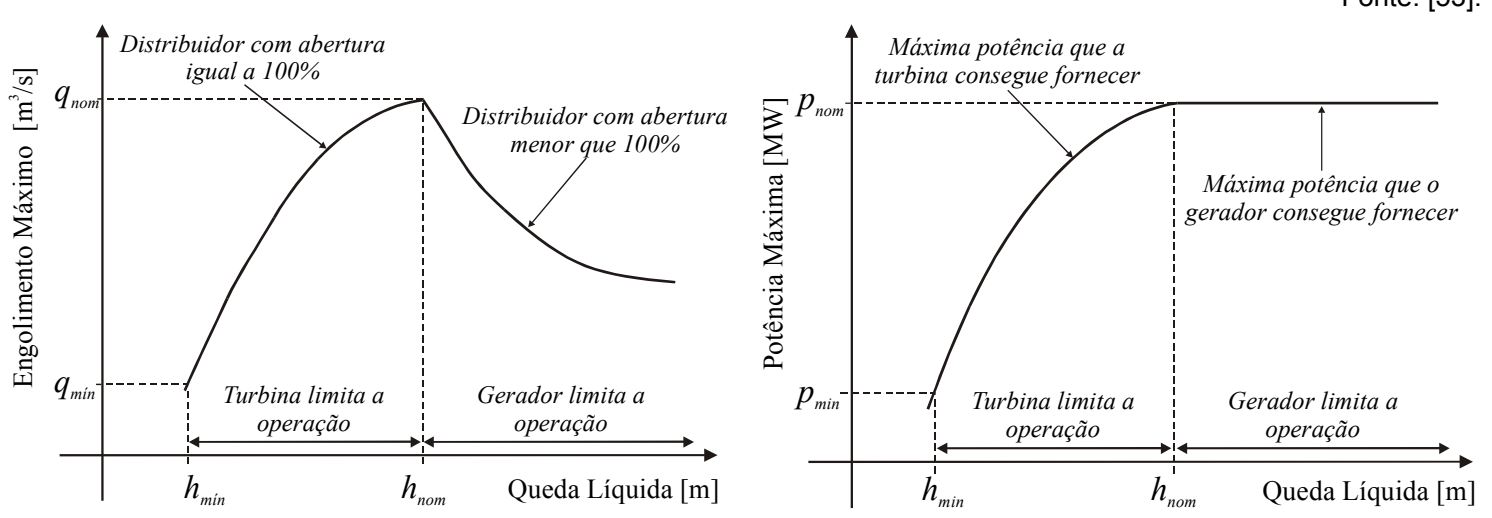

Figura 3.8 - Relação entre altura de queda efetiva, engolimento máximo e máxima potência gerada para um conjunto turbina-gerador.

De acordo com o que foi mostrado, a queda e a vazão de referência da turbina devem ser escolhidas de forma coerente com a potência instalada do gerador. Um exemplo vai ilustrar alguns dos compromissos envolvidos na escolha do ponto de referência da turbina ${ }^{12}$ [9].

Assume-se que um conjunto turbina-gerador esteja sendo dimensionado para operar em uma faixa de queda que varia de $100 m$ a $190 m$, com queda mais provável de $152 \mathrm{~m}$. Supõe-se que a turbina a ser instalada será do tipo Francis, com curva de rendimento igual à mostrada na Figura 3.10, queda de projeto igual a $152 \mathrm{~m}$, e características energéticas esquematicamente representadas na Figura 3.9. Deseja-se também que a turbina seja capaz de turbinar uma vazão mínima de $28,3 \mathrm{~m}^{3} / \mathrm{s}$ quando submetida à sua queda de projeto.

São consideradas três diferentes alturas de queda de referência: $100 \mathrm{~m}, 152 \mathrm{~m}$ e $190 \mathrm{~m}$. Poderiam ser utilizados quaisquer outros valores situados entre as queda mínima e máxima; no entanto, estes três valores serão suficientes para ilustrar o impacto da queda de referência sobre a operação da usina.

Inicialmente considera-se a queda de referência igual a $152 m$ (igual à queda de projeto), Figura 3.9 (a). Analisando o esquema, nota-se que a turbina produziria $36 \mathrm{MW}$ quando submetida à queda de $152 \mathrm{~m}$ com o distribuidor totalmente aberto, resultando em uma vazão de referência igual a $28,3 \mathrm{~m}^{3} / \mathrm{s}$. Para casar o gerador à turbina, a potência instalada seria $36 \mathrm{MW}$. Para quedas inferiores a $152 \mathrm{~m}$, a turbina limitaria a operação do conjunto e para quedas superiores a este valor o gerador imporia o limite superior de geração. As linhas tracejadas indicam potências que poderiam ser geradas, mas que não seriam devido aos limites do gerador.

\footnotetext{
${ }^{12}$ Por ponto de referência entende-se a altura de queda líquida e a vazão de referência.
} 
Se a queda de referência fosse $190 \mathrm{~m}$, Figura 3.9 (b), a potência do gerador seria 49,5 MW, com uma vazão de referência igual a $31,7 \mathrm{~m}^{3} / \mathrm{s}$. Nesta condição, garantiria-se que toda a capacidade da turbina seria utilizada, devido à possibilidade de vazões elevadas serem turbinadas quando a queda fosse grande. Para compatibilizar o gerador e a turbina, a potência instalada do gerador seria igual à máxima potência da turbina. Entretanto, nesta condição elevar-se-iam os custos do gerador, do transformador e dos equipamentos elétricos associados. $\mathrm{Na}$ maioria dos projetos, raramente verifica-se a ocorrência simultânea de altos valores de vazão e queda, o que normalmente não justifica economicamente a escolha de uma altura de queda de referência tão alta.

Por outro lado, se a queda de referência fosse $100 \mathrm{~m}$, Figura 3.9 (c), a potência do gerador seria $17,5 \mathrm{MW}$, com uma vazão de referência igual a $22,4 \mathrm{~m}^{3} / \mathrm{s}$. Utilizando estes valores, seria possível gerar a potência instalada do gerador para quaisquer valores possíveis de queda, fazendo com que a potência garantida da usina fosse igual à própria potência instalada. Entretanto, para a queda de projeto de $152 \mathrm{~m}$, a máxima vazão turbinada seria de apenas $13,6 \mathrm{~m}^{3} / \mathrm{s}$, bem abaixo dos $28,3 \mathrm{~m}^{3} / \mathrm{s}$ desejados. Para conseguir fazer com que a vazão turbinada fosse $28,3 \mathrm{~m}^{3} / \mathrm{s}$ com a queda de $100 \mathrm{~m}$, a potência instalada deveria ser $36,4 \mathrm{MW}$, o que seria possível se um rotor maior, com descarga de referência de $46,4 \mathrm{~m}^{3} / \mathrm{s}$, fosse instalado. Esta alteração de projeto elevaria os custos da turbina e de seu caracol, do canal de adução e do tubo de sucção, além das estruturas de adução e da casa de força.

Assim, o exemplo mostra que a adoção da queda de referência da turbina igual aos valores extremos de queda, mínimo ou máximo, não é usualmente desejável, principalmente se a altura de queda variar bastante durante a operação da usina. Quedas de referência próximas à altura de queda máxima superdimensionam o gerador, enquanto quedas de referência próximas à altura de queda mínima superdimensionam a turbina.

Além disso, a escolha de uma queda de referência próxima aos limites pode impor restrições operativas ao conjunto turbina gerador que limitam a operação da usina em condições de vazão normalmente encontradas na prática. 


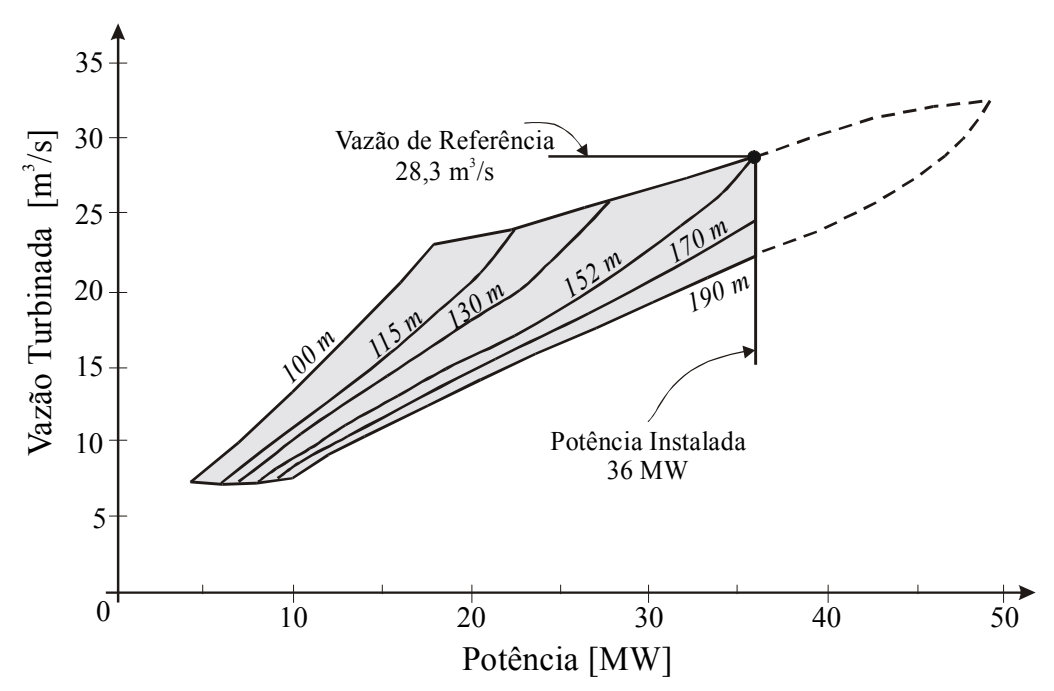

Fonte: [9].

(a) Queda de referência igual a $152 \mathrm{~m}$.

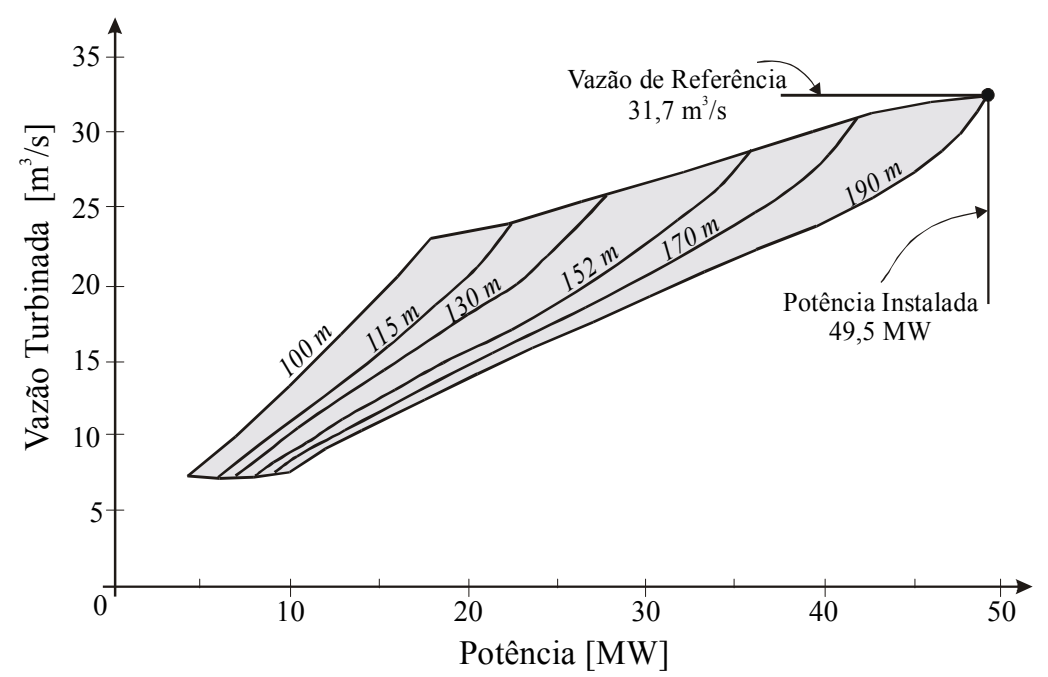

(b) Queda de referência igual a 190m.

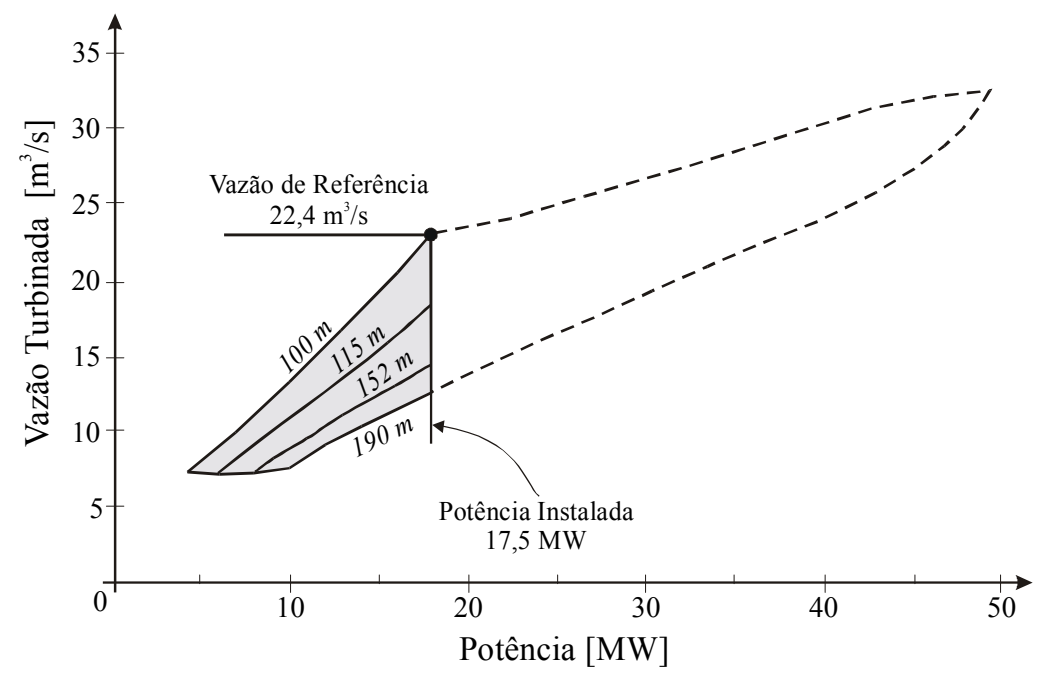

(c) Queda de referência igual a $100 \mathrm{~m}$.

Figura 3.9 - Impactos energéticos da escolha da queda de referência da turbina. 
Fonte: [9].

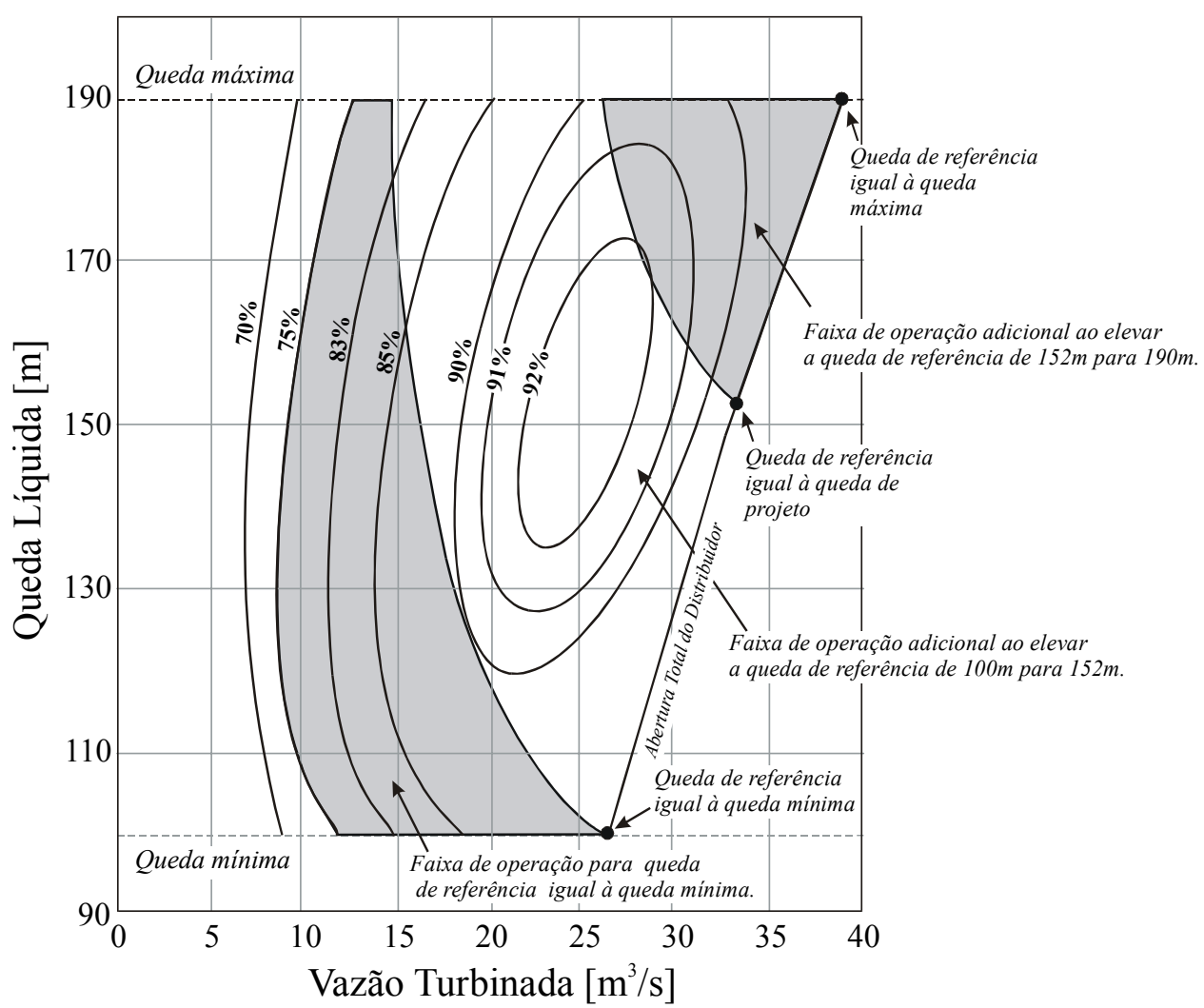

Figura 3.10 - Impactos da escolha da queda de referência da turbina sobre sua eficiência.

Finalmente, as limitações das faixas de operação do conjunto turbina-gerador impostas pela adoção da queda de referência determinam os valores de rendimento que a turbina vai poder operar. Observando a Figura 3.10, para a queda de referência igual a $100 \mathrm{~m}$, a turbina trabalharia apenas em regiões de baixo rendimento. Ao elevar a queda de referência para $152 \mathrm{~m}$, a faixa de operação aumentaria, permitindo inclusive a operação sob máxima eficiência. Ao elevar a queda de referência para $190 \mathrm{~m}$, a turbina ganharia mais uma faixa adicional de operação, podendo operar em todas as faixas de queda e de vazão.

Após identificar os parâmetros de dimensionamento energético, resta saber como defini-los de forma a otimizar o projeto de uma usina hidroelétrica. Esta tarefa é executada na próxima seção. 



\section{Determinação dos Parâmetros de Dimensionamento Energético}

Conforme já citado, de acordo com a abordagem normalmente adotada pelo Setor Elétrico Brasileiro, o princípio básico que norteia o dimensionamento de uma usina hidroelétrica é a busca por parâmetros de projeto que maximizem a diferença entre os benefícios e os custos do empreendimento [59].

O cálculo dos custos pode ser feito através de orçamentos, ainda que aproximados, para cada conjunto de parâmetros de dimensionamento que caracterizam uma usina hidroelétrica. Opcionalmente, podem ser utilizadas funções aproximadas que definam estimativas do custo do empreendimento para cada valor de N.A.Max, N.A.Min e potência instalada $[52,114]$.

O cálculo dos benefícios normalmente requer simulações computacionais da operação da usina [51]. Utilizando os resultados das simulações, os benefícios econômicos são determinados através da valorização dos benefícios energéticos que a usina proporciona. Assim, as formas como as simulações são realizadas e como os valores de energia são transformados em receitas financeiras determinam as características da usina sob dimensionamento.

Para explicar as formas como os benefícios energéticos podem ser interpretados, a influência dos estudos de simulação e algumas dificuldades inerentes à busca pelas dimensões ótimas da usina, foram elaboradas as próximas três subseções.

\section{Interpretação dos Benefícios Energéticos}

$O$ benefício energético que uma usina proporciona pode ser interpretado de diferentes formas sob os pontos de vista do sistema elétrico como um todo e de um empreendedor privado. Na realidade, não se trata exatamente de uma "interpretação", mas da alocação dos benefícios energéticos a jusante do aproveitamento.

Por exemplo, quando uma usina de cabeceira é construída, a regularização proporcionada pelo seu reservatório beneficia as usinas de jusante, elevando suas Energias Firmes. Sob o ponto de vista do sistema, é interessante maximizar o benefício global, isto é, a soma da Energia Firme da nova usina mais os incrementos de Energia Firme das usinas a jusante. No entanto, esta situação pode não ser a preferida, por exemplo, por um investidor privado, caso o benefício econômico de seu empreendimento refira-se apenas à sua Energia Firme, ou sejam, se não forem a ele alocados os benefícios incrementais de jusante. 
Na prática, em um sistema composto por várias usinas pertencentes a empresas diferentes, esta alocação de benefícios energéticos gera conflitos de interesses, os quais devem ser resolvidos pelo órgão regulador. Esta resolução deve estabelecer parâmetros energéticos mínimos para evitar a mutilação do potencial hidroenergético e, simultaneamente, alocar os benefícios energéticos para estimular a expansão.

Com o intuito de avaliar o impacto desta alocação de benefícios nas dimensões de um novo aproveitamento, definem-se duas formas de cálculo dos benefícios, ilustradas na seqüência.

\section{Benefício Energético Global (aloca ganhos de jusante à nova usina)}

O cálculo do benefício global de um empreendimento é ilustrado na Figura 3.11. Primeiro adota-se um Sistema de Referência (SR), definido como o sistema no qual a usina vai inserir-se quando começar a ser operada. Realiza-se então a simulação da operação deste sistema e calculam-se seus valores de Energia Firme, Energia Secundária e Ponta Garantida, denotados por $E F_{R}, E S_{R}$ e $P G_{R}$, respectivamente. Em seguida, adiciona-se a usina sob dimensionamento ao SR e simula-se a operação do Sistema Completo (SC), determinando seus valores de Energia Firme, Energia Secundária e Ponta Garantida, denotados por $E F_{C}, E S_{C}$ e $P G_{C}$. As diferenças entre os valores encontrados nas duas simulações caracterizam os benefícios energéticos proporcionados pela usina, denominados $B_{E F G}, B_{E S G}$ e $B_{P G G}$.

Este tipo de abordagem permite que a usina seja valorizada não apenas pela sua geração, mas também pelos ganhos que ela proporciona ao restante do sistema, regularizando melhor as vazões e permitindo que outras usinas se beneficiem [99].

\section{Benefício Energético Local (aloca ganhos de jusante às usinas de jusante)}

O cálculo dos benefícios ilustrado anteriormente (ponto de vista global) só será atraente para um empreendedor privado se ele puder se apropriar dos benefícios que a sua usina vai proporcionar às outras. Isso implica um sistema de remuneração que define para cada usina uma parcela devido à sua própria geração e outra devido ao ganho sistêmico que a usina promove. Entretanto, a parcela do ganho sistêmico não pode corresponder à valorização de todo o acréscimo de geração que a usina promove, já que as usinas que passam a gerar mais também deverão ser remuneradas por isso. Assim, deve haver uma metodologia de rateio do ganho sistêmico.

Para efeito de comparação das implicações da valorização entre os ganhos sistêmico e local, assume-se o caso extremo em que o empreendedor privado 
dimensiona seu empreendimento como se os benefícios econômicos correspondessem única e exclusivamente à valorização da energia gerada na própria usina. Neste caso, conforme ilustrado na Figura 3.12, simula-se a operação do Sistema Completo (SC), determinando os valores de Energia Firme, Energia Secundária e Ponta Garantida da própria usina sob dimensionamento, denotados por $E F_{U S D}, E S_{U S D}$ e $P G_{U S D}$, caracterizando assim os benefícios energéticos locais, denominados $B_{E F L}, B_{E S L}$ e $B_{P G L}$.

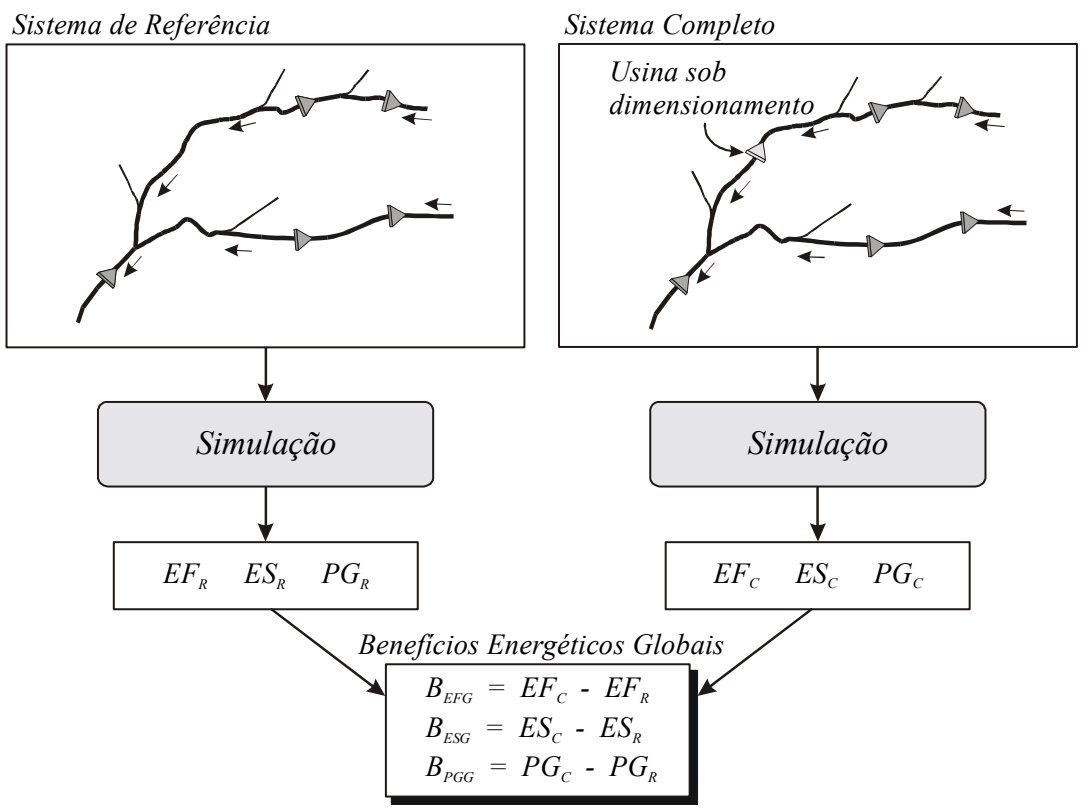

Figura 3.11 - Cálculo dos beneficios energéticos globais de uma usina hidroelétrica.

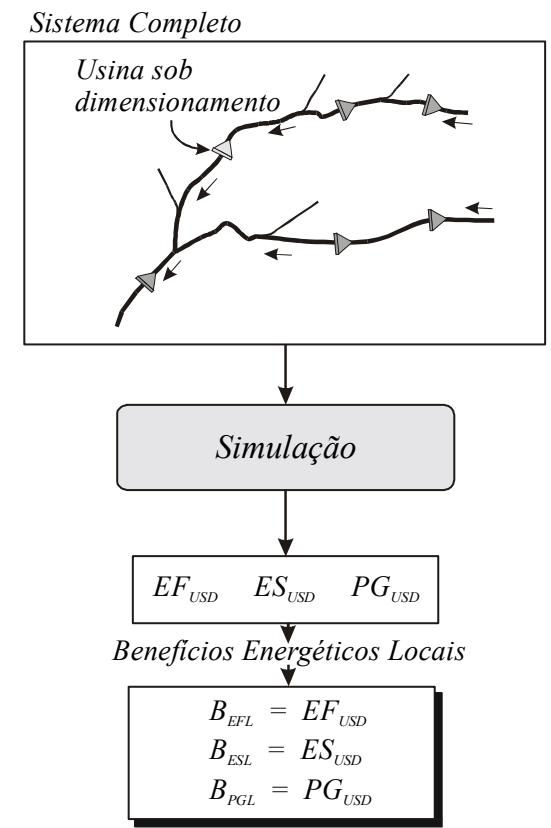

Figura 3.12 - Cálculo dos benefícios energéticos locais de uma usina hidroelétrica. 


\section{Dependência das Simulações}

Analisando o processo de dimensionamento, observa-se uma dependência direta entre o mesmo e os estudos de simulação, pois todos os cálculos dos benefícios energéticos são realizados por simuladores da operação das usinas. Esta dependência acaba fazendo com que o modelo de simulação adotado influencie de forma decisiva o dimensionamento ótimo de uma usina hidroelétrica.

Uma das características dos modelos de simulação que pode alterar sensivelmente os estudos de dimensionamento é a política de operação adotada, a qual define a participação de cada usina hidroelétrica no suprimento da carga total do sistema. Dependendo da política de operação, alteram-se os benefícios energéticos das usinas e, conseqüentemente, as dimensões ótimas dos aproveitamentos [99, 105].

Outro parâmetro que pode alterar significativamente os resultados dos estudos de simulação é o conjunto de vazões afluentes às usinas. Dependendo do período do histórico ou mesmo das séries sintéticas de vazões utilizadas, pode-se ter mais ou menos água disponível para a geração de eletricidade, determinando diferentes ganhos de Energia Firme, Energia Secundária e Ponta Garantida.

\section{Busca pelos Parâmetros de Dimensionamento}

Conforme já citado, uma das dificuldades encontradas no processo de dimensionamento é a forma como será realizada a busca por valores ótimos para os parâmetros, já que não há uma função analítica explícita para os benefícios energéticos; estes benefícios são medidos através de simulação. Por exemplo, ao especificar uma potência instalada de 1000MW a uma usina, não há como saber de forma direta o benefício proporcionado por este valor; primeiro deve-se realizar uma simulação da operação do Sistema Completo, para só então o benefício ser avaliado. Assim, valores para os conjuntos de parâmetros devem ser adotados, a respectiva simulação é realizada e medem-se os benefícios energéticos; com base nos resultados alteram-se os valores dos parâmetros e realiza-se outro estudo de simulação, até que valores "apropriados" sejam encontrados.

O problema reside justamente na dependência entre todos os parâmetros [37]. Não é possível, por exemplo, otimizar o valor de N.A.Max, depois N.A.Min e depois a potência instalada, pois os benefícios resultantes da definição de um determinado valor de potência instalada se alterarão em função da escolha de N.A.Max e N.A.Min. Da mesma forma, os benefícios decorrentes da adoção de diferentes N.A.Max serão diferentes se a potência instalada for alterada. 
Como os benefícios são medidos através de simulação, a dificuldade surge na definição de como alterar simultaneamente os valores de N.A.Max, N.A.Min e potência instalada para encontrar as melhores características de um aproveitamento. A resolução desta questão, conforme será visto, dá origem a vários métodos de dimensionamento.

Conforme observado nas subseções anteriores, existem vários parâmetros que podem alterar de forma decisiva o dimensionamento ótimo de uma usina hidroelétrica. Como já citado, o objetivo deste trabalho é justamente desenvolver um modelo que realize de forma automática a busca por valores ótimos dos parâmetros de dimensionamento de uma usina hidroelétrica. Além disso, este modelo deve ser suficientemente flexível para permitir que sejam realizadas análises de sensibilidade para determinar como os diversos fatores que alteram o processo de dimensionamento podem influenciar as características da usina em questão.

Para explicar o modelo desenvolvido, primeiro apresenta-se o modelo de dimensionamento utilizado pelo Setor Elétrico Brasileiro nos estudos de dimensionamento, depois mostram-se outros modelos divulgados na literatura especializada, e na seqüência propõe-se o modelo desenvolvido neste trabalho.

\subsection{Modelo Adotado pelo Setor Elétrico Brasileiro}

O dimensionamento de usinas hidroelétricas no Brasil tem sido feito através de uma série de modelos que foram unificados no Sistema de Inventário Hidroelétrico de Bacias Hidroelétricas (SINV) [58]. Este sistema tem como objetivo automatizar os métodos para execução dos estudos energéticos, econômicos e ambientais, além de permitir a comparação e a seleção de alternativas de divisão de quedas ${ }^{13}$.

Os estudos são iniciados através da escolha de um conjunto de locais onde seja conveniente a instalação de aproveitamentos hidroelétricos ou onde estes já existam. Estes locais são chamados de locais barráveis.

A cada local barrável associam-se os seguintes dados:

- Nome do rio onde o aproveitamento será instalado;

- Curva descrevendo o nível de montante do reservatório em função do volume d'água armazenado;

\footnotetext{
${ }^{13}$ Por alternativa de divisão de quedas entende-se um conjunto de usinas sob dimensionamento.
} 
- Curva descrevendo a área inundada pelo reservatório em função do nível de montante;

- Curva descrevendo o nível de jusante em função da vazão defluente da usina;

- Vazão defluente mínima, determinada para manter a qualidade da água e/ou níveis navegáveis a jusante do aproveitamento;

- Um posto que caracterize a vazão afluente natural;

- Coeficientes de evaporação;

- Informações sobre retiradas d'água a montante do aproveitamento para irrigação e outros usos d'água;

- Custos para implementação do projeto;

- Caracterização dos impactos ambientais através de componentes-síntese.

Os cálculos energéticos são realizados em relação a um Sistema de Referência, no qual é considerada a inserção de uma alternativa de divisão de quedas. Desta forma, os benefícios calculados referem-se a um conjunto de aproveitamentos e pretende-se determinar simultaneamente as dimensões mais apropriadas para todos os projetos.

Durante a fase de inventário, o modelo considera como benefício energético apenas a Energia Firme como variável de decisão, sem valorizar a Energia Secundária e contabilizando apenas de forma implícita os ganhos de Ponta Garantida [37].

A energia secundária não é considerada porque, segundo [58], a incerteza quanto à sua utilização efetiva é muito grande ${ }^{14}$. Ainda de acordo com [58], a inclusão explícita dos benefícios de ponta durante a fase de inventário não se justifica porque a disponibilidade de ponta depende apenas da motorização. Adota-se um fator de capacidade de referência comum a todos os projetos de uma alternativa de dimensionamento, pretendo-se garantir um tratamento homogêneo entre os projetos.

O Sistema SINV determina os níveis máximo e mínimo de operação do reservatório, a potência instalada, a vazão nominal e a queda de referência das turbinas. A determinação de cada parâmetro é feita da seguinte forma [37]:

\section{N.A.Max}

O nível máximo de operação não é submetido a processo de otimização pelo SINV, sendo fixado na definição do aproveitamento. 
N.A.Min

O nível mínimo é determinado através de otimização, sendo definido como o nível mínimo que apresenta o maior ganho de Energia Firme ao Sistema de Referência.

\section{Queda de Referência}

Adota-se como queda de referência a queda líquida máxima do aproveitamento, definida como a queda calculada quando o reservatório está no seu nível máximo normal e o nível de jusante é igual ao nível observado para uma vazão $10 \%$ maior que a vazão média ao longo do período crítico. Caso haja efeito de remanso, considera-se o nível do reservatório de jusante.

\section{Potência Instalada}

Conforme já citado, o dimensionamento da potência instalada é feito considerando um mesmo fator de capacidade de referência para todos os aproveitamentos. Partindo-se do pressuposto que a Energia Firme é conhecida, primeiro determina-se a potência de referência e depois a potência instalada. Os cálculos são realizados da seguinte forma:

$$
\begin{aligned}
& p_{\text {ref }}=\frac{E F}{f_{c a p_{r e f}}} \\
& p_{\text {inst }}=p_{\text {ref }} \cdot\left(\frac{h_{\text {máx }}}{h_{\text {méd }}}\right)^{\alpha}
\end{aligned}
$$

nas quais:

- $\quad p_{\text {ref }}$ : potência de referência do aproveitamento, em $M W$;

- $E F$ : energia firme do aproveitamento, $\overline{\mathrm{MW}}$;

- $\quad f_{c a p}$ ref fator de capacidade de referência, adimensional;

- $\quad p_{\text {inst }}$ : potência instalada do aproveitamento, em $M W$;

- $h_{\text {máx }}$ : altura de queda líquida máxima do aproveitamento, em $m$;

- $\quad h_{\text {méd }}$ : altura de queda líquida média do aproveitamento, em $m$;

- $\alpha$ : coeficiente que depende do tipo de turbina (1,2 para turbinas Kaplan e 1,5 para turbinas Francis ou Pelton).

\footnotetext{
14 Atualmente a energia secundária tem sido valorizada, já que ela pode ser vendida no mercado atacadista de energia, sendo valorizada de acordo com as condições de mercado (preço spot).
} 


\section{Vazão Nominal}

Após a definição da queda de referência e da potência instalada de um aproveitamento, a vazão nominal das turbinas é obtida da seguinte forma:

$$
q_{\text {nom }}=\frac{p_{\text {inst }}}{9,81 \cdot 10^{-6} \cdot h_{\text {nom }} \cdot \eta}
$$

na qual:

- $q_{\text {nom }}$ : vazão nominal das turbinas, em $\mathrm{m}^{3} / \mathrm{s}$;

- $\quad p_{\text {inst }}$ : potência instalada do aproveitamento, em $M W$;

- $h_{\text {nom }}$ : altura de referência nominal das turbinas, em $m$;

- $\quad \eta$ : rendimento médio do conjunto turbina-gerador.

O dimensionamento energético de uma usina hidroelétrica pelo SINV é feito através do seguinte algoritmo [37]:

\section{Fase 1 - Iniciação}

Durante esta fase são utilizados procedimentos aproximados que não fazem uso de simulação. Os dados são compostos por estimativas dos níveis mínimo e máximo de armazenagem, rendimentos do conjunto turbina-gerador e tipos de turbina.

Supõe-se que as vazões naturais da bacia ao longo do Período Crítico serão completamente aproveitadas, acrescidas dos volumes úteis dos reservatórios, descontadas as perdas por evaporação e as retiradas para outros usos d'água.

O algoritmo de otimização do volume útil, apresentado após a Fase 4, é utilizado para dimensionar as quedas de referência, as potências instaladas e as depleções máximas de cada aproveitamento de cada alternativa de divisão de quedas.

Quando um aproveitamento pertence a mais de uma alternativa de divisão de quedas, ele possui mais de um valor para cada um de seus parâmetros de dimensionamento. Nestes casos, faz-se a queda de referência igual à menor queda de referência encontrada, enquanto a máxima depleção e a potência instalada são adotadas como iguais a seus respectivos valores máximos.

\section{Fase 2-Dimensionamento da Queda de Referência}

O dimensionamento da queda de referência é feito de forma iterativa para que possam ser consideradas as alterações nas depleções máximas, nas potências instaladas e nas próprias quedas de referência. 
No primeiro passo consideram-se as quedas de referência e as potências instaladas obtidas na Fase 1. O algoritmo de otimização do volume útil é aplicado a todas as alternativas analisadas, obtendo a depleção máxima de cada reservatório em cada alternativa, bem como as quedas de referência e as potências instaladas. Com os mesmos critérios de valores máximo e mínimo utilizados na Fase 1, determinam-se os valores dos parâmetros de cada dimensionamento. O processo é repetido três vezes.

\section{Fase 3 -Dimensionamento da Depleção Máxima}

Nesta fase consideram-se conhecidas as quedas de referência, adotando-se os valores resultantes da Fase 2, e realiza-se um processo iterativo para considerar a influência da potência instalada.

No primeiro passo as potências instaladas são consideradas iguais aos valores obtidos na Fase 2. Utilizando novamente o algoritmo de otimização do volume útil aplicado a todas as alternativas de divisão de queda, calcula-se a potência instalada de cada aproveitamento pelo maior valor.

O processo é refeito com os novos valores encontrados. Após quatro iterações, a depleção máxima obtida para cada aproveitamento é o valor final deste parâmetro e a respectiva potência instalada corresponde a uma estimativa inicial para a Fase 4.

\section{Fase 4 - Dimensionamento da Potência Instalada}

Nesta fase adotam-se as quedas de referência obtidas na Fase 2 e as depleções máximas da Fase 3. Utilizando estes valores, aplica-se novamente um processo iterativo para avaliar a influência da potência instalada sobre seu próprio dimensionamento.

No primeiro passo, as potências instaladas são consideradas iguais aos valores encontrados no final da Fase 3. As alternativas de divisão de quedas são novamente simuladas, obtendo-se as potências instaladas de cada aproveitamento em cada alternativa. A potência instalada de cada aproveitamento é então feita igual ao maior valor encontrado nas simulações de todas as alternativas de queda.

O processo é refeito utilizando como valores iniciais os que acabaram de ser determinados. São realizadas três iterações e ao final têm-se as potências instaladas de cada aproveitamento.

\section{Algoritmo de Otimização do Volume Útil}

Esta função determina os volumes úteis dos aproveitamentos de uma alternativa de divisão de quedas. Inicialmente estabelece-se que a depleção máxima de cada 
aproveitamento de uma alternativa de divisão de quedas será igual a um terço de sua queda bruta máxima e, através de cálculo aproximado ou por simulação, determina-se a Energia Firme da alternativa. Eleva-se então o N.A.Min do último reservatório de jusante e recalcula-se a Energia Firme. Se esta alteração aumentar o benefício energético, é feita nova elevação, seguida de nova simulação. Determinado o volume útil do último reservatório de jusante, o processo é repetido para o penúltimo, para o antepenúltimo, e assim sucessivamente até o reservatório mais a montante da alternativa de divisão de quedas.

O processo completo é repetido mais três vezes, reiniciando-se sempre do último reservatório a jusante. $\mathrm{Na}$ Fase 1 utilizam-se cálculos simplificados para cálculo da energia firme, enquanto nas outras são realizados estudos de simulação.

Os parâmetros determinados através do processo iterativo acima são otimizados para maximizar o benefício energético de Energia Firme das alternativas de divisão de quedas. No entanto, os aproveitamentos são escolhidos de acordo com critérios econômicos, através de índices Custo/Benefício. Para cada alternativa há um custo associado a cada projeto e um ganho energético devido à sua construção. O modo como estes índices são calculados é explicado a seguir [58].

\subsubsection{Valorização Econômica}

A valorização econômica de um aproveitamento hidroelétrico corresponde às receitas devido à venda de energia que a usina proporcionará quando entrar em operação. Para tanto, podem ser valorizados de forma diferenciada a Energia Firme, a Energia Secundária e a Potência Garantida ${ }^{15}$.

Durante a valorização econômica normalmente são utilizados custos de referência, balizados pelo custo marginal de expansão do sistema. Este custo é um indicador macroeconômico muito importante, já que sinaliza quando determinadas fontes primárias de geração de energia ou mesmo empreendimentos específicos serão competitivos e poderão ser incorporados ao parque gerador [57].

Para desempenhar este papel estratégico, o custo marginal de expansão deve considerar a evolução de longo prazo do parque gerador, prevendo como será a participação das diferentes fontes primárias na geração de energia e quais serão os

\footnotetext{
${ }^{15}$ Embora o SINV valorize apenas a Energia Firme, outros modelos podem valorizar explicitamente a Energia Secundária e a Potência Garantida.
} 
empreendimentos construídos. No caso brasileiro, os estudos de longo prazo envolvem cenários econômicos e energéticos definidos entre o $10^{\circ}$ e o $25^{\circ}$ ano do horizonte de estudos de expansão da geração. Os custos marginais de expansão são calculados para cada qüinqüênio, gerando assim uma série de valores crescentes. $\mathrm{O}$ valor presente desta série de custos qüinqüenais corresponde ao custo de referência para dimensionamento de usinas hidroelétricas, refletindo as variações do custo da energia ao longo do tempo.

A Energia Firme pode ser valorizada de acordo com o Custo Unitário de Referência de Energia (CRE). O CRE, expresso em US\$/MWh, é o valor a partir do qual a contribuição de Energia Firme de uma usina hidroelétrica ou alternativa de divisão de quedas deixa de ser economicamente competitiva com outras fontes de energia. O CRE corresponde ao custo de produção de energia de uma fonte alternativa num horizonte de longo prazo do Sistema de Referência.

A Energia Secundária costumava ser valorizada pelo custo de geração térmica esperada do sistema e por custos de combustíveis fornecidos pela Eletrobrás [34]. Esta abordagem era utilizada quando o sistema operava de forma centralizada, na qual a energia gerada nos períodos de vazões elevadas era utilizada para reduzir a geração termoelétrica. No novo cenário do Setor Elétrico, a Energia Secundária pode ser avaliada como o benefício econômico advindo da venda da energia gerada acima da energia assegurada da usina. Neste contexto, o valor de venda da Energia Secundária pode ser estimado, por exemplo, como o valor esperado do custo marginal de operação para os meses em que há energia secundária.

A Potência Garantida é valorizada pelo Custo Unitário de Referência de Ponta (CIP). O CIP, expresso em US\$/kW/ano, é o valor a partir do qual o benefício de motorização adicional de usinas hidroelétricas deixa de ser economicamente competitivo. Corresponde ao custo de instalação de ponta de uma fonte alternativa de geração num horizonte de longo prazo do Sistema de Referência.

Tem-se ainda a valorização da combinação de energia e ponta, dada pelo Custo Unitário de Referência (CUR), expresso em US\$/MWh. O CUR representa o valor acima do qual a contribuição energética das usinas deixa de ser economicamente competitiva. O CUR corresponde ao custo de longo prazo no sistema de referência para a produção de energia a um fator de capacidade de referência $f$ cap ${ }_{\text {ref, }}$, resultante da combinação da fonte alternativa de energia e da fonte alternativa de ponta. O CUR é calculado da seguinte forma: 


$$
C U R=C R E+\frac{C I P}{8,76 \cdot f c a p_{\text {ref }}}
$$

na qual:

- $\quad C U R$ : custo unitário de referência, em $U S \$ / M W h$;

- $C R E$ : custo unitário de referência de energia, em $U S \$ / M W h$;

- $C I P$ : custo unitário de referência de ponta, em US\$/kw/ano;

- $f_{c a p}$ ref fator de capacidade de referência, adimensional.

Note que o CUR considera de forma implícita a valorização do atendimento à ponta do sistema.

\subsection{2 Índice Custo/Benefício de um Aproveitamento}

O índice custo/benefício de um aproveitamento de uma alternativa de divisão de quedas é medido pelo acréscimo de Energia Firme do Sistema de Referência proporcionado pela adição do aproveitamento após a construção das outras usinas da alternativa. Este valor é chamado de ganho de Energia Firme de última adição.

O índice custo/benefício é definido como a razão entre o custo total anual do aproveitamento e o seu benefício energético:

$$
I_{C B, i}=\frac{C T_{i}}{8760 \cdot \Delta E F_{i}}
$$

na qual:

- $\quad I_{C B, i}$ : índice custo/benefício da usina $i$, em $U S \$ / M W h$;

- $\quad C T_{i}$ : custo total anual da usina $i$, em US\$;

- $\Delta E F_{i}$ : acréscimo de energia firme do sistema de referência proporcionado pela usina $i$ em última adição, em $\overline{\mathrm{MW}}$.

O custo total anual da usina $i, C T_{i}$, é calculado pela soma do custo de implantação do aproveitamento transformado em receitas anuais e do custo anual de operação e manutenção:

$$
\begin{aligned}
& C T_{i}=C_{i} \cdot \operatorname{FRC}\left(t_{d}, T_{U}\right)+10^{3} \cdot \operatorname{COM}_{i} \\
& \operatorname{FRC}\left(t_{d}, T_{U}\right)=\frac{\left(1+t_{d}\right)^{T_{U}} \cdot t_{d}}{\left(1+t_{d}\right)^{T_{U}}-1}
\end{aligned}
$$

nas quais: 
- $C_{i}$ : custo de implantação da usina $i$, incluindo juros durante a construção, em US\$;

- $F R C\left(t_{d}, T_{U}\right)$ : fator de recuperação de capital a uma taxa de desconto anual $t_{d}$, ao longo da vida útil do aproveitamento $T_{U}$, em anos;

- $C O M_{i}$ : custo anual de operação e manutenção do aproveitamento $i$, em $10^{3}$ US\$/ano, estimado como uma função da potência instalada da usina através da seguinte expressão [52]:

$$
C O M_{i}=a \cdot p_{\text {inst }, i}^{b+1}, \text { tal que }\left\{\begin{array}{l}
a=118,94 \text { e } b=-0,6064, \text { para } p_{\text {inst }, i} \leq 146,71 M W \\
a=10,94 \text { e } b=-0,1281, \text { para } p_{\text {inst }, i}>146,71 M W
\end{array}\right.
$$

- $\quad p_{\text {inst }, i}$ : potência instalada da usina $i$, em MW.

A comparação de alternativas de divisão de quedas é realizada de forma similar, utilizando um índice custo/benefício para a alternativa.

\subsection{3 Índice Custo/Benefício de uma Alternativa}

O benefício energético de uma alternativa de divisão de quedas é medido pelo acréscimo de Energia Firme que esta alternativa traz ao sistema de referência no qual ela é inserida. O índice custo/benefício da alternativa é definido como a razão entre o custo anual total dos aproveitamentos e o benefício energético total.

Como a cada alternativa de divisão de quedas pode corresponder um ganho de Energia Firme diferente, as comparações entre as alternativas são realizadas de forma relativa. Complementa-se a produção associada a cada alternativa em relação à de maior benefício energético, valorizando-se esta diferença com o Custo Unitário de Referência.

Assim, o índice custo/benefício de cada alternativa é calculado como:

$$
I_{C B, a}=\frac{C T_{a}+8760 \cdot C U R \cdot\left(\Delta E F_{a}^{*}-\Delta E F_{a}\right)}{8760 \cdot \Delta E F_{a}^{*}}
$$

na qual:

- $I_{C B, a}$ : índice custo/benefício da alternativa $a$, em $U S \$ / M W h$;

- $\quad C T_{a}$ : custo total anual da alternativa $a$, em US\$;

- $\quad C U R$ : Custo Unitário de Referência, em US\$/MWh;

- $\Delta E F_{a}^{*}$ : acréscimo de Energia Firme do sistema de referência proporcionado pela alternativa com maior Energia Firme, em $\overline{\mathrm{MW}}$. 
- $\Delta E F_{a}:$ acréscimo de energia firme do sistema de referência proporcionado pela alternativa $a$, em $\overline{\mathrm{MW}}$.

Um aproveitamento ou uma alternativa de divisão de quedas só é economicamente competitiva se o seu índice custo/benefício for menor que o Custo Unitário de Referência.

Finalmente, os estudos ambientais são feitos de forma a medir os impactos dos aproveitamentos, sem influenciar diretamente nas características energéticas dos mesmos. Ao final do processo, seleciona-se um conjunto de Soluções Eficientes [123] que estabelecem um compromisso entre minimização do impacto ambiental e minimização do índice custo/benefício. As alternativas eficientes são então passadas a outras fases do dimensionamento, nas quais estudos mais aprofundados são realizados.

\subsection{Outros Modelos}

Esta seção mostra algumas metodologias de dimensionamento de reservatórios e de usinas hidroelétricas. Inicia-se com modelos bastante simples e refinamentos vão sendo adicionados de forma progressiva. O objetivo é chegar ao fim da seção com uma lista de características desejáveis a um procedimento de dimensionamento que servirá de base para o desenvolvimento dos modelos propostos.

Em [69], definem-se modelos para determinação da capacidade de armazenagem de reservatórios. Os modelos partem do conceito de vazão firme. Uma vez fornecida a série histórica de vazões afluentes naturais ao local onde será construído o reservatório, define-se a vazão firme como sendo a máxima vazão que pode ser garantida a jusante do aproveitamento em $100 \%$ do tempo. Esta garantia é dada assumindo-se que secas mais severas que a observada no histórico não ocorrerão no futuro.

Inicialmente nota-se que a vazão firme depende de vários fatores, dentre os quais destacam-se:

- Tamanho do reservatório: quanto maior o reservatório, maior sua capacidade de regularização. Mesmo durante períodos secos, nos quais as vazões afluentes são muito baixas, o reservatório poderá garantir a vazão firme utilizando a água armazenada. De forma oposta, durante as 
cheias o reservatório poderá armazenar os picos de vazão, evitando vertimento.

- Política de operação: o reservatório deve ser operado de forma a estar cheio no início dos períodos secos e relativamente vazio no início dos períodos chuvosos. Isto garante o aproveitamento da água armazenada para elevar a vazão durante a seca e da capacidade de armazenagem disponível para estocar os picos de vazão durante os períodos úmidos.

- Seqüência de vazões afluentes: se as vazões afluentes adotadas nos estudos não representarem com probidade ${ }^{16}$ as vazões que efetivamente o reservatório vai receber durante sua vida útil, os benefícios esperados a partir dos resultados dos modelos matemáticos podem nunca ser observados.

Os modelos apresentados referem-se basicamente à minimização do volume útil do reservatório, garantido-se, com certa confiabilidade preestabelecida, uma vazão regularizada mínima de jusante. O primeiro modelo apresentado, o mais simples, trata da resolução do seguinte problema de Programação Linear [14]:

$$
\begin{gathered}
\min x_{\text {util }} \\
\text { s.a. }\left\{\begin{array}{l}
f_{\mathcal{C}} \cdot(x(t+1)-x(t))=y(t)-u g_{r}-v(t) \\
x(t) \leq x_{\text {util }}
\end{array}\right.
\end{gathered}
$$

nas quais:

- $x_{\text {útil }}$ : volume útil do reservatório, em $\mathrm{hm}^{3}$;

- $\quad f_{c}$ : fator de conversão entre as unidades de volume e vazão;

- $x(t)$ : volume armazenado no reservatório, em $\mathrm{hm}^{3}$, ao início do intervalo $t$;

- $y(t)$ : vazão afluente média ao reservatório, em $\mathrm{m}^{3} / \mathrm{s}$, durante o intervalo $t$;

- $u g_{r}$ : vazão defluente média garantida, em $\mathrm{m}^{3} / \mathrm{s}$, com nível de confiabilidade $r$;

- $v(t)$ : vazão vertida média, em $\mathrm{m}^{3} / \mathrm{s}$, durante o intervalo $t$;

- os intervalos de tempo, para este caso, são anuais.

\footnotetext{
${ }^{16}$ Representar com probidade significa, neste caso, retratar não somente os valores possíveis de vazão, mas também a forma como a vazão distribui-se. A utilização de várias séries de vazão afluente, todas com mesmo número de valores e iguais valores médio, mínimo e máximo, mas com diferentes distribuições ao longo do tempo, não garante reservatórios de mesmo tamanho.
} 
O número de restrições do modelo cresce linearmente com o tamanho da série de vazões utilizada, principalmente se mais de um reservatório está sendo dimensionado. Através da análise da solução apresentada para vários casos de estudo, os autores constataram que apenas uma pequena seqüência do histórico era responsável pelo dimensionamento do reservatório: o Período Crítico. Este fato sugeriu a redução do número de períodos dos estudos, considerando somente o Período Crítico para análise.

O segundo modelo apresentado em [69] explora a variabilidade da vazão ao longo do ano. São encontrados valores para dois volumes úteis: um para garantir a regulação das vazões anuais e outro para garantir a regulação das vazões verificadas ao longo das estações climáticas de um ano. Constata-se que regularizar vazões em uma base anual requer reservatórios menores, uma vez que a variabilidade verificada entre as estações do ano é grande.

$\mathrm{Na}$ seqüência desenvolve-se um modelo com uma função objetivo mais elaborada, através da qual se maximiza a diferença entre os benefícios oriundos da construção do reservatório e seu respectivo custo de construção. Também são considerados dois níveis de confiabilidade, com remunerações diferentes, e perdas por evaporação.

Desenvolve-se ainda um modelo com considerações implícitas da aleatoriedade das vazões. O objetivo é minimizar a capacidade do reservatório e os resultados também incluem uma política de operação que especifica o volume meta de cada intervalo. Se esta política é seguida, garante-se, com confiabilidades preestabelecidas, que a vazão defluente se limitará a uma faixa de valores possíveis e que o volume armazenado será menor que a capacidade máxima do reservatório. Por exemplo, as restrições que especificam os valores possíveis das variáveis para um intervalo de tempo $t$ podem ser escritas da seguinte forma:

$$
\begin{aligned}
& \operatorname{Pr}\left(x(t) \leq x_{\text {máx }}(t)\right) \geq P_{1}(t) \\
& \operatorname{Pr}\left(u(t) \leq u_{\text {máx }}(t)\right) \geq P_{2}(t) \\
& \operatorname{Pr}\left(u(t) \geq u_{\text {min }}(t)\right) \geq P_{3}(t)
\end{aligned}
$$

nas quais:

- $\quad$ Pr: denota probabilidade;

- $x(t)$ : volume armazenado no reservatório, em $\mathrm{hm}^{3}$, ao início do intervalo $t$;

- $x_{\max }(t)$ : máximo volume armazenado ao início do intervalo $t$, em $\mathrm{hm}^{3}$; 
- $u(t)$ : vazão defluente média durante o intervalo $t$, em $\mathrm{m}^{3} / \mathrm{s}$;

- $u_{\text {min }}(t)$ e $u_{\text {máx }}(t)$ : limites mínimo e máximo de vazão defluente média durante o intervalo $t$, em $\mathrm{m}^{3} / \mathrm{s}$;

- $\quad P_{1}(t), P_{2}(t)$ e $P_{3}(t)$ : níveis de confiabilidade requeridos para os valores de volume e vazão defluente média no intervalo $t$.

Um exemplo de aplicação desta metodologia pode ser observado em [69]. Estas restrições com valores probabilísticos são transformadas em equações determinísticas através de algumas manipulações algébricas e da distribuição de probabilidade da série de vazões afluentes ao reservatório. Esta metodologia ainda pode ser desenvolvida para modelos em que haja valores metas para o volume e para a vazão defluente ao reservatório.

Em [114], um sistema de suprimento de água composto por três reservatórios em paralelo é dimensionado de acordo com quatro modelos distintos: (i) VMM - modelo linear baseado em Vazões Médias Mensais, (ii) VPC - um modelo linear baseado somente nas Vazões do Período Crítico, (iii) EI - um modelo Estocástico Implícito apresentado em [69], e (iv) EE - um modelo Estocástico Explícito introduzido em [95].

O objetivo é determinar as dimensões dos três reservatórios de forma a minimizar seus custos, garantindo que a demanda a jusante do sistema seja atendida com uma confiabilidade preestabelecida.

Para avaliar os resultados encontrados pelos diferentes modelos, realizam-se estudos de simulação em horizontes de mil anos, adotando-se políticas de operação similares às adotadas na prática ${ }^{17}$. Como resultado das simulações, determina-se a confiabilidade do atendimento à demanda, podendo-se constatar se estes valores equivalem aos especificados em projeto.

Analisando os resultados, podem ser elaboradas as seguintes conclusões:

- Modelo VMM: por trabalhar com vazões médias mensais, não considera as variações que podem ocorrer entre os mesmos meses de anos distintos. Essa uniformidade da série de vazões faz com que o modelo determine capacidades muito pequenas para os reservatórios, fazendo com que durante a simulação em condições reais a demanda seja

\footnotetext{
${ }^{17}$ Mais especificamente, utiliza-se a regra desenvolvida em [17].
} 
garantida com uma confiabilidade muito aquém da especificada em projeto. Esta abordagem equivale à preexistência de outros reservatórios a montante, os quais se encarregariam da regularização da vazão natural e forneceriam vazões "bem comportadas" (vazões médias) aos reservatórios sob dimensionamento. Estes não teriam que ter grandes capacidades de regularização, já que as suas vazões afluentes já estariam regularizadas.

- Modelo VPC: por trabalhar com o período mais severo do histórico, este modelo superdimensiona os reservatórios, elevando os custos do sistema. Quando a simulação é realizada, a confiabilidade é maior que a desejada.

- Modelo EI: duas variantes deste modelo foram testadas. Em ambos os casos valores próximos aos de projeto foram verificados na simulação.

- Modelo EE: duas variantes deste modelo foram testadas. Um dos problemas encontrados neste modelo é que as confiabilidades fornecidas na fase de projeto, como pré-especificadas, referem-se a meses, enquanto o modelo de simulação e todos os outros modelos de projeto trabalham com confiabilidades anuais de suprimento. Os resultados deste modelo foram desanimadores: em certos casos os reservatórios foram superdimensionados, fornecendo a vazão demandada a jusante do sistema em $100 \%$ do tempo; em outros o sistema foi subdimensionado, com confiabilidade de $60 \%$.

Em [109], desenvolve-se um modelo para dimensionamento de reservatórios considerando vários usos da água, incluindo geração de eletricidade. O objetivo é minimizar os custos de construção dos reservatórios, aquisições de terras e operação e manutenção. Deseja-se determinar as capacidades de armazenagem dos reservatórios, os valores de vazão de suprimento d'água e confiabilidade para serem estabelecidos em contratos com municípios e indústrias, e a potência dos geradores elétricos associados aos reservatórios.

No artigo observam-se as vantagens e desvantagens das técnicas de otimização e simulação. Enquanto na simulação a representação dos vários componentes do sistema é feita de forma detalhada, é muito difícil dimensionar um sistema multireservatório apenas através de simulação porque em cada estudo todas as características de todas as usinas do sistema devem ser especificadas, mesmo as sob dimensionamento. Como 
conseqüência, um número muito reduzido de soluções possíveis é explorado e dificilmente se consegue uma configuração ótima. Por outro lado, técnicas de otimização proporcionam uma busca eficiente no espaço de soluções, mas os modelos do sistema físico normalmente devem ser simplificados para viabilizar a solução através de técnicas tradicionais. Estas simplificações devem ser bem cautelosas, principalmente na especificação das funções de custo, já que sinalizações equivocadas nesta fase podem originar respostas com ganho aparente muito maior que o observado na prática.

Nesse artigo, utiliza-se uma técnica que combina otimização e simulação para dimensionamento de um sistema multireservatório localizado na Índia. O modelo de otimização considera apenas as metas anuais de vazão; os valores especificados pelo modelo de otimização são fornecidos ao modelo de simulação, o qual determina:

- capacidade do reservatório através de um algoritmo regressivo de seqüência de picos que considera perdas por evaporação;

- capacidade do gerador através de uma heurística de ordenação que considera apenas os ganhos com energia firme;

- funções de restrição para a capacidade total do reservatório, necessidade de enchimento, limite de volume morto, demanda de irrigação, valor mínimo de vazão defluente e energia firme mínima.

A integração simulação/otimização produziu projetos para o sistema com custos bem inferiores às metodologias tradicionalmente empregadas, nas quais modelos de simulação são atrelados a buscas heurísticas baseadas na experiência de especialistas. Mostraram-se assim os benefícios da criação de métodos que sistematicamente exploram o espaço de soluções.

Além disso, os métodos resultantes da integração entre simulação e otimização permitem que quaisquer políticas de operação sejam consideradas, uma vez que as simulações são feitas de forma independente às otimizações.

Em [108] apresenta-se um modelo praticamente idêntico ao anterior, porém enfatiza-se a utilização de uma técnica especial utilizada no cálculo das derivadas do modelo de otimização [107]. Esta técnica é um método exato de cálculo de derivadas de qualquer grau, baseado no fato de que toda função, independentemente de sua complicação, é executada em um computador através de uma seqüência de operações elementares como adições, multiplicações, senos, co-senos, etc. Aplicando a regra da cadeia sobre estas operações e suas composições, as derivadas podem ser calculadas de 
forma exata e completamente mecânica, tirando-se proveito das características das operações realizadas pelos microprocessadores.

De acordo com os resultados encontrados para os casos de dimensionamento, estudos com derivadas calculadas automaticamente chegam a ser quase $80 \%$ mais rápidos que estudos com derivadas escritas pelo programador.

Em [16] apresenta-se um modelo para análise de viabilidade de usinas hidroelétricas que considera o impacto do mercado spot e Mecanismos de Realocação de Energia (MRE) no cálculo dos benefícios energéticos de um aproveitamento.

É importante enfatizar que este modelo presta-se a um agente privado identificar a lucratividade de um aproveitamento, as melhores opções de financiamento, o tempo de retorno do capital investido, etc. Estas características não devem influenciar as dimensões da usina, já que o importante na fase de dimensionamento é a garantia do bom aproveitamento do recurso natural disponível. Em outras palavras, trata-se de um modelo de viabilidade e não de um modelo de dimensionamento. Ele foi citado nesta etapa porque a forma clara com que os custos e as receitas foram apresentados é uma característica extremamente desejável em um modelo de dimensionamento.

Embora o mercado de energia brasileiro esteja passando por um momento de indefinição, com reavaliações do modelo que estava começando a ser adotado, a metodologia apresentada nesse capítulo apresenta uma série de características atrativas para análise da viabilidade de um projeto.

Primeiro, o sistema de remuneração da energia é bem detalhado. Uma parte da geração é remunerada segundo os contratos de suprimento e outra pode ser vendida e ou comprada no mercado spot, com preços estabelecidos pelo Custo Marginal de Operação estabelecido, no trabalho, pelo modelo NEWAVE [76, 89] (atualmente, o Custo Marginal de Operação é semanal e determinado pelo modelo DECOMP). Além disso, o sistema de remuneração também permite o uso do MRE para minimizar o risco hidrológico.

Segundo, apesar dos dados de vazão afluente serem os do histórico, utilizou-se um sistema de varredura, chamado no artigo de "método pente", que permitiu que o impacto da série de vazões utilizada nos estudos fosse minimizado através da utilização de vários períodos de mesma amplitude. Por exemplo, primeiro utilizaram-se as vazões de 1931 a 1951, depois de 1932 a 1952, e assim sucessivamente.

Terceiro, a análise financeira do empreendimento também foi bem detalhada, 
construindo-se um fluxo de caixa com custos provenientes da construção, participação de capital próprio e de terceiros no investimento, cronograma de desembolso da obra, sistema de financiamento, taxas de juros dos empréstimos, forma de pagamento, encargos legais, etc. Como resultado final o modelo proporcionou uma amostra de parâmetros quantitativos, proporcionando uma análise de risco financeiro do empreendimento.

A metodologia foi aplicada à usina hidroelétrica Jataizinho, localizada no rio Tibagi, Estado do Paraná. Os resultados, além de mostrarem a adequação do modelo ao ambiente competitivo, mostraram a importância do MRE na viabilidade da usina.

\subsection{Características Atraentes dos Modelos}

Analisando os modelos estudados, pode-se criar uma lista de características desejáveis em um modelo de dimensionamento eletro-energético. Estas características, listadas abaixo, foram agrupadas por "categoria".

\section{Séries de Vazões Afluentes}

Pelos modelos analisados, constata-se que dimensionar com vazões médias gera reservatórios muito pequenos e incapazes de atender aos requisitos de projeto. Por outro lado, utilizar o Período Crítico cria reservatórios grandes, capazes de atender aos requisitos de projeto com folga, porém a um custo mais elevado que o necessário. Além disso, foi constatado que a distribuição das vazões é muito importante na determinação do reservatório.

Assim, acredita-se que os estudos de dimensionamento devam empregar várias séries de vazões afluentes, aumentando as chances de que durante os estudos de dimensionamento sejam exploradas as possíveis condições em que o reservatório será operado. Evita-se assim que as vazões afluentes de uma única série de valores influenciem de forma determinativa as dimensões do reservatório.

\section{Políticas de Operação}

Há um grande número de políticas de operação que podem ser utilizadas em sistemas multireservatórios $[5,9,17,21,24,27,67,70,77,85,122]$. Como as políticas de operação podem mudar as características ótimas de um aproveitamento, sugere-se que elas sejam um parâmetro do modelo de dimensionamento.

Vários estudos realizados com usinas hidroelétricas brasileiras têm mostrado que a eficiência da operação energética altera-se sensivelmente em função de diferentes 
políticas de operação [20, 21, 24, 27, 111]. Como resultado, as análises realizadas durante os estudos de dimensionamento também devem se alterar [105, 106], indicando uma forte relação entre política de operação e dimensionamento ótimo de um aproveitamento.

Para que a relação entre a política de operação e as dimensões ótimas de uma usina possa ser analisada, faz-se com que a política de operação seja um parâmetro do modelo de dimensionamento proposto.

\section{Função Objetivo}

Há várias funções objetivos que podem ser utilizadas como "guias" na escolha das melhores características de um aproveitamento. A própria definição do que torna um aproveitamento melhor que outro depende das condições nas quais o sistema será dimensionado. Por exemplo, conforme mostrado anteriormente em alguns modelos, há casos em que são conhecidas as demandas exigidas, seja de água ou energia, e deseja-se atendê-las ao menor custo possível.

Em outros casos, deseja-se aproveitar ao máximo os recursos energéticos disponíveis e para tanto se tenta construir o reservatório ou a usina hidroelétrica de forma a obter o menor índice custo/benefício, ou a maior diferença entre benefícios e custos. Neste caso, deve-se ainda especificar como os benefícios são calculados, Conforme já mostrado, há dois casos extremos para o cálculo dos benefícios de um aproveitamento: (i) no cálculo do benefício global, o ganho energético que uma usina proporciona é igual à sua própria geração somada aos acréscimos de geração de todas as outras usinas do sistema que se beneficiam com a sua construção; (ii) no cálculo do benefício local, o ganho energético de uma usina equivale única e exclusivamente à sua própria geração.

O cálculo do benefício sistêmico global parece ser mais atrativo para estudos com usinas hidroelétricas, já que o dimensionamento deve garantir o aproveitamento do potencial disponível. De forma a garantir este aproveitamento, o órgão regulador pode especificar ganhos energéticos mínimos e permitir que os responsáveis pela construção otimizem o projeto de acordo com seus interesses, mas garantindo os ganhos mínimos. 


\section{Algoritmo para Determinação das Dimensões Ótimas}

A determinação das dimensões ótimas envolve a exploração do espaço de possíveis soluções do problema de dimensionamento. De acordo com os casos examinados, a utilização conjunta de simulação e de heurísticas baseadas na experiência dos operadores pode ser ineficiente por serem testados apenas alguns poucos pontos do conjunto de soluções possíveis. No entanto, o emprego de estudos de simulação é desejável, pois permite que o sistema seja avaliado de forma bem detalhada.

A solução adotada através do emprego simultâneo de técnicas de simulação e otimização parece ser bastante adequada para os estudos de dimensionamento.

\section{Análise Econômica}

Os ganhos energéticos devem ser contabilizados de forma detalhada, permitindo que sejam utilizados esquemas de preços condizentes com a realidade, valorização da energia de acordo com diferentes patamares de geração, atribuição de valor à Energia Assegurada em consonância com o mercado existente, descrição do cronograma de construção da usina, etc.

\section{Compatibilidade dos Estudos Energéticos com Necessidades de Potência}

Os estudos de dimensionamento são normalmente realizados com modelos de simulação que trabalham com discretização mensal. As simulações executadas visam aproveitar o ganho energético resultante da construção da usina, medido em termos de gerações médias mensais de energia (as energias firme e secundária, por exemplo, correspondem a valores médios mensais). No entanto, a usina gera energia continuamente e, dependendo da concepção do aproveitamento, pode ter que atender a cargas que variam sensivelmente ao longo do dia. Esta característica faz com que a potência instalada da usina deva corresponder a um valor maior que aquele necessário para promover os ganhos energéticos esperados da usina.

Uma das formas de estabelecer uma relação entre as necessidades de ponta e os benefícios energéticos é a utilização de fatores de capacidade de referência sobre a Energia Firme do aproveitamento [52]. Por exemplo, se um aproveitamento apresentar uma Energia Firme de $500 \overline{\mathrm{MW}}$ e o fator de capacidade de referência for 0,5 (adimensional), a potência instalada do aproveitamento deverá ser $1.000 \mathrm{MW}$. Esta abordagem permite que a potência instalada considere, ainda que de forma implícita, os benefícios de ponta que a usina pode fornecer.

No entanto, conforme apresentado em [30], a expansão da capacidade de ponta 
deve utilizar um esquema de valorização explícita que justifique a sua expansão, já que alguns subsistemas brasileiros têm apresentado problemas de suprimento nos horários de pico.

Desta forma, acredita-se que a consideração explícita da ponta seja uma característica atraente para um modelo de dimensionamento. 


\section{Capítulo IV}

\section{Modelo Proposto}

O modelo proposto tem por objetivo principal realizar o dimensionamento de uma usina hidroelétrica de forma automática, no sentido das características ótimas da usina serem determinadas sem a necessidade de intervenções manuais para aplicação de heurísticas elementares ao longo do processo de otimização.

Adicionalmente, deseja-se que o modelo proposto incorpore o maior número possível de características "atraentes" listadas anteriormente e que ele seja suficientemente flexível para que as influências destas características possam ser analisadas como parâmetros do modelo, sem grandes complicações no que se refere à manipulação de dados ou códigos computacionais [100].

Para que estes objetivos possam ser alcançados, o modelo de dimensionamento proposto neste trabalho integra técnicas de otimização e de simulação. De forma geral, o método baseia-se no esquema mostrado na Figura 4.1. Este esquema apresenta a visão mais abrangente do modelo, indicando quais são os dados necessários para sua utilização, o método empregado na solução do problema e os resultados gerados.

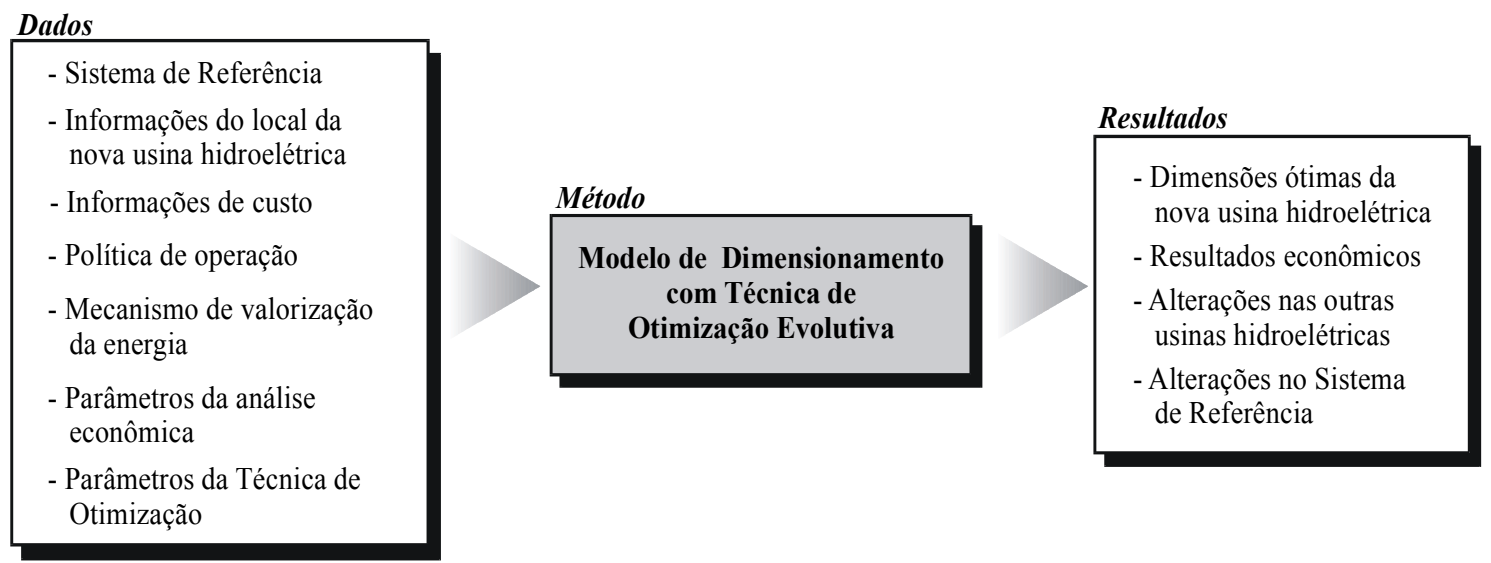

Figura 4.1 - Esquema do Modelo Proposto. 
O objetivo deste trabalho é justamente desenvolver um modelo que realize de forma automática a busca por valores ótimos dos parâmetros de dimensionamento de uma usina hidroelétrica. Adicionalmente, este modelo deve ser suficientemente flexível para permitir que sejam realizadas análises de sensibilidade para determinar como os diversos fatores que alteram o processo de dimensionamento influenciam as características ótimas da usina em questão. Dentre estes fatores destacam-se o modo como a energia gerada é valorizada, as considerações sobre as capacidades instaladas de base e de ponta, o conjunto de vazões afluentes e as políticas de operação empregadas nas simulações, o entendimento de os benefícios serem "sistêmicos" ou "locais", o sistema existente onde a nova usina será inserida (Sistema de Referência) e a própria posição relativa que esta usina vai ocupar no sistema (se será uma usina de montante ou de jusante, por exemplo).

As próximas seções deste capítulo prestam-se a explicar cada um dos blocos da Figura 4.1. Na Seção 1 apresentam-se os dados requeridos pelo modelo, na Seção 2 apresenta-se o método de otimização evolutiva, e na Seção 3 apresentam-se os resultados produzidos. Na Seção 4 são abordados alguns aspectos computacionais sobre a forma como o método foi implementado e na Seção 5 apresenta-se um exemplo de estudo de dimensionamento. 


\section{Dados}

\subsection{Sistema de Referência}

O Sistema de Referência (SR), conforme já explicado no capítulo anterior, é definido como o sistema no qual a nova usina vai inserir-se quando começar a ser operada. Isto significa que os benefícios energéticos resultantes desta inserção serão medidos através de estudos de simulação considerando a operação conjunta da usina sob dimensionamento com o SR. A simulação do SR fornece valores de Energia Firme, Energia Secundária e Ponta Garantida denotados respectivamente por $E F_{R}, E S_{R}$ e $P G_{R}$.

\subsection{Informações do Local da Nova Usina Hidroelétrica}

Os dados do local da nova usina hidroelétrica devem ser capazes de caracterizar o novo aproveitamento de forma que sua operação possa ser simulada conjuntamente com o SR. Conforme já definido anteriormente, a adição da usina sob dimensionamento ao SR origina o Sistema Completo (SC). Os resultados da simulação do SC fornecem seus benefícios de Energia Firme, Energia Secundária e Ponta Garantida, denotados respectivamente por $E F_{C}, E S_{C}$ e $P G_{C}$.

Os dados necessários são os seguintes:

- Conjunto de vazões afluentes: este conjunto será utilizado na simulação da operação do SC, determinando, portanto, os ganhos energéticos proporcionados pela nova usina. Estas vazões podem referir-se ao histórico de vazões naturais, a séries sintéticas ou a quaisquer outros valores desejados pelo usuário, todos expressos em $\mathrm{m}^{3} / \mathrm{s}$.

- Faixa de valores viáveis para o volume máximo: estes dados, baseados em análises da topografia da região, evitam que o reservatório seja dimensionado de forma exagerada, inundando grandes áreas ou regiões onde haja cidades ou indústrias. Os valores mínimo e máximo fornecidos são denotados respectivamente por $x f_{\min }$ e $x f_{\max }$, em $\mathrm{hm}^{3}$.

- Vazão defluente mínima: fornecida para manter condições sanitárias do rio ou para atender a demandas de navegação, suprimento de água ou outros usos da água. É denotada por $u_{\min }, \mathrm{em} \mathrm{m}^{3} / \mathrm{s}$. 
- Curva Cota $x$ Volume: fornece o nível d'água de montante da usina, $h_{m o n}(x)$, medido em $m$ e em relação ao nível do mar, como função do volume total armazenado no reservatório, $x$, em $\mathrm{hm}^{3}$.

- Curva Cota $x$ Vazão ou Curva-Chave: fornece o nível d'água de jusante, $h_{\text {jus }}(u)$, medido em $m$ e em relação ao nível do mar, como função da vazão defluente total, $u$, em $\mathrm{m}^{3} / \mathrm{s}$. Esta curva é utilizada nas simulações para cálculo da altura de queda da usina e da geração de energia elétrica. Associado a ela ainda há o nível médio do canal de fuga, $c f_{m e ́ d}$, em $m$.

- Curva Cota $x$ Área: fornece a área do espelho d'água, $a_{e}\left(h_{m o n}\right), \mathrm{em} \mathrm{km}^{2}$, em função de $h_{m o n}$, em $m$ e em relação ao nível do mar. Esta curva é utilizada no cálculo das perdas por evaporação.

- Coeficientes de evaporação: correspondem a doze coeficientes, denotados por $c e_{m e ̂ s}$, um para cada mês, que expressam a evaporação mensal em $\mathrm{mm}$. O cálculo do volume evaporado depende ainda da área do espelho d'água.

- Tipo de turbina: determinado a partir das condições de queda e vazão do local do aproveitamento, especifica os coeficientes utilizados para cálculo do engolimento máximo e a máxima potência em função da queda líquida.

- Rendimento médio do conjunto turbina-gerador: utilizado no cálculo da geração de energia elétrica. Este valor, denotado por $\eta_{\text {méd, }}$ pode ser aproximado através de uma análise dos valores de rendimento das turbinas das usinas em operação.

- Modelo aproximado para perda de carga: empregado na determinação da altura de queda líquida da usina. Este valor também pode ser aproximado através de uma análise dos valores das usinas em operação. Deve-se especificar o tipo de modelo empregado e seu coeficiente (mais detalhes no Capítulo V).

\subsection{Informações de Custo}

As informações de custo resumem-se a tabelas e funções que estabelecem relações entre as variáveis de decisão, as características da usina sob dimensionamento, e seus respectivos custos de construção e operação.

Os custos do empreendimento compreendem a construção do reservatório, a aquisição de terras, a compra dos geradores e turbinas de base e de ponta, e os gastos 
com operação e manutenção. São utilizadas quatro tabelas e uma função matemática, cada uma relacionando características específicas da usina e os custos nos quais elas interferem de forma direta. As tabelas e a função utilizada são as seguintes:

- Tabela de custo de construção: relaciona valores de volume máximo, $x_{m a ́ x}$ em $h m^{3}$, e o custo de construção da barragem, $c_{c r}\left(x_{m a ́ x}\right)$, em US\$.

- Tabela de custo de aquisição de terras: relaciona valores de área alagada máxima, $a_{\text {máx }}$ em $\mathrm{km}^{2}$, e o custo de aquisição de terras, $c_{a t}\left(a_{\text {máx }}\right)$ em US\$, incluindo relocações de vilas ou cidades e eventuais gastos extras decorridos em função da construção do reservatório.

- Tabela de custo dos geradores e turbinas: o cálculo do custo dos geradores e turbinas da usina é dividido em duas partes: uma referente à capacidade instalada de base, $p_{\text {nom }, b}$ em $M W$, e outra à capacidade instalada de ponta, $p_{n o m, p}$ também em $M W$. Assim, o custo total dos geradores e das turbinas, $c_{\text {gt }}\left(p_{\text {nom }}\right)$ em US\$, pode ser escrito como:

$$
c_{g t}\left(p_{\text {nom }, b}, p_{\text {nom }, p}\right)=c_{g t, b}\left(p_{\text {nom }, b}\right)+c_{g t, p}\left(p_{\text {nom }, p}\right)
$$

na qual:

- $\quad p_{\text {nom }, b}$ : capacidade instalada de base, em $M W$;

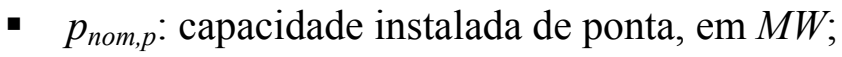

- $p_{\text {nom }}$ : capacidade instalada total, $p_{\text {nom }}=p_{\text {nom }, b}+p_{\text {nom }, p}$, em $M W$;

- $c_{g t, b}$ : custo dos geradores e turbinas de base, em US\$.

- $\quad c_{g t, p}$ : custo dos geradores e turbinas de ponta, em US\$.

Esta diferenciação dos custos de base e de ponta faz-se necessária porque os custos para adição de $1 \mathrm{MW}$ de capacidade de base e de $1 \mathrm{MW}$ de capacidade de ponta são diferentes. Enquanto a capacidade de base alavanca a construção do empreendimento, garantindo a geração de Energia Firme, a capacidade de ponta resume-se a investimentos incrementais, aproveitandose da infra-estrutura existente destinada à motorização de base. Em outras palavras, se o custo da casa de força com motorização de base for dividido por $p_{\text {nom }, b}$, obtém-se um valor superior ao resultante da divisão do custo da instalação da capacidade de ponta por $p_{n o m, p}$. 
Sob o ponto de vista dos dados fornecidos, o custo da casa de força é formado por duas tabelas: uma para motorização de base, $c_{g t, b}$, e outra para motorização de ponta, $c_{g t, p}$.

- Custo de operação e manutenção: expresso através de uma equação que depende apenas da potência nominal total da usina, $p_{\text {nom }}$ em $M W$, denotado por $c_{o m}\left(p_{n o m}\right)$, em $10^{3}$ US $\$$, e calculado através da seguinte expressão [52]:

$$
\begin{gathered}
c_{\text {om }}\left(p_{\text {nom }}\right)=a \cdot p_{\text {nom }}{ }^{b+1} \\
\left\{\begin{array}{l}
a=118,94 \text { e } b=-0,6064, \text { para } p_{\text {nom }} \leq 146,71 M W \\
a=10,94 \text { e } b=-0,1281, \text { para } p_{\text {nom }}>146,71 M W
\end{array}\right.
\end{gathered}
$$

\subsection{Política de Operação}

A Política de Operação é utilizada no modelo de simulação para definir como as demandas são supridas de forma conjunta pelas usinas que compõem o sistema hidroelétrico. Para o desenvolvimento dos trabalhos são utilizadas duas políticas de operação: a Regra Paralela (RP) e a Regra Baseada em Otimização (RO). Mais detalhes são fornecidos no Capítulo VI, na descrição do Modelo de Simulação.

\subsection{Mecanismo de Valorização da Energia}

O Mecanismo de Valorização da Energia (MVE) determina como o benefício energético proporcionado pela construção da usina é transformado em benefício econômico. Conforme já mencionado, por benefícios energéticos entendem-se os benefícios de Energia Firme, Energia Secundária, $B_{E F}, B_{E S}$ em $\overline{\mathrm{MW}}$, e Ponta Garantida, $B_{P G}$ em $M W$. Uma vez realizado o estudo de simulação, estes três valores são conhecidos. Resta saber como transformá-los em receitas.

\section{- Benefício de Energia Firme}

O benefício de Energia Firme é considerado como sendo despachado em dois patamares, tal como ilustrado na Figura 4.2. O patamar de ponta refere-se ao benefício de Ponta Garantida, $B_{P G}$, enquanto o patamar de base é determinado de forma complementar. Reescrevendo este despacho através de equações, obtêm-se:

$$
E_{P}=n_{h p} \cdot B_{P G} \quad E_{B}=24 \cdot B_{E F}-E_{P}
$$

nas quais: 
- $n_{h p}$ : número de horas diárias do período de ponta.

- $B_{P G}$ : benefício de Ponta Garantida, em $M W$;

- $E_{P}$ : energia diária despachada na ponta, em $M W h$;

- $B_{E F}$ : benefício de Energia Firme, em $\overline{\mathrm{MW}}$;

- $E_{B}$ : energia diária despachada na base, em $M W h$.

Os preços das energias geradas nos dois patamares são determinados através do preço médio da Energia Firme, $P_{E F}$ em $U S \$ / M W h$, e da razão $r$ entre os preços das energias de ponta e de base, $P_{E F P}$ e $P_{E F B}$ em $U S \$ / M W h$, respectivamente.

Para determinar $P_{E F P}$ e $P_{E F B}$ a partir do preço médio da Energia Firme, $P_{E F}$, fazse com que a receita diária proveniente do despacho com diferentes preços seja igual à receita do benefício de Energia Firme, $B_{E F}$, ao preço médio $P_{E F}$. Matematicamente:

$$
\underbrace{P_{E F P} \cdot\left(n_{h p} \cdot B_{E F}\right)}_{\text {Receita de ponta }}+\underbrace{P_{E F B} \cdot\left(\left(24-n_{h p}\right) \cdot B_{E F}\right)}_{\text {Receita de base }}=\underbrace{P_{E F}\left(24 \cdot B_{E F}\right)}_{\text {Receita no prȩ̣o médio }}
$$

Dividindo toda a equação por $B_{E F}$ :

$$
n_{h p} \cdot P_{E F P}+\left(24-n_{h p}\right) \cdot P_{E F B}=24 \cdot P_{E F}
$$

Introduzindo a definição de $r$ :

$$
\begin{aligned}
& r=\frac{P_{E F P}}{P_{E F B}} \\
& n_{h p} \cdot r \cdot P_{E F B}+\left(24-n_{h p}\right) \cdot P_{E F B}=24 \cdot P_{E F}
\end{aligned}
$$

Isolando o preço da energia de base e escrevendo o preço da energia de ponta pela própria definição da razão $r$, obtém-se:

$$
P_{E F B}=\frac{24 \cdot P_{E F}}{n_{h p} \cdot(r-1)+24} \quad P_{E F P}=r \cdot P_{E F B}
$$

nas quais:

- $P_{E F}$ : preço médio da Energia Firme, em $U S \$ / M W h$;

- $P_{E F B}$ : preço da energia despachada no horário de base, em $U S \$ / M W h$;

- $P_{E F P}$ : preço da energia despachada no horário de ponta, em $U S \$ / M W h$;

- $r$ : razão entre $P_{E F P}$ e $P_{E F B}$, adimensional.

Finalmente, a receita anual obtida com o benefício de Energia Firme, $R_{E F} \mathrm{em}$ US\$/ano, pode ser determinada da seguinte forma:

$$
R_{E F}=360 \cdot\left(P_{E F B} \cdot E_{B}+P_{E F P} \cdot E_{P}\right)
$$


Por exemplo, para $P_{E F}=30 U S \$ / M W h, r=2$ e $n_{h p}=3$, obtêm-se $P_{E F P}=53,33 U S \$ / M W h$ e $P_{E F B}=26,67 U S \$ / M W h$. Supondo que a usina possua um benefício de ponta $B_{P G}=850 \mathrm{MW}$ e $B_{E F}=520 \overline{\mathrm{MW}}$, resulta a seguinte receita anual:

$$
\begin{aligned}
& E_{P}=3 \cdot 850=2.550 \mathrm{MWh} \\
& E_{B}=24 \cdot 520-2550=9.930 \mathrm{MWh} \\
& R_{E F}=360 \cdot(26,67 \cdot 9.930+53,33 \cdot 2.550)=144.296 .856 \text { US } \$ / \text { ano }
\end{aligned}
$$

Este despacho em dois patamares pode ser visto como um incentivo à expansão da oferta de ponta, à medida que para um mesmo $B_{E F}$, incrementos de $B_{P G}$ proporcionam aumentos de receita. Retornando ao exemplo, se fossem adicionadas mais máquinas à usina, o benefício de Energia Firme seria mantido, mas o de Ponta Garantida aumentaria. Supondo um novo $B_{P G}=1.000 \mathrm{MW}$, a nova receita anual de Energia Firme seria:

$$
\begin{aligned}
& E_{P}=3 \cdot 1000=3.000 M W h \\
& E_{B}=24 \cdot 520-3.000=9.480 M W h \\
& R_{E F}=360 \cdot(26,67 \cdot 9.480+53,33 \cdot 3.000)=148.615 .776 \mathrm{USS} / \text { ano }
\end{aligned}
$$

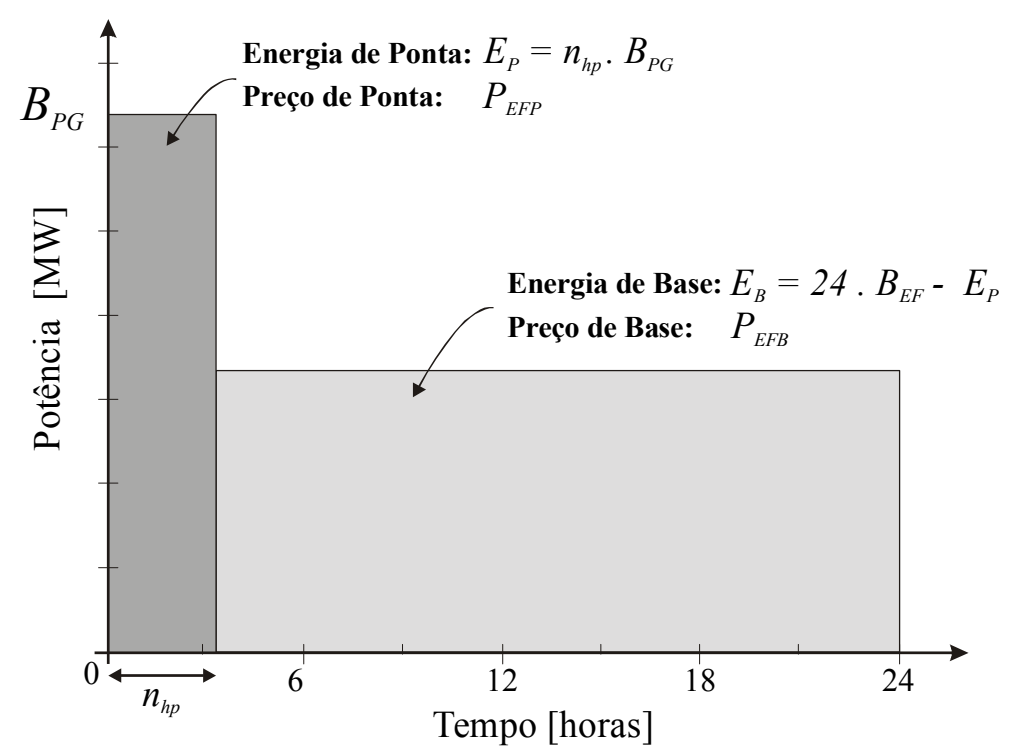

Figura 4.2 - Despacho de Energia Firme em dois patamares. 


\section{- Beneficio de Energia Secundária}

$\mathrm{O}$ benefício de Energia Secundária, $B_{E S} \mathrm{em} \overline{\mathrm{MW}}$, é transformado em receita através de sua valorização pelo valor esperado do preço da Energia Secundária, $P_{E S}$ em $U S \$ / M W h$. A receita anual obtida com o benefício de Energia Secundária, $R_{E S}$ em US\$/ano, é calculada utilizando-se a expressão abaixo, na qual a constante 8760 equivale ao número de horas do ano:

$$
R_{E S}=8760 \cdot P_{E S} \cdot B_{E S}
$$

\section{- Benefício de Ponta Garantida}

O benefício de Ponta Garantida, $B_{P G}$ em $M W$, é transformado em receita através de sua valorização pelo preço atribuído à capacidade disponível, $P_{P G}$ em $U S \$ /(M W$.ano). A receita anual obtida com o benefício de Ponta Garantida, $R_{P G}$ em US\$/ano, é calculada da seguinte forma:

$$
R_{P G}=P_{P G} \cdot B_{P G}
$$

\section{- Benefício Econômico Anual Total}

O benefício econômico anual total oriundo da construção da usina hidroelétrica é expresso através da receita anual total, $R_{T}$ em US\$/ano, calculada como a soma das receitas anuais dos benefícios de Energia Firme, Energia Secundária e Ponta Garantida:

$$
R_{T}=R_{E F}+R_{E S}+R_{P G}
$$

Apesar de estar definido como o benefício econômico é calculado, resta ainda definir como os benefícios energéticos são determinados. Para efeito de comparação entre possíveis formas de valorizar a energia gerada por uma usina, foram definidos dois MVEs distintos, explicados a seguir.

\subsubsection{MVE Global}

O MVE Global determina os benefícios energéticos de Energia Firme, Energia Secundária e Ponta Garantida de forma sistêmica, alocando à nova usina os seus próprios benefícios energéticos e também os benefícios de todas as usinas a jusante. Conforme já ilustrado na Figura 3.11, os benefícios energéticos globais, $B_{E F G}, B_{E S G}$ e $B_{P G G}$, são calculados da seguinte forma:

$$
\left\{\begin{array}{l}
B_{E F G}=E F_{C}-E F_{R} \\
B_{E S G}=E S_{C}-E S_{R} \\
B_{P G G}=P G_{C}-P G_{R}
\end{array}\right.
$$


nas quais:

- $E F_{C}$ : Energia Firme do Sistema Completo, em $\overline{\mathrm{MW}}$;

- $E S_{C}$ : Energia Secundária do Sistema Completo, em $\overline{\mathrm{MW}}$;

- $P G_{C}$ : Ponta Garantida do Sistema Completo, em $M W$;

- $E F_{R}$ : Energia Firme do Sistema de Referência, em $\overline{\mathrm{MW}}$;

- $E S_{R}$ : Energia Secundária do Sistema de Referência, em $\overline{\mathrm{MW}}$;

- $\quad P G_{R}$ : Ponta Garantida do Sistema de Referência, em $M W$.

A transformação destes benefícios em receitas econômicas é realizada utilizando-se as Equações 4.3 a 4.9, fazendo com que os benefícios $B_{E F}, B_{E S}$ e $B_{P G}$ sejam iguais a $B_{E F G}, B_{E S G}$ e $B_{P G G}$, respectivamente.

\subsubsection{MVE Local}

O MVE Local corresponde ao caso extremo em que os benefícios econômicos correspondem única e exclusivamente à valorização da energia gerada na própria usina. Neste caso, conforme já ilustrado na Figura 3.12, simula-se a operação do Sistema Completo, determinando os valores de Energia Firme, Energia Secundária e Ponta Garantida da própria usina sob dimensionamento, denotados por $E F_{U S D}, E S_{U S D}$ e $P G_{U S D}$, caracterizando assim os benefícios energéticos locais, denominados $B_{E F L}, B_{E S L}$ e $B_{P G L}$.

A transformação destes benefícios em receitas econômicas é novamente realizada utilizando-se as Equações 4.3 a 4.9, fazendo com que os benefícios $B_{E F}, B_{E S}$ e $B_{P G}$ sejam iguais a $B_{E F L}, B_{E S L}$ e $B_{P G L}$, respectivamente.

\subsection{Parâmetros de Análise Econômica}

Os parâmetros de análise econômica visam quantificar de forma genérica os desembolsos e os recebimentos provenientes da construção da usina hidroelétrica. Os parâmetros são os seguintes:

- Investimento total da usina: corresponde a todo o capital a ser investido durante o tempo de construção do empreendimento, denotado por $I_{T}$.

- Tempo de construção da obra: número de anos em que a usina será construída, denotado por $T_{C}$.

- Vida útil da usina: número de anos em que a usina funcionará, proporcionando benefícios econômicos. É denotada por $T_{U}$. 
- Cronograma de desembolso: define frações do investimento total $I_{T}$ a serem pagas durante a construção do empreendimento. A fração paga no ano $j, 0 \leq j \leq T_{C}$, é denotada por $D_{j}$. O valor da parcela é $D_{j} I_{T}$.

- Taxa anual de juros durante a construção: denotada por $t_{j d c}$, refere-se à taxa anual de juros que o investidor poderia aplicar os montantes investidos na usina durante sua construção. Sob o ponto de vista econômico, representa o custo de oportunidade. Sob o ponto de vista financeiro, seriam as taxas reais de financiamento (custo real do capital).

- Taxa de desconto: denotada por $t_{d}$, é a taxa anual utilizada para trazer os recebimentos e os custos futuros ao valor presente.

Todos estes parâmetros são utilizados para construir um fluxo de caixa referente ao investimento, tal como ilustrado na Figura 4.3 [113]. Apesar de fluxos de caixa estarem normalmente associados a análises financeiras, neste caso eles são utilizados simplesmente para ilustrar a análise econômica do empreendimento, permitindo a visualização de todos os custos e receitas ao longo do tempo.

Retornando à Figura 4.3, observam-se os desembolsos, custos de operação e manutenção, e receitas provenientes da venda de energia. Para calcular a atratividade econômica do empreendimento, calcula-se a receita líquida anual ao longo da vida útil da usina. O procedimento é dividido em duas partes: uma referente aos custos e outra às receitas.

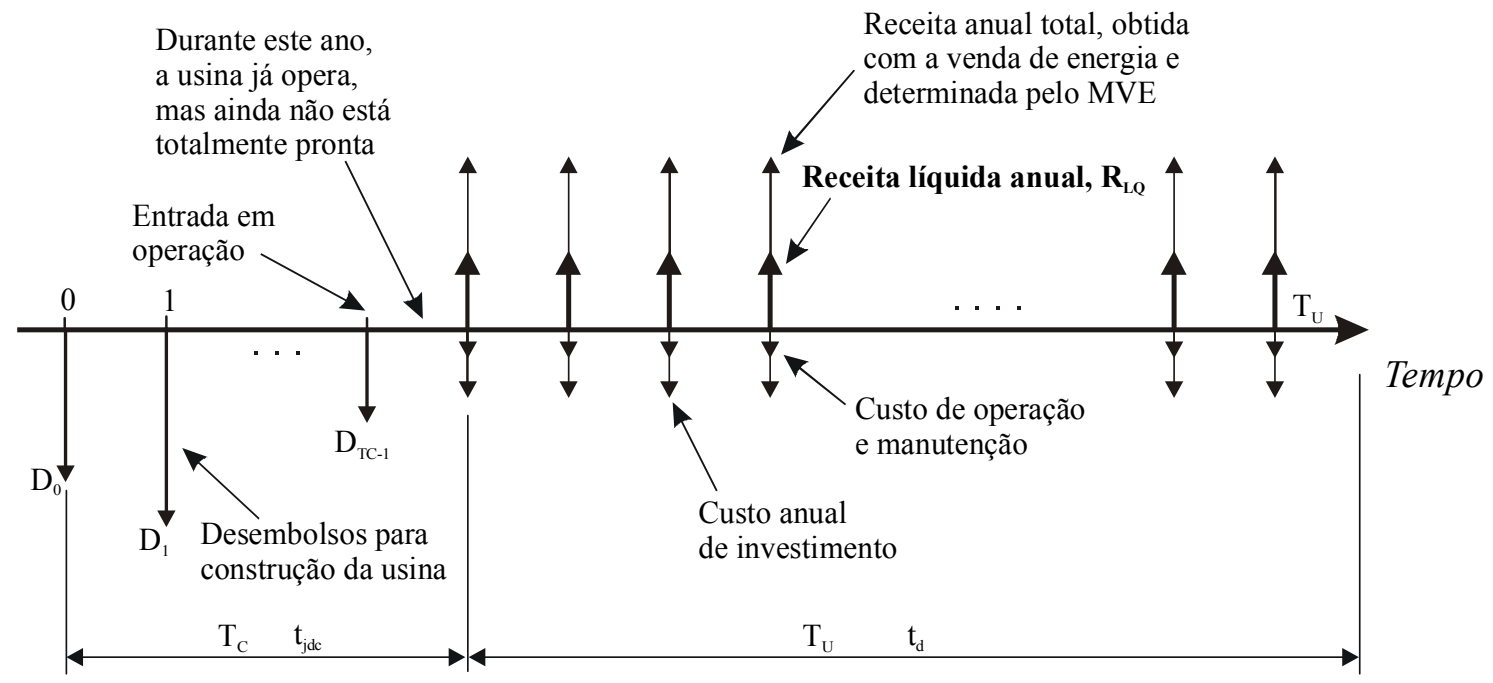

Figura 4.3 - Fluxo de caixa do investimento. 


\subsubsection{Cálculo dos Custos Anuais}

Os custos anuais ao longo da vida útil da usina podem ser vistos como a soma dos custos de operação e manutenção, que de fato ocorrem anualmente durante a vida útil da usina, e dos custos de investimento, que apesar de ocorrerem principalmente antes da entrada em operação da usina, podem ser transformados em uma série anual de pagamentos ao longo da vida útil da usina.

Uma vez definidas as características da usina (volumes mínimo e máximo, e potência nominal), segue-se o seguinte procedimento:

1. Cálculo do investimento total, $I_{T}$, com base nas tabelas de custo:

$$
I_{T}=\underbrace{c_{c r}\left(x_{\text {máx }}\right)}_{\text {construção }}+\underbrace{c_{a t}\left(a e\left(h_{\text {mon }}\left(x_{\text {máx }}\right)\right)\right)}_{\text {aquisição de terras }}+\underbrace{c_{g t, b}\left(p_{\text {nom }, b}\right)+c_{\text {gt, }}\left(p_{\text {nom }, p}\right)}_{\text {equipamentos de base ponta }}
$$

na qual:

- $c_{c r}\left(x_{\text {máx }}\right)$ : custo de construção do reservatório como função do volume máximo, em $\mathrm{hm}^{3}$;

- $a_{e}\left(h_{m o n}\left(x_{\text {máx }}\right)\right)$ : área do espelho d'água, em $\mathrm{km}^{2}$, em função do nível máximo de montante, em $m$. O nível de montante para o reservatório completamente cheio é calculado pelo polinômio cota $x$ volume $h_{\text {mon }}\left(x_{\text {máx }}\right)$;

- $c_{g t, b}\left(p_{n o m, b}\right):$ custo dos geradores e das turbinas de base como função da capacidade instalada de base, em $M W$.

- $\quad c_{g t, p}\left(p_{n o m, p}\right)$ : custo dos geradores e das turbinas de ponta como função da capacidade instalada de ponta, em $M W$.

2. Cálculo do valor presente do investimento total, $I_{T, V P}$, considerando a taxa anual de juros durante a construção:

Conforme já mencionado, o valor do investimento total é transformado em parcelas de acordo com o cronograma de desembolso. Os desembolsos são fornecidos como frações do investimento total. Se $D_{j}$ é a fração de desembolso no início do ano $j$, deve-se garantir a seguinte relação:

$$
\sum_{j=0}^{T_{C}-1} D_{j}=1
$$

onde $T_{C}$ é o tempo de construção da obra, em anos.

O valor presente do investimento é calculado como: 


$$
\begin{gathered}
I_{T, V P}=D_{0} \cdot I_{T} \cdot\left(1+t_{j d c}\right)^{T C-1}+D_{1} \cdot I_{T} \cdot\left(1+t_{j d c}\right)^{T C-2}+\cdots+D_{T C-1} \cdot I_{T} \\
I_{T, V P}=\sum_{j=0}^{T C-1} D_{j} \cdot I_{T} \cdot\left(1+t_{j d c}\right)^{T C-j-1}
\end{gathered}
$$

Por exemplo, para $T_{C}=5$ anos, $t_{j d c}=0,10 ; D_{0}=0,10 ; D_{1}=0,10 ; D_{2}=0,35$; $D_{3}=0,30 ; D_{4}=0,15 ;$ e $I_{T}$ literal, tem-se o valor presente calculado abaixo e ilustrado na Figura 4.4.

$$
\begin{gathered}
I_{T, V P}=I_{T} \cdot D_{0} \cdot(1,10)^{4}+I_{T} \cdot D_{1} \cdot(1,10)^{3}+I_{T} \cdot D_{2} \cdot(1,10)^{2}+I_{T} \cdot D_{3} \cdot(1,10)+I_{T} \cdot D_{4} \\
I_{T, V P}=I_{T} \cdot\left(0,10 \cdot(1,10)^{4}+0,10 \cdot(1,10)^{3}+0,35 \cdot(1,10)^{2}+0,30 \cdot(1,10)+0,15\right) \\
I_{T, V P}=1,1830 \cdot I_{T}
\end{gathered}
$$

Isso indica que a construção da usina de acordo com o cronograma e com a taxa de juros especificada, implica o pagamento de $18,30 \%$ de juros sobre o investimento total. Este valor é relativamente baixo devido à taxa anual de juros do exemplo. Em casos reais observam-se pagamentos de juros durante a construção podem alcançar de $20 \%$ a $30 \%$ do investimento total.

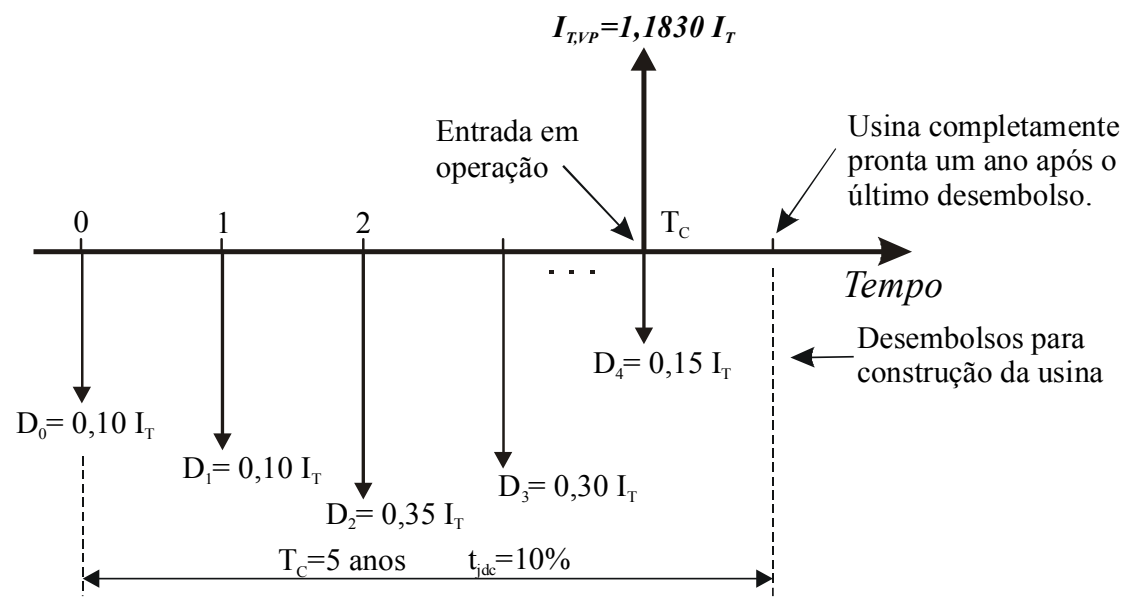

Figura 4.4 - Exemplo de cálculo do valor presente do investimento total.

3. Transformação do valor presente do investimento total, $I_{T, V P}$, em custos anuais de investimento ao longo da vida útil da usina, $C_{I T}$ :

$$
C_{I T}=I_{T, V P} \cdot \operatorname{FRC}\left(t_{d}, T_{U}\right)
$$




$$
\operatorname{FRC}\left(t_{d}, T_{U}\right)=\frac{\left(1+t_{d}\right)^{T_{U}} \cdot t_{d}}{\left(1+t_{d}\right)^{T_{U}}-1}
$$

nas quais:

- $\quad C_{I T}$ : custo anual de investimento, em US\$;

- $\quad I_{T, V P}$ : valor presente do investimento total, US\$;

- $\quad F C R\left(t_{d}, T_{U}\right)$ : fator de recuperação de capital a uma taxa anual de desconto $t_{d}$, ao longo da vida útil do aproveitamento $T_{U}$, em anos.

4. Estimativa do custo anual de operação e manutenção, $C O M$, em $10^{3}$ US\$/ano, através da seguinte expressão [48]:

$$
C O M=a \cdot p_{\text {nom }}{ }^{b+1}
$$

na qual:

- $\left\{\begin{array}{l}a=118,94 \text { e } b=-0,6064, \text { para } p_{\text {nom }} \leq 146,71 M W \\ a=10,94 \text { e } b=-0,1281, \text { para } p_{\text {nom }}>146,71 M W\end{array}\right.$

- $\quad p_{\text {nom: }}$ potência nominal total da usina $i$, em MW;

5. Cálculo do custo anual total da usina, $C_{T}$, em US\$/ano, através da soma dos custos anuais de investimento, $C_{I T}$, e de operação e manutenção, $C O M$ :

$$
C_{T}=C_{I T}+10^{3} \cdot C O M
$$

\subsubsection{Cálculo das Receitas Anuais}

Após realizar os cálculos de custo, as dimensões da usina são fornecidas ao modelo de simulação, no qual são determinados os valores de Energia Firme, Energia Secundária e Ponta Garantida de cada usina do Sistema de Completo. As respostas deste modelo são fornecidas ao Mecanismo de Valorização da Energia (MVE), explicado na Seção 1.5, o qual retorna a receita anual em US\$/ano.

\subsubsection{Cálculo da Receita Líquida Anual}

Finalmente, o fluxo de caixa mostrado na Figura 4.3 pode ser aplicado. A receita líquida anual do empreendimento, $R_{L Q}$ em US\$/ano, indica a rentabilidade do aproveitamento. Eventualmente, se $R_{L Q}<0$, a obra não é viável.

$$
R_{L Q}=R_{T}-C_{T}
$$

na qual: 
- $R_{T}$ : receita anual total expressa pela Equação 4.9, página 99, em US\$/ano. Esta receita pode provir dos benefícios energéticos globais ou locais, dependendo do MVE utilizado;

- $C_{T}$ : custo anual total da usina, Equação 4.17, em US\$/ano.

\subsection{Parâmetros da Técnica de Otimização}

A técnica de otimização utilizada, explicada em detalhes na Seção 2, é chamada Algoritmos Genéticos.

Os parâmetros que precisam ser especificados são os seguintes:

- Tamanho da população: corresponde ao número de indivíduos em cada geração, denotado por $n_{\text {ind }}$.

- População inicial: forma de iniciação dos indivíduos da primeira população.

- Taxa de cruzamento: taxa utilizada para determinar se dois indivíduos sofrerão cruzamento, denotada por $t_{c}$.

- Taxa de mutação: taxa utilizada para determinar se um indivíduo sofrerá mutação, denotada por $t_{m}$.

- Critério de parada: indica quando o processo iterativo deve deixar de ocorrer, indicando a convergência do método. Entre os critérios implementados, destacam-se o número máximo de gerações, o número máximo de gerações sem melhoria, o tempo de processamento ou a obtenção de valores da "função objetivo" considerados apropriados para o problema.

- Valores mínimo e máximo de cada variável: normalmente as variáveis do algoritmo genético variam entre 0 e 1 , mas os valores da variável no sistema físico pertencem a um intervalo $\left[a_{i}, b_{i}\right]$ fornecido. A transformação entre os intervalos $[0,1]$ e $\left[a_{i}, b_{i}\right]$ é feita de forma linear, de forma que 0 equivalha ao valor mínimo e 1 ao valor máximo. 



\section{Método de Otimização Evolutiva}

O método de otimização utilizado neste trabalho é o método de otimização evolutiva conhecido como Algoritmos Genéticos (AGs). O método dos AGs é uma técnica de busca baseada nos mecanismos de evolução e seleção natural [60, 61]. A escolha desta técnica é justificada pelo "casamento" entre suas características e as necessidades do problema a ser resolvido [39].

No caso específico do dimensionamento de uma usina hidroelétrica, a necessidade dos estudos de simulação no cálculo dos benefícios faz com que não haja uma função objetivo analítica explícita para o problema. Esta característica praticamente inviabiliza o uso de técnicas convencionais de otimização, já que na busca por soluções melhores, estas técnicas normalmente recorrem à determinação de uma direção de caminhada e de um máximo passo a ser dado nesta direção [15]. Tanto o cálculo da direção quanto o cálculo do passo normalmente baseiam-se em avaliações da função objetivo e/ou de suas derivadas, não disponíveis de forma explícita no problema de dimensionamento.

Sob este aspecto, a vantagem dos Algoritmos Genéticos reside na necessidade apenas do valor da função objetivo no processo de otimização. A busca por melhores soluções baseia-se inteiramente nesta informação, sem necessidade de cálculo de derivadas ou da disponibilidade de uma expressão analítica da função objetivo. Esta característica, aliada à relativa robustez dos Algoritmos Genéticos definiu a utilização desta técnica no modelo proposto.

Adicionalmente, os Algoritmos Genéticos são relativamente fáceis de serem implementados e ajustados para trabalhar na solução de diferentes problemas ou modelos. Esta facilidade de adequação deve permitir que a metodologia desenvolvida para otimizar as dimensões de uma usina hidroelétrica seja futuramente expandida para dimensionar várias usinas de forma simultânea, incluindo a escolha de quais são as melhores opções de divisão de queda. Neste caso, o problema admite uma natureza combinatória, a qual já vem sendo resolvida através dos Algoritmos Genéticos em outras áreas do conhecimento [94]. 


\subsection{Visão Geral dos Algoritmos Genéticos}

Conforme já citado, os Algoritmos Genéticos (AGs) são técnicas de busca aleatória baseadas nos mecanismos de evolução e seleção natural [60, 61]. Os Algoritmos Genéticos, diferentemente das técnicas convencionais de otimização que utilizam uma única solução do problema e tentam melhorá-la o máximo possível, trabalham simultaneamente com um conjunto de soluções chamado de população. Cada indivíduo da população, geralmente chamado de cromossomo, representa uma solução do problema que está sendo resolvido. Um cromossomo ${ }^{18}$ é um vetor de símbolos, classicamente um vetor de números binários.

A idéia do método é fazer com que os cromossomos (indivíduos da população) evoluam ao longo das iterações, chamadas de gerações, produzindo soluções cada vez melhores até que se chegue a uma boa solução do problema, sem garantia de que ela seja a solução ótima global. Para que a evolução ocorra, é necessário que os indivíduos da população sejam avaliados a partir da aplicação de uma função de aptidão, a qual indica o quanto o indivíduo é bom em relação aos objetivos desejados.

A criação de uma nova população nada mais é que a criação de novos indivíduos, geralmente a partir dos existentes, gerando assim um novo conjunto formado por indivíduos do conjunto antigo e por seus descendentes. Os descendentes são gerados de duas formas: $(i)$ cruzando indivíduos da população atual através de uma operação de cruzamento, e/ou (ii) modificando indivíduos através de um operador de mutação. A nova população é formada através da seleção de indivíduos entre a população atual e os seus descendentes, sendo que a chance de um indivíduo ser transferido para a nova população é normalmente proporcional à sua aptidão, ou seja, há uma tendência de aproveitar os indivíduos mais aptos, que representam soluções melhores para o problema a ser solucionado. Para garantir que os melhores indivíduos sejam mantidos, pode-se utilizar um operador de elitismo, o qual copia para a nova população os melhores indivíduos (um ou dois, normalmente) da população original. Depois de várias gerações serem criadas, o algoritmo converge para o melhor cromossomo, o qual representa uma "boa" solução do problema (reforça-se que não necessariamente trata-se da solução ótima global).

Sendo $P(t)$ a população existente na geração $t$, a estrutura geral de um AG pode ser descrita da seguinte forma:

\footnotetext{
${ }^{18}$ Neste trabalho, considera-se que cada indivíduo possui somente um cromossomo.
} 
- Iniciação:

- $t=0 ;$

- Inicie população $P(t)$;

- Enquanto nenhum critério de parada for satisfeito:

- Avalie $P(t)$;

- Selecione indivíduos de $P(t)$ e sobre eles aplique as operações de elitismo, cruzamento e mutação para produzir $P(t+1)$;

- $t=t+1$;

De uma forma genérica, o processo de otimização através dos AGs utiliza apenas dois tipos de operação:

- Operações Genéticas: cruzamento e mutação;

- Operação de Evolução: seleção, incluindo o operador de elitismo.

Enquanto as operações genéticas imitam o processo de hereditariedade dos genes para criar os descendentes, a seleção imita o processo de evolução descrito por Darwin para criar populações que evoluam de geração a geração [38].

Na Figura 4.5 apresenta-se o esquema geral de um AG, indicando a seqüência de aplicação dos operadores de seleção, elitismo, cruzamento e mutação.

Em [79] descreve-se um conjunto de componentes básicos que todo AG deve possuir para poder ser aplicado à solução de um problema. Estes componentes são listados abaixo e descritos na seqüência com a ajuda de um exemplo numérico.

- Representação das soluções do problema como indivíduos da população do Algoritmo Genético.

- Função de avaliação que fornece a cada indivíduo da população uma indicação de quão bom ele é (aptidão).

- Modo de criação da população inicial.

- Operadores de evolução que promovem a sobrevivência dos mais aptos.

- Conjunto de operadores genéticos que promovem a troca de informação entre os indivíduos ao longo do processo evolutivo ("iterativo").

- Valores dos parâmetros, tais como tamanho da população, taxas de cruzamento e mutação, etc.

- Critério de parada para o processo iterativo. 


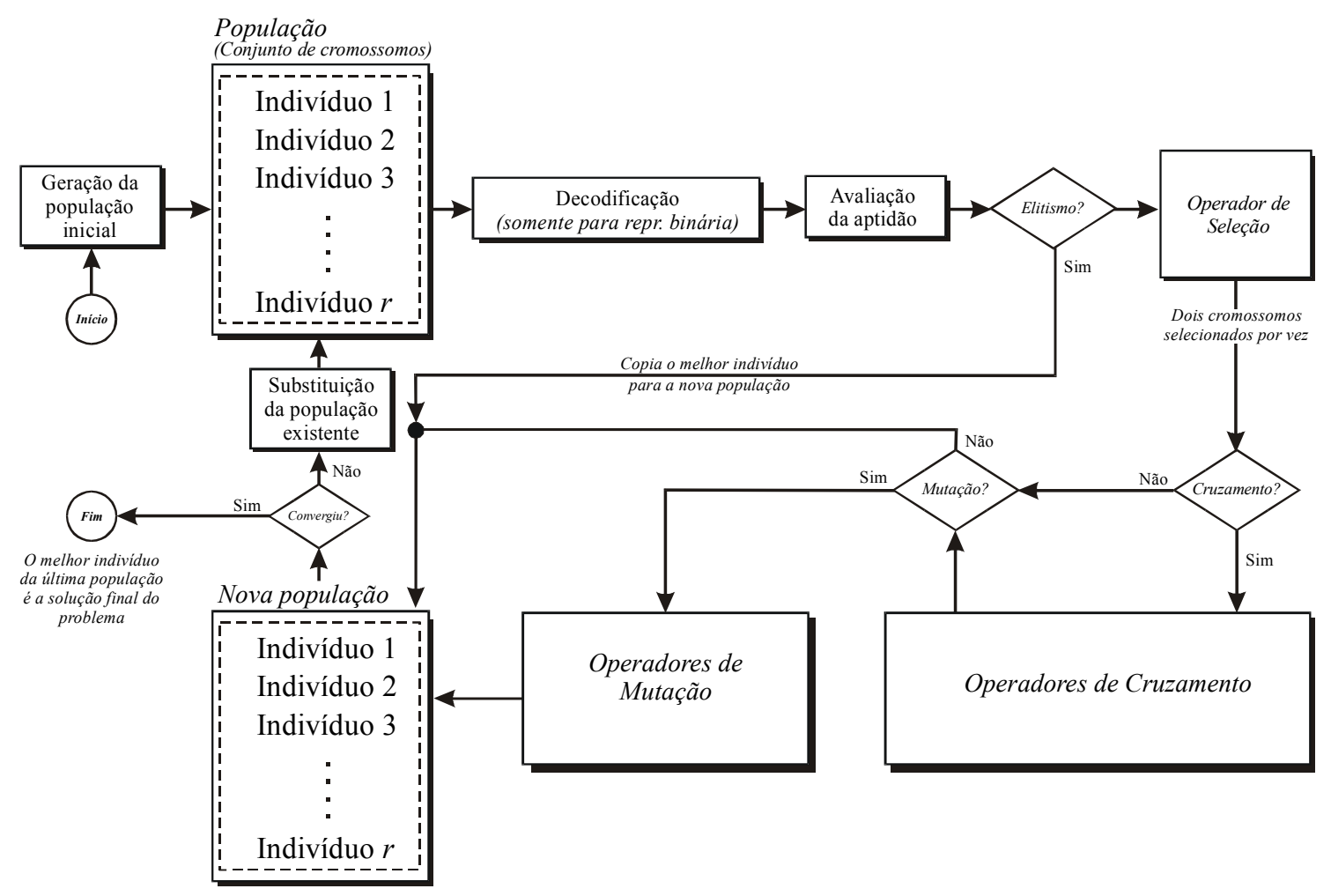

Figura 4.5 - Representação esquemática de um AG com representação binária.

\subsubsection{Exemplo numérico}

O exemplo numérico presta-se a explicar melhor alguns dos aspectos dos AGs que serão mostrados na seqüência. Como o dimensionamento de uma usina hidroelétrica é um problema de programação matemática na qual as variáveis de decisão são números reais, optou-se por um exemplo numérico de mesma natureza. Trata-se da resolução do problema de otimização abaixo, cujo gráfico tridimensional da função de avaliação é mostrado na Figura 4.6.

$$
\begin{aligned}
& \max f\left(x_{1}, x_{2}\right)=1+\exp \left(-1,5 \cdot\left(x_{1}^{2}+x_{2}^{2}\right)\right) \cdot \cos \left(2 \cdot \pi \cdot x_{2}\right) \cdot \operatorname{sen}\left(2 \cdot \pi \cdot x_{1}\right) \\
& \text { s.a. }\left\{\begin{array}{l}
x_{1} \geq-1 \\
x_{1} \leq 1 \\
x_{2} \geq-1 \\
x_{2} \leq 1
\end{array}\right.
\end{aligned}
$$




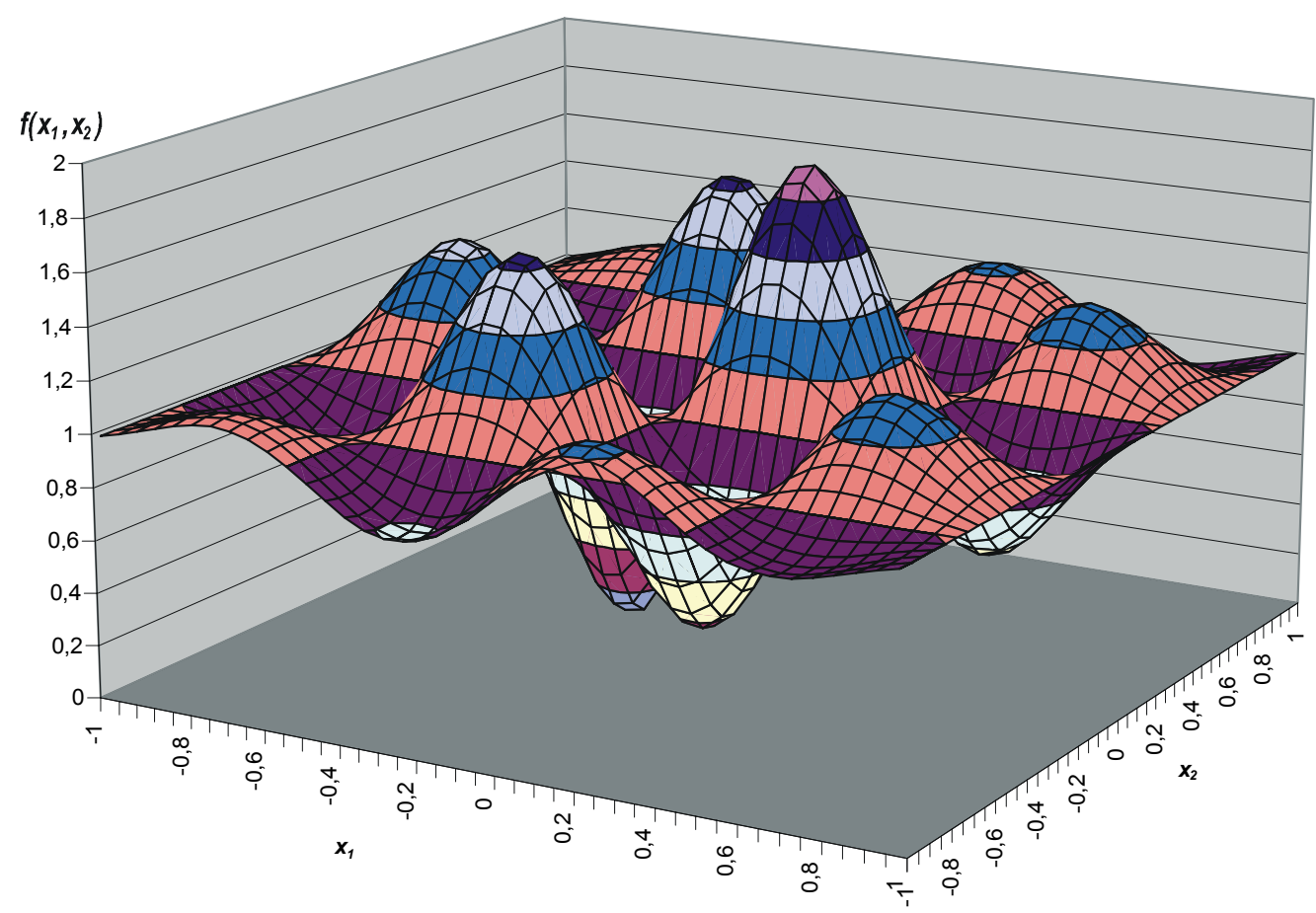

Figura 4.6 - Gráfico tridimensional da função de avaliação.

\subsubsection{Representação das Soluções do Problema}

As soluções de um problema normalmente são representadas através de vetores de símbolos, chamados de indivíduos da população. Classicamente, os indivíduos da população são representados por números binários. Supondo que os vetores de números binários estejam representando números reais (caso de interesse), deve-se estabelecer um procedimento de decodificação, de forma que as seqüências de zeros e uns apresentem algum sentido prático relacionado com o problema a ser resolvido [61].

Se o domínio da variável $x_{j}$ é $\left[a_{j}, b_{j}\right]$, deve-se estabelecer uma série de procedimentos para determinar o número de bits dos vetores binários (indivíduos) e a forma como estas seqüências são transformadas em números reais. Para o exemplo, uma precisão de 3 casas decimais implica a utilização de 11 números binários para representar cada variável. Logo, o cromossomo terá 22 genes, onze representando $x_{1}$ e onze representando $x_{2}$, tal como ilustrado na Figura 4.7.

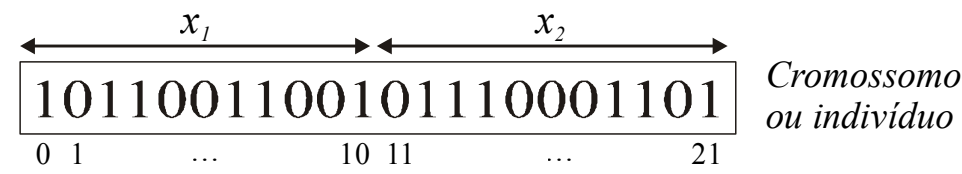

Figura 4.7 - Representação binária das variáveis $x_{1}$ e $x_{2}$. 
O processo de transformação de números binários em números reais apresenta algumas desvantagens. Primeiro, a transformação em si pode envolver um esforço computacional considerável, dependendo da aplicação. Segundo, conforme o número de variáveis e suas respectivas precisões aumentam, a quantidade de bits necessária para representar uma solução pode tornar-se demasiadamente grande, o que pode comprometer a eficiência do algoritmo. Terceiro, quando uma solução é apresentada em termos binários, ela não é diretamente compreendida, sendo necessários cálculos para transformá-la em números que efetivamente representam soluções do problema.

Para superar estas dificuldades, os indivíduos podem ser representados diretamente através de vetores de números reais. Assim, um indivíduo representante de uma solução do exemplo numérico seria simplesmente composto por dois números reais, tal como ilustrado na Figura 4.8.

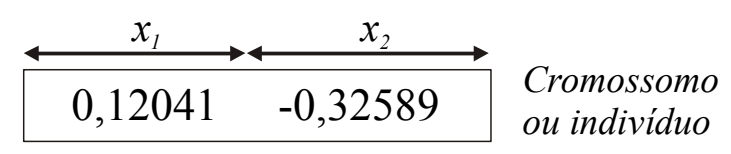

Figura 4.8 - Representação real das variáveis $x_{1}$ e $x_{2}$.

Devido à normalização, os valores de $x_{1}$ e $x_{2}$ devem ser ajustados para que os valores resultantes pertençam aos intervalos $\left[a_{1}, b_{1}\right]$ e $\left[a_{2}, b_{2}\right]$, respectivamente. Esta desnormalização é feita de acordo com a Equação 4.19.

$$
x_{j}=\left(b_{j}-a_{j}\right) \cdot x_{j}+a_{j}
$$

A primeira pergunta que surge é qual das duas representações é a melhor. A literatura tem mostrado que em problemas onde os parâmetros são naturalmente números reais, a representação real apresenta melhores resultados [63, 80] [72-75].

Conforme será visto adiante, a escolha entre as representações real e binária também tem implicações sobre o conjunto de operadores que o algoritmo poderá utilizar ao longo do processo de otimização.

\subsubsection{Função de Avaliação}

A função de avaliação é responsável por indicar "quão bom” um indivíduo é em termos do objetivo do problema a ser resolvido. Para problemas de maximização de uma função positiva, a aptidão de um indivíduo, $a p\left(x_{i}\right)$, pode ser o próprio valor da função objetivo, isto é, ap $\left(x_{i}\right)=f\left(x_{i}\right)$.

Para a representação binária, os passos para a avaliação de um indivíduo são os 
seguintes:

1. Conversão dos valores binários dos cromossomos, $v_{i}$, em variáveis reais, $x_{i}$;

2. Avaliação da função objetivo através dos valores reais das variáveis, $x_{i}$;

3. Conversão da função objetivo em um valor de aptidão.

Para a representação real, somente os passos 2 e 3 são necessários, o que implica menor esforço computacional. A tabela a seguir ilustra as aptidões de alguns indivíduos do exemplo numérico. Observando os resultados, tem-se que o cromossomo 2 é o "mais apto" do grupo, enquanto o cromossomo 9 é o "menos apto".

\begin{tabular}{c} 
Tabela $4.1-$ Valores de aptidão de individuos da população iniciat \\
\hline$a p\left(v_{1}\right)=f(0,128481,0,806546)=1,092397$ \\
\hline$a p\left(v_{2}\right)=f(0,290669,-0,533952)=1,543172$ \\
\hline$a p\left(v_{3}\right)=f(0,694187,-0,192965)=0,848807$ \\
\hline$a p\left(v_{4}\right)=f(-0,968735,0,798730)=1,005529$ \\
\hline$a p\left(v_{5}\right)=f(0,863214,0,999023)=0,944565$ \\
\hline$a p\left(v_{6}\right)=f(-0,415730,-0,427455)=1,266058$ \\
\hline$a p\left(v_{7}\right)=f(-0,422570,-0,857352)=0,925836$ \\
\hline$a p\left(v_{8}\right)=f(-0,999023,0,833903)=1,000244$ \\
\hline$a p\left(v_{9}\right)=f(-0,059111,-0,143136)=0,782195$ \\
\hline$a p\left(v_{10}\right)=f(-0,714704,-0,153884)=1,248482$ \\
\hline
\end{tabular}

\subsubsection{População Inicial}

A população inicial representa o primeiro conjunto de indivíduos a partir do qual todo o processo de evolução será realizado. Para garantir a exploração do espaço composto pelas soluções do problema é importante que a população inicial seja criada de forma a conter indivíduos que representem diversas soluções possíveis e distintas.

Uma forma tradicional de determinar a população inicial é simplesmente sortear aleatória e uniformemente os valores dos indivíduos. Neste caso, são grandes as possibilidades de que algumas regiões do espaço de busca não sejam representadas na população inicial. A tabela seguinte ilustra uma população inicial aleatória de dez indivíduos para o problema do exemplo numérico.

Uma forma de melhorar o desempenho inicial do algoritmo é gerar a primeira população com um número de indivíduos maior que o número de indivíduos que será efetivamente utilizado ao longo do processo de otimização. Estes indivíduos iniciais 
serão avaliados e somente os melhores passam a integrar a população a partir da qual o processo será iniciado. Por exemplo, se o AG fosse trabalhar com uma população de dez indivíduos, a população inicial poderia conter trinta indivíduos. Os dez melhores seriam selecionados e o processo de otimização começaria por eles.

Tabela 4.2 - População inicial aleatória.

\begin{tabular}{ccc}
\hline$v_{1}=$ & {$[1001000001111100111001]$} & $(0,128481,0,806546)$ \\
\hline$v_{2}=$ & {$[0101101011000111011101]$} & $(-0,290669,-0,533952)$ \\
\hline$v_{3}=$ & {$[1101100011001100111010]$} & $(0,694187,-0,192965)$ \\
\hline$v_{4}=$ & {$[0000010000011100110001]$} & $(-0,968735,0,798730)$ \\
\hline$v_{5}=$ & {$[1110111001111111111110]$} & $(0,863214,0,999023)$ \\
\hline$v_{6}=$ & {$[0100101011001001001010]$} & $(-0,415730,-0,427455)$ \\
\hline$v_{7}=$ & {$[0100100111100010010010]$} & $(-0,422570,-0,857352)$ \\
\hline$v_{8}=$ & {$[0000000000111101010101]$} & $(-0,999023,0,833903)$ \\
\hline$v_{9}=$ & {$[0111100001101101101101]$} & $(-0,059111,-0,143136)$ \\
\hline$v_{10}=$ & {$[0010010010001101100010]$} & $(-0,714704,-0,153884)$ \\
\hline
\end{tabular}

Outra opção é gerar os indivíduos uniformemente, de forma a explorar todo o espaço de busca. Por exemplo, para o exemplo numérico sendo resolvido com representação real, uma população inicial uniforme com variação de 0,20 em cada variável (cada variável varia de -1 a 1 ) conteria indivíduos com os seguintes valores: $[-1,00 ;-1,00],[-0,80 ;-1,00],[-0,60 ;-1,00], \ldots,[-1,00 ;-0,80],[-0,80 ;-0,80], \ldots$, [1,00; 1,00]. Dentre os 121 (11 valores de $x_{1}$ e 11 valores de $x_{2}$ ) indivíduos produzidos, os dez melhores seriam utilizados para iniciar a otimização.

Uma outra opção para explorar o espaço de busca é gerar metade da população de forma aleatória e a outra metade de forma complementar à inicial. A tabela seguinte ilustra este procedimento com uma população inicial de dez indivíduos binários e outra com dez indivíduos reais. Esta população inicial poderia ser incrementada (trinta indivíduos, por exemplo) e somente os melhores copiados para o início do processo de otimização.

Finalmente, algumas aplicações de AG inserem indivíduos conhecidos que possuem bons valores de aptidão na população inicial ${ }^{19}$. Se estes indivíduos são

\footnotetext{
${ }^{19}$ Esta técnica é conhecida como "seeding".
} 
resultantes de outras técnicas de otimização, por exemplo, isto garante que a solução final do AG não será pior que a solução da outra técnica ${ }^{20}$. No entanto, estes indivíduos iniciais, exatamente por serem bons, podem "viciar" o processo de seleção e impedir que outras regiões promissoras do espaço de busca sejam exploradas.

Tabela 4.3 - População inicial metade aleatória e metade complementar (binária e real).

\begin{tabular}{cc}
\hline$[1001000001111100111001]$ & $(0,128481 ; 0,806546)$ \\
\hline$[0101101011000111011101]$ & $(-0,290669 ;-0,533952)$ \\
\hline$[1101100011001100111010]$ & $(0,694187 ;-0,192965)$ \\
\hline$[0000010000011100110001]$ & $(-0,968735 ; 0,798730)$ \\
\hline$[1110111001111111111110]$ & $(0,863214 ; 0,999023)$ \\
\hline$[0110111110000011000110]$ & $(-0,128481 ;-0,806546)$ \\
\hline$[1010010100111000100010]$ & $(0,290669 ; 0,533952)$ \\
\hline$[0010011100110011000101]$ & $(-0,694187 ; 0,192965)$ \\
\hline$[1111101111100011001110]$ & $(0,968735 ;-0,798730)$ \\
\hline$[0001000110000000000001]$ & $(-0,863214 ;-0,999023)$ \\
\hline
\end{tabular}

\subsubsection{Operadores de Elitismo}

Os operadores de elitismo têm por objetivo garantir que os melhores indivíduos pertencentes à população atual estarão presentes na geração seguinte. Para tanto, após a população ser avaliada, os $N$ melhores indivíduos são copiados diretamente à próxima população e a eles é proibida a aplicação de operadores que podem alterar suas características.

Por exemplo, se $N=2$ para o problema numérico, de acordo com a Tabela 4.1, os indivíduos 2 e 6 seriam automaticamente copiados para a população seguinte. Após a aplicação do operador de elitismo, aplicam-se os operadores de seleção.

\subsubsection{Operadores de Seleção}

Os operadores de seleção imitam o processo de seleção natural, fazendo com que os indivíduos mais aptos tenham maiores chances de sobreviver e serem passados à população seguinte. O método tradicional de execução da seleção é o Método da Roleta.

O Método da Roleta pode ser realizado através das seguintes operações:

- Calcula-se o valor da aptidão $\operatorname{ap}\left(v_{i}\right)$ para cada cromossomo :

$$
\operatorname{ap}\left(v_{i}\right)=f\left(x^{i}\right), \quad i=1,2, \cdots, n_{\text {ind }}
$$

\footnotetext{
${ }^{20}$ Supõe-se a utilização do operador de elitismo.
} 
sendo $n_{\text {ind }}$ o número de indivíduos da população e $x^{i}=\left(x_{1}, x_{2}, \ldots, x_{r}\right)$ o vetor contendo todas as $r$ variáveis reais do problema.

- Calcula-se a aptidão total da população:

$$
F=\sum_{i=1}^{n_{\text {ind }}} a p\left(x^{i}\right)
$$

- Calcula-se a probabilidade de seleção de cada cromossomo:

$$
p_{i}=\frac{a p\left(x^{i}\right)}{F}, i=1, \cdots, n_{\text {ind }}
$$

- Calcula-se a probabilidade acumulada $q_{i}$ para cada cromossomo:

$$
q_{i}=\sum_{j=1}^{i} p_{j}, i=1, \cdots, n_{\text {ind }}
$$

Um cromossomo é selecionado para a nova população da seguinte forma:

- Gera-se um número aleatório $r$ pertencente ao intervalo $[0,1]$;

- Seleciona-se o indivíduo $i$ de forma que $q_{i-1} \leq r<q_{i}$ (assume-se $q_{0}=0$ ).

Voltando ao exemplo numérico e à Tabela 4.4, a aptidão total da população é:

$$
F=\sum_{i=1}^{n_{\text {ind }}} a p\left(x^{i}\right)=10,65729
$$

A probabilidade de seleção $p_{i}$ de cada cromossomo e sua respectiva probabilidade acumulada $q_{i}$ são mostradas na Tabela 4.4 .

Possuindo esses valores, selecionam-se dois cromossomos, sorteando-se dois números aleatórios $r_{l}$ e $r_{2}$, pertencentes ao intervalo [0,1]. Na seqüência, verifica-se se os indivíduos sofrerão cruzamento e/ou mutação, aplicam-se os respectivos operadores genéticos e os cromossomos resultantes são inseridos na nova população. Sorteiam-se dois novos indivíduos e o processo continua até que a nova população seja gerada.

Por exemplo, supõe-se que os dois primeiros números sorteados sejam $r_{1}=0,907896$ e $r_{2}=0,681362$. Estes números farão com que os cromossomos 10 e 7 sejam selecionados. 
Tabela 4.4 - Probabilidades de seleção e acumulada.

\begin{tabular}{ccc}
\hline$i$ & $p\left(x^{i}\right)$ & $q\left(x^{i}\right)$ \\
\hline 1 & 0,102502 & 0,102502 \\
\hline 2 & 0,144800 & 0,247302 \\
\hline 3 & 0,079646 & 0,326948 \\
\hline 4 & 0,094351 & 0,421299 \\
\hline 5 & 0,088631 & 0,509930 \\
\hline 6 & 0,118797 & 0,628728 \\
\hline 7 & 0,086873 & 0,715601 \\
\hline 8 & 0,093855 & 0,809456 \\
\hline 9 & 0,073395 & 0,882852 \\
\hline 10 & 0,117148 & 1,000000 \\
\hline
\end{tabular}

Outro método de seleção bem conhecido é o Método do Torneio. Neste método, vários indivíduos são selecionados da população original e o melhor dentre deles passa a fazer parte da nova população. Uma variação do Método do Torneiro pode "rodar a roleta" para selecionar os vários indivíduos e então escolher o melhor para fazer parte da nova população.

\subsubsection{Operadores Genéticos de Cruzamento}

Os operadores genéticos são responsáveis por promover a troca de informações entre os indivíduos. Dependendo do tipo de representação adotada, esta informação poderá ser representada por números binários ou reais, o que altera de forma significativa o procedimento a ser seguido. Assim, optou-se por dividir os operadores em subseções, indicando explicitamente se eles se aplicam às representações binária ou real.

Em qualquer um dos operadores de cruzamento, após os indivíduos serem selecionados, deve-se determinar se eles realmente sofrerão cruzamento ou se serão copiados diretamente à nova população. Esta decisão é feita com base na taxa de cruzamento. Sorteia-se um número aleatório de uma distribuição uniforme de valores entre 0 e 1 , denominado $p_{c}$, e compara-se este valor à taxa de cruzamento. Se $p_{c}$ for menor que a taxa, ocorre cruzamento; caso contrário, copiam-se os indivíduos selecionados para a população nova.

Para explicar os operadores de cruzamento, supõe-se em todos os casos que o valor sorteado de $p_{c}$ foi menor que a taxa de cruzamento, devendo assim haver troca de informação (cruzamento) entre os indivíduos selecionados. 


\section{- Cruzamento Binário de Um Ponto}

O cruzamento binário de um ponto seleciona aleatoriamente um ponto de corte e realiza troca de material genético entre os cromossomos que estão sendo cruzados. Inicialmente, escolhe-se aleatoriamente um ponto de corte nos dois cromossomos pais e geram-se os descendentes da seguinte forma:

- O primeiro filho herda a parte que está à esquerda do ponto de corte do primeiro pai e à direita do ponto de corte do segundo pai;

- O segundo filho herda a parte que está à direita do ponto de corte do primeiro pai e à esquerda do ponto de corte do segundo pai.

A forma como esta troca é realizada é explicada recorrendo-se ao exemplo numérico e supondo-se que os indivíduos 10 e 7 foram selecionados para fazer cruzamento. Supondo ainda o ponto de corte igual a 3, obtêm-se os cromossomos mostrados na Figura 4.9. Os indivíduos gerados são os candidatos a primeiros indivíduos da nova população. Resta saber se eles sofrerão mutação ou não.

$$
\begin{aligned}
& v_{10} \underset{001,0010010001101100010}{\stackrel{x_{1}}{\longleftrightarrow}} \\
& v_{7} \quad 01010100111100010010010 \\
& \begin{array}{c|c|c|}
v_{\text {(nova pop.) }} & 001 & 0100111100010010010 \\
\hline
\end{array} \\
& \begin{array}{c|c|c|}
v_{2} & 010 & 0010010001101100010 \\
\text { (nova pop.) }
\end{array}
\end{aligned}
$$

Figura 4.9 - Resultado do operador de cruzamento binário de um ponto.

\section{- Cruzamento Binário de Dois Pontos}

O cruzamento binário de dois pontos é bem semelhante ao de um ponto. Neste caso, selecionam-se aleatoriamente dois pontos de corte e então se realiza a troca de material genético entre os cromossomos que estão sendo cruzados. Escolhem-se aleatoriamente dois pontos de corte nos dois cromossomos pais e geram-se os descendentes da seguinte forma:

- O primeiro filho herda duas partes do primeiro pai: as localizadas à esquerda do primeiro ponto de corte e à direita do segundo ponto de corte. Em seguida, o primeiro filho herda do segundo pai as informações localizadas entre os dois pontos de corte. 
- Com o segundo filho ocorre o contrário. Ele herda do primeiro pai as informações localizadas entre os pontos de corte, e herda do segundo pai as informações localizadas à esquerda e à direita dos primeiro e segundo pontos de corte, respectivamente.

Novamente recorre-se ao exemplo numérico e supõe-se que os indivíduos 10 e 7 foram selecionados para fazer cruzamento. Supondo pontos de corte iguais a 3 e 12, obtêm-se os indivíduos mostrados na Figura 4.10.

$$
\begin{aligned}
& v_{10} \underset{001 ! 001001000 ! 1101100010}{\stackrel{x_{1}}{\stackrel{1}{\longrightarrow}}} \\
& v_{7} \quad 0101010011110: 0010010010
\end{aligned}
$$

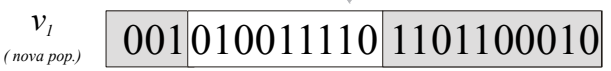

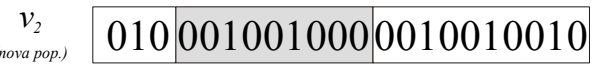

Figura 4.10 - Resultado do operador de cruzamento binário de dois pontos.

\section{- Cruzamento Binário Uniforme}

O cruzamento binário uniforme é uma generalização dos operadores de um ponto e de dois pontos. Neste caso, gera-se uma máscara de números binários aleatórios e as informações dos pais são passadas aos filhos da seguinte forma:

- O filho um herda características do primeiro pai quando a máscara possui valor unitário e características do segundo pai quando a máscara possui valor nulo.

- Com o filho dois ocorre o contrário.

Novamente recorre-se ao exemplo numérico e supõe-se que os indivíduos 10 e 7 foram selecionados para fazer cruzamento. Supondo a máscara mostrada na Figura 4.11, obtêm-se os indivíduos filhos ilustrados na mesma figura.

$$
\begin{aligned}
& v_{10} \underset{0010010010001101100010}{\stackrel{x_{1}}{\longleftrightarrow}} \\
& v_{7} \quad 0100100111100010010010 \\
& \text { máscara } 0000100111001110010000 \\
& \begin{array}{l}
\underset{\text { (nova pop) }}{v_{l^{\prime}}} \\
v_{2}
\end{array} \quad 0100000010101100000010
\end{aligned}
$$

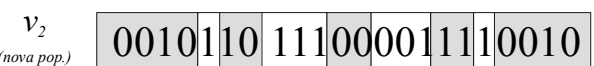

Figura 4.11 - Resultado do operador de cruzamento binário uniforme. 


\section{- Cruzamento Real Média Aritmétrica}

O cruzamento real média aritmética gera apenas um indivíduo filho a partir dos dois indivíduos pais. Cada gene do filho é calculado como a média aritmética dos respectivos genes dos pais. Assim, se os pais forem os indivíduos $x^{p 1}=\left[x^{p l, 1}, \ldots, x^{p l, r}\right] \mathrm{e}$ $x^{p 2}=\left[x^{p 2,1}, \ldots, x^{p 2, r}\right]$, onde $r$ é o número de variáveis que o cromossomo codifica, o filho $x^{f}=\left[x^{f, 1}, \ldots, x^{f, r}\right]$ será calculado da seguinte forma:

$$
x^{f, i}=\frac{x^{p 1, i}+x^{p 2, i}}{2}, \text { para } i=1, \cdots, r
$$

Por exemplo, se os indivíduos 10 e 7 forem selecionados para cruzamento, obtém-se o filho ilustrado na figura a seguir.

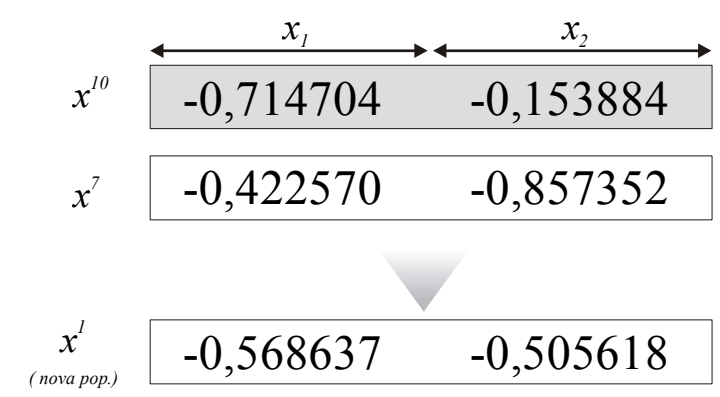

Figura 4.12 - Resultado do operador de cruzamento real média aritmética.

\section{- Cruzamento Real Média Geométrica}

O cruzamento real média geométrica também gera apenas um indivíduo filho a partir dos dois indivíduos pais. Cada gene do filho é calculado como a média geométrica dos respectivos genes dos pais. Assim, se os pais forem os indivíduos $x^{p 1}=\left[x^{p l, 1}, \ldots, x^{p l, r}\right] \mathrm{e}$ $x^{p 2}=\left[x^{p 2,1}, \ldots, x^{p 2, r}\right]$, e $r$ for o número de variáveis que o cromossomo codifica, o filho $x^{f}$ $=\left[x^{f, 1}, \ldots, x^{f, r}\right]$ será calculado da seguinte forma:

$$
x^{f, i}=\operatorname{sinal}\left(x^{p 1, i} \cdot x^{p 2, i}\right) \cdot \sqrt{\left|x^{p 1, i} \cdot x^{p 2, i}\right|}, \text { para } i=1, \cdots, r
$$

Na Figura 4.13 ilustra-se um indivíduo gerado pelo cruzamento real média geométrica. Os valores numéricos dos pais foram feitos iguais aos indivíduos 10 e 7 utilizados anteriormente, porém utilizaram-se os valores absolutos de seus genes para evitar problemas com a extração da raiz quadrada. 


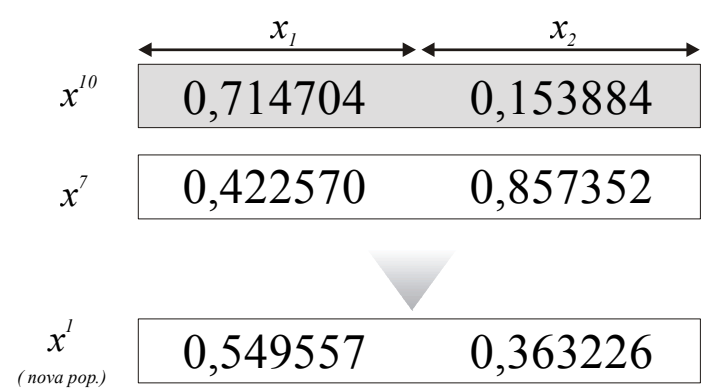

Figura 4.13 - Resultado do operador de cruzamento real média geométrica.

\section{- Cruzamento Real BLX- $\alpha$}

O cruzamento real BLX- $\alpha$ foi desenvolvido para tentar evitar a perda de diversidade normalmente verificada nos cruzamentos com operadores médios vistos acima. Esta perda de diversidade deve-se ao fato dos filhos sempre apresentarem valores de genes entre os valores dos pais, já que os genes filhos são valores médios dos genes dos pais.

Se os pais forem os indivíduos $x^{p 1}=\left[x^{p 1,1}, \ldots, x^{p 1, r}\right]$ e $x^{p 2}=\left[x^{p 2,1}, \ldots, x^{p 2, r}\right]$, e $r$ for o número de variáveis que o cromossomo codifica, o filho $x^{f}=\left[x^{f, 1}, \ldots, x^{f, r}\right]$ será calculado da seguinte forma pelo cruzamento BLX- $\alpha$ (do inglês blend crossover) [118]:

$$
x^{f, i}=(1-\beta) \cdot x^{p 1, i}+\beta \cdot x^{p 2, i}, \text { para } i=1, \cdots, r
$$

onde $\beta$ é um número uniforme pertencente ao intervalo $[-\alpha ; 1+\alpha]$. Quando $\alpha$ é nulo, os genes dos filhos sempre ficarão entre os limites dos genes dos pais. Para $\alpha$ maior que zero, os genes dos filhos poderão ser maiores ou menores que os genes dos pais, dependendo do valor de $\beta$ sorteado. Por exemplo, para $\alpha=0,5,-0,5 \leq \beta \leq 1,5$. Supondo $\beta=1,25$, e os pais $x^{7}$ e $x^{10}$ novamente, tem-se o resultado mostrado abaixo, ilustrado na Figura 4.14 .

$$
\begin{aligned}
& x^{f, 1}=(1-1,25) \cdot x^{10,1}+1,25 \cdot x^{7,1}=-0,25 \cdot-0,714704+1,25 \cdot-0,422570=-0,349537 \\
& x^{f, 2}=(1-1,25) \cdot x^{10,2}+1,25 \cdot x^{7,2}=-0,25 \cdot-0,153884+1,25 \cdot-0,857352=-1,033219
\end{aligned}
$$

Nota-se que $x^{f, 1}>\max \left\{x^{10,1}, x^{7,1}\right\}$, o mesmo ocorrendo com $x^{f 2}$. Isso ocorreu porque $\beta$ foi maior que 1 . Se $\beta$ fosse negativo, os valores dos genes seriam menores que os mínimos valores dos genes dos pais, e se $\beta$ fosse positivo e menor que um, os valores dos genes seriam compreendidos entre os valores dos genes pais. Em outras palavras, o parâmetro $\alpha$ positivo estende o intervalo de possíveis valores dos genes dos filhos. 


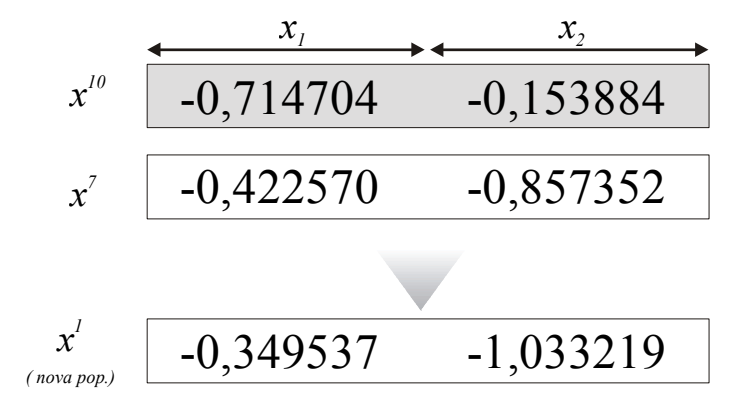

Figura 4.14 - Resultado do operador de cruzamento real BLX- $\alpha$.

\section{- Cruzamento Real Heurístico}

O cruzamento real heurístico realiza uma extrapolação linear dos valores dos genes dos pais utilizando seus valores de aptidão [80]. Se os pais forem os indivíduos $x^{p 1}=\left[x^{p 1,1}\right.$, $\left.\ldots, x^{p 1, r}\right]$ e $x^{p 2}=\left[x^{p 2,1}, \ldots, x^{p 2, r}\right]$, e se $r$ for o número de variáveis que o cromossomo codifica e $\operatorname{ap}\left(x^{p 1}\right)>\operatorname{ap}\left(x^{p 2}\right)$, o filho $x^{f}=\left[x^{f, 1}, \ldots, x^{f, r}\right]$ será calculado da seguinte forma pelo cruzamento real heurístico:

$$
x^{f, i}=(1+\beta) \cdot x^{p 1, i}-\beta \cdot x^{p 2, i}, \text { para } i=1, \cdots, r
$$

na qual $\beta$ é um número uniforme pertencente ao intervalo $[0 ; 1]$. Supondo $\beta=0,25$, e os pais $x^{7}$ e $x^{10}$ novamente $a p\left(x^{10}\right)>a p\left(x^{7}\right)$, tem-se o resultado mostrado a seguir e ilustrado na Figura 4.15.

$$
\begin{aligned}
& x^{f, 1}=(1+0,25) \cdot x^{10,1}-0,25 \cdot x^{7,1}=1,25 \cdot-0,714704-0,25 \cdot-0,422570=-0,787738 \\
& x^{f, 2}=(1+0,25) \cdot x^{10,2}-0,25 \cdot x^{7,2}=1,25 \cdot-0,153884-0,25 \cdot-0,857352=0,021983
\end{aligned}
$$

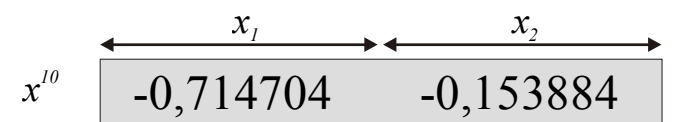

$$
\begin{aligned}
& x^{7} \quad-0,422570 \quad-0,857352 \\
& \underset{\substack{\text { (nova pop.) } \\
x^{l}}}{ }-0,787738 \quad 0,021983
\end{aligned}
$$

Figura 4.15 - Resultado do operador de cruzamento real heurístico.

\subsubsection{Operadores Genéticos de Mutação}

A mutação é um operador que produz mudanças aleatórias espontâneas nos indivíduos, alterando um ou mais de seus genes. O objetivo da mutação é aumentar a diversidade da população, compensando a perda de variedade genética ocorrida durante o processo iterativo e acrescentando à população novos indivíduos. 
De forma similar ao cruzamento, há um teste para verificar se os indivíduos serão mutados ou não. Esta decisão é feita com base na taxa de mutação. Sorteia-se um número aleatório de uma distribuição uniforme de valores entre 0 e 1 , denominado $p_{m}$, e compara-se este valor à taxa de mutação. Se $p_{m}$ for menor que a taxa, ocorre mutação.

\section{- Mutação Binária}

A mutação binária é a mais simples das mutações. Supondo que um indivíduo vai sofrer mutação, sorteia-se um dos genes e seu valor é alterado, isto é, se for zero vira um e se for um vira zero.

Supondo que a taxa de mutação é 0,1 , se os números sorteados para os cromossomos $v_{1}$ e $v_{2}$, resultantes do cruzamento dos cromossomos $v_{10}$ e $v_{7}$ da população atual, forem 0,659823 e 0,002455, somente o cromossomo $v_{2}$ sofrerá mutação. Se o gene escolhido para mutação for o sétimo, a mutação ocorrerá conforme o esquema ilustrado na Figura 4.16.

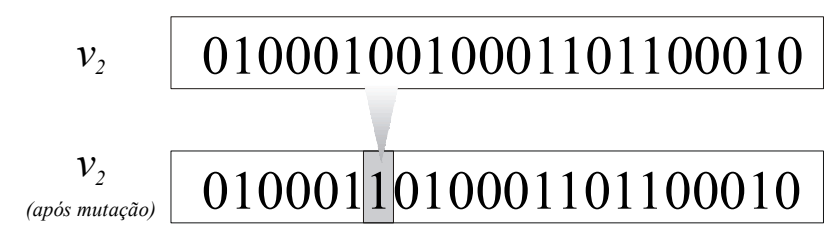

Figura 4.16-Resultado do operador de mutação binária.

\section{- Mutação Real Uniforme}

A mutação real uniforme simplesmente substitui o valor de um gene por um número aleatório. Um indivíduo $x^{i}=\left[x^{i, 1}, \ldots, x^{i, r}\right]$ possui $r$ variáveis codificadas, cada uma com limites inferior e superior, isto é, $x^{i, j} \in\left[a_{j}, b_{j}\right], 1 \leq j \leq r$. A mutação uniforme simplesmente seleciona um dos genes do indivíduo $i$, gene $g$, e substitui seu valor por um número aleatório uniforme $u$ pertencente ao intervalo $\left[a_{j}, b_{j}\right]$, isto é, $u \in U\left(a_{j}, b_{j}\right)$. Os valores dos outros genes permanecem inalterados.

De forma resumida, se o indivíduo mutado é chamado de $x^{i}$, pode-se escrever:

$$
x^{i, j}= \begin{cases}u \in U\left(a_{j}, b_{j}\right), & \text { se } j=g \\ x^{i, j} & \text { caso contrário }\end{cases}
$$




\section{- Mutação Real “Creep”}

A mutação real creep adiciona ao valor de um gene um pequeno número aleatório sorteado de uma distribuição normal de média zero e desvio padrão pequeno. O número aleatório pequeno faz com que o indivíduo mutado seja praticamente igual ao indivíduo original, exceto por uma pequena diferença no valor de um dos genes (gene $g$ ). Esta característica de alterar pouco o indivíduo faz com que esta mutação seja indicada para as últimas gerações do processo iterativo, evitando que os bons indivíduos encontrados sejam destruídos pela operação de mutação.

De forma resumida, um indivíduo $x^{i}=\left[x^{i, 1}, \ldots, x^{i, r}\right]$ com $r$ variáveis codificadas, originará um indivíduo mutado $x^{i^{\prime}}$ da seguinte forma:

$$
x^{i, j}= \begin{cases}x^{i, j}+d, d \in N(0, \sigma), & \text { se } j=g \\ x^{i, j} & \text { caso contrário }\end{cases}
$$

\section{- Mutação Real Limite}

A mutação limite faz com o gene $g$ a ser mutado adquira valor igual a um dos seus limites. Esta variação geralmente provoca um aumento na diversidade da população, criando indivíduos em pontos extremos e possibilitando uma exploração mais efetiva do espaço das possíveis soluções.

De forma resumida, um indivíduo $x^{i}=\left[x^{i, 1}, \ldots, x^{i, r}\right]$ com $r$ variáveis codificadas, cada uma com limites inferior e superior, isto é, $x^{i, j} \in\left[a_{j}, b_{j}\right], 1 \leq j \leq r$, sofrerá a mutação limite da seguinte forma:

1. Sorteia-se um número real $d$ de uma distribuição uniforme: $d \in U(0,1)$.

2. Sorteia-se um número inteiro $g$ de uma distribuição uniforme: $g \in U(1, r)$.

3. Faz-se:

$$
x^{i^{\prime}, j}= \begin{cases}a_{j} & \text { se } j=g \text { e } d \leq 0,5 \\ b_{j} & \text { se } j=g \text { e } d>0,5 \\ x^{i, j} & \text { caso contrário }\end{cases}
$$

\subsubsection{Outros Parâmetros}

Além de decidir quais operadores serão utilizados no processo evolutivo, há basicamente outros três parâmetros extremamente importantes: o tamanho da população, e as taxas de cruzamento e mutação.

O número de indivíduos da população, $N_{\text {ind }}$, determina com quantas soluções o algoritmo vai trabalhar simultaneamente. Um elevado número de indivíduos aumenta as chances de exploração efetiva do espaço das soluções, visitando praticamente todas as 
regiões possíveis, reduzindo as chances de convergência para um mínimo local. No entanto, conforme o número de indivíduos cresce, cresce também o esforço computacional para avaliar uma população. Além disso, se o tamanho da população for excessivo, aumentam as chances de haver indivíduos muito semelhantes, de forma que o tempo gasto nas operações de cruzamento traduza-se em redundância de processamento, selecionando-se indivíduos semelhantes e produzindo indivíduos semelhantes, sem melhoria da convergência do algoritmo.

O número de indivíduos da população deve ser escolhido de forma a determinar um compromisso entre a exploração do espaço de busca e a efetiva melhoria das soluções existentes através das operações de cruzamento.

A taxa de cruzamento especifica qual proporção da população sofrerá cruzamento. Após dois indivíduos serem selecionados, sorteia-se um número aleatório de uma distribuição uniforme de números reais compreendidos entre zero e um. Se o número sorteado for menor que a taxa de cruzamento, ocorre cruzamento. Taxas de cruzamento elevadas permitem uma exploração mais abrangente do espaço de soluções e geralmente evitam mínimos locais; o preço que se paga é um maior esforço computacional. Tradicionalmente, utilizam-se taxas de cruzamento entre 0,6 e 1,0.

A taxa de mutação é definida como a proporção de genes da população que sofre mutação. Para cada cromossomo selecionado, independentemente de ele ter sofrido cruzamento, sorteia-se um número aleatório; se o seu valor obtido for menor que a taxa de mutação, sorteia-se um dos genes do cromossomo e seu valor é mutado, de acordo com o operador. Como essa taxa controla a razão na qual novos genes são introduzidos na população, se ela for pequena corre-se o risco da diversidade genética reduzir-se e o método deixar de explorar diferentes regiões do espaço de busca; por outro lado, se ela for muito alta, o processo de otimização pode comportar-se como uma busca aleatória. Tradicionalmente, utilizam-se taxas de mutação entre 0,01 e 0,05.

Observa-se que dependendo dos números aleatórios sorteados, um indivíduo selecionado pode sofrer cruzamento e mutação, somente cruzamento, somente mutação ou pode ser simplesmente copiado na nova população. 


\subsubsection{Critérios de Parada}

O critério de parada especifica quando o processo iterativo deve cessar. Uma forma simples de estabelecer um critério de parada é o número máximo de gerações. Especificam-se a priori quantas gerações serão executadas, o processo iterativo inicia-se e quando o número máximo de gerações é alcançado, o algoritmo é parado, fornecendo como solução o melhor indivíduo encontrado.

Outro critério de parada é o número máximo de gerações sem ser verificada melhoria da função de aptidão. Por exemplo, se o algoritmo ficar 500 gerações sem conseguir melhorar o valor da função de aptidão, cessa-se o processo iterativo.

Um terceiro critério pode ser utilizado quando já é conhecida uma solução boa (ou mesmo a solução ótima) para o problema a ser resolvido e deseja-se determinar o esforço computacional do AG para encontrar uma solução melhor ou igual a ela. Neste caso, executa-se o algoritmo até que a aptidão do melhor indivíduo seja menor ou igual ao valor equivalente fornecido de meta para a função objetivo do problema.

Finalmente, um quarto critério pode ser baseado no tempo. Fornece-se ao algoritmo por quanto tempo o processo iterativo deve ser repetido e quando o limite de tempo é atingido, o melhor indivíduo encontrado é fornecido como solução do problema. Este critério de parada é particularmente interessante quando se deseja comparar diferentes operadores de cruzamento, mutação, ou mesmo determinar o melhor tamanho da população. Para cada caso analisado, permite-se que o AG seja executado pelo mesmo intervalo de tempo e depois se comparam os valores encontrados. De forma geral, a menos do fator aleatório dos AGS, soluções melhores indicam que os parâmetros utilizados nos testes são melhores, já que conseguem uma solução mais eficiente no mesmo período de tempo.

\subsection{Codificação Utilizada}

O primeiro passo a ser tomado para a aplicação dos Algoritmos Genéticos no problema de dimensionamento de usinas hidroelétricas é a definição da representação a ser utilizada: real ou binária. Como o processo de dimensionamento trata da determinação das características de uma usina hidroelétrica e estas características são números reais, optou-se pela utilização da representação real. De acordo com a literatura, esta representação deve se adequar melhor ao problema [79].

Quanto à definição da informação a ser codificada nos indivíduos, primeiro são 
listados os parâmetros que precisam ser determinados para caracterizar uma usina hidroelétrica e, em seguida, são realizados alguns estudos de simulação para verificar quais dos parâmetros listados influenciam de fato o desempenho energético da usina. A partir das análises dos resultados dos estudos de simulação, determinam-se quais características da usina sob dimensionamento serão codificadas nos indivíduos do AG e como será o processo de determinação da aptidão.

\subsubsection{Parâmetros da Usina Sob Dimensionamento}

Conforme já mencionado, o dimensionamento energético de uma usina hidroelétrica resume-se à determinação dos seguintes parâmetros:

- volume mínimo do reservatório, $x_{\min }, \mathrm{em} \mathrm{hm}^{3}$;

- volume máximo do reservatório, $x_{\text {máx }}$, em $\mathrm{hm}^{3}$;

- potência instalada total, $p_{\text {nom }}$, em $M W$;

- vazão de referência nominal das turbinas, $q_{\text {nom }}, \mathrm{em} \mathrm{m}^{3} / \mathrm{s}$;

- queda de referência nominal das turbinas, $h_{n o m}$, em $m$;

- queda de projeto das turbinas, $h_{p r o j}$, em $m$.

Deve-se estabelecer como estes parâmetros serão determinados pelo modelo de dimensionamento. Alguns serão codificados de forma direta, como variáveis de decisão do modelo, e outros serão calculados indiretamente, a partir dos resultados de estudos de simulação ou dos valores de outros parâmetros. A opção de determinar o valor de um parâmetro por uma destas formas depende basicamente de seu significado físico e da sensibilidade dos ganhos energéticos em relação aos seus valores.

Por exemplo, se variações de um parâmetro não ocasionarem variações de benefício energético, este parâmetro não deve ser codificado de forma direta, já que diferentes valores do parâmetro proporcionarão reservatórios diferentes com mesmos valores de receita líquida anual. Nesta situação, seria difícil decidir qual valor seria adotado como ótimo.

Em outros casos, o próprio significado físico do parâmetro define sua forma de cálculo. Como exemplo pode-se citar a determinação da altura de projeto através da média ponderada das gerações pelas alturas líquidas, ou mesmo pelo valor modal da queda líquida. Neste caso, o importante é garantir que a geração nas mais diversas condições de operação seja realizada com rendimento próximo ao máximo.

Para especificar a melhor forma de determinação de cada um dos parâmetros de 
dimensionamento, vários estudos de simulação são realizados. As análises dos resultados destes estudos servem de base para a definição do algoritmo de cálculo da aptidão de cada indivíduo do AG.

\subsubsection{Estudos de Simulação}

Os estudos de simulação são realizados para analisar como alterações das características de uma usina (volumes mínimo e máximo, potência instalada, vazão de referência e quedas das turbinas) podem influenciar os benefícios energéticos do sistema no qual ela vai se inserir.

Por um estudo de simulação entende-se a determinação do Período Crítico do sistema teste, bem como os valores de Energia Firme, Energia Secundária e Geração Média. O sistema teste utilizado é composto por quatro usinas: Emborcação, Itumbiara, São Simão e Ilha Solteira ${ }^{21}$. As vazões afluentes históricas referem-se ao histórico de 1931 a 1994 e a política de operação adotada é a regra paralela.

As características da usina de Emborcação foram variadas para que os efeitos destas variações pudessem ser medidos sobre os benefícios energéticos do sistema teste. A estratégia de realização dos testes é explicada a seguir, separando-se cada variável utilizada nos estudos.

\section{- Volume Mínimo}

A influência do volume mínimo foi medida adotando-se um volume máximo constante e variando-se o volume mínimo de Emborcação. O valor de volume máximo adotado foi $18.000 \mathrm{hm}^{3}$. Foram adotados oito valores de volume mínimo, indo desde o limite máximo, $18.000 \mathrm{hm}^{3}$, até o limite mínimo de volume, $5.000 \mathrm{hm}^{3}$. As outras características da usina foram ajustadas de forma a não interferirem nos resultados (queda de referência bem baixa e potência instalada infinita).

Na Figura 4.17 apresenta-se a Energia Firme do sistema em função do volume mínimo de Emborcação, na qual observa-se a diminuição da Energia Firme do sistema com a elevação do volume mínimo desta usina. Esta diminuição é explicada por dois motivos. Primeiro, como o volume máximo é mantido constante, conforme o volume mínimo aumenta, diminui o volume de água (volume útil) que a usina de Emborcação pode efetivamente utilizar durante o Período Crítico; com a redução da quantidade de água disponível nesta usina de cabeceira, reduzem-se as vazões turbinadas nas usinas de

\footnotetext{
${ }^{21}$ Mais detalhes sobre a forma de determinação do Período Crítico e as políticas de operação são fornecidos no Capítulo IV.
} 
jusante, diminuindo assim a geração média de todas as usinas ao longo do Período Crítico e, conseqüentemente, a Energia Firme do sistema.

Segundo, conforme o volume mínimo aumenta, a capacidade de regularização das vazões afluentes naturais por parte de Emborcação reduz-se, fazendo com que as outras usinas sejam obrigadas a variar a quantidade de água armazenada em seus reservatórios para complementar a regularização. Estas variações da quantidade de água armazenada fazem com que as usinas trabalhem com reservatórios mais vazios, com produtividades mais baixas. Esta influência é melhor observada na Figura 4.18, na qual mostra-se que a Geração Média do sistema ao longo do histórico decresce com o aumento do volume mínimo de Emborcação.

Resumindo, a elevação do volume mínimo da usina de cabeceira provoca redução da Energia Firme e da Geração Média do sistema. Há ainda um outro ponto a ser explorado. Observando a Energia Firme e a Geração Média para os valores extremos de volume mínimo $\left(x_{\min }=5.000 \mathrm{hm}^{3}\right.$ e $\left.x_{\min }=18.000 \mathrm{hm}^{3}\right)$, constata-se uma redução de $692 \overline{\mathrm{MW}}$ de Energia Firme, e uma redução de Geração Média de apenas $65 \overline{\mathrm{MW}}$. Este fato sugere que a Energia Secundária do sistema eleva-se à medida que o volume mínimo de Emborcação aumenta (ressalta-se que a potência instalada adotada nos estudos é suficientemente grande para permitir quaisquer acréscimos de Energia Secundária). A forma como esta elevação de Energia Secundária ocorre é mostrada na Figura 4.19.

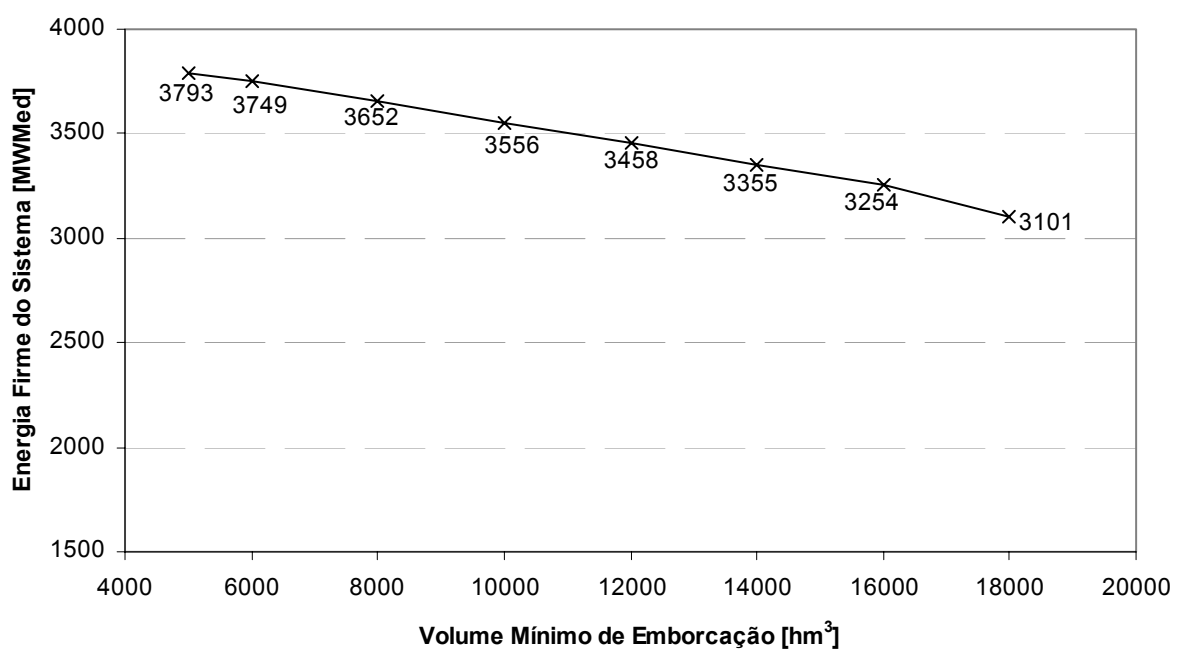

Figura 4.17 - Energia Firme do sistema para diferentes volumes mínimos de Emborcação. 


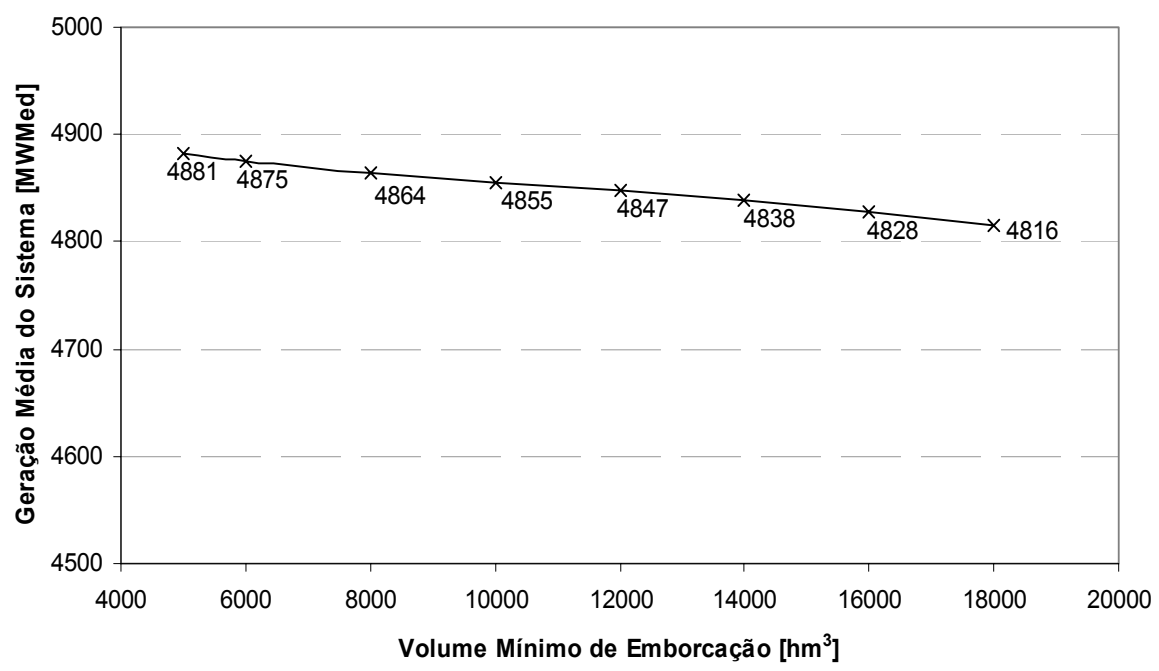

Figura 4.18 - Geração Média do sistema para diferentes volumes mínimos de Emborcação.

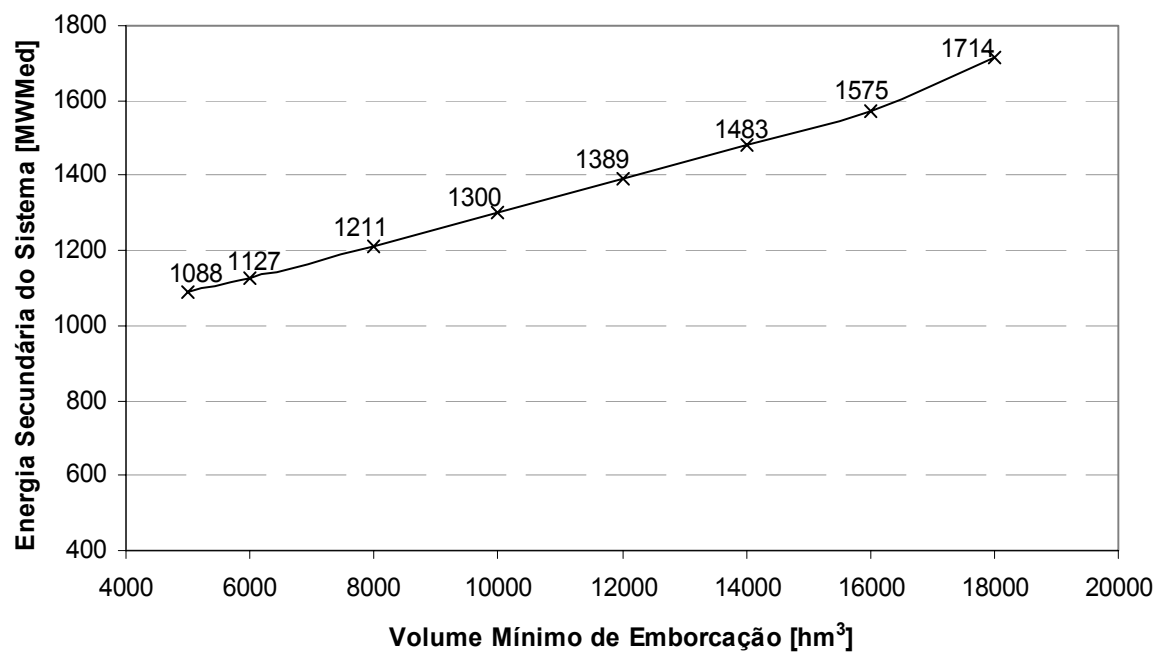

Figura 4.19 - Energia Secundária do sistema para diferentes volumes mínimos de Emborcação.

\section{- Volume Máximo}

A influência do volume máximo foi medida de forma semelhante à influência do volume mínimo. Adotou-se um volume mínimo constante e igual a $5.000 \mathrm{hm}^{3}$, e variouse o volume máximo de $5.000 \mathrm{hm}^{3}$ a $18.000 \mathrm{hm}^{3}$. As outras características da usina foram ajustadas de forma a não interferirem nos resultados (queda de referência bem baixa e potência instalada infinita).

Na Figura 4.20 apresenta-se a Energia Firme do sistema em função do volume máximo de Emborcação, na qual observa-se a elevação da Energia Firme do sistema com os acréscimos de volume máximo desta usina. Esta elevação é explicada por três motivos. Primeiro, conforme o volume máximo aumenta e o volume mínimo mantém-se constante, aumenta o volume de água que a usina de Emborcação pode efetivamente utilizar (volume útil) durante o Período Crítico; com a elevação da quantidade de água 
disponível nesta usina de cabeceira, elevam-se as vazões turbinadas nas usinas de jusante, aumentando assim a geração média de todas as usinas ao longo do Período Crítico e, conseqüentemente, a Energia Firme do sistema.

Segundo, conforme o volume máximo aumenta, a capacidade de regularização das vazões afluentes naturais por parte de Emborcação eleva-se, fazendo com que as outras usinas variem menos a quantidade de água armazenada em seus reservatórios para complementar a regularização. Estas menores variações da quantidade de água armazenada fazem com que as usinas trabalhem com reservatórios mais cheios, com produtividades mais elevadas, aumentando assim a Energia Firme. Finalmente, volumes máximos maiores implicam alturas de queda maiores, fazendo com que um mesmo volume de água turbinado produza mais energia. Mais uma vez, este aumento de produtividade implica em elevações de Energia Firme.

O aumento de volume útil, o conseqüente aumento da capacidade de regularização e o ganho de produtividade também influenciam a Geração Média do sistema. Esta influência pode ser observada na Figura 4.21, na qual mostra-se que a Geração Média eleva-se com o aumento do volume máximo de Emborcação.

Resumindo, o aumento do volume máximo da usina provoca elevação da Energia Firme e da Geração Média do sistema. Observando a Energia Firme e a Geração Média para os valores extremos de volume máximo $\left(x_{\text {máx }}=5.000 \mathrm{hm}^{3} \mathrm{e}\right.$ $x_{\text {máx }}=18.000 \mathrm{hm}^{3}$ ), constatam-se elevações de $768 \overline{\mathrm{MW}}$ de Energia Firme e $198 \overline{\mathrm{MW}}$ de Geração Média. Este fato sugere que a Energia Secundária do sistema reduz-se à medida que o volume máximo de Emborcação aumenta, Figura 4.22.

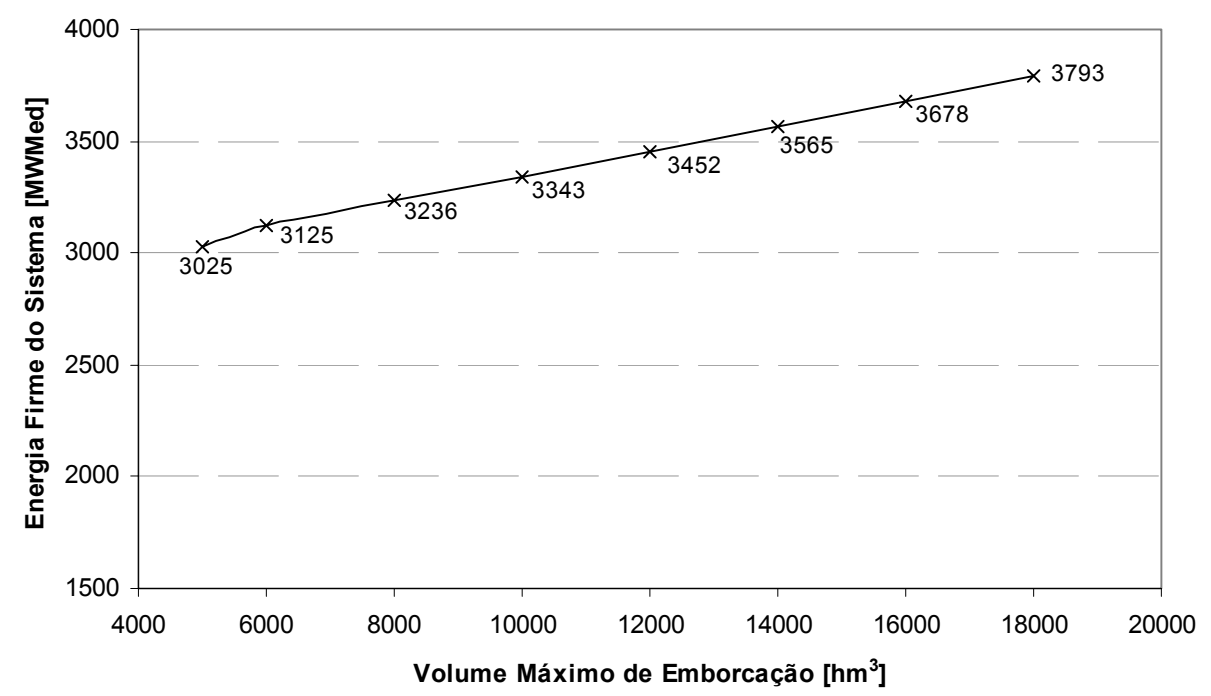

Figura 4.20 - Energia Firme do sistema para diferentes volumes máximos de Emborcação. 


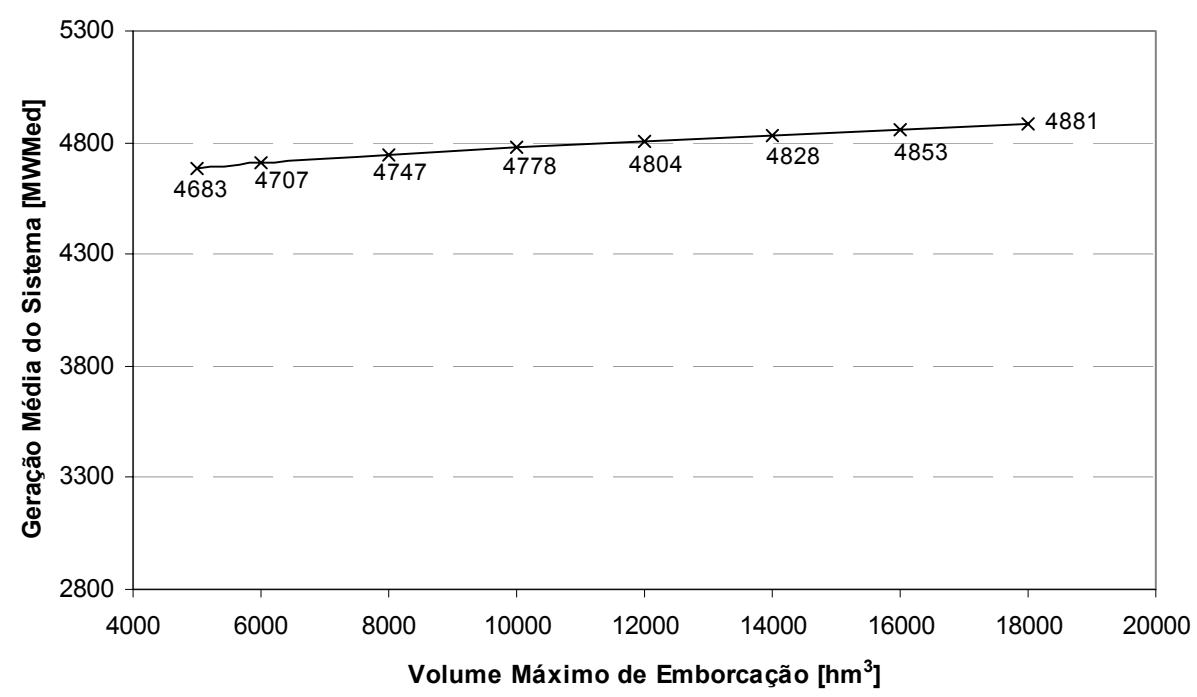

Figura 4.21 - Geração Média do sistema para diferentes volumes máximos de Emborcação.

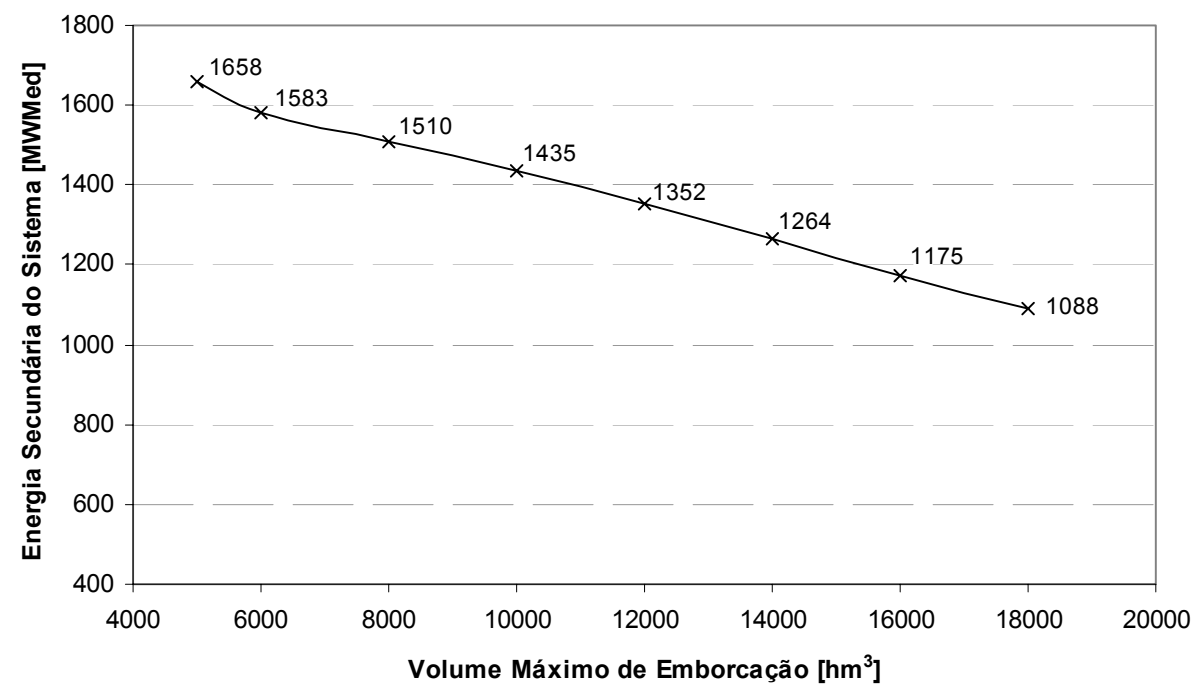

Figura 4.22 - Energia Secundária do sistema para diferentes volumes máximos de Emborcação.

\section{- Vazão de Referência e Potência Instalada}

A vazão de referência e a potência instalada serão tratadas de forma conjunta, já que aumentos (reduções) da vazão de referência implicam aumentos (reduções) da potência instalada total, e vice-versa. Para analisar a influência destes parâmetros sobre os ganhos energéticos sistêmicos, primeiro foram adotados valores constantes de volumes mínimo e máximo, e queda de referência $\left(x_{\min }=6.000 \mathrm{hm}^{3}, x_{\text {máx }}=18.000 \mathrm{hm}^{3} \mathrm{e}\right.$ $\left.h_{n o m}=130,3 \mathrm{~m}\right)$. Em seguida, variam-se os valores de vazão de referência de $400 \mathrm{~m}^{3} / \mathrm{s}$ a $1.600 \mathrm{~m}^{3} / \mathrm{s}$, observando-se os impactos destas variações sobre os valores sistêmicos das Energias Firme e Secundária, além da Geração Média.

Na Figura 4.23 apresenta-se a Energia Firme do sistema em função da vazão de referência de Emborcação. De acordo com a figura, constata-se que a Energia Firme 
eleva-se sensivelmente com a vazão de referência apenas quando esta varia de $400 \mathrm{~m}^{3} / \mathrm{s}$ a $600 \mathrm{~m}^{3} / \mathrm{s}$. Para as demais variações, a Energia Firme mantém-se praticamente constante em função da vazão de referência. Este fato mostra que existe uma quantidade mínima de máquinas para garantir a turbinagem das vazões do Período Crítico e, portanto, a Energia Firme da usina. Se mais máquinas são adicionadas à usina, com conseqüente aumento de vazão de referência, estas máquinas simplesmente não serão utilizadas ao longo do Período Crítico, onde as vazões turbinadas são baixas, não implicando em incrementos de Energia Firme.

Conforme mostrado na Figura 4.24, aumentar a vazão de referência (potência nominal) implica aumentar a Geração Média da usina. Inicialmente, quando a vazão de referência eleva-se de $400 \mathrm{~m}^{3} / \mathrm{s}$ a $600 \mathrm{~m}^{3} / \mathrm{s}$, o aumento de Geração Média é de $95 \overline{\mathrm{MW}}$. Porém, quando a vazão de referência eleva-se de $1.400 \mathrm{~m}^{3} / \mathrm{s}$ a $1.600 \mathrm{~m}^{3} / \mathrm{s}$, o aumento de Geração Média é de apenas $7 \overline{\mathrm{MW}}$. Esta relativa saturação ocorre porque quando a vazão de referência é baixa, incrementar o seu valor significa aproveitar grande parte das vazões históricas que estavam sendo vertidas, aumentando sensivelmente a Geração Média. À medida que a vazão de referência vai aumentando, incrementar ainda mais seu valor implica turbinar apenas as vazões de alguns períodos úmidos, reduzindo os acréscimos relativos de Geração Média.

As variações de Energia Firme e de Geração Média determinam o comportamento da Energia Secundária, mostrado na Figura 4.25. De acordo com esta figura, enquanto os incrementos de vazão de referência traduzem-se em incrementos de Energia Firme, a Energia Secundária mantém-se praticamente constante (trecho entre $400 \mathrm{~m}^{3} / \mathrm{s}$ a $600 \mathrm{~m}^{3} / \mathrm{s}$ ). A partir do momento que a Energia Firme mantém-se constante, todos os ganhos de Geração Média são convertidos em Ganhos de Energia Secundária.

Resumindo, incrementos da vazão de referência e da potência nominal da usina sempre causam ganhos de Geração Média. Quando a potência é inferior à necessária para turbinar as vazões do Período Crítico, os ganhos de Geração Média traduzem-se em ganhos de Energia Firme. A partir do momento que a Energia Firme deixa de aumentar, os ganhos de Geração Média são convertidos em ganhos de Energia Secundária. 


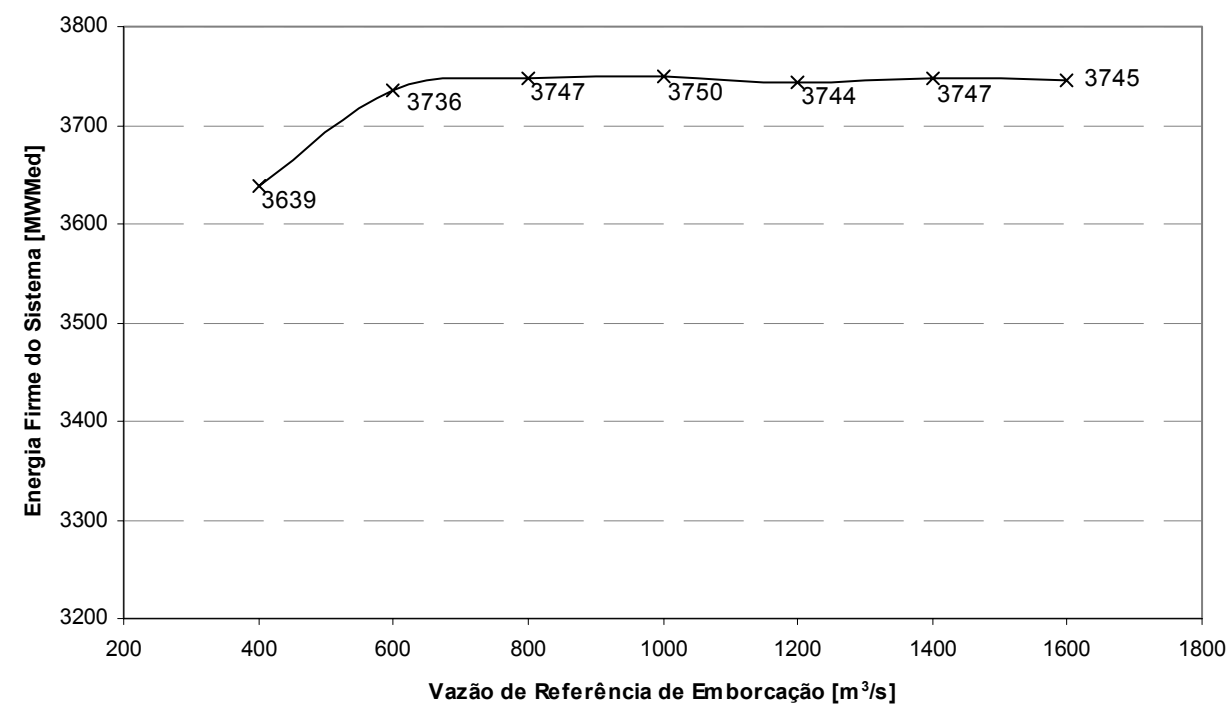

Figura 4.23 - Energia Firme do sistema para diferentes vazões de referência de Emborcação.

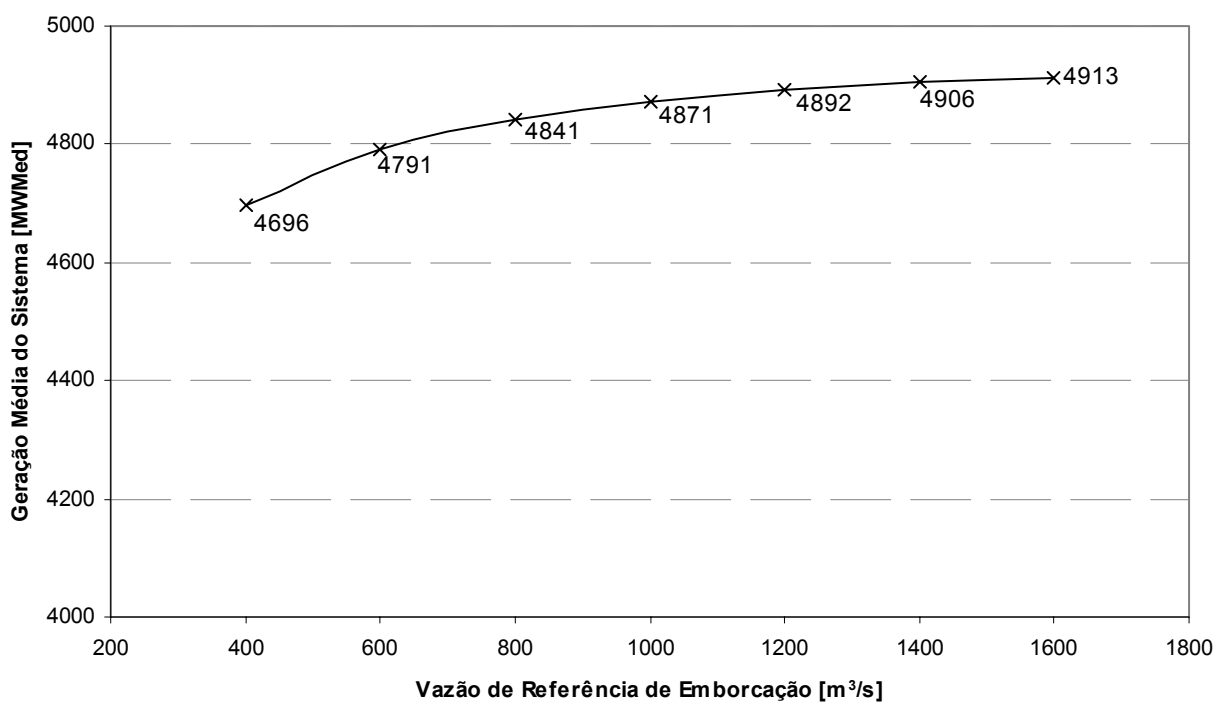

Figura 4.24 - Geração Média do sistema para diferentes vazões de referência de Emborcação.

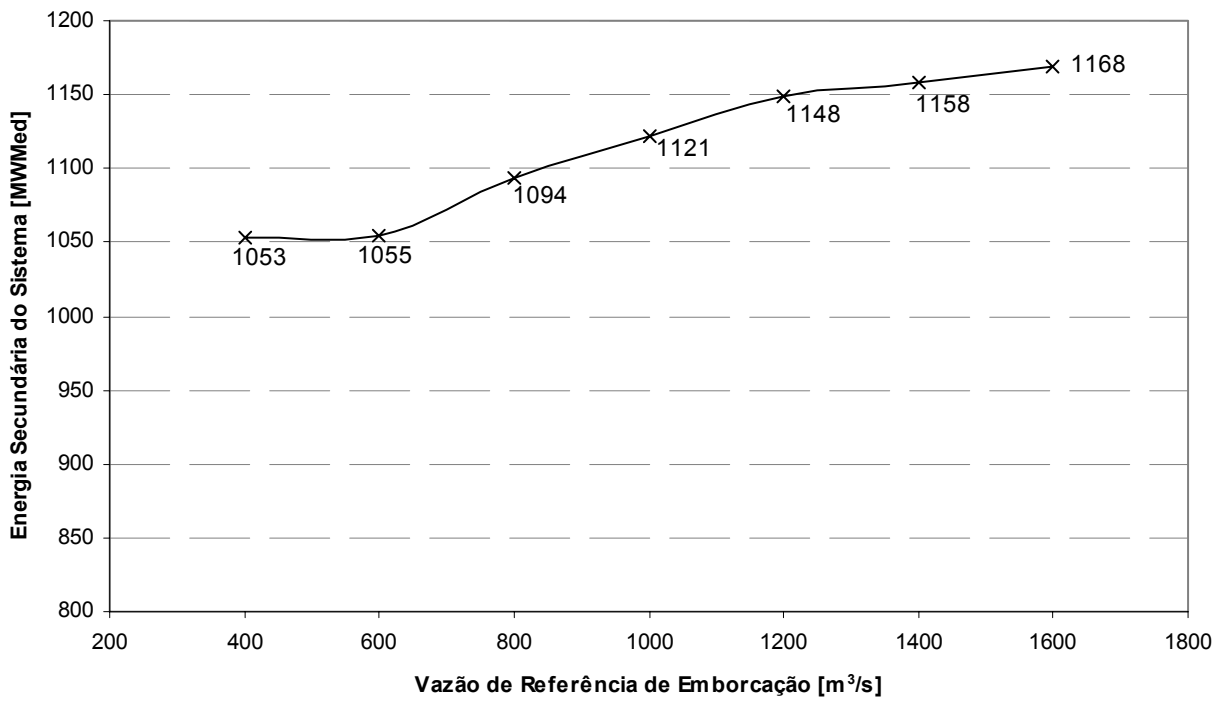

Figura 4.25 - Energia Secundária do sistema para diferentes vazões de referência de Emborcação. 


\section{- Queda de Referência das Turbinas}

A influência da queda de referência das turbinas sobre os ganhos energéticos sistêmicos será analisada adotando-se valores constantes de volumes mínimo e máximo, e potência nominal de referência $\left(x_{\min }=6.000 \mathrm{hm}^{3}, x_{\text {máx }}=18.000 \mathrm{hm}^{3}\right.$ e $\left.p_{\text {nom }}=1.500 \mathrm{MW}\right)$. Em seguida, variam-se os valores de queda de referência de $90 \mathrm{~m}$ a $150 \mathrm{~m}$, observando-se os impactos destas variações sobre os valores sistêmicos das Energias Firme e Secundária, além da Geração Média.

Na Figura 4.26 apresenta-se a Energia Firme do sistema em função da queda de referência de Emborcação. De acordo com a figura, constata-se que a Energia Firme é praticamente insensível às variações da queda de referência. Este fato ocorre porque a queda de referência influencia apenas o engolimento máximo da usina. Durante Período Crítico, com vazões afluentes e turbinadas relativamente baixas, a redução do engolimento máximo não restringe a geração de energia, não alterando, portanto, o benefício de Energia Firme.

Observando a Figura 4.27, conclui-se que a Geração Média do sistema teste também não se altera para a maioria das variações da queda de referência. Apenas quando esta queda torna-se muito alta são notadas reduções de Geração Média. Isso ocorre porque quando a queda de referência torna-se muito elevada, a usina passa a trabalhar a maior parte do tempo com quedas líquidas bem inferiores à queda de referência, traduzindo-se em engolimento máximo reduzido. Esta redução do engolimento máximo faz com que vazões antes turbinadas passem a ser vertidas, diminuindo a geração da usina com conseqüente redução de Geração Média e Energia Secundária, tal como ilustrado na Figura 4.28.

Resumindo, incrementos da queda de referência não alteram a Energia Firme e só conseguem reduzir marginalmente os benefícios de Energia Secundária e Geração Média em situações extremas (quedas de referência excessivamente altas). 


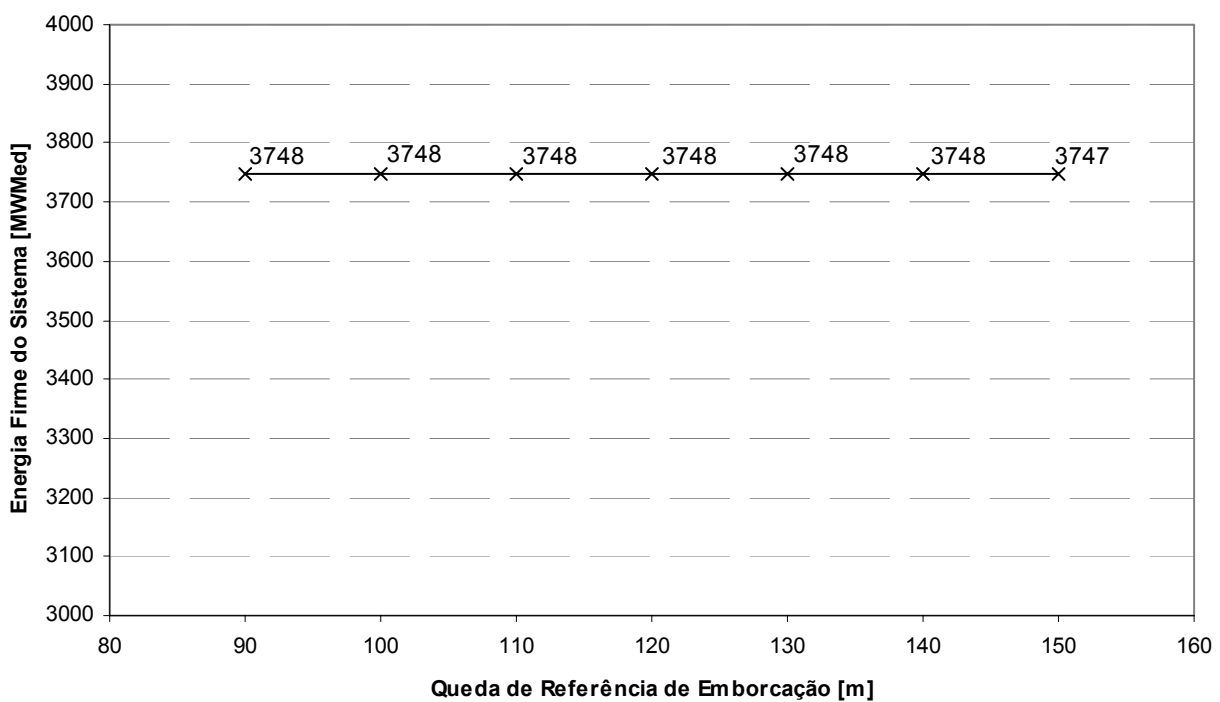

Figura 4.26 - Energia Firme do sistema para diferentes quedas de referência de Emborcação.

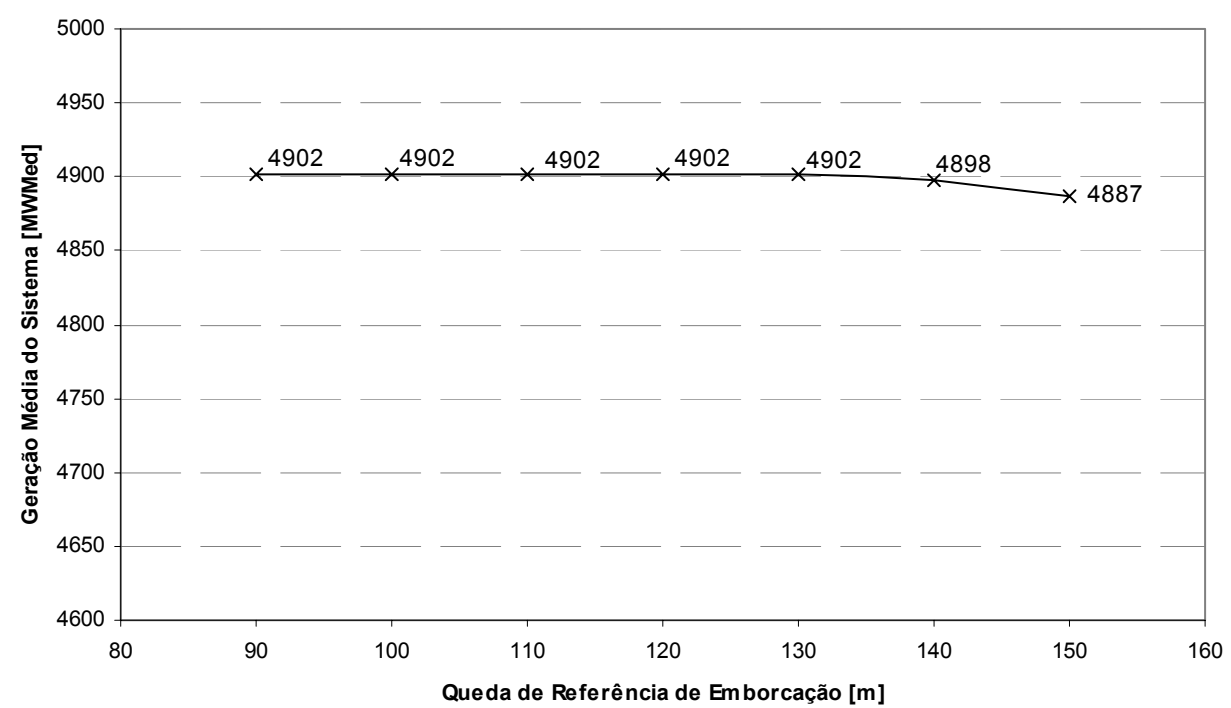

Figura 4.27 - Geração Média do sistema para diferentes quedas de referência de Emborcação.

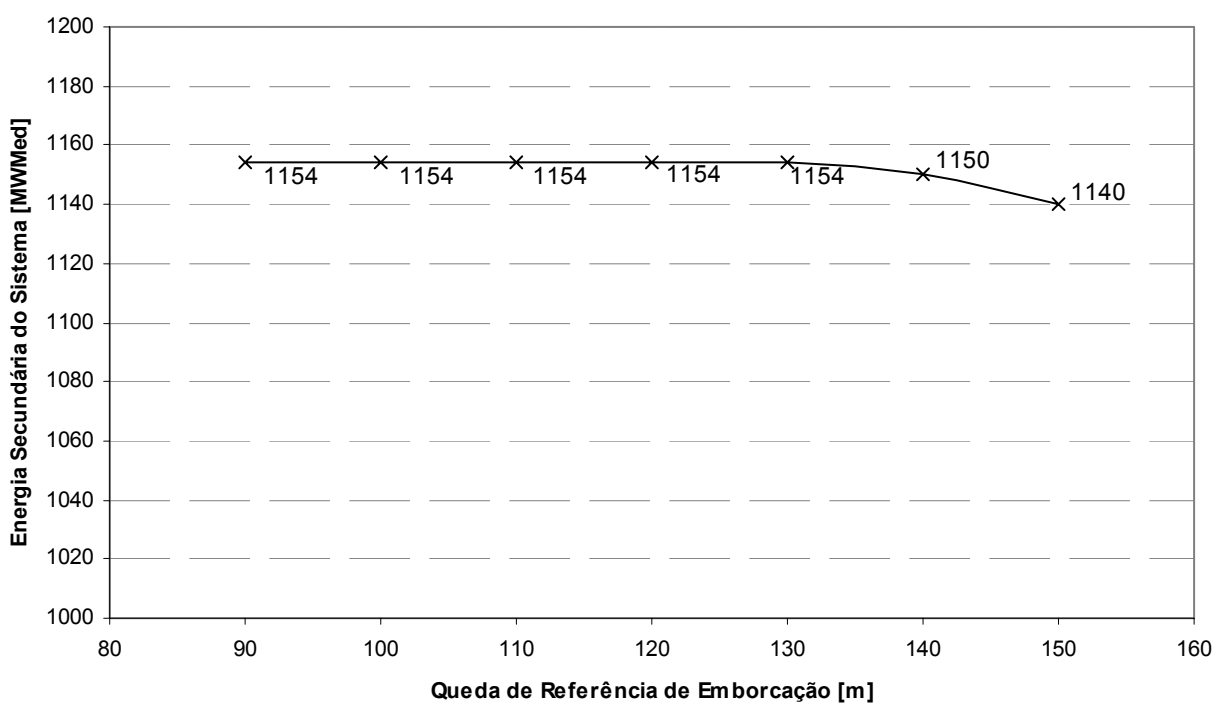

Figura 4.28 - Energia Secundária do sistema para diferentes quedas de referência de Emborcação. 


\section{- Queda de Projeto das Turbinas}

A influência da queda de projeto das turbinas sobre os ganhos energéticos sistêmicos não pode ser analisada pelos modelos de otimização e de simulação utilizados neste trabalho, já que eles trabalham com intervalos mensais e variações de rendimento poderiam ser observadas de forma precisa apenas em intervalos de menor duração (intervalos horários, de preferência).

Desta forma, a altura de projeto será determinada simplesmente através da média ponderada das alturas de queda líquida pelas respectivas gerações. A idéia é fornecer como queda de projeto um valor que represente a queda líquida na qual a usina gera as maiores quantidades de energia. Estudos mais refinados podem ser realizados posteriormente, em outras etapas dos estudos de dimensionamento.

\section{- Resumo e Conclusões}

A influência das características de uma usina sobre os benefícios energéticos sistêmicos pode ser resumida de acordo com a tabela abaixo. Por exemplo, classificar a variação da Energia Firme em relação ao volume mínimo de negativa e sensível significa dizer que, para um volume máximo constante, à medida que o volume mínimo cresce, a Energia Firme decresce sensivelmente. Em outras palavras, este benefício energético "sente" as variações deste parâmetro de dimensionamento. Interpretações similares estendem-se a todos os outros parâmetros.

Baseando-se nos resultados resumidos na tabela, pretende-se determinar quais variáveis classificam-se como variáveis de decisão do modelo, codificadas diretamente nos indivíduos do Algoritmo Genético, e quais serão calculadas de forma indireta.

Tabela 4.5 - Resumo da forma como os parâmetros de dimensionamento influenciam os beneficios energéticos.

\begin{tabular}{cccc}
\hline & Energia Firme & Geração Média & $\begin{array}{c}\text { Energia } \\
\text { Secundária }\end{array}$ \\
\hline Volume Mínimo & $\begin{array}{c}\text { Variação Negativa e } \\
\text { Sensível }\end{array}$ & $\begin{array}{c}\text { Variação Negativa e } \\
\text { Sensível }\end{array}$ & $\begin{array}{c}\text { Variação Positiva e } \\
\text { Sensível }\end{array}$ \\
\hline \multirow{2}{*}{ Volume Máximo } & $\begin{array}{c}\text { Variação Positiva e } \\
\text { Sensível }\end{array}$ & $\begin{array}{c}\text { Variação Positiva e } \\
\text { Sensível }\end{array}$ & $\begin{array}{c}\text { Variação Negativa e } \\
\text { Sensível }\end{array}$ \\
\hline \multirow{2}{*}{ Vazão de Referência } & $\begin{array}{c}\text { Variação Positiva e } \\
\text { Parcial }\end{array}$ & $\begin{array}{c}\text { Variação Positiva e } \\
\text { Sensível }\end{array}$ & $\begin{array}{c}\text { Variação Positiva e } \\
\text { Sensível }\end{array}$ \\
\hline \multirow{2}{*}{ Potência de Referência } & $\begin{array}{c}\text { Variação Positiva e } \\
\text { Parcial }\end{array}$ & $\begin{array}{c}\text { Variação Positiva e } \\
\text { Sensível }\end{array}$ & Variação Positiva e \\
Sensível
\end{tabular}


O primeiro fato observado é a sensível variação dos benefícios energéticos em função dos volumes mínimo e máximo da usina. Isso qualifica estas duas variáveis a serem variáveis de decisão do modelo, codificadas diretamente no algoritmo.

Tanto a vazão quanto a potência de referência também poderiam ser variáveis de decisão. Neste caso, apenas uma destas variáveis seria utilizada, já que variações em uma delas implicam variações na outra. No entanto, como a Energia Firme varia apenas parcialmente em função destas variáveis, deve-se desenvolver um modelo que consiga separar a influência direta da vazão e da potência de referência sobre a Energia Firme, e as demais influências destes parâmetros sobre a Energia Secundária e a Geração Média.

A queda de referência não pode ser considerada uma variável de decisão devido à insensibilidade da Energia Firme em relação às suas variações. Além disso, os outros benefícios só são sensíveis a variações extremas de queda de referência.

Finalmente, conforme já explicado, a queda de projeto também será um parâmetro calculado indiretamente, já que os modelos de simulação e otimização baseados em intervalos mensais não conseguem captar o efeito de suas variações sobre os benefícios energéticos ${ }^{22}$.

Com base nestas análises, define-se o procedimento de cálculo da aptidão de um indivíduo, ilustrado na próxima subseção.

\footnotetext{
${ }^{22}$ Salienta-se que os intervalos mensais são necessários para permitir a avaliação da operação da usina sob diversas condições hidrológicas. Além disso, variações de rendimento médio ocasionadas por alterações da queda de projeto não devem alterar sensivelmente os benefícios energéticos, a menos de erros grosseiros de dimensionamento.
} 


\subsubsection{Cálculo da Aptidão de um Indivíduo}

O cálculo da aptidão de um indivíduo é dividido em duas etapas, tal como ilustrado na Figura 4.29. Na primeira, os valores codificados são transformados nas características da usina, permitindo assim a simulação de sua operação e o cálculo dos respectivos ganhos energéticos. $\mathrm{Na}$ segunda etapa, os ganhos energéticos e as características da usina são fornecidas aos modelos de custo e de valorização da energia gerada. Os resultados destes modelos compõem o fluxo de caixa do empreendimento e terminam por avaliar a receita líquida anual, $R_{L Q}$, utilizada como medida de aptidão do indivíduo.

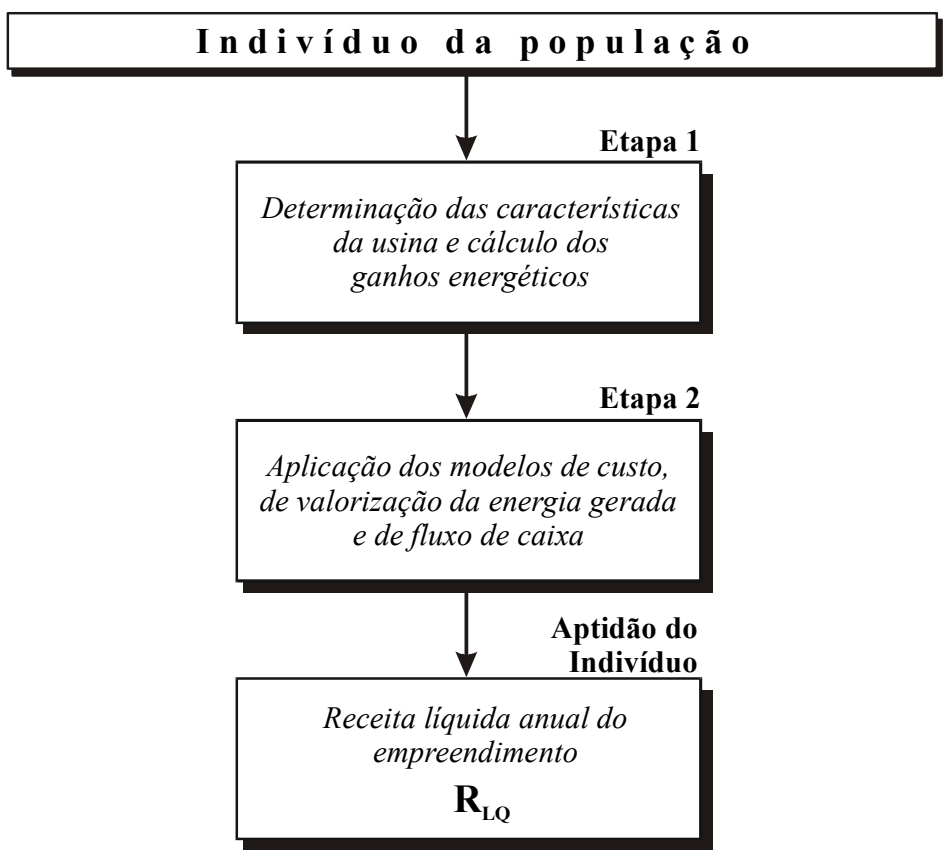

Figura 4.29 - Etapas do cálculo da aptidão de um indivíduo.

\section{- Etapa 1}

A primeira etapa do cálculo da aptidão de um indivíduo é esquematicamente mostrada na Figura 4.30. As três variáveis codificadas no indivíduo da população, $x_{1}, x_{2}$ e $x_{3}$, pertencem ao intervalo $[0,1]$ e correspondem respectivamente aos valores normalizados de volumes mínimo e máximo do reservatório, $x_{\min }$ e $x_{\operatorname{máx}}$, e potência de ponta da usina, $p_{\text {nom }, p}$. 


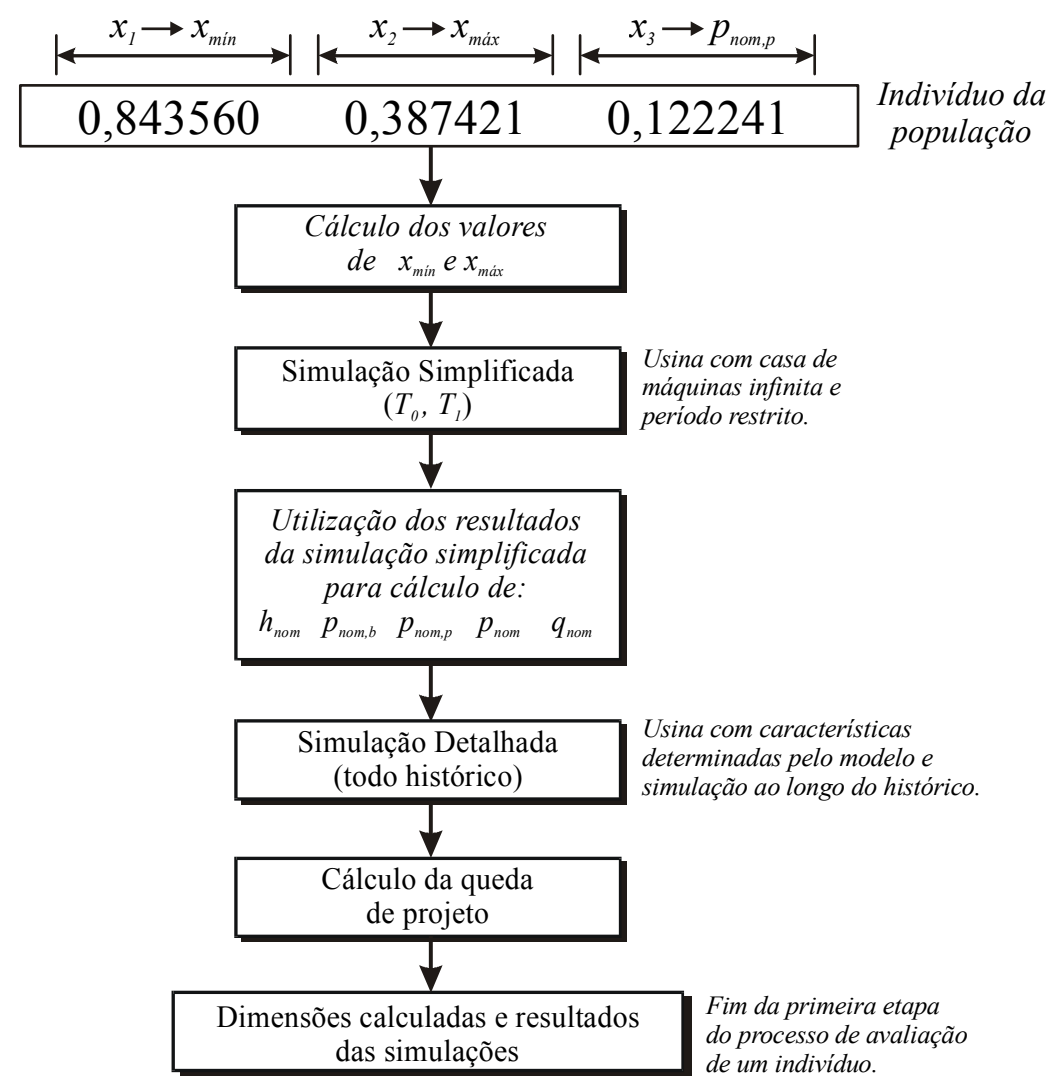

Figura 4.30 - Primeira etapa do processo cálculo da aptidão de um indivíduo.

A escolha das variáveis de volume como variáveis de decisão justifica-se pela alta sensibilidade dos ganhos energéticos às suas variações, tal como ilustrado anteriormente nos estudos da Seção 2.2.2. A utilização da potência de ponta como variável de decisão decorre de um princípio básico utilizado no processo de dimensionamento: a utilização plena e efetiva do reservatório da usina. Assim, uma vez definidos os volumes mínimo e máximo do reservatório, a usina deve ter uma potência instalada, conhecida como potência de base, capaz de gerar energia ao longo do Período Crítico sem apresentar vazões vertidas. Em outras palavras, a definição da potência de base, $p_{n o m, b}$, é praticamente automática. Porém, recorrendo-se novamente aos estudos de simulação da Seção 2.2.2, aumentos da potência instalada acima da necessária para produção da Energia Firme implicam elevações de Geração Média e Energia Secundária. Logo, deve haver alguma variável para especificar estes ganhos adicionais, justificando a utilização da potência de ponta, $p_{n o m, p}$, como variável de decisão.

As variáveis de decisão codificadas devem ser transformadas em características físicas da usina. Inicialmente, os valores de volume codificados no indivíduo do Algoritmo Genético, $x_{1} \in[0,1]$ e $x_{2} \in[0,1]$, são transformados em volumes em $\mathrm{hm}^{3}$, 
$x_{\text {min }}$ e $x_{\text {máx }}$, respectivamente. Esta transformação é feita através de limites, $x f_{\text {min }}$ e $x f_{\text {máx }}$, ambos em $\mathrm{hm}^{3}$, que especificam a faixa de valores possíveis do volume máximo. Para evitar que o volume máximo $x_{\text {máx }}$ seja menor que o volume mínimo $x_{\min }$, utiliza-se o seguinte esquema de decodificação:

$$
\left\{\begin{array}{l}
x_{\text {min }}=x_{1} \cdot\left(x f_{\text {máx }}-x f_{\text {min }}\right)+x f_{\text {min }} \\
x_{\text {máx }}=x_{2} \cdot\left(x f_{\text {máx }}-x_{\text {min }}\right)+x_{\text {min }}
\end{array}\right.
$$

Após esta especificação, assume-se que a potência instalada e o engolimento sejam infinitos, e que a queda de referência seja bem pequena, de forma que estes parâmetros não limitem a operação da usina. Realiza-se então uma simulação da operação do Sistema Completo entre os intervalos $T_{0}$ e $T_{1}$ (valores fornecidos como dados de entrada), determinando-se o Período Crítico com este conjunto reduzido de vazões. Este estudo de simulação é chamado de simulação simplificada ${ }^{23}$ e seus resultados são empregados na determinação da potência de base e da queda de referência das turbinas. Como estas informações referem-se somente ao Período Crítico, a simulação entre os intervalos $T_{0}$ e $T_{1}$, e não em relação a todo o histórico, representa uma economia significativa de tempo de processamento.

Os resultados da simulação simplificada são utilizados nos cálculos dos parâmetros da seguinte forma:

- Altura de referência nominal das turbinas, $\boldsymbol{h}_{\text {nom }} \mathbf{e m} \boldsymbol{m}$ : calculada como a altura de queda líquida com permanência de $95 \%$ ao longo do Período Crítico. Esta escolha faz com que a turbina limite a operação da usina somente em condições extremas, quando o reservatório estiver muito vazio. Sob o ponto de vista econômico, esta abordagem evita que os geradores, normalmente bem mais caros que as turbinas, sejam freqüentemente subaproveitados devido às limitações das turbinas.

- Potência instalada de base, $p_{n o m, b}$ em $M W$ : calculada como sendo a máxima geração verificada ao longo do Período Crítico, $g_{\text {máx,pc }}$ em $\overline{\mathrm{MW}}$.

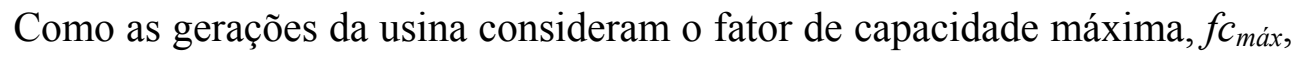

\footnotetext{
${ }^{23}$ Ressalta-se que o termo "simulação simplificada" não se refere ao fato de serem feitos cálculos heurísticos ou utilizadas fórmulas aproximadas na simulação. A conotação "simplificada" refere-se à utilização de um conjunto reduzido de vazões e de características da casa de máquinas da usina que a fazem capaz de turbinar qualquer valor de vazão sem que haja vertimento. É imperativo para o funcionamento do modelo que o intervalo $\left[T_{0}, T_{1}\right]$ contenha o Período Crítico histórico, de forma que a seca mais severa registrada pela simulação simplificada seja idêntica à verificada historicamente.
} 
e as taxas de manutenção e de indisponibilidade forçada, $t_{\text {man }}$ e $t_{i f}$, respectivamente, o cálculo de $p_{n o m, b}$ é feito da seguinte forma ${ }^{24}$ :

$$
p_{\text {nom }, b}=\frac{g_{\text {máx }, p c}}{f c_{\text {máx }} \cdot\left(1-t_{\text {man }}\right) \cdot\left(1-t_{\text {if }}\right)}
$$

- Potência instalada de ponta, $p_{n o m, p}$ em $M W$ : calculada a partir da terceira variável codificada no Algoritmo Genético, $x_{3} \in[0,1]$ :

$$
p_{\text {nom }, p}=9,81 \cdot 10^{-3} \cdot \eta_{\text {méd }} \cdot h_{\text {nom }} \cdot x_{3} \cdot q f_{\text {máx }}
$$

na qual:

- $\quad \eta_{\text {méd}}$ : rendimento médio do conjunto turbina-gerador, adimensional;

- $h_{n o m}$ : queda de referência nominal das turbinas, em $m$;

- $q f_{\text {máx: }}$ vazão máxima da usina, em $\mathrm{m}^{3} / \mathrm{s}$, estimada a partir do histórico de vazões afluentes.

- Potência instalada total, $\boldsymbol{p}_{\text {nom }}$ em $\boldsymbol{M W}$ : corresponde simplesmente à soma das potências instaladas de base e de ponta, ambas em $M W$ :

$$
p_{\text {nom }}=p_{\text {nom }, b}+p_{\text {nom }, p}
$$

- Vazão de referência, $\boldsymbol{q}_{\text {nom }} \mathrm{em} \mathrm{m}^{3} / \mathrm{s}$ : corresponde à vazão necessária para a produção da potência instalada total quando à altura de queda é igual à queda de referência:

$$
q_{\text {nom }}=\frac{p_{\text {nom }}}{9,81 \cdot 10^{-3} \cdot \eta_{\text {méd }} \cdot h_{\text {nom }}}
$$

na qual:

- $p_{\text {nom: }}$ potência instalada total, em $M W$;

- $\eta_{m e ́ d}$ : rendimento médio do conjunto turbina-gerador, adimensional;

- $h_{\text {nom }}$ : queda de referência nominal das turbinas, em $m$;

Com base em todos os valores calculados acima, realiza-se a simulação detalhada. Neste caso, o período de simulação é o histórico total e a usina é modelada com as potências de base e de ponta determinadas pelos resultados da simulação simplificada, bem como os valores de queda e vazão de referência.

Os resultados da simulação detalhada são utilizados para calcular a queda de projeto das turbinas, $q_{\text {proj }}$ em $m$, através da ponderação da altura de queda líquida pela geração da usina ao longo de todos os intervalos de simulação:

\footnotetext{
${ }^{24}$ Detalhes sobre $f \mathcal{C}_{\text {máx }}, t_{\text {man }}$ e $t_{i f}$ são apresentados no Capítulo V.
} 


$$
q_{p r o j}=\frac{\sum_{t=1}^{T} h_{l}(t) \cdot p(t)}{\sum_{t=1}^{T} p(t)}
$$

na qual:

- $h_{l}(t)$ : altura de queda líquida da usina no intervalo $t$, em $m$;

- $p(t)$ : geração média da usina no intervalo $t$, em $\overline{\mathrm{MW}}$;

- $T$ : número de intervalos do histórico.

Ainda a partir dos resultados da simulação detalhada, determinam-se os valores de Energia Firme, Energia Secundária, Geração Média e Ponta Garantida, os quais caracterizam os benefícios energéticos do aproveitamento. Estes valores, mais os valores das características da usina, constituem os resultados da primeira etapa.

\section{- Etapa 2}

A segunda etapa do cálculo da aptidão de um indivíduo, Figura 4.31, resume-se basicamente ao fornecimento dos resultados da primeira etapa aos modelos de custo e de valorização econômica dos benefícios energéticos, produzindo como resultado final a receita líquida anual do empreendimento.

Os modelos de custo, de valorização da energia gerada e de fluxo de caixa foram detalhados nas Seções 1.6.1, 1.6.2 e 1.6.3, respectivamente.

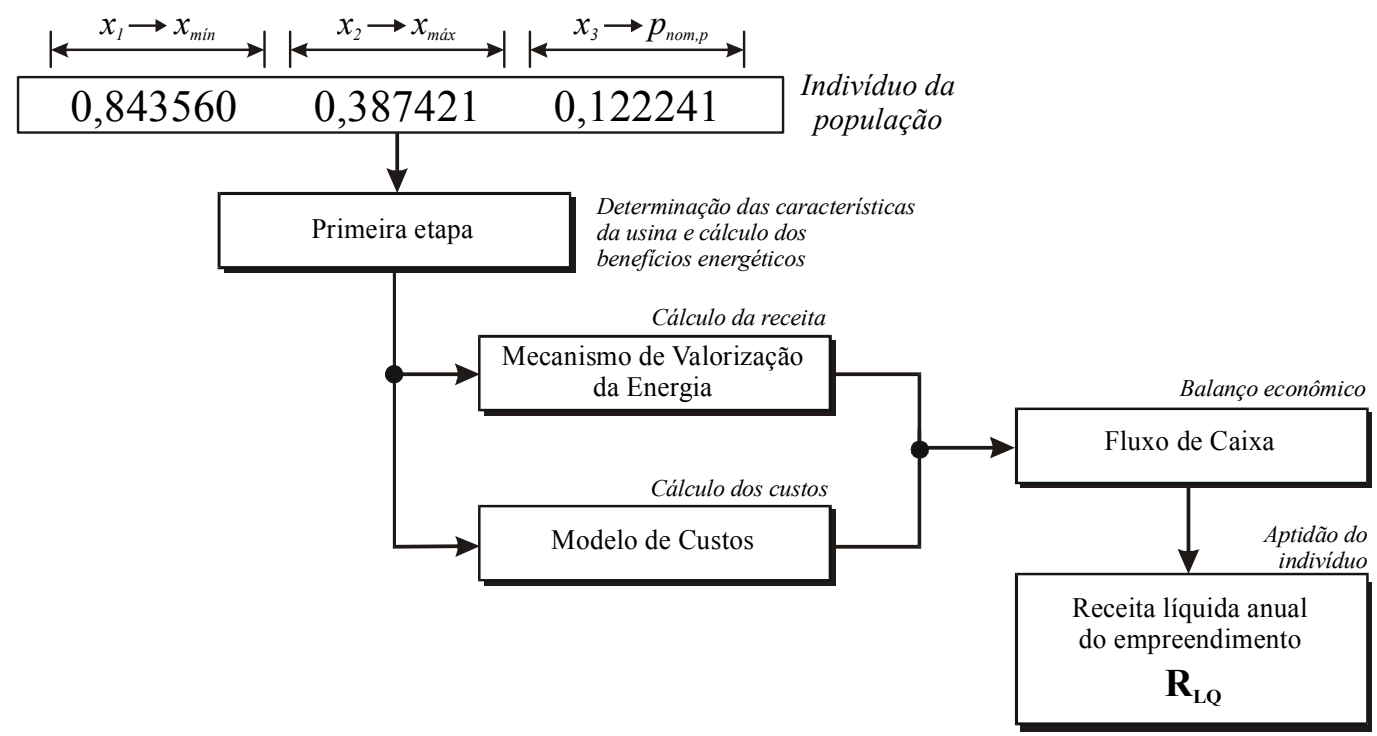

Figura 4.31 - Segunda etapa do processo de cálculo da aptidão de um indivíduo. 



\section{Resultados do Modelo}

\subsection{Dimensões Ótimas da Nova Usina Hidroelétrica}

O resultado principal do modelo é o conjunto de dimensões ótimas da usina sob dimensionamento. As características fornecidas são os volumes mínimo e máximo do reservatório, as quedas de referência e de projeto das turbinas, as potências instaladas de base e de ponta, e a vazão de referência.

Também são fornecidos os valores de custo e de receita. Os valores de custo englobam aquisição de terra, construção do reservatório e da casa de máquinas, operação e manutenção, e juros durante a construção. Estes valores são utilizados para calcular o custo anual da usina. Por outro lado, os valores de receita referem-se aos ganhos oriundos da valorização dos benefícios energéticos de Energia Firme, Energia Secundária e Ponta Garantida. A receita total também é transformada em um valor de receita anual.

Adicionalmente, são calculados três parâmetros que relacionam diferentes características da usina. Estes parâmetros são o Fator de Capacidade, $f_{c a p} \mathrm{em} \%$, o Custo de Instalação, $C I$ em $U S \$ / k W$, e o Índice de Mérito, $I M$ em $U S \$ / M W h$. Estes parâmetros são calculados da seguinte forma:

$$
\begin{aligned}
& f_{\text {cap }}=\frac{B_{E F}}{p_{\text {nom }}} \\
& C I=\frac{I_{T}}{10^{3} \cdot p_{\text {nom }}} \quad\left[\frac{\mathrm{US} \$}{\mathrm{~kW}}\right] \\
& I M=\frac{C_{T}}{n h a \cdot B_{E F}} \quad\left[\frac{\mathrm{US} \$}{\mathrm{MWh}}\right]
\end{aligned}
$$

nas quais:

- $p_{\text {nom: }}$ : potência instalada total da usina, em $M W$;

- $B_{E F}$ : benefício de Energia Firme, em $\overline{\mathrm{MW}}$;

- $I_{T}$ : investimento total do empreendimento, descrito na Seção 1.6;

- $C_{T}$ : custo total anual do empreendimento, descrito na Seção 1.6.

- nha: o número de horas em um ano, igual a 8760. 


\subsection{Alterações nas Outras Usinas Hidroelétricas}

Quando uma usina é construída, ela passa a valorizar a água das usinas localizadas a sua montante e também valoriza a água de seu reservatório nas usinas localizadas a sua jusante. Isto pode fazer com que as gerações das usinas existentes (as do Sistema de Referência) se alterem, alterando seus valores de Energia Firme, Energia Secundária e Potência Garantida. Em casos extremos, o próprio Período Crítico pode se alterar.

Para poder avaliar as mudanças que a construção da usina proporciona, na saída do modelo mostram-se os benefícios energéticos de cada usina, antes e depois da construção do novo empreendimento. Eventualmente, algumas usinas beneficiam-se e outras acabam sendo prejudicadas. A contabilidade destas perdas e ganhos deve ajudar, por exemplo, na criação de mecanismos de partição dos ganhos sistêmicos. 


\section{Aspectos Computacionais}

Implementar a metodologia sugerida é um grande desafio porque o programa necessita realizar várias tarefas:

- Leitura e manipulação de uma grande quantidade de dados;

- Simulação da operação;

- Ajuste das características das usinas em tempo de execução;

- Realização dos cálculos de custo;

- Realização dos cálculos de benefício;

- Implementação do Algoritmo Genético;

- Ajuste do sistema de referência, etc.

Além disso, deve haver a possibilidade de serem gerados relatórios de execução e análises das operações efetuadas com o algoritmo.

Desenvolver um software com essas características requer a criação de unidades específicas para o tratamento de cada tarefa que o programa tem que desempenhar. Para tanto, utilizou-se o paradigma de Programação Orientada por Objetos.

\subsection{Programação Orientada por Objetos}

O conceito principal da Programação Orientada por Objetos é a própria noção de objeto. Segundo esse paradigma de programação, um programa é um conjunto de objetos que se comunicam entre si para cooperativamente resolverem uma tarefa $[64,65,115]$.

Trata-se de uma filosofia de programação na qual as partes do código abstraem o mundo real, tentando imitar as relações existentes entre as partes envolvidas na solução de um problema.

Devido à generalidade do próprio conceito, é muito difícil definir os objetos que vão compor um programa. Supondo, por exemplo, a implementação de um sistema de mensagens eletrônicas, há várias entidades distintas que o compõem: sistemas de armazenagem de mensagens, mensagens, senhas, menus, etc. A parte complicada da implementação de um programa orientado por objetos é determinar quais destas entidades serão objetos e como será feita a interação entre os objetos para que o sistema de mensagens funcione.

Visto sob o ponto de vista de programação, a idéia principal da Programação Orientada por Objetos é quebrar o programa em blocos reduzidos, cada um com responsabilidades restritas, facilitando assim a tarefa do programador de gerenciar todas as unidades de código. 
Os objetos são usualmente caracterizados pelas seguintes propriedades:

- Estado

- Operações

- Identidade

Um objeto pode armazenar informações, as quais são resultados de operações passadas e podem determinar como operações futuras serão desenvolvidas. O conjunto de todas as informações contidas em um objeto determina seu estado, o qual pode mudar ao longo do tempo devido à realização de operações.

Considerando o sistema de mensagens eletrônicas, o sistema de armazenagem pode estar vazio após a criação do objeto, e pode estar cheio depois do objeto receber uma grande quantidade de mensagens. Estes estados alteram o comportamento do objeto: se ele estiver cheio ele pode rejeitar novas mensagens, ao passo que se ele estiver vazio não será possível excluir mensagens.

Um objeto pode realizar uma série de operações relacionadas à sua natureza. Por exemplo, um sistema de mensagens pode receber e enviar mensagens, mas não é sensato desejar que ela faça cálculos numéricos ou manipule matrizes.

Somente o estado e o conjunto de operações não caracterizam um objeto. Um mesmo programa pode ter dois sistemas de mensagens eletrônicas, as quais precisam ser acessadas independentemente. Para que isso seja possível é necessário que cada objeto tenha uma identidade única. Assim, eles podem ter estados diferentes e podem responder a solicitações também diferentes.

Unindo as idéias de estado, operações e identidade, pode-se pensar na definição de tipos abstratos de dados, chamados genericamente de classe. Objetos de uma mesma classe podem realizar o mesmo conjunto de operações e têm o mesmo conjunto possível de estados.

Para exemplificar a implementação de uma classe na Linguagem $C++$, o código da Tabela 4.6 mostra a definição da classe TData ${ }^{25}$. Essa classe, conforme o próprio nome indica, abstrai o conceito de data, armazenando dados de dia, mês e ano. O " $T$ " que inicia o nome da classe faz parte de uma convenção para dizer que a classe especifica um Tipo abstrato de dado.

Analisando a tabela, deve-se inicialmente estabelecer a diferença entre a definição de uma variável e a declaração de uma operação ou função. A definição de 
uma variável é feita especificando-se o tipo da variável e em seguida o seu nome. Assim, a definição int_Dia; especifica uma variável do tipo inteiro chamada_Dia.

Já na declaração de uma função devem ser especificados o tipo de retorno da função, seu nome, e mais o conjunto de parâmetros necessário para que ela seja executada. Por exemplo, a declaração void Avanca(const long NumeroDias); especifica uma função chamada Avanca que não retorna nenhum valor, é void, e deve ser chamada passando-se como parâmetro um dado do tipo long, o número de dias que se deseja que a data avance, o qual não pode ser alterado pela função devido à sua definição como constante, const.

Tabela 4.6 - Definição da classe TData.

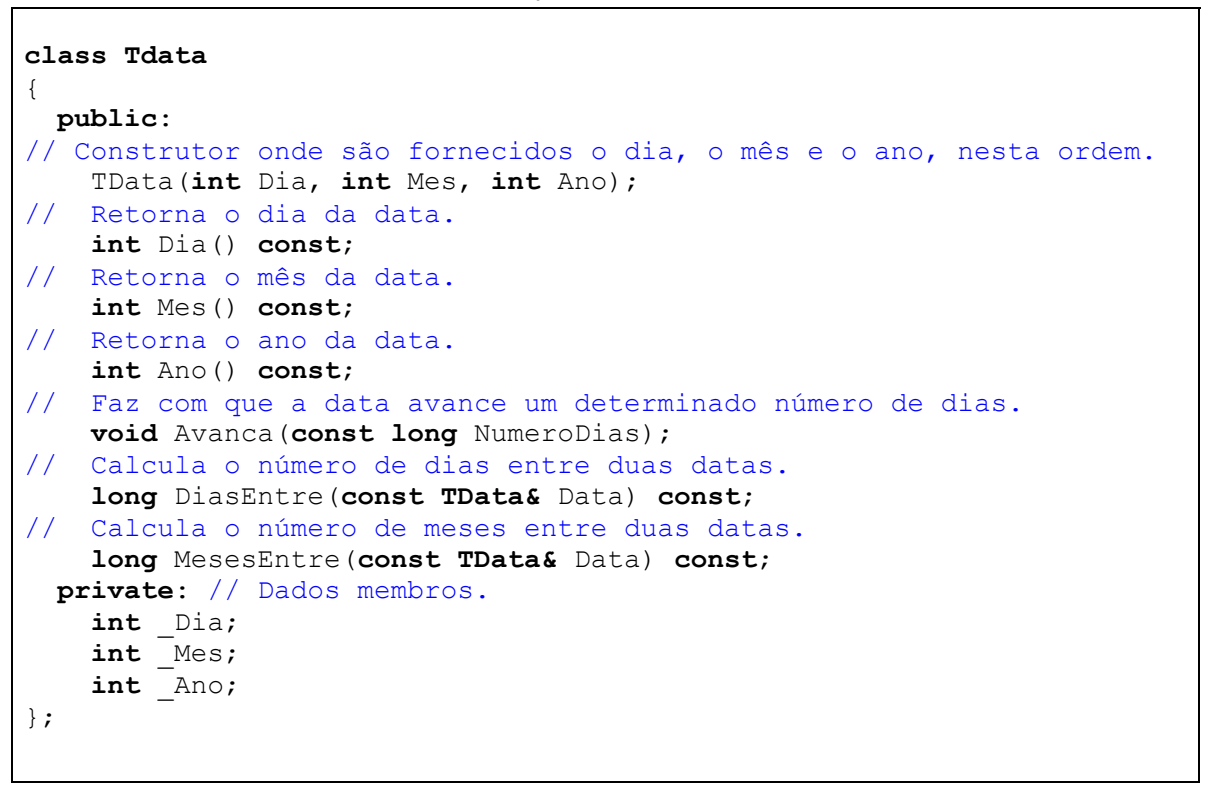

Para explicar a utilização de um dado do tipo TData, mostra-se o trecho de código da Tabela 4.7.

Tabela 4.7 - Utilização da classe TData.

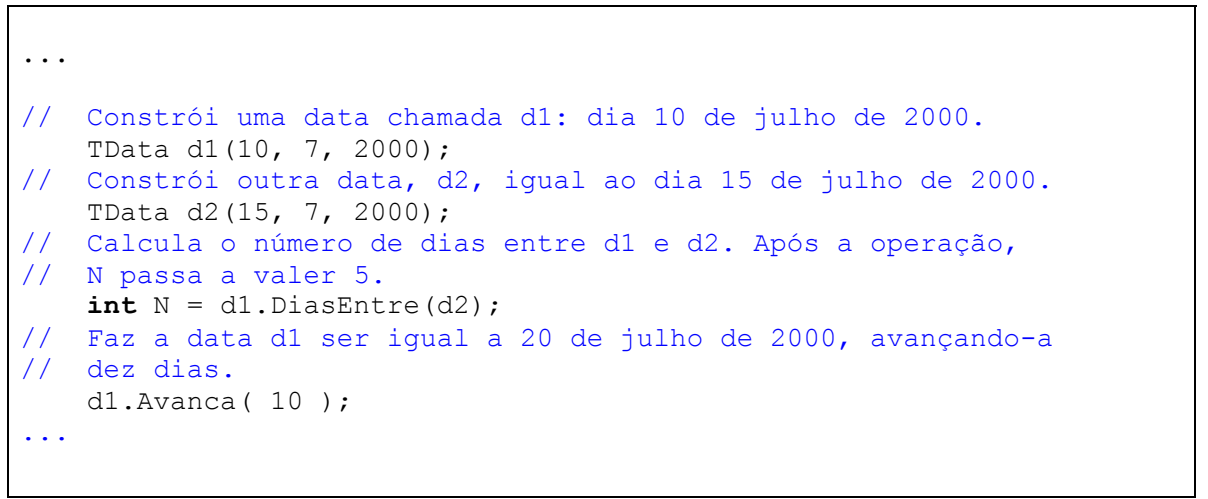

25 Quando há duas barras, “//”, no início de uma linha, o código não é compilado, tratando-se simplesmente de um comentário. 
Nesse trecho de código são definidas duas datas, d1 e d2, e são feitas algumas manipulações com elas, através da execução das operações DiasEntre e Avanca. Embora o exemplo possa parecer muito simples, é interessante notar o conceito no qual esta implementação está baseada. Primeiro, o programa conta com um tipo de dado especial para a definição de datas, possibilitando assim que todas as operações que possam ser realizadas com uma data passem a ser organizadas em um único local: a classe TData. Isso facilita em muito o gerenciamento de projetos grandes pois, por exemplo, se um software gigantesco, com milhares de linhas de código, começa a realizar cálculos errados com as datas que ele manipula, sabe-se que a única porção do programa que altera as datas é a classe TData. Para resolver os problemas, basta depurar a classe TData.

Outra característica que ajuda a garantir que somente as operações da classe TData consigam alterar os dados de uma data é o encapsulamento dos dados. Analisando novamente a Tabela 4.6, observam-se as palavras public e private. A declaração public: no início da definição da classe indica que todas as funções desde esta declaração até a palavra private: podem ser acessadas por quaisquer partes do programa. Já os dados definidos depois da palavra private: só podem ser alterados por funções da própria classe, garantindo assim que outras partes do programa não interfiram no estado das datas. Por exemplo, a inserção do comando d1. Dia = 35 no código da Tabela 4.7 gera um erro de compilação, já que o dado _Dia não é acessível.

Para finalizar as explicações sobre classe, deve-se observar que na Tabela 4.7 é mostrada apenas a declaração da classe; para a classe TData funcionar é necessário que seu código seja escrito, isto é, implementado. Por exemplo, a implementação da função que constrói uma data a partir de seu dia, mês e ano é apresentada na Tabela 4.8. Dentro da função TData podem-se alterar os valores das variáveis protegidas _Dia, _Mes e _Ano, fazendo-os iguais ao parâmetros que são fornecidos à função, variáveis Dia, Mes e Ano.

Tabela 4.8 - Implementação de uma operação da classe TData.

/// Construtor onde são fornecidos o dia, o mês e o ano, nesta ordem.
TData: :TData(int Dia, int Mes, int Ano)
f $\mathrm{Dia}=$ Dia;
$\quad$-Mes = Mes;
$\quad$-Ano = Ano;


Voltando à simulação da operação de usinas hidroelétricas, a classe TData pode ser utilizada, por exemplo, na especificação de períodos de simulação.

Se o problema começar a ser analisado mais profundamente, pode-se começar a pensar em uma classe TUsinaHidroelétrica, em outra TSistemaHidroeletrico, etc. Para conseguir visualizar todas as classes necessárias para a implementação do modelo de dimensionamento projetou-se um software, descrevendo-se todos os tipos de dados abstratos necessários e as relações entre eles. Uma breve descrição das partes que compõem o software é mostrada na próxima seção.

\subsection{Descrição do Software Desenvolvido}

O software desenvolvido foi implementado com o objetivo de realizar o dimensionamento de usinas hidroelétricas utilizando-se Algoritmos Genéticos. Como há uma grande variedade de objetos a serem definidos para que o objetivo do programa seja atingido, as classes implementadas foram agrupadas em pacotes, formando conjuntos de tipos de dados abstratos, conjuntos de classes, que possuem objetivos comuns.

Na Figura 4.32 apresentam-se as relações entre os conjuntos de pacotes que compõem o modelo de dimensionamento. Ao pacote principal foi dado o nome de Dime, que é na realidade o nome do programa principal, que coloca todas as classes do programa para trabalhar juntas.

As setas das figuras indicam as relações entre os pacotes. Observando o diagrama, pode-se concluir que todas as partes do programa utilizam classes do pacote Suporte, que o pacote Simulação utiliza as classes do pacote Sistema Hidroelétrico, e que o pacote Dime utiliza as classes do pacote Algoritmos Genéticos e Simulação. A seguir, cada um dos pacotes será explicado com mais detalhes.

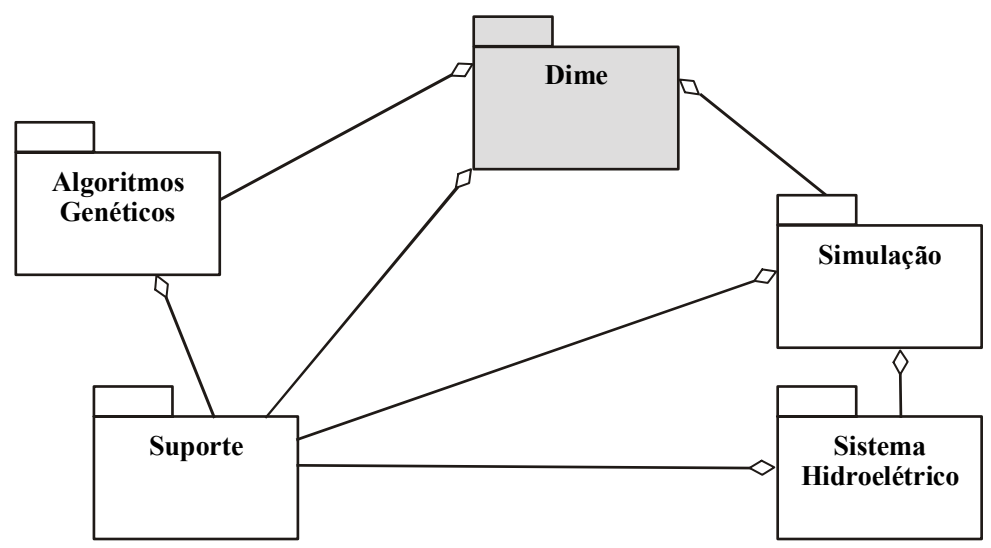

Figura 4.32 - Conjunto de pacotes que compõem o modelo. 


\subsubsection{Pacote Suporte}

Esse pacote tem como objetivo agrupar as classes que a princípio não possuem uma relação direta com a operação de Sistemas Hidroelétricos nem com o Dimensionamento de usinas, mas que facilitam, dão suporte, à implementação dos outros tipos de dados. Esse pacote é formado por nove classes:

- TLeitor: esta classe é responsável pela leitura de dados a partir de arquivos ou banco de dados. É nela que estão implementadas as funções que lêem os dados de modelagem das usinas hidroelétricas, os dados de vazão, as redes topológicas do sistema hidroelétrico, as configurações dos estudos de simulação, os dados do algoritmo genético e também dos estudos de dimensionamento.

- TEscritor: esta classe é bem semelhante à classe TLeitor, porém ela serve para escrever os dados, ao invés de lê-los. Ela cria os arquivos com os resultados dos estudos e os relatórios descrevendo os dados utilizados.

- TDiretorio: para que as classes TLeitor e TEscritor possam desempenhar suas tarefas, é necessário o conhecimento da localização dos dados, isto é, de onde ler e onde gravar os arquivos. Esta classe desempenha esse papel, armazenando os caminhos onde estão gravados os dados de afluência, os dados das usinas, os dados dos períodos de simulação disponíveis, os dados dos algoritmos genéticos, dos estudos de dimensionamento, etc.

- TPolinomio: a modelagem de uma usina hidroelétrica envolve pelo menos três polinômios: cota a montante em função do volume, cota a jusante em função da vazão defluída e área do espelho d'água do reservatório em função da cota de montante. Para facilitar a implementação de uma usina hidroelétrica, implementou-se esta classe. A classe TPolinomio possui o grau do polinômio, um vetor contendo os seus coeficientes, e realiza as operações de cálculo do polinômio em um ponto e de integração do polinômio em um intervalo definido.

- TData: esta classe armazena e manipula datas. Ela é particularmente útil na definição dos períodos de simulação e das datas iniciais e finais do histórico disponível no programa.

- TPeriodo: esta classe contém duas datas em seu interior (variáveis do tipo TData) e abstrai o conceito de períodos ou horizontes de simulação. Nesta 
classe especificam-se também a duração de cada intervalo de simulação e o histórico de dados disponível.

- TIdentificacao: esta classe armazena um nome e um comentário e serve para identificar objetos como estudos de simulação, usinas, sistemas hidroelétricos, etc.

- TMatriz: esta classe implementa uma matriz de dados com $n$ linhas e $m$ colunas. Além de armazenar os dados, ela possui métodos específicos para gerenciar a utilização da memória e permitir que sejam inseridas colunas, linhas, etc.

- TConjuntoDado: esta classe armazena um conjunto de dados. Na realidade, além de armazenar uma matriz de dados, esta classe permite que cada coluna seja identificada com um nome, permitindo que as variáveis de volume, vazão afluente, vazão turbinada, etc., de cada usina sejam facilmente identificadas.

\subsubsection{Pacote Sistema Hidroelétrico}

Este pacote implementa todas as classes necessárias para definição de um tipo de dado abstrato que represente um sistema hidroelétrico. Este pacote é formado pelas seguintes classes:

- TUsinaHidroeletrica: esta classe armazena todos os dados necessários para a representação de uma usina hidroelétrica, indo desde sua identificação, localização e empresa, até as características do vertedor, reservatório, polinômios de modelagem e casa de máquinas. Entre as principais operações desta classe estão o cálculo do engolimento máximo e da geração da usina.

- TTopologia: esta classe abstrai a topologia de um sistema de geração, sendo responsável por determinar que usina recebe água de que usina, especificando-se assim como deve ser aplicada a equação do balanço d'água durante as simulações. Esta classe é necessária porque testes podem ser realizados com sistemas incompletos, diferentes do que realmente existe em operação, e os postos de montante e jusante das usinas precisam ser atualizados. 
- TSistemaHidroeletrico: esta classe armazena um conjunto de usinas hidroelétricas e a relação topológica existente entre elas, de forma a abstrair o conceito de Sistema Hidroelétrico.

- TAfluencia: esta classe armazena os dados de vazão afluente de um sistema Hidroelétrico ao longo de um período de simulação. Para ela funcionar é necessário que sejam especificados um dado da classe TSistemaHidroeletrico e outro da classe TPeriodo.

\subsubsection{Pacote Simulação}

Este pacote define as classes necessárias para realização de uma simulação e é formado pelas seguintes classes:

- TMercado: esta classe é utilizada para especificar o mercado a ser atendido pelo sistema hidroelétrico a cada período de simulação. Pode ser um mercado constante ou variável, definindo-se um valor para cada intervalo de simulação.

- TPolitica : esta classe é responsável pela implementação da política ou da regra de operação do sistema hidroelétrico. Ela é responsável pela parte principal do trabalho, uma vez que todos os estudos são baseados na comparação da operação do sistema sob diferentes políticas de operação. Há duas políticas implementados: TPOtimizada e TPParalela. A primeira é a regra de operação baseada em critérios ótimos e a segunda é a regra de operação em paralelo.

- TSimulacao: esta classe é responsável pela execução da simulação. Para realizar uma simulação deve-se definir um Sistema Hidroelétrico, um período, um mercado e uma política de operação.

- TSPeriodoCritico: esta classe é responsável pela execução de simulações para determinação do período crítico. Para realizar uma simulação deste tipo deve-se definir um Sistema Hidroelétrico e uma política de operação. O mercado atendido é determinado automaticamente. 


\subsubsection{Pacote Algoritmos Genéticos}

Este pacote contém o conjunto de classes necessário para implementar processos de otimização baseados em Algoritmos Genéticos. O AG desenvolvido foi batizado de GOOAL - Genetic Object Oriented ALgorithm [74, 96]. Na Figura 4.33 apresenta-se o diagrama de classes do algoritmo.

A classe principal, responsável por fazer todas as outras trabalharem juntas, é a TGOOAL. Esta classe contém objetos das outras classes, tais como TPopulacaoInicial, TCruzamento, TMutacao, TPopulacao, TEscalonamento, TSelecao, TEstrutura, TParada, TElitismo e TImpressao.

Os nomes das classes auto-sugerem seus propósitos. Por exemplo, a classe TCruzamento implementa os operadores de cruzamento. Como há diversos operadores de cruzamento possíveis, a classe TCruzamento é implementada como abstrata, ou seja, ela apenas estabelece quais métodos os operadores de cruzamento devem ter: Cruza() e NFilho()

As classes que realmente combinam indivíduos são aquelas implementadas como diferentes tipos de TCruzamento, usando mecanismos de herança. Estas classes são a TCUniforme, TCUmPonto, TCDoisPontos, etc. A classe TCUniforme realiza o cruzamento uniforme entre dois indivíduos através de seu método Cruza(), a classe TCUmPonto realiza o cruzamento de um ponto, e assim por diante.

As classes TCromossomo e TEstrutura também estabelecem padrões, mas nesse caso elas estão focadas na estruturação do algoritmo. A classe TEstrutura define como os dados são alocados na memória. Por exemplo, o número de genes de uma representação binária que codifica três variáveis depende da precisão adotada, enquanto que para a representação real, o número de genes é igual ao número de variáveis. Desta forma, diferentes métodos NGene() são implementados para as classes TEBinario, TEReal e TEInteiro. Similarmente, a classe TCromossomo apresenta comportamentos diferenciados dependendo do tipo de representação: binária, real ou inteira.

Outras classes desenvolvem seus papéis sem a necessidade de mecanismos de especialização. Estas classes são a TImpressao, que imprime relatórios sobre o processo de busca, TElitismo, que copia os melhores cromossomos de uma geração a outra, e a TParada, que decide quando o processo de busca deve parar. 


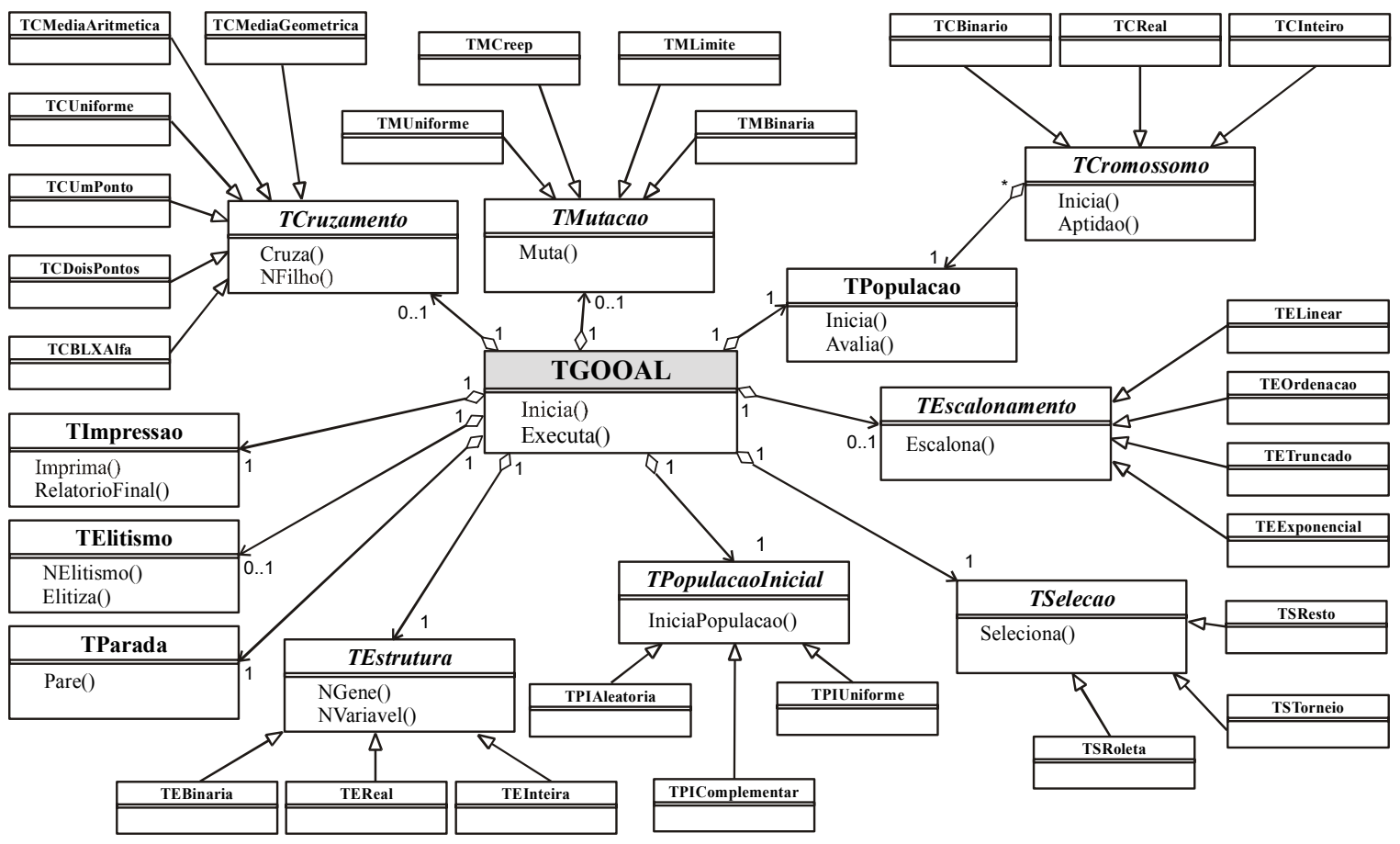

Figura 4.33 - Diagrama de classes do GOOAL.

\subsubsection{Pacote Dimensionamento}

Este pacote implementa a classe principal de todo o projeto, a classe TDime (Dime de Dimensionamento). Esta classe coloca todas as outras classes do modelo para trabalharem juntas, permitindo assim que os estudos de dimensionamentos sejam realizados.

Na Figura 4.34 mostra-se o diagrama de classes do pacote de dimensionamento. A classe principal é a TDime. Ela possui objetos das classes TGOOAL, TSimulacao, TMVE, TFluxoCaixa, TCusto e TIdentificacao.

O objeto da classe TIdentificacao serve simplesmente para identificar o estudo de dimensionamento com um nome e um comentário. O objeto da classe TGOOAL desenvolve o processo de otimização através do Algoritmo Genético. O objeto da classe TSimulacao presta-se a simular os sistemas hidroelétricos, tanto o de Referência quanto o Completo, determinando seus respectivos Períodos Críticos e benefícios energéticos.

O objeto da classe TMVE "usa" (esta relação é indicada pela seta de TSimulacao e para TMVE) os resultados da simulação para atribuir valor econômico aos ganhos energéticos. O objeto da classe TCusto determina os custos de construção de um aproveitamento e, finalmente, o objeto da classe TFluxoCaixa usa os resultados de TMVE e TCusto para determinar a receita líquida anual da usina, utilizada como aptidão para os indivíduos do TGOOAL. 


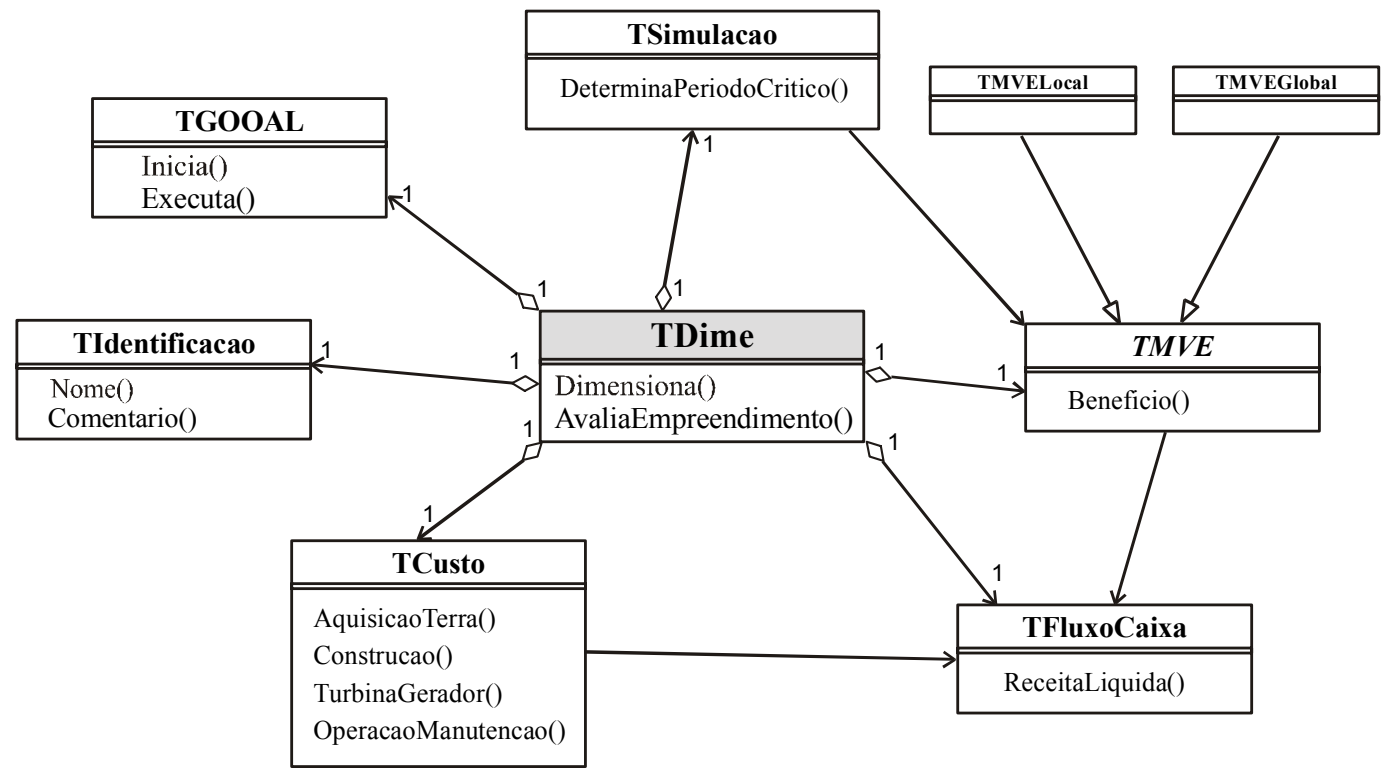

Figura 4.34 - Diagrama de classes do pacote Dimensionamento. 



\section{Exemplo de Estudo de Dimensionamento}

$\mathrm{O}$ exemplo de estudo de dimensionamento presta-se simplesmente a mostrar como os dados são fornecidos ao modelo, a forma de aplicação do método de otimização e os resultados produzidos.

O exemplo será realizado supondo-se o dimensionamento da usina hidroelétrica de Emborcação, localizada no rio Paranaíba. Os dados desta usina são mostrados no Anexo A. Na Tabela 4.9 mostra-se o arquivo com os dados do dimensionamento. As linhas iniciadas pelo caractere \# são comentários.

O nome do exemplo tenta explicar os parâmetros utilizados. Trata-se de um estudo realizado com a usina de Emborcação (Emb), com o sistema completo composto por 37 usinas (37), utilizando-se a regra paralela de operação (Par), com o custo de referência da Energia Firme igual a 30,00 US\$/MWh e razão de modulação igual a 1 (30M1), calculando os benefícios globais de energia $(B G)$ e utilizando-se o histórico total de vazões $(H T)$.

Tabela 4.9-Dados do estudo de dimensionamento.

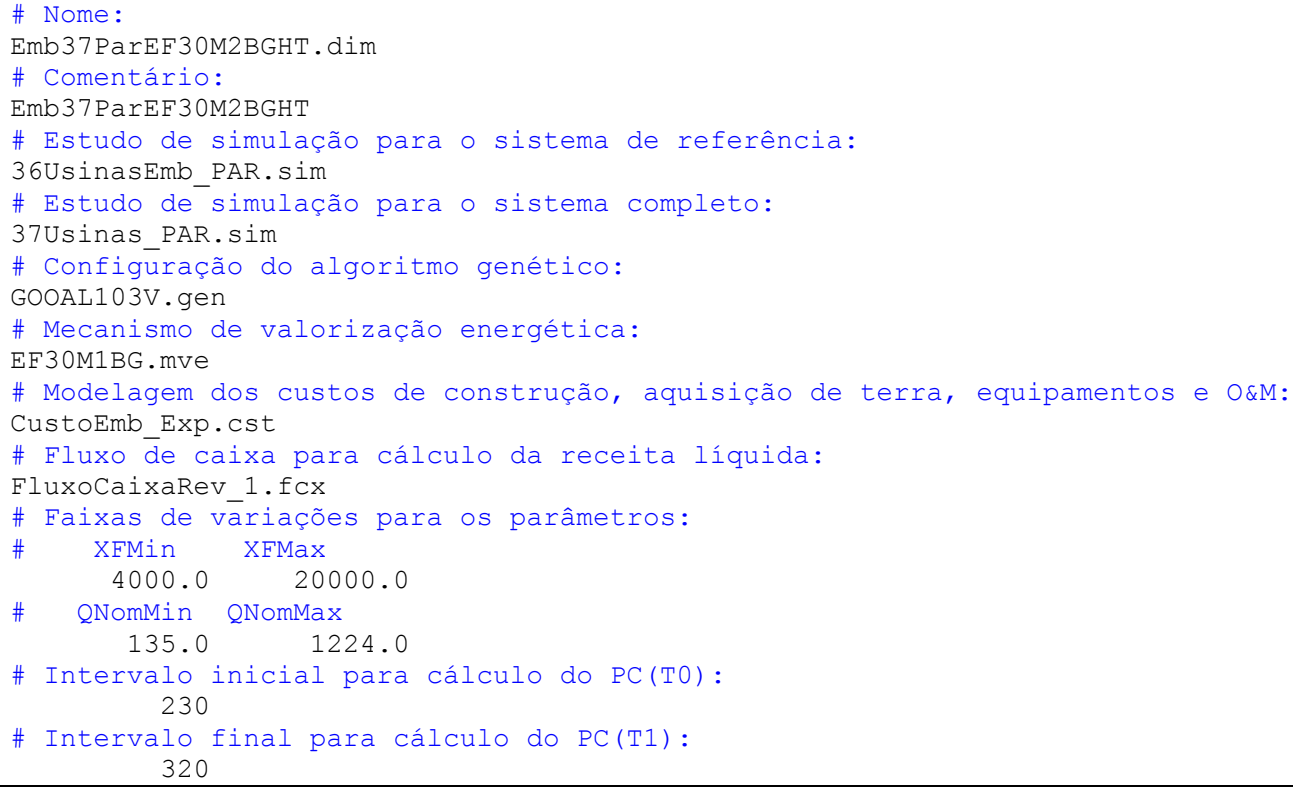

O estudo de simulação para o Sistema de Referência, 36UsinasEmb_PAR.sim, é mostrado na Tabela 4.10. Conforme o próprio nome sugere, trata-se de um sistema composto por 36 usinas, operadas de acordo com regra de operação paralela. Os dados do Sistema de Referência são mostrados na Tabela 4.11. A regra paralela é definida com mais detalhes no Capítulo VI.

Os outros dados do estudo de simulação referem-se a parâmetros do processo 
iterativo utilizado para determinar o Período Crítico. Estes parâmetros são explicados com mais detalhes no Capítulo VI.

Tabela 4.10 - Dados do estudo de simulação do sistema de referência.

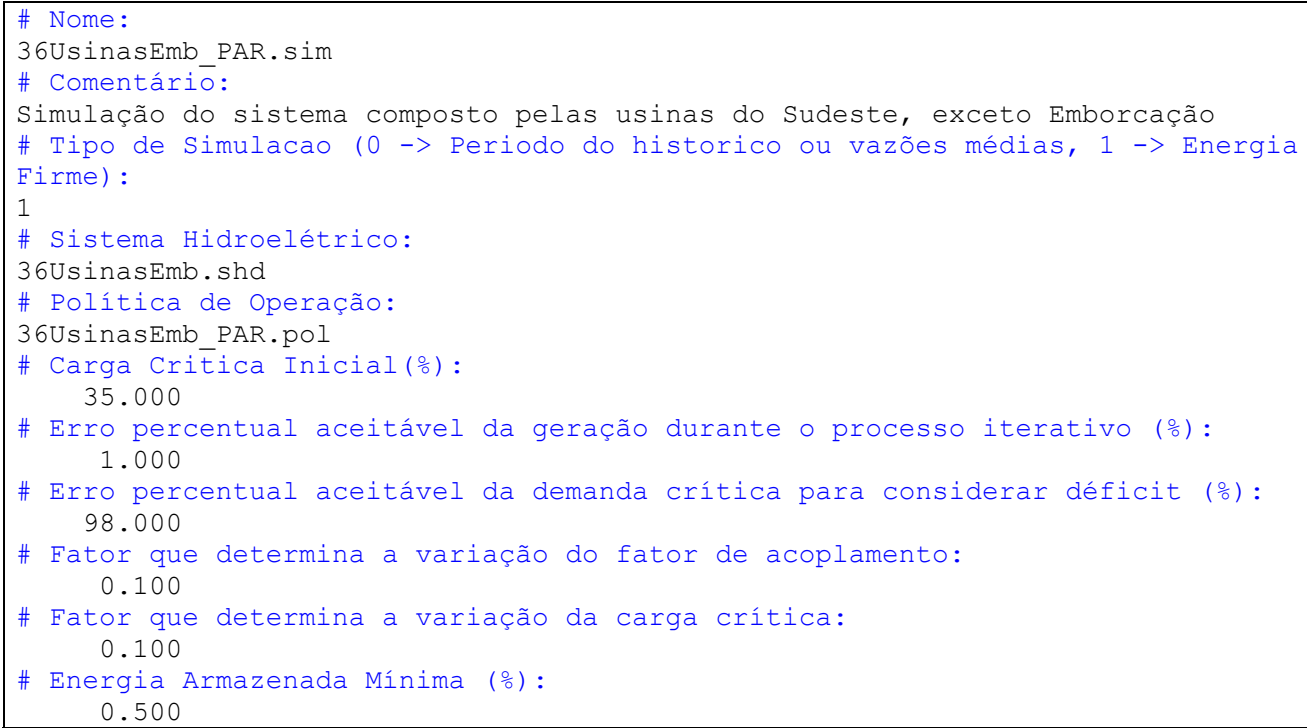

Tabela 4.11 - Dados do sistema de referência.

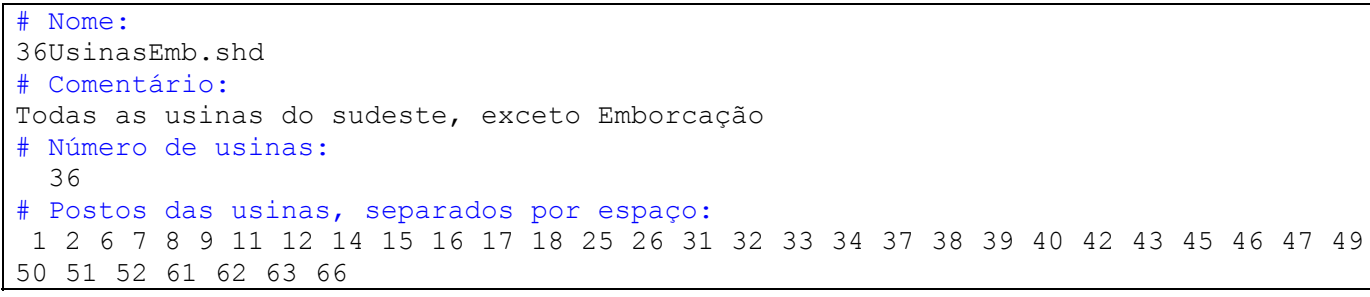

$\mathrm{O}$ arquivo de configuração do Algoritmo Genético é mostrado na Tabela 4.12. Este arquivo é relativamente extenso porque contém todos os parâmetros do algoritmo, incluindo número de indivíduos, número de variáveis, forma de iniciar a população inicial, operadores de seleção, elitismo, cruzamento e mutação, forma de impressão dos resultados, etc.

Tabela 4.12 - Dados do algoritmo genético.

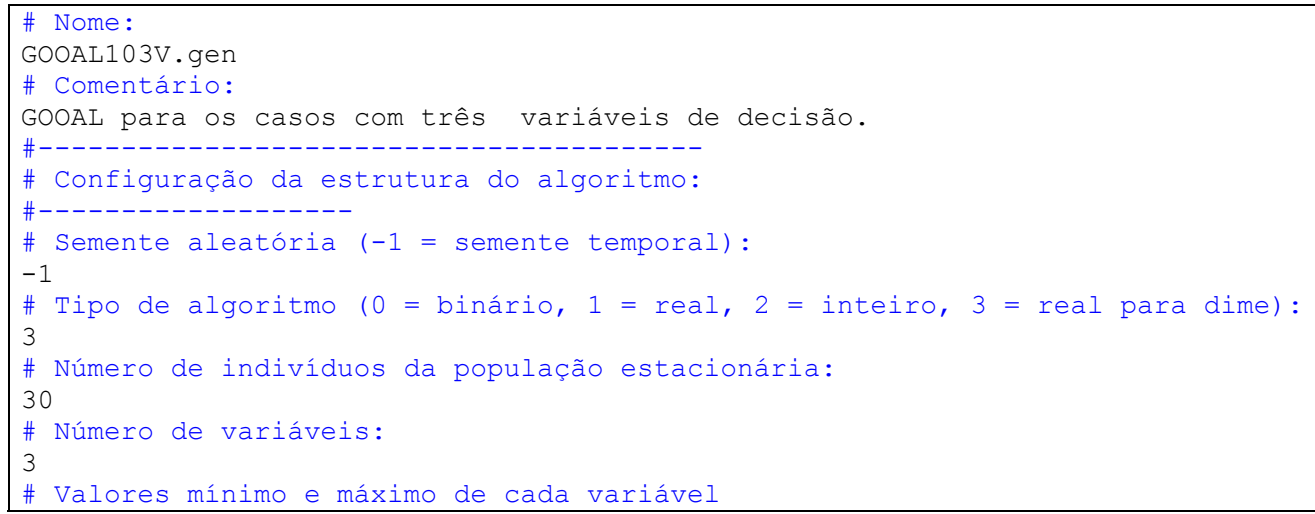




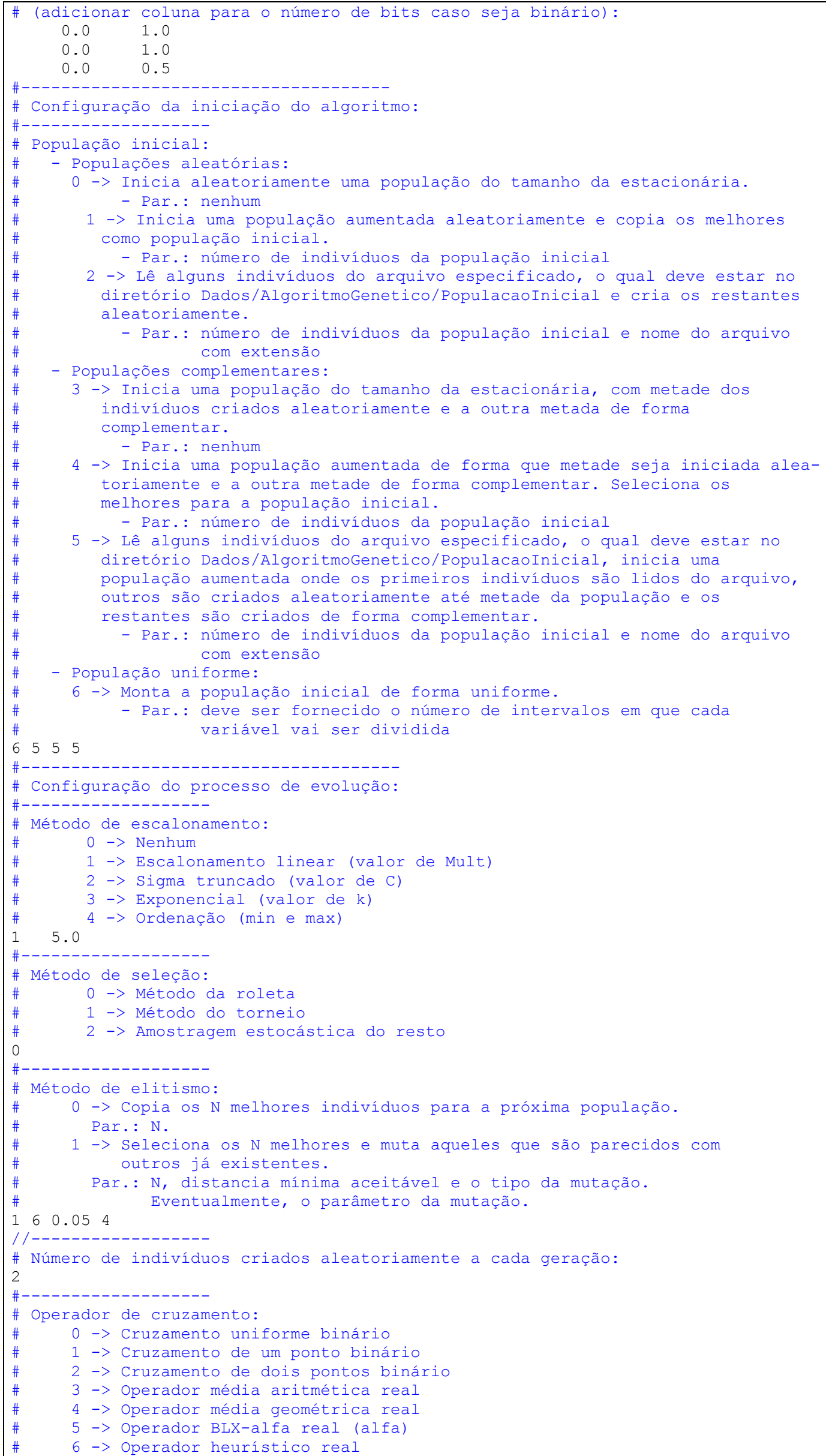




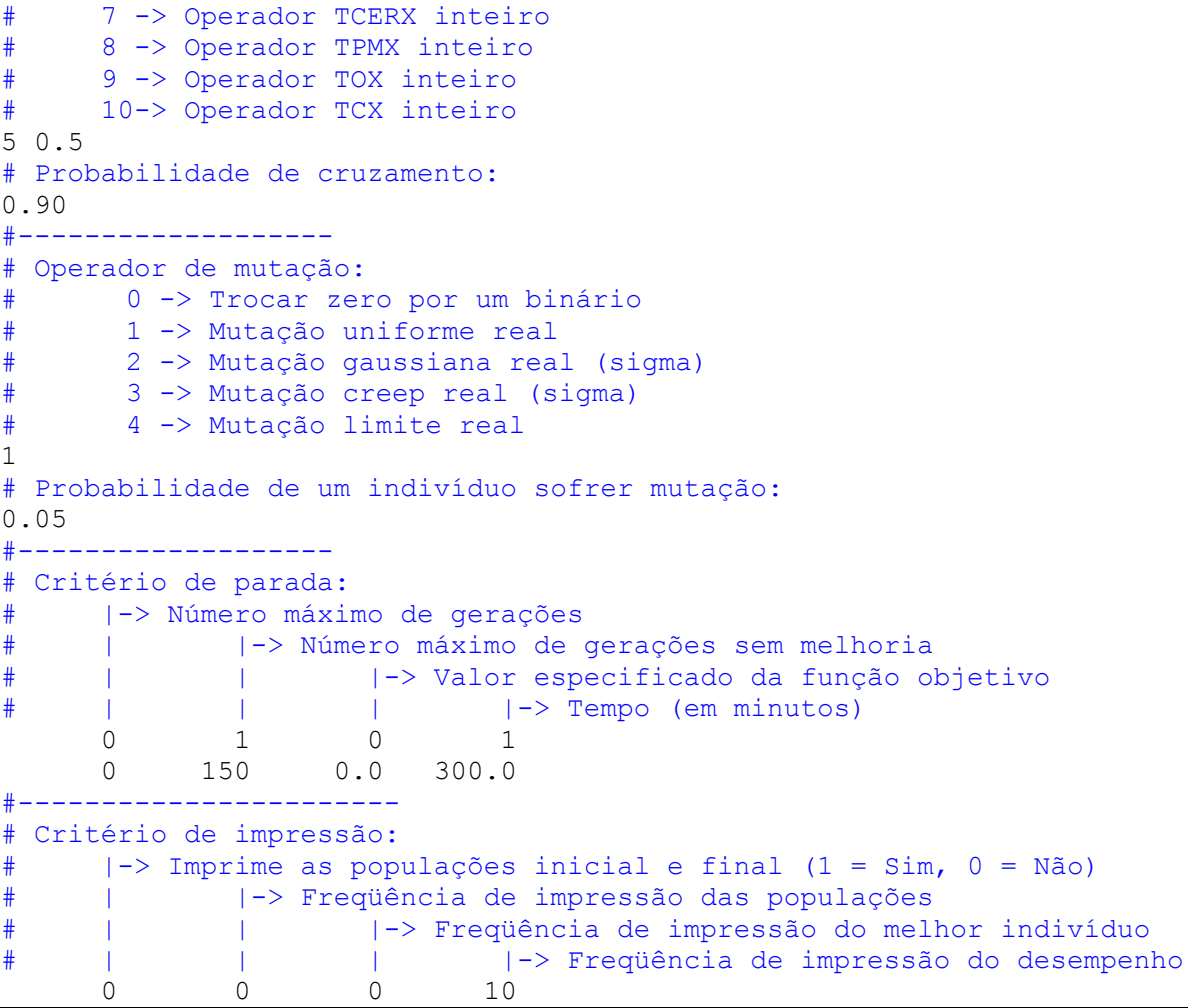

Para finalizar a parte dos dados, as próximas três tabelas apresentam o MVE utilizado, os dados de custo e os parâmetros do fluxo de caixa. Os comentários das tabelas explicam seus significados.

Tabela 4.13 - Dados do mecanismo de valorização da energia.

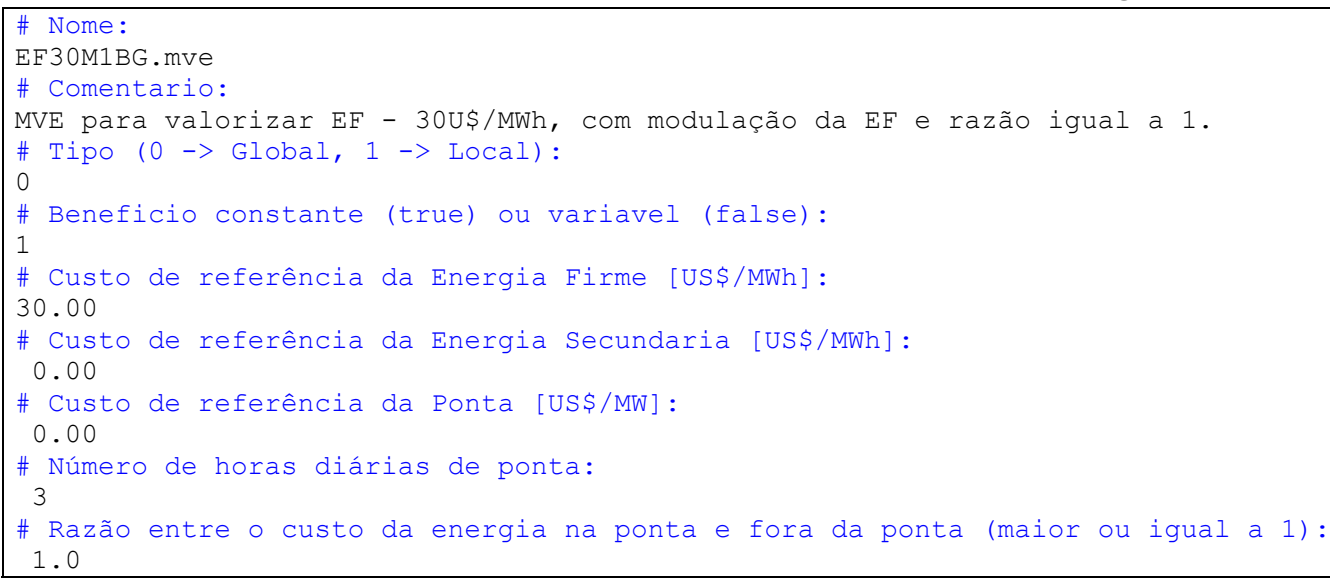

Tabela 4.14 - Dados de custo.

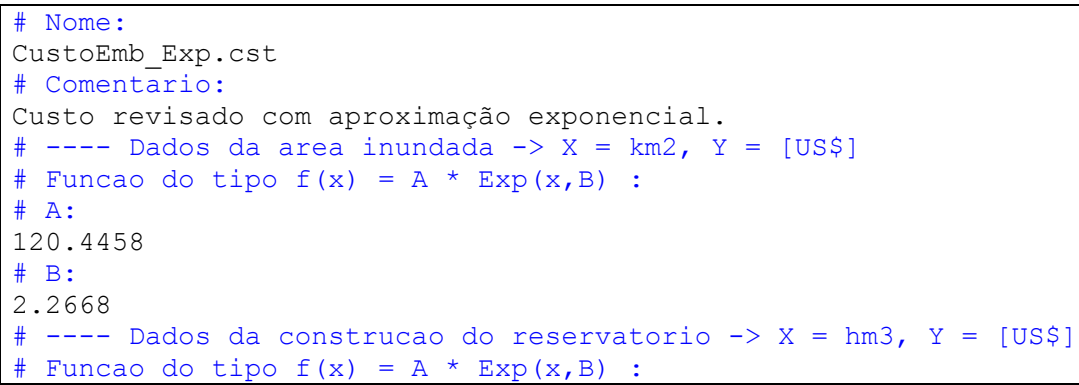




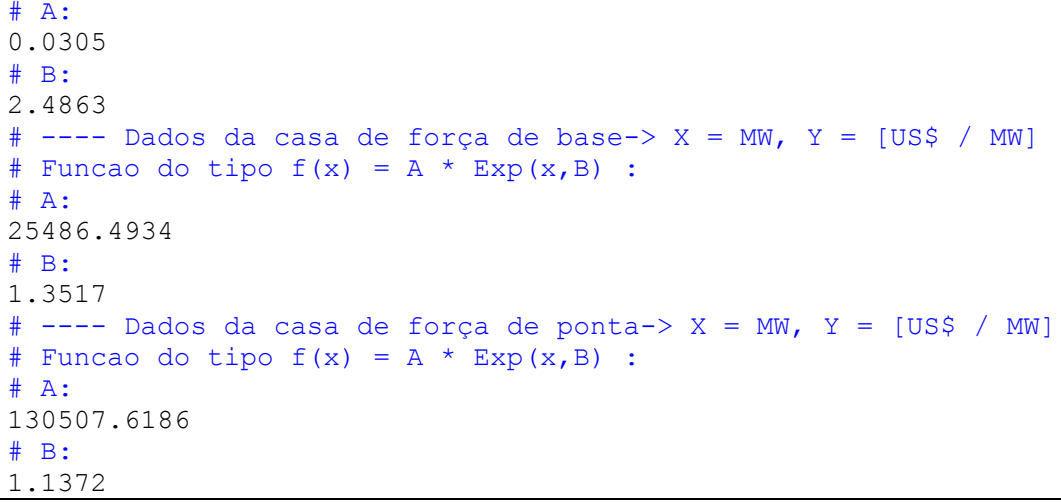

Tabela 4.15 - Dados do fluxo de caixa.

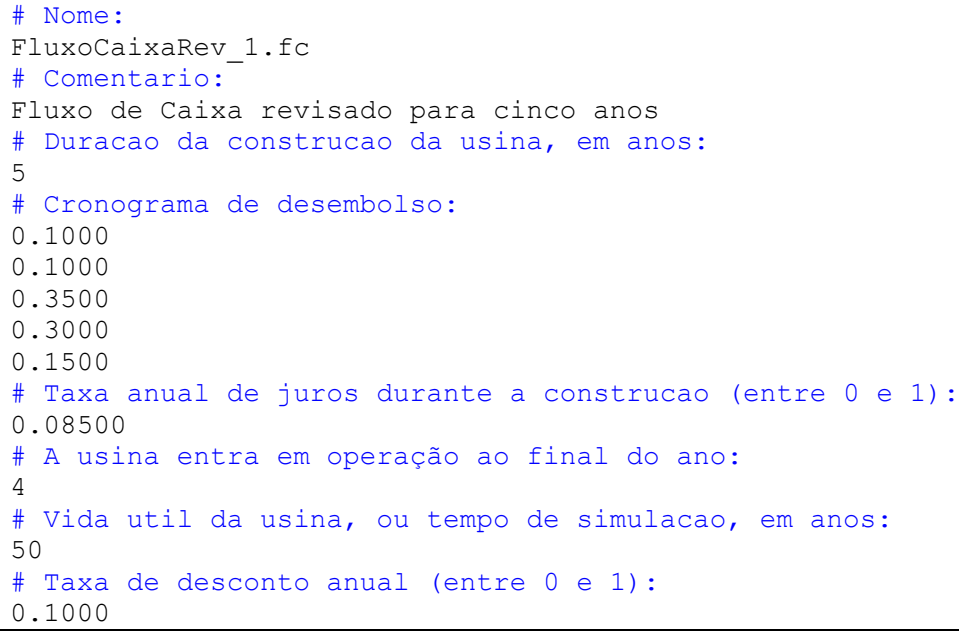

Conforme pôde ser observado no arquivo de dados do AG, o critério de parada escolhido foi o tempo de execução, fixado em cinco horas. Isso significa que as características ótimas da usina sob dimensionamento serão conhecidas após cinco horas de processamento ou quando não forem observadas melhorias em 150 gerações consecutivas.

Ao final da execução, o programa produz o relatório mostrado na Tabela 4.16. Neste relatório podem ser observadas as dimensões ótimas da usina, os ganhos energéticos sistêmicos, os valores de custos e de receitas. É interessante observar que embora a Energia Firme de Emborcação seja 388,0 $\overline{M W}$, o benefício sistêmico de Energia Firme é 615,9 $\overline{M W}$. Isso significa que a inserção de Emborcação, uma usina de cabeceira, faz com que as outras usinas recebam vazões mais regularizadas, aumentando suas Energias Firmes. Outro efeito desta regularização é a redução da Energia Secundária do Sistema de Referência, e a elevação da Geração Média além da geração média da usina dimensionada. 
Tabela 4.16-Resultados do modelo de dimensionamento.

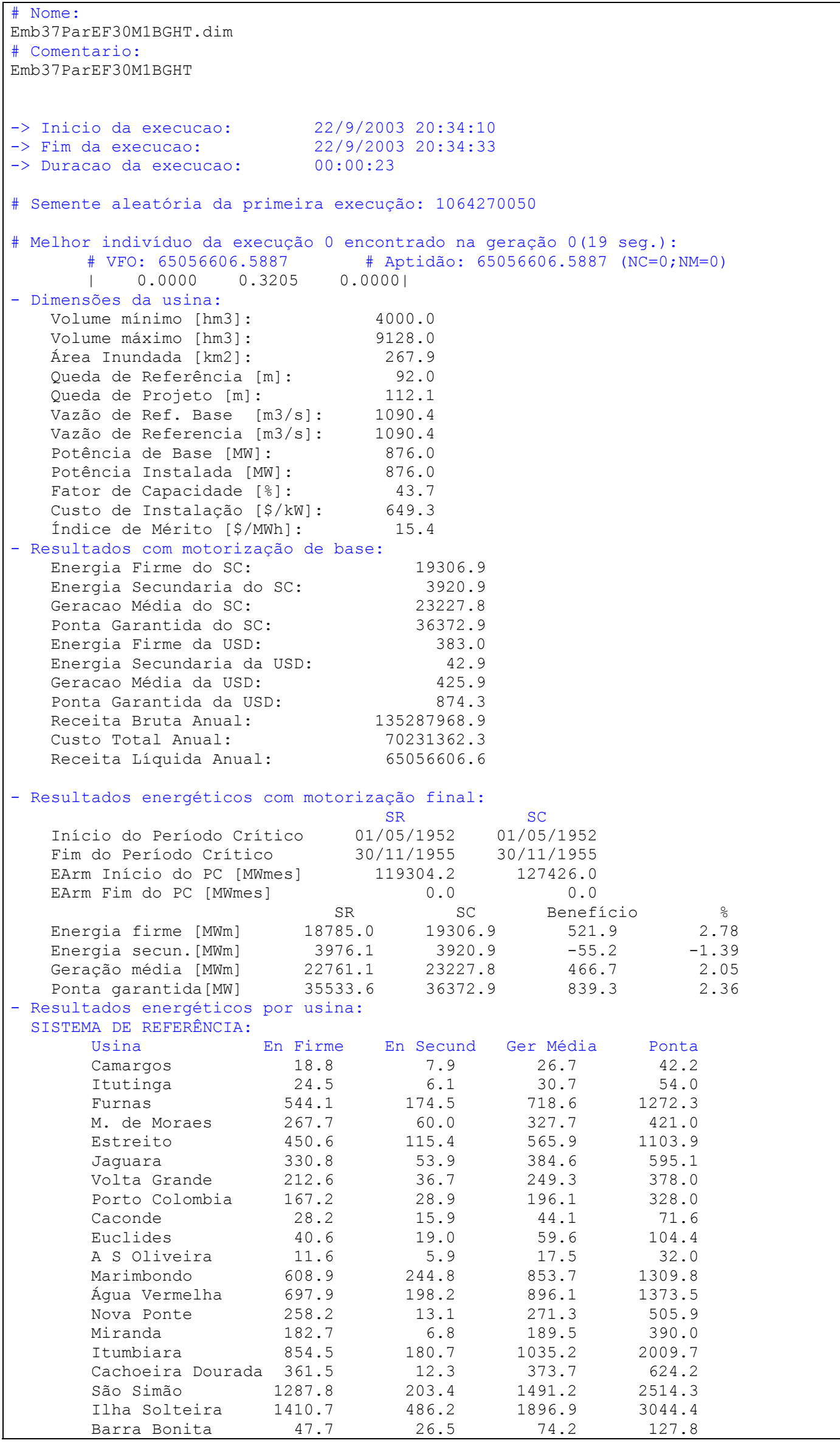




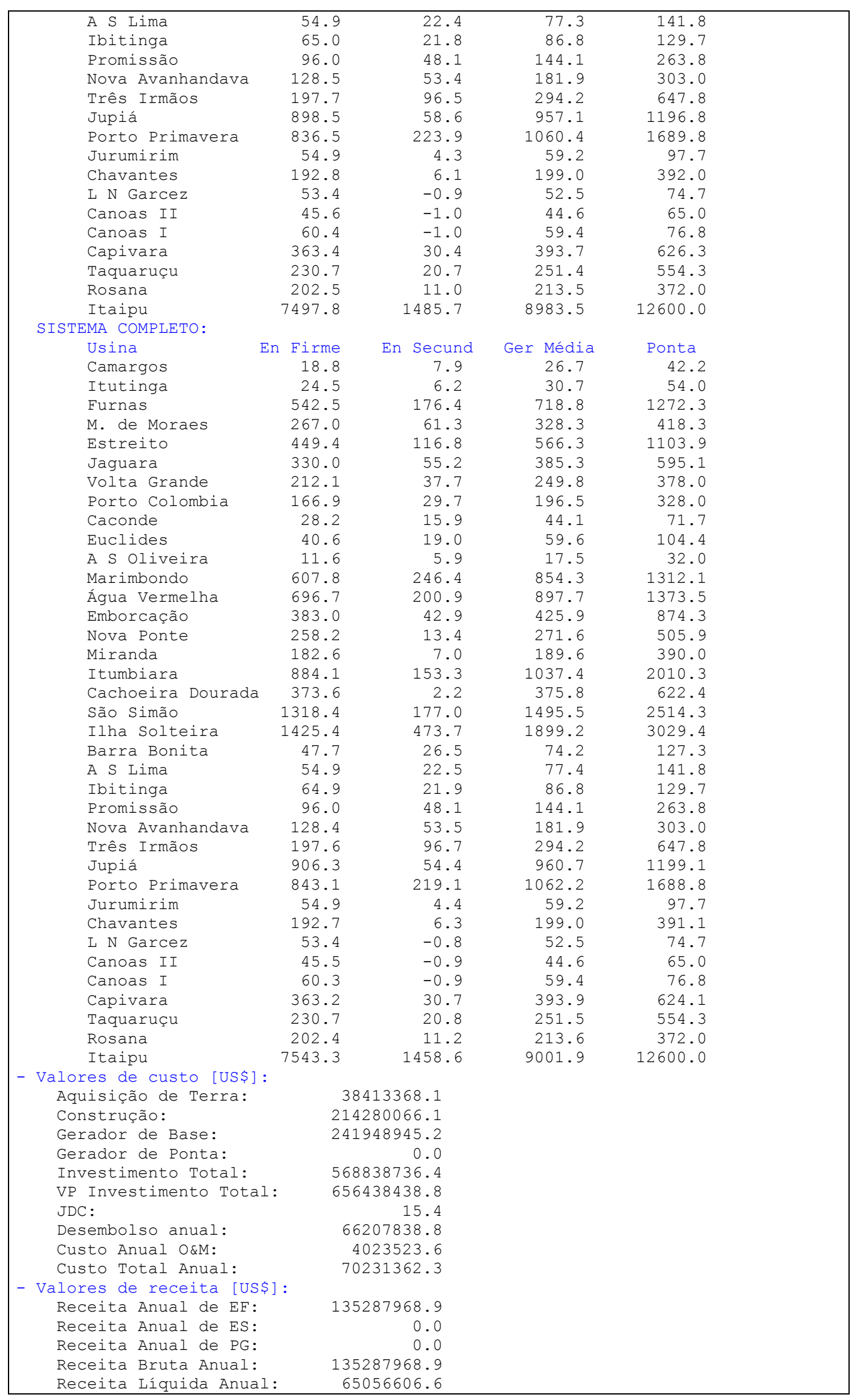





\section{Capítulo V}

\section{Modelagem de Usinas Hidroelétricas}

A modelagem de usinas hidroelétricas é o processo pelo qual as usinas são representadas através de conjuntos de equações matemáticas. Trata-se de um processo necessário para que a energia gerada por estas usinas possa ser calculada com base em informações comumente associadas às suas operações. Assim, para desenvolver o modelo matemático para uma usina hidroelétrica, deve-se inicialmente definir o que se deseja deste modelo, quais serão suas entradas e quais serão suas saídas.

Pelo modelo matemático de uma usina entende-se, neste trabalho, focado em aspectos energéticos, a função de geração da usina, isto é, a função que relaciona variáveis mensuráveis do aproveitamento à energia gerada. Estas variáveis mensuráveis são o volume de água armazenado no reservatório e as vazões turbinada e vertida. A partir destas variáveis deve-se determinar a energia gerada pela usina, tal como ilustrado na Figura 5.1.

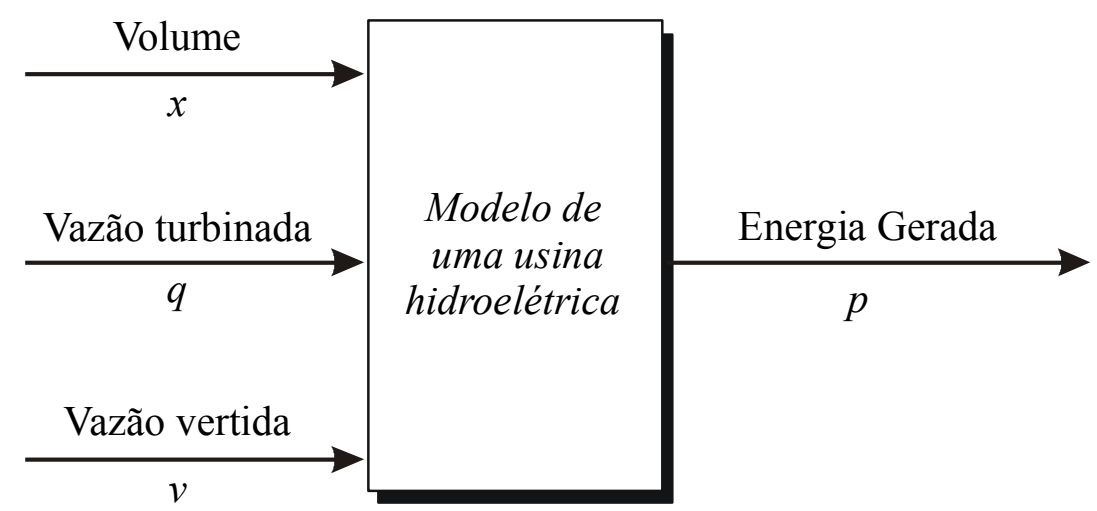

Figura 5.1 - Visão geral do modelo de uma usina hidroelétrica. 
Para explicar este modelo matemático, todos os componentes de uma usina hidroelétrica são descritos em detalhes na Seção 1, bem como todas as variáveis envolvidas na transformação de energia hidráulica em energia elétrica que ocorre dentro de uma usina hidroelétrica.

Na seqüência, na Seção 2, descreve-se a modelagem das perdas de energia por evaporação. Na Seção 3, apresenta-se a forma como as séries de vazões afluentes são calculadas. Finalmente, na Seção 4, apresentam-se os significados de cada variável utilizada nos estudos. 


\section{Função de Geração de Usinas Hidroelétricas}

O modelo matemático de uma usina hidroelétrica será explicado com o auxílio da Figura 5.2. De acordo com esta figura, alguns componentes de uma usina podem ser listados:

- Uma barragem que represa a água, com conseqüente formação do reservatório que exerce, para algumas usinas, um importante papel na regulação das vazões afluentes naturais. Os reservatórios que possuem esta capacidade de regularização são chamados de reservatórios de acumulação e, dependendo dos volumes disponíveis para realizar a regularização, esta pode ser diária, semanal, mensal, anual ou mesmo plurianual.

- Um conduto forçado que conduz a água armazenada no reservatório para as turbinas. Normalmente, entrada do canal de adução existe a estrutura de tomada d'água, composta por grades para evitar que objetos entrem no conduto e atinjam as turbinas, danificando-as. Logo após a tomada d'água também existem comportas que são fechadas para que as turbinas possam sofrer manutenção.

- Um vertedouro por onde a água em excesso, aquela que não será utilizada na geração de energia e que não pode ser armazenada no reservatório, retorna ao rio. Em alguns casos, o vertedouro é utilizado para manter vazões mínimas a jusante do reservatório quando o nível de carga é baixo e as vazões turbinadas não são suficientes para satisfazer tais restrições.

- Uma casa de máquinas, onde estão localizadas as turbinas, os geradores e todos os equipamentos responsáveis pela transformação de energia potencial hidráulica em energia elétrica.

- Um canal de fuga que conduz a água de volta ao rio. 


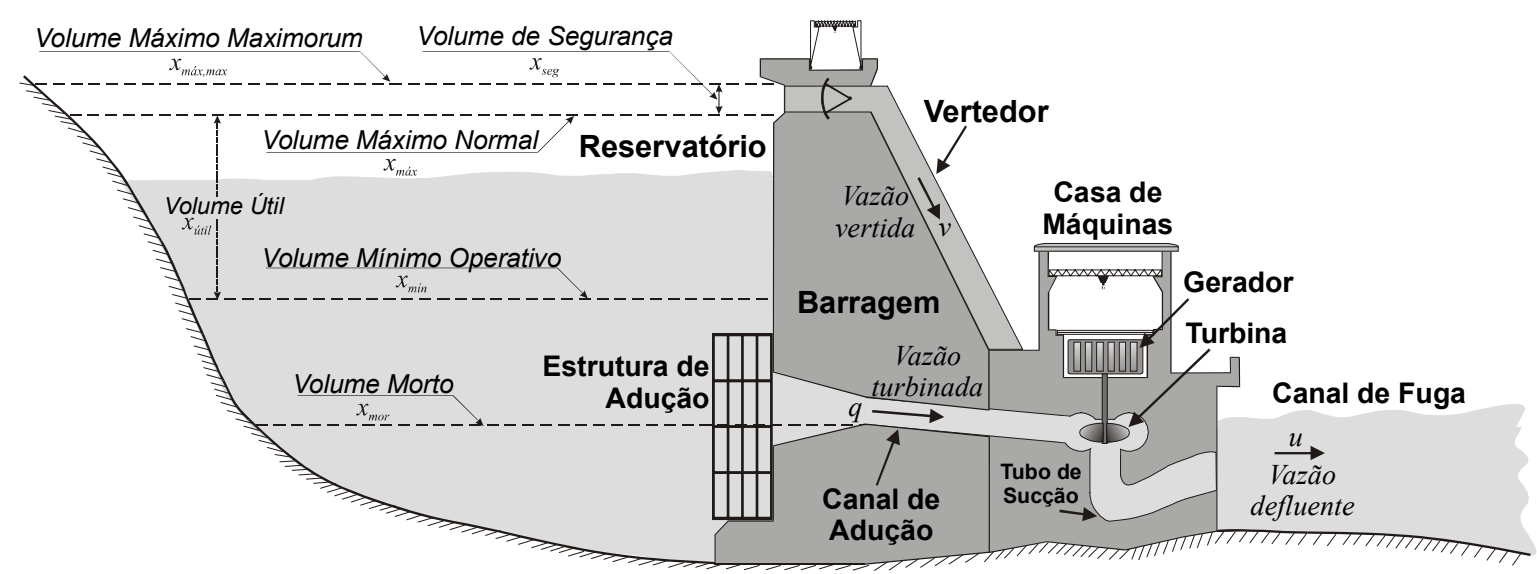

Figura 5.2 - Esquema de uma usina hidroelétrica.

Para representar algumas limitações físicas do reservatório e os fluxos de água que passam pelas diferentes partes da usina, algumas variáveis são definidas:

- $x_{m o r}$ : é o volume morto do reservatório, em $\mathrm{hm}^{3}$. É o volume de água armazenado abaixo do nível mínimo do canal de adução e que não pode ser retirado do reservatório.

- $x_{\text {min }}$ : é o volume mínimo operativo, em $\mathrm{hm}^{3}$. É o mínimo volume de água necessário para que a usina possa gerar energia. Normalmente está associado à altura mínima na qual a turbina pode operar ou ao nível necessário do reservatório para manter as estruturas de adução submersas.

- $x_{\text {máx }}$ : é o volume máximo operativo, em $h m^{3}$. É o máximo volume de água que o reservatório armazena em condições normais de operação. A diferença entre os volumes máximo e mínimo é chamada de volume útil, $x_{u}$ útl.

- $x_{\text {máx,max }}$ : é o volume máximo maximorum, em $h^{3}$. É o volume máximo extremo que o reservatório pode armazenar sem que haja comprometimento da estrutura da barragem. Este volume é atingido apenas em condições anormais de operação, tais como grandes cheias.

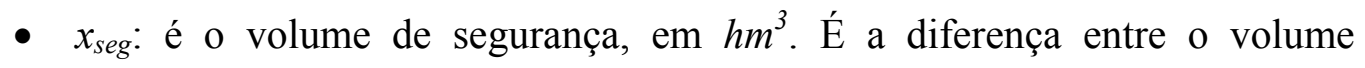
máximo maximorum e o volume máximo operativo. É como se fosse um “espaço vazio" que pode ser preenchido em condições anormais, quando há excesso de água.

- $q$ : é a vazão turbinada, em $\mathrm{m}^{3} / \mathrm{s}$. É a vazão que efetivamente gera energia, fluindo do reservatório à casa de máquinas através do canal de adução, e fazendo com que as turbinas girem e acionem os geradores. 
- $\quad v$ : é a vazão vertida, em $\mathrm{m}^{3} / \mathrm{s}$. É a vazão que flui diretamente do reservatório ao rio, através do vertedouro, sem passar pela casa de máquinas e sem gerar energia. É vista como desperdício, mas às vezes é um mal necessário para que sejam satisfeitas restrições de vazão defluente mínima da usina ou critérios de segurança da barragem.

- $u$ : é a vazão defluente, em $\mathrm{m}^{3} / \mathrm{s}$. É a soma das vazões turbinada e vertida.

A quantidade de energia elétrica produzida por um certo volume de água $x$ é o resultado da transformação da energia potencial desta massa de água em energia elétrica. Logo, se $e_{e}$ e $e_{p}$ são respectivamente as energias elétrica e potencial, pode-se escrever $^{26}$ :

$$
e_{e} \propto e_{p}
$$

A energia potencial $e_{p}$ é expressa em Joules, $J$, e é calculada como:

$$
e_{p}=m \cdot g \cdot h
$$

sendo $m$ a massa do volume de água $x$, em $\mathrm{kg}, \mathrm{g}$ a aceleração da gravidade, igual a $9,81 \mathrm{~m} / \mathrm{s}^{2}$, e $h$ a altura da qual o volume de água cairá para produzir energia, em metros. A massa de água $m$ pode ser substituída pelo volume $x$ :

$$
\rho=\frac{m}{x} \rightarrow m=\rho \cdot x
$$

na qual $\rho$ é a massa específica da água, igual a $10^{3} \mathrm{~kg} / \mathrm{m}^{3}$. Assim, (5.2) pode ser reescrita utilizando (5.3):

$$
e_{p}=\rho \cdot g \cdot h \cdot x
$$

Se um coeficiente de rendimento $\eta$, associado aos rendimentos da turbina e do gerador, é suposto estar envolvido no processo de transformação de energia potencial hidráulica em energia elétrica, pode-se escrever:

$$
e_{e}=\eta \cdot \rho \cdot g \cdot h \cdot x
$$

A Equação 5.5 especifica a energia elétrica que o volume $x$ de água gera ao passar pelas turbinas. No entanto, normalmente tem-se disponível a vazão que passa pelas turbinas, $q$, e deseja-se determinar a potência gerada pelos geradores. Se o volume $x$ gasta um intervalo de tempo $\Delta t$ para produzir a quantidade de energia elétrica $e_{e}$, pode-se determinar a potência média dividindo-se a Equação 5.5 por $\Delta t$ :

$$
\frac{e_{e}}{\Delta t}=\eta \cdot \rho \cdot g \cdot h \cdot \frac{x}{\Delta t}
$$

\footnotetext{
${ }^{26} \mathrm{O}$ símbolo $\propto$ significa proporcional.
} 
A energia dividida pelo intervalo de tempo $\Delta t$ especifica a taxa média de transformação de energia, ou seja, a potência média. De forma similar, volume dividido por tempo especifica o fluxo médio de água através das turbinas, denominado vazão turbinada. Fazendo o intervalo de tempo tender a zero e definindo a potência instantânea $p$, em Watts, e a vazão turbinada instantânea $q$, em $\mathrm{m}^{3} / \mathrm{s}$, tem-se:

$$
\begin{aligned}
& \lim _{\Delta t \rightarrow 0} \frac{e_{e}}{\Delta t}=\eta \cdot \rho \cdot g \cdot h \cdot \lim _{\Delta t \rightarrow 0} \frac{x}{\Delta t} \\
& p=\eta \cdot \rho \cdot g \cdot h \cdot q
\end{aligned}
$$

Deve-se observar que todas as grandezas de (5.8) são expressas utilizando-se o Sistema Internacional. Logo, a potência instantânea $p$ é expressa em Watts, a altura $h$ em metros e a vazão turbinada $q \mathrm{em} \mathrm{m}^{3} / \mathrm{s}$; o rendimento $\eta$ é adimensional, a densidade da água $\rho$ é igual a $10^{3} \mathrm{~kg} / \mathrm{m}^{3}$ e a aceleração da gravidade $g$ é $9,81 \mathrm{~m} / \mathrm{s}^{2}$.

Analisando-se a Equação 5.8, observa-se que $\rho$ e $g$ são constantes. Para conseguir definir a função de geração hidráulica de uma usina hidroelétrica tal como ilustrado na Figura 5.1, os valores de $\eta$ e $h$ devem ser determinados a partir das variáveis de entrada do modelo. Além disso, a vazão turbinada $q$ deve possuir um limitante superior, $q_{\text {máx }}$, que reflita a máxima potência que pode ser gerada pela usina com base nas entradas do modelo e nas características das turbinas e dos geradores. Os desenvolvimentos das expressões de $\eta, h$ e $q_{\text {máx }}$ são realizados nas próximas seções.

\subsection{Altura h}

A altura $h$ da Equação 5.8 equivale à altura em $m$ da qual a água efetivamente "cai" ao gerar energia. Esta é conhecida como altura de queda líquida e será denotada por $h_{l}$. O valor de $h_{l}$ será determinado pela diferença entre a altura de queda bruta $h_{b}$ e a altura de perdas hidráulicas $h_{p}$. As próximas duas subseções prestam-se ao cálculo de $h_{b}$ e $h_{p}$; na seqüência calcula-se $h_{l}$.

\subsubsection{Altura de Queda Bruta}

A altura de queda bruta de uma usina hidroelétrica, tal como ilustrado na Figura 5.3, é uma função dos níveis d'água de montante e de jusante. Para estabelecer uma referência comum a todas as usinas hidroelétricas, estes níveis d'água são usualmente expressos em relação à referência de nível do Instituto Brasileiro de Geografia e Estatística (IBGE), conhecido como "Zero do IBGE".

O nível de montante é uma função não-linear do volume total de água 
armazenado no reservatório, $x$, em $h m^{3}$. Esta função, denotada por $h_{m o n}(x)$, é normalmente côncava e sua forma depende basicamente do relevo da região na qual o reservatório foi construído.

Similarmente ao nível de montante, o nível de jusante também é uma função não-linear côncava, mas que depende da vazão defluente total da usina, $u$, em $\mathrm{m}^{3} / \mathrm{s}$. A forma desta função, chamada de $h_{j u s}(u)$, depende do canal de fuga da usina e das características do rio a jusante do reservatório. O nível médio a jusante do reservatório é chamado de cota média do canal de fuga, $c f_{m e d}$, e é usualmente fornecido como um dado da usina hidroelétrica (o Anexo A contém uma lista com dados de usinas hidroelétricas obtidos do Sistema de Informações da Eletrobrás).

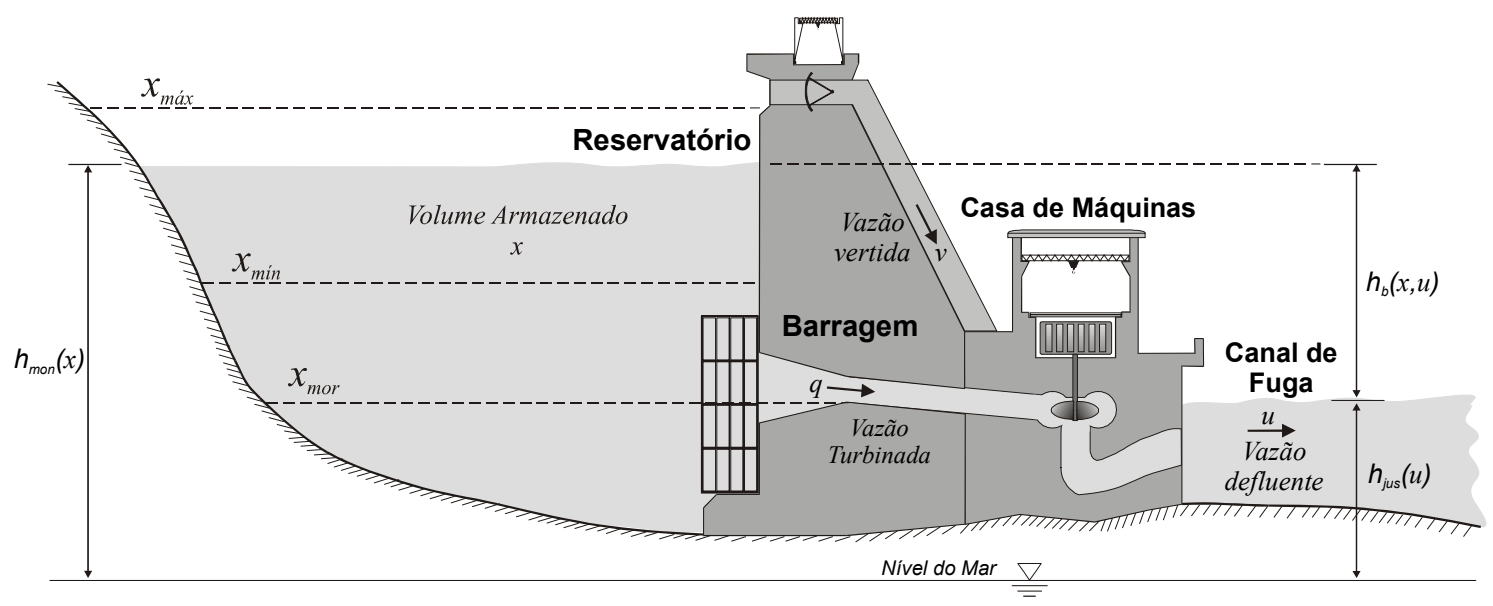

Figura 5.3 - Queda bruta de uma usina hidroelétrica.

Ambas as funções $h_{m o n}(x)$ e $h_{j u s}(u)$ podem ser determinadas por medições realizadas no próprio local da barragem ou por modelos computacionais capazes de descrever as características da região e processar modelos de hidrodinâmica. No Brasil, adotam-se polinômios de até quarto grau para representar os níveis de montante e jusante das usinas.

Assim, a altura de queda bruta passa a depender tanto do volume armazenado $x$ quanto da vazão defluente $u$ :

$$
h_{b}(x, u)=h_{\text {mon }}(x)-h_{j u s}(u)
$$

Por exemplo, para a usina de Emborcação, localizada no rio Paranaíba, têm-se os polinômios mostrados abaixo, cujos gráficos são plotados nas Figuras 5.4 e 5.5. Os limites mínimo e máximo para o volume armazenado equivalem respectivamente aos limites mínimo e máximo operativos. Quanto às vazões defluentes, seus limites são os valores mínimo e máximo encontrados no histórico de vazões afluentes médias mensais. 


$$
\begin{gathered}
h_{\text {mon }}(x)=5,68089 \cdot 10^{2}+1,45059 \cdot 10^{-2} \cdot x-1,20279 \cdot 10^{-6} \cdot x^{2}+ \\
5,83029 \cdot 10^{-11} \cdot x^{3}-1,12449 \cdot 10^{-15} \cdot x^{4} \\
h_{\text {jus }}(u)=5,19774 \cdot 10^{2}+3,99663 \cdot 10^{-3} \cdot u-1,09869 \cdot 10^{-6} \cdot u^{2}+ \\
2,34375 \cdot 10^{-10} \cdot u^{3}-1,76460 \cdot 10^{-14} \cdot u^{4}
\end{gathered}
$$

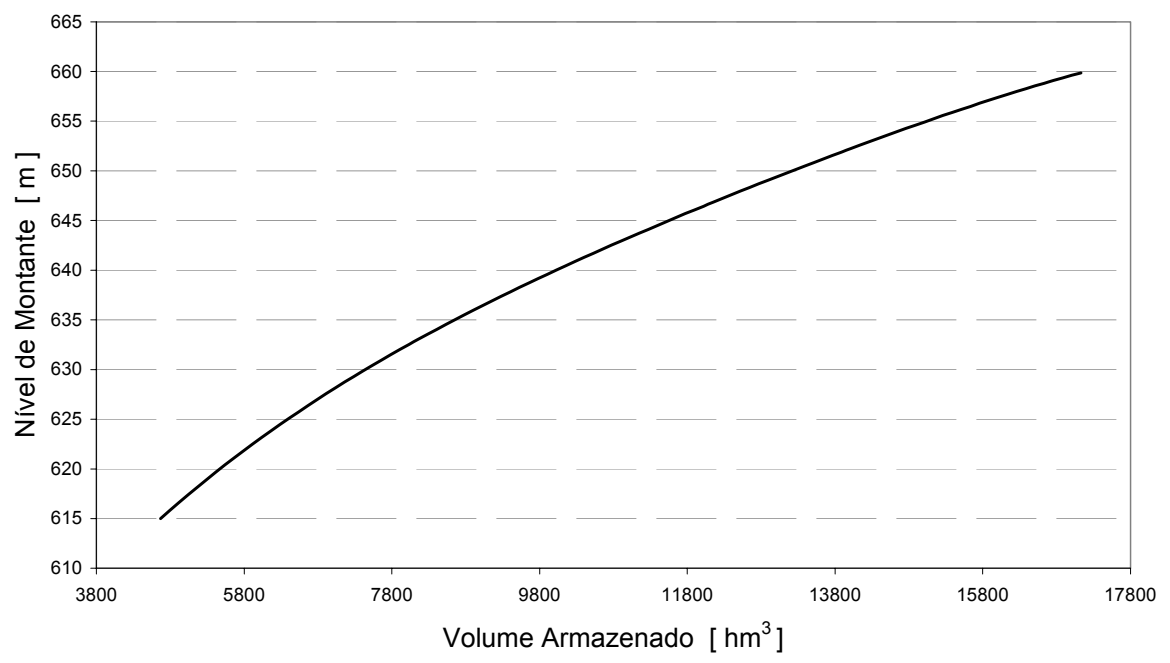

Figura 5.4 - Nivel de montante para a usina de Emborcação.

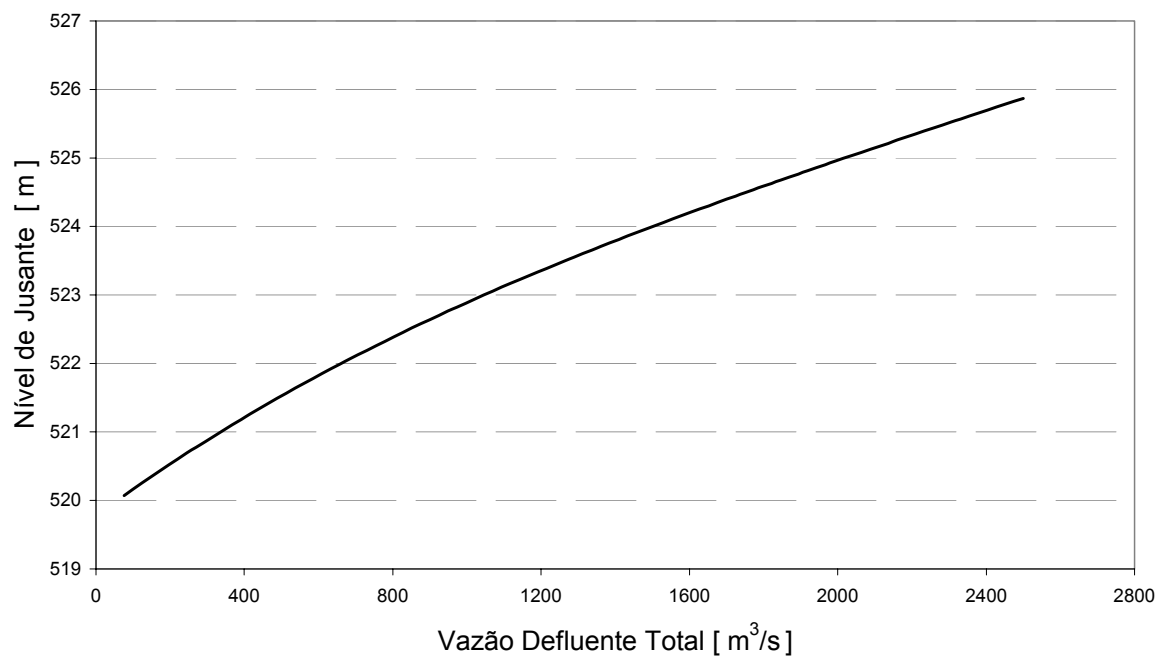

Figura 5.5 - Nivel de jusante para a usina de Emborcação.

Analisando o gráfico do polinômio $h_{m o n}(x)$, observa-se que a altura de montante da usina é altamente dependente do volume de água armazenado no reservatório. Quando o reservatório varia de vazio, $x=x_{\min }$, a cheio, $x=x_{\text {máx }}$, o nível de montante varia cerca de 45 metros. Esta influência do volume d'água armazenado na queda 
disponível para geração é chamada de Efeito Cota, EC, e pode ser medida pela seguinte relação:

$$
E C=\frac{h_{\text {mon }}\left(x_{\text {max }}\right)-h_{\text {mon }}\left(x_{\text {min }}\right)}{h_{\text {mon }}\left(x_{\text {máx }}\right)-c f_{\text {med }}} \cdot 100
$$

Para a usina de Emborcação, tem-se:

$$
\begin{aligned}
& E C=\frac{h_{\text {mon }}(17190)-h_{\text {mon }}(4669)}{h_{\text {mon }}(17190)-522} \cdot 100=\frac{660-615}{660-522} \cdot 100 \\
& E C=32,6 \%
\end{aligned}
$$

Para as usinas de Jurumirim e Chavantes, ambas localizadas no rio Paranapanema, os efeitos cotas são $23 \%$ e $12 \%$, respectivamente. Estes valores indicam que a altura de queda de Chavantes depende pouco do volume de água armazenado em seu reservatório, ou seja, o efeito cota de Chavantes é baixo. Para Jurumirim este efeito pode ser classificado como médio e para Emborcação como alto.

A forma do polinômio $h_{j u s}(u)$ retrata como a vazão defluente da usina pode influenciar de modo adverso sua operação. Quando a vazão defluente eleva-se, o nível de jusante também se eleva, reduzindo a queda d'água. Este efeito é conhecido como efeito de afogamento do canal de fuga, EA, e pode ser medido pela seguinte expressão:

$$
E A=\frac{h_{\text {jus }}\left(u_{\text {máx }}\right)-h_{\text {jus }}\left(u_{\text {min }}\right)}{h_{\text {mon }}\left(x_{\text {máx }}\right)-c f_{\text {med }}} \cdot 100
$$

Para a usina de Emborcação, obtém-se o seguinte valor para $E A$ :

$$
\begin{aligned}
& E A=\frac{h_{\text {jus }}(2500)-h_{\text {jus }}(76)}{h_{\text {mon }}(17190)-522} \cdot 100=\frac{526-520}{660-522} \cdot 100 \\
& E A=4,3 \%
\end{aligned}
$$

O efeito do canal de fuga para Emborcação é bastante baixo, o que significa que o nível a jusante do reservatório não varia de forma significativa com a vazão defluente.

Fato completamente oposto ocorre na usina de Itaipu, cujo polinômio $h_{j u s}(u)$ é mostrado abaixo e plotado na Figura 5.6 [22]. As vazões defluentes mínima e máxima utilizadas nos gráficos também equivalem aos valores mínimo e máximo encontrados no histórico de vazões afluentes médias mensais.

$$
h_{j u s}(u)=8,24420 \cdot 10^{1}+2,16260 \cdot 10^{-3} \cdot u-5,36280 \cdot 10^{-8} \cdot u^{2}+
$$


Calculando o valor de $E A$ para Itaipu, tem-se:

$$
\begin{aligned}
& E A=\frac{h_{j u s}(30000)-h_{j u s}(2000)}{h_{\text {mon }}(29000)-100} \cdot 100=\frac{116-87}{220-100} \cdot 100 \\
& E A=24,2 \%
\end{aligned}
$$

Este alto valor de $E A$ indica que, ao contrário do que ocorre com Emborcação, a vazão defluente de Itaipu eleva de forma sensível seu nível d'água de jusante. Para explicar a razão de comportamentos tão diversos em Emborcação e Itaipu, recorre-se à Figura 5.7, onde são apresentadas fotos destas usinas. Analisando as fotos observa-se que o vertedouro de Itaipu localiza-se bem à frente da usina, fazendo com que vazões vertidas elevem o nível a jusante de forma significativa. Além disso, também se observa que a declividade do rio a jusante da usina é bastante baixa, o que reduz a velocidade da água, contribuindo também para a elevação do nível d'água a jusante. Já para a usina de Emborcação, a vazão vertida retorna ao rio bem distante da casa de máquinas e a declividade do rio a jusante da usina é relativamente elevada, explicando seu baixo $E A$.

Em alguns casos o nível de jusante não depende somente da vazão defluente da usina, mas também da condição de reservatórios ou rios de jusante. São os chamados efeitos de remanso.

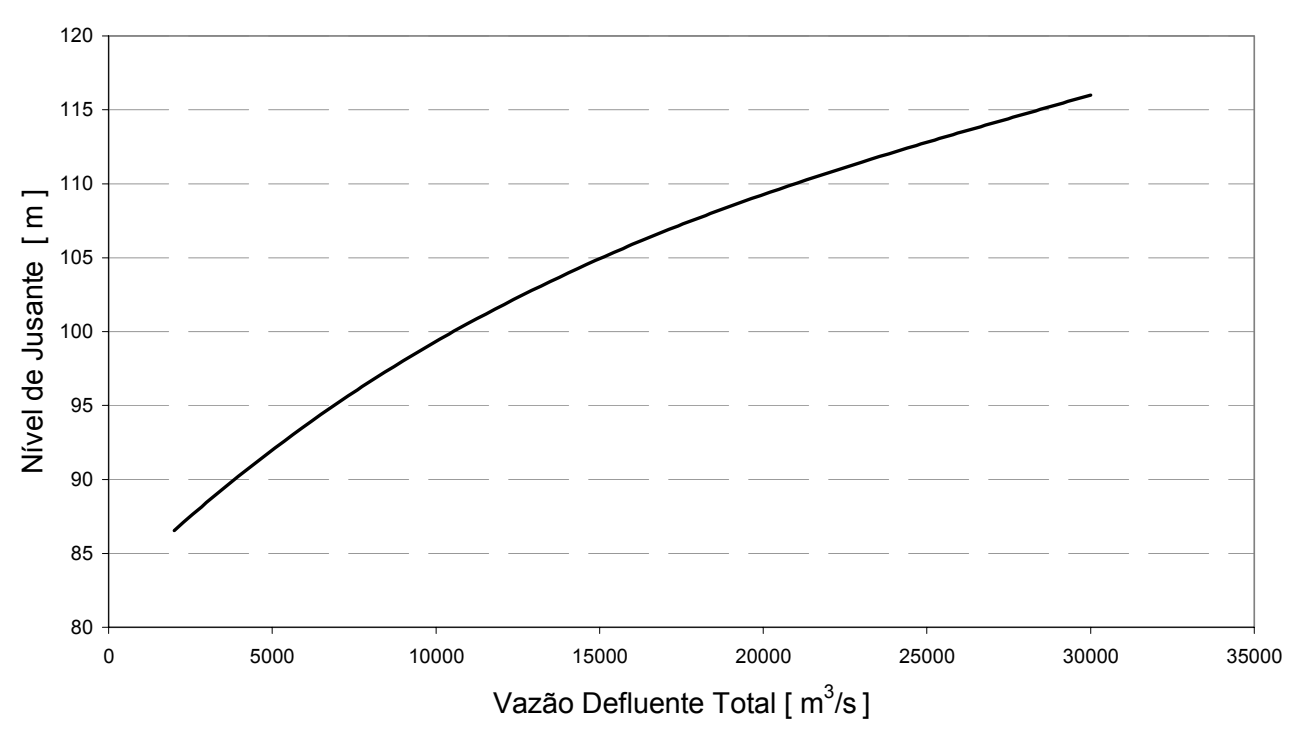

Figura 5.6 - Nivel de jusante para a usina de Itaipu. 


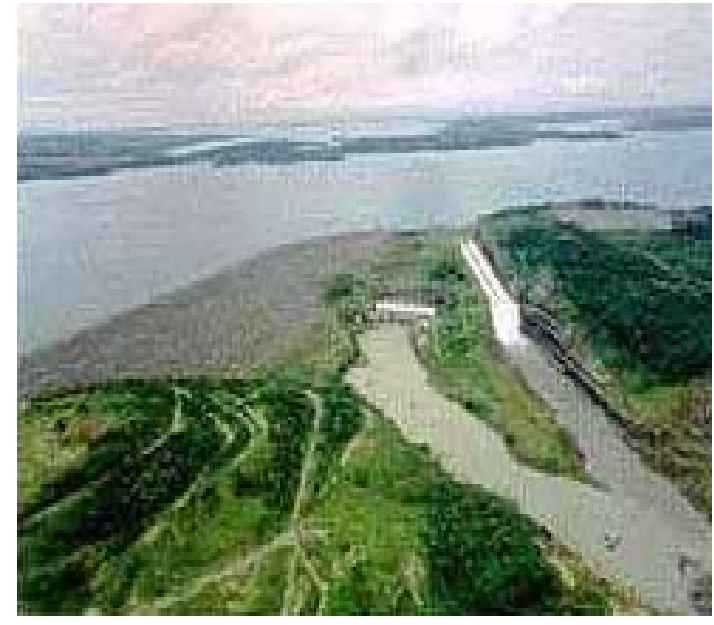

(a) Emborcação

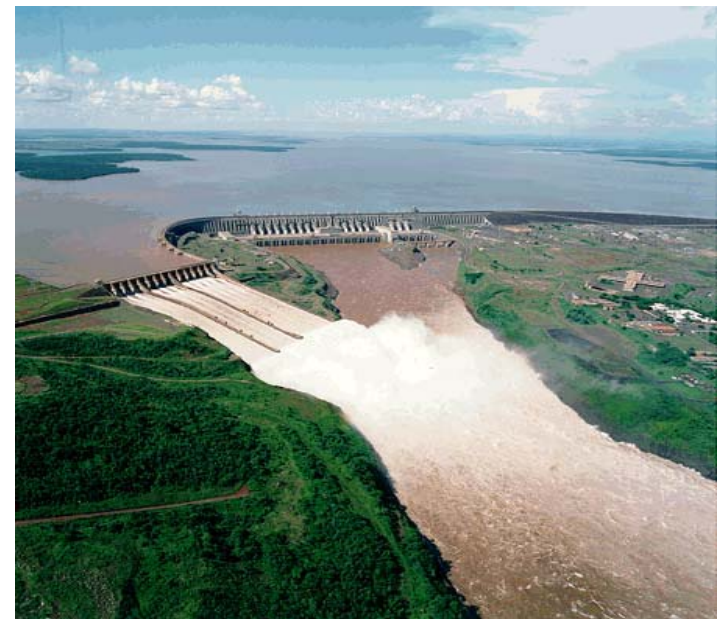

(b) Itaipu

Figura 5.7 - Usinas de Emborcação e Itaipu.

\section{- Efeitos de remanso}

O efeito de remanso caracteriza-se pela influência que o volume armazenado em uma usina hidroelétrica de jusante ou as águas de um rio de jusante podem ter sobre o nível do canal de fuga de uma usina hidroelétrica. A explicação do efeito de remanso torna-se mais fácil através de exemplos.

O primeiro exemplo é a usina de São Simão, última usina localizada no rio Paranaíba. O nível de jusante desta usina depende não somente de sua vazão defluente, mas também do nível d'água de montante da usina localizada a jusante, Ilha Solteira. Ao analisar o posicionamento relativo destas usinas na Figura 5.8, nota-se que conforme Ilha Solteira enche seu reservatório, o volume acumulado eleva a cota a jusante de São Simão, dificultando o escoamento de sua vazão defluente. Quanto mais cheia estiver Ilha Solteira, mais sensível é o efeito de remanso em São Simão.

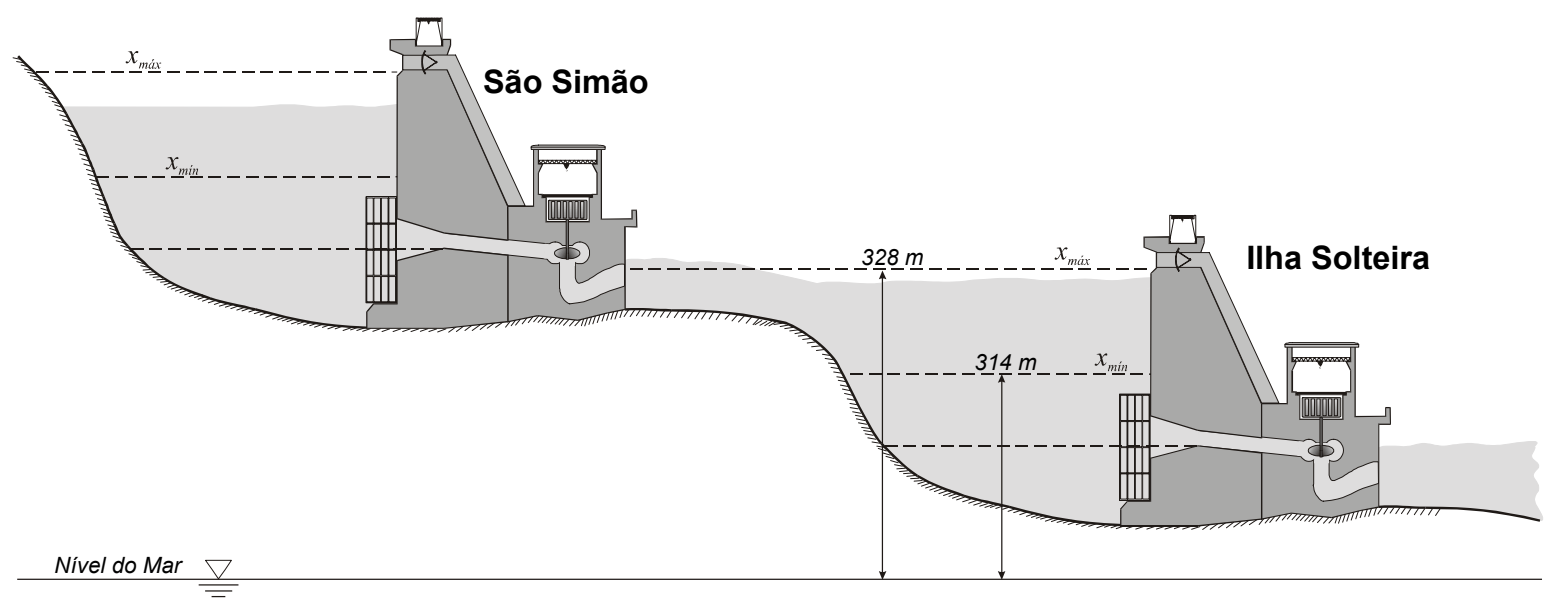

Figura 5.8 - Efeito de remanso em São Simão. 
Ao localizar o polinômio $h_{j u s}(u)$ da usina de São Simão na base de dados da Eletrobrás, nota-se que há quatro polinômios, cada um relacionado a um nível d'água a montante da usina de Ilha Solteira, chamados de níveis de referência, $n r$. Estes polinômios são mostrados na Tabela 5.1 e plotados na Figura 5.9. Os gráficos mostram que para um mesmo de valor de vazão defluente, o nível de jusante de São Simão elevase à medida que o nível de montante de Ilha Solteira eleva-se.

Além disso, analisando as inclinações das curvas, verifica-se que o nível de jusante de São Simão passa a ser menos sensível à sua vazão defluente conforme o reservatório de Ilha Solteira enche-se. Isso ocorre porque à medida que Ilha Solteira enche-se, a água de seu reservatório passa a dificultar mais intensamente o escoamento da vazão defluente de São Simão devido à elevação do nível de jusante desta usina.

Para determinar a cota a jusante de São Simão devido à vazão defluente $u$, primeiro deve-se identificar o nível a montante de Ilha Solteira; o valor deste nível é utilizado na escolha do polinômio $h_{j u s}(u)$ de São Simão e então realiza-se o cálculo.

Tabela 5.1 - Polinômios $h_{\text {jus }}(u)$ para São Simão.

\begin{tabular}{|c|c|c|c|c|c|}
\hline \multirow{2}{*}{$\begin{array}{c}h_{\text {mon }} \text { de Ilha } \\
\text { Solteira em } m\end{array}$} & \multicolumn{5}{|c|}{ Coeficientes do polinômio $h_{j u s}(u)=a_{0}+a_{1} \cdot u+a_{2} \cdot u^{2}+a_{3} \cdot u^{3}+a_{4} \cdot u^{4}$} \\
\hline & $a_{0}$ & $a_{1}$ & $a_{2}$ & $a_{3}$ & $a_{4}$ \\
\hline & $3,15584.10^{2}$ & $2,35031.10^{-3}$ & $-1,38024 \cdot 10^{-7}$ & $5,23395.10^{-12}$ & $-7,85937.10^{-17}$ \\
\hline$n r_{2}=322$ & $3,21730.10^{2}$ & $1,93288.10^{-4}$ & $1,13388.10^{-7}$ & $-6,63000 \cdot 10^{-12}$ & $1,16693.10^{-16}$ \\
\hline$n r_{3}=325$ & $3,25156.10^{2}$ & $-2,02317.10^{-4}$ & $1,10615.10^{-7}$ & $-5,16993.10^{-12}$ & $7,89793.10^{-17}$ \\
\hline$n r_{4}=328$ & $3,27963.10^{2}$ & $-3,79015.10^{-5}$ & $4,89739.10^{-8}$ & $-1,68298.10^{-12}$ & $2,04098.10^{-17}$ \\
\hline
\end{tabular}

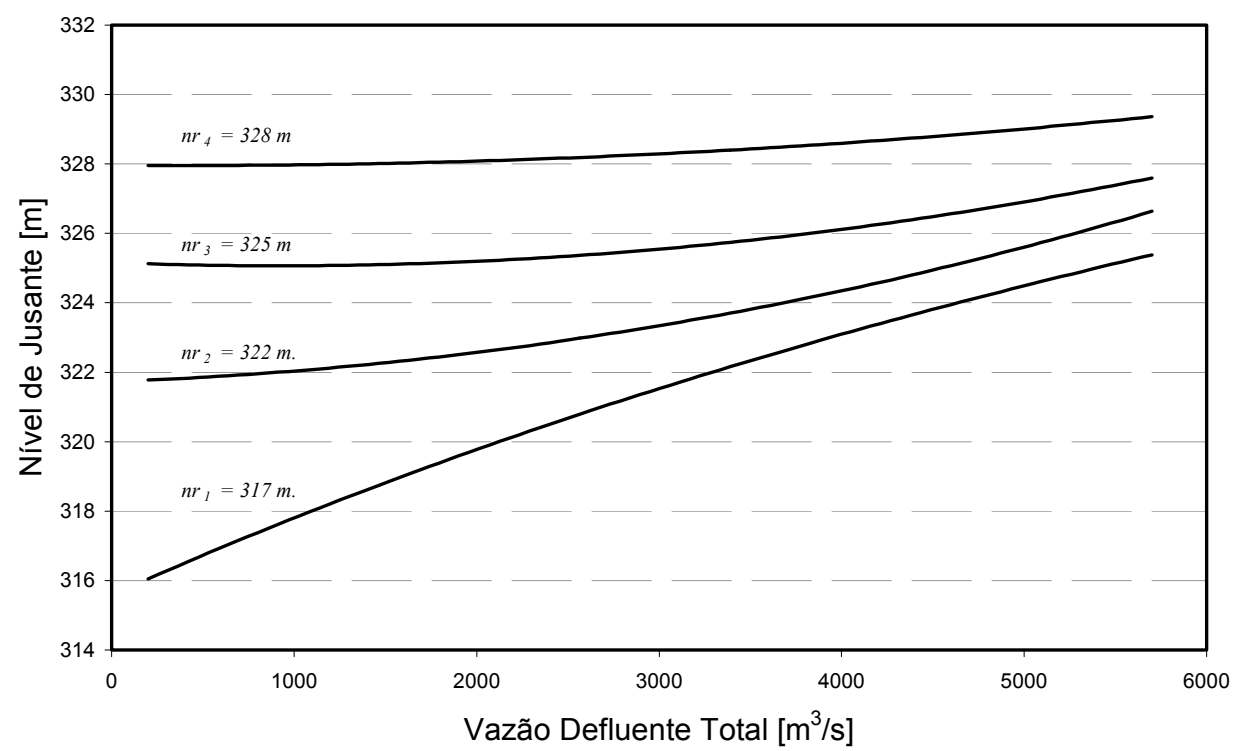

Figura 5.9 - Polinômios $h_{\text {jus }}(u)$ para São Simão. 
Se o nível de montante de Ilha Solteira é menor que $317 \mathrm{~m}$, utiliza-se apenas o polinômio especificado para $n r_{1}$; de forma semelhante, se o nível de montante de Ilha Solteira é maior que $328 \mathrm{~m}$, situação que só ocorre quanto o volume de segurança é utilizado, utiliza-se apenas o polinômio especificado para $n r_{4}$. Na maioria das vezes o nível de montante de Ilha Solteira não é igual a um dos níveis utilizados como referência para os polinômios de São Simão; nestes casos realiza-se interpolação linear entre os polinômios correspondentes aos níveis de referência que compreendem o valor do nível de montante de Ilha Solteira.

Os cálculos são feitos da seguinte forma:

1. Calcula-se o nível de montante de Ilha Solteira utilizando o volume armazenado neste reservatório, $x_{i s}$, e o polinômio $h_{m o n}(x)$ desta usina. Se o valor deste nível é denotado por $n r$ (nível de referência), tem-se:

$$
n r=h_{\text {mon }}\left(x_{i s}\right)
$$

2. Faz-se uma busca entre os níveis de referência dos polinômios de São Simão, $n r_{i}$ para $i=1, \ldots, 4$, e encontram-se os níveis tais que $n r_{\mathrm{i}} \leq n r<n r_{\mathrm{i}+1}$.

3. Calculam-se os níveis de jusante que ocorreriam para os polinômios de referência $i$ e $i+1$ para a vazão defluente $u$ da usina de São Simão e realizase a interpolação linear utilizando-se a seguinte equação:

$$
h_{j u s}(u)=h_{j u s}^{n r_{i}}(u)+\frac{n r-n r_{i}}{n r_{i+1}-n r_{i}} \cdot\left(h_{j u s}^{n n_{i+1}}(u)-h_{j u s}^{n r_{i}}(u)\right)
$$

Afogamento semelhante também ocorre entre as usinas de Porto Primavera e Jupiá. Neste caso, o efeito é tão significativo que operação de Porto Primavera, usina a jusante, a cotas reduzidas (produtividade menor) traz benefícios ao conjunto formado pelas duas usinas devido ao não-afogamento do canal de fuga de Jupiá.

Outro tipo de efeito de remanso ocorre quando uma usina está próxima à foz de seu rio ou à foz de um tributário do rio no qual ela se encontra. Por exemplo, o nível de jusante da usina de Rosana, Figura 5.10, última usina localizada no rio Paranapanema, sofre influência do rio Paraná. Quando a vazão do rio Paraná na foz do rio Paranapanema é elevada, o nível d'água a jusante de Rosana eleva-se, caracterizando o efeito de remanso.

Como grande parte das vazões do rio Paraná neste trecho é composta pela vazão defluente de Porto Primavera, pode-se estabelecer uma relação entre a vazão defluente de Porto Primavera e o nível d'água a jusante de Rosana. Neste caso, os níveis de referência $n r$ são determinados a partir do polinômio $h_{j u s}(u)$ de Porto Primavera. 


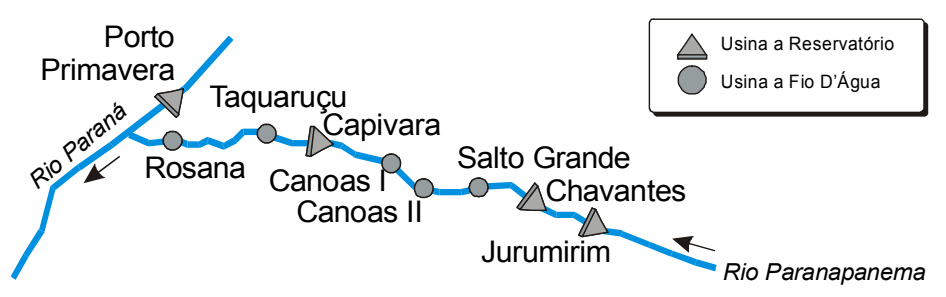

Figura 5.10 - Efeito de remanso na usina de Rosana.

Fato semelhante ocorre para a usina hidroelétrica de Itaipu, Figura 5.11. Neste caso, consideram-se os efeitos da confluência do rio Iguaçu com o rio Paraná na variação do nível do canal de fuga da usina. Os níveis de referência $n r$ são determinados a partir da vazão defluente do rio Iguaçu, considerada igual à vazão na estação hidrometeorológica de Capanema.

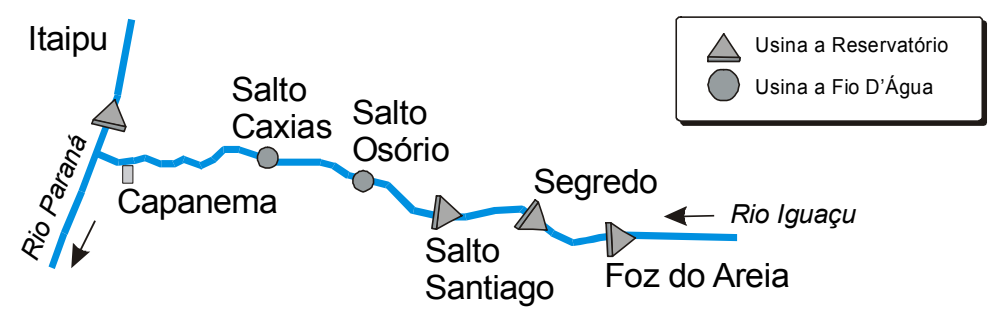

Figura 5.11 - Efeito de remanso na usina de Itaipu.

\subsubsection{Altura de Perdas Hidráulicas}

Quando a água flui dentro de uma usina hidroelétrica, ela perde energia por causa do atrito contra seis estruturas principais da usina: a estrutura de adução, a entrada do canal de adução, o canal de adução, o caracol da turbina, a turbina e o tubo de sucção. Estas perdas são ilustradas na Figura 5.12 [78].

Apesar de todas as seis perdas deverem ser consideradas em benefício da precisão do modelo, apenas as três primeiras são consideradas diretamente no cálculo das perdas hidráulicas. As outras são consideradas de forma indireta no cálculo da eficiência da turbina. A adoção desta metodologia simplifica a árdua tarefa de medir perdas em um ambiente turbulento, tal como o caracol da turbina ou o tubo de sucção. 


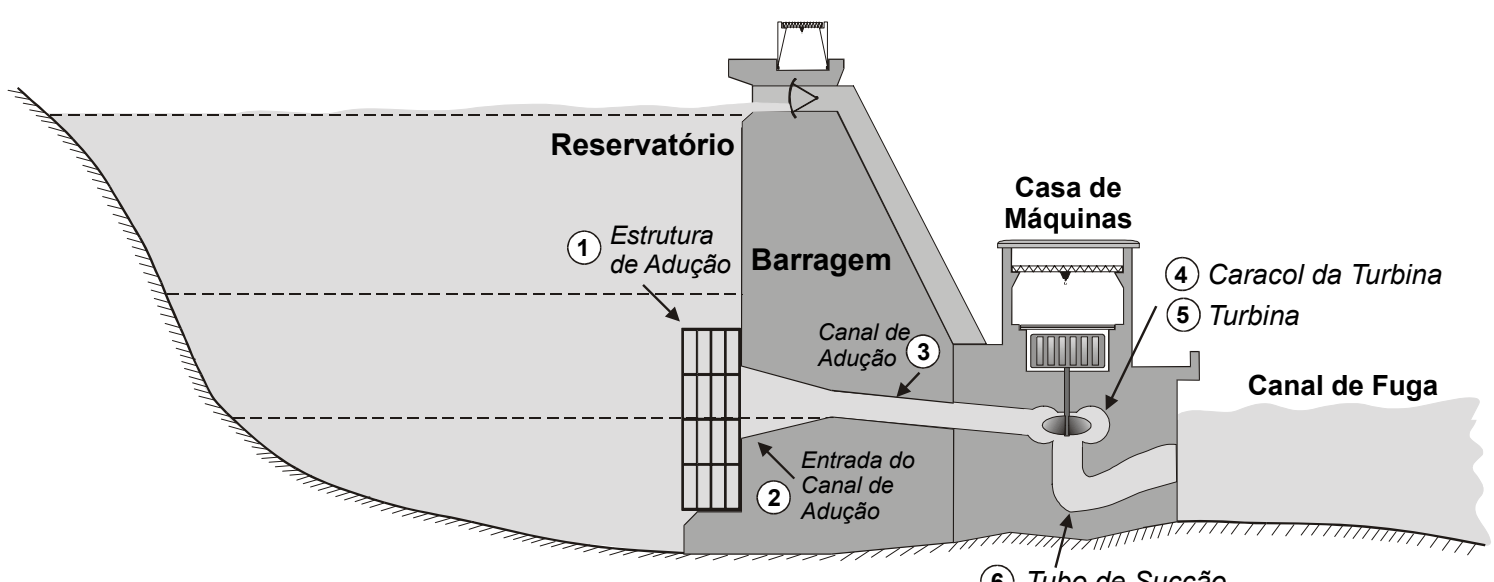

(6) Tubo de Sucção

Figura 5.12 - Perdas hidráulicas em uma usina hidroelétrica.

As perdas devido à estrutura de adução, à entrada do canal de adução e ao próprio canal de adução podem ser calculadas utilizando a Equação de Bernoulli [83]. A Equação de Bernoulli estabelece que a soma das alturas devido à elevação, à pressão e à velocidade deve permanecer constante para fluxos estacionários, não-viscosos e incompressíveis. Baseando-se na ilustração mostrada na Figura 5.13, a Equação de Bernoulli pode ser escrita como:

$$
z_{1}+h_{1}+\frac{V_{1}^{2}}{2 \cdot g}=z_{2}+h_{2}+\frac{V_{2}^{2}}{2 \cdot g}
$$

na qual $z_{l}$ é a elevação no ponto 1 , em $m ; h_{l}$ é a pressão estática no ponto 1 , em $m ; V_{l}$ é a velocidade da água no ponto 1 , em $\mathrm{m} / \mathrm{s} ; \mathrm{g}$ é a aceleração da gravidade, igual a 9,81 $m / s^{2} ; z_{2}$ é a elevação no ponto 2 , em $m ; h_{2}$ é a pressão estática no ponto 2 , em $m ; V_{2}$ é a velocidade da água no ponto 2 , em $\mathrm{m} / \mathrm{s}$. As elevações são calculadas com base em uma referência comum; os tubos $t_{a}$ e $t_{c}$ medem apenas a pressão estática, enquanto os tubos $t_{b}$ e $t_{d}$ medem as pressões estática e dinâmica.

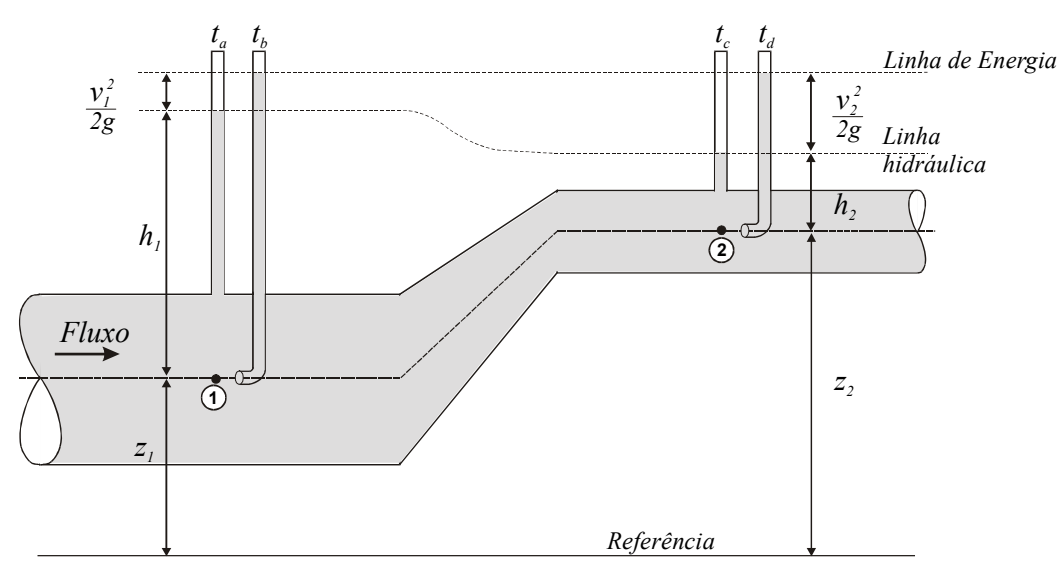

Fonte: [83].

Figura 5.13 - Fluxo através de uma tubulação. 
Se há perdas hidráulicas entre os pontos 1 e 2, a altura de perdas hidráulicas $h_{p}$, em $m$, pode ser introduzida na última equação da seguinte forma:

$$
z_{1}+h_{1}+\frac{V_{1}^{2}}{2 \cdot g}=z_{2}+h_{2}+\frac{V_{2}^{2}}{2 \cdot g}+h_{p}
$$

Retornando a uma usina hidroelétrica, Figura 5.14, a Equação de Bernoulli pode ser aplicada duas vezes: uma entre os pontos $a$ e $b$, e outra entre os pontos $b$ e $c$.

Aplicando a Equação de Bernoulli entre os pontos $a$ e $b$ tem-se:

$$
z_{a}+h_{a}+\frac{V_{a}^{2}}{2 \cdot g}=z_{b}+h_{b}+\frac{V_{b}^{2}}{2 \cdot g}+h_{p}
$$

Como a altura de perdas é o valor de interesse, esta equação pode ser reescrita:

$$
h_{p}=z_{a}+h_{a}+\frac{V_{a}^{2}}{2 \cdot g}-\left(z_{b}+h_{b}+\frac{V_{b}^{2}}{2 \cdot g}\right)
$$

Aplicando a Equação de Bernoulli entre os pontos $b$ e $c$ e considerando as perdas hidráulicas desta parte nulas ${ }^{27}$, obtém-se:

$$
z_{b}+h_{b}+\frac{V_{b}^{2}}{2 \cdot g}=z_{c}+h_{c}+\frac{V_{c}^{2}}{2 \cdot g}
$$

Combinando as Equações 5.15 e 5.16:

$$
h_{p}=z_{a}+h_{a}+\frac{V_{a}^{2}}{2 \cdot g}-\left(z_{c}+h_{c}+\frac{V_{c}^{2}}{2 \cdot g}\right)
$$

Apesar das elevações $h_{a}$ e $h_{b}$ poderem ser medidas de forma direta, a expressão destes valores através de variáveis do modelo parece ser mais adequada. Assim, pode-se escrever:

$$
\begin{aligned}
& h_{a}=h_{\text {mon }}(x)-z_{a} \\
& h_{c}=h_{\text {jus }}(u)-z_{c}
\end{aligned}
$$

Após algumas manipulações algébricas promovidas pela inserção de (5.18) em (5.17), a altura de perdas hidráulicas pode ser escrita como:

$$
h_{p}=h_{m o n}(x)-h_{j u s}(u)+\frac{V_{a}^{2}-V_{c}^{2}}{2 \cdot g}
$$

Assim, quanto maior a queda bruta, diferença entre os níveis de montante e de jusante, maior a perda hidráulica. Além disso, quanto maior a diferença das velocidades dos fluxos da entrada do canal de adução e na saída do tubo de sucção, maior a perda hidráulica. Deve-se observar que $V_{c}>V_{a}$. 
A equação resultante não é de uso prático nos modelos, principalmente porque as velocidades $V_{a}$ e $V_{c}$ não são normalmente medidas. As variáveis que podem ser medidas são a altura de queda bruta e a vazão através das turbinas. Dependendo dos objetivos da operação e dos dados disponíveis, as perdas hidráulicas $h_{p}$, também conhecidas como perdas de carga, podem ser estimadas a partir dos seguintes modelos.

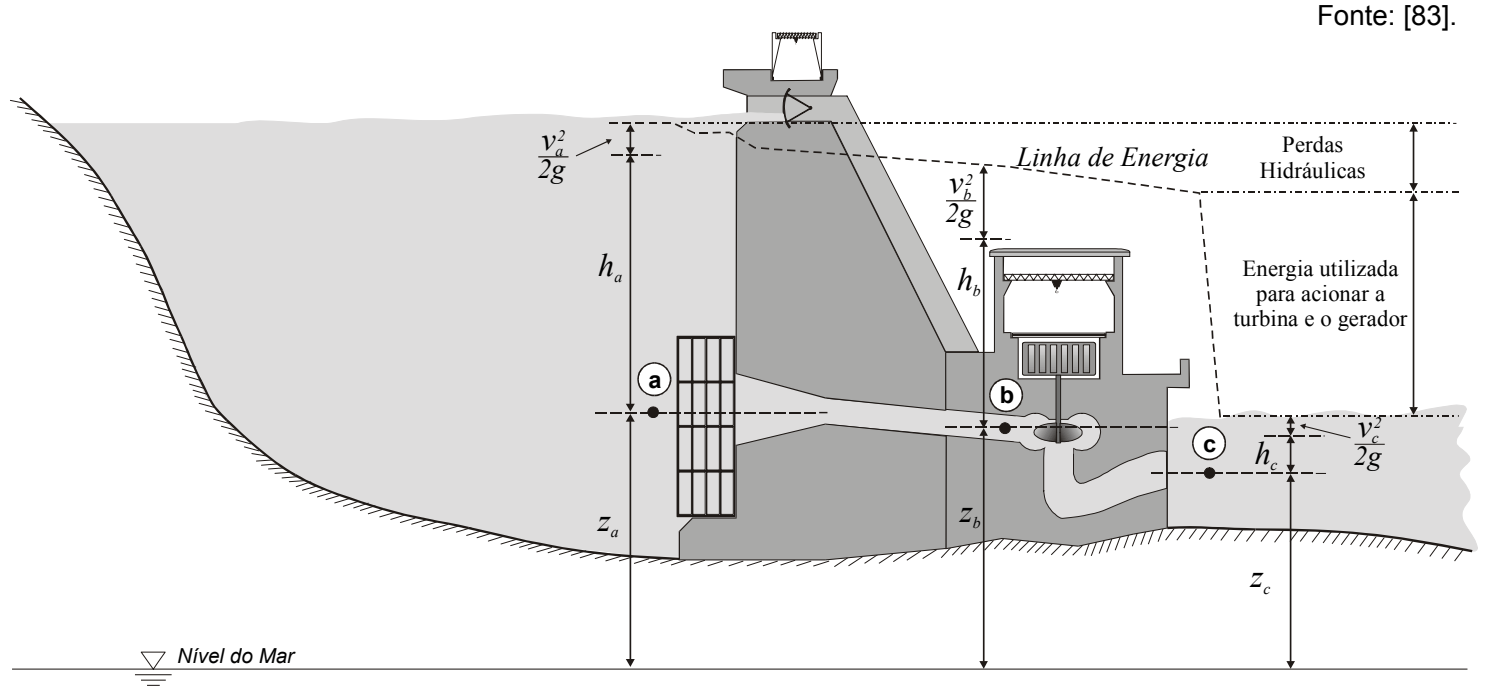

Figura 5.14 - Esquema de uma usina hidroelétrica para aplicação da Equação de Bernoulli.

\section{- Perda hidráulica constante:}

Este é o modelo mais simples que pode ser adotado e também o menos preciso. A perda de carga, ou perda hidráulica, é considerada constante e igual a algum valor médio. Este modelo é usado quando não há informação disponível para calcular as perdas hidráulicas de forma mais precisa, tais como estudos de expansão ou mesmo planejamento de longo prazo, onde outras fontes de incerteza são mais importantes para os estudos.

$$
h_{p}=\text { constante }
$$

\section{- Perda hidráulica proporcional à queda bruta:}

Este modelo é inspirado no resultado mostrado na Equação 5.19 e considera que a altura de perdas $h_{p}$ depende da queda bruta disponível. As variações da altura de perdas em relação às velocidades de escoamento não são consideradas. O parâmetro $k$ é um número positivo que depende da usina hidroelétrica em estudo.

$$
h_{p}(x, u)=k \cdot h_{b}(x, u)
$$

\footnotetext{
27 As perdas hidráulicas entre os pontos $b$ e $c$ não são nulas. No entanto, elas são consideradas indiretamente no cálcudo da eficiência da turbina e não no cálculo das perdas hidráulicas.
} 


\section{- Perda hidráulica proporcional ao quadrado da vazão turbinada:}

Este modelo também é baseado no resultado mostrado na Equação 5.19. Neste caso a altura de perdas $h_{p}$ depende do quadrado da vazão turbinada, mas não depende da queda bruta. $\mathrm{Na}$ realidade, a Equação 5.19 afirma que a altura de perdas depende da velocidade e não da vazão; entretanto, velocidade e vazão são diretamente relacionadas, de forma que $h_{p}$ possa ser calculada utilizando a equação abaixo. O parâmetro $k$ é um número positivo que depende da usina em estudo, e a vazão $q$ é a vazão turbinada.

$$
h_{p}(q)=k \cdot q^{2}
$$

Voltando às usinas hidroelétricas brasileiras, a usina de Emborcação, localizada no rio Paranaíba, possui sua queda líquida modelada como sendo proporcional à queda bruta. O coeficiente $k$ para Emborcação é 0,0194 (adimensional). A usina de Jurumirim, localizada no rio Paranapanema, possui queda líquida modelada como proporcional ao quadrado da vazão turbinada. O coeficiente $k$ para Jurumirim é $2,17.10^{-5} \mathrm{~m} /\left(\mathrm{m}^{6} / \mathrm{s}^{2}\right)$. Os gráficos de perda de carga para estas duas usinas são mostrados nas Figuras 5.15 e 5.16.

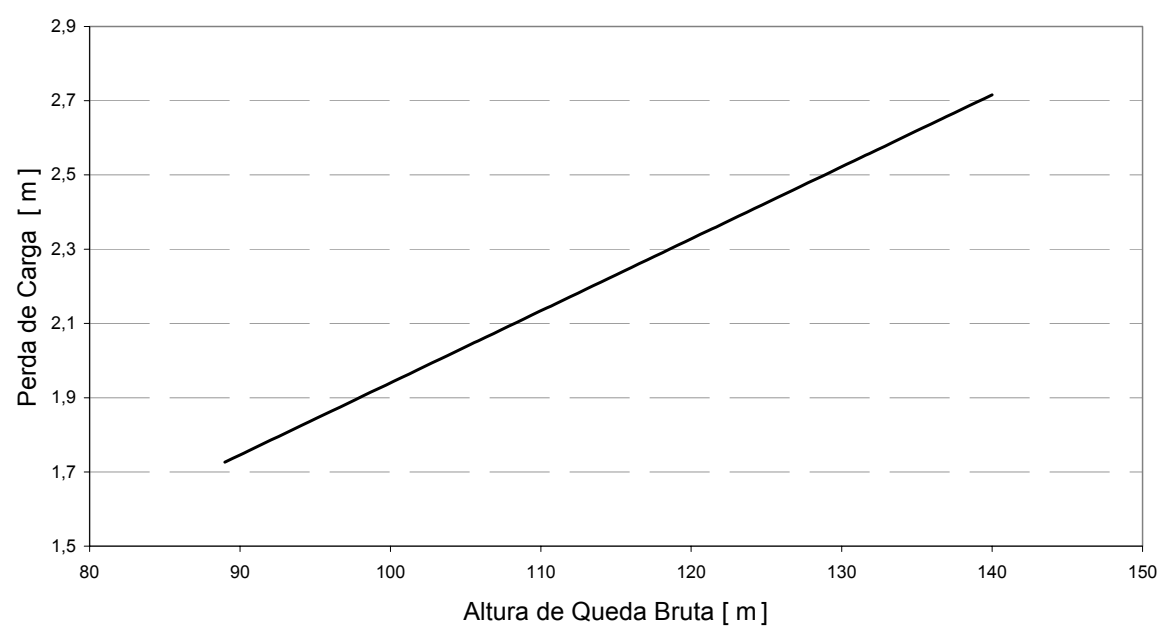

Figura 5.15 - Perda de carga para usina de Emborcação.

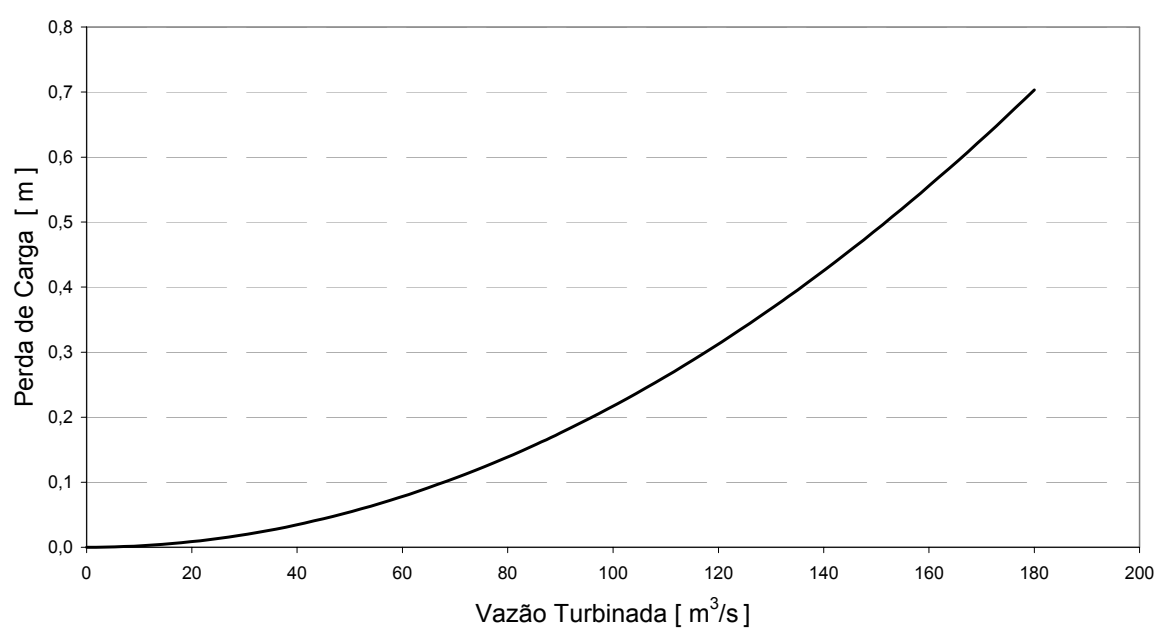

Figura 5.16 - Perda de carga para usina de Jurumirim. 


\subsubsection{Altura de queda líquida $h_{l}$}

A altura de queda líquida $h_{l}$, em $m$, é a altura $h$ procurada, integrante da Equação 5.8. Trata-se da altura da qual a água efetivamente "cai" ao gerar energia. A altura de queda líquida é calculada pela diferença entre a altura de queda bruta, $h_{b}$, e altura de perdas hidráulicas, $h_{p}$. A altura de queda bruta, $h_{b}$, conforme expresso na Equação 5.9, depende do volume armazenado no reservatório, $x$, e da vazão defluente total, $u$. A altura de perdas hidráulicas, dependendo do modelo adotado, pode ser constante, dependente da altura de queda bruta ou da vazão turbinada. Logo, altura de queda líquida $h_{l}$ passa a depender de todos estes parâmetros e pode ser genericamente escrita como:

$$
\begin{aligned}
& h_{l}(x, q, v)=h_{b}(x, u)-h_{p}(x, q, v) \\
& h_{l}(x, q, v)=h_{\text {mon }}(x)-h_{j u s}(u)-h_{p}(x, q, v)
\end{aligned}
$$

Na Figura 5.17 mostra-se a altura de queda líquida da usina de Emborcação em função do volume de água armazenado no reservatório. São mostradas três curvas, relacionadas a diferentes valores de vazão defluente. Pelo formato das curvas nota-se que quanto maior o volume armazenado, maior a queda líquida. Isto se deve à elevação de montante devido ao aumento do volume de água armazenado no reservatório (Emborcação tem efeito cota elevado). Comparando a posição relativa entre as três curvas, nota-se que para um mesmo valor de volume, a altura de queda líquida reduz-se conforme a vazão defluente eleva-se. Isto ocorre porque o nível d'água a jusante da usina eleva-se.

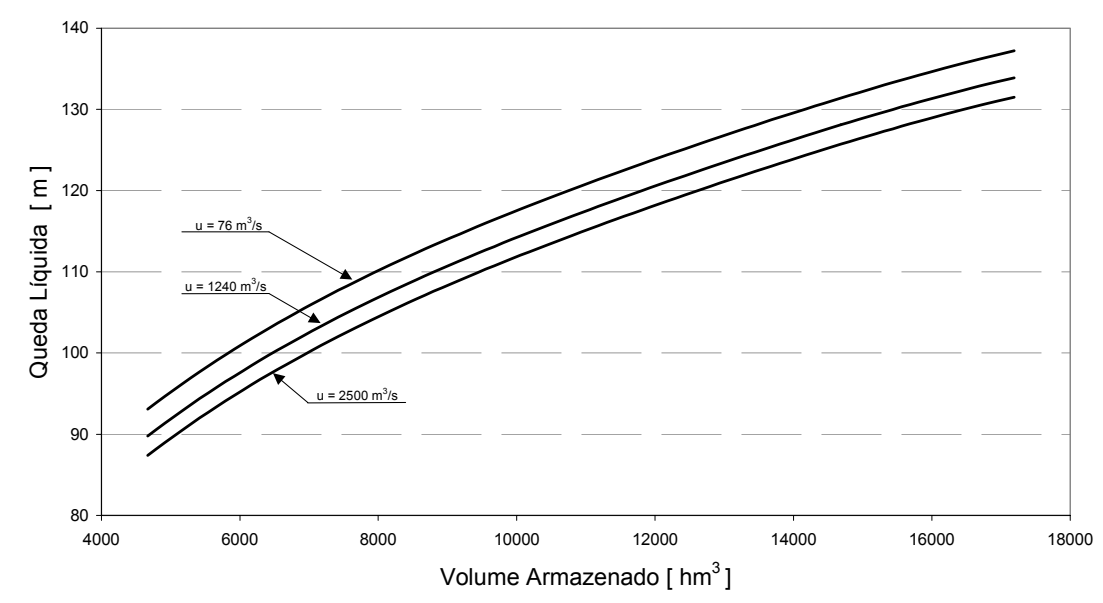

Figura 5.17 - Altura de queda líquida para a usina de Emborcação. 


\subsection{Rendimento $\eta$}

O rendimento $\eta$ refere-se ao rendimento combinado da turbina e do gerador, normalmente referido como rendimento do conjunto turbina/gerador. Dependendo dos dados disponíveis e da precisão desejada ou requerida pelo modelo da usina hidroelétrica, o rendimento pode ser modelado de diferentes modos.

Para estudos de longo prazo, com intervalos de discretização mensais, usualmente adota-se $\eta$ constante e igual a um rendimento médio. No entanto, o catálogo de dados da Eletrobrás não apresenta o rendimento médio das usinas, mas sim um parâmetro chamado de produtibilidade específica, pe. Para explicar este parâmetro, reescreve-se abaixo a Equação 5.8, a equação da potência gerada pela usina.

$$
p(t)=\eta \cdot \rho \cdot g \cdot h_{l} \cdot q(t)
$$

Se o rendimento $\eta$ é feito constante e igual a um valor médio $\eta_{\text {med }}$, a equação passa a ter três parâmetros constantes: $\rho, g$ e $\eta_{\text {med. }}$ O produto destes três parâmetros é que define a produtibilidade específica $p e$.

Resta fazer apenas uma ressalva. Na Equação 5.24, se todos os parâmetros fossem expressos em unidades do Sistema Internacional de medidas, a potência $p(t)$ seria expressa em Watts. Expressar a potência $p(t)$ em Watts não é usual para uma usina hidroelétrica; usualmente este valor é expresso em $10^{6} \mathrm{Watts,} \mathrm{ou} \mathrm{seja,} \mathrm{em} \mathrm{MW}$. Para manter a coerência entre as unidades, deve-se dividir a equação por $10^{6}$, o que é feito no próprio parâmetro pe. Escrevendo pe tem-se:

$$
p e=\frac{\rho \cdot g}{10^{6}} \cdot \eta_{\text {med }} \quad \frac{\mathrm{MW}}{\left(\mathrm{m}^{3} / \mathrm{s}\right) \cdot \mathrm{m}}
$$

ou ainda, substituindo-se os valores de $\rho$ e $g$ :

$$
p e=9,81 \cdot 10^{-3} \cdot \eta_{\text {med }} \quad \frac{M W}{\left(\mathrm{~m}^{3} / \mathrm{s}\right) \cdot \mathrm{m}}
$$

A potência gerada pela usina pode ser reescrita utilizando-se a produtibilidade específica. Neste caso a potência $p(t)$ passa a ser expressa em $M W, h_{l}$ continua sendo expresso em $m$ e $q(t)$ em $m^{3} / s$.

$$
p(t)=p e \cdot h_{l} \cdot q(t)
$$

Para a usina de Emborcação, tem-se $p e=0,0087309 \mathrm{MW} /\left(\left(\mathrm{m}^{3} / \mathrm{s}\right) \cdot \mathrm{m}\right)$, e para a usina de Jurumirim, tem-se $p e=0,0089088 \mathrm{MW} /\left(\left(\mathrm{m}^{3} / \mathrm{s}\right) . \mathrm{m}\right)$.

Modelos que trabalham com a operação de uma usina hidroelétrica em intervalos de discretização menores, tais como dias, horas ou tempo real, devem 
considerar as variações do rendimento $\eta$ em função das condições de operação da turbina. Por "condições de operação" entende-se a altura de queda líquida e a potência gerada; a relação entre estas variáveis é complexa e usualmente modelada através de curvas de desempenho das turbinas.

Na Figura 5.18, extraída de [59], apresenta-se a curva de desempenho de uma turbina do tipo Francis ${ }^{28}$. Nesta figura estão relacionadas quatro variáveis:

- Altura de queda líquida: esta variável foi especificada em termos porcentuais, onde para a queda de projeto $^{29}$ definiu-se a queda líquida como $100 \%$. A área sombreada da figura especifica a faixa de operação da turbina, delimitada pelas alturas de queda mínima e máxima.

- Potência da turbina: também especificada em termos porcentuais. Adotou-se a potência na qual a turbina apresenta rendimento máximo, chamada de potência de projeto, como $100 \%$. O ponto de intersecção entre a queda de projeto e a potência de projeto é chamado de Ponto de Projeto. Pela figura observa-se que a turbina pode até mesmo gerar potências mais elevadas que a de projeto, porém o rendimento associado é sempre menor que o rendimento do ponto de projeto.

- Rendimento da turbina: representado pelas curvas contínuas; a cada curva está associado um valor constante de rendimento, indicado na parte superior do gráfico.

- Abertura das palhetas da turbina: representada pelas curvas pontilhadas. $\mathrm{O}$ ângulo de abertura das palhetas indica a vazão a ser turbinada; quanto maior o ângulo, maior o fluxo de água pela turbina.

${ }^{28}$ Como o desempenho do gerador é considerado constante, a curva de desempenho do conjunto turbina/gerador será idêntica à da turbina, exceto por um fator de escala obtido ao multiplicar cada ponto da curva de desempenho da turbina pelo rendimento do gerador.

${ }^{29}$ A queda de projeto é a altura de queda líquida na qual a usina apresenta rendimento máximo. 


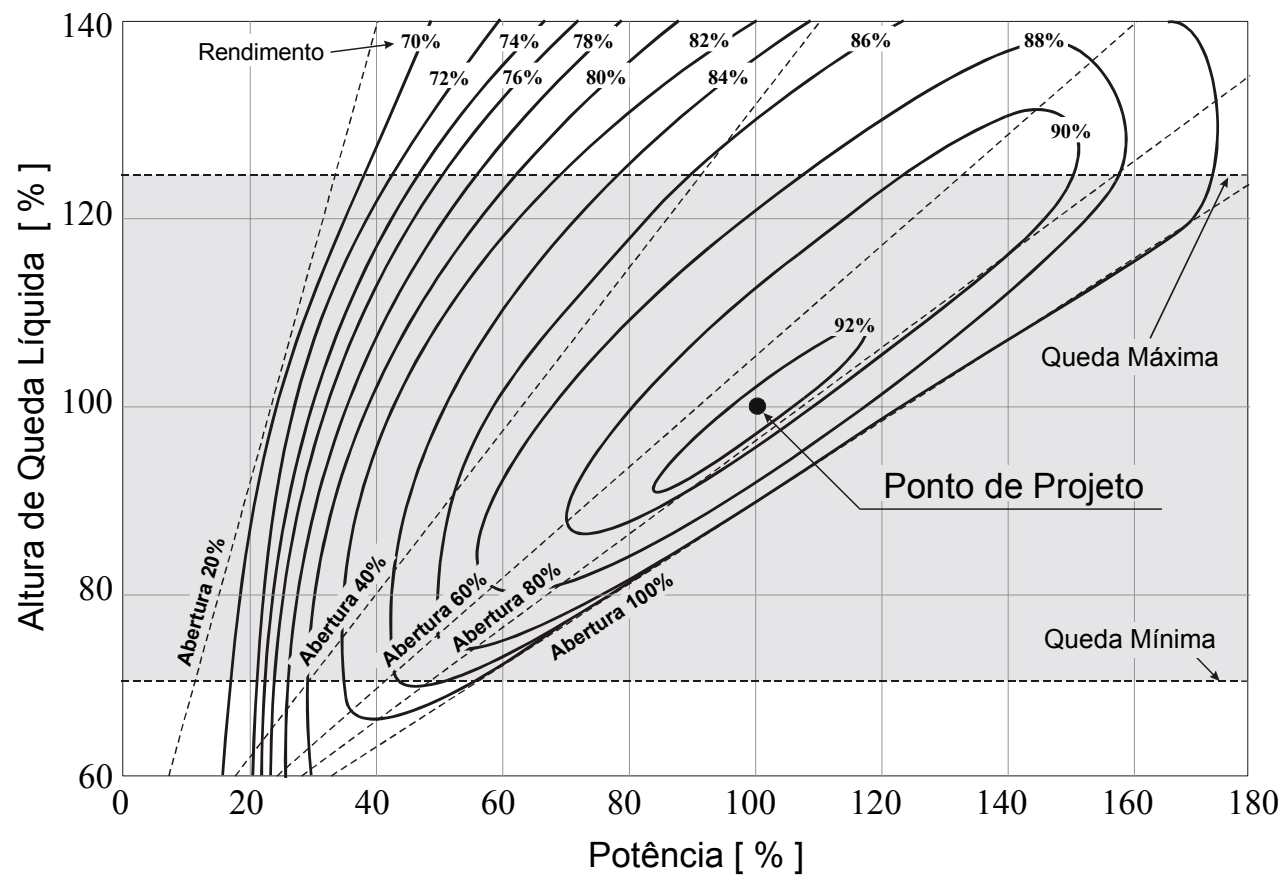

Figura 5.18-Curvas de desempenho de uma turbina tipo Francis.

Algumas características da turbina podem ser explicadas através da Figura 5.18. Observa-se que há um ponto em que o rendimento é máximo, chamado de Ponto de Projeto. Devido às definições dos valores de referência utilizados para expressão em porcentagem da potência e da altura de queda, o ponto de projeto é aquele no qual a potência e a altura de queda são ambas iguais a 100\%. Em todas as outras condições de operação da turbina, o rendimento será menor que aquele do Ponto de Projeto. Isto não significa que a potência gerada pela turbina no Ponto de Projeto seja máxima! Por exemplo, no Ponto de Projeto a abertura das palhetas é de $72 \%$; se a altura de queda for mantida constante e as palhetas continuarem a ser abertas até $100 \%$, a potência gerada pela turbina vai elevar-se e chegar a $123 \%$. Porém, o rendimento associado a este ponto será menor que o do Ponto de Projeto. Isto significa que a turbina gasta mais água por MW produzido quando ela gera $123 \%$ do que quando ela gera $100 \%$ de sua potência.

Pela Figura 5.18 também pode-se observar que para uma mesma abertura das palhetas da turbina, à medida que altura de queda eleva-se, a potência gerada aumenta. Isto ocorre por causa de dois fatores. Primeiro, a potência gerada é proporcional à altura; logo, se a altura eleva-se, a potência gerada também se eleva. Segundo, quando a altura eleva-se e as palhetas são mantidas com a mesma abertura, devido ao aumento de pressão, o fluxo de água através da turbina aumenta. Como a potência gerada também é proporcional à vazão turbinada, a potência gerada aumenta. 
O segundo efeito também explica porque as taxas de incremento da potência gerada devido ao aumento de altura são diferentes para diferentes aberturas. Por exemplo, para abertura de $20 \%$, a potência gerada varia de $14 \%$ para $23 \%$ quando a queda varia de $80 \%$ para $100 \%$. Já para abertura de $100 \%$, admitindo-se a mesma variação de queda, a potência gerada varia de $77 \%$ para $123 \%$. Como as variações de altura de queda são as mesmas, conclui-se que o aumento nas variações de potência é causado pelo aumento da vazão turbinada.

As Figuras 5.19 e 5.20 também podem ser utilizadas para explicar algumas características da turbina. Considerando uma altura de queda fixa, ao progressivamente variar a abertura das palhetas de $20 \%$ a $100 \%$, o fluxo de água pela turbina sempre aumenta, aumentando também a potência gerada. Isso ocorre porque a potência é determinada basicamente através do produto entre a altura de queda e a vazão turbinada; como a altura de queda é considerada constante, conforme as palhetas são abertas, a vazão turbinada aumenta e a potência gerada eleva-se.

$\mathrm{O}$ rendimento da turbina apresenta um comportamento diferente. No início, quando as palhetas começam a ser abertas, o rendimento vai progressivamente aumentando; atinge-se então o ponto com rendimento máximo para a altura de queda especificada e a partir daí o rendimento diminui com o aumento da abertura.

Fonte: [59].

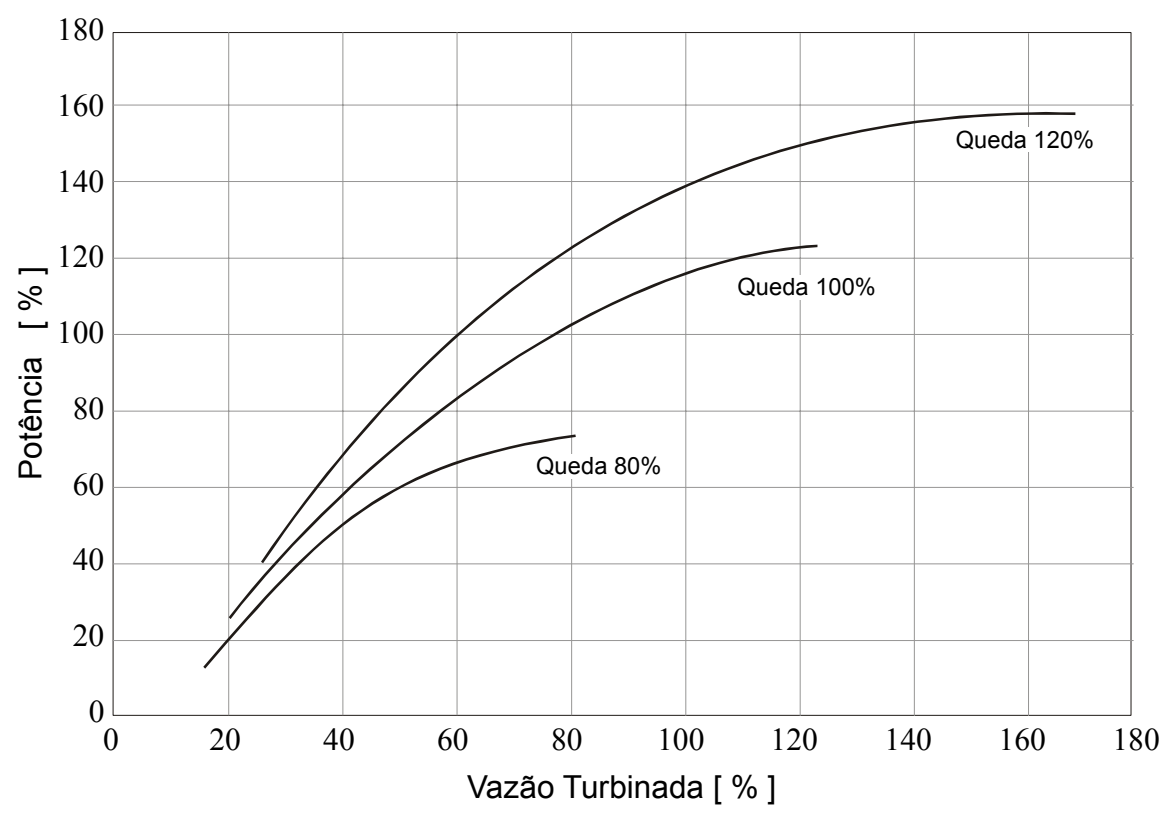

Figura 5.19- Potência gerada pela turbina para diferentes quedas líquidas. 
Fonte: [59].

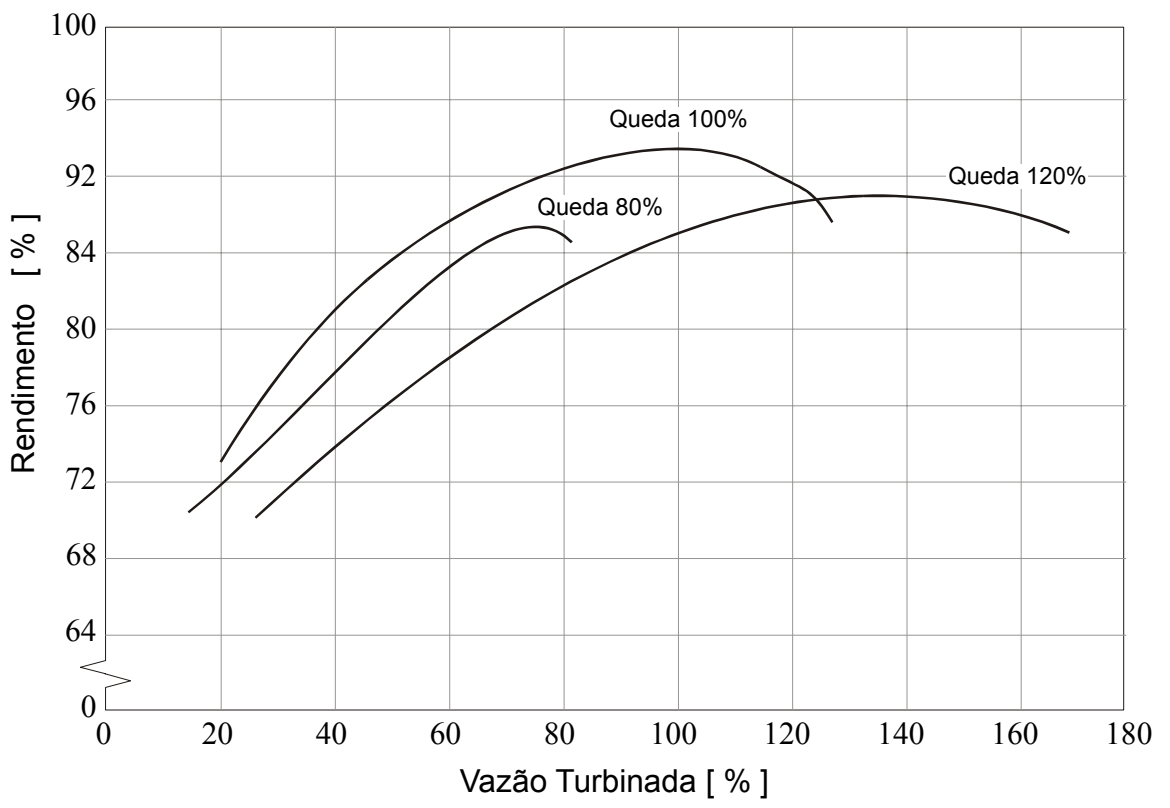

Figura 5.20 - Rendimento da turbina para diferentes quedas líquidas.

\subsection{Engolimento máximo $q_{\text {máx }}$}

O engolimento máximo $q_{\text {máx }}$ a ser determinado é o engolimento máximo total de uma usina hidroelétrica, ou seja, a maior vazão que pode ser turbinada por todas as turbinas da usina ao mesmo tempo. Juntamente com o cálculo de $q_{\text {máx }}$ também é realizado o cálculo de $p_{\text {máx }}$, a máxima potência que pode ser gerada pela usina.

Como numa mesma usina podem haver máquinas (turbinas e/ou geradores) diferentes, divide-se a usina em $n_{c o n j}$ conjuntos de máquinas, cada um composto por $n_{\text {máq }}$ máquinas idênticas. Para cada conjunto $j, j=1, \ldots, n_{\text {conj, }}$ primeiro calcula-se o engolimento máximo e a potência máxima de uma de suas máquinas, e depois multiplica-se o resultado pelo número de máquinas do conjunto. A soma do engolimento máximo de cada conjunto é o engolimento máximo total da usina.

Para evitar confusões na interpretação das variáveis, os valores de potência e engolimento de uma única máquina (turbina e/ou gerador) conterão o subscrito "máq", enquanto os valores totais de uma usina não conterão subscritos.

O engolimento máximo de uma turbina é definido pela vazão turbinada quando suas palhetas estão completamente abertas (abertura igual a 100\%). De acordo com o que foi visto na seção anterior, durante a interpretação da Figura 5.18, a vazão turbinada para uma determinada abertura das palhetas varia em função da altura de queda líquida: quanto maior a altura de queda, maior a vazão turbinada. Logo, o engolimento máximo 
de uma turbina é função da altura de queda líquida.

No entanto, o engolimento máximo de uma máquina, $q_{\text {máx,máq, deve representar }}$ as limitações não somente da turbina, mas também do gerador. O gerador possui uma potência máxima que pode ser gerada, denominada potência efetiva ou potência

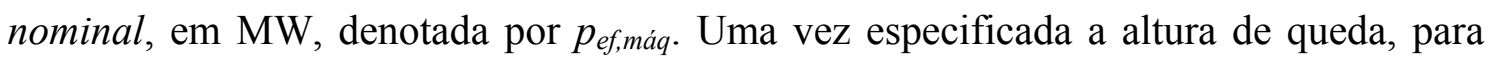
assegurar a integridade do gerador deve-se garantir que a potência gerada pela turbina seja menor que a potência efetiva do gerador. Dependendo da altura de queda líquida, diferentes situações podem ocorrer:

- Se a altura de queda líquida é muito baixa, mesmo com as palhetas completamente abertas, a potência gerada pela turbina pode ser menor que a potência efetiva do gerador. Neste caso, a máxima potência gerada pelo conjunto é a potência da turbina com abertura de 100\%; o gerador não pode gerar sua potência efetiva porque a turbina não é capaz de fornecê-la. Diz-se que nesta situação a turbina limita a operação do conjunto.

- Se a altura de queda líquida é alta, a potência gerada pela turbina com as palhetas completamente abertas pode ser maior que a potência efetiva do gerador. Neste caso, a máxima potência gerada pelo conjunto é a potência do gerador; as palhetas da turbina não podem ser abertas a 100\%. Diz-se que nesta situação o gerador limita a operação do conjunto.

- Há ainda um ponto de operação que separa as duas situações descritas acima. Para determinar este ponto, deve-se começar a operar a turbina com as palhetas completamente abertas a partir de sua queda mínima; nesta condição a turbina provavelmente será capaz de gerar uma potência menor que a potência efetiva do gerador. Mantendo-se as palhetas completamente abertas e progressivamente aumentando a queda líquida, a potência gerada pela turbina vai aumentar até sua potência gerada ser igual à potência efetiva do gerador. A altura de queda líquida referente a esta situação é chamada de altura de queda efetiva, em $m$, denotada por $h_{\text {ef,máq. }}$. Ao aumentar ainda mais a altura de queda líquida, será necessário fechar as palhetas da turbina, reduzindo seu engolimento máximo e fazendo sua potência gerada ser constante e igual à potência efetiva do gerador.

As situações descritas acima podem ser visualizadas na Figura 5.21. No gráfico de Engolimento Máximo são distinguidas as regiões onde a turbina e onde o gerador limitam a operação do conjunto. Na região onde a turbina limita a operação do conjunto, 
o engolimento máximo equivale à operação da turbina com as palhetas totalmente abertas. Como a altura de queda é relativamente baixa, a potência gerada pela turbina é menor que a potência efetiva do gerador. Logo, a máxima potência do conjunto é a máxima potência que a turbina pode gerar, tal como indicado no gráfico da potência máxima do conjunto. Na região onde o gerador limita a operação do conjunto, a turbina é obrigada a fechar as palhetas para que a potência fornecida não exceda a potência efetiva do gerador.

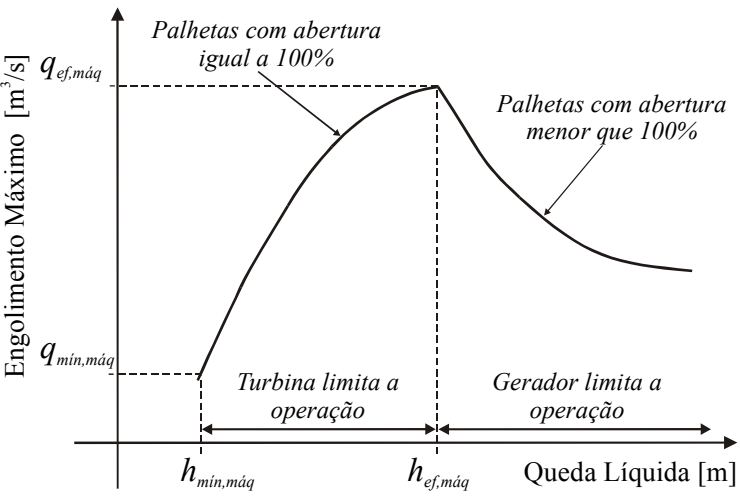

(a) Engolimento máximo.

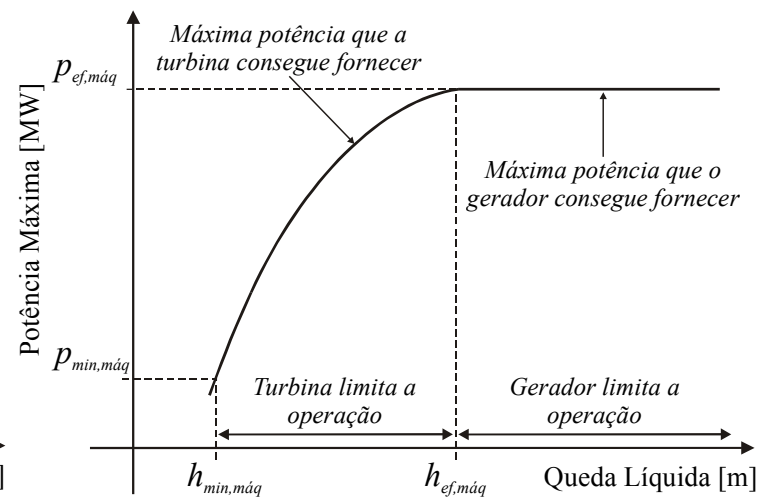

(b) Potência máxima.

Figura 5.21 - Engolimento máximo e potência máxima de um conjunto turbina/gerador em função da altura de queda líquida.

No caso das usinas brasileiras, são especificadas três funções para modelagem das curvas mostradas na Figura 5.21:

- $q_{\text {máx,tur: }}$ expressa o engolimento máximo da turbina para alturas de queda menores que a altura de queda efetiva, onde a turbina limita a operação do conjunto.

- $q_{m a ́ x, g e r}$ : expressa o engolimento máximo da turbina para alturas de queda maiores que a altura de queda efetiva, onde o gerador limita a operação do conjunto.

- $p_{\text {máx,tur: }}$ expressa a máxima potência do conjunto para alturas de queda menores que a altura de queda efetiva ${ }^{30}$.

O engolimento máximo e a máxima potência do conjunto turbina/gerador, já explicados graficamente, podem ser expressos através das seguintes equações:

$$
q_{\text {máx } x \text { máq }}=\left\{\begin{array}{lll}
q_{\text {máx }, \text { tur }}, & \text { se } & h_{l}<h_{\text {ef,máq }} \\
q_{\text {máx }, \text { ger }}, & \text { se } & h_{l} \geq h_{\text {ef,máq }}
\end{array}\right.
$$

\footnotetext{
${ }^{30}$ Para alturas de queda maiores que a altura de queda efetiva, a máxima potência do conjunto é simplesmente a potência efetiva do gerador.
} 


$$
p_{\text {máx,máq }}=\left\{\begin{array}{llll}
p_{\text {máx }, \text { tur }}, & \text { se } & h_{l}<h_{e f, \text { máq }} \\
p_{e f}, & \text { se } & h_{l} \geq h_{e f, \text { máq }}
\end{array}\right.
$$

sendo:

- $q_{\text {máx,máq }}$ : engolimento máximo do conjunto turbina/gerador, em $\mathrm{m}^{3} / s$.

- $p_{m a ́ x, m a ́ q}$ : potência máxima do conjunto turbina/gerador, em $M W$.

- $q_{e f, m a ́ q}$ : engolimento efetivo da turbina, em $\mathrm{m}^{3} / s$.

- $p_{e f, m a ́ q}$ : potência efetiva do gerador, em $M W$.

- $h_{e f, m a ́ q}$ : altura de queda líquida efetiva da turbina, em $m$.

- $h_{l, m a ́ q}:$ altura de queda líquida, em $m$.

Há duas possibilidades, chamadas de modelagem simplificada e modelagem detalhada, para expressar as funções $q_{\text {máx,tur, }} q_{\text {máx,ger }}$ e $p_{\text {máx,tur. }}$ Na modelagem simplificada, estas funções são expressas da seguinte forma:

$$
\begin{aligned}
& q_{\text {máx }, \text { máq }}=\left\{\begin{array}{l}
q_{\text {máx }, \text { tur }}=\left(\frac{h_{l}}{h_{e f, m a \dot{q}}}\right)^{\alpha} \cdot q_{e f, m a ́ q}, \text { se } h_{l}<h_{e f, m a \dot{q} q} \\
q_{\text {máx,ger }}=\left(\frac{h_{l}}{h_{e f, m a ́ q}}\right)^{-1} \cdot q_{e f, m a ́ q}, \text { se } h_{l} \geq h_{e f, m a ́ q}
\end{array}\right. \\
& p_{\text {máx }, \text { máq }}= \begin{cases}p_{\text {máx }, \text { tur }}=\left(\frac{h_{l}}{h_{e f, m a ́ q}}\right)^{\beta} \cdot p_{e f, m a ́ q}, & \text { se } h_{l}<h_{e f, m a ́ q} \\
p_{\text {ef,máq }} & , \text { se } h_{l} \geq h_{e f, m a ́ q}\end{cases}
\end{aligned}
$$

onde $\alpha$ e $\beta$ são coeficientes que dependem do tipo de turbina:

- $\alpha=0,5$ e $\beta=1,5$ para turbinas do tipo Francis e Pelton;

- $\alpha=0,2$ e $\beta=1,2$ para turbinas do tipo Kaplan;

Por exemplo, para a usina de Emborcação, as turbinas são do tipo Francis, possuem altura efetiva de $130,30 \mathrm{~m}$ e engolimento efetivo de $262 \mathrm{~m}^{3} / \mathrm{s}$; os geradores possuem potência efetiva de $298 \mathrm{MW}$. Como a usina possui quatro turbinas e quatro geradores iguais, há apenas um conjunto de máquinas, o engolimento máximo da usina é $1048 \mathrm{~m}^{3} / \mathrm{s}$ e a potência efetiva da usina é $1192 \mathrm{MW}$.

As equações para engolimento máximo e potência máxima de uma máquina de Emborcação são apresentadas abaixo e suas curvas são mostradas na Figura 5.22. 


$$
\begin{aligned}
& q_{\text {máx }}=\left\{\begin{array}{l}
q_{\text {máx } x \text { tur }}=\left(\frac{h_{l}}{130,30}\right)^{0,5} \cdot 262, \text { se } h_{l}<130,30 \\
q_{\text {máx } x \text { ger }}=\left(\frac{h_{l}}{130,30}\right)^{-1} \cdot 262, \text { se } h_{l} \geq 130,30
\end{array}\right. \\
& p_{\text {máx }}= \begin{cases}p_{\text {máx }, \text { tur }}=\left(\frac{h_{l}}{130,30}\right)^{0,2} \cdot 298, & \text { se } h_{l}<130,30 \\
p_{\text {ef }} & , \text { se } h_{l} \geq 130,30\end{cases}
\end{aligned}
$$

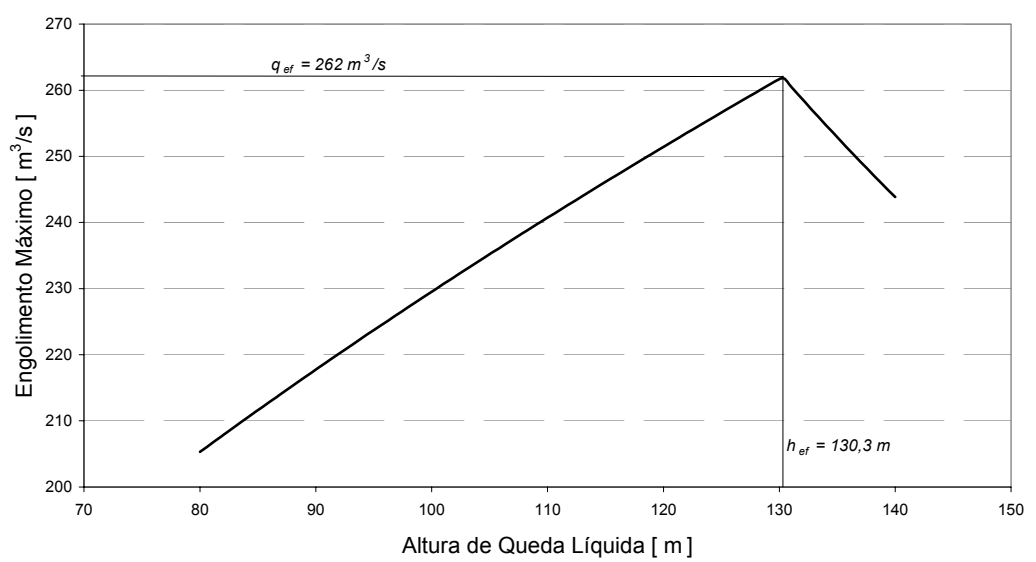

(a) Engolimento máximo de uma máquina de Emborcação.

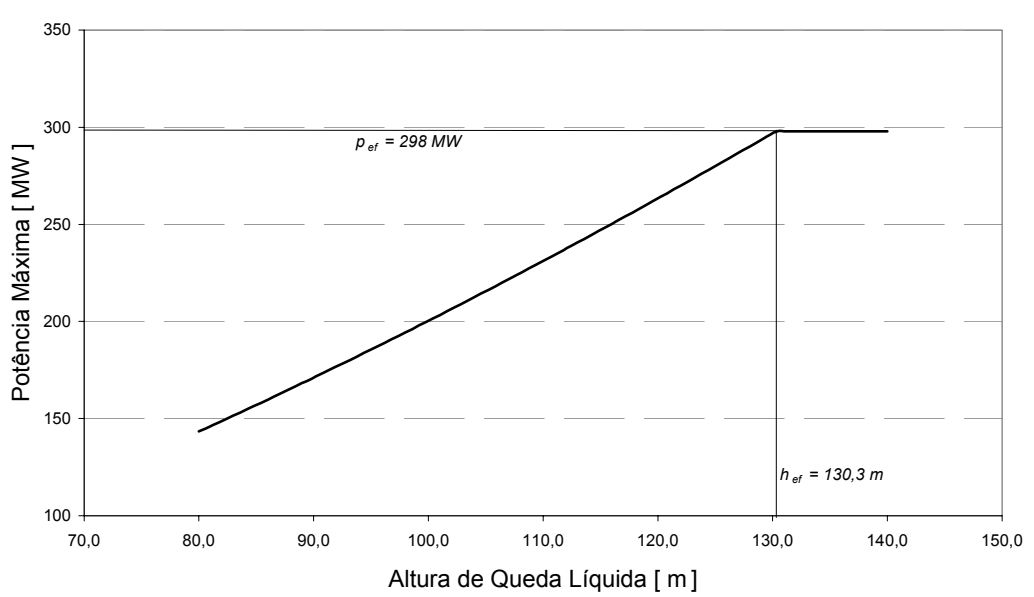

(b) Potência máxima de uma máquina de Emborcação.

Figura 5.22 - Engolimento máximo e potência máxima para uma máquina da usina de Emborcação.

$\mathrm{Na}$ modelagem detalhada são feitas várias medidas de pontos de operação do conjunto turbina/gerador da usina, e sobre estes pontos são ajustadas curvas, normalmente polinômios, para representar $q_{\text {máx,tur, }} q_{\text {máx,ger }}$ e $p_{\text {máx,tur }}$.

Independentemente da modelagem adotada, a partir destas curvas pode-se determinar o engolimento máximo de uma usina, uma vez definidos o volume armazenado no reservatório, $x$, e a vazão total a ser defluida, $u$. No entanto, o cálculo 
não é direto porque as variáveis envolvidas são interdependentes: para calcular o engolimento máximo da usina, $q_{\text {máx }}$, necessita-se da queda líquida, mas para calcular a queda líquida necessita-se da altura de queda de jusante e da perda de carga, as quais dependem da vazão turbinada pela usina, $q$, que ainda não foi determinada porque $o$ engolimento máximo é desconhecido. Por causa desta interdependência utiliza-se o seguinte processo iterativo:

1. Passo inicial:

a. Utilizando o volume de água armazenado no reservatório, $x$, calculase o nível de montante da usina, $h_{\text {mon }}(x)$.

b. A vazão defluente total da usina é feita igual ao valor fornecido da vazão defluente desejada, $u$, fornecida.

c. Calcula-se o nível de jusante, $h_{j u s}(u)$.

d. A vazão turbinada do conjunto de máquinas $j, q_{c o n j j}$, é determinada de forma proporcional ao engolimento efetivo do conjunto ${ }^{31}$, de forma que a soma das vazões turbinadas por cada conjunto seja igual à vazão defluente desejada.

e. A vazão turbinada de uma máquina do conjunto de máquinas $j, q_{\text {máq,j } j}$, é feita igual à vazão turbinada do conjunto, $q_{c o n j, j}$, dividida pelo número de máquinas do conjunto, $n_{m a ́ q, j}$.

f. Calcula-se a altura de queda líquida de cada conjunto de máquinas $j$,

$$
\begin{aligned}
& \operatorname{para} j=1, \ldots, n_{\text {conj }}: \\
& h_{l, j}=h_{m o n}(x)-h_{j u s}(u)-h_{p}\left(x, q_{\text {máq }, j}, v\right)
\end{aligned}
$$

${ }^{31}$ Esta divisão de vazão turbinada é utilizada apenas em modelos de longo prazo. Em modelos de curto prazo deve haver um estudo de otimização para despachar as máquinas, isto é, para determinar quanto cada uma deverá gerar de forma que a usina como um todo atenda à demanda solicitada. 
2. Processo iterativo:

a. Enquanto $\Delta h_{l}$ for significativo ${ }^{32}$ :

- Com o valor atual da altura de queda líquida do conjunto de máquinas $j, j=1, \ldots, n_{c o n j}$, calcula-se o engolimento máximo de uma

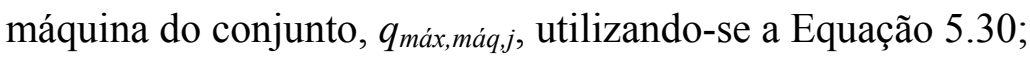

- Calcula-se o engolimento máximo do conjunto $j, j=1, \ldots, n_{\text {conj }}$, utilizando-se o número de máquinas do conjunto, $n_{m a ́ q, j}$ :

$$
q_{\text {máx,conj,j }}=n_{\text {máq,j }} \cdot q_{\text {máx,máq,j }}
$$

- Calcula-se o engolimento máximo da usina, utilizando-se o número de conjuntos de máquinas, $n_{\text {conj }}$ :

$$
q_{\text {máx }}=\sum_{j=1}^{n_{\text {conj }}} q_{\text {máx } x \text { conj }, j}
$$

- Se $q_{\text {máx }}>u$, fazem-se $u=q_{\text {máx }}$ e $q=q_{\text {máx }}$. Neste caso supõe-se que a vazão defluente será a vazão turbinada máxima;

- Se $q_{\text {máx }}<u$, faz-se $q=q_{\text {máx }}$. Neste caso haverá vertimento;

- Calcula-se a altura de queda líquida de cada conjunto de máquinas $j, j=1, \ldots, n_{c o n j}$, correspondente aos novos valores de vazão turbinada:

$$
h_{l, n o v o, j}=h_{m o n}(x)-h_{j u s}(u)-h_{p}\left(x, q_{m a ́ x, m a ́ q, j}, v\right)
$$

- Calcula-se $\Delta h_{l}$ :

$$
\Delta h_{l}=\operatorname{máx}_{1 \leq j \leq n_{\text {conj }}}\left\{\left|\frac{h_{l, n o v o, j}-h_{l, j}}{h_{l, j}}\right|\right\}
$$

- Atualiza-se o valor de $h_{l, j}$ do passo anterior:

$$
h_{l, j}=h_{l, n o v o, j}
$$

3. Cálculo da potência máxima:

a. Com os valores finais de $h_{l, j}, j=1, \ldots, n_{c o n j}$, resultantes do passo 2 , determinam-se as potências máximas das máquinas de cada conjunto de máquinas, $p_{\text {máx,máq,j, }}$ através da Equação 5.31.

b. Calcula-se a potência máxima da usina, $p_{\text {máx }}$ :

$$
p_{\text {máx }}=\sum_{j=1}^{n_{\text {conj }}} n_{\text {máq }, j} \cdot p_{\text {máx } x \text { máq }, j}
$$

\footnotetext{
${ }^{32}$ Ser "significativo" implica em ser maior que uma determinada precisão numérica $\left(10^{-3}\right.$, por exemplo).
} 
Por exemplo, pode-se determinar o engolimento máximo e a potência máxima de Emborcação para um volume armazenado $x=8000 \mathrm{hm}^{3}$ e vazão defluente total $u=600 \mathrm{~m}^{3} / \mathrm{s}$. Seguindo o processo iterativo, tem-se:

1. Passo inicial:

a. Nível de montante: $h_{m o n}(x)=632,4 m$.

b. Vazão defluente total da usina: $600 \mathrm{~m}^{3} / \mathrm{s}$.

c. Nível de jusante, $h_{j u s}(600)=521,8 m$.

d. Vazão turbinada do conjunto de máquinas $1: q_{\text {conj, } 1}=600 \mathrm{~m}^{3} / \mathrm{s}$.

e. Vazão turbinada de uma máquina do conjunto de máquinas 1 :

$$
q_{\text {máq, } 1}=\frac{600}{4}=150 \mathrm{~m}^{3} / \mathrm{s}
$$

f. Altura de queda líquida do conjunto de máquinas 1 :

$$
h_{l, 1}=632,4-521,8-1,94 \cdot 10^{-2} \cdot(632,4-521,8)=108,5 m
$$

2. Processo Iterativo:

- Enquanto $\Delta h_{l}$ for significativo:

\# Iteração 1:

- Com o valor atual da altura de queda líquida do conjunto de máquinas 1 , calcula-se o engolimento máximo de uma máquina do conjunto, $q_{\text {máx,máq,1, }}$ utilizando-se a Equação 5.32:

$$
q_{\text {máx } x \text { máq, }}=239,1 \mathrm{~m}^{3} / \mathrm{s} \text { para } h_{l, 1}=108,5 \mathrm{~m}
$$

- Calcula-se o engolimento máximo do conjunto de máquinas 1, utilizando-se o número de máquinas do conjunto, $n_{\text {máq, }}=4$ :

$$
q_{\text {máx,con }, j, 1}=4 \cdot 239,1=956,4 m^{3} / s
$$

- Calcula-se o engolimento máximo da usina, utilizando o número de conjuntos de máquinas, $n_{\text {conj }}=1$ :

$$
q_{\text {máx }}=956,4 \mathrm{~m}^{3} / \mathrm{s}
$$

- Como $q_{\text {máx }}>u$, fazem-se $u=956,4 \mathrm{~m}^{3} / \mathrm{s}$ e $q=956,4 \mathrm{~m}^{3} / \mathrm{s}$.

- Calcula-se a altura de queda líquida do conjunto de máquinas 1 , correspondente aos novos valores de vazão turbinada:

$$
\begin{aligned}
h_{l, \text { novo }, 1}= & h_{\text {mon }}(8000)-h_{\text {jus }}(956,4)-1,94 \cdot 10^{-2} \cdot\left(h_{\text {mon }}(8000)-h_{\text {jus }}(956,4)\right)= \\
& 632,4-522,8-1,94 \cdot 10^{-2} \cdot(632,4-522,8)=107,5 m
\end{aligned}
$$

- Calcula-se $\Delta h_{l}$ : 


$$
\Delta h_{l}=\operatorname{má}_{1 \leq j \leq 1}\left\{\left|\frac{107,5-108,5}{108,5}\right|\right\}=0,00922
$$

- Atualiza-se o valor de $h_{l, l}$ do passo anterior:

$$
h_{l, 1}=107,5 m
$$

- Como $\Delta h_{l}>10^{-3}$, faz-se nova iteração:

\section{\# Iteração 2:}

- Com o valor atual da altura de queda líquida do conjunto de máquinas 1 , calcula-se o engolimento máximo de uma máquina do

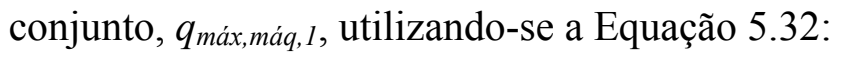

$$
q_{\text {máx, máq, } 1}=238,0 \mathrm{~m}^{3} / \mathrm{s} \text { para } h_{l, 1}=107,5 \mathrm{~m}
$$

- Calcula-se o engolimento máximo do conjunto 1, utilizando-se o número de máquinas do conjunto, $n_{\text {máq, }}=4$ :

$$
q_{m a ́ x, c o n, j, 1}=4 \cdot 238,0=952,0 \mathrm{~m}^{3} / \mathrm{s}
$$

- Calcula-se o engolimento máximo da usina, utilizando o número de conjuntos de máquinas, $n_{\text {conj }}=1$ :

$$
q_{\text {máx }}=952,0 \mathrm{~m}^{3} / \mathrm{s}
$$

- Como $q_{\text {máx }}>u$, fazem-se $u=952,0 \mathrm{~m}^{3} / \mathrm{s}$ e $q=952,0 \mathrm{~m}^{3} / \mathrm{s}$.

- Calcula-se a altura de queda líquida do conjunto de máquinas 1 , correspondente aos novos valores de vazão turbinada:

$$
\begin{aligned}
h_{l, \text { novo }, 1}= & h_{\text {mon }}(8000)-h_{\text {jus }}(952,0)-1,94 \cdot 10^{-2} \cdot\left(h_{\text {mon }}(8000)-h_{\text {jus }}(952,0)\right)= \\
& 632,4-522,8-1,94 \cdot 10^{-2} \cdot(632,4-522,8)=107,5 m
\end{aligned}
$$

- Calcula-se $\Delta h_{l}$ :

$$
\Delta h_{l}=\operatorname{máx}_{1 \leq j \leq 1}\left\{\left|\frac{107,5-107,5}{107,5}\right|\right\}=0,00
$$

- Atualiza-se o valor de $h_{l, l}$ do passo anterior:

$$
h_{l, 1}=107,5 m
$$

- Como $\Delta h_{l}<10^{-3}$, o processo iterativo convergiu. 
3. Cálculo da potência máxima:

a. Com o valor final da altura de queda líquida do conjunto de máquinas 1, calcula-se a potência máxima de uma máquina do conjunto,

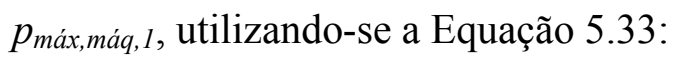

$$
p_{\text {máx,máq, } 1}=223,3 M W \text { para } h_{l, 1}=107,5 m
$$

b. Calcula-se a máxima potência da usina, $p_{\text {máx }}$ :

$$
p_{\text {máx }}=4 \cdot 223,3=893,2 M W
$$

Concluindo o exemplo, para $x=8000 \mathrm{hm}^{3}$ e $u=600 \mathrm{~m}^{3} / \mathrm{s}$, o engolimento máximo de Emborcação é $952 \mathrm{~m}^{3} / \mathrm{s}$ e a potência máxima é 893,2 $\mathrm{MW}$. Comparando o valor do engolimento máximo nesta condição de operação, $952 \mathrm{~m}^{3} / \mathrm{s}$, ao valor do engolimento efetivo da usina, $1048 \mathrm{~m}^{3} / \mathrm{s}$, nota-se que a baixa queda reduz a máxima vazão que pode passar pelas turbinas. Além disso, apesar da usina possuir $1192 \mathrm{MW}$ de máquinas instaladas, o baixo nível do reservatório faz com que a potência máxima nesta condição, 893,2 MW, seja bem inferior à potência efetiva da usina.

\subsection{Geração Máxima Contínua p páx,con}

A geração máxima contínua de uma usina hidroelétrica é definida como a máxima potência que pode ser gerada continuamente pela usina, considerando a potência máxima relacionada ao estado do reservatório, $p_{m a ́ x}$, o fator de capacidade máxima, $f \mathcal{c}_{\text {máx }}$, a taxa de manutenção programada, $t_{\text {man }}$, e a taxa de indisponibilidade forçada, $t_{i f}$.

A potência máxima relacionada ao estado do reservatório, $p_{\text {máx }}$, é a potência máxima determinada na seção anterior, a qual considera a perda de potência da usina devido à redução de altura de queda provocada pelo esvaziamento do reservatório.

$\mathrm{O}$ fator de capacidade máxima, $f \mathcal{C}_{\text {máx }}$, é definido como a máxima potência que a usina pode produzir em relação à sua potência efetiva. Por exemplo, $f \mathcal{c}_{\max }=0,75$ indica que a usina pode gerar no máximo $75 \%$ de sua potência efetiva.

A taxa de manutenção programada, $t_{\text {man }}$, indica a porcentagem de tempo em que a usina fica desligada para manutenção de suas máquinas.

A taxa de indisponibilidade forçada, $t_{i f}$, indica a porcentagem de tempo em que a usina fica desligada devido a falhas em suas máquinas.

A geração máxima contínua, $p_{m a ́ x, c o n}$, é determinada como:

$$
p_{\text {máx } x \text { con }}=p_{\text {máx }} \cdot f \mathcal{C}_{\text {máx }} \cdot\left(1-t_{\text {man }}\right) \cdot\left(1-t_{\text {if }}\right)
$$

Por exemplo, para a usina de Emborcação, tem-se $f c_{\text {max }}=1,0 ; t_{\text {man }}=0,12122 \mathrm{e}$ 
$t_{i f}=0,02917$. Se o volume da usina for $x=8000 \mathrm{hm}^{3}$ e a vazão defluente for $u=600 \mathrm{~m}^{3} / \mathrm{s}$, mesmos valores utilizados no item 1.3 , tem-se $p_{\text {máx }}=893,2 M W$. Pode-se então calcular a geração máxima contínua da usina:

$$
p_{\text {máx } x \text { con }}=893,2 \cdot 1 \cdot(1-0,12122) \cdot(1-0,02917)=762,0 \mathrm{MW}
$$

Isto indica que durante um intervalo de simulação e/ou otimização, dados os valores de $x$ e $u$, embora a usina seja capaz de fornecer uma potência máxima $p_{\text {máx }}=893,2 \mathrm{MW}$, ela não pode garanti-la ao longo de todo o intervalo por causa do fator de carga máximo, do cronograma de manutenção e da indisponibilidade forçada. Podese apenas garantir uma geração contínua de $762,0 \mathrm{MW}$ ao longo do intervalo.

\subsection{Exemplo de Função de Geração}

Para ilustrar os conceitos vistos anteriormente, esta seção apresenta a função de geração da usina hidroelétrica de Emborcação. Esta função é o modelo matemático utilizado para representar a usina hidroelétrica de Emborcação em estudos de longo prazo. Genericamente, esta função é dada pela Equação 5.27, reproduzida abaixo:

$$
\begin{aligned}
& p(x, q, v)=p e \cdot h_{l}(x, q, v) \cdot q \\
& q \leq q_{\text {máx }}(x, q, v)
\end{aligned}
$$

Para a usina de Emborcação, tem-se $p e=0,0087309 \mathrm{MW} /\left(\left(\mathrm{m}^{3} / \mathrm{s}\right) . \mathrm{m}\right)$. A altura de queda líquida é dada por:

$$
\begin{gathered}
h_{l}(x, q, v)=h_{\text {mon }}(x)-h_{\text {jus }}(u)-h_{p}(x, q, v) \\
\text { - } h_{\text {mon }}(x)=5,68089 \cdot 10^{2}+1,45059 \cdot 10^{-2} \cdot x-1,20279 \cdot 10^{-6} \cdot x^{2}+ \\
5,83029 \cdot 10^{-11} \cdot x^{3}-1,12449 \cdot 10^{-15} \cdot x^{4} \\
\text { - } h_{j u s}(u)=5,19774 \cdot 10^{2}+3,99663 \cdot 10^{-3} \cdot u-1,09869 \cdot 10^{-6} \cdot u^{2}+ \\
2,34375 \cdot 10^{-10} \cdot u^{3}-1,76460 \cdot 10^{-14} \cdot u^{4} \\
\text { - } h_{p}(x, q, v)=0,0194 \cdot\left(h_{\text {mon }}(x)-h_{j u s}(q+v)\right)
\end{gathered}
$$

A vazão turbinada $q$ é limitada pelo engolimento máximo $q_{\text {máx }}(x, q, v)$, calculado seguindo o algoritmo do item 1.3. Para calcular o valor da potência gerada para as diversas combinações de volume armazenado no reservatório e vazões turbinada, vertida e defluente, seguem-se os seguintes passos:

1. Assume-se a hipótese de haver vazão vertida $v$ não-nula somente se a vazão defluente for maior que o engolimento máximo. Assim, para vazões defluentes menores que o engolimento máximo, a vazão turbinada será igual 
à vazão defluente, e a vazão vertida será nula.

2. Varia-se progressivamente o valor do volume armazenado $x$ entre os limites operativos $x_{\min }$ e $x_{\text {máx }}$ (para o exemplo foram utilizados cinqüenta valores). Para cada valor de volume, varia-se a vazão defluente $u$ entre os valores mínimo e máximo de vazão afluente natural verificados no histórico (também foram utilizados cinqüenta valores).

3. Para cada par de valores de volume e vazão defluente, $\operatorname{par}(x, u)$, faz-se:

a. Determina-se a queda líquida $h_{l}$ e o engolimento máximo $q_{\text {máx }}$ através do algoritmo do item 1.3;

b. Se a vazão defluente $u$ for menor que $q_{\text {máx }}$, faz-se $v=0, q=u$; caso contrário, faz-se $v=u-q_{\text {máx }}$ e $q=q_{\text {máx }}$;

c. Determina-se a potência $p(x, q, v)$ através do produto entre a produtibilidade específica, a queda líquida e a vazão turbinada.

Seguindo os passos descritos acima, obtém a curva de potência gerada mostrada na Figura 5.23. Nesta figura mostra-se a potência gerada em função do volume $x$ e da vazão defluente $u$. A vazão turbinada é igual à vazão defluente para valores de $q_{\text {máx }}$ menores que $u$; para vazões defluentes superiores a $q_{\text {máx }}$ há vertimento e a vazão turbinada é igual a $q_{\text {máx }}$.

Na Figura 5.23 são identificadas três regiões, denotadas por regiões (1), (2) e (3). A região (1) caracteriza-se por valores baixos de vazão defluente, sempre menores que o engolimento máximo. Assim, nesta região a vazão defluente é igual à vazão turbinada e a vazão vertida é sempre nula. Aumentos de volume elevam a altura de queda líquida, fazendo com que uma mesma potência $p$ seja gerada com menores vazões turbinadas.

A região (2) caracteriza-se por valores altos de vazão defluente, e valores relativamente baixos de altura de queda; nesta região a altura de queda líquida é inferior à altura efetiva da usina e a vazão defluente é alta, fazendo com que haja vertimento. Nesta região a turbina limita a operação da usina e os valores de potência são menores que a potência efetiva dos geradores. Aumentos de volume na região (2) provocam significativos aumentos na potência $p$ porque além de aumentar a altura de queda líquida, aumenta-se também o engolimento máximo.

A região (3) caracteriza-se por valores altos de vazão defluente e altura de queda. Nesta região a altura de queda líquida é superior à altura efetiva da usina e a vazão defluente é alta, fazendo com que haja vertimento. Nesta região o gerador limita a operação da usina e os valores de potência gerada são iguais à potência efetiva dos geradores. Aumentos de volume na região (3) não provocam aumentos de potência 
porque as turbinas são obrigadas a fechar suas palhetas já que os geradores estão nos seus limites. Neste caso, para uma mesma vazão defluente, aumentos de volume reduzem a vazão turbinada e elevam a vazão vertida.

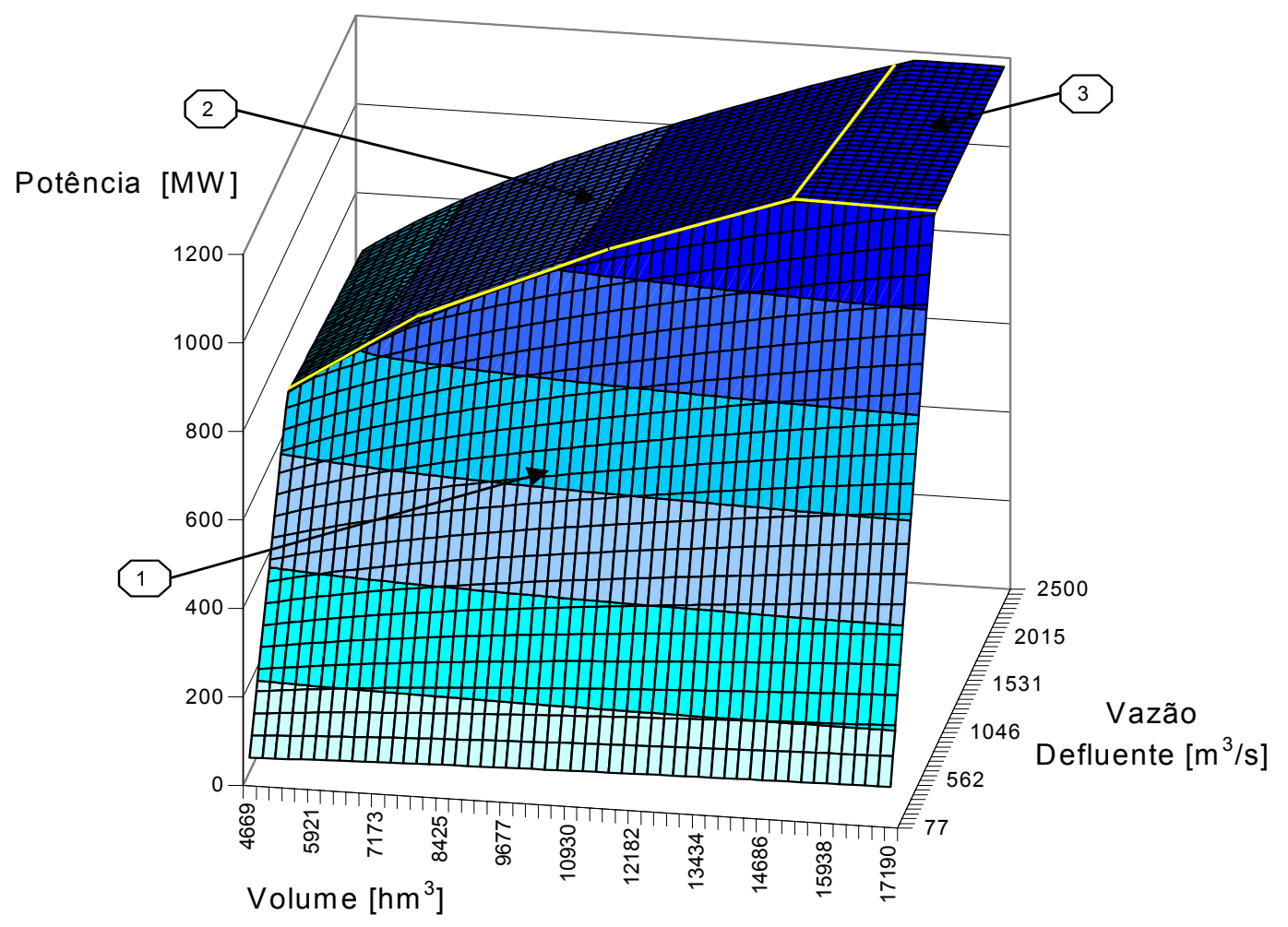

Figura 5.23 - Função de Geração de Emborcação. 


\section{Perdas por Evaporação}

Evaporação é o processo físico no qual um líquido passa ao estado gasoso. Em meteorologia, o termo evaporação restringe-se à mudança da água no estado líquido para o estado gasoso, devido à radiação solar, à temperatura do ar, ao vento e à pressão de vapor.

Modelos matemáticos para quantitativamente avaliar esta importante fase do ciclo hidrológico são utilizados na resolução de diversos problemas relacionados ao gerenciamento de recursos hídricos. Apenas como exemplo, o planejamento de áreas agrícolas, a previsão de cheias e a construção e operação de reservatórios requerem dados confiáveis de evaporação [86].

$\mathrm{Na}$ operação energética de usinas hidroelétricas, modelos de evaporação são utilizados praticamente em duas fases: (a) os dados de evaporação do local de um reservatório antes de sua implantação servem para reconstituir as séries de vazões afluentes naturais, utilizadas em estudos de otimização e simulação; (b) os dados de evaporação de um reservatório existente servem para avaliar a perda energética que ocorre devido à evaporação, já que a água evaporada não é utilizada na geração de energia.

Nos estudos energéticos, com discretização mensal, as perdas por evaporação são modeladas através de doze coeficientes de evaporação, $c e_{j a n}, c e_{m a r}, \ldots, c e_{d e z}$, um para cada mês do ano, expressos em $\mathrm{mm}$. Para obter o volume de água evaporado, $x_{e v}$, em $\mathrm{hm}^{3}$, multiplica-se a área do espelho d'água do reservatório, $a_{e}$, pelo coeficiente de evaporação do mês desejado.

No Brasil, similarmente aos níveis d'água de montante e jusante de uma usina hidroelétrica, a área do espelho d'água também é especificada através de um polinômio de no máximo quarto grau. Este polinômio determina a área do espelho d’água do reservatório, $a_{e}$, em $\mathrm{km}^{2}$, a partir da cota de montante, em $m$. Assim, uma vez especificado o volume armazenado no reservatório, $x$, primeiro determina-se a cota de montante, $h_{m o n}(x)$, e na seqüência determina-se a área do espelho d'água, $a_{e}$. O produto entre a área e o coeficiente de evaporação especifica o volume evaporado $x_{e v}$ :

$$
x_{e v}=10^{-3} \cdot c e_{\text {mês }} \cdot a_{e}\left(h_{m o n}(x)\right) \quad\left[\mathrm{hm}^{3}\right]
$$

Por exemplo, para a usina de Emborcação têm-se os seguintes dados:

- Coeficientes de evaporação, em $\mathrm{mm}$ : 


$$
\begin{array}{llllll}
c e_{\text {jan }}=21 & c e_{\text {fev }}=23 & c e_{\text {mar }}=33 & c e_{\text {abr }}=42 & c e_{\text {mai }}=49 & c e_{\text {jun }}=53 \\
c e_{\text {jul }}=49 & c e_{\text {ago }}=48 & c e_{\text {set }}=49 & c e_{\text {out }}=27 & c e_{\text {nov }}=12 & c e_{\text {dez }}=26
\end{array}
$$

- Polinômio do nível de montante ( $h_{m o n}$ em $m$ para $x$ em $\mathrm{hm}^{3}$ ):

$$
\begin{aligned}
h_{\text {mon }}(x)=5,68089 \cdot 10^{2}+1,45059 \cdot 10^{-2} \cdot x-1,20279 \cdot 10^{-6} \cdot x^{2}+ \\
5,83029 \cdot 10^{-11} \cdot x^{3}-1,12449 \cdot 10^{-15} \cdot x^{4}
\end{aligned}
$$

- Polinômio da área do espelho d'água, mostrado abaixo e na Figura 5.24:

$$
\begin{aligned}
a_{e}(h)= & -1,81944 \cdot 10^{4}+5,65776 \cdot 10^{1} \cdot h+4,51828 \cdot 10^{-2} \cdot h^{2}+ \\
& -2,91219 \cdot 10^{-4} \cdot h^{3}+2,39007 \cdot 10^{-7} \cdot h^{4}
\end{aligned}
$$

Para $x=8000 \mathrm{hm}^{3}$, o volume evaporado no mês de março será:

- Nível de montante:

$$
h_{\text {mon }}(8000)=632,4 m
$$

- Área do espelho d'água:

$$
a_{e}(632,4)=229,1 \mathrm{~km}^{2}
$$

- Volume evaporado:

$$
x_{e v}=10^{-3} \cdot 33 \cdot 229,1=7,56 \mathrm{hm}^{3}
$$

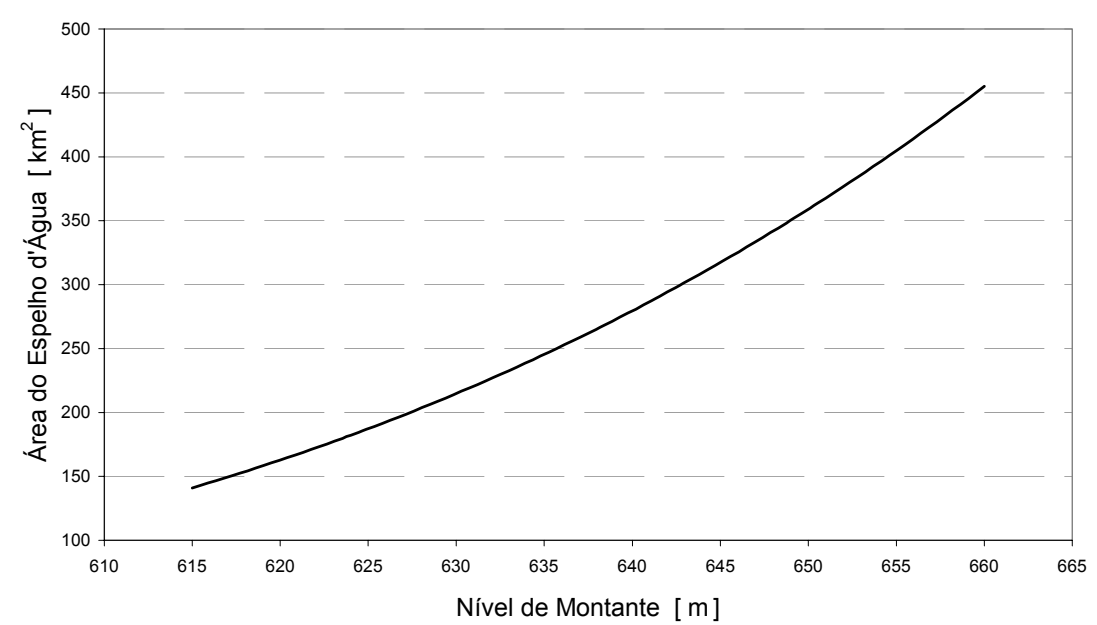

Figura 5.24 - Polinômio cota x área para a usina de Emborcação.

Concluindo, para o volume armazenado de $8000 \mathrm{hm}^{3}$, o volume evaporado no reservatório de Emborcação durante o mês de março é de 7,56 $\mathrm{hm}^{3}$. 


\section{Séries de Vazões Afluentes}

As séries de vazões afluentes representam o fluxo de água médio que flui em postos de medição durante determinados intervalos de discretização. No caso do Brasil, há registros históricos das vazões afluentes às principais usinas hidroelétricas do Sistema Interligado Nacional desde 1931. Estes registros são chamados de "série histórica" [59].

As séries históricas de vazões afluentes naturais são obtidas basicamente a partir do processo mostrado na Figura 5.25 [59]. Este processo inicia-se pela elaboração de curvas-chaves, curvas que especificam a vazão através de uma seção transversal do rio em função do nível d'água do rio. Inicia-se então uma série de medidas do nível d'água do rio; estas medidas de nível são transformadas em medidas de vazão através das curvas-chaves determinadas previamente. Como os postos de medição de vazão não são normalmente localizados nas próprias usinas, faz-se uma transformação das vazões nos postos para as vazões nas usinas. Têm-se assim as vazões diárias das usinas, que por sua vez são utilizadas no cálculo das vazões diárias naturais através do desconto das variações de volume dos reservatórios e da evaporação. Finalmente, os valores de vazão diária são utilizados para cálculo das vazões naturais semanais, mensais e anuais.

Os modelos de otimização e simulação empregados neste trabalho utilizam séries de vazões com intervalos de discretização mensal. Por exemplo, na Figura 5.26 mostra-se a série de vazões naturais afluentes à usina de Emborcação para o período de janeiro de 1931 a dezembro de 1994. Nesta curva nota-se uma certa sazonalidade das vazões: em cada ano há períodos úmidos e períodos secos, característicos dos meses em que a precipitação é elevada e em que há estiagem.

Para melhor caracterizar as vazões afluentes, na Figura 5.27 são apresentados os valores mínimo, médio e máximo da vazão natural afluente da usina de Emborcação para cada um dos meses do ano. O mês de maio, primeiro mês mostrado no gráfico, marca o início do período seco da região sudeste, o qual estende-se até outubro ou novembro. Os meses de janeiro, fevereiro e março são os mais úmidos do ano para esta região, e o mês de abril marca o fim do período chuvoso. É interessante notar que nos períodos de seca, a variação das vazões afluentes é relativamente pequena, ao passo que nos meses de janeiro, fevereiro e março a diferença entre os valores mínimo e máximo é bem grande. Estas diferenças são mostradas na Figura 5.28, onde apresentam-se as vazões médias de cada mês, também conhecidas como Média de Longo Termo (MLT), e os respectivos desvios padrões. 


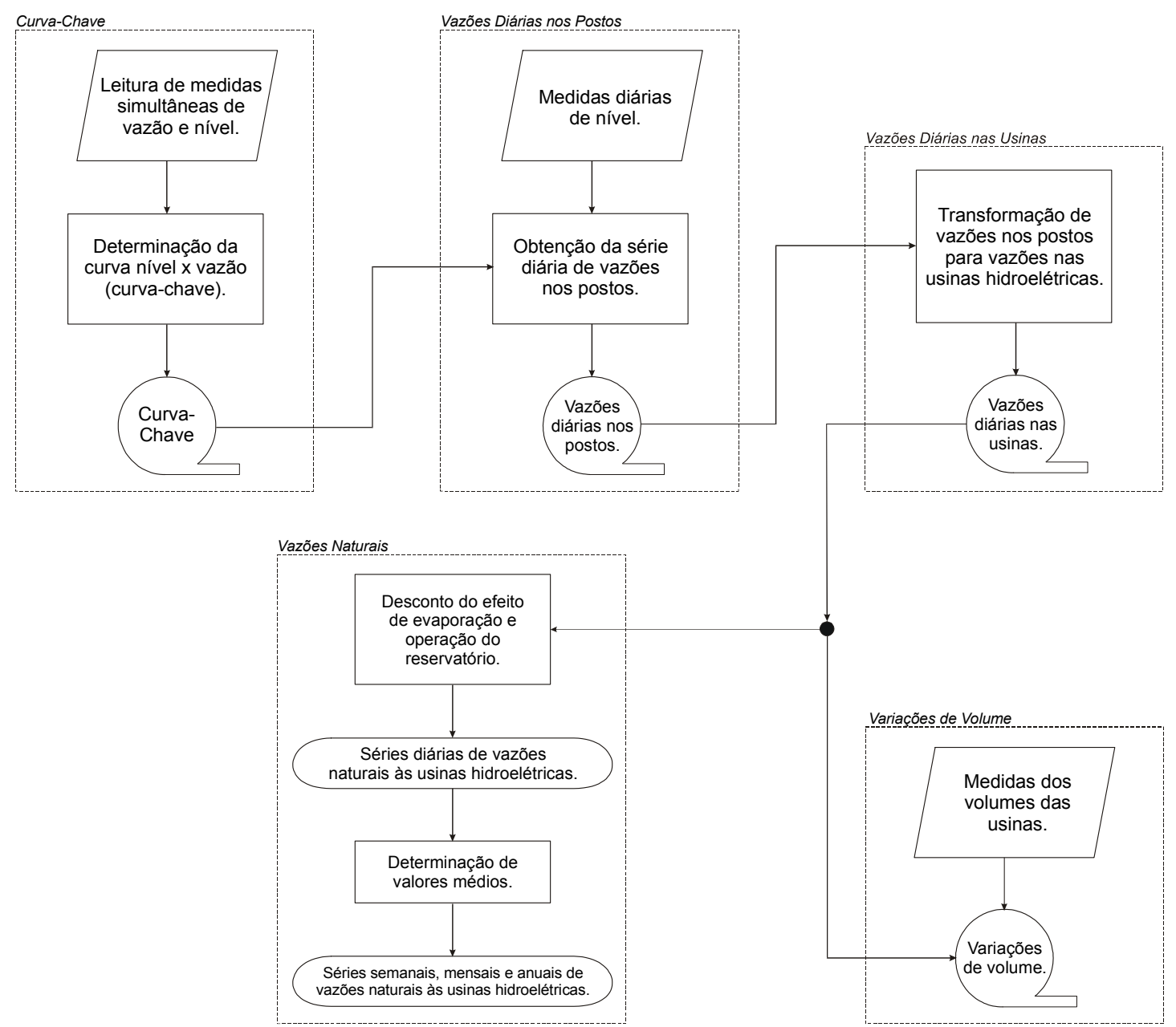

Figura 5.25 - Obtenção de séries históricas de vazões afluentes.

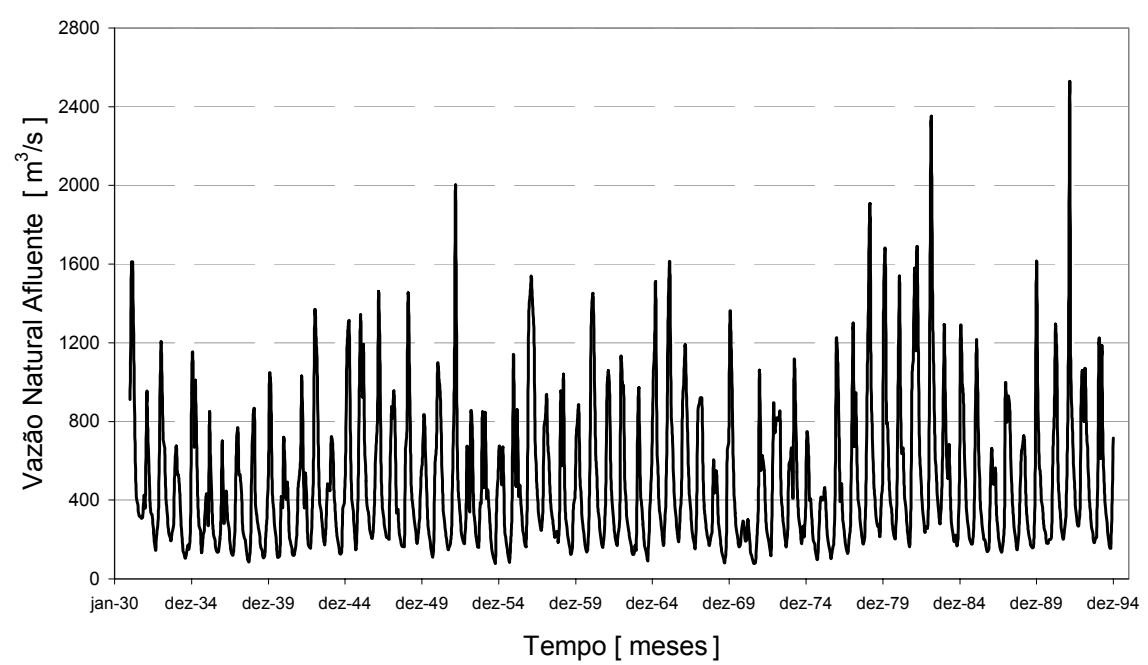

Figura 5.26 - Vazão natural afluente à usina de Emborcação. 


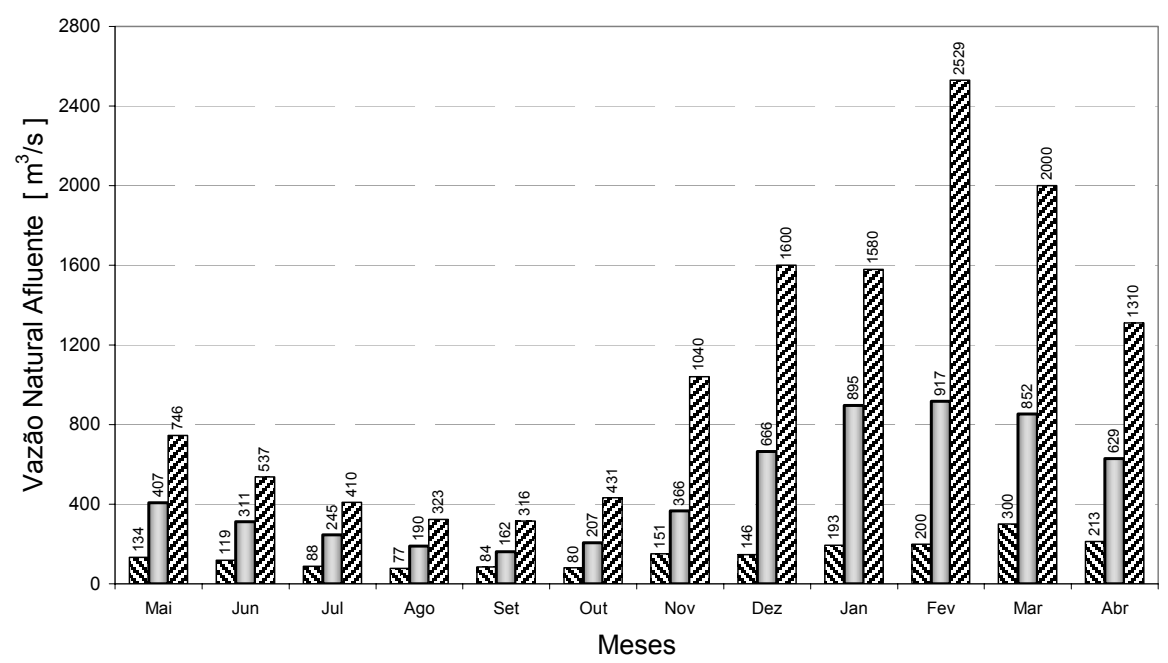

Figura 5.27 - Valores mínimo, médio e máximo da vazão natural afluente de Emborcação.

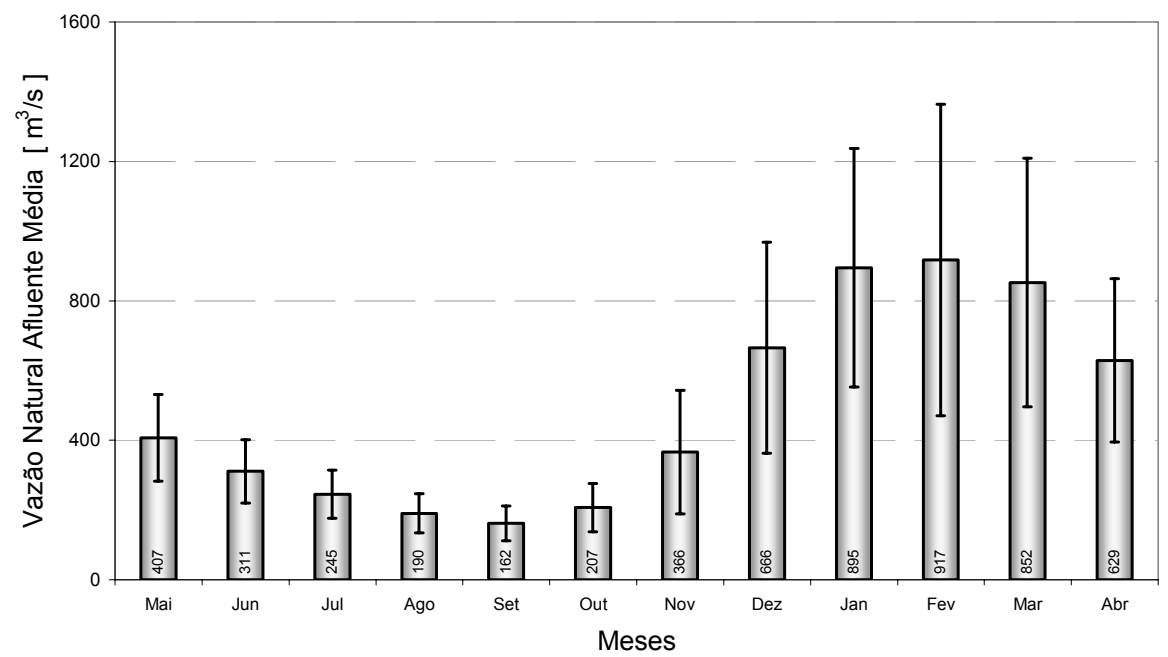

Figura 5.28 - Valores médios e desvio padrão da vazão natural afluente de Emborcação.

$\mathrm{Na}$ realização de estudos de otimização e simulação, é comum a existência de sistemas com várias usinas interconectadas hidraulicamente. A interconexão hidráulica entre as usinas faz com que as vazões afluentes a um reservatório difiram sensivelmente de suas vazões afluentes naturais por causa da operação dos reservatórios de montante.

Considerando as usinas mostradas na Figura 5.29, as vazões afluentes às usinas 1 e $2, y_{1}$ e $y_{2}$, respectivamente, são iguais às vazões afluentes naturais destas usinas, $y_{n a t, 1}$ e $y_{n a t, 2}$. A vazão afluente à usina $3, y_{3}$, só será igual à sua vazão afluente natural, $y_{n a t, 3}$, se a usina 1 for operada a fio d'água, isto é, se o volume de água armazenado no seu reservatório for mantido constante. Como esta operação nem sempre é verificada, a vazão $y_{3}$ pode ser determinada genericamente como a soma da vazão defluente da usina $1, u_{1}$, e da vazão incremental ou lateral da usina $3, y_{i n c, 3}$. Os seguintes cálculos são realizados: 


$$
\begin{aligned}
& y_{\text {inc }, 3}=y_{\text {nat }, 3}-y_{\text {nat }, 1} \\
& y_{3}=u_{1}+y_{i n c, 3}
\end{aligned}
$$

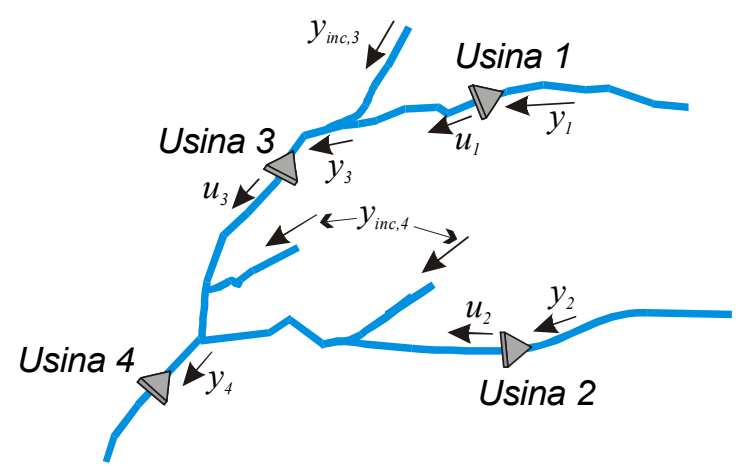

Figura 5.29 - Conjunto de usinas para cálculo da vazão incremental.

As vazões incrementais não podem ser alteradas pela operação dos reservatórios e por isso são chamadas de vazões não-controláveis. O contrário ocorre para a vazão defluente da usina 1, que por isso é chamada de vazão controlável. Assim, a usina 3 tem uma parcela de vazão afluente que é controlável e outra que é não-controlável.

A situação da usina 4 é um pouco mais complicada porque ela recebe duas parcelas de vazão controlável, provenientes das usinas 2 e 3 . A vazão na usina 4 pode ser determinada da seguinte forma:

$$
\begin{aligned}
& y_{i n c, 4}=y_{n a t, 4}-y_{n a t, 2}-y_{n a t, 3} \\
& y_{4}=u_{2}+u_{3}+y_{i n c, 4}
\end{aligned}
$$

De forma geral, a vazão afluente de uma usina $i$ qualquer, $y_{i}$, pode ser determinada utilizando-se as seguintes equações:

$$
\begin{aligned}
& y_{\text {inc }, i}=y_{n a t, i}-\sum_{j \in \Omega} y_{n a t, j} \\
& y_{i}=y_{i n c, i}+\sum_{j \in \Omega} u_{j}
\end{aligned}
$$

na qual $\Omega$ é o conjunto formado pelas usinas que estão a montante da usina $i$. 


\section{Variáveis Utilizadas nos Estudos}

Nos estudos de otimização e simulação são utilizadas diversas variáveis para descrever o modelo matemático dos sistemas hidroelétricos, incluindo as usinas hidroelétricas que os compõem. Como exemplos destas variáveis têm-se as vazões afluente, turbinada, vertida e defluente, o volume de água armazenado, a potência gerada, a duração dos intervalos de discretização, etc.

Estas variáveis normalmente são fontes de dúvidas por causa das unidades utilizadas e por causa dos seus significados. Para evitar os problemas com as unidades, neste trabalho será utilizada a seguinte padronização:

- Volumes:

$\checkmark$ Os volumes armazenado, mínimo, máximo, máximo maximorum, de segurança e evaporado são expressos em $\mathrm{hm}^{3}$;

- Alturas:

$\checkmark$ As variáveis que representam altura, tais como níveis de montante e jusante, alturas de queda bruta e líquida, e perdas de carga, são expressas em $m$;

- Vazões:

As vazões afluente, turbinada, vertida e defluente são sempre expressas em $\mathrm{m}^{3} / \mathrm{s}$

- Potência e geração:

$\checkmark$ As variáveis que representam potências, tal como a potência máxima da usina, são expressas em $M W$. Variáveis que representam gerações médias ao longo dos intervalos de discretização são expressas em MW.méd ou $\overline{M W}$.

- Energia:

As variáveis que representam energia, tal como a energia armazenada em um reservatório, são expressas em MW.mês;

- Tempo:

$\checkmark$ As variáveis que representam tempo, tal como a duração dos intervalos de discretização, são expressas em s (segundos);

A interpretação do significado das variáveis utilizadas nos estudos é feita com o auxílio da Figura 5.30. Admite-se que o horizonte dos estudos de otimização ou 
simulação seja discretizado em intervalos de duração igual a $\Delta t$ segundos. Dado um intervalo $t$ qualquer do horizonte de planejamento, os valores de vazão afluente, turbinada, defluente e vertida, volume e volume evaporado variam ao longo dos $\Delta t$ segundos de duração do intervalo. No entanto, na realização dos cálculos para o intervalo $t$ deve haver apenas um valor para cada um destas variáveis. O problema é justamente determinar quais serão estes valores.

Os valores de vazão são adotados como sendo os valores médios ao longo do intervalo com duração de $\Delta t$ segundos. Conforme ilustrado na Figura 5.30, o valor $y(t)$ associado à vazão afluente à usina durante o intervalo $t$, é a vazão afluente média à usina durante o intervalo $t$. O mesmo ocorre para as vazões turbinada, vertida e defluida.

A quantidade de água evaporada também varia ao longo do intervalo e neste caso deseja-se determinar o volume de água evaporado. Logo, o volume evaporado será a área sobre a curva que expressa o volume evaporado em cada instante do intervalo, equivalente à área hachurada indicada na Figura 5.30.

O valor de volume armazenado no intervalo $t$ é uma conseqüência da aplicação da equação de balanço hídrico ou equação de conservação da água aos fluxos de água que afluem e defluem da usina. Como estes valores de fluxo são valores médios ao longo do intervalo, adota-se como valor do volume armazenado no intervalo $t, x(t)$, o volume armazenado no reservatório no início do intervalo. Tem-se a seguinte equação:

$$
x(t+1)=x(t)+\frac{\Delta t}{10^{6}} \cdot(y(t)-q(t)-v(t))-x_{e v}(t)
$$

Esta equação diz que o volume armazenado no início do intervalo $t+1$ será igual ao volume armazenado no início do intervalo $t$, mais a diferença entre os valores médios do quanto de água aflui à usina e deflui da mesma ao longo do intervalo, menos o volume perdido por evaporação. Determinam-se assim os volumes no início de cada intervalo com base nos fluxos médios ao longo dos intervalos de duração $\Delta t$ segundos.

$\mathrm{O}$ fator $\Delta t / 10^{6}$ presta-se à conversão das vazões afluentes, expressas em $\mathrm{m}^{3} / \mathrm{s}$, em valores de volume, expressos em $\mathrm{hm}^{3}$. 


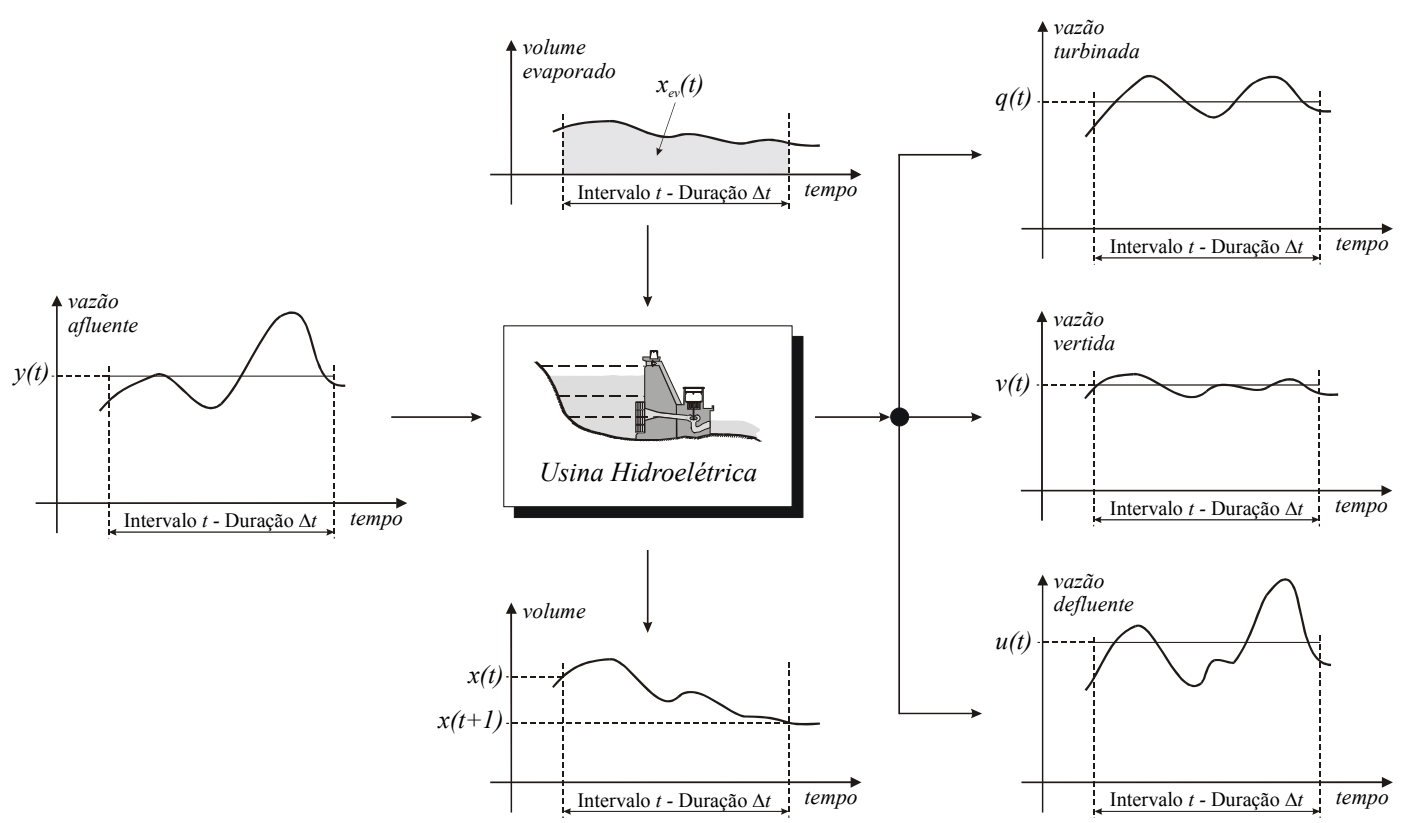

Figura 5.30 - Interpretação das variáveis utilizadas nos estudos. 



\section{Capítulo VI}

\section{Modelos de Otimização e Simulação}

Ao longo das últimas décadas, os computadores passaram a ser utilizados em grande parte das atividades produtivas desenvolvidas pelos seres humanos. Atualmente computadores automatizam sistemas de estoque em supermercados e lojas, calculam a movimentação bancária de correntistas e investidores, manipulam ferramentas automáticas de produção em indústrias, processam dados e ajustam modelos matemáticos complexos em centros de pesquisas, manipulam informações para o desenvolvimento da agricultura, e desempenham papel fundamental até mesmo na realização de cirurgias de alta precisão.

Dentre as inúmeras tarefas que podem ser desempenhadas por estas máquinas, a realização de estudos de otimização e simulação interessa de forma direta este trabalho. Estes estudos normalmente são aplicados à análise de problemas que envolvem decisões a serem tomadas, às quais estão associadas medidas de performance. Dependendo da decisão, a performance poderá ser maior ou menor.

Estudos de simulação baseiam-se no estabelecimento de regras para determinar os valores das variáveis de decisão. Estas regras podem ser empíricas, baseadas em sugestões de especialistas, ou determinadas a partir de modelos matemáticos, econômicos, ou de áreas relacionadas ao problema. Uma vez especificados os valores das variáveis de decisão pelo modelo de simulação, o desempenho é medido e pode-se avaliar o impacto da regra adotada.

Estudos de otimização geralmente baseiam-se em técnicas que utilizam cálculo diferencial e integral para determinar os valores das variáveis de decisão. Normalmente deseja-se conhecer os valores das variáveis de decisão que otimizam alguma medida de desempenho, tais como minimização de custos, maximização de receitas ou de benefícios líquidos, etc.

Modelos de simulação usualmente são capazes de serem utilizados em 
problemas bastante complexos, com relações não-lineares entre as variáveis e muitas restrições aplicáveis aos possíveis valores que elas podem assumir. No entanto, há uma enorme variedade de regras que podem ser adotadas, tornando difícil a escolha de valores para as variáveis que conduzam a soluções próximas às mais eficientes possíveis. Por outro lado, modelos de otimização normalmente não são aptos a trabalhar com todas as complexidades e não-linearidades que podem ser abordadas em modelos de simulação. No entanto, quando modelos de otimização podem ser construídos para resolver uma aproximação adequada do problema real, eles produzem soluções eficientes que ajudam significativamente na resolução do problema [69].

No caso específico deste trabalho, modelos de otimização e simulação são aplicados à operação energética de sistemas hidrotérmicos de potência. A resolução deste problema visa basicamente determinar como as usinas hidroelétricas e termoelétricas que compõem um sistema hidrotérmico devem ser operadas para que os recursos disponíveis para geração de energia elétrica sejam utilizados de forma eficiente. Por eficiência entendem-se custos mínimos de operação alcançados garantindo-se níveis mínimos de confiabilidade.

Embora haja modelos disponíveis para realizar a otimização e a simulação de sistemas hidrotérmicos de potência, muitos destes modelos desenvolvidos por empresas do setor elétrico brasileiro, neste trabalho optou-se por desenvolver um modelo de simulação e utilizar um modelo de otimização anteriormente desenvolvido pelo grupo de pesquisa do Laboratório de Sistemas de Energia Elétrica do Departamento de Engenharia Elétrica da Escola de Engenharia de São Carlos / USP.

O desenvolvimento do modelo de simulação foi necessário porque os programas disponíveis, desenvolvidos pelas empresas, trabalham apenas com a regra paralela ou com suas variantes, além de possuírem códigos fechados que dificultam a interação automática com outros programas.

A escolha do modelo de otimização previamente desenvolvido justifica-se porque os resultados gerados por este modelo são utilizados na definição de regras de operação empregadas no modelo de simulação. Faz-se uma conexão entre os modelos de simulação e otimização, permitindo que as regras de operação do simulador sejam definidas considerando-se critérios ótimos.

As duas seções deste capítulo explicam em detalhes os modelos de otimização e simulação utilizados neste trabalho. 


\section{Modelo de Otimização}

O verbo otimizar significa melhorar, tornar ótimo. Os sentidos atribuídos a este verbo no dia-a-dia são os mais diversos possíveis: otimiza-se a arrumação dos armários em uma residência, o custo das compras no supermercado, a performance dos carros, o percurso de casa para o trabalho, os lucros de uma indústria ou comércio, etc.

Mesmo em áreas específicas do conhecimento, tal como o Gerenciamento de Recursos Hídricos, os sentidos do verbo otimizar variam de acordo com as características do problema abordado. Este fato pode ser constatado em [122], onde apresenta-se uma revisão bibliográfica de modelos matemáticos desenvolvidos para operação de reservatórios. As aplicações variam desde a minimização de custos esperados futuros com intervalos mensais de discretização, até a operação em tempo real. São estudadas abordagens determinísticas e estocásticas, e os métodos de otimização dos modelos incluem Programação Linear, Programação Dinâmica, Programação Não-Linear e também ferramentas de simulação.

Em [121] mostra-se uma série de aplicações de Programação Dinâmica a problemas de gerenciamento de recursos hídricos em geral. Os objetivos da operação envolvem manutenção da qualidade da água nos rios, minimização de custos com irrigação e operações determinística e estocástica de reservatórios.

Em [5] desenvolve-se um modelo de operação de reservatórios em tempo real para navegação e geração de energia elétrica. O objetivo neste caso é a minimização de uma soma de penalidades associadas a desvios em relação a valores desejados de geração e de nível d'água dos rios. A técnica de solução adotada combina Programação Não-Linear e simulação utilizando o Método dos Elementos Finitos.

No caso deste trabalho, o modelo de otimização está relacionado com as decisões de longo prazo de um sistema hidrotérmico de potência, aquelas relacionadas às variações de volume dos reservatórios ao longo dos anos e ao nível de utilização das usinas termoelétricas. O objetivo é encontrar políticas de operação que minimizem o custo de operação do sistema e que garantam níveis mínimos de confiabilidade de suprimento [93] [26] e [110].

Um método comumente utilizado, que enfoca o aspecto estocástico do problema, é a representação do sistema hidroelétrico através de um reservatório equivalente [10]. A agregação das várias usinas hidroelétricas em um único reservatório equivalente tem por objetivo reduzir o número de variáveis e permitir a aplicação de 
Programação Dinâmica Estocástica (PDE) na resolução do problema [11]. O resultado da PDE é uma política de operação do sistema que pode ser simulada para obtenção das metas de armazenagem de cada reservatório. No Brasil, as empresas do setor de energia elétrica e o Operador Nacional do Sistema Elétrico (ONS) utilizam modelos baseados em PDE e representação equivalente [89, 93].

A principal limitação da representação equivalente é sua inabilidade em adequadamente abordar alguns aspectos importantes da operação das usinas hidroelétricas, tais como o efeito-cota, a diversidade hidrológica e vertimentos localizados em algumas usinas [110].

Uma abordagem alternativa à representação equivalente é a utilização conjunta de representação individualizada para as usinas hidroelétricas, ferramentas de otimização determinística e métodos de previsão para as vazões futuras [112] [77]. Para efetivamente ser utilizada na operação de um sistema hidrotérmico, esta abordagem deve considerar de forma implícita a aleatoriedade das vazões afluentes. Isto significa que decisões tomadas com base em vazões previstas devem ser atualizadas a cada intervalo de otimização com base nos valores observados e em novas previsões.

O modelo de otimização utilizado neste trabalho presta-se à otimização determinística de sistemas hidrotérmicos de potência com representação individualizada para as usinas hidroelétricas. A versão original do modelo é apresentada em [29]; melhorias no método de otimização foram introduzidas em [84]; e uma abordagem orientada por objetos resultou em [35]. Exemplos de aplicações dos modelos mencionados podem ser encontrados em [28] [19].

A fim de explicar o modelo de otimização, a próxima subseção descreve um sistema hidrotérmico. Na seqüência apresentam-se o modelo de custo operacional, a formulação matemática do modelo de otimização e exemplos de operação ótima para sistemas com uma, duas e três usinas hidroelétricas.

\subsection{Sistema Hidrotérmico}

Na Figura 6.1 apresenta-se de forma esquemática um sistema hidrotérmico de potência. De acordo com o esquema, identificam-se dois subsistemas:

- Subsistema Hidráulico: constituído basicamente pelas usinas hidroelétricas. O custo de operação deste subsistema é praticamente nulo, 
uma vez que o "combustível” empregado na obtenção de energia é a água ${ }^{33}$. Mesmo em situações em que são cobradas taxas pelo uso da água, o custo de operação das usinas hidroelétricas continua sendo relativamente baixo quando comparado ao custo das usinas termoelétricas, o que não invalida esta abordagem.

- Subsistema Térmico: representado através de uma função de custo que engloba o custo do combustível utilizado na operação das usinas termoelétricas, o custo de importação de energia de outros sistemas, e o custo da falta de suprimento de energia, chamado de custo do déficit.

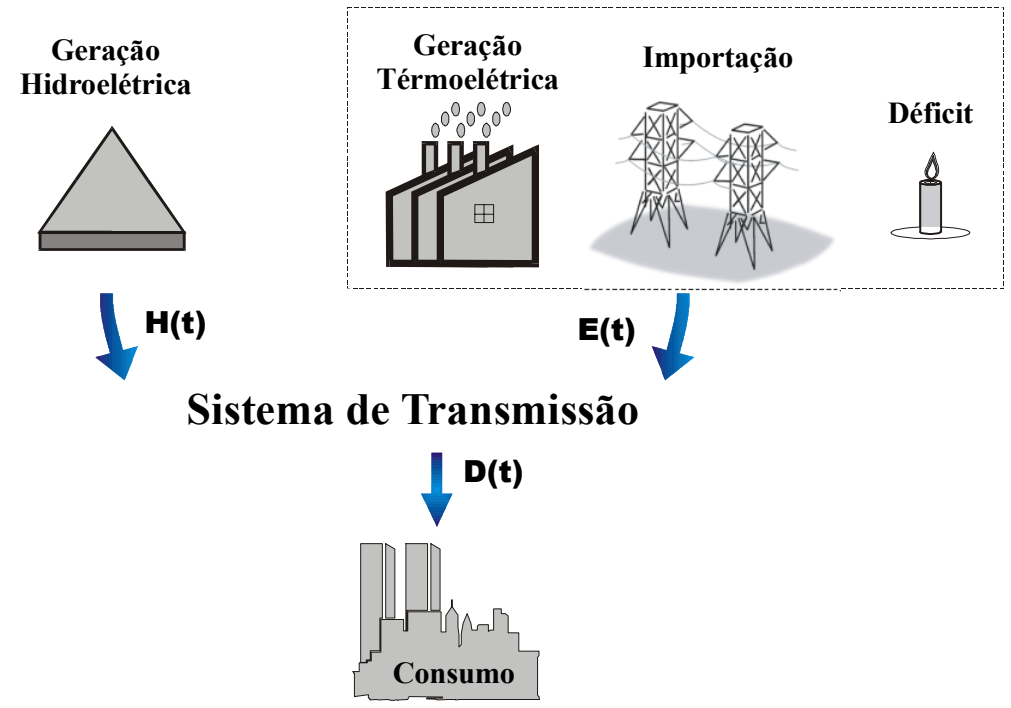

Figura 6.1 - Esquema de um sistema hidrotérmico de potência.

As variáveis indicadas são:

- $D(t)$ : demanda média durante o intervalo $t$, em $\overline{M W}$;

- $H(t)$ : geração média total das hidroelétricas durante o intervalo $t$, em $\overline{M W}$;

- E(t): geração média das fontes não-hidráulicas, também chamada de complementação térmica, durante o intervalo $t$, em $\overline{M W}$.

Dependendo do modo de operação do sistema hidrotérmico, a participação dos subsistemas será diferente. Estudar o comportamento ótimo de um sistema de geração predominantemente hidroelétrico, significa, em linhas gerais, encontrar as trajetórias de volume armazenado nos reservatórios e a vazão turbinada pelas usinas para substituir, na medida do possível, a geração de origem não-hidráulica por geração hidráulica [110].

\footnotetext{
${ }^{33}$ Embora no modelo seja atribuído um valor nulo à água, nos estudos referentes à operação hidrotérmica atribui-se um valor à água armazenada nos reservatórios, equivalente ao custo de geração não-hidráulica que esta água pode potencialmente substituir, caracterizando o chamado "valor da água".
} 
Estas trajetórias, como será visto adiante, são determinadas pelas características intrínsecas dos próprios reservatórios, pelo conjunto das outras usinas e também pelas condições operativas que lhes são impostas [28].

\subsection{Formulação Matemática}

O objetivo da operação de longo prazo é a minimização do custo de operação do sistema ao longo do horizonte de planejamento. Conforme já citado anteriormente, sob o ponto de vista da operação, o sistema hidrotérmico tem um custo bem definido, dado pelo custo de operação do sistema não-hidráulico.

Assim, para cada intervalo mensal $t$, o sistema hidrotérmico tem como custo de operação justamente o custo do sistema não-hidráulico complementar, $C(t)$, o qual depende da demanda $D(t)$ e da geração hidráulica $H(t)$. Quanto maior a geração hidráulica, menor a complementação térmica $E(t)$ correspondente.

A função $C(t)$, esquematicamente representada na Figura 6.2, é o resultado do despacho do sistema não-hidráulico. Observa-se que primeiro são utilizadas as fontes mais baratas de energia não-hidráulica e conforme a participação destas fontes aumenta, usinas mais caras vão sendo despachadas até que sejam necessárias importações ${ }^{34} \mathrm{e}$, em último caso, cortes de carga cujos custos são representados pelo custo do déficit.

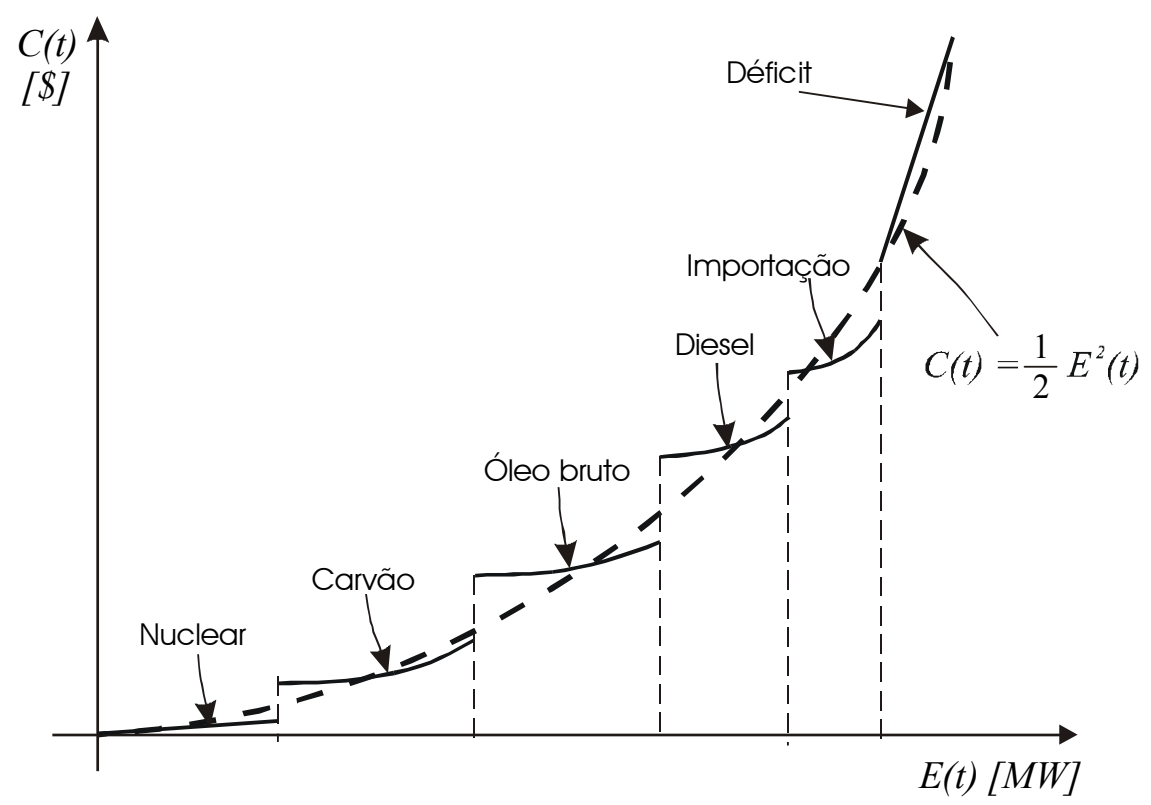

Figura 6.2 - Custo de operação do sistema não-hidráulico complementar.

\footnotetext{
${ }^{34}$ Em alguns casos a importação pode ser mais barata que algumas fontes de geração existentes no próprio sistema. Isto depende basicamente da fonte da energia importada e das fontes disponíveis no sistema importador.
} 
$\mathrm{Na}$ figura anterior sugere-se que a função $C(t)$ seja aproximada por uma função quadrática $^{35}$, tal como realizado em [110]. Adotando-se esta abordagem, o modelo de otimização pode ser escrito como:

$$
\begin{gathered}
\min \sum_{t=1}^{T} C(t) \\
\text { s.a. }\left\{\begin{array}{l}
x_{i}(t+1)=x_{i}(t)+2,628 \cdot\left(y_{\text {inc,i }}(t)+\sum_{k \in \Omega_{i}} u_{k}(t)-u_{i}(t)\right) \\
u_{\text {min }, i}<u_{i}(t)<u_{\text {máx }, i} \\
x_{\text {min }, i}<x_{i}(t)<x_{\text {máx }, i}
\end{array}\right.
\end{gathered}
$$

sendo:

- T: número de intervalos do horizonte de planejamento;

- $C(t)$ : custo de operação ao longo do intervalo $t$, definido em alguma unidade monetária, genericamente denotada por $\$$ :

$$
C(t)=\frac{1}{2} \cdot r(t) \cdot E^{2}(t)
$$

- E(t): geração média das fontes não-hidráulicas durante o intervalo $t$, em $\overline{M W}$, calculada por:

$$
E(t)= \begin{cases}D(t)-H(t), & \text { para } D(t) \geq H(t) \\ 0, & \text { para } D(t)<H(t)\end{cases}
$$

- $r(t)$ : fator de valor atual do capital no intervalo $t$. Se $j$ for a taxa de desconto relativa a cada intervalo do horizonte de planejamento, tem-se $r(t)=1 /(1+j)^{t}$.

- $H(t)$ : geração média total das hidroelétricas durante o intervalo $t$, em $\overline{M W}$, calculada através do somatório da produção hidráulica de cada usina hidroelétrica, dada pela Equação 5.27 (como os intervalos são mensais, o rendimento do conjunto turbina/gerador foi considerado constante e igual a um valor médio), reproduzida a seguir:

$$
\begin{aligned}
& H(t)=\sum_{i=1}^{N} p_{i}(t) \\
& \left\{\begin{array}{l}
p_{i}(t)=p e_{i} \cdot h_{l, i}\left(x_{\text {méd }, i}(t), q_{i}(t), v_{i}(t)\right) \cdot q_{i}(t) \\
q_{i}(t) \leq q_{\text {máx }, i}\left(x_{\text {méd }, i}(t), q_{i}(t), v_{i}(t)\right)
\end{array}\right.
\end{aligned}
$$

- $p_{i}(t)$ : geração média da usina hidroelétrica $i$ durante o intervalo $t$, em $\overline{M W}$;

\footnotetext{
${ }^{35}$ Outras funções poderiam ser adotadas pelo modelo.
} 
- $N$ : número de usinas hidroelétricas;

- $x_{\text {méd, } i}(t)$ : volume médio armazenado no reservatório da usina hidroelétrica $i$ durante o intervalo $t$, em $\mathrm{hm}^{3}$. Este volume é calculado como a média entre os volumes no início e no fim do intervalo, ou seja, $x_{\text {méd, } i}=(x(t)+x(t+1)) / 2$;

- $q_{i}(t)$ : vazão turbinada média da usina hidroelétrica $i$ durante o intervalo $t$, em $\mathrm{m}^{3} / \mathrm{s}$;

- $v_{i}(t)$ : vazão vertida média da usina hidroelétrica $i$ durante o intervalo $t$, em $\mathrm{m}^{3} / \mathrm{s}$;

- $u_{i}(t)$ : vazão defluente média da usina hidroelétrica $i$ durante o intervalo $t$, em $\mathrm{m}^{3} / \mathrm{s}$. Esta vazão é calculada como $u_{i}(t)=q_{i}(t)+v_{i}(t)$;

- $y_{i n c, i}(t)$ : vazão afluente incremental à usina $i$ durante o intervalo $t$, em $\mathrm{m}^{3} / \mathrm{s}$;

- $q_{\text {máx, } i}(t)$ : engolimento máximo da usina hidroelétrica $i$ durante o intervalo $t$, em $\mathrm{m}^{3} / \mathrm{s}$. O cálculo do engolimento máximo é realizado de acordo com o item 1.3 do Capítulo V; - $\Omega_{i}$ : conjunto das usinas situadas imediatamente a montante da usina hidroelétrica $i$;

- $x_{\text {min }, i}$ e $x_{\text {máx }, i}$ : limites mínimo e máximo para o volume armazenado na usina $i$, em $\mathrm{hm}^{3}$;

- $u_{m i n, i}$ e $u_{m a ́ x, i}:$ limites mínimo e máximo para a vazão defluente total da hidroelétrica $i$, em $m^{3} / s$.

Os estados inicial e final do reservatório são conhecidos e a função de custo é calculada antes da otimização através de um Despacho Econômico Térmico (DET) [71].

O problema apresentado pelas Equações 6.1 a 6.4 pode ser eficientemente resolvido por um algoritmo de fluxo em redes. No caso específico deste trabalho, os testes foram realizados utilizando um algoritmo baseado no apresentado em [29].

\subsection{Exemplo de Operação Ótima}

Na Figura 6.3 apresenta-se um sistema bastante simples, composto apenas pelas usinas a reservatório localizadas no rio Paranapanema. Os principais dados destas usinas são mostrados na Tabela 6.1.

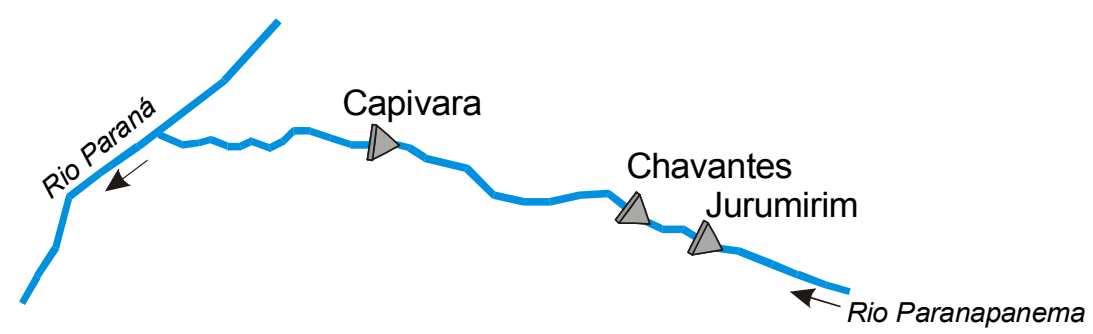

Figura 6.3 - Sistema teste para o exemplo de operação ótima. 
Tabela 6.1 - Principais dados das usinas do sistema teste.

\begin{tabular}{cccc}
\hline & Jurumirim & Chavantes & Capivara \\
\hline Volume Mínimo $\left[\mathrm{hm}^{3}\right]$ & 3843 & 5754 & 4816 \\
\hline Volume Máximo $\left[\mathrm{hm}^{3}\right]$ & 7008 & 8795 & 10540 \\
\hline Volume Util $\left[\mathrm{hm}^{3}\right]$ & 3165 & 3041 & 5724 \\
\hline Altura Efetiva $[\mathrm{m}]$ & 30,9 & 73,6 & 44,0 \\
\hline Engolimento Efetivo $\left[\mathrm{m}^{3} / \mathrm{s}\right]$ & 356 & 660 & 1460 \\
\hline Potência Efetiva $\left[\mathrm{MW}^{3}\right.$ & 103,2 & 423,9 & 608,0 \\
\hline Produtibilidade $\left[\mathrm{MW} / \mathrm{m}^{3} / \mathrm{sm}\right]$ & 0,008621 & 0,008779 & 0,008854 \\
\hline
\end{tabular}

Na Figura 6.4 são mostradas as trajetórias ótimas de volume para a operação do sistema teste com vazões afluentes iguais à MLT. Através dessa figura nota-se o papel diferenciado que as usinas exercem durante a operação ótima, dependendo da posição relativa que elas ocupam dentro da cascata. A usina de Jurumirim, localizada a montante do sistema, exerce o papel de reguladora das vazões afluentes naturais, variando a quantidade de água armazenada em seu reservatório a fim de fornecer vazões afluentes mais regulares ao restante do sistema [111].

A usina de Capivara apresenta comportamento completamente oposto ao de Jurumirim, mantendo-se sempre cheia. Como esta usina localiza-se a jusante do sistema, por ela passa um grande volume de água; assim, se sua cota de montante for reduzida, ou seja, se seu reservatório baixar, uma grande quantidade de água será turbinada com uma queda menor, gerando menos energia, o que representa uma grande perda de energia.

Finalmente, a usina de Chavantes possui comportamento intermediário, tentando manter-se com cota elevada, com alta produtividade, mas também variando a quantidade de energia armazenada em seu reservatório para ajudar na regularização das vazões afluentes.

Realizando uma série de outros testes com vários sistemas de geração, variando a carga a ser atendida, as vazões afluentes, o número de usinas e uma série de outros fatores, constata-se que os padrões de comportamento mostrados mantêm-se [24]. Isto motiva o desenvolvimento de metodologias que consigam captar estas características a fim de que a simulação da operação dos sistemas seja realizada com base em critérios ótimos de operação. 


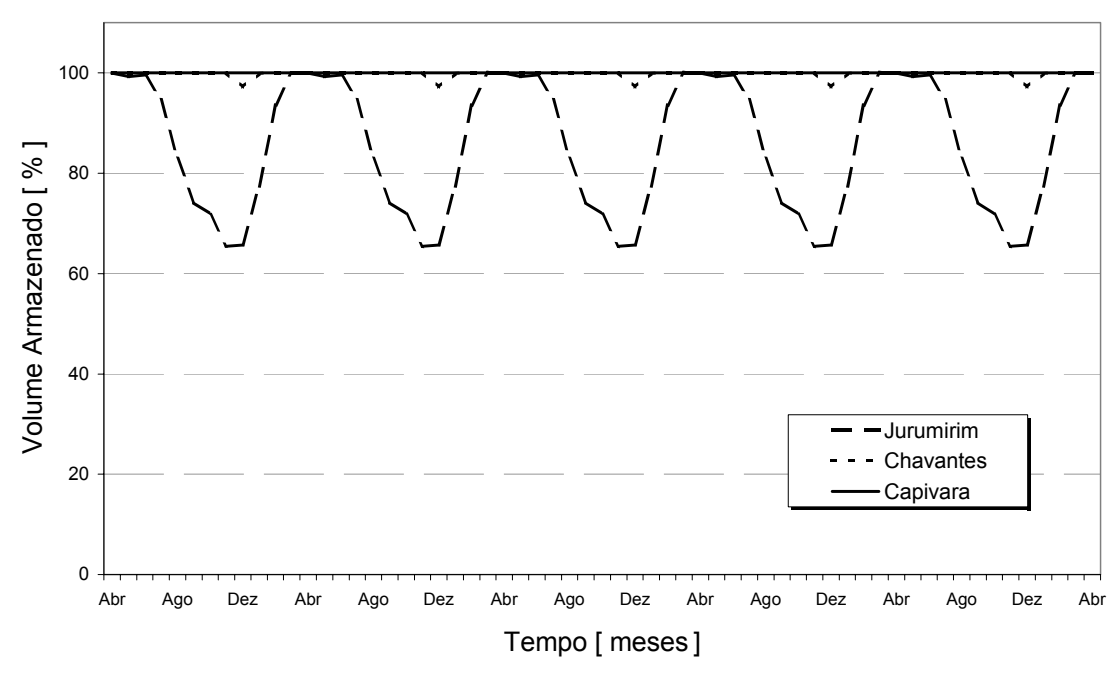

Figura 6.4 - Operação ótima para vazões afluentes iguais à MLT.

Este modelo é utilizado no estabelecimento da Política de Operação baseada em otimização, onde são realizados vários estudos de operação ótima e sobre os resultados destes estudos ajustam-se curvas que passam a determinar a forma de enchimento e esvaziamento dos reservatórios, tal como será ilustrado na próxima seção. 


\section{Modelo de Simulação}

O verbo simular originou-se do latim, do verbo simulare, cujo significado é fingir, representar com semelhança, aparentar. Assim, quando se realiza uma simulação em um computador, está-se tentando reproduzir virtualmente o comportamento de um sistema físico, "fingindo" que ele existe, representando-o com semelhança através de equações, fornecendo valores às suas entradas, determinando alguns de seus estados e observando o seu comportamento.

No caso específico da simulação de um sistema de usinas hidroelétricas, as usinas são modeladas matematicamente, representadas por uma série de dados e equações, e a partir de algumas suposições a respeito de seus relacionamentos com o meio e das regras que regem estas relações, a evolução do sistema pode ser analisada.

Os modelos de simulação de sistemas hidroelétricos podem variar na forma como o sistema é representado, no modo como o sistema evolui ao longo do tempo e na consideração ou não de restrições de interligação [92].

A representação do sistema hidráulico pode ser feita basicamente de duas formas:

- Modelos a Reservatório Equivalente: o sistema hidroelétrico é agregado na forma de um reservatório equivalente de energia, ao qual aflui e do qual deflui energia ao invés de água. A capacidade de armazenagem do reservatório equivalente representa o valor energético da água armazenada nos reservatórios.

- Modelos a Usinas Individualizadas: cada usina é representada individualmente, com dados de modelagem compatíveis com suas características físicas e com o lugar de sua instalação.

A evolução do parque gerador ao longo do tempo pode ser de dois tipos:

- Modelos Dinâmicos: são especificadas as datas de entrada em operação de cada usina hidroelétrica, ou mesmo de suas diferentes unidades geradoras. Desta forma, em cada intervalo de simulação, a demanda é atendida de acordo com a capacidade instalada disponível naquele intervalo. Estes modelos são úteis em estudos de análise conjuntural, como por exemplo, na avaliação do impacto de atraso nos cronogramas de construção das usinas, ou na análise de diferentes projeções futuras de demanda. 
- Modelos Estáticos: através destes modelos determinam-se os benefícios energéticos de um sistema, supondo que o número de unidades geradoras que o compõe não evolui ao longo do tempo, e que o mercado de energia permanece constante. Em cada intervalo de simulação a capacidade instalada do sistema e a demanda a ser atendida são iguais.

Quanto à consideração ou não de restrições de interligação, os sistemas podem ser:

- Modelos a Subsistemas: cada macro região do país é considerada individualmente, sendo que a capacidade de troca de energia entre as regiões é limitada pelos troncos de transmissão.

- Modelos a Barramento Único: ao contrário dos modelos a subsistemas, neste caso não há limites de interligação entre as regiões. É como se houvesse um único barramento elétrico, com todas as usinas ligadas a uma extremidade e toda a carga ligada à outra.

O Modelo de Simulação desenvolvido neste trabalho presta-se à avaliação energética de sistemas hidroelétricos de geração, com representação individualizada das usinas. Para a realização dos estudos deste projeto adotou-se uma base de tempo mensal, com sistemas estáticos e a barramento único [101, 102].

Uma vez definidos um sistema hidroelétrico e uma carga a ser atendida por este sistema, o modelo de simulação desenvolvido trata especificamente do rateio do pacote total de geração hidroelétrica entre as várias usinas do sistema. Para ilustrar o papel exato do modelo de simulação, a Figura 6.5 ilustra uma situação onde o sistema composto pelas oito usinas do rio Paranapanema deve gerar $800 \overline{\mathrm{MW}}$ para ajudar no atendimento a uma carga de $1000 \overline{\mathrm{MW}}$. O modelo de simulação não determinou que a geração total das usinas hidroelétricas devia ser $800 \overline{\mathrm{MW}}$; esta meta de geração foi estabelecida por outros modelos. O modelo de simulação desenvolvido trabalha em um estágio posterior, determinando quanto cada usina hidroelétrica deve gerar para que a meta de geração hidroelétrica de $800 \overline{\mathrm{MW}}$ seja atendida.

Há infinitas formas de fazer com que as oitos usinas juntas gerem $800 \overline{\mathrm{MW}}$. Dependendo de como esta decisão for tomada, a geração de cada usina será diferente, implicando em diferentes gastos de água. Para o rateio da geração entre as usinas utilizam-se regras de operação que acoplam a operação das usinas e determinam como 
elas variarão seus volumes de forma que os excessos e/ou faltas de água sejam gerenciados e a carga total seja atendida.

$\mathrm{O}$ código computacional foi implementado em Linguagem $\mathrm{C}++$ orientada por objetos, desenvolvida no compilador Builder $\mathrm{C}++$ da Borland, trabalhando em plataforma Windows. O programa possui uma interface gráfica que facilita a manipulação de dados, a realização de estudos e a análise de resultados.

As próximas seções deste capítulo apresentam o modelo de simulação desenvolvido .

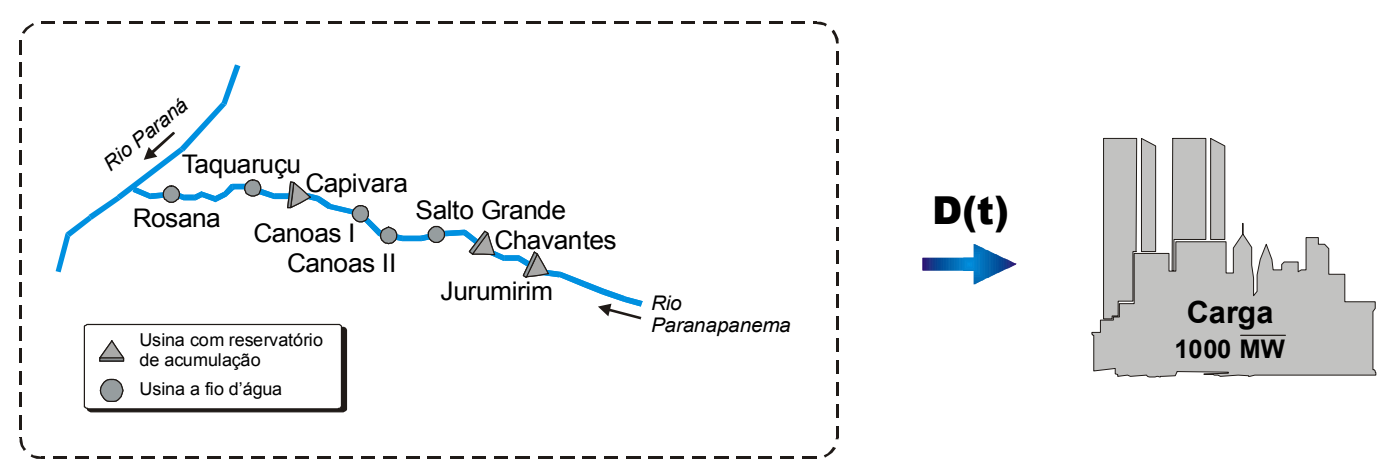

Figura 6.5 - Ilustração da metodologia de simulação.

\subsection{Simulação de um Período do Histórico ou com Vazões Médias}

Para facilitar o entendimento de como o modelo de simulação funciona, utiliza-se o esquema apresentado na Figura 6.6. Primeiro explicam-se as condições de operação que devem ser especificadas para que uma simulação possa ser realizada, em seguida explica-se o processo iterativo utilizado durante a realização de uma simulação e na seqüência mostram-se os resultados gerados pelo modelo. Para concluir, alguns exemplos de simulação de períodos do histórico e com vazões médias são apresentados.

\subsubsection{Condiç̃̃es de Operação}

A simulação de um período do histórico ou com vazões médias visa identificar como um sistema de geração de energia elétrica se comportaria se fosse submetido a determinadas condições de operação, explicadas a seguir. 


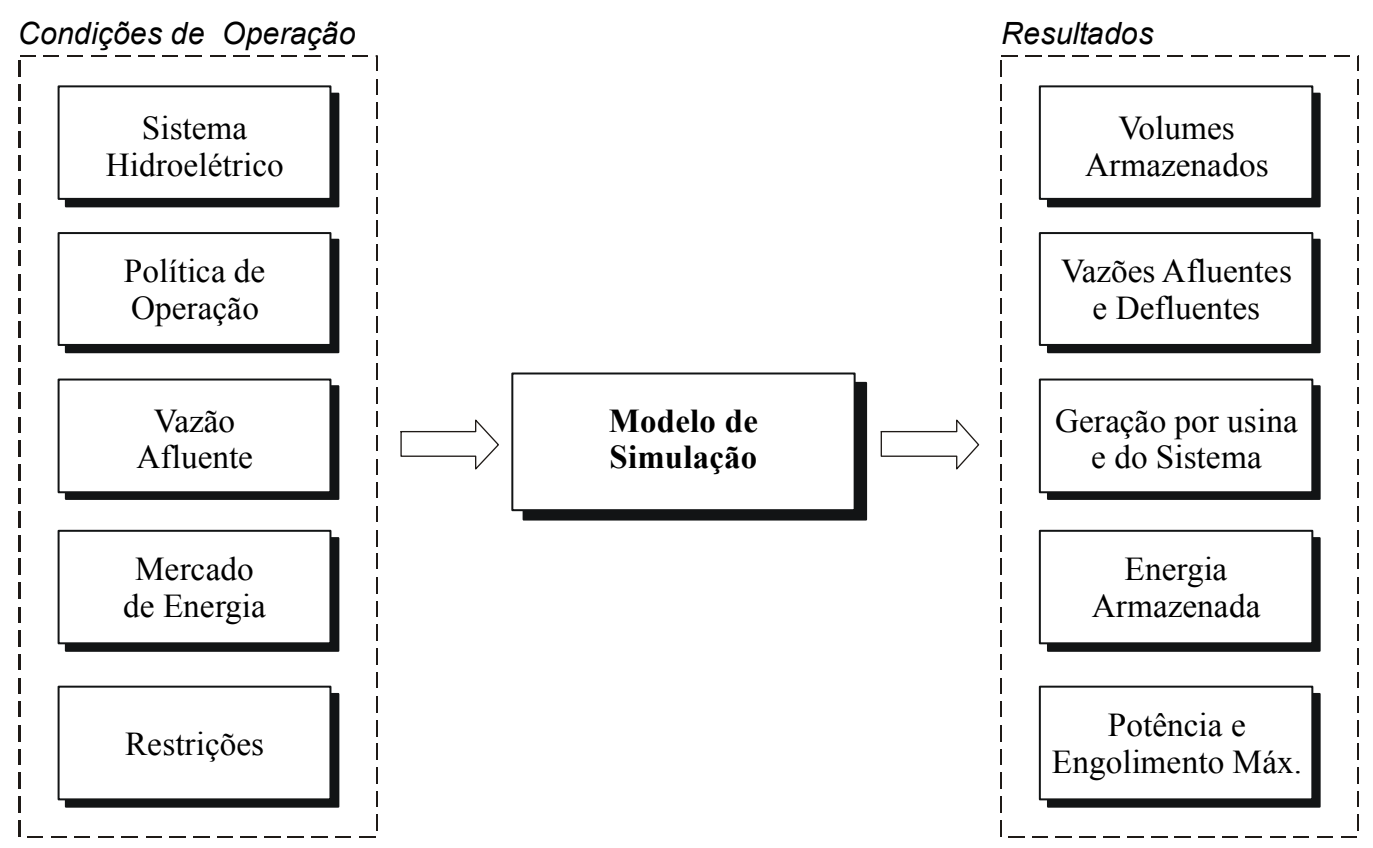

Figura 6.6 - Condições de operação e resultados do modelo de simulação.

- Sistema Hidroelétrico

A primeira condição de operação a ser definida é o próprio sistema de geração utilizado nos estudos. O usuário pode definir as usinas que farão parte do sistema, escolhendo entre qualquer combinação envolvendo as usinas pertencentes à base de dados do modelo.

\section{- Política de Operação}

Depois de escolhido o sistema hidroelétrico, é necessário que seja selecionada uma política de operação. Entende-se por política de operação um conjunto de regras de operação, uma para cada usina a reservatório do sistema hidroelétrico, que define como as usinas a reservatório vão trabalhar de forma acoplada.

A política de operação do sistema é especificada pelas usinas com reservatório de acumulação porque sob o ponto de vista da operação energética, exceto por pequenas variações de volume, praticamente não há controle direto sobre as usinas a fio d'água. Somente as usinas com reservatório de acumulação podem variar a quantidade de água armazenada e alterar as vazões afluentes naturais do sistema. O problema que surge é como operar os reservatório de forma conjunta, "enxergando" o efeito das decisões em todas as usinas $[97,98]$.

Uma idéia simples para realizar o acoplamento da operação do sistema de forma conjunta é definir um fator de acoplamento entre as usinas, denotado por $\lambda, 0 \leq \lambda \leq 1$, e fazer com que o volume de cada usina seja função deste fator. Uma regra que pode ser 
utilizada para a operação do sistema é a Regra Paralela (RP). Embora não haja critérios matemáticos ou mesmo intuitivos que a suportem como meio de utilização racional dos recursos hídricos, ela serve para ilustrar alguns aspectos da operação [21].

A RP estabelece que todos os reservatórios do sistema devem manter-se com a mesma porcentagem de seus volumes úteis. Se, por exemplo, para um determinado período de operação, tem-se $\lambda=0,3$, isto significa que todas as usinas com reservatório de acumulação devem apresentar neste período um volume equivalente a $30 \%$ de seus volumes úteis. Assim, o volume de cada usina pode ser escrito como:

$$
x(\lambda)=x_{\min }+\lambda \cdot\left(x_{\max }-x_{\min }\right)
$$

sendo:

- $\lambda$ : fator de acoplamento dos reservatórios, $0 \leq \lambda \leq 1$;

$-x(\lambda)$ : volume determinado em função do fator de acoplamento;

- $x_{\min }$ : volume mínimo operativo da usina;

- $x_{m a ́ x}$ : volume máximo operativo da usina;

- A diferença $\left(x_{\operatorname{máx}}-x_{\min }\right)$ é conhecida como volume útil da usina.

A forma da regra em paralelo pode ser visualizada na Figura 6.7. Como todos os reservatórios devem permanecer a uma mesma percentagem de seus volumes úteis, a RP pode ser representada por uma reta. Quando $\lambda=0$ a reta passa pelo volume mínimo do reservatório; quando $\lambda=1$ a reta passa pelo volume máximo do reservatório.

A política de enchimento/esvaziamento dos reservatórios é determinada fazendo com que todos os reservatórios obedeçam à Equação 6.5. Para explicar esse mecanismo, supõe-se inicialmente que somente as vazões afluentes naturais em um determinado período não são suficientes para fazer com que o sistema da Figura 6.5 supra o mercado de $800 \overline{\mathrm{MW}}$. Neste caso, as usinas com reservatório de acumulação deverão utilizar a água armazenada nos reservatórios para elevar a energia gerada. $\mathrm{O}$ esvaziamento é feito de forma que todos os reservatórios reduzam seus volumes em quantidades proporcionais às suas capacidades de armazenagem, mantendo o mesmo valor de $\lambda$, até que a vazão turbinada pelas usinas seja capaz de gerar energia elétrica a ponto de suprir o mercado $[23,24]$.

Por outro lado, se as vazões naturais afluentes são maiores que a quantidade de água necessária para atender ao mercado, o excesso de água deve ser armazenado, enchendo-se os reservatórios. De forma análoga ao esvaziamento, o enchimento é feito proporcionalmente às capacidades de armazenagem dos reservatórios, de modo que 
todos se mantenham com um mesmo $\lambda$, até que a água disponível para turbinagem seja exatamente a necessária para suprir a demanda.

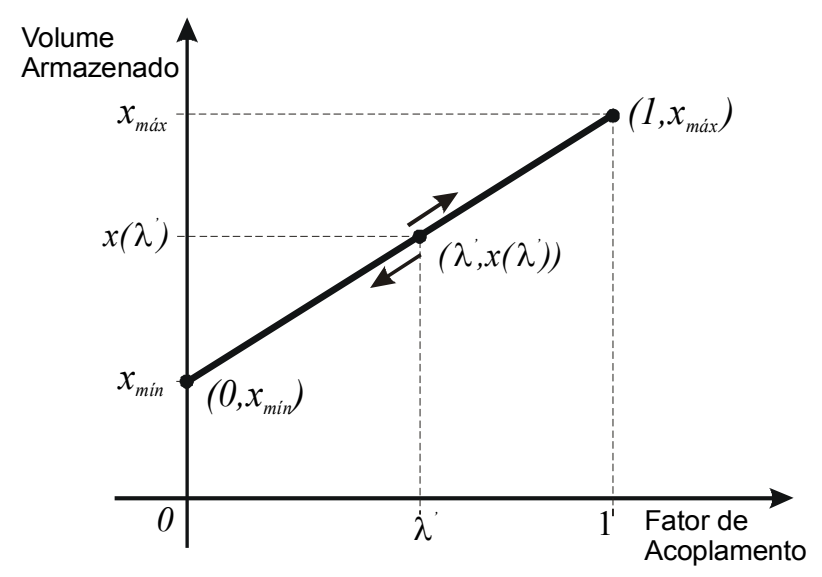

Figura 6.7 - Visualização da regra de operação em paralelo.

Durante as variações de $\lambda$ deve-se garantir que $0 \leq \lambda \leq 1$. Se durante 0 esvaziamento atinge-se $\lambda=0$, isso significa que todos os reservatórios estão em seus limites mínimos de armazenagem; se nessa condição a demanda ainda não estiver sido suprida, haverá um déficit de energia e o mercado não poderá ser completamente atendido. Da mesma forma, se durante o enchimento atinge-se $\lambda=1$, isso significa que todos os reservatórios estão em seus limites máximos de armazenagem; se ainda houver excesso de água, haverá vertimento.

Tem-se assim um método de operação dos reservatórios que é bastante simples e que permite que as decisões de quanto esvaziar ou encher cada reservatório sejam feitas de forma integrada, operando-se cada usina em função de um parâmetro global. Entretanto, embora a simplicidade dessa política de operação seja atraente, de acordo com os resultados encontrados pelo otimizador determinístico mostrados na Seção 1, nota-se que as usinas a reservatório possuem padrões diferenciados de comportamento durante a operação ótima do sistema. As usinas a montante esvaziam-se mais, regularizando as vazões afluentes, enquanto as usinas a jusante mantém-se cheias, com produtividade elevada [25].

Para incorporar critérios de otimalidade às regras de operação e, ao mesmo tempo, manter a simplicidade da regra anterior, inicialmente define-se o fator de acoplamento da operação como a energia armazenada no sistema. Estabelece-se assim uma relação física entre as variáveis a serem utilizadas na regra: o dado de entrada é a energia armazenada no sistema e a resposta determinada pela regra é o volume de cada reservatório. Para facilitar as análises, os volumes são expressos em p.u. (por unidade); 
assim, quando o volume é zero, a usina está em seu volume mínimo, e quando o volume é um, a usina está em seu volume máximo.

Dois pontos da regra de operação são automaticamente determinados pela própria definição: quando o volume de todos os reservatórios é um, a energia armazenada também é um; quando o volume de todos os reservatórios é zero, a energia armazenada também é zero. Assim, os pontos $(0,0)$ e $(1,1)$ fazem parte da regra de cada usina. Resta agora estabelecer como será feita a união entre estes dois pontos. Sabe-se que a união destes pontos através de uma reta é a operação em paralelo, bastante simples, mas longe de expressar o que é esperado da operação ótima.

Sob o ponto de vista matemático, esta nova regra de operação pode ser entendida como uma generalização da Equação 6.4. Ao invés do parâmetro $\lambda$, cada usina $i$ possui uma função deste parâmetro, $f_{i}(\lambda)$, tal como indicado na equação abaixo. Estas funções expressam as regras de enchimento/esvaziamento de cada reservatório e precisam ser determinadas com base nos resultados dos estudos de otimização.

$$
x_{i}(\lambda)=x_{\min , i}+f_{i}(\lambda) \cdot\left(x_{\operatorname{má} x, i}-x_{\min , i}\right)
$$

A função $f_{i}(\lambda)$ deve satisfazer às restrições já comentadas:

$$
\left\{\begin{array}{l}
f_{i}(0)=0 \\
f_{i}(1)=1
\end{array}\right.
$$

Para facilitar a explicação de como as regras são determinadas, as regras das usinas de Jurumirim, Chavantes e Capivara serão determinadas passo a passo. Segundo a metodologia utilizada nesse trabalho, o sistema completo composto por todas as usinas deve ser inicialmente otimizado sobre as mais diversas condições hidrológicas possíveis. Para o estudo de caso utilizou-se o histórico de afluências mensais com dados de 1931 a 2000. O mercado de energia atendido foi constante e igual a $1800 \overline{\mathrm{MW}}$; o período inicial foi abril de 1931 e o final foi março de 2000; nesses dois períodos estipulou-se que os reservatórios deveriam estar cheios, com volumes iguais a 1 p.u..

Para cada um dos 828 meses de operação, cada reservatório possui um valor de volume e o sistema possui um valor de energia armazenada. Plotando-se os volumes dos reservatórios em função da energia armazenada do sistema têm-se as nuvens de pontos mostradas nas próximas figuras [111]. 


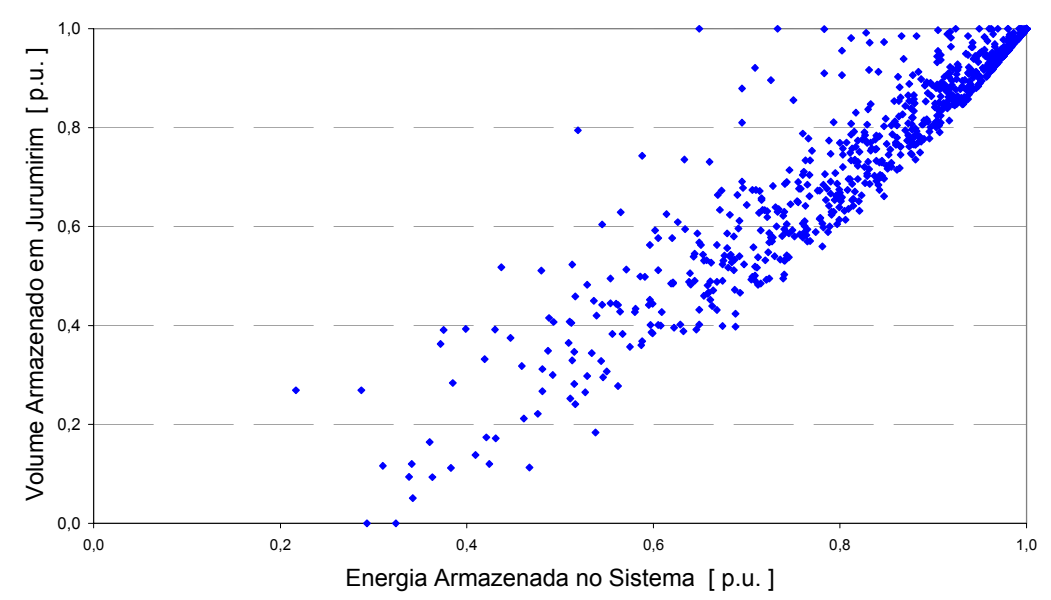

Figura 6.8 - Nuvem de pontos da usina de Jurumirim.

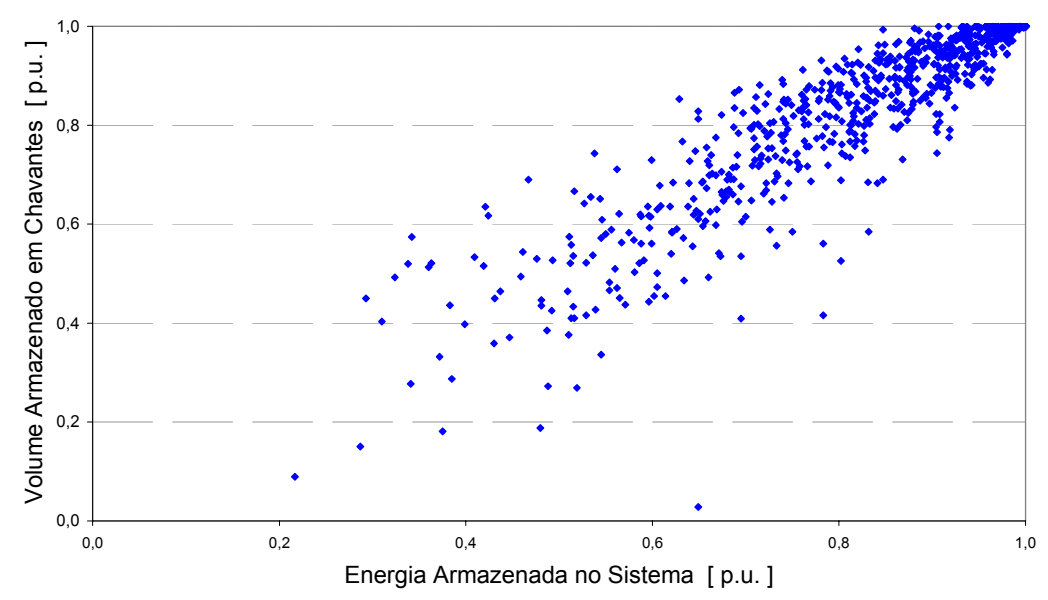

Figura 6.9 - Nuvem de pontos da usina de Chavantes.

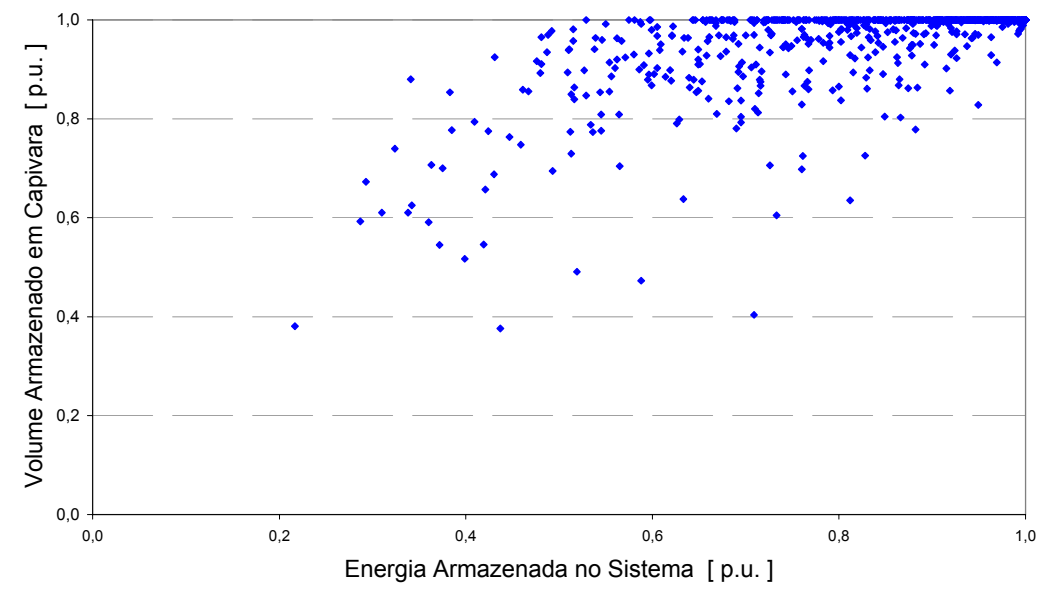

Figura 6.10 - Nuvem de pontos da usina de Capivara. 
As nuvens de pontos apresentadas nos três gráficos anteriores possuem características distintas. A nuvem de pontos da usina de Jurumirim apresenta-se mais concentrada na parte inferior do gráfico; a nuvem de pontos da usina de Capivara apresenta-se mais concentrada na parte superior do gráfico; já a usina de Chavantes apresenta um comportamento intermediário, com os pontos concentrados no centro do gráfico [103, 104].

Observando a posição que cada usina ocupa no sistema, vê-se que Jurumirim é uma usina de cabeceira, Chavantes é uma usina intermediária e Capivara é uma usina de jusante. De fato, as nuvens de pontos estão dizendo que Capivara mantém-se cheia a maior parte do tempo, reduzindo seu volume somente quando a situação do sistema é realmente crítica, isto é, quando a energia armazenada é realmente baixa. Por outro lado, Jurumirim reduz o volume de água armazenado em seu reservatório tão logo a energia armazenada no sistema reduz-se, indicando que sempre que o sistema precisa esvaziar-se, essa usina é a primeira a esvaziar-se. Já Chavantes apresenta um comportamento intermediário; sua redução em volume não é tão rápida quanto a de Jurumirim, mas também não é tão lenta quanto a de Capivara.

De certo modo, os comportamentos apresentados no parágrafo anterior já haviam sido discutidos anteriormente, quando os resultados do operador determinístico foram mostrados e analisados. Assim, as regras de operação baseadas em critérios ótimos nada mais são que a utilização dos padrões ótimos de comportamento dos reservatórios na definição das políticas de operação do sistema. A questão agora é como utilizar as nuvens de pontos para realizar a operação do sistema.

$\mathrm{Na}$ realidade, as nuvens de pontos não serão utilizadas diretamente; sobre estas nuvens serão ajustadas curvas que representam, pelo menos em média, o comportamento ótimo dos reservatórios. O ajuste das curvas pode ser feito de diferentes modos, tal com o ilustrado em [20, 21, 23]. Neste trabalho será empregada uma técnica chamada Método da Montanha [119, 120], explicada no Anexo B.

A aplicação do Método da Montanha às nuvens de pontos das usinas de Jurumirim, Chavantes e Capivara gera as funções $f_{i}(\lambda)$ mostradas na Figura 6.11. Dependendo da disponibilidade de água no sistema e da demanda total a ser atendida pelas usinas, pode ser preciso estocar o excedente de água ou utilizar água armazenada nos reservatórios. Tanto o enchimento quanto o esvaziamento do sistema são realizados variando-se $\lambda$ e fazendo com que o volume de cada usina seja determinado por sua respectiva função $f_{i}(\lambda)$. 


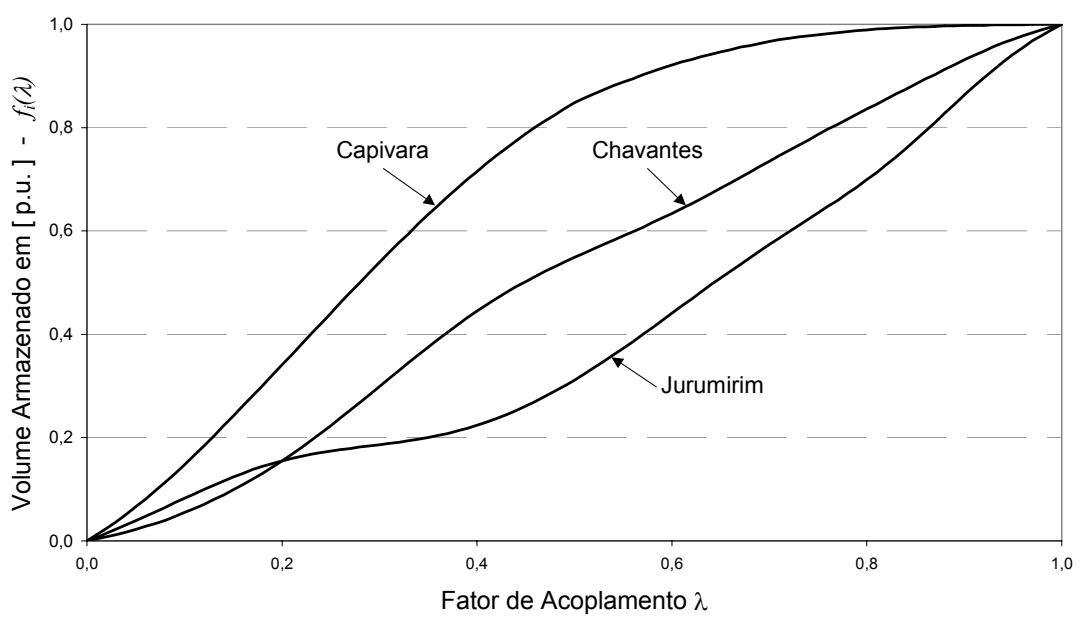

Figura 6.11 - Política de operação para as três usinas a reservatório do rio Paranapanema.

\section{- Vazões Afluentes}

O próximo passo é a definição da quantidade de água disponível para o sistema hidroelétrico durante a simulação. Esta definição é realizada especificando-se o período de simulação.

O usuário possui três opções para definir o período de simulação. Na primeira opção define-se um período do histórico de vazões afluentes médias mensais. Definemse os meses e anos iniciais e finais do estudo, as vazões são carregadas pelo programa e a simulação é realizada como se para cada mês do estudo se repetissem as vazões medidas no passado.

A segunda opção refere-se à utilização da Média de Longo Termo (MLT) das vazões afluentes. A MLT corresponde à média das vazões afluentes médias mensais. A vazão MLT da usina de Jurumirim para o mês de janeiro, por exemplo, corresponde à média das vazões de todos os meses de janeiro registrados no histórico para esta usina.

Quando as MLTs de todos os meses são colocadas juntas, tem-se um ano de vazões da MLT para cada usina hidroelétrica. Este um ano de vazões é então utilizado para criar séries de vazões afluentes de quaisquer comprimentos, simplesmente repetindo-se os anos de vazões afluentes iguais à MLT. Assim, por exemplo, para um estudo de 24 meses, iniciando-se em abril e possuindo vazões afluentes iguais à MLT, o primeiro valor de vazão será a MLT de abril, depois a de maio, junho, ... , dezembro, janeiro, fevereiro, março, abril, ..., março. Totalizando os dois anos desejados! Também podem ser utilizadas porcentagens da MLT, podendo assim configurar períodos mais cheios ou mais secos.

Nas opções um e dois, os dados utilizados são fornecidos automaticamente pelo 
programa através dos registros do histórico de vazões afluentes. Se o usuário desejar fornecer valores de vazão afluente diretamente ao programa, ele deve utilizar a terceira opção, na qual ele pode importar dados de planilhas geradas pelo programa Excel da Microsoft ou digitar os valores de vazão. Esta opção é particularmente interessante para realização de estudos com vazões previstas ou com séries sintéticas de vazões.

\section{- Mercado de Energia}

Depois de definir o sistema hidroelétrico, a política de operação e o período contendo os dados de vazão afluente, é necessário definir o mercado de energia a ser atendido a cada intervalo da simulação.

A definição do mercado de energia é feita especificando-se uma demanda média mensal. Esta demanda pode ser constante ou podem ser definidos fatores de sazonalidade que determinam como a demanda média varia para cada intervalo de tempo. Similarmente às vazões afluentes, o usuário também pode importar os dados de arquivos ou planilhas.

\section{- Restrições}

Finalmente, definem-se restrições operativas para as usinas. Estas restrições podem relacionar-se a valores de volume mínimo e máximo, de vazão defluente mínima e máxima, e de geração mínima e máxima. Estas restrições aplicam-se a cada usina e são consideradas na simulação de todos os intervalos do estudo de simulação.

Uma vez definidas todas as condições de realização do estudo de simulação, o programa está apto a iniciar o processo iterativo em que se simula de fato a operação do sistema hidroelétrico.

\subsubsection{Processo Iterativo}

Por processo iterativo entende-se o conjunto de operações realizadas em cada intervalo de tempo da simulação de forma a fazer com que a demanda seja atendida pelo sistema hidroelétrico, utilizando-se a quantidade de água disponível e respeitando-se as restrições impostas às usinas.

Na Figura 6.12 ilustra-se de forma simplificada todas as etapas do processo iterativo. Na seqüência cada etapa mostrada na figura é explicada. Define-se como $T$ o número de intervalos do período de simulação e como $t$ o intervalo sendo simulado. 


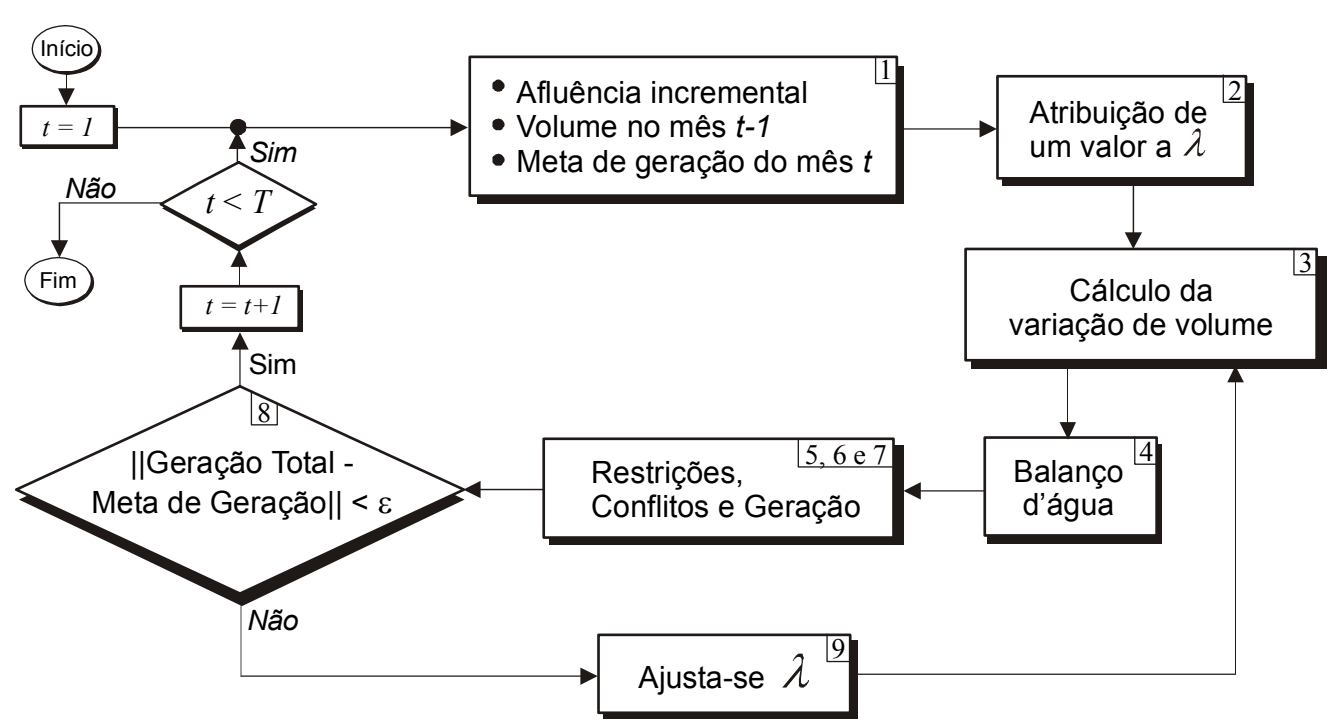

Figura 6.12 - Algoritmo Simplificado do Processo Iterativo.

1. Dados iniciais do intervalo:

- Atualizam-se os valores de vazões naturais afluentes e vazões incrementais, os dados de volume no mês anterior e a meta de geração no mês atual de cada usina hidroelétrica.

2. Atribuição do valor inicial a $\lambda$ :

- O valor inicial de $\lambda$ é feito igual ao valor da energia armazenada no sistema em p.u.. Este cálculo é realizado dividindo-se a energia armazenada no sistema ao final do intervalo $t-1$ pela energia armazenada máxima no sistema.

3. Cálculo dos volumes pela política:

- O valor de $\lambda$ é utilizado pela política e tem-se assim o valor de volume armazenado de cada usina para o intervalo $t$.

4. Balanço d'água:

- Conhecendo-se os volumes ao final do intervalo $t$ e as vazões afluentes a cada reservatório durante este intervalo, determinam-se os valores de vazão defluente de cada usina através da equação de balanço d'água ou equação de conservação de massa.

5. Cálculo das restrições:

- Limites de geração:

Neste caso é necessário que sejam determinados os valores mínimo e máximo de geração média de cada usina ao longo do intervalo $t$. Estes valores podem ser relacionados a restrições físicas da própria usina ou a 
restrições externas, impostas pelo usuário, como por exemplo, restrições elétricas. Consideram-se as seguintes variáveis:

- $\quad p e_{\min , i}$ : geração elétrica mínima da usina $i$, em $\overline{\mathrm{MW}}$, fornecida pelo usuário como restrição elétrica. $\mathrm{O}$ valor padrão para esta restrição é zero.

- $\quad p e_{\text {máx, } i}$ : geração elétrica máxima da usina $i$, em $\overline{\mathrm{MW}}$, fornecida pelo usuário como restrição elétrica. $\mathrm{O}$ valor padrão para esta restrição é a potência instalada da usina.

- $\quad p_{\text {máx,con,i }}$ : geração hidráulica máxima contínua da usina $i$, em $\overline{\mathrm{MW}}$.

Este valor é determinado considerando-se a potência disponível, o fator de carga, e as taxas de indisponibilidade forçada e programada da usina (seção 1.4 do Capítulo V).

Os limites mínimo e máximo de geração da usina $i, p_{m i n, i}$ e $p_{\text {máx, }, i}$ respectivamente, são calculados da seguinte forma:

$$
\left\{\begin{array}{l}
p_{\text {máx }, i}=\min \left(p e_{\text {máx }, i}, p_{\text {máx } x \text { con }, i}\right) \\
p_{\text {min }, i}=\min \left(p e_{\text {min }, i}, p_{\text {máx }, i}\right)
\end{array} \quad[\overline{\mathrm{MW}}]\right.
$$

- Limites de geração:

Inicialmente, os limites mínimo e máximo de geração, $p_{m i n, i}$ e $p_{m a ́ x, i}$, são transformados em limites de vazão turbinada, $q e_{\text {min,i }}$ e $q e_{\text {máx, }, i}$ respectivamente. Esta transformação é feita utilizando-se uma estimativa da produtividade média da usina, denotada por $\hat{\rho}_{i}$. As equações utilizadas são:

$$
\begin{aligned}
& \left\{\begin{array}{l}
q e_{\text {min }, i}=\frac{p_{\min , i}}{\hat{\rho}_{i}} \quad\left[\mathrm{~m}^{3} / s\right] \\
q e_{\text {máx }, i}=\frac{p_{\operatorname{máx}, i}}{\hat{\rho}_{i}}\left[\mathrm{~m}^{3} / \mathrm{s}\right]
\end{array}\right. \\
& \hat{\rho}_{i}=p e_{i} \cdot \hat{h}_{l i} \quad\left[\frac{\mathrm{MW}}{\left(\mathrm{m}^{3} / \mathrm{s}\right)}\right] \\
& \hat{h}_{l i}=h_{\text {mon }, i}\left(x_{i}(t)\right)-c f_{\text {med }, i}-h_{p, \text { méd }, i} \quad[\mathrm{~m}]
\end{aligned}
$$

sendo:

- $p e_{i}$ : produtibilidade específica da usina $i$, em $M W /\left(m^{3} / s\right) \cdot m$;

- $\hat{h}_{l i}$ : estimativa da altura de queda líquida da usina $i$, em $m$; 
- $h_{\text {mon, } i}\left(x_{i}(t)\right)$ : cota de montante da usina $i$, em $m$, calculada com base no volume de água armazenado no reservatório, $x_{i}(t)$, em $\mathrm{hm}^{3}$;

- $c f_{\text {méd, }, i}$ : cota média do canal de fuga da usina $i$, em $m$;

- $h_{p, \text { méd, }, i}$ : perda de carga média da usina $i$, em $m$.

Os vazões limites $q e_{\min , i}$ e $q e_{\text {máx, } i}$ referem-se às vazões turbinadas e consideram os limites de geração da usina e as restrições elétricas do sistema.

Adicionalmente a estas restrições, consideram-se também os limites mínimo e máximo, $u_{\text {min }, i}$ e $u_{\text {máx }, i}$, respectivamente, impostos à vazão total defluente da usina:

$$
\begin{cases}u_{\min , i}=\operatorname{máx}\left(u e_{\min , i}, q_{\min , i}\right) & {\left[\mathrm{m}^{3} / s\right]} \\ u_{\operatorname{máx}, i}=\min \left(u e_{\max , i}, q_{\max , i}\right) & {\left[\mathrm{m}^{3} / s\right]}\end{cases}
$$

sendo:

- $u e_{m i n, i}$ : vazão defluente mínima, fornecida pelo usuário, em $\mathrm{m}^{3} / \mathrm{s}$;

- ue máx,i : vazão defluente máxima, fornecida pelo usuário, em $\mathrm{m}^{3} / \mathrm{s}$;

- Limites de volume armazenado:

O usuário ainda pode especificar restrições de volume armazenado mínimo e máximo, $x e_{\text {min, } i}$ e $x e_{\text {máx, }}$, em $h m^{3}$. Estes valores são comparados com os volumes mínimo e máximo operativos da usina, $x_{\min , i}$ e $x_{\text {máx }, i}$, e determinam-se então os valores finais adotados como restrições de volume:

$$
\begin{cases}x a_{\text {min }, i}=\operatorname{máx}\left(x e_{\min , i}, x_{\min , i}\right) & {\left[\mathrm{hm}^{3}\right]} \\ x a_{\text {máx }, i}=\min \left(x e_{\text {máx }, i}, x_{\text {máx }, i}\right) & {\left[\mathrm{hm}^{3}\right]}\end{cases}
$$

6. Resolução de conflitos:

A resolução de conflitos presta-se a ajustar a decisão da política de operação às restrições operativas do sistema. Quando há falta de água em uma usina, tenta-se buscar água em seu reservatório e nas usinas de montante. Se há excesso de água em uma usina, tenta-se armazenar o excesso; caso isto não seja possível, há vertimento. O processo é realizado seguindo-se uma lista de prioridades: 
- Restrições de vazão turbinada máxima;

- Restrições de volume mínimo e máximo;

- Restrições de vazão defluente mínima;

- Restrições de vazão defluente máxima;

7. Cálculo de geração:

Calcula-se a geração de cada usina através de sua função de geração. $\mathrm{Na}$ seqüência calcula-se a geração total do sistema hidroelétrico, de $H(t)$, calculada pela Equação 6.4.

8. Comparação com a meta de geração:

Se a geração total for igual à meta de geração, incrementa-se $t$; caso contrário, altera-se $\lambda$ de duas possíveis formas:

- Excesso de geração: se a geração hidroelétrica total $H(t)$ é maior que o mercado $D(t)$, eleva-se $\lambda$ de forma a armazenar o excesso de água e reduzir a vazão turbinada, com conseqüente redução de geração. Se $\lambda$ igualar-se a um, indicando que todos os reservatórios estão cheios, e ainda houver excesso de água, este excesso é vertido.

- Déficit de geração: se a geração hidroelétrica total $H(t)$ é menor que o mercado $D(t)$, reduz-se $\lambda$ de forma a utilizar a água dos reservatórios e elevar a vazão turbinada, com conseqüente elevação da geração. Se $\lambda$ igualar-se a zero, indicando que todos os reservatórios estão vazios, e ainda a geração total do sistema for menor que o mercado, caracteriza-se um déficit de suprimento.

9. Ajuste de $\lambda$ :

$\mathrm{O}$ ajuste de $\lambda$ pode ser feito da seguinte forma:

$$
\lambda=\lambda+\alpha \cdot \frac{(H(t)-D(t))}{D(t)}
$$

na qual $\alpha$ é uma constante positiva, cujo valor determina a intensidade da variação de $\lambda$.

\subsubsection{Resultados}

Após a realização da simulação em todo o horizonte de estudo, o simulador gera um conjunto de resultados que retrata como foi realizada a operação em cada usina hidroelétrica e no sistema de forma geral. 
Para o sistema de forma geral os resultados referem-se a quatro variáveis: geração total do sistema, demanda, energia armazenada no sistema e fator de acoplamento.

Para cada usina são gerados os seguintes resultados para cada intervalo de simulação: volume de água armazenado no reservatório, vazão afluente natural, vazão afluente durante a simulação (considerando a operação dos reservatórios), vazão turbinada, vazão vertida, vazão defluente, potência disponível, engolimento máximo, geração, energia armazenada, nível de montante, nível de jusante e perda de carga.

\subsubsection{Exemplo}

Para exemplificar a simulação da operação de um sistema hidroelétrico de geração são realizados alguns estudos com o sistema mostrado na Figura 6.3. Todos os estudos possuem horizontes de cinco anos discretizados mensalmente com vazões afluentes iguais à MLT, restrições de volume iguais aos limites operativos, restrições de geração mínima e máxima iguais respectivamente a zero e à potência instalada de cada usina, e restrições de vazão defluente mínima e máxima iguais a zero e a infinito.

Inicialmente o mercado de energia é feito igual a $650 \overline{\mathrm{MW}}$ e a política de operação adotada é aquela mostrada na Figura 6.11. Na Figura 6.13 pode-se observar a demanda de energia, reta horizontal indicando $650 \overline{\mathrm{MW}}$, e a geração do sistema, reta tracejada. Notam-se alguns períodos em que a geração é maior que a demanda, indicando que o sistema poderia atender a cargas maiores porque há vazão disponível que não pode ser armazenada; se houvesse espaço para armazenagem nos reservatórios, a geração durante os picos seria reduzida e a água seria armazenada. No entanto, como a carga é de apenas $650 \overline{\mathrm{MW}}$, ocorre vertimento de vazões que poderiam ser turbinadas, caracterizando o chamado vertimento turbinável. 


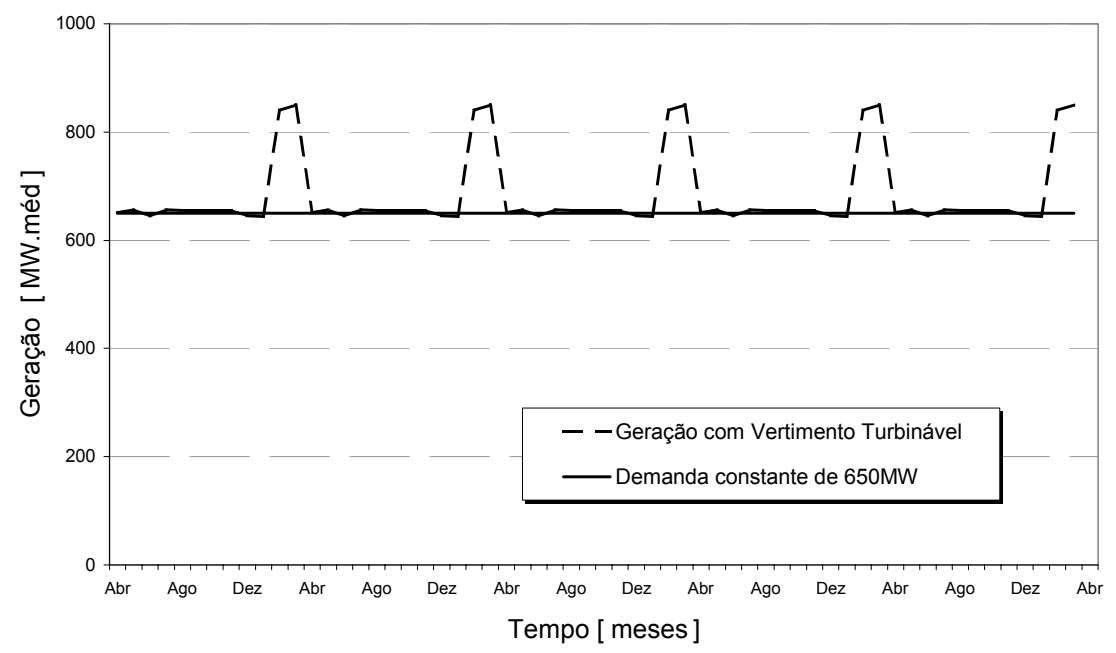

Figura 6.13 - Geração e demanda do sistema para um mercado de 650MW.

Na Figura 6.14 apresentam-se as trajetórias de volume das três usinas. Nota-se pelas trajetórias de volume que a simulação utilizando a $\mathrm{RO}$ segue os princípios da operação ótima discutidos anteriormente: Jurumirim, a usina mais a montante, varia de forma intensa a quantidade de água armazenada no reservatório; Capivara, a usina mais a jusante, mantém-se praticamente cheia com produtividade máxima; e Chavantes apresenta comportamento intermediário. A regularização das vazões afluentes naturais da usina de Capivara pode ser observada na Figura 6.15, onde são observadas vazões afluentes durante a simulação que variam de forma menos intensa que as vazões afluentes naturais.

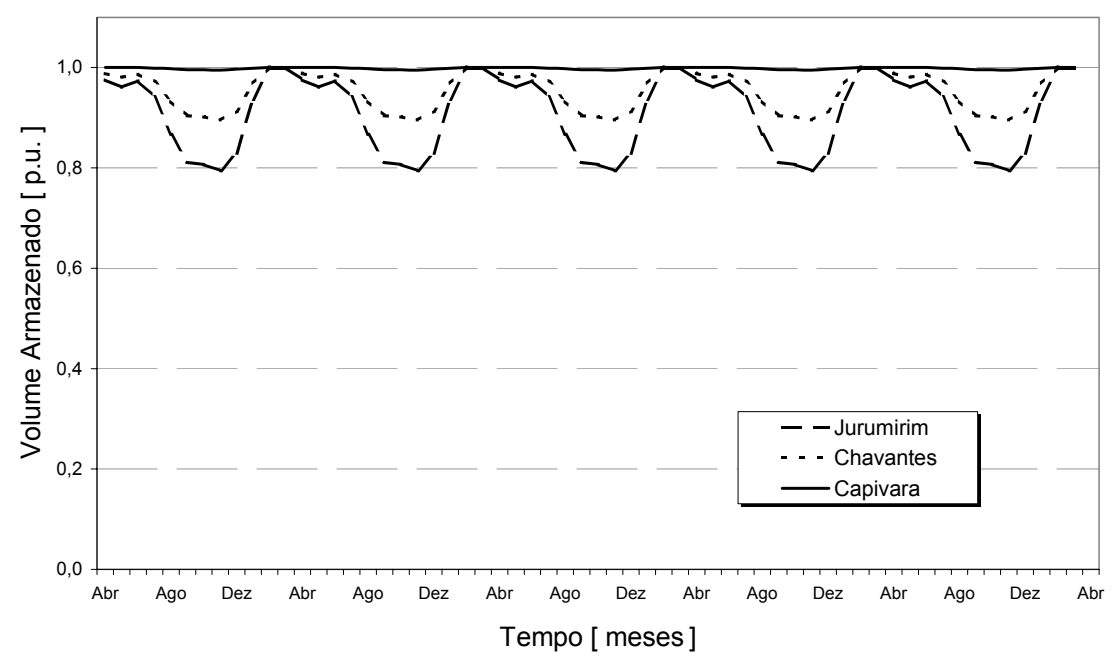

Figura 6.14 - Trajetórias de volume para um mercado de 650MW. 


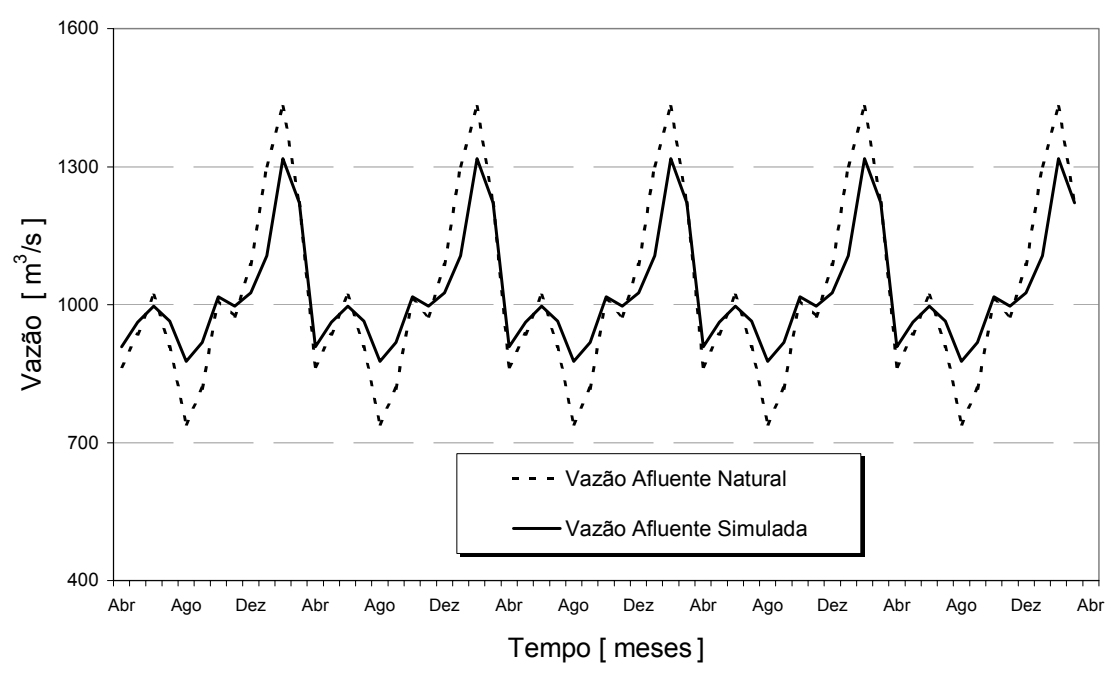

Figura 6.15 - Vazão afluente natural e vazão afluente simulada para a usina de Capivara.

Na Figura 6.16 apresentam-se três trajetórias de energia armazenada no sistema para três simulações realizadas sob as mesmas condições das anteriores, alterando-se apenas os mercados de energia atendidos. Nota-se um resultado de certa forma previsível: como as condições iniciais são as mesmas e as vazões afluentes são as mesmas em cada teste, conforme o mercado a ser atendido cresce, o volume de água acumulado nas usinas passa a ser utilizado de forma mais intensa, reduzindo assim a energia armazenada no sistema. Logo, para o maior mercado, $690 \overline{\mathrm{MW}}$, a quantidade de energia armazenada ao final do quinto ano é bem menor que para o mercado de $650 \overline{\mathrm{MW}}$. Em outras palavras, para atender ao mercado maior, utilizou-se mais água estocada nos reservatórios. O que pode não ser previsível é a procedência desta água, isto é, os reservatórios que foram esvaziados. Comparando a Figura 6.17 e a Figura 6.18 , nota-se que o volume armazenado de Jurumirim é bem mais sensível às variações de mercado que o volume armazenado em Capivara. Isto resulta da preocupação da operação ótima de manter as usinas de jusante o mais cheias possível para elevar a produtividade do sistema como um todo. Quando a carga eleva-se, primeiro utiliza-se a água das usinas de montante; esta água percorre a cascata e quando passa pelas usinas de jusante as encontra com altas alturas de quedas, altas produtividades, elevando a eficiência da geração do sistema como um todo. 


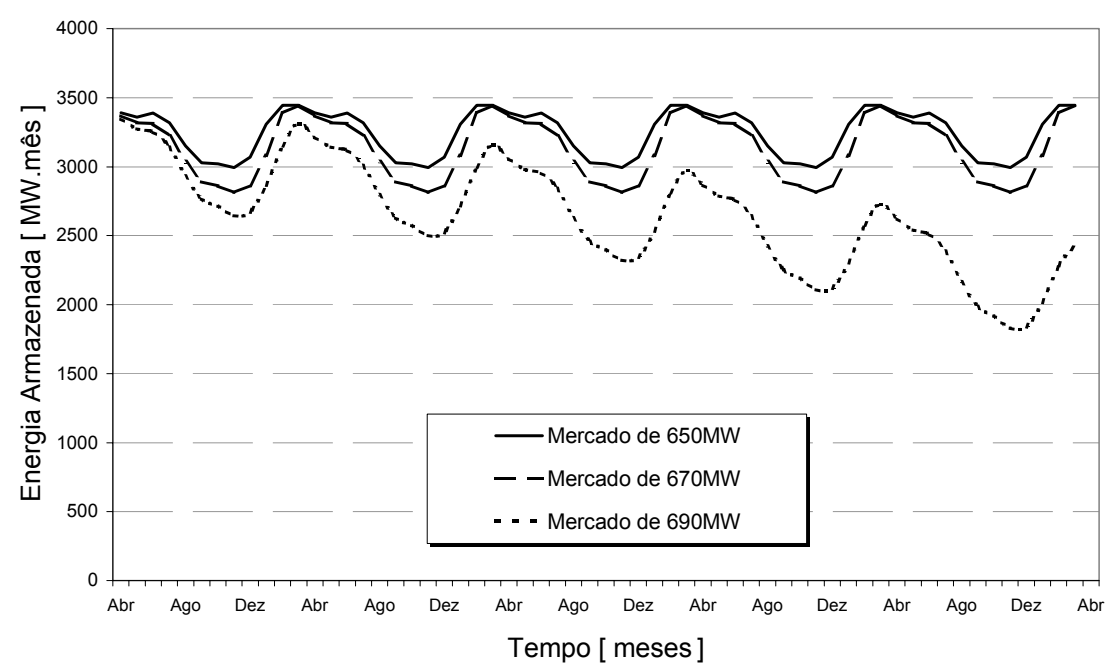

Figura 6.16-Energia armazenada no sistema para diferentes mercados.

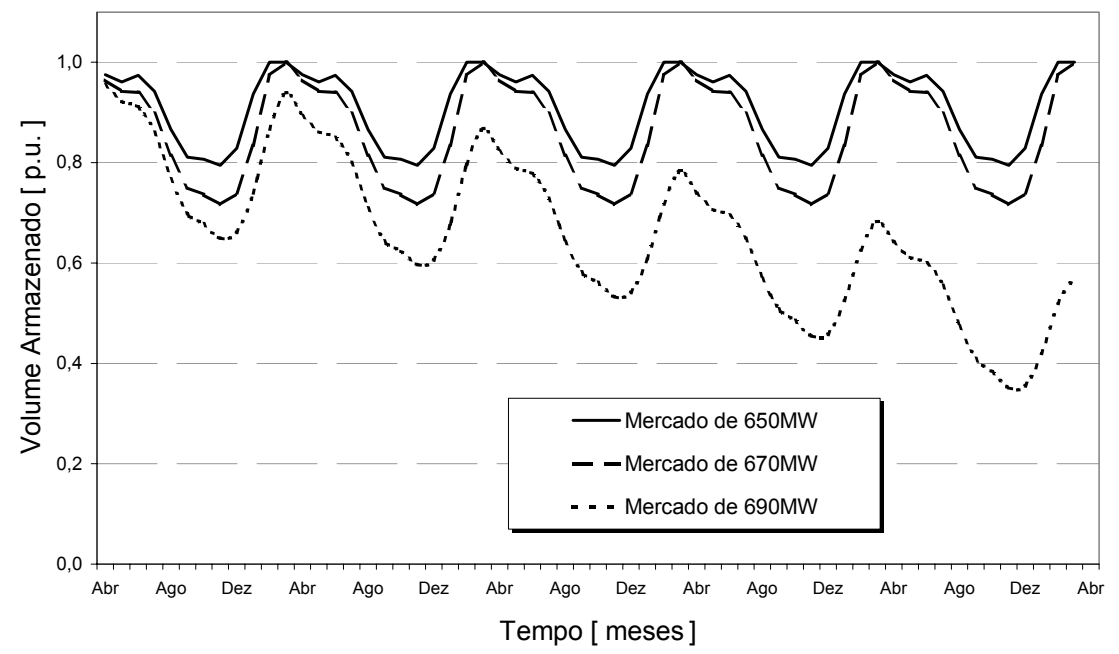

Figura 6.17 - Volume armazenado em Jurumirim para diferentes mercados.

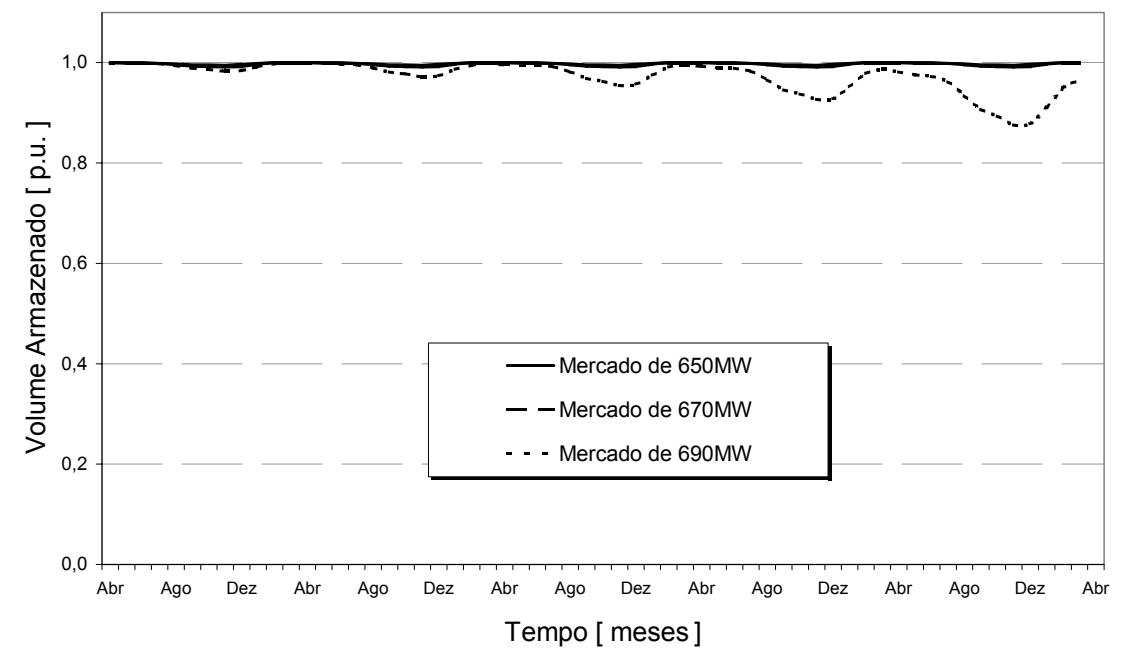

Figura 6.18 - Volume armazenado em Capivara para diferentes mercados. 
Finalmente, comparam-se duas políticas de operação: a Regra Paralela (RP) e a Regra baseada em Otimização (RO). Para realizar esta comparação, dois estudos foram feitos sob as mesmas condições de operação, exceto pelo fato de serem utilizadas duas políticas de operação diferentes. As condições de operação iguais aos dois estudos incluem vazões afluentes iguais à MLT, estados iniciais dos reservatórios iguais a 1 p.u. e mercado de energia igual a $690 \overline{\mathrm{MW}}$. Como os estados iniciais, as vazões afluentes e o mercado são idênticos, diferenças de comportamento provirão exclusivamente das políticas de operação. Na Figura 6.19 observa-se a energia armazenada no sistema ao longo dos cinco anos de simulação para cada uma das políticas. Pela figura nota-se que o esvaziamento dos reservatórios é bem mais intenso quando se utiliza a RP, indicando que esta política necessita de mais água para atender ao mesmo mercado sob as mesmas condições de operação que a RO. Além disso, ao final do período nota-se que a RP não consegue atender a toda a carga requerida, havendo déficit que pode ser visualizado na Figura 6.20. Com a RO não há déficit e a carga é plenamente atendida ao longo de todo o período de cinco anos.

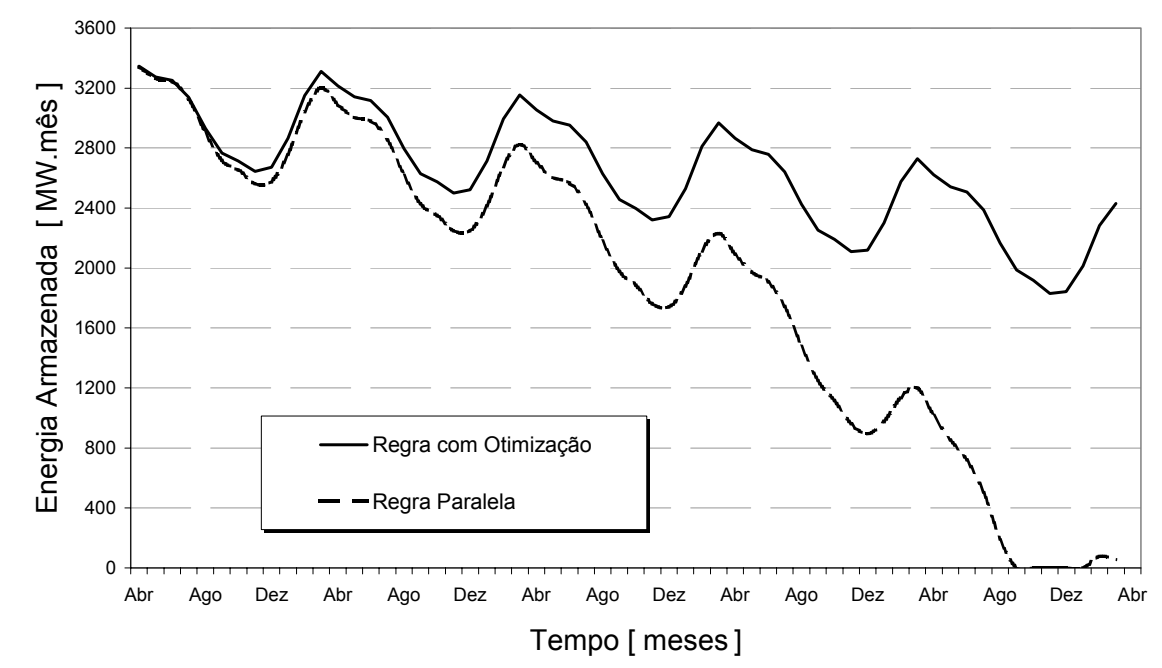

Figura 6.19 - Energia armazenada no sistema para mesmo mercado e diferentes políticas de operação. 


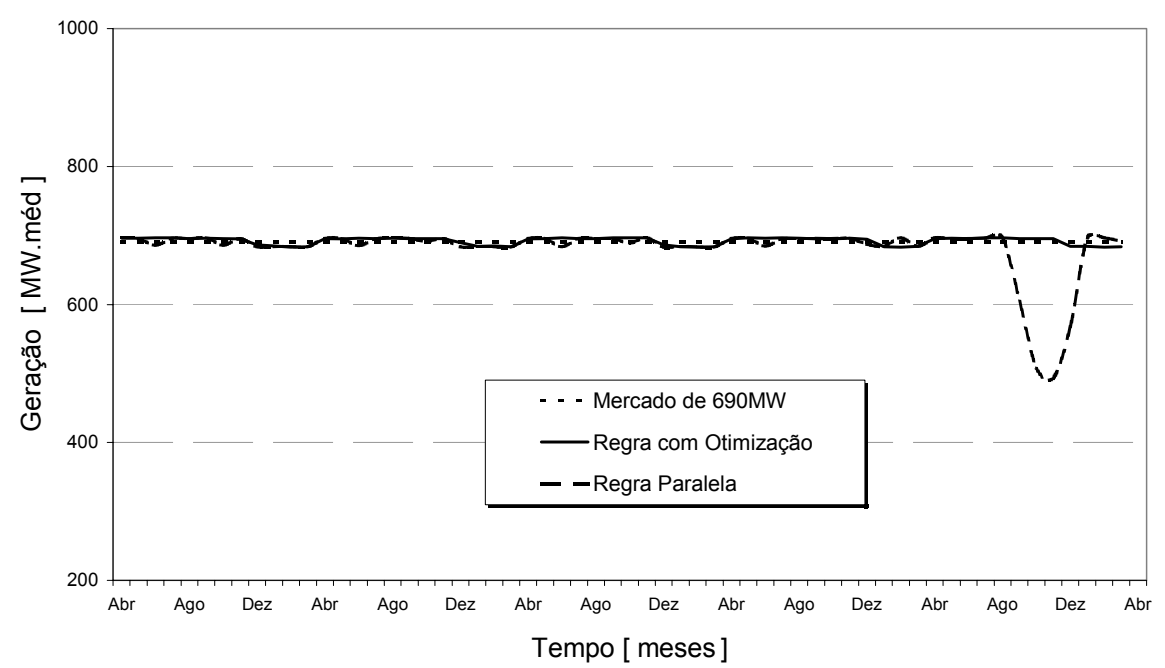

Figura 6.20 - Geração do sistema para mesmo mercado e diferentes políticas de operação.

\subsection{Simulação para Cálculo da Energia Firme}

Um dos critérios utilizados para determinar a capacidade de suprimento de um sistema hidroelétrico é o Critério Determinístico, baseado no conceito de Energia Firme.

Embora atualmente os valores contratuais das empresas do Setor Elétrico Brasileiro venham sendo calculados através de critérios probabilísticos, onde o conceito de Energia Firme foi, de certa forma, substituído pelo conceito de Energia Assegurada, o cálculo da Energia Firme com diferentes políticas de operação permite que as políticas de enchimento/esvaziamento sejam comparadas.

Assim, na próxima subseção apresenta-se como a Energia Firme é calculada e, em seguida, mostram-se os resultados encontrados para as usinas a reservatório da bacia do rio Paranapanema.

\subsubsection{Metodologia para Cálculo da Energia Firme}

Para explicar como a Energia Firme é calculada, utiliza-se a Figura 6.21, onde $N$ usinas hidroelétricas, $H_{1} \ldots H_{N}$, devem atender a um mercado global de energia $D$ [92]. 


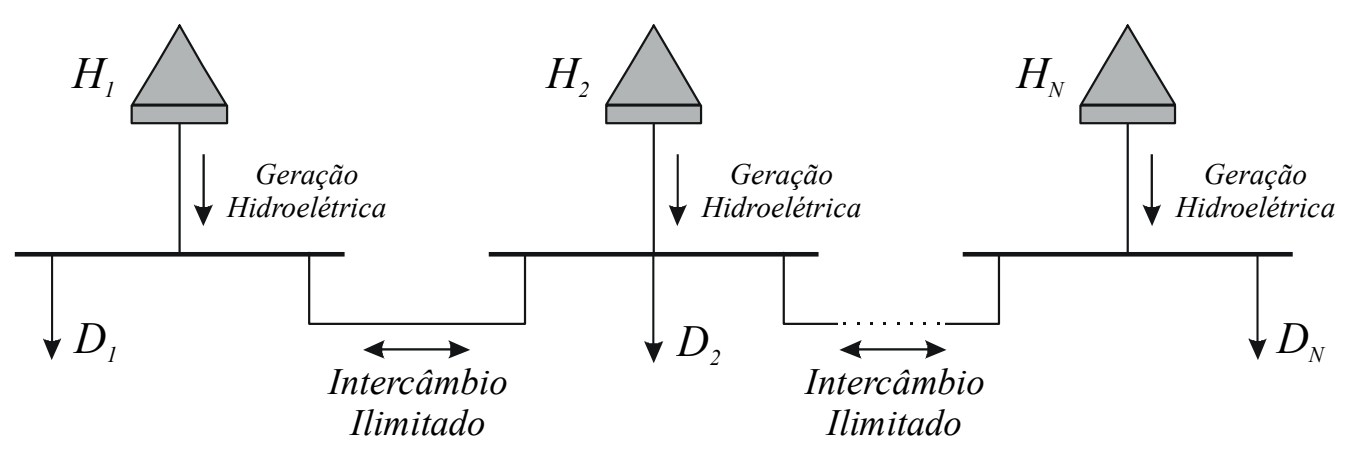

Figura 6.21 - Sistema para cálculo da Energia Firme.

Os passos para determinação dos benefícios energéticos são os seguintes:

1. Atribui-se um valor $D$ ao mercado global do sistema $\left(D=D_{1}+\ldots+D_{N}\right)$.

2. Simula-se a operação do sistema hidroelétrico com o histórico conhecido de vazões naturais, procurando-se atender ao mercado $D$ a cada mês.

3. Se não for possível atender ao mercado ao longo de toda a simulação, isto é, se houver déficit, reduz-se o valor de $D$ e retorna-se ao passo 2 . Se não houver déficit, há duas possibilidades:

i. Se houver sobras de energia armazenada, aumenta-se o valor de $D$ e retorna-se ao passo 2 .

ii. Se não houver sobras de energia, o valor de $D$, identificado como $D^{*}$, corresponde à Energia Firme, ou Carga Crítica do Sistema. Segue-se para o passo 4.

4. Identifica-se o período do histórico de vazões no qual o sistema hidroelétrico evoluiu de totalmente cheio para totalmente vazio, sem que o sistema voltasse a encher totalmente em períodos intermediários. Este é o Período Crítico. Calculam-se as gerações médias $E_{l} \ldots E_{N}$, das usinas $H_{1}$ $\ldots H_{N}$, respectivamente, ao longo do Período Crítico. Os valores $E_{l} \ldots E_{N}$ são as Energias Firmes das usinas:

$$
E_{i}=\frac{1}{N_{P C}} \cdot \sum_{k \in P C} p_{i}(k) \quad \text { para } i=1, \ldots, N
$$

sendo:

- $\quad P C$ - conjunto de meses pertencentes ao Período Crítico;

- $\quad N_{P C}$ - número de meses do Período Crítico;

- $\quad k$ - índice para os meses do Período Crítico;

- $\quad p_{i}(k)$ - geração da usina $i$ no mês $k$. 
5. Calcula-se a geração média de cada usina durante todo o histórico. A diferença entre a geração média e a Energia Firme de uma usina é chamada de Energia Secundária. A Energia Secundária corresponde ao aproveitamento de vazões afluentes maiores que as do Período Crítico, sendo utilizada na substituição da geração termoelétrica.

$$
\begin{aligned}
& E_{M, i}=\frac{1}{N_{H I S T}} \cdot \sum_{t \in H I S T} p_{i}(t) \quad \text { para } i=1, \ldots, N \\
& E_{S, i}=E_{M, i}-E_{i} \quad \text { para } i=1, \ldots, N
\end{aligned}
$$

sendo:

- $E_{S, i}$ - Energia Secundária da usina $i$;

- $\quad E_{M, i}$ - Geração Média da usina $i$ ao longo do histórico;

- $E_{i}$ - Energia Firme da usina $i$;

- HIST - conjunto de meses pertencentes ao histórico;

- $\quad N_{H I S T}$ - número de meses do histórico;

- $t$ - índice para os meses;

- $\quad p_{i}(t)$ - geração da usina $i$ no mês $t$.

Na Figura 6.22 ilustra-se o algoritmo utilizado para cálculo da Energia Firme de um sistema hidroelétrico.

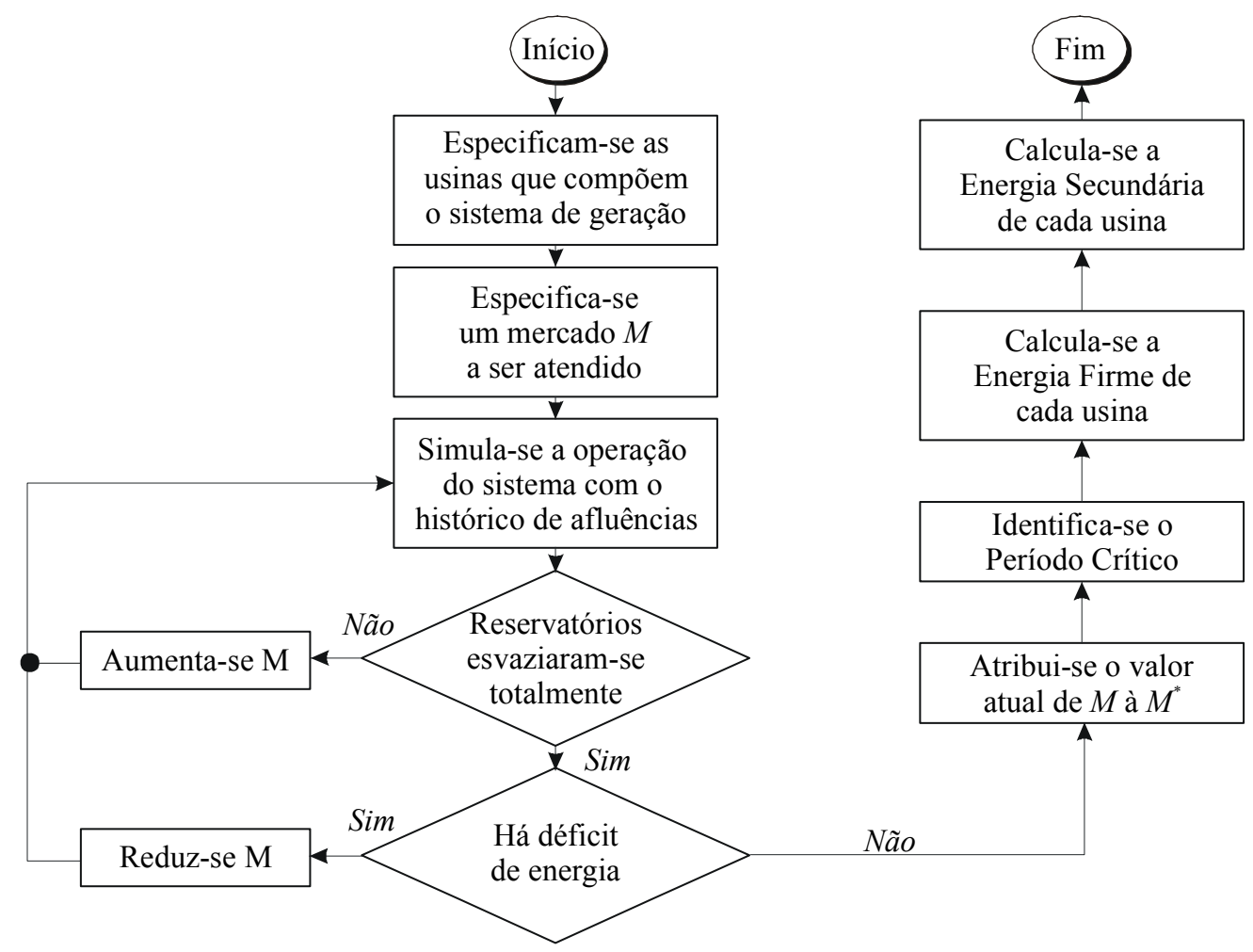

Figura 6.22 - Algoritmo para cálculo da Energia Firme. 
Conforme já observado anteriormente, dependendo da política de operação adotada, o desempenho de um mesmo sistema sob as mesmas condições de operação pode ser diferente. Logo, dependendo da política de operação das usinas, diferentes valores de Energias Firme e Secundária podem ser encontrados. A próxima seção ilustra esta situação.

\subsubsection{Exemplo}

Conforme já foi explicado anteriormente, os benefícios obtidos com a utilização da Regra baseada em Otimização, RO, são conseqüências da manutenção de níveis mais elevados nas usinas com reservatório de acumulação localizadas a jusante do sistema. Para exemplificar os benefícios da utilização da RO, é realizado um estudo onde se simula a operação das usinas do rio Paranapanema que possuem reservatórios de acumulação, isto é, Jurumirim, Chavantes e Capivara (Figura 6.3).

Todos os testes referem-se à determinação da Energia Firme do sistema supondo sua operação isolada, como se a carga estivesse ligada diretamente ao sistema de geração. Este fato é importante porque os valores de Energia Firme determinados através das simulações referem-se ao Período Crítico do sistema do rio Paranapanema quando ele é operado isoladamente, e não ao Período Crítico do Sistema Interligado Sul/Sudeste. Os estudos são realizados utilizando-se intervalos mensais e o histórico de vazões naturais de 1931 a 2000.

Os valores de Energia Firme de cada uma das usinas e do sistema, utilizando-se as diferentes regras, são mostrados nas próximas três tabelas. Na Tabela 6.2 são apresentados os dados que caracterizam o Período Crítico; primeiro mostram-se os intervalos inicial e final, depois a energia armazenada no sistema no início e no fim do Período Crítico, o Mercado de Energia, as Energias Firme e Secundária do sistema formado pelas três usinas e a geração média.

O Mercado de Energia é o valor do mercado que deve ser atendido continuamente durante toda a simulação; o valor percentual entre parênteses é a porcentagem da potência instalada que este valor representa. Já a Energia Firme do sistema equivale à soma das Energias Firmes de cada usina; teoricamente, a Energia Firme do sistema e o Mercado de Energia deveriam ser iguais, mas isto não ocorre por dois motivos: (i) há uma pequena sobra de energia armazenada no final do Período Crítico, devido ao erro aceitável na convergência do processo iterativo; (ii) o cálculo dos valores médios das gerações das usinas introduz pequenos erros numéricos. 
Para calcular o benefício que a RO traz ao sistema calculam-se as diferenças absoluta e percentual entre os valores de Energia Firme obtidos através da RO e da RP, isto é:

$$
\begin{aligned}
& B_{R O}=E F_{R O}-E F_{R P} \\
& B_{R O, \%}=\frac{B_{R O}}{E F_{R P}} \cdot 100
\end{aligned}
$$

sendo:

- $B_{R O}$ : benefício que a RO traz ao sistema, em $\overline{\mathrm{MW}}$;

- $B_{R O, \%}$ : benefício que a RO traz ao sistema, em \%;

- $E F_{R P}$ : Energia Firme do sistema quando operado com a RP;

- $E F_{R O}$ : Energia Firme do sistema quando operado com a RO;

De acordo com os dados da Tabela 6.2, tem-se:

$$
B_{R O}=476,73-464,02=12,71 \overline{\mathrm{MW}}
$$

Percentualmente:

$$
B_{R O, \%}=\frac{12,71}{464,02} \cdot 100=2,74 \%
$$

Analisando os valores de Energia Secundária do sistema, observa-se que a utilização da RO reduz a Energia Secundária do sistema. Este fato será explicado posteriormente, junto com a análise dos valores de Energia Secundária de cada usina.

$\mathrm{Na}$ Tabela 6.3 apresentam-se os valores de Energia Firme para cada usina segundo a RP e a RO. É interessante notar que embora o sistema apresente um ganho de 2,74\% ao ser operado com a RO, nem todas as usinas apresentam ganhos de Energia Firme. De acordo com os dados da tabela, comparando-se a RO e a RP, a usina de Jurumirim tem sua Energia Firme reduzida, praticamente não há alterações para Chavantes, e Capivara apresenta um acréscimo de Energia Firme elevado. Estas alterações são o resultado da utilização da RO; enquanto a usina de Jurumirim é obrigada a esvaziar seu reservatório freqüentemente, reduzindo assim sua produtividade, a usina de Capivara mantém-se cheia a maior parte do tempo, com produtividade elevada. Como a vazão a jusante do sistema é muito maior que na cabeceira, o "sacrifício" da usina de Jurumirim e o "ganho" da usina de Capivara traduzem-se em benefícios para todo o sistema.

Na Tabela 6.4 apresentam-se os valores de Energia Secundária para cada uma das usinas, de acordo com as diferentes regras. Analisando os resultados, verifica-se que 
as usinas de Jurumirim e Chavantes apresentam ganhos de Energia Secundária, enquanto a usina de Capivara apresenta uma redução. Para explicar este resultado, devese ter em mente que a principal diferença entre a RP e a RO é que a primeira esvazia os reservatórios de montante, e mantém Capivara cheia a maior parte do tempo, enquanto a RP esvazia e enche os reservatório paralelamente.

Deste modo, quando ocorrem valores elevados de vazão afluente, responsáveis pela Energia Secundária, as usinas de Jurumirim e Chavantes encontram-se mais vazias quando são operadas com a RO, podendo encher seus reservatórios e turbinar estas vazões; já com a usina de Capivara, como a RO determina que o seu reservatório permaneça cheio a maior parte do tempo, sua única opção é verter os grandes picos de afluência. Como as vazões afluentes de Capivara são elevadas, seu vertimento reduz não apenas sua Energia Secundária, mas também a Energia Secundária de todo o sistema, tal como já observado na Tabela 6.2.

Tabela 6.2 - Caracterização do Periodo Crítico das usinas com reservatório de acumulação.

\begin{tabular}{lrr}
\hline & \multicolumn{1}{c}{ RP } & \multicolumn{1}{c}{ RO } \\
\hline Período Crítico (PC) & Abr/1943 a Dez/1945 & Abr/1943 a Dez/1945 \\
\hline Energia arm. no início do PC & 3418,99 MW.mês & 3418,99 MW.mês \\
\hline Energia arm. no fim do PC & $0,86 \mathrm{MW} \cdot m e ̂ s$ & $13,26 \mathrm{MW} . m e ̂ s$ \\
\hline Mercado de Energia D & $464,86 \overline{\mathrm{MW}}(40,28 \%)$ & $477,17 \overline{\mathrm{MW}}(41,35 \%)$ \\
\hline Energia Firme & $464,02 \overline{\mathrm{MW}}$ & $476,73 \overline{\mathrm{MW}}$ \\
\hline Energia Secundária & $154,07 \overline{\mathrm{MW}}$ & $146,65 \overline{\mathrm{MW}}$ \\
\hline Geração Média & $618,10 \overline{\mathrm{MW}}$ & $623,38 \overline{\mathrm{MW}}$ \\
\hline
\end{tabular}

Tabela 6.3 - Valores de Energia Firme das usinas a reservatório do rio Paranapanema.

\begin{tabular}{lcccc}
\hline & $\begin{array}{c}\text { Regra } \\
\text { Paralela }\end{array}$ & $\begin{array}{c}\text { Regra com } \\
\text { Otimização }\end{array}$ & $\begin{array}{c}\text { Melhoria proporcionada pela RO } \\
\text { MW }\end{array}$ & \begin{tabular}{c} 
\% \\
\hline Jurumirim
\end{tabular} \\
\hline Chavantes & $15,74 \overline{\mathrm{MW}}$ & $47,07 \overline{\mathrm{MW}}$ & $-1,67 \overline{\mathrm{MW}}$ & $-3,43 \%$ \\
\hline Capivara & $260,15 \overline{\mathrm{MW}}$ & $155,34 \overline{\mathrm{MW}}$ & $0,21 \overline{\mathrm{MW}}$ & $0,14 \%$ \\
\hline
\end{tabular}

Tabela 6.4 - Valores de Energia Secundária das usinas a reservatório do rio Paranapanema.

\begin{tabular}{lcccc}
\hline & $\begin{array}{c}\text { Regra } \\
\text { Paralela }\end{array}$ & $\begin{array}{c}\text { Regra com } \\
\text { Otimização }\end{array}$ & $\begin{array}{c}\text { Melhoria proporcionada pela RO } \\
\text { MW }\end{array}$ & \begin{tabular}{c} 
\% \\
\hline Jurumirim
\end{tabular} \\
\hline Chavantes & $11,77 \overline{\mathrm{MW}}$ & $12,92 \overline{\mathrm{MW}}$ & $1,15 \overline{\mathrm{MW}}$ & $9,77 \%$ \\
\hline Capivara & $37,10 \overline{\mathrm{MW}}$ & $38,31 \overline{\mathrm{MW}}$ & $1,21 \overline{\mathrm{MW}}$ & $3,26 \%$ \\
\hline
\end{tabular}




\section{Capítulo VII}

\section{Estudos de Casos}

O objetivo deste capítulo é apresentar e analisar os resultados do modelo de dimensionamento de uma usina hidroelétrica proposto no Capítulo IV. Conforme já apresentado, este modelo baseia-se em uma técnica de otimização evolucionária, onde os indivíduos da população representam as dimensões da usina. A aptidão de cada indivíduo é avaliada por um modelo de simulação da operação energética, por um modelo de valorização da energia gerada e por um modelo responsável pelo cálculo do custo do empreendimento.

Os estudos realizados e seus resultados são organizados para promover a investigação da influência de cada um destes modelos.

Inicialmente, na Seção 1, apresentam-se as usinas utilizadas nos estudos, incluindo as que são dimensionadas e as que pertencem aos Sistemas de Referência. Mostra-se um mapa com as posições de todos os aproveitamentos e uma tabela com suas principais características.

Na Seção 2 apresenta-se a modelagem dos custos de uma usina hidroelétrica, mostrando dados coletados junto à ANEEL - Agência Nacional de Energia Elétrica e a forma pela qual estes dados foram utilizados para estimar os custos das usinas sob dimensionamento.

Na Seção 3 apresentam-se conjuntos de testes realizados exclusivamente para determinar os melhores parâmetros do Algoritmo Genético. Entre estes parâmetros destacam-se o tamanho da população, o operador de cruzamento, a forma de iniciação da primeira população e o critério de parada do processo iterativo.

$\mathrm{Na}$ Seção 4 apresentam-se os estudos de dimensionamento. Estes estudos foram organizados de forma que seus resultados possam ser utilizados para determinar a forma pela qual as características ótimas de uma usina hidroelétrica podem ser influenciadas pelos próprios parâmetros do processo de dimensionamento. 
Elaborou-se um conjunto de testes abrangente, variando-se a usina sob dimensionamento, o preço de referência da Energia Firme, as remunerações da Energia Secundária e da Ponta Garantida, a política de operação do sistema hidroelétrico, o fato de serem considerados benefícios locais ou globais, além de alterações nas vazões afluentes, no sistema de referência utilizado e na própria usina sob dimensionamento.

Finalmente, na Seção 5, apresentam-se os resultados encontrados, destacando-se a influência de cada fator citado no parágrafo anterior. 


\section{Usinas Utilizadas nos Testes}

Esta seção tem por objetivo mostrar as usinas do Sistema Interligado Nacional que são utilizadas na aplicação da metodologia de dimensionamento. Os aproveitamentos utilizados como sob dimensionamento são as usinas de Emborcação e Porto Primavera, cujas características são detalhadamente apresentadas no Anexo A. As posições destas usinas e também de outras pertencentes ao Sistema Sudeste/Centro-Oeste são mostradas na Figura 7.1, e suas principais características são apresentadas na Tabela 7.1.

A escolha destas duas hidroelétricas foi norteada principalmente pela disponibilidade dos dados exigidos pelo modelo de dimensionamento (vazão afluente natural, polinômios para modelagem dos níveis de montante e jusante, etc.). Como as usinas estão em operação, as informações necessárias para execução dos estudos encontram-se disponíveis e consolidadas. Isso facilita o desenvolvimento da pesquisa, pois dados de usinas que atualmente estão em processo de dimensionamento são difíceis de serem conseguidos, além de nem sempre serem completamente seguros (antes da consolidação os dados normalmente são revistos várias vezes ao longo dos estudos realizados pelas empresas).

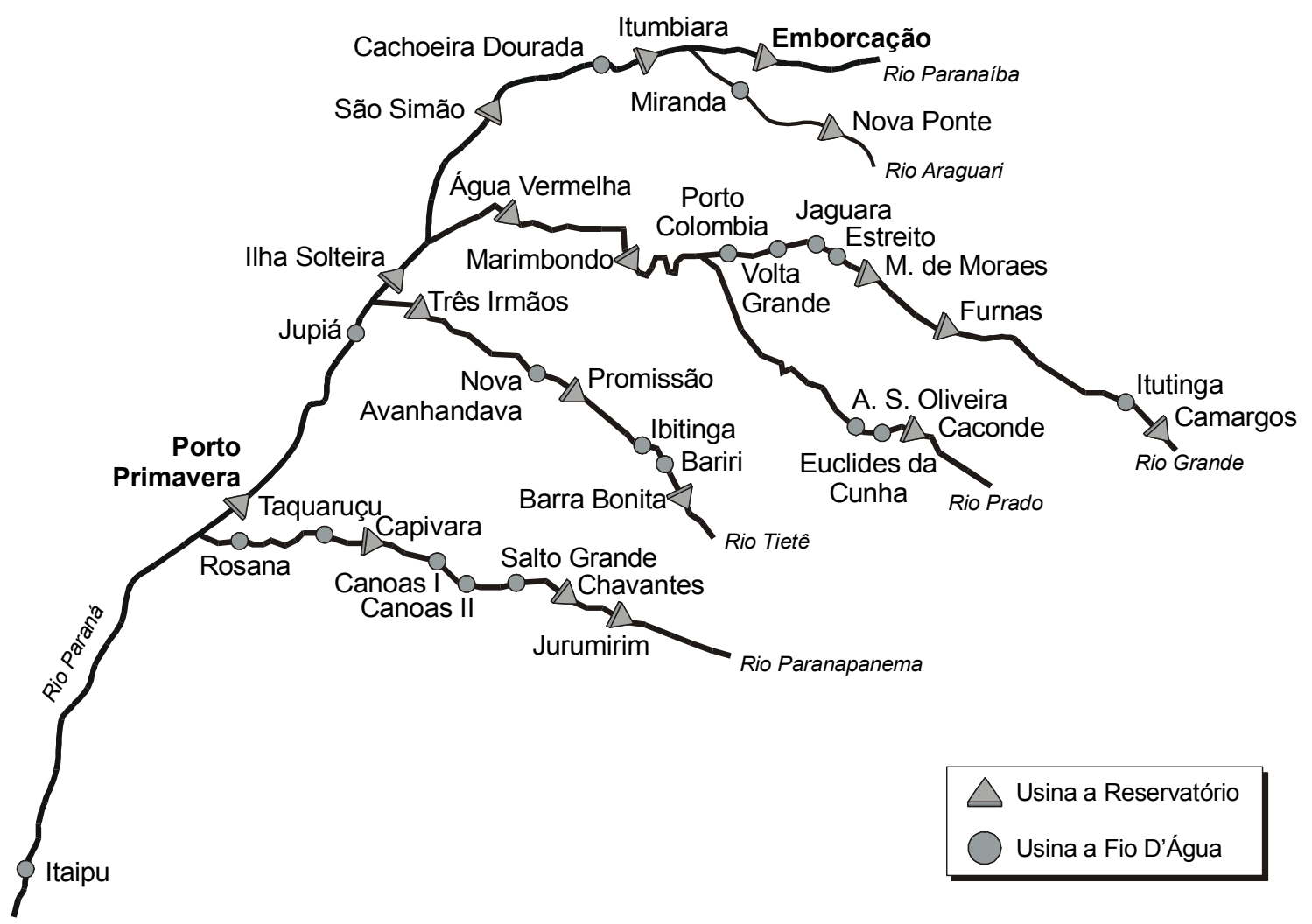

Figura 7.1 - Principais usinas hidroelétricas do Sistema Sudeste/Centro-Oeste. 
Tabela 7.1 - Principais características de algumas usinas utilizadas nos testes.

\begin{tabular}{|c|c|c|c|c|c|}
\hline Usina & $x_{\min }\left[\mathrm{hm}^{3}\right]$ & $x_{\max }\left[\mathrm{hm}^{3}\right]$ & $h_{e f}[\mathrm{~m}]$ & $q_{e f}\left[m^{3} / s\right]$ & $p_{e f}[M W]$ \\
\hline Emborcação & 4.669 & 17.190 & 130,3 & 1.048 & 1.192 \\
\hline Itumbiara & 4.573 & 17.027 & 80,2 & 3.222 & 2.280 \\
\hline Cachoeira Dourada & 300 & 460 & 30,7 & 2.514 & 638 \\
\hline São Simão & 7.000 & 12.540 & 70,9 & 2.622 & 1.680 \\
\hline Nova Ponte & 2.435 & 12.810 & 96,0 & 594 & 510 \\
\hline Miranda & 1.120 & 1.120 & 66,4 & 666 & 390 \\
\hline Camargos & 120 & 792 & 24,7 & 228 & 48 \\
\hline Itutinga & 4,1 & 11,4 & 25,0 & 245 & 54 \\
\hline Furnas & 5.733 & 22.950 & 90,0 & 1.692 & 1.312 \\
\hline M. de Moraes & 1.540 & 4.040 & 43,0 & 1.328 & 478 \\
\hline Estreito & 1.245 & 1.423 & 61,7 & 2.028 & 1.104 \\
\hline Jaguara & 360 & 450 & 44,1 & 1.564 & 616 \\
\hline Volta Grande & 1.950 & 2.244 & 26,6 & 1.584 & 380 \\
\hline Porto Colombia & 1.291 & 1.524 & 18,9 & 1.988 & 328 \\
\hline Marimbondo & 890 & 6.150 & 59,2 & 2.944 & 1.488 \\
\hline Água Vermelha & 5.856 & 11.025 & 53,5 & 2.922 & 1.380 \\
\hline Caconde & 51 & 555 & 101,0 & 94 & 80 \\
\hline Euclides da Cunha & 8,7 & 13,4 & 88,0 & 148 & 108 \\
\hline A. S. Oliveira & 8,8 & 25,2 & 21,7 & 178 & 32 \\
\hline Barra Bonita & 569 & 3135 & 21,4 & 756 & 140 \\
\hline Bariri & 482 & 544 & 22,1 & 771 & 144 \\
\hline Ibitinga & 925 & 985 & 21,2 & 705 & 132 \\
\hline Promissão & 5.280 & 7.408 & 23,1 & 1.293 & 264 \\
\hline Nova Avanhandava & 2.340 & 2.700 & 27,5 & 1.248 & 303 \\
\hline Três Irmãos & 10.110 & 13.550 & 42,0 & 1.748 & 648 \\
\hline Ilha Solteira & 8.232 & 21.060 & 41,5 & 8.840 & 3.240 \\
\hline Jupiá & 2.450 & 3.680 & 21,3 & 7.602 & 1.414 \\
\hline Porto Primavera & 14.400 & 20.000 & 18,0 & 11.430 & 1.818 \\
\hline Jurumirim & 3.843 & 7.008 & 30,9 & 180 & 49 \\
\hline Chavantes & 5.754 & 8.795 & 73,6 & 165 & 104 \\
\hline Salto Grande & 45 & 45 & 15,3 & 140 & 18,7 \\
\hline Canoas II & 146 & 146 & 14,5 & 227 & 24 \\
\hline Canoas I & 207 & 207 & 16,3 & 226 & 27,5 \\
\hline Capivara & 4.816 & 10.540 & 44,0 & 365 & 160 \\
\hline Taquaruçu & 677 & 677 & 21,9 & 533 & 111 \\
\hline Rosana & 1.909 & 1.909 & 14,9 & 652 & 93 \\
\hline Itaipu & 29.000 & 29.000 & 117,0 & 1.1826 & 12.600 \\
\hline
\end{tabular}

Obs.: - $x_{\text {min }}$ : volume mínimo, $x_{\text {máx }}$ : volume máximo, $h_{e f}$ : queda de referência efetiva, $q_{e f}$ : vazão de referência efetiva, $p_{e f}$ : potência de referência efetiva. 


\section{Modelagem dos Custos}

A modelagem dos custos refere-se à representação dos custos de construção da usina através de funções matemáticas. Conforme mencionado no Capítulo IV, o custo total do aproveitamento foi dividido em três grandes parcelas:

- Custo de construção, denotado por $c_{c r}\left(x_{\text {máx }}\right)$, em US\$, define o custo de construção do reservatório em função do volume máximo, $x_{\max x} \mathrm{em} \mathrm{hm}^{3}$.

- Custo de aquisição de terras, denotado por $c_{a t}\left(a_{\text {maxx }}\right)$, em US\$, define o custo de aquisição de terras, incluindo relocações de vilas ou cidades e eventuais gastos extras decorridos em função da construção do reservatório, em função da área alagada máxima, $a_{\max } \mathrm{em} \mathrm{km}^{2}$.

- Custo dos geradores e turbinas, denotado por $c_{g t}\left(p_{n o m}\right)$, em US\$. Este custo foi subdividido em duas partes: uma referente à capacidade instalada de base e outra à capacidade instalada de ponta. Assim, o custo total dos geradores e das turbinas, pode ser escrito como:

$$
c_{g t}\left(p_{\text {nom }, b}, p_{\text {nom }, p}\right)=c_{g t, b}\left(p_{\text {nom }, b}\right)+c_{g t, p}\left(p_{\text {nom }, p}\right)
$$

na qual:

- $\quad p_{n o m, b}$ : capacidade instalada de base, em $M W$;

- $\quad p_{\text {nom, }}$ : capacidade instalada de ponta, em $M W$;

- $\quad p_{\text {nom: }}$ : capacidade instalada total, $p_{\text {nom }}=p_{\text {nom }, b}+p_{\text {nom }, p}$, em $M W$;

- $\quad c_{g, t b}$ : custo dos geradores e turbinas de base, em US\$.

- $\quad c_{g t p}$ : custo dos geradores e turbinas de ponta, em US\$.

Como as usinas utilizadas para os estudos já estão operando, o primeiro passo para realizar seus estudos de dimensionamento com a metodologia proposta foi um levantamento de custos junto às suas respectivas empresas. Como não se obteve sucesso em tais buscas, foram realizadas pesquisas no Centro de Documentação da ANEEL. Infelizmente, os dados das usinas de interesse (Emborcação e Porto Primavera, basicamente) não estavam disponíveis nas bases de dados da Agência, já que os estudos que antecederam o início da construção destas usinas são relativamente antigos. Optouse então por fazer uma coleta de dados em cerca de vinte projetos que se encontravam disponíveis, principalmente daqueles no formato de Orçamento Padrão Eletrobrás OPE. A partir destes dados foram estipulados índices médios, os quais foram utilizados para estimar os custos das usinas sob dimensionamento. 
Obviamente, trata-se de uma abordagem simplificada, utilizada apenas para viabilizar os testes experimentais com a metodologia de dimensionamento proposta. Esta simplicidade pode ser facilmente substituída por dados reais porque os dados de custo são sempre fornecidos ao modelo na forma de tabelas ou funções. Se os custos forem levantados especificamente para um determinado aproveitamento, eles podem ser fornecidos ao programa e o estudo desejado pode então ser executado. Deseja-se com isto deixar claro que a simplificação deve-se ao contexto em que o trabalho foi desenvolvido, onde não se dispunha de dados de custo específicos dos aproveitamentos sob dimensionamento, e não de características limitantes de modelagem.

Na próxima seção apresentam-se os dados coletados e os cálculos envolvidos para determinação dos índices médios de custo. Na seqüência mostram-se as funções de custo de Emborcação e Porto Primavera.

\section{1 Índices Específicos de Custo}

Inicialmente, foram levantados os dados de vinte e um aproveitamentos disponíveis no Centro de Documentação da ANEEL. A coleta de dados de cada aproveitamento foi dividida em duas etapas. Na primeira etapa, foram catalogadas as informações relacionadas às características a partir das quais deveriam ser determinados os custos, isto é, o volume máximo do reservatório, a respectiva área alagada e a potência instalada. Posteriormente, foram catalogados os dados de custo.

$\mathrm{Na}$ etapa de custos, estavam disponíveis valores gastos com desapropriação e aquisição de terras, barragem, estruturas físicas da casa de força, turbinas, geradores, equipamentos elétricos e mecânicos, além de custos indiretos com a obra. Estes custos foram agrupados em três valores por aproveitamento:

- Grupo 1: barragem.

- Grupo 2: desapropriação e aquisição de terras.

- Grupo 3: casa de força + turbinas + geradores + equipamentos elétricos e mecânicos.

$\mathrm{Na}$ Tabela 7.2 apresentam-se os aproveitamentos com suas respectivas características físicas e valores de custo. Os dados $x_{\text {máx }}$, $a_{\text {máx }}$ e $p_{\text {inst }}$ referem-se respectivamente ao volume máximo da usina, à área alagada máxima e à potência instalada. Observando os valores de potência instalada e volume máximo, nota-se que a maioria das usinas são relativamente pequenas. Isso faz com que os dados de custos 
sejam bem variados, uma vez que para estes empreendimentos os custos dependem muito de suas características específicas e de seus locais de instalação.

Por este motivo, os dados da tabela não são utilizados diretamente. Eles são utilizados para criar três índices de custos específicos. É feita a divisão do Grupo 1 por $x_{\text {máx }}$, criando um índice do tipo $U S \$ / \mathrm{hm}^{3}$, divisão do Grupo 2 por $a_{\text {máx }}$, criando um índice do tipo $U S \$ / \mathrm{km}^{2}$, e finalmente a divisão do Grupo 3 por $p_{\text {inst }}$, criando um índice do tipo US\$/MW. Estes índices são mostrados na Tabela 7.3.

Tabela 7.2 - Aproveitamentos catalogados com características fisicas principais e custos.

\begin{tabular}{crrrrrr}
\hline Usina & \multicolumn{3}{c}{ Característica Física } & \multicolumn{1}{c}{ Custo } \\
\hline & $x_{\text {máx }}$ & \multicolumn{1}{c}{$a_{\text {máx }}$} & \multicolumn{1}{c}{$p_{\text {inst }}$} & \multicolumn{1}{c}{ Grupo 1 } & Crupo 2 & \multicolumn{1}{c}{ Grupo 3 } \\
& {$\left[\mathrm{hm}^{3}\right]$} & {$\left[\mathrm{km}^{2}\right]$} & {$[M W]$} & \multicolumn{1}{c}{$[$ US $]$} & \multicolumn{1}{c}{$[$ US\$ $]$} & \multicolumn{1}{c}{ [ US\$ ] } \\
\hline 1 & 164,3 & 8,0 & 46,0 & 56.070 .183 & 3.613 .045 & 11.901 .885 \\
2 & 414,8 & 19,9 & 73,0 & 40.083 .757 & 4.176 .581 & 16.696 .960 \\
3 & 1397,3 & 47,7 & 106,0 & 75.433 .428 & 6.831 .008 & 21.051 .207 \\
4 & 84,8 & 7,2 & 20,0 & 20.534 .902 & 6.094 .142 & 12.613 .531 \\
5 & 1673,4 & 64,3 & 21,0 & 50.443 .658 & 6.232 .832 & 8.626 .461 \\
6 & 4350,6 & 111,1 & 64,0 & 85.544 .990 & 7.023 .064 & 9.038 .151 \\
7 & 225,3 & 15,4 & 31,0 & 26.483 .421 & 3.150 .973 & 12.952 .130 \\
8 & 3626,2 & 179,9 & 125,0 & 45.368 .122 & 11.739 .025 & 29.240 .278 \\
9 & 15176,9 & 519,7 & 236,0 & 130.468 .280 & 149.450 .665 & 42.330 .428 \\
10 & 1968,8 & 123,1 & 86,0 & 81.759 .656 & 24.963 .564 & 26.563 .929 \\
11 & 7270,7 & 343,2 & 149,0 & 165.633 .615 & 70.881 .399 & 44.471 .179 \\
12 & 2690,0 & 110,0 & 20,0 & 54.276 .627 & 10.959 .829 & 12.266 .248 \\
13 & 1001,1 & 73,7 & 22,0 & 32.135 .032 & 7.656 .339 & 8.096 .310 \\
14 & 13803,1 & 692,9 & 130,0 & 91.072 .470 & 450.290 .527 & 29.873 .846 \\
15 & 2480,8 & 200,5 & 142,0 & 80.799 .744 & 28.195 .066 & 36.527 .728 \\
16 & 2588,0 & 61,3 & 290,0 & 111.044 .000 & 33.439 .000 & 43.040 .794 \\
17 & 76,2 & 5,5 & 45,0 & 18.321 .900 & 3.281 .986 & 22.447 .404 \\
18 & 46,3 & 7,3 & 150,0 & 50.149 .340 & 3.248 .656 & 30.613 .946 \\
19 & 82,3 & 6,0 & 60,0 & 22.880 .250 & 4.069 .601 & 23.259 .602 \\
20 & 5400,0 & 590,0 & 110,0 & 249.612 .000 & 62.919 .830 & 258.938 .986 \\
21 & 231,8 & 16,8 & 65,0 & 27.570 .261 & 5.119 .782 & 12.867 .892 \\
\hline
\end{tabular}

Estes índices permitem que os projetos sejam comparados em termos de gastos por unidade de potência, área alagada e volume do reservatório. Por exemplo, nota-se que o custo por unidade de volume do reservatório do projeto 18 foi excessivamente alto, enquanto o custo por $M W$ instalado foi relativamente baixo.

Os custos específicos podem ser utilizados para classificar um projeto como muito caro, caro, razoável, barato e muito barato. Esta classificação é feita com bases nos quartis da distribuição dos valores de custos específicos. Determinando as 
distribuições dos valores de preços e na seqüência calculando os quartis, obtêm-se os valores mostrados na Tabela 7.4.

Com base nesta classificação de índices de custos específicos são determinadas, de forma aproximada, as curvas de custo das usinas sob dimensionamento. A forma como estes cálculos são feitos é mostrada na próxima seção.

Tabela 7.3 - Índices de custos especificos.

\begin{tabular}{crrr}
\hline Usina & $\begin{array}{r}\text { Volume } \\
\text { US\$ / hm }\end{array}$ & $\begin{array}{c}\text { Área } \\
\text { US\$ / } \mathrm{km}^{2}\end{array}$ & $\begin{array}{c}\text { Potência } \\
\text { US\$ / MW }\end{array}$ \\
\hline 1 & 341.371 & 451.631 & 258.737 \\
2 & 96.625 & 210.090 & 228.725 \\
3 & 53.984 & 143.148 & 198.596 \\
4 & 242.231 & 841.035 & 630.677 \\
5 & 30.144 & 96.893 & 410.784 \\
6 & 19.663 & 63.200 & 141.221 \\
7 & 117.540 & 204.463 & 417.811 \\
8 & 12.511 & 65.246 & 233.922 \\
9 & 8.597 & 287.573 & 179.366 \\
10 & 41.528 & 202.781 & 308.883 \\
11 & 22.781 & 206.523 & 298.464 \\
12 & 20.177 & 99.653 & 613.312 \\
13 & 32.101 & 103.942 & 368.014 \\
14 & 6.598 & 649.864 & 229.799 \\
15 & 32.569 & 140.638 & 257.238 \\
16 & 42.907 & 545.943 & 148.417 \\
17 & 240.413 & 597.812 & 498.831 \\
18 & 1.084 .076 & 448.090 & 204.093 \\
19 & 278.010 & 678.267 & 387.660 \\
20 & 46.224 & 106.644 & 233.278 \\
21 & 118.940 & 304.568 & 197.968 \\
\hline & & &
\end{tabular}

Tabela 7.4 - Classificação dos índices de custos especificos.

\begin{tabular}{clrrr}
\hline Projeto & & $\begin{array}{c}\text { Volume } \\
{\left[U S \$ / \mathrm{hm}^{3}\right]}\end{array}$ & $\begin{array}{c}\text { Área } \\
{\left[U S \$ / \mathrm{km}^{2}\right]}\end{array}$ & $\begin{array}{c}\text { Potência } \\
{[U S \$ / \mathrm{MW}]}\end{array}$ \\
\hline Muito barato & (quartil zero) & 6.598 & 63.200 & 141.221 \\
Barato & (primeiro quartil) & 22.130 & 105.968 & 202.719 \\
Razoável & (valor médio) & 41.528 & 204.463 & 257.238 \\
Caro & (terceiro quartil) & 118.590 & 521.480 & 405.003 \\
Muito caro & (quarto quartil) & 1.084 .076 & 678.267 & 613.312 \\
\hline
\end{tabular}




\subsection{Curvas de Custo de Emborcação}

As curvas de custo de Emborcação são modeladas com base nos índices de custo mostrados na Tabela 7.4. Primeiro, estabelecem-se intervalos de valores possíveis para o volume do reservatório, para a área alagada e para a potência a ser instalada na usina. Depois estes intervalos são divididos em quatro valores. Cada um destes quatro valores são multiplicados por índices de custos específicos Muito Barato, Barato, Razoável e Caro, originando assim quatro valores de custo. Estes valores de custo são plotados e sobre os pontos ajusta-se uma curva exponencial.

Para ilustrar o processo, na Tabela 7.5 são mostradas as faixas de valores de volume, os custos específicos utilizados e o custo total de construção de Emborcação. O quarto quartil foi desprezado por fazer com que o custo do projeto passasse a ser excessivamente elevado, verificando-se em estudos de dimensionamento que a maioria das opções de projeto apresentavam valores de receita líquida anual negativos, os quais os inviabilizavam. Somente seria possível construir uma usina muito pequena, incompatível com o porte real de Emborcação. Situação semelhante também forçou a redução do custo específico Caro, adotando-se 75\% do valor do terceiro quartil.

Depois de calculados os custos totais referentes aos quatro valores, plotam-se os pontos e ajusta-se a curva mostrada na Figura 7.2. Este procedimento é repetido mais duas vezes, ajustando-se a curva de aquisição de terras, Tabela 7.6 e Figura 7.3, e a curva de custos da turbina e do gerador de base, Tabela 7.7 e Figura 7.4. Para o custo da expansão da casa de força (capacidade de ponta), Tabela 7.8 e Figura 7.5, os custos específicos são obtidos a partir dos projetos mais baratos, sendo portanto um pouco menores que os valores utilizados no cálculo da instalação da capacidade de base.

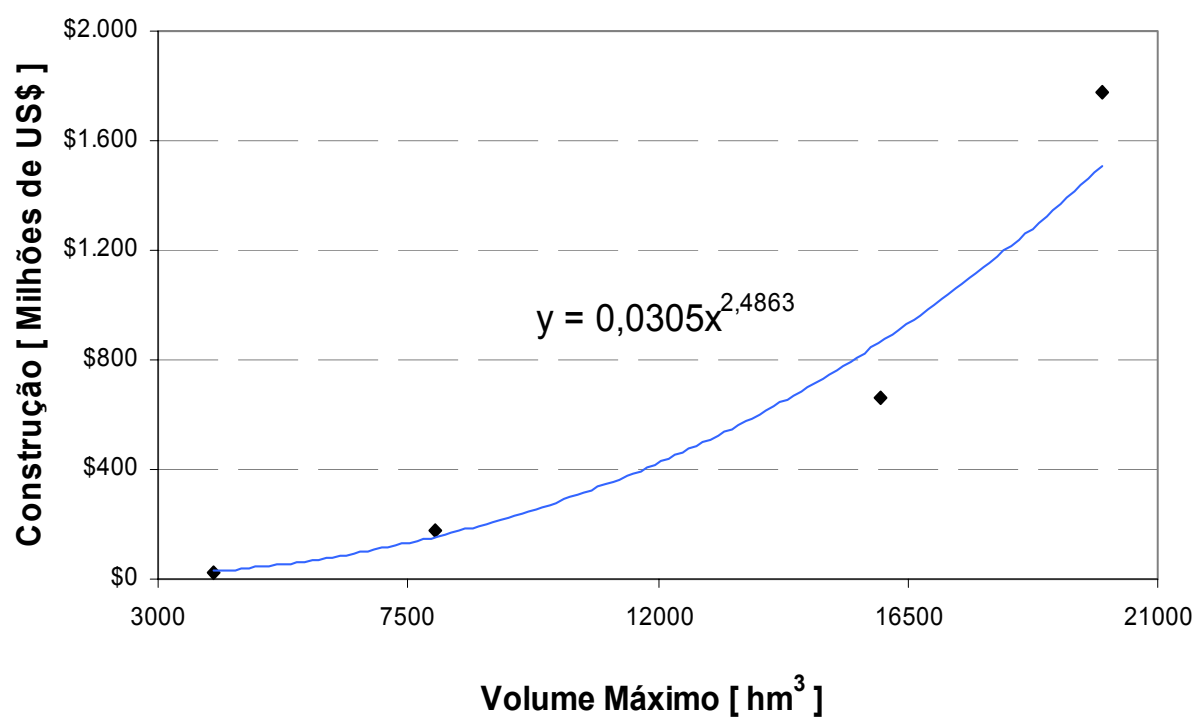

Figura 7.2 - Curva de custo de construção para Emborcação. 
Tabela 7.5 - Dados da curva de custo de construção para Emborcação.

\begin{tabular}{clrr}
\hline $\begin{array}{c}\text { Volume Máximo } \\
{\left[\mathrm{hm}^{3}\right]}\end{array}$ & & $\begin{array}{c}\text { Custo Espec. } \\
{\left[U S \$ / \mathrm{hm}^{3}\right]}\end{array}$ & \multicolumn{1}{c}{$\begin{array}{c}\text { Custo Total } \\
{[U S \$]}\end{array}$} \\
\hline 4000,0 & (muito barato) & 6.598 & 26.391 .961 \\
8000,0 & (barato) & 22.130 & 177.040 .438 \\
16000,0 & (razoável) & 41.528 & 664.451 .327 \\
20000,0 & (caro) & 88.942 & 1.778 .846 .763 \\
\hline
\end{tabular}

Tabela 7.6 - Dados da curva de custo de aquisição de terras para Emborcação.

\begin{tabular}{clrr}
\hline $\begin{array}{c}\text { Área } \\
{\left[\mathrm{km}^{2}\right]}\end{array}$ & & $\begin{array}{c}\text { Custo Espec. } \\
{\left[\text { US\$ } / \mathrm{km}^{2}\right]}\end{array}$ & \multicolumn{1}{c}{$\begin{array}{c}\text { Custo Total } \\
{[\text { US\$] }}\end{array}$} \\
\hline 131,8 & (muito barato) & 63.200 & 8.327 .821 \\
225,4 & (barato) & 105.968 & 23.888 .513 \\
412,8 & (razoável) & 204.463 & 84.392 .472 \\
506,4 & (caro) & 391.110 & 198.063 .297 \\
\hline
\end{tabular}

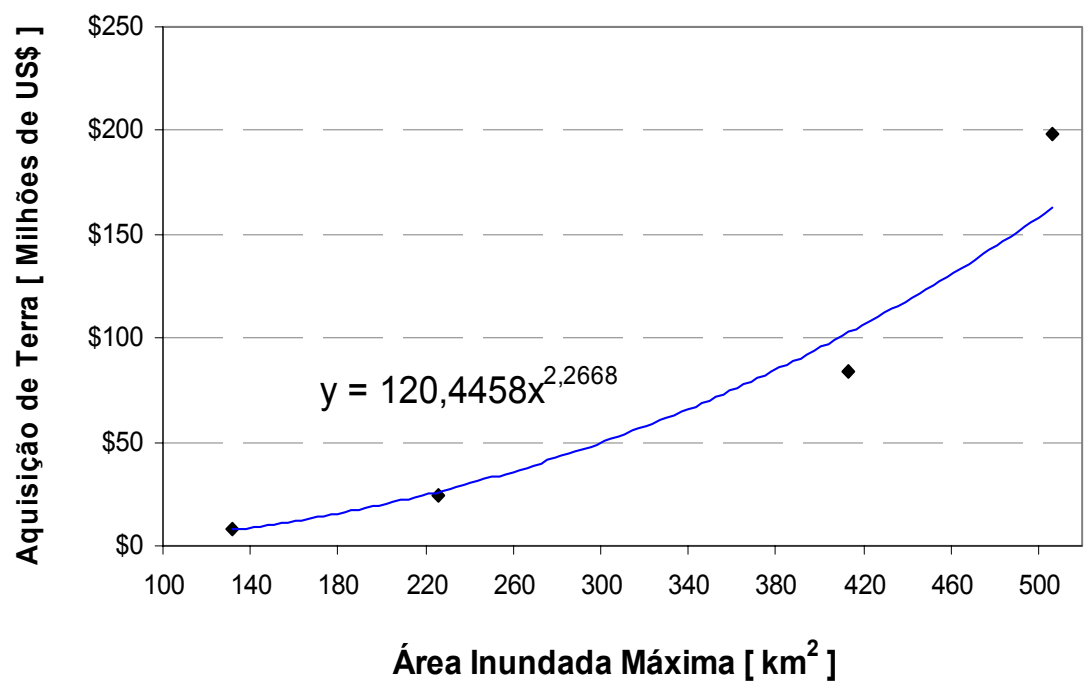

Figura 7.3 - Curva de custo de aquisição de terras para Emborcação.

Tabela 7.7 - Dados da curva de custo da turbina/gerador de base para Emborcação.

\begin{tabular}{clcc}
\hline $\begin{array}{c}\text { Potência } \\
{[M W]}\end{array}$ & & $\begin{array}{c}\text { Custo Espec. } \\
{[\text { US\$ / MW] }}\end{array}$ & \multicolumn{1}{c}{$\begin{array}{c}\text { Custo Total } \\
\text { [US\$] }\end{array}$} \\
\hline 111,6 & (muito barato) & 141.221 & 15.763 .853 \\
458,3 & (barato) & 202.719 & 92.896 .602 \\
1151,5 & (razoável) & 257.238 & 296.211 .540 \\
1498,1 & (caro) & 405.003 & 606.750 .246 \\
\hline
\end{tabular}




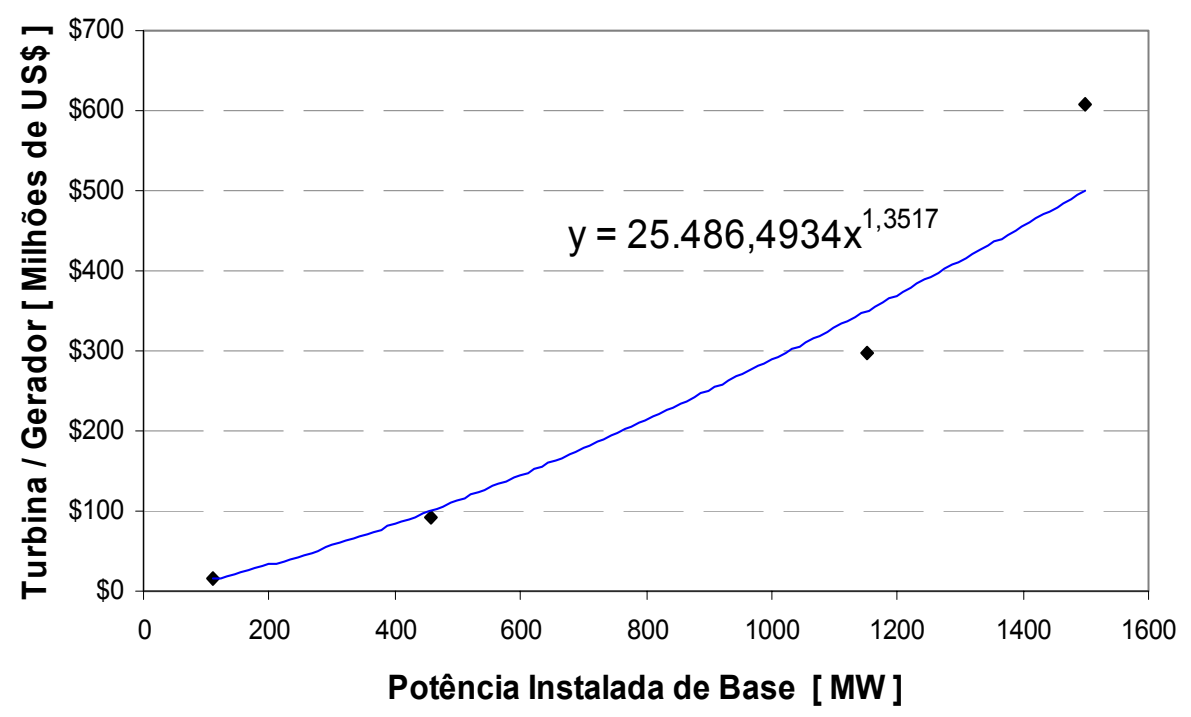

Figura 7.4 - Curva de custo da turbina/gerador de base para Emborcação.

Tabela 7.8 - Dados da curva de custo da turbina/gerador de ponta para Emborcação.

\begin{tabular}{rlcc}
\hline $\begin{array}{c}\text { Potência } \\
{[M W]}\end{array}$ & & $\begin{array}{c}\text { Custo Espec. } \\
{[U S \$ / M W]}\end{array}$ & \multicolumn{1}{c}{$\begin{array}{c}\text { Custo Total } \\
\text { [US\$] }\end{array}$} \\
\hline 50,0 & (muito barato) & 233.600 & 11.680 .015 \\
287,5 & (barato) & 257.987 & 74.171 .284 \\
762,5 & (razoável) & 303.674 & 231.551 .114 \\
$1.000,0$ & (caro) & 377.837 & 377.837 .062 \\
\hline
\end{tabular}

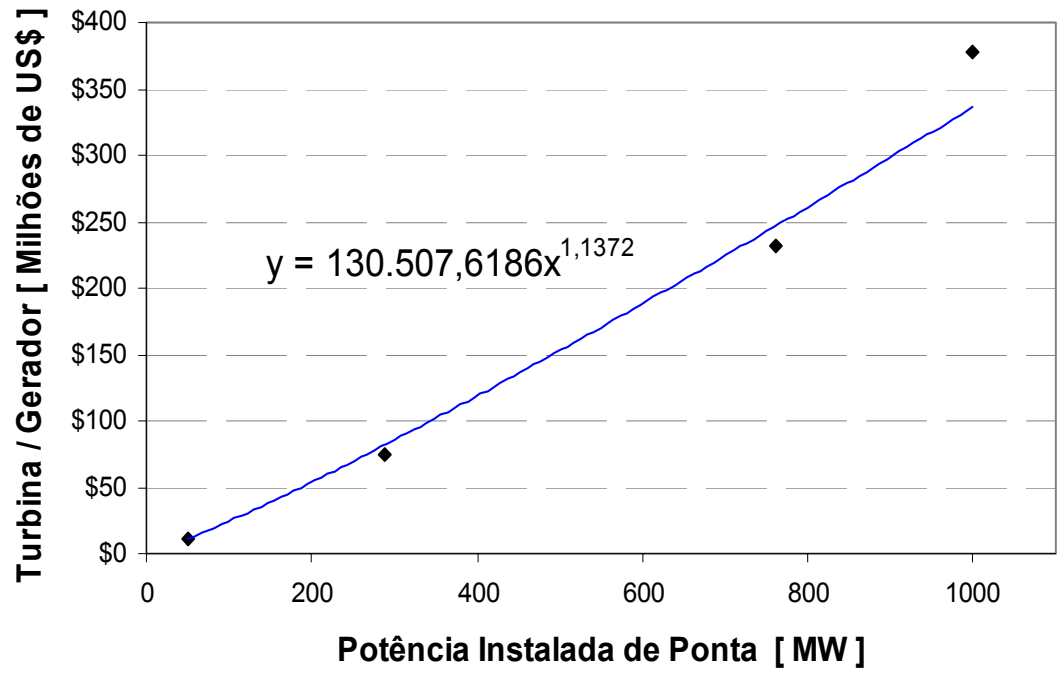

Figura 7.5 - Curva de custo da turbina/gerador de ponta para Emborcação. 


\subsection{Curvas de Custo de Porto Primavera}

As curvas de custo de Porto Primavera são modeladas de forma semelhante às curvas de custo de Emborcação. Houve apenas uma redução nos custos específicos relacionados ao reservatório, para que opções de projeto factíveis pudessem ser obtidas.

As tabelas e os gráficos de custo são mostrados na seqüência, seguindo-se a seguinte ordem:

- Custo de construção: Figura 7.6 e Tabela 7.9;

- Custo de aquisição de terra: Tabela 7.10 e Figura 7.7;

- Custo do conjunto turbina/gerador de base: Figura 7.8 e Tabela 7.11;

- Custo do conjunto turbina/gerador de ponta: Figura 7.9 e Tabela 7.12.

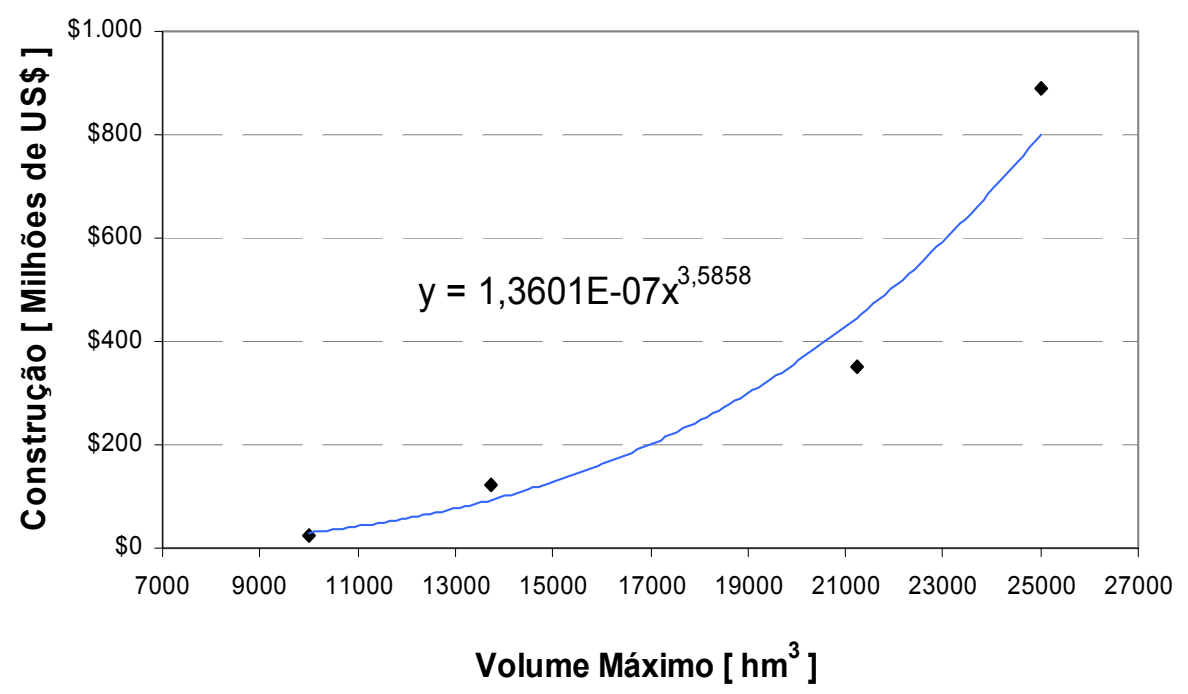

Figura 7.6 - Curva de custo de construção para Porto Primavera.

Tabela 7.9 - Dados da curva de custo de construção para Porto Primavera.

\begin{tabular}{clrr}
\hline $\begin{array}{c}\text { Volume Máximo } \\
{\left[\mathrm{hm}^{3}\right]}\end{array}$ & & $\begin{array}{r}\text { Custo Espec. } \\
{\left[U S \$ / \mathrm{hm}^{3}\right]}\end{array}$ & \multicolumn{1}{c}{$\begin{array}{c}\text { Custo Total } \\
{[\text { US\$] }}\end{array}$} \\
\hline $10.000,0$ & (muito barato) & 2.639 & 26.391 .961 \\
$13.750,0$ & (barato) & 8.852 & 121.715 .301 \\
$21.250,0$ & (razoável) & 16.611 & 352.989 .767 \\
$25.000,0$ & (caro) & 35.577 & 889.423 .381 \\
\hline
\end{tabular}

Tabela 7.10 - Dados da curva de custo de aquisição de terras para Porto Primavera.

\begin{tabular}{llrr}
\hline $\begin{array}{l}\text { Área } \\
{\left[\mathrm{km}^{2}\right]}\end{array}$ & & $\begin{array}{r}\text { Custo Espec. } \\
{\left[U S \$ / \mathrm{km}^{2}\right]}\end{array}$ & \multicolumn{1}{c}{$\begin{array}{c}\text { Custo Total } \\
\text { [US\$] }\end{array}$} \\
\hline $1.609,5$ & (muito barato) & 25.280 & 40.687 .128 \\
$1.782,5$ & (barato) & 42.387 & 75.555 .773 \\
$2.128,6$ & (razoável) & 81.785 & 174.087 .204 \\
$2.301,6$ & (caro) & 156.444 & 360.077 .175 \\
\hline
\end{tabular}




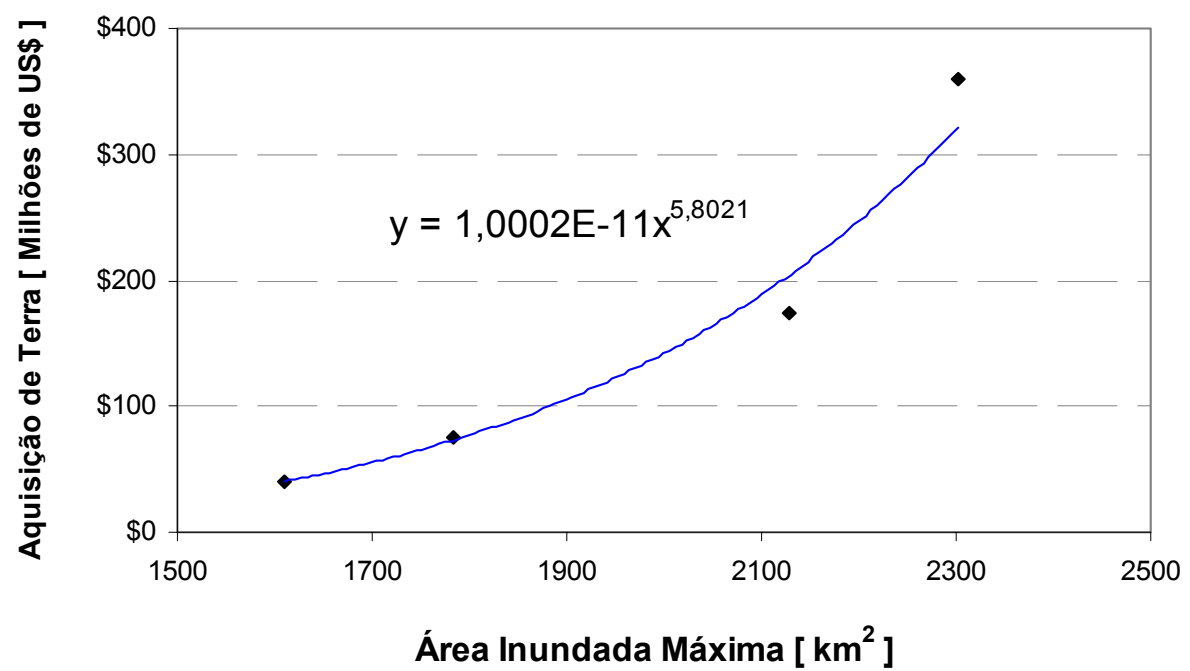

Figura 7.7 - Curva de custo de aquisição de terras para Porto Primavera.

Tabela 7.11 - Dados da curva de custo da turbina/gerador de base para Porto Primavera.

\begin{tabular}{clcr}
\hline $\begin{array}{c}\text { Potência } \\
{[M W]}\end{array}$ & & $\begin{array}{c}\text { Custo Espec. } \\
\text { [US\$ / MW] }\end{array}$ & \multicolumn{1}{c}{$\begin{array}{c}\text { Custo Total } \\
\text { [US\$] }\end{array}$} \\
\hline 338,6 & (muito barato) & 141.221 & 47.813 .307 \\
891,2 & (barato) & 202.719 & 180.659 .048 \\
$1.996,4$ & (razoável) & 257.238 & 513.549 .110 \\
$2.549,0$ & (caro) & 405.003 & 1.032 .356 .631 \\
\hline
\end{tabular}

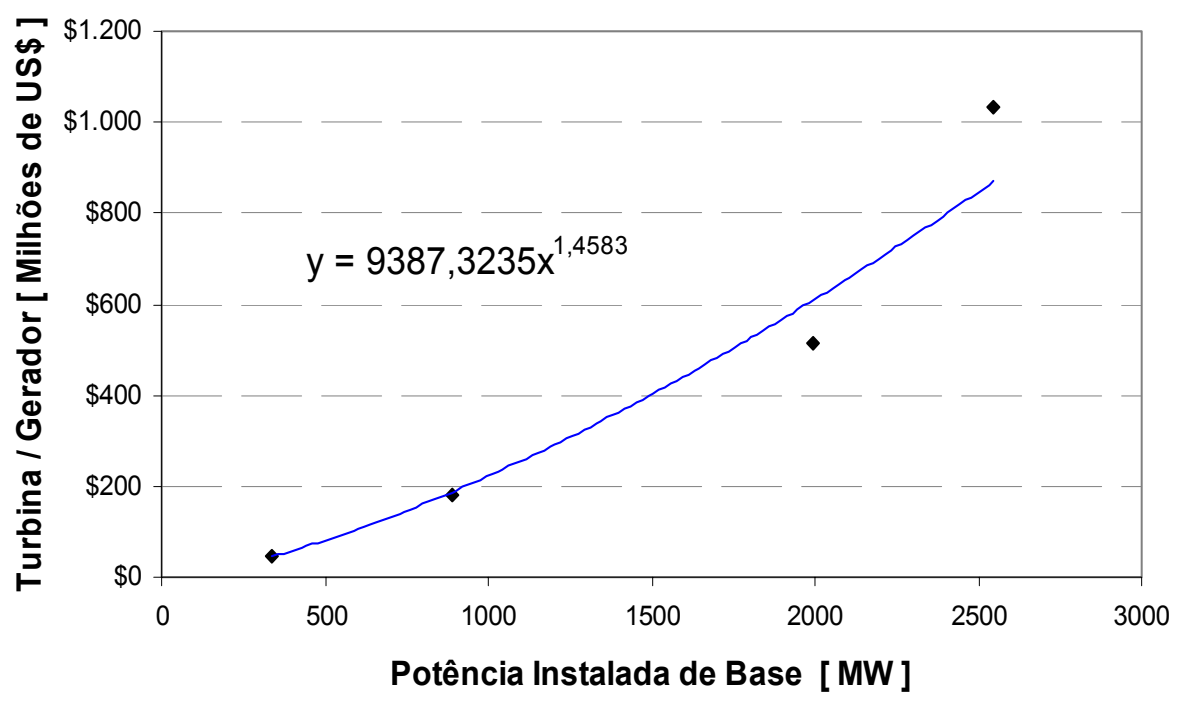

Figura 7.8 - Curva de custo da turbina/gerador de base para Porto Primavera. 
Tabela 7.12 - Dados da curva de custo da turbina/gerador de ponta para Porto Primavera.

\begin{tabular}{clcc}
\hline $\begin{array}{c}\text { Potência } \\
{[M W]}\end{array}$ & & $\begin{array}{c}\text { Custo Espec. } \\
{[U S \$ / M W]}\end{array}$ & \multicolumn{1}{c}{$\begin{array}{c}\text { Custo Total } \\
\text { [US\$] }\end{array}$} \\
\hline 50,0 & (muito barato) & 233.600 & 11.680 .015 \\
287,5 & (barato) & 257.987 & 74.171 .284 \\
762,5 & (razoável) & 303.674 & 231.551 .114 \\
1000,0 & (caro) & 377.837 & 377.837 .062 \\
\hline
\end{tabular}

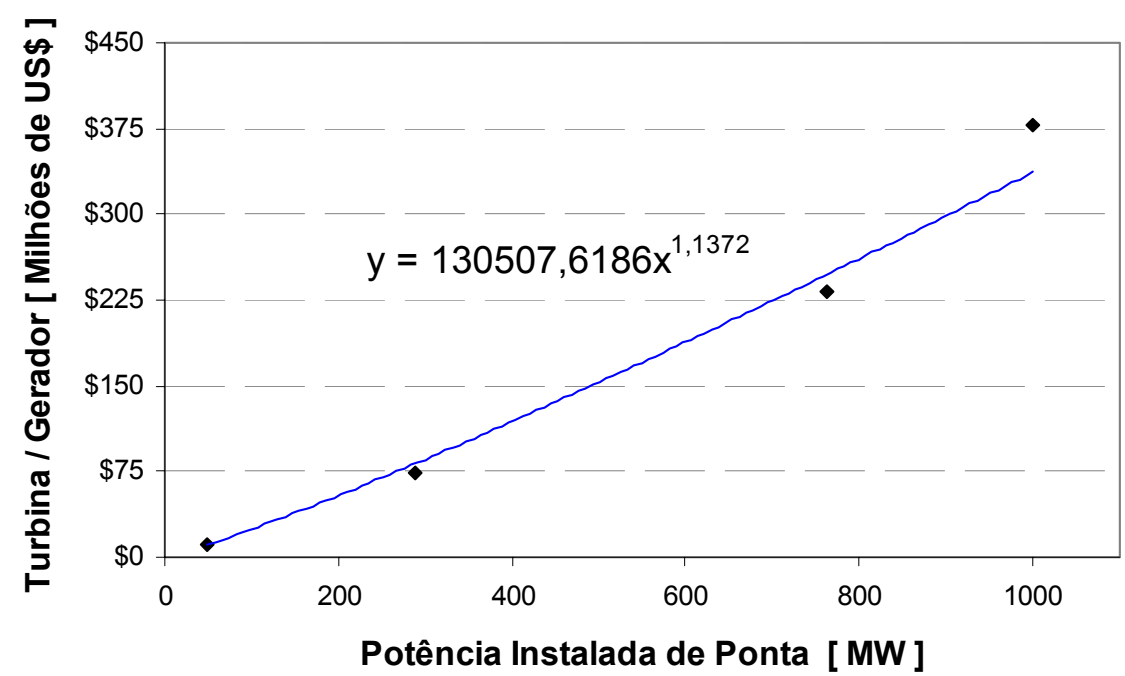

Figura 7.9 - Curva de custo da turbina/gerador de ponta para Porto Primavera. 


\section{Ajustes dos Parâmetros do Algoritmo Genético}

Um dos procedimentos necessários para a aplicação dos Algoritmos Genéticos é o ajuste dos parâmetros do algoritmo. Há a necessidade de determinar o número de indivíduos da população, a forma de criação da população inicial, as taxas de mutação e cruzamento, o operador de elitismo e o critério de parada.

Estes parâmetros foram divididos em dois grupos. O primeiro grupo contém os parâmetros considerados principais, aqueles cujos valores devem ser alterados e testes realizados para medir suas influências sobre o resultado do processo de otimização. O segundo grupo contém os parâmetros considerados secundários, aqueles cujas influências sobre o resultado final são pequenas ou cujos valores tradicionais são sugeridos na literatura.

Os parâmetros considerados principais são o tamanho da população, o operador de cruzamento, a forma de iniciação da população e o critério de parada. Os parâmetros considerados secundários são os operadores de mutação e elitismo, as taxas de cruzamento e mutação, e o critério de parada.

Os parâmetros do AG para os testes realizados são mostrados na Tabela 7.13. Foram definidas dezoito diferentes configurações, com os seguintes parâmetros:

- Três tamanhos de população: com 20,30 e 40 indivíduos;

- Três operadores de cruzamento: Operador Média Aritmética, Operador BLX- $\alpha$ e Operador Heurístico;

- Dois tipos de solução inicial: (i) população inicial criada metade aleatoriamente e metade como complemento dos indivíduos iniciais $(1 / 2$ A 1/2 C). Neste caso, a população inicial sempre contém o dobro de indivíduos da população estacionária. (ii) população inicial criada uniformemente, com seis valores para cada variável do modelo. Neste caso, a população inicial contém 216 indivíduos $\left(6^{3}\right)$, já que o modelo possui três variáveis de decisão.

- O operador de elitismo copia para a população seguinte um número de indivíduos mais aptos igual a $20 \%$ do tamanho da população estacionária. A cópia não é direta: se um indivíduo que estiver sendo copiado for muito parecido com indivíduos elitistas que já foram copiados, este indivíduo sofre mutação. Isto evita a criação de um 
conjunto de soluções boas iguais entre si e aumenta a diversidade do processo de busca.

- A mutação adotada em todos os testes é a Mutação Uniforme. Como a mutação tem um papel reduzido na busca do ótimo, não foram testados diferentes operadores.

- O critério de parada utilizado é o tempo máximo de processamento igual a cinco horas ${ }^{36}$.

- As taxas de cruzamento e mutação são feitas iguais a $90 \%$ e $5 \%$, respectivamente.

Cada um dos AGs foi aplicado dez vezes a três tipos de caso de dimensionamento escolhidos para balizarem a escolha dos parâmetros do Algoritmo Genético. O conjunto de testes é mostrado na Tabela 7.14. Os estudos foram divididos em três grupos: $E F, E F E S$ e EFESPG. O primeiro trata apenas da valorização da Energia Firme, no segundo valorizam-se as Energias Firme e Secundária, e no terceiro valorizam-se as Energias Firme e Secundária, e também a Potência Garantida.

Tabela 7.13 - Conjuntos de parâmetros dos Algoritmos Genéticos.

\begin{tabular}{ccccccc}
\hline AG & N Individuo & Cruzamento & Sol. Inicial & Elitismo & Mutação & Parada \\
\hline G1 & 20 & Med Arit & $1 / 2$ A $1 / 2 \mathrm{C}$ & 4 & Uniforme & 5 horas \\
G2 & 20 & Med Arit & Uniforme & 4 & Uniforme & 5 horas \\
G3 & 20 & BLX-Alfa & $1 / 2$ A $1 / 2 \mathrm{C}$ & 4 & Uniforme & 5 horas \\
G4 & 20 & BLX-Alfa & Uniforme & 4 & Uniforme & 5 horas \\
G5 & 20 & Heurístico & $1 / 2$ A $1 / 2 \mathrm{C}$ & 4 & Uniforme & 5 horas \\
G6 & 20 & Heurístico & Uniforme & 4 & Uniforme & 5 horas \\
G7 & 30 & Med Arit & $1 / 2$ A $1 / 2 \mathrm{C}$ & 6 & Uniforme & 5 horas \\
G8 & 30 & Med Arit & Uniforme & 6 & Uniforme & 5 horas \\
G9 & 30 & BLX-Alfa & $1 / 2$ A 1/2 C & 6 & Uniforme & 5 horas \\
G10 & 30 & BLX-Alfa & Uniforme & 6 & Uniforme & 5 horas \\
G11 & 30 & Heurístico & $1 / 2$ A $1 / 2 \mathrm{C}$ & 6 & Uniforme & 5 horas \\
G12 & 30 & Heurístico & Uniforme & 6 & Uniforme & 5 horas \\
G13 & 40 & Med Arit & $1 / 2$ A $1 / 2 \mathrm{C}$ & 8 & Uniforme & 5 horas \\
G14 & 40 & Med Arit & Uniforme & 8 & Uniforme & 5 horas \\
G15 & 40 & BLX-Alfa & $1 / 2$ A 1/2 C & 8 & Uniforme & 5 horas \\
G16 & 40 & BLX-Alfa & Uniforme & 8 & Uniforme & 5 horas \\
G17 & 40 & Heurístico & $1 / 2$ A 1/2 C & 8 & Uniforme & 5 horas \\
G18 & 40 & Heurístico & Uniforme & 8 & Uniforme & 5 horas \\
\hline
\end{tabular}

\footnotetext{
${ }^{36}$ Mais detalhes sobre o algoritmo de Busca Exaustiva são mostrados no Anexo C. O tempo máximo de processamento de cinco horas é explicado após a apresentação dos testes para determinação dos parâmetros.
} 
Tabela 7.14 - Testes utilizados para balizar a escolha dos parâmetros do AG.

\begin{tabular}{cccc}
\hline AG & $\boldsymbol{E F}$ & Nome do Teste de Dimensionamento & EFES \\
\hline G1 & Emb37ParEF40M2BGHTG1 & Emb37ParEF40M2ESBGHTG1 & Emb37ParEF40M2ESPGBGHTG1 \\
G2 & Emb37ParEF40M2BGHTG2 & Emb37ParEF40M2ESBGHTG2 & Emb37ParEF40M2ESPGBGHTG2 \\
G3 & Emb37ParEF40M2BGHTG3 & Emb37ParEF40M2ESBGHTG3 & Emb37ParEF40M2ESPGBGHTG3 \\
G4 & Emb37ParEF40M2BGHTG4 & Emb37ParEF40M2ESBGHTG4 & Emb37ParEF40M2ESPGBGHTG4 \\
G5 & Emb37ParEF40M2BGHTG5 & Emb37ParEF40M2ESBGHTG5 & Emb37ParEF40M2ESPGBGHTG5 \\
G6 & Emb37ParEF40M2BGHTG6 & Emb37ParEF40M2ESBGHTG6 & Emb37ParEF40M2ESPGBGHTG6 \\
G7 & Emb37ParEF40M2BGHTG7 & Emb37ParEF40M2ESBGHTG7 & Emb37ParEF40M2ESPGBGHTG7 \\
G8 & Emb37ParEF40M2BGHTG8 & Emb37ParEF40M2ESBGHTG8 & Emb37ParEF40M2ESPGBGHTG8 \\
G9 & Emb37ParEF40M2BGHTG9 & Emb37ParEF40M2ESBGHTG9 & Emb37ParEF40M2ESPGBGHTG9 \\
G10 & Emb37ParEF40M2BGHTG10 & Emb37ParEF40M2ESBGHTG10 & Emb37ParEF40M2ESPGBGHTG10 \\
G11 & Emb37ParEF40M2BGHTG11 & Emb37ParEF40M2ESBGHTG11 & Emb37ParEF40M2ESPGBGHTG11 \\
G12 & Emb37ParEF40M2BGHTG12 & Emb37ParEF40M2ESBGHTG12 & Emb37ParEF40M2ESPGBGHTG12 \\
G13 & Emb37ParEF40M2BGHTG13 & Emb37ParEF40M2ESBGHTG13 & Emb37ParEF40M2ESPGBGHTG13 \\
G14 & Emb37ParEF40M2BGHTG14 & Emb37ParEF40M2ESBGHTG14 & Emb37ParEF40M2ESPGBGHTG14 \\
G15 & Emb37ParEF40M2BGHTG15 & Emb37ParEF40M2ESBGHTG15 & Emb37ParEF40M2ESPGBGHTG15 \\
G16 & Emb37ParEF40M2BGHTG16 & Emb37ParEF40M2ESBGHTG16 & Emb37ParEF40M2ESPGBGHTG16 \\
G17 & Emb37ParEF40M2BGHTG17 & Emb37ParEF40M2ESBGHTG17 & Emb37ParEF40M2ESPGBGHTG17 \\
G18 & Emb37ParEF40M2BGHTG18 & Emb37ParEF40M2ESBGHTG18 & Emb37ParEF40M2ESPGBGHTG18 \\
\hline
\end{tabular}

Os nomes dos testes sugerem os parâmetros utilizados. Por exemplo, o teste Emb37ParEF40M2BGHTG1 implica o dimensionamento da usina de Emborcação com o Sistema de Referência composto por 36 usinas (37 usinas no Sistema Completo), regra de operação paralela, valorização apenas da Energia Firme a um valor médio de US\$40,00/MWh, relação entre preços de ponta e fora da ponta igual a 2, Benefício Global $(B G)$, Histórico Total $(H T)$ de vazões afluentes e Algoritmo Genético G1.

De forma semelhante, o teste Emb37ParEF40M2ESBGHTG10 trata do dimensionamento da usina de Emborcação com o sistema completo composto por 37 usinas, regra de operação paralela, valorização da Energia Firme a um valor médio de US\$40,00/MWh, relação entre os preços de ponta e fora de ponta igual a 2, valorização da Energia Secundária ao valor de US\$11/MWh (este valor foi o mesmo em todos os testes e por isso não se utilizou o acrônimo ES11), Benefício Global, Histórico Total e o Algoritmo Genético $610^{37}$.

Finalmente, os testes do grupo EFESPG envolvem além dos parâmetros dos outros testes, a valorização da Potência Garantida a um valor de US\$10.000,00/MW.ano em todos os casos.

\footnotetext{
${ }^{37}$ O cálculo dos valores da Energia Secundária e da Ponta Garantida são explicados na Seção 5.
} 
Voltando ao critério de avaliação da solução encontrada, cada teste foi executado dez vezes e o mínimo valor encontrado da função objetivo foi comparado com o valor da função objetivo encontrado pelo método de Busca Exaustiva (BEX). Como o método de Busca Exaustiva teoricamente fornece a solução ótima, a menos de erros de discretização, a solução encontrada por ele é utilizada como valor padrão para avaliar a solução encontrada pelo AG.

Nas Figuras 7.10, 7.11 e 7.12 são mostrados os resultados dos estudos de dimensionamento relativamente à BEX. Por exemplo, na Figura 7.10, para a configuração do Algoritmo Genético igual a $G 1$, a Receita Líquida Anual $\left(R_{L Q}\right)$ de $100,2 \%$ indica que a pior das dez soluções encontradas pelo AG proporciona uma $R_{L Q}$ $0,2 \%$ mais elevada que a solução encontrada pela Busca Exaustiva.

Esta pequena melhora de performance em relação à BEX deve-se ao fato do AG não depender da discretização adotada; as variáveis de decisão podem continuamente assumir quaisquer valores. Obviamente, esta melhora de $0,2 \%$ não é de fato a grande vantagem da utilização do $\mathrm{AG}$, mas sim os tempos de processamento envolvidos. Enquanto a BEX necessita de mais de 92 horas de processamento (computador AMD Athlon $^{\mathrm{TM}}$ XP $1600+, 1,40 \mathrm{GHz}$ e $512 \mathrm{MB}$ de RAM), o AG converge em cinco horas e ainda consegue, na maioria dos casos, resultados relativamente melhores.

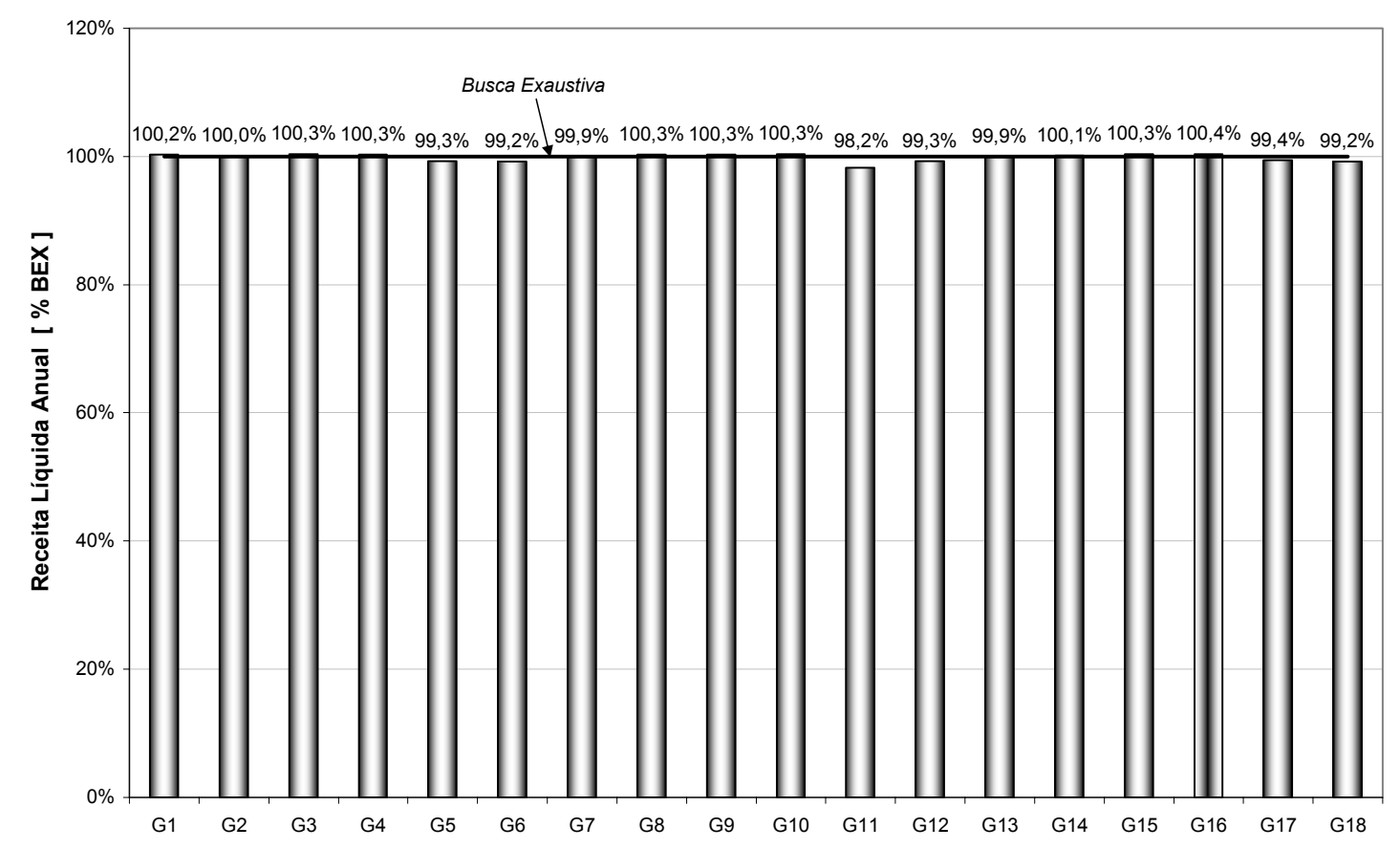

Figura 7.10 - Resultados do AG para os testes do grupo EF. 


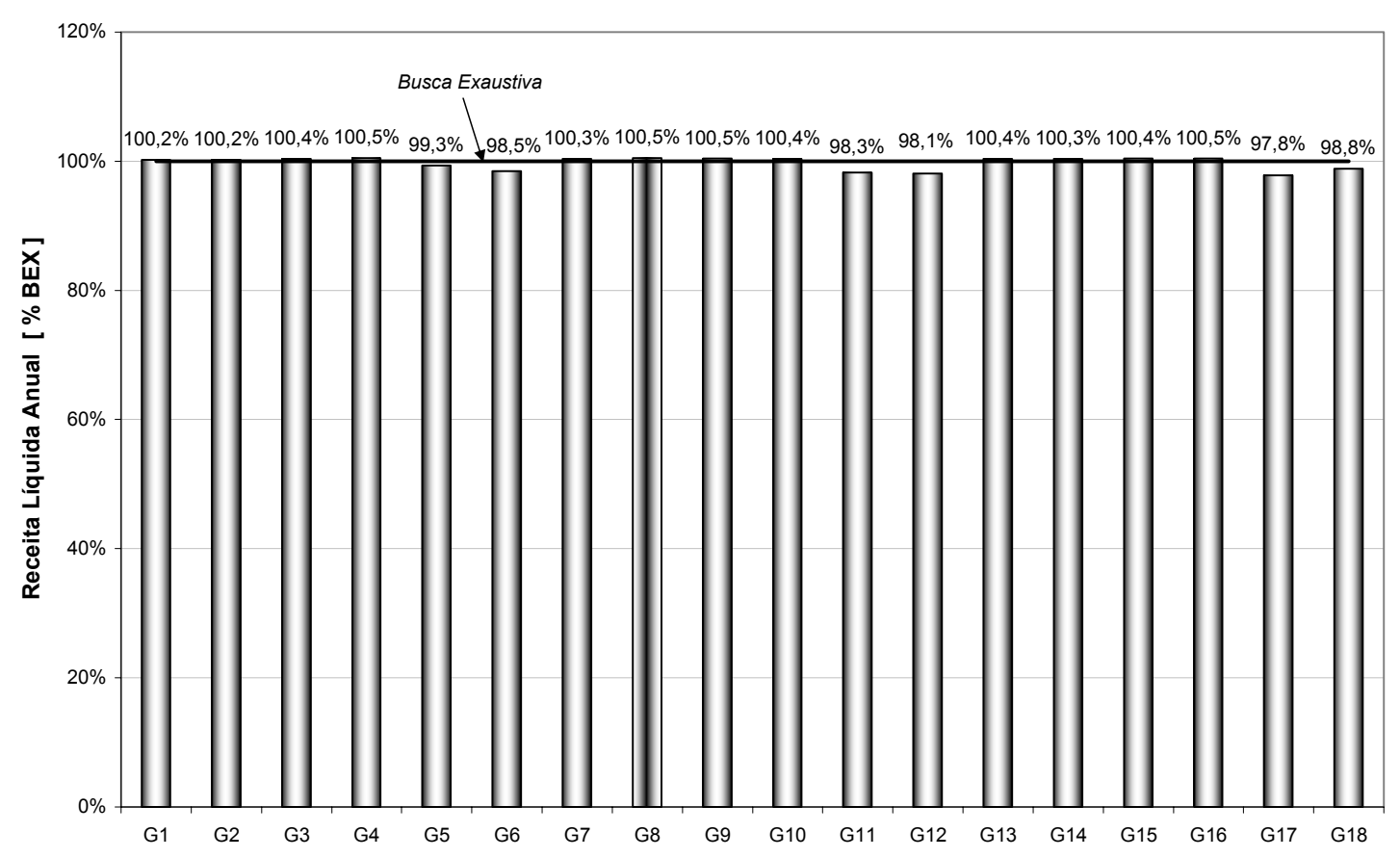

Figura 7.11 - Resultados do AG para os testes do grupo EFES.

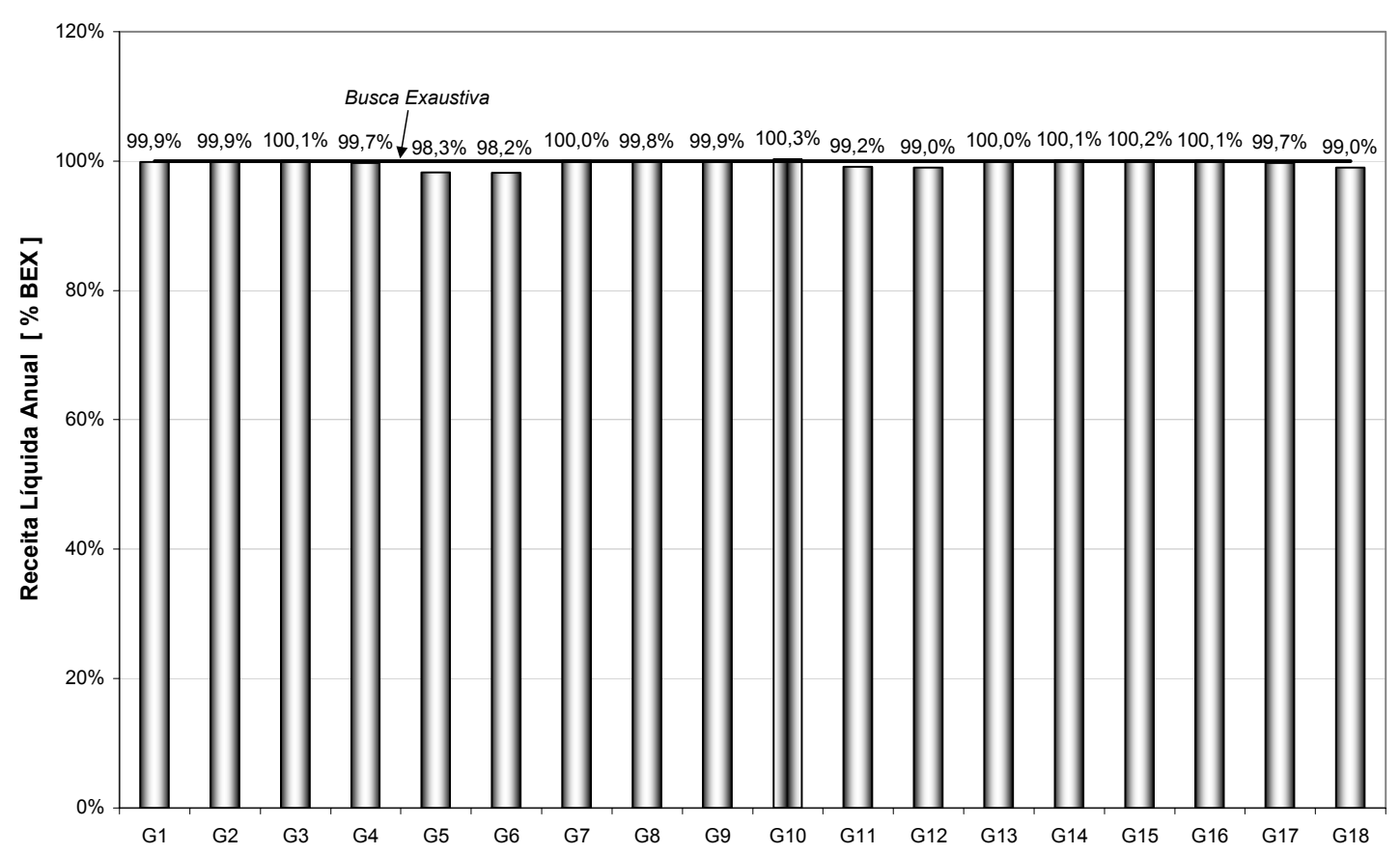

Figura 7.12 - Resultados do AG para os testes do grupo EFESPG.

Analisando os resultados em qualquer uma das três figuras, observa-se que os AGs G5, G6, G11, G12, G17 e G18 sempre apresentam desempenhos inferiores a 100\%. Retornando-se à Tabela 7.13, constata-se que estes casos possuem em comum o operador de cruzamento heurístico. Este comportamento indica que este operador não deve ser utilizado nos estudos de dimensionamento. 
As configurações $G 1, G 2, G 3, G 4, G 7, G 8, G 9$ e $G 13$ apresentam desempenhos relativos instáveis, ora sendo mais e ora sendo menos eficientes que a BEX, o que as desqualifica para utilização nos testes.

Finalmente, observando os gráficos mais uma vez, nota-se que as configurações G10, G14, G15 e G16 sempre apresentam desempenhos superiores a $100 \%$, o que a princípio as qualifica para serem utilizadas nos outros estudos. Como a configuração G10 apresenta a maior performance mínima, ela foi escolhida para ser utilizada nos outros casos. Isso não significa que as configurações $G 14, G 15$ e $G 16$ não apresentariam bons resultados, o problema é que os tempos de processamento não permitem que todas as configurações sejam testadas para cada estudo de dimensionamento.

Por referir-se aos tempos de processamento, deve-se ainda explicar como o tempo de processamento de cinco horas foi determinado. Para determinar tal número, realizou-se o conjunto de testes mostrado na Tabela 7.15. Para cada um dos nove testes listados na tabela, o procedimento adotado foi o seguinte:

1. Executou-se a Busca Exaustiva e determinou-se o valor da função objetivo $(V F O)$ referente à máxima Receita Líquida Anual $\left(R_{L Q}\right)$ do aproveitamento, bem como o respectivo tempo de processamento. Por exemplo, para o teste 1, a $B E X$ gastou 92 horas, 14 minutos e 21 segundos para encontrar a $R_{L Q}$ de $U S \$ 94.436 .488$.

2. Utilizando-se a configuração G10 para o Algoritmo Genético, adotou-se como critério de parada o valor de $V F O$ encontrado pela $B E X$, executou-se o modelo de dimensionamento dez vezes e observou-se quanto tempo era necessário para o modelo de dimensionamento encontrar uma $R_{L Q}$ maior ou igual à encontrada pela $B E X$. Citando novamente o teste 1 , no melhor caso o Dime gastou 3 minutos e 37 segundos e no pior ele gastou 55 minutos e 57 segundos para encontrar uma $R_{L Q}$ superior ou igual a $U S \$ 94.436 .488$. Além disso, dentre as dez execuções do Dime, a pior, a média e a melhor $R_{L Q}$ encontradas foram, respectivamente, $0,8 \%, 1,3 \%$ e $1,7 \%$ superiores às encontradas pela $B E X^{38}$.

\footnotetext{
${ }^{38}$ Ressalta-se que estes percentuais não constituem a vantagem da utilização dos Algoritmos Genéticos na busca pelas dimensões ótimas, mas sim as diferenças observadas entre os tempos de processamento.
} 
3. Baseando-se nos máximos tempos de processamento necessários para o modelo de dimensionamento encontrar respostas superiores à Busca Exaustiva, concluiu-se que o tempo de processamento de cinco horas seria suficiente para que o modelo encontrasse uma boa solução para o problema.

Tabela 7.15 - Testes para determinação do tempo de processamento do modelo de Dimensionamento.

\begin{tabular}{lccccccc}
\hline \multicolumn{1}{c}{ Teste } & \multicolumn{2}{c}{ BEX } & \multicolumn{2}{c}{ Tempo Dime } & \multicolumn{3}{c}{ VFO Dime } \\
& Tempo $^{(*)}$ & VFO & Mín & Máx & Mín & Méd & Máx \\
\hline 1. Emb37ParEF30M2BGHT & $92: 14: 21$ & 94.436 .488 & $0: 03: 37$ & $0: 55: 57$ & $100,8 \%$ & $101,3 \%$ & $101,7 \%$ \\
2. Emb37ParEF30M2ESBGHT & $92: 22: 51$ & 80.834 .275 & $0: 02: 54$ & $0: 22: 13$ & $101,2 \%$ & $101,9 \%$ & $102,0 \%$ \\
3. Emb37ParEF30M2ESPGBGHT & $92: 30: 30$ & 91.294 .936 & $0: 03: 04$ & $0: 35: 00$ & $100,3 \%$ & $101,0 \%$ & $101,3 \%$ \\
4. Emb37ParEF40M2BGHT & $92: 11: 48$ & 153.840 .158 & $0: 00: 18$ & $4: 46: 37$ & $100,0 \%$ & $100,0 \%$ & $100,0 \%$ \\
5. Emb37ParEF40M2ESBGHT & $92: 48: 21$ & 139.219 .512 & $0: 00: 27$ & $0: 02: 53$ & $100,0 \%$ & $100,1 \%$ & $100,1 \%$ \\
6. Emb37ParEF40M2ESPGBGHT & $92: 33: 03$ & 151.332 .515 & $0: 03: 35$ & $0: 51: 36$ & $100,0 \%$ & $100,1 \%$ & $100,1 \%$ \\
7. Emb37ParEF50M2BGHT & $92: 13: 30$ & 216.184 .473 & $0: 06: 45$ & $2: 54: 21$ & $100,0 \%$ & $100,0 \%$ & $100,0 \%$ \\
8. Emb37ParEF50M2ESBGHT & $92: 23: 42$ & 202.222 .032 & $0: 00: 15$ & $4: 53: 39$ & $100,0 \%$ & $100,1 \%$ & $100,1 \%$ \\
9. Emb37ParEF50M2ESPGBGHT & $92: 29: 39$ & 216.149 .176 & $0: 02: 51$ & $0: 11: 03$ & $100,9 \%$ & $101,2 \%$ & $101,5 \%$ \\
\hline
\end{tabular}

(*) Testes realizados em um computador AMD Athlon ${ }^{\mathrm{TM}}$ XP $1600+, 1,40 \mathrm{GHz}$ e $512 \mathrm{MB}$ de RAM.

Resumindo os resultados encontrados nesta seção, os estudos de dimensionamento utilizarão o Algoritmo Genético $G 10$ e terão como critério de parada o tempo de processamento de cinco horas. Resta apresentar os estudos realizados e analisar e comentar os seus resultados, o que é feito nas duas próximas seções. 



\section{Definição dos Estudos de Dimensionamento}

Os estudos de dimensionamento foram realizados com o objetivo de apresentar e analisar as respostas do modelo proposto. Definiu-se uma estratégia de apresentação dos resultados de forma que as análises sejam progressivamente desenvolvidas, acrescentando-se a cada passo a influência de novos parâmetros.

Inicialmente, discute-se detalhadamente o resultado de um teste julgado básico, em que são abordados os princípios do dimensionamento ótimo de uma usina hidroelétrica. Posteriormente, são realizadas comparações entre os resultados de vários testes elaborados para subsidiar a análise da influência dos parâmetros do modelo de dimensionamento sobre as características da nova usina.

Para evitar repetições excessivas e desnecessárias das explicações das condições de realização dos estudos, adotou-se uma convenção para fazer com que os nomes dos testes sejam auto-explicativos. Esta convenção, já brevemente explicada na Seção 3, é apresentada em detalhes na Seção 4.1.

\subsection{Convenção de Nomenclatura dos Testes}

A convenção de nomenclatura dos testes foi desenvolvida para tornar os nomes dos testes auto-explicativos, no sentido do nome conseguir conter informações que permitam identificar a usina sob dimensionamento, o sistema ao qual esta usina vai pertencer, a regra de operação utilizada nos estudos de simulação, a forma de valorização da energia gerada, o fato de serem utilizados benefícios locais ou globais, e o conjunto de vazões afluentes.

A convenção de nomenclatura é ilustrada na Figura 7.13. O nome de um teste é dividido em seis partes: uma referente à definição da própria usina e as demais referentes aos outros parâmetros de dimensionamento. No exemplo da figura, nomeia-se um estudo em que a usina sob dimensionamento é Emborcação, o sistema completo é composto por 37 usinas, a regra de operação é a paralela, o mecanismo de valorização da energia atribui o valor médio de $30 \mathrm{US} \$ / M W h$ à Energia Firme e considera-se o preço de ponta igual ao dobro do preço fora de ponta, o benefício energético é considerado global, e utiliza-se nas simulações o histórico de vazões de 1931 a 1994. 


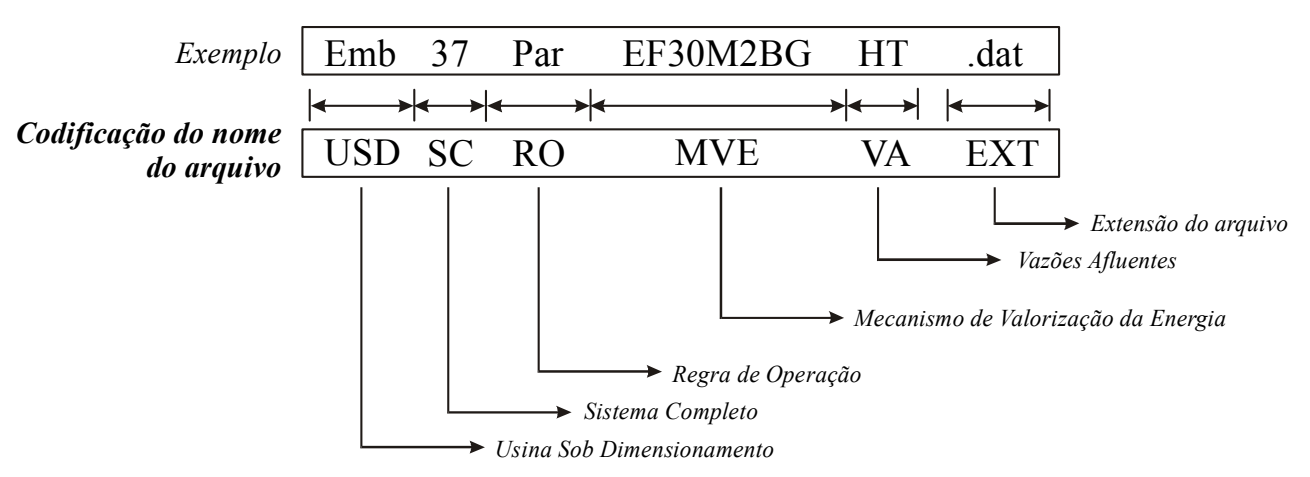

Figura 7.13 - Convenção de nomenclatura dos testes.

Para apresentar os significados dos códigos que aparecerão nos nomes dos testes, listam-se a seguir todas as possibilidades de usina sob dimensionamento, sistema completo, regra de operação, mecanismo de valorização da energia, etc.

\section{- Usina Sob Dimensionamento (USD)}

As usinas sob dimensionamento a serem utilizadas nos testes são duas: Emborcação e Porto Primavera. Para Emborcação, o código que aparece no nome do arquivo é $E m b$, enquanto para Porto Primavera o código é Pri. Por exemplo, o arquivo Pri37ParEF30M2BGHT.dat refere-se ao dimensionamento de Porto Primavera nas mesmas condições do dimensionamento de Emborcação ilustrado na Figura 7.13.

\section{- Sistema Completo (SC)}

São definidos dois sistemas completos para serem utilizados nos testes. O primeiro deles, chamado simplesmente de 37, contém as principais usinas do Sistema Sudeste, tal como já ilustrado na Figura 7.1. O sistema 37 é utilizado como Sistema Completo tanto no dimensionamento de Emborcação quanto no dimensionamento de Porto Primavera. Quando a usina sob dimensionamento é Emborcação, o Sistema de Referência é composto por todas as 37 usinas do Sistema Sudeste, exceto Emborcação. De forma semelhante, quando a usina sob dimensionamento é Porto Primavera, o Sistema de Referência é composto por todas as 37 usinas do Sistema Sudeste, exceto Porto Primavera.

Em alguns testes realizados com Emborcação, alteram-se o Sistema de Referência e o Sistema Completo. O Sistema Completo utilizado nestes testes é chamado de 4, por ser simplesmente composto pelas usinas de Emborcação, Itumbiara, São Simão e Ilha Solteira. O Sistema de Referência é composto por estas quatro usinas, exceto Emborcação. 
Análises posteriores comparando as dimensões ótimas de Emborcação com os sistemas 4 e 37 determinarão a influência do Sistema de Referência utilizado durante o processo de dimensionamento.

\section{- Regra de Operação (RO)}

Todos os testes são realizados basicamente de acordo com duas Regras de Operação: a Regra Paralela (Par) e a Regra Baseada em Otimização (Roo). A RP independe do sistema teste, sendo utilizada indiferentemente tanto na simulação dos sistemas de referência quanto dos sistemas completos.

Por outro lado, a Roo depende de cada sistema a ser simulado. Por exemplo, para definir a regra de operação para o Sistema Completo 37 utilizado para dimensionar Emborcação, primeiro otimiza-se a operação do Sistema Completo sem a usina de Emborcação, obtendo-se nuvens de pontos para cada usina, sobre as quais são ajustadas curvas utilizadas como regras de operação para simulação da operação do Sistema de Referência. Em seguida, acrescenta-se a usina sob dimensionamento ao Sistema de Referência e repetem-se o estudo de otimização e o ajuste de curvas, obtendo-se as regras de operação para simulação do Sistema Completo.

Processo semelhante é desenvolvido para o dimensionamento de Emborcação com o Sistema Completo composto por 4 usinas e para o dimensionamento de Porto Primavera com o Sistema Completo composto por 37 usinas.

Para efeito de caracterizar as condições nas quais os estudos de dimensionamento foram realizados, a variável $R O$ contida nos nomes será simplesmente igual a Par ou a Roo, referindo-se, respectivamente, à Regra Paralela e à Regra Baseada em Otimização. A forma de obtenção da Roo fica implicitamente definida pela Usina Sob Dimensionamento e pelo Sistema Completo utilizado.

\section{- Mecanismo de Valorização da Energia (MVE)}

Os Mecanismos de Valorização da Energia (MVEs) devem ser capazes de considerar diferentes valores de Energia Firme, valorizações de Energia Secundária e Ponta Garantida, além de considerar medidas de benefícios energéticos globais ou locais. Para contemplar todos estes aspectos, a variável MVE utilizada nos nomes dos testes pode possuir vários valores:

- $E F 30 M 1 B G, E F 40 M 1 B G$ e EF50M1BG: estes MVEs valorizam a Energia Firme a US\$30/MWh, US\$40/MWh e US\$50/MWh, respectivamente, atribuem preços iguais à energia de ponta e fora de ponta (modulação igual 
a 1), atribuem custos de referência nulos aos benefícios de Energia Secundária e Ponta Garantida, e consideram Benefícios Energéticos Globais (diferença entre os benefícios dos Sistemas Completo e de Referência).

- EF30M2BG, EF40M2BG e EF50M2BG: estes três MVEs valorizam a Energia Firme a custos médios de US\$30/MWh, US\$40/MWh e US\$50/MWh, e consideram o preço de ponta igual a duas vezes o preço fora de ponta (Modulação igual a 2 - M2), além de atribuírem custos de referência nulos aos benefícios de Energia Secundária e Ponta Garantida, e considerarem Benefícios Energéticos Globais.

- EF30M2ESBG, EF40M2ESBG e EF50M2ESBG: estes MVEs valorizam a Energia Firme a valores médios de US\$30/MWh, US\$40/MWh e US\$50/MWh, com o preço da energia de ponta igual ao dobro do preço da energia fora de ponta, valorizam a Energia Secundária a US\$11/MWh, atribuem custo de referência nulo ao benefício de Ponta Garantida, e consideram Benefícios Energéticos Globais.

- EF30M2ESPGBG, EF40M2ESPGBG e EF50M2ESPGBG: idem aos anteriores e também valorizam a Ponta Garantida a US\$10.000/MW.ano.

- EF30BL, EF40BL e EF50BL, EF30M2BL, EF40M2BL e EF50M2BL, EF30M2ESBL, EF40M2ESBL e EF50M2ESBL, EF30M2ESPGBL, EF40M2ESPGBL e EF50M2ESPGBL: seguem as mesmas definições dos MVEs anteriores, porém consideram Benefícios Energéticos Locais.

\section{- Conjunto de Vazões Afluentes (VA)}

Nos estudos realizados são considerados dois conjuntos de vazões afluentes. O primeiro conjunto, chamado de Histórico Total (HT), engloba todas as vazões históricas de 1931 a 1994. O segundo conjunto, chamado de Histórico Parcial (HP), engloba somente as vazões de 1960 a 1994.

A escolha destes dois conjuntos de vazão possui o objetivo de mostrar como as dimensões ótimas podem ser alteradas em função dos recursos hidrológicos disponíveis nos estudos de simulação. Além disso, muito tem se discutido no Setor Elétrico sobre as alterações climáticas e de uso do solo ocorridas a partir da década de sessenta, fazendo com que as vazões afluentes mais recentes (de 1960 em diante) tenham características distintas das vazões anteriores a este período. Desta forma, os estudos realizados 
também podem ajudar a mostrar a influência que estas variações climáticas podem ter sobre o dimensionamento de novos empreendimentos hidroelétricos.

\section{- Algoritmo Genético}

Conforme justificado na Seção 3 deste capítulo, o Algoritmo Genético utilizado foi o definido como $G 10$.

\section{- Limites das Variáveis de Volume}

As variáveis que determinam os volumes mínimo e máximo da usina sob dimensionamento são consideradas como pertencentes a intervalos pré-definidos de valores. Para a usina de Emborcação, o menor valor possível de volume mínimo é $4.000 \mathrm{hm}^{3}$ e o maior valor possível de volume máximo é $20.000 \mathrm{hm}^{3}$. Para a usina de Porto Primavera, estes valores são $10.000 \mathrm{hm}^{3}$ e $25.000 \mathrm{hm}^{3}$, respectivamente.

Estes limites são definidos com base nas características do local de instalação da usina hidroelétrica. Para o caso das usinas utilizadas, definiram-se intervalos de valores que envolvem os valores reais dos aproveitamentos existentes.

\section{- Modelo de Fluxo de Caixa}

O modelo de fluxo de caixa descreve basicamente a taxa de juros durante a construção, a taxa de descontos e o cronograma de desembolso. Foi utilizado apenas um modelo para fluxo de caixa em todos os estudos, com taxa de desconto igual a $10 \%$ ao ano, taxa de juros durante a construção de $8,5 \%$ ao ano, tempo de construção de cinco anos, cronograma de desembolso em cinco parcelas respectivamente iguais a $10 \%, 10 \%, 35 \%$, $30 \%$ e $15 \%$ do investimento total e vida útil da usina de 50 anos.

Após esta descrição de todas as variações de dados do modelo de dimensionamento, resta iniciar a apresentação dos resultados dos estudos. 



\section{Resultados}

Conforme já mencionado, os primeiros testes cujos resultados são analisados são testes bem básicos, visando apenas a apresentação dos resultados do modelo. Os fatores que podem alterar as dimensões de um aproveitamento serão adicionados de forma progressiva ao longo das explicações.

\subsection{Estudo Detalhado}

Na Tabela 7.16 apresenta-se o resultado completo do estudo Emb37ParEF40M1BGHT. Esta seção presta-se justamente a discutir de forma detalhada cada um dos resultados apresentados. Para organizar as discussões, serão analisados os resultados encontrados em cada um dos blocos da Tabela 7.16: Dimensões Ótimas da USD, Benefícios Energéticos Sistêmicos, Beneficios Energéticos da USD, Custos, Receitas e Balanço Econômico Anual.

\section{- Dimensões Ótimas da USD}

Inicialmente, observam-se os volumes mínimo e máximo da usina sob dimensionamento, iguais a $4.000,0 \mathrm{hm}^{3}$ e $10.893,5 \mathrm{hm}^{3}$, respectivamente. $\mathrm{O}$ volume mínimo corresponde exatamente ao limite mínimo de volume permitido para esta usina, informado no conjunto de dados de entrada. Isto significa que o modelo entende que para uma usina de cabeceira (caso de Emborcação), é preferível possuir um volume mínimo pequeno e poder esvaziar-se totalmente, liberando água para as usinas a jusante, a ter um limite mínimo de armazenagem elevado e poder gerar energia com produtividades relativamente maiores (maiores alturas de quedas). Visto de outra forma, o modelo enxerga que a usina de montante traz maiores benefícios ao sistema se ela puder ter uma grande capacidade de regularização, o que é conseguido reduzindo-se o seu volume mínimo ao menor valor possível.

Já volume máximo determinado pelo modelo, $10.893,5 \mathrm{hm}^{3}$, corresponde a um compromisso econômico, uma vez que o limite superior de volume máximo permitido para esta usina é $20.000 \mathrm{hm}^{3}$. Este compromisso ocorre quando os benefícios econômicos incrementais decorrentes do aumento do reservatório igualam-se aos respectivos custos incrementais. Esta situação pode ser visualizada na Figura 7.14, onde apresentam-se os custos e os benefícios econômicos anuais para a usina de Emborcação em função de seu volume máximo, considerando-se o volume mínimo constante de $4.000 \mathrm{hm}^{3}$ e capacidade instalada de ponta nula. 
Tabela 7.16 - Resultado completo do estudo Emb37ParEF40M1BGHT.

\begin{tabular}{|c|c|c|c|c|c|}
\hline \multicolumn{6}{|c|}{ Benefícios Energéticos Sistêmicos } \\
\hline & \multirow{2}{*}{$\begin{array}{l}\text { Sistema de } \\
\text { Referência }\end{array}$} & \multicolumn{2}{|c|}{ Sistema Completo } & \multicolumn{2}{|c|}{ Benefício Sistêmico } \\
\hline & & Mot. Bas & Mot. Complete & Mot. Base & Mot. Completa \\
\hline Energia Firme $[\overline{\mathrm{MW}}]$ & $18.785,0$ & $19.465,8$ & $19.465,8$ & 680,8 & 680,8 \\
\hline Energia Secundária $[\overline{\mathrm{MW}}]$ & $3.976,1$ & $3.800,5$ & $3.800,5$ & $-175,6$ & $-175,6$ \\
\hline 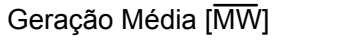 & $22.761,1$ & $23.266,3$ & $23.266,3$ & 505,2 & 505,2 \\
\hline Ponta Garantida [MW] & $35.533,6$ & $36.452,7$ & $36.452,7$ & 919,1 & 919,1 \\
\hline \multicolumn{2}{|c|}{ Dimensões Ótimas da USD } & \multicolumn{4}{|c|}{ Benefícios Energéticos da USD } \\
\hline Volume Mínimo $\left[\mathrm{hm}^{3}\right]$ : & $4.000,0$ & \multicolumn{2}{|r|}{ Motoriz } & zação de Base & Motorização Final \\
\hline Volume Máximo $\left[\mathrm{hm}^{3}\right]$ : & $10.893,5$ & \multicolumn{2}{|c|}{ Energia Firme $[\overline{\mathrm{MW}}]$} & 415,3 & 415,3 \\
\hline Área Inundada [km²]: & 311,9 & \multicolumn{2}{|c|}{ Energia Secundária $[\overline{\mathrm{MW}}]$} & 36,1 & 36,1 \\
\hline Queda Referência [m]: & 89,9 & \multicolumn{2}{|c|}{ 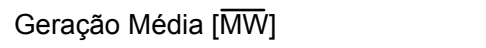 } & 451,4 & 451,4 \\
\hline Queda Projeto [m]: & 117,8 & & 927,4 & 927,4 \\
\hline Vazão Ref. Base $\left[\mathrm{m}^{3} / \mathrm{s}\right]$ : & $1.183,6$ & \multicolumn{2}{|c|}{ Custos (Mot. Final) [ US\$ ] } & \multicolumn{2}{|c|}{ Receitas (Mot. Final) [ US\$ ] } \\
\hline Vazão Ref. Total [m³/s]: & $1.183,6$ & Aquisição Terra: & $54.234 .107,4$ & \multicolumn{2}{|c|}{ Energia Firme: $\quad 235.273 .057,5$} \\
\hline Potência Base [MW]: & 928,6 & Construção: & $332.587 .790,1$ & \multicolumn{2}{|c|}{ Energia Séc.: $\quad 0,0$} \\
\hline Potência Total [MW]: & 928,6 & Gerador Base: & $261.760 .335,9$ & Ponta Garant.: & 0,0 \\
\hline Fator de Capacidade [\%]: & 44,7 & Gerador Ponta: & 0,0 & & \\
\hline Custo Instalação [\$/kW]: & 803,5 & JDC [\%]: & 15,4 & & \\
\hline Índice de Mérito [\$/MWh]: & 15,3 & O\&M Anual: & $4.233 .056,6$ & NLQ & \\
\hline & & Balanço Econôm & Anual [US\$] & & \\
\hline & & Motc & ação de Base & Motori & ização Final \\
\hline Receita Bruta An & [ US\$ ] & & $.273 .057,5$ & 235. & $273.057,5$ \\
\hline Custo Total Anu & US\$ ] & & $.045 .731,1$ & 91. & $045.731,1$ \\
\hline Receita Líquida $\mathrm{Ar}$ & [ US\$ ] & & $.227 .326,3$ & 144. & $227.326,3$ \\
\hline
\end{tabular}

Analisando a figura, observa-se que o custo total anual da usina cresce quase que exponencialmente em função dos acréscimos de volume máximo. Este crescimento decorre das elevações do custo de construção da usina, do custo de aquisição de terras, do custo de instalação da casa de máquinas (quanto maior o volume máximo, maior a capacidade instalada de base) e do custo de operação e manutenção.

A receita líquida anual também aumenta à medida que o volume máximo elevase. A cada elevação de volume máximo, passa a haver mais água disponível para a usina de Emborcação e para as usinas de jusante utilizarem durante o Período Crítico, aumentando a Energia Firme ${ }^{39}$ da própria usina sob dimensionamento e das outras usinas do sistema que dela se beneficiam ${ }^{40}$. Observa-se, entretanto, que as variações dos benefícios econômicos não são uniformes no trecho em que o volume máximo aumenta

\footnotetext{
${ }^{39}$ Somente a Energia Firme está sendo valorizada neste estudo.

${ }^{40} \mathrm{O}$ benefício energético considerado é o global, ou seja, valorizam-se economicamente os ganhos energéticos referentes à diferença entre o benefício energético do Sistema Completo e do Sistema de Referência.
} 


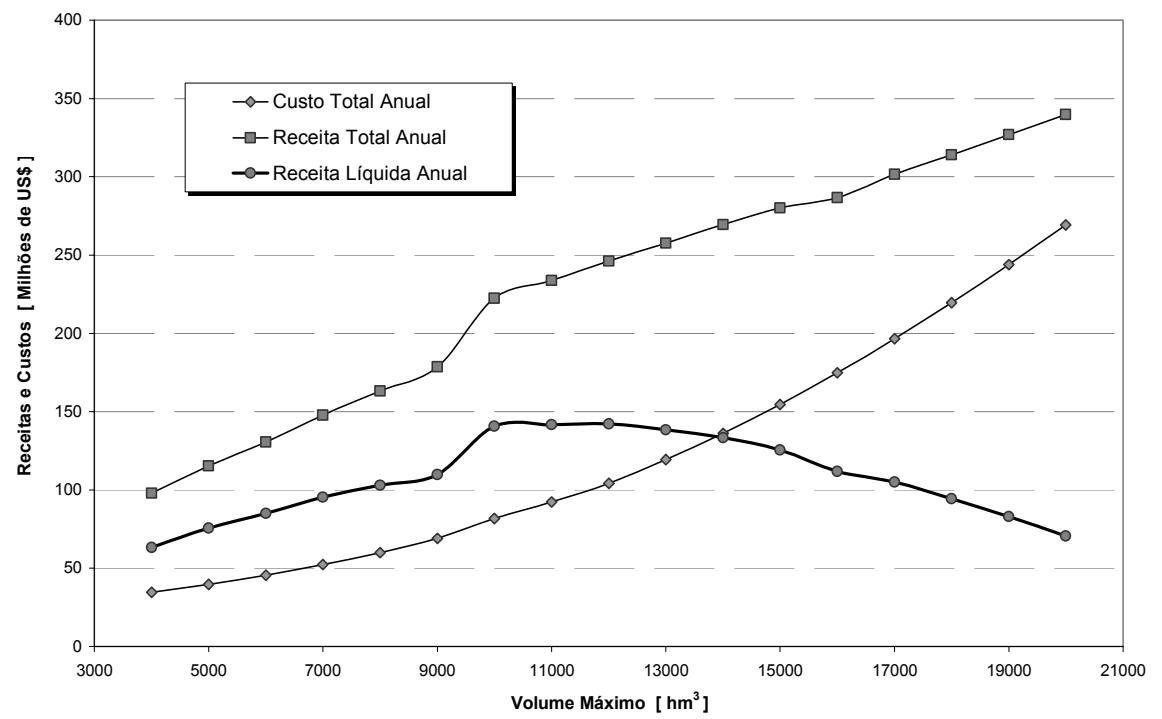

Figura 7.14 - Visualização dos custos e beneficios anuais em função do volume máximo de Emborcação, mantendo-se o volume mínimo e a capacidade instalada de ponta nulos.

de $9.000 \mathrm{hm}^{3}$ para $10.000 \mathrm{hm}^{3}$, havendo uma elevação abrupta do benefício energético, o que acaba traduzindo-se em uma elevação também abrupta de receita líquida anual. Este relativo "salto" ocorre em função da alteração do Período Crítico: no primeiro trecho do gráfico, antes do salto, o Período Crítico do Sistema Completo vai de maio de 1952 a novembro de 1955, enquanto no segundo trecho ele inicia-se em maio de 1952, mas termina somente em novembro de 1956.

Quando o volume máximo aumenta progressivamente de $4.000 \mathrm{hm}^{3}$ até o valor ótimo, $10.893,5 \mathrm{hm}^{3}$, a cada acréscimo de volume máximo há um acréscimo de receita total anual superior ao respectivo acréscimo de custo total anual, justificando os aumentos de capacidade do reservatório. Quando o volume máximo é superior ao valor ótimo, acréscimos de volume máximo elevam os benefícios econômicos a uma taxa inferior aos aumentos de custo, ocasionando reduções de receita líquida. Assim, sendo $C_{T}$ e $R_{T}$ o custo e a receita total anual, e $x_{m a ́ x}$ o volume máximo da usina, no ponto ótimo observa-se a seguinte relação entre estas variáveis:

$$
\frac{\partial C_{T}}{\partial x_{\text {máx }}}=\frac{\partial R_{T}}{\partial x_{\text {máx }}}
$$

Numericamente, este valor pode ser determinado pelo conjunto de pontos utilizado para gerar os gráficos da Figura 7.14, obtendo-se o seguinte resultado:

$$
\frac{\partial C_{T}}{\partial x_{\text {máx }}}=\frac{\partial R_{T}}{\partial x_{\text {máx }}}=12.888,10 \frac{U S \$}{\mathrm{hm}^{3}}
$$

Concluindo, no ponto ótimo, um aumento marginal de volume máximo implica aumentos de custo e de receita iguais a $12.888,10$ US\$. 
Retornando às dimensões ótimas da usina sob dimensionamento mostradas na Tabela 7.16, observa-se a área inundada de $311,9 \mathrm{~km}^{2}$, conseqüência do valor de $x_{\text {máx }}$. Também se observa a diferença relativamente grande entre a queda de referência, $h_{n o m}=$ $88,90 \mathrm{~m}$, e a queda de projeto, $h_{p r o j}=117,8 \mathrm{~m}$. Esta diferença decorre das próprias definições das quedas: enquanto a queda de referência equivale à queda com garantia de 95\% do tempo, a queda de projeto equivale a uma média das quedas líquidas observadas durante a simulação, ponderadas pelos valores de geração.

Isto significa que o projeto foi realizado para fazer com que as turbinas limitem a geração da usina somente em condições extremamente críticas, com o reservatório praticamente vazio, a ponto de fazer com que a queda líquida seja inferior à queda de referência. Por outro lado, a média ponderada das quedas líquidas pela geração, utilizada no cálculo da queda de projeto, imprime às turbinas a característica de apresentarem rendimento elevado nas situações em que a usina gera mais energia.

Também se observam na tabela de resultados a vazão de referência de base e a potência de base, $q_{r e f, b}$ e $p_{n o m, b}$. Estas variáveis, juntamente com a queda de referência, $h_{\text {nom }}$, “amarram" a relação existente entre altura de queda, vazão e potência:

$$
\begin{aligned}
& p_{\text {nom }, b}=9,81 \cdot 10^{-3} \cdot \eta_{\text {méd }} \cdot h_{\text {nom }} \cdot q_{\text {ref }, b} \\
& 928,6=9,81 \cdot 10^{-3} \cdot 0,88 \cdot 89,9 \cdot 1183,6
\end{aligned}
$$

na qual $\eta_{\text {méd }}$ é o rendimento médio do conjunto turbina-gerador, adimensional.

É importante frisar ainda o significado de $p_{n o m, b}$, uma vez que se trata da mínima capacidade a ser instalada na usina para que não sejam verificadas vazões vertidas ao longo do Período Crítico. Em outras palavras, reduzir a capacidade instalada de base implica reduzir a Energia Firme da usina. De forma oposta, instalar uma capacidade superior à de base implica custos adicionais que só se justificam se houver valorização econômica dos benefícios associados. Conforme já discutido em sessões anteriores, esta valorização pode ser feita pela modulação da Energia Firme gerada, pela valorização da Energia Secundária ou da Ponta Garantida.

Nas condições em que este estudo foi realizado, não havia nenhuma sinalização econômica favorável à expansão da casa de força, uma vez que não há modulação da Energia Firme, nem tampouco atribuições de valores à Energia Secundária ou à Ponta Garantida. Esta ausência de incentivos resulta em valores iguais de potência instalada de base e potência instalada total, isto é, $p_{n o m, b}=p_{n o m}=928,6 \mathrm{MW}$. Em outras palavras, a potência instalada de ponta é nula: $p_{n o m, p}=0 \mathrm{MW}$. 
Há ainda mais três resultados apresentados na seção Dimensões Ótimas da USD: o Fator de Capacidade, o Custo de Instalação e o Índice de Mérito. O Fator de Capacidade igual a 44,7\% significa que a Energia Firme da USD equivale a 44,7\% da potência instalada total da usina. Este número pode ser facilmente obtido a partir dos dados da Tabela 7.16, simplesmente dividindo-se a Energia Firme da USD, 415,3 $\overline{M W}$, pela potência instalada final, 928,6 $\mathrm{MW}$.

O Custo de Instalação é calculado como o investimento total realizado na construção da usina, dividido pela potência instalada final. O valor encontrado, 803,2 US\$/kW, significa que para cada $M W$ instalado na usina foi necessário um investimento de cerca de oitocentos mil dólares.

Finalmente, o Índice de Mérito é calculado como uma razão entre o custo total anual da usina (incluindo custo de investimento e custo de operação e manutenção) e o benefício anual global de Energia Firme que esta usina proporciona. Para o caso em estudo, o Índice de Mérito igual a 15,30 US\$/MWh significa que para cada $M W h$ adicionado ao Sistema de Referência, tanto pelo novo empreendimento quanto pelos ganhos a jusante, foram gastos 15,30 US\$.

\section{- Benefícios Energéticos Sistêmicos}

A seção da Tabela 7.16 referente aos benefícios energéticos sistêmicos trata dos ganhos que a usina sob dimensionamento proporciona quando são comparados os benefícios energéticos do Sistema de Referência e do Sistema Completo.

Por exemplo, analisando somente a motorização de base, o benefício global de Energia Firme, $B_{E F G}=680,8 \overline{M W}$, equivale à diferença entre a Energia Firme do Sistema de Completo, $E F_{S}=19.465,8 \overline{M W}$, e a Energia firme do Sistema de Referência, $E F_{R}=18.785,0 \overline{M W}$. Este ganho global deve-se a dois fatores: $(i)$ a geração que a própria usina proporciona ao longo do Período Crítico, (ii) os ganhos de geração ao longo do Período Crítico que as usinas a jusante apresentam devido ao fato de receberem vazões mais elevadas devido ao esvaziamento do novo reservatório.

Observando os valores de Energia Secundária, observa-se que a construção da nova usina proporciona um benefício sistêmico negativo, $B_{E S G}=-175,6 \overline{M W}$. A Energia Secundária do Sistema de Referência, $E S_{R}=3.976,1 \overline{M W}$, é maior que a Energia Secundária do Sistema Completo, $E S_{C}=3.800,5 \overline{M W}$. Esta redução deve-se ao fato da nova usina ser de cabeceira. Logo, sua construção proporciona vazões mais 
regularizadas ao restante do sistema, amortecendo os picos de vazão ao longo dos períodos de cheia e, conseqüentemente, reduzindo os valores de Energia Secundária.

A maior regularização das vazões afluentes proporcionada pelo novo reservatório é um dos fatores que eleva a Geração Média sistêmica em 505,2 $\overline{M W}$, tal como observado na Tabela 7.16. O outro fator é a existência do novo aproveitamento, que também gera energia e obviamente eleva a Geração Média do Sistema Completo.

Observa-se também o ganho global de Ponta Garantida, $B_{P G G}=919,1 \mathrm{MW}$, equivalente à diferença entre a Ponta Garantida do Sistema Completo, $P G_{C}=$ 36.452,7 MW, e do Sistema de Referência, $P G_{R}=35.533,6 \mathrm{MW}$.

Como última observação desta seção, como a motorização final é igual à motorização de base, os benefícios sistêmicos com motorização de base e final são exatamente os mesmos.

\section{- Benefícios Energéticos da USD}

Os Benefícios Energéticos da USD mostrados na Tabela 7.16 referem-se aos valores de Energia Firme, Energia Secundária, Geração Média e Ponta Garantida somente da usina sob dimensionamento.

O primeiro fato a ser observado é o valor da Energia Firme da usina sob dimensionamento, $E F_{U S D}=415,3 \overline{M W}$. Comparando este valor com o benefício global de Energia Firme, $B_{E F G}=680,8 \overline{M W}$, constata-se que o ganho que a usina proporciona ao sistema é bem superior (cerca de 64\%) ao seu ganho próprio. Visto de outra forma, isto significa que outras usinas passaram a gerar mais energia ao longo do Período Crítico devido à entrada em operação de Emborcação. Por exemplo, a usina de São Simão eleva sua Energia Firme de $854,5 \overline{M W}$ a $869,6 \overline{M W}$ devido à construção de Emborcação. Elevações de Energia Firme também são observadas em outras usinas a jusante, destacando-se o caso de Itaipu, cuja Energia Firme eleva-se de 7497,8 $\overline{M W}$ para 7777,9 $\overline{M W}$; um acréscimo de $280,1 \overline{M W}$.

O segundo fato a ser observado é o valor da Energia Secundária da usina sob dimensionamento, $E S_{U S D}=36,1 \overline{M W}$. O fato de haver uma Energia Secundária positiva mesmo com a usina possuindo apenas a sua motorização de base pode, a princípio, parecer estranho, já que a casa de força foi, neste caso, dimensionada única e 
exclusivamente para proporcionar a Energia Firme do aproveitamento.

No entanto, esta Energia Secundária observada justifica-se porque a potência instalada é dimensionada como sendo igual à geração máxima observada ao longo do Período Crítico, a fim de evitar a existência de vazões vertidas no período mais seco do histórico. Logo, a potência instalada de base (valor máximo) é maior que a Energia Firme (valor médio). Este fato faz com que a Geração Média ao longo de todo o histórico seja maior que a geração média ao longo do Período Crítico (Energia Firme), caracterizando-se assim uma Energia Secundária positiva.

O valor positivo de Energia Secundária ainda permite caracterizar bem o benefício sistêmico proporcionado pela regularização das vazões. Embora a Energia Secundária da nova usina seja positiva, $E S_{U S D}=36,1 \overline{M W}$, o benefício sistêmico de Energia Secundária é negativo, $B_{E S G}=-175,6 \overline{M W}$. Isto significa que com a inserção da nova usina, o sistema como um todo eleva sua Energia Firme e sua Geração Média a ponto de reduzir a Energia Secundária sistêmica. Este fato reforça a importância da nova usina, uma vez que a Energia Secundária possui valor econômico reduzido quando comparada à Energia Firme.

O benefício sistêmico proporcionado pela melhor regularização das vazões também pode ser observado comparando-se as gerações médias da Usina Sob Dimensionamento, 451,4 $\overline{M W}$, e o benefício sistêmico de geração média, 505,2 $\overline{M W}$. Isso mostra que devido à nova usina, o restante do sistema eleva sua Geração Média em mais de $50 \overline{M W}$.

Finalmente, comparando-se a Ponta Garantida da usina sob dimensionamento, $P G_{U S D}=927,4 M W$ e o benefício sistêmico de Ponta Garantida, $B_{P G G}=919,1 \mathrm{MW}$, constata-se uma pequena diferença entre os valores, ocasionada pela alteração de comportamento das outras usinas.

\section{- Custos}

A seção de custos da Tabela 7.16 resume-se a apresentar o custo de aquisição de terras, função da área alagada total pelo reservatório, o custo de construção da barragem, função do volume máximo do reservatório, e o custo das casas de força de base e de ponta. Além disso, também apresentam-se a taxa de juros durante a construção e o custo anual de operação e manutenção.

Para calcular o custo total anual apresentado na tabela, deve-se realizar o seguinte procedimento: 
1. Calcula-se o investimento total $I_{T}$, em US\$, igual à soma dos custos de aquisição de terra, construção, gerador de base e gerador de ponta, mais um adicional de $15 \%$ relativo a custos indiretos (administração do projeto, engenharia, etc):

$$
\begin{gathered}
I_{T}=1,15 \cdot(54.234 .107,4+332.587 .790,1+261.760 .335,9) \\
\therefore \quad I_{T}=745.869 .568,4 U S \$
\end{gathered}
$$

2. Adiciona-se ao investimento total $I_{T}$, os juros durante a construção, obtendose o valor presente do investimento total, $I_{T, V P}$ :

$$
I_{T}=1,154 \cdot 745.869 .568,4=860.733 .481,9 \text { US } \$
$$

3. Multiplica-se o valor presente do investimento total, $I_{T, V P}$, pelo Fator de Recuperação de Capital a uma taxa de retorno de $10 \%$ ao ano, durante o tempo de vida da usina de 50 anos, calculando-se assim o custo anual de investimento:

$$
C_{I T}=860.733 .481,9 \cdot \operatorname{FRC}(10 \%, 50)=86.812 .674,5 \frac{U S \$}{\text { ano }}
$$

4. Adiciona-se ao custo anual de investimento, $C_{I T}$, o custo anual de manutenção e operação, $C O M$, obtendo-se o custo total anual, $C_{T}$ :

$$
C_{T}=86.812 .674,5+4.233 .056,6=91.045 .731,1 \frac{U S \$}{\text { ano }}
$$

\section{- Receitas}

O cálculo das receitas para este caso é bastante simples porque a única receita da usina advém do Benefício Global de Energia Firme, $B_{E F G}=680,8 \overline{M W}$, sem realizar qualquer modulação. Conforme já mencionado, os benefícios de Energia Secundária e Ponta Garantida não são considerados neste estudo.

Assim, a Receita Total Anual, $R_{T}$, mostrada na Tabela 7.16, resume-se à Receita Anual de Energia Firme, $R_{E F}$, calculada da seguinte forma:

$$
R_{T}=R_{E F}=\underbrace{360}_{\text {dias do ano }} \cdot \underbrace{40,00}_{\text {prẹo da energia }} \cdot \underbrace{680,8}_{B_{E F G}} \cdot \underbrace{24}_{\text {horas do dia }}=235.273 .057,5 \frac{\text { US } \$}{\text { ano }}
$$

Ressalta-se apenas que a realização das multiplicações acima de forma direta resulta em um número um pouco diferente do apresentado na tabela, devido a erros de arredondamento. 


\section{- Balanço Econômico Anual}

O balanço econômico anual simplesmente apresenta as receitas e os custos anuais totais, permitindo o cálculo da Receita Líquida Anual, $R_{L Q}$. A maximização deste valor corresponde ao objetivo final do estudo de dimensionamento. Conforme o resultado produzido, o melhor projeto encontrado para a usina de Emborcação nas situações apresentadas proporciona uma Receita Líquida Anual de US\$ 144.227.326,3.

\subsection{Variações do Preço Médio da Energia Firme}

As variações do preço médio da Energia Firme visam mostrar como as dimensões ótimas da usina variam quando diferentes valores são atribuídos à energia produzida pela usina. Para tanto, foram realizados três estudos de dimensionamento: Emb37ParEF30M1BGHT, Emb37ParEF40M1BGHT e Emb37ParEF50M1BGHT, ou seja, a Energia Firme foi valorizada a 30,00US\$/MWh, 40,00US\$/MWh e $50,00 U S \$ / M W h$.

Na Tabela 7.17 apresentam-se os volumes mínimo e máximo da usina sob dimensionamento, $x_{\min }$ e $x_{\text {máx }}$, bem como o Custo Total Anual, $C_{T}$, a Receita Total Anual, $R_{T}$, e a Receita Líquida Anual, $R_{L Q}$.

Os resultados para os valores de volume também são ilustrados na Figura 7.15. Analisando esta figura, constata-se que os volumes mínimos mantêm-se, nos três estudos realizados, iguais ao limite inferior de volume fornecido ao modelo de dimensionamento, $4.000 \mathrm{hm}^{3}$. Isto significa que o modelo entende que uma usina de cabeceira deve ser capaz de esvaziar-se ao máximo ao longo do Período Crítico, elevando a geração de todas as usinas da cascata. Além disso, quanto maior o volume útil, maior a regularização das vazões naturais, ocasionando uma maior geração média do sistema, tal como já ilustrado na seção anterior.

Os volumes máximos encontrados apresentam um padrão diferente: quanto maior o preço, maior o valor do volume máximo. Isto significa que os custos incorridos para aumentar o reservatório (custos da barragem, aquisição de terras, casa de força e custos de operação e manutenção) são compensados pelo aumento de receita proporcionado pela elevação da Energia Firme da usina, elevando a Receita Líquida Anual. Este comportamento de custos e receitas é ilustrado na Figura 7.16 . 
Tabela 7.17 - Volume mínimo e máximo, custos e receitas em função do preço médio da Energia Firme, $P_{E F}$.

\begin{tabular}{cccccr}
\hline $\begin{array}{c}P_{E F} \\
\text { [US\$/MWh] }\end{array}$ & $\begin{array}{c}x_{\min } \\
{\left[\mathrm{hm}^{3}\right]}\end{array}$ & $\begin{array}{c}x_{\max } \\
{\left[\mathrm{hm}^{3}\right]}\end{array}$ & $\begin{array}{c}C_{T} \\
{[\mathrm{US} \$]}\end{array}$ & $\begin{array}{c}R_{T} \\
{[\mathrm{US} \$]}\end{array}$ & \multicolumn{1}{c}{$\begin{array}{c}R_{L Q} \\
{[\mathrm{US} \$]}\end{array}$} \\
\hline 30,00 & $4.000,0$ & $9.128,0$ & $70.231 .362,3$ & $135.287 .968,9$ & $65.056 .606,6$ \\
40,00 & $4.000,0$ & $10.892,5$ & $91.035 .000,6$ & $235.262 .624,1$ & $144.227 .623,5$ \\
50,00 & $4.000,0$ & $12.190,7$ & $106.856 .024,0$ & $311.470 .656,8$ & $204.614 .632,8$ \\
\hline
\end{tabular}

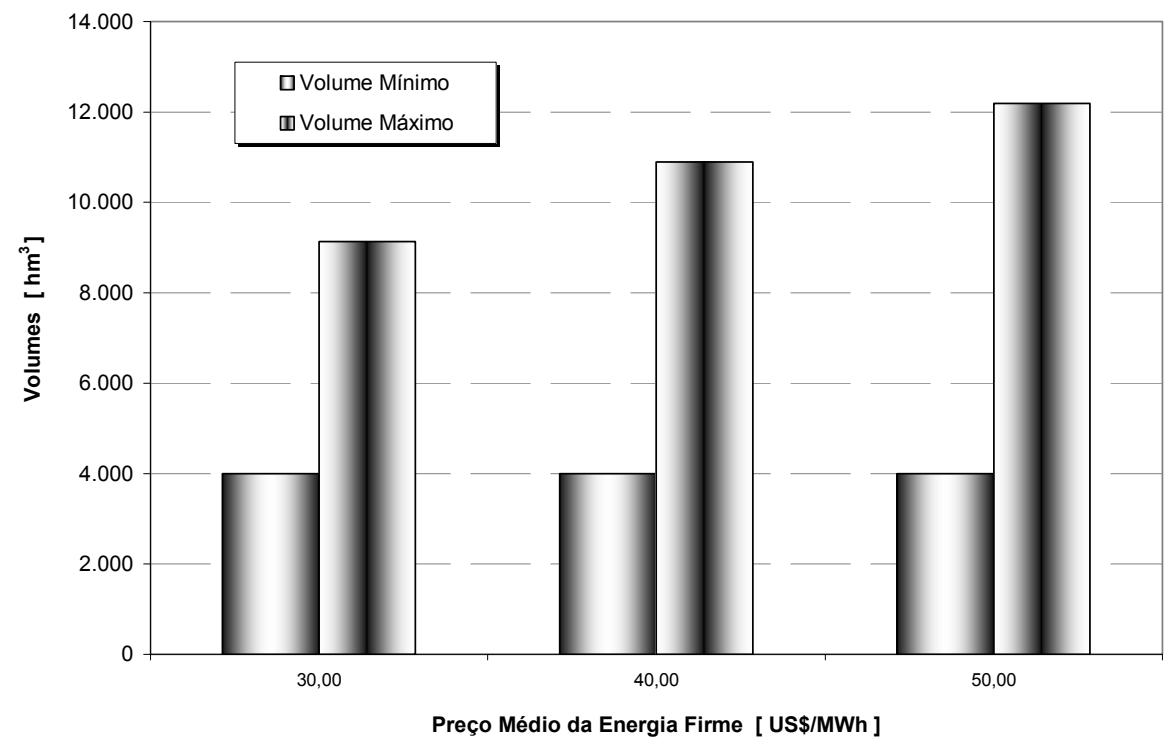

Figura 7.15 - Volumes mínimo e máximo em função do preço médio da Energia Firme..

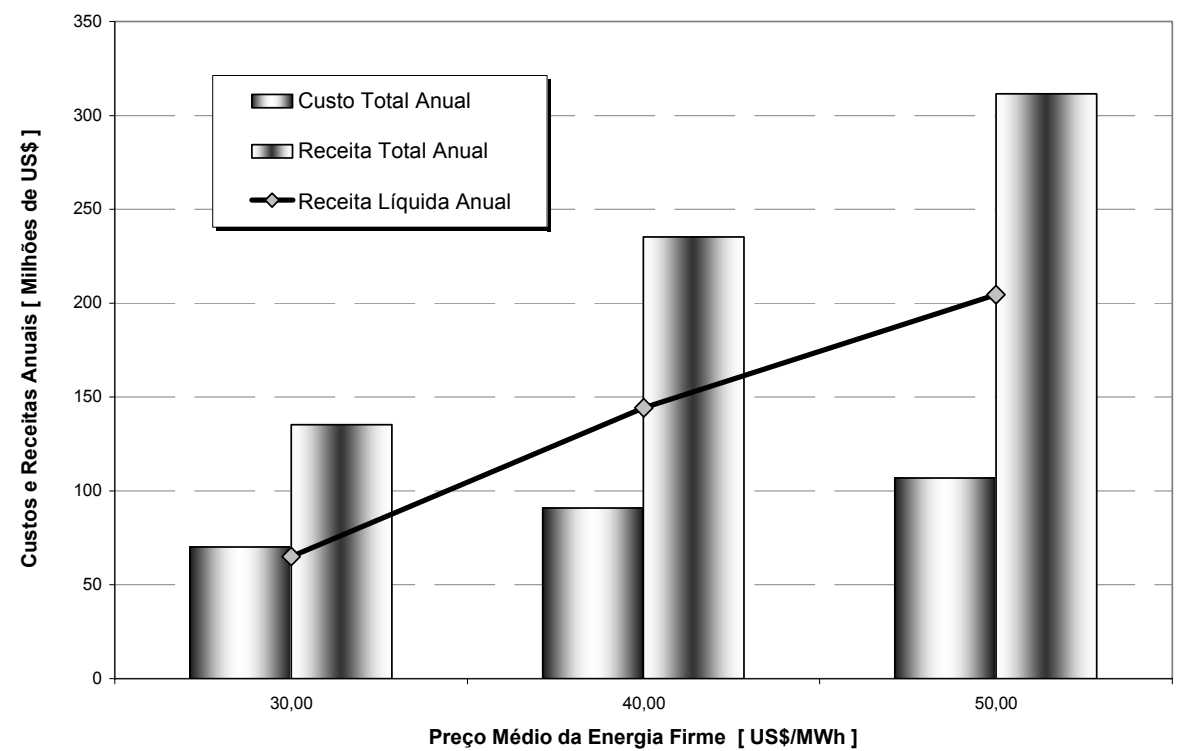

Figura 7.16-Custos e receitas em função do preço médio da Energia Firme. 
A constatação de que o tamanho do reservatório é sensível às variações do preço da energia reforça a necessidade de estudos bem elaborados de planejamento. A ausência de um planejamento cauteloso de longo prazo, incluindo a determinação da participação das diferentes fontes de geração no horizonte que envolve o cálculo dos custos marginais de expansão, pode levar a estimativas de preços futuros equivocadas, influenciando de forma sensível as dimensões dos novos aproveitamentos. Se os custos previstos não forem verificados, haverá uma deterioração das relações custo/benefício das usinas dimensionadas, podendo diminuir a eficiência do aproveitamento dos recursos naturais.

\subsection{Inserção do Fator de Modulação}

O Fator de Modulação refere-se à modelagem do benefício de Energia Firme em dois patamares: um de base e outro de ponta. Relembrando o Capítulo IV, o montante de energia alocado no patamar de ponta é igual ao benefício de Ponta Garantida multiplicado pelo número de horas de ponta ( 3 horas, no caso deste trabalho). O restante do benefício de Energia Firme é alocado como energia de base:

$$
E_{P}=n_{h p} \cdot B_{P G} \quad E_{B}=24 \cdot B_{E F}-E_{P}
$$

na qual:

- $n_{h p}$ : número de horas diárias do período de ponta.

- $B_{P G}$ : benefício de Ponta Garantida, em $M W$;

- $E_{P}$ : energia diária despachada na ponta, em $M W h$;

- $B_{E F}$ : benefício de Energia Firme, em $\overline{\mathrm{MW}}$;

- $E_{B}$ : energia diária despachada na base, em $M W h$.

A modulação do benefício de Energia Firme também pressupõe preços diferenciados às energias de base e de ponta. Chamando o preço médio para valorização da Energia Firme de $P_{E F}$, em $U S \$ / M W h$, mostrou-se que:

$$
P_{E F B}=\frac{24 \cdot P_{E F}}{n_{h p} \cdot(r-1)+24} \quad P_{E F P}=r \cdot P_{E F B}
$$

na qual:

- $P_{E F}$ : preço médio da Energia Firme, em $U S \$ / M W h$;

- $P_{E F B}$ : preço da energia despachada no horário de base, em $U S \$ / M W h$;

- $P_{E F P}$ : preço da energia despachada no horário de ponta, em $U S \$ / M W h$;

- $\quad r$ : razão entre $P_{E F P}$ e $P_{E F B}$, adimensional. 
Conforme já mencionado no Capítulo IV, quanto mais se aumenta a razão $r$, mais se incentiva a expansão da casa de força, uma vez que uma parcela maior de energia é valorizada ao preço de ponta, $P_{E F P}, r$ vezes superior ao preço de base, $P_{E F B}$.

As questões básicas relacionadas à inserção do fator de modulação referem-se ao valor de $r$ a ser adotado nos estudos e à capacidade da casa de força que deve ser expandida até que haja equilíbrio entre custos e benefícios incrementais. Na seqüência, responde-se a estas questões e também se realizam estudos para mostrar como o modelo se comporta quando o fator $r$ é alterado.

\subsubsection{Estimativa do Valor do Fator de Modulação}

A estimativa do valor do fator de modulação pode ser feita através da análise de séries históricas de custos marginais de operação nos patamares de ponta e fora de ponta, denominados $C M O_{P}$ e $C M O_{F P}$, respectivamente. Estas séries históricas de custos marginais foram obtidas através de simulações realizadas com o modelo Newave [76].

Na Figura 7.17 apresentam-se os custos marginais de operação médios anuais para o subsistema Sudeste/Centro-Oeste, obtidos simulando-se todo o histórico de vazões disponíveis no modelo (janeiro de 1931 a dezembro de 2002). Os valores mostrados na Figura 7.18 e na Figura 7.19 referem-se aos mesmos custos marginais, porém considerando-se nos cálculos somente os anos mais secos e os anos mais úmidos do histórico, respectivamente.

O primeiro fato a ser notado é a ordem de grandeza dos custos marginais: enquanto para as séries secas o menor custo marginal de operação é da ordem de 130,00 US\$/MWh, para as séries úmidas o máximo custo marginal de operação observado é da ordem de 20,00 US\$/MWh. Para o histórico todo, os limites mínimo e máximo situam-se entre estes valores. Estas ordens de grandeza refletem basicamente o tipo de combustível utilizado na geração de energia elétrica: para os anos secos, a reduzida capacidade de geração das hidroelétricas faz com que termoelétricas caras sejam despachadas, de forma que atender a qualquer carga incremental do sistema implique em custos marginais elevados. Para os anos úmidos, a geração hidroelétrica atende quase completamente à carga, de forma que atender a qualquer carga incremental implique somente na elevação da geração das usinas hidroelétricas, a baixos custos. 


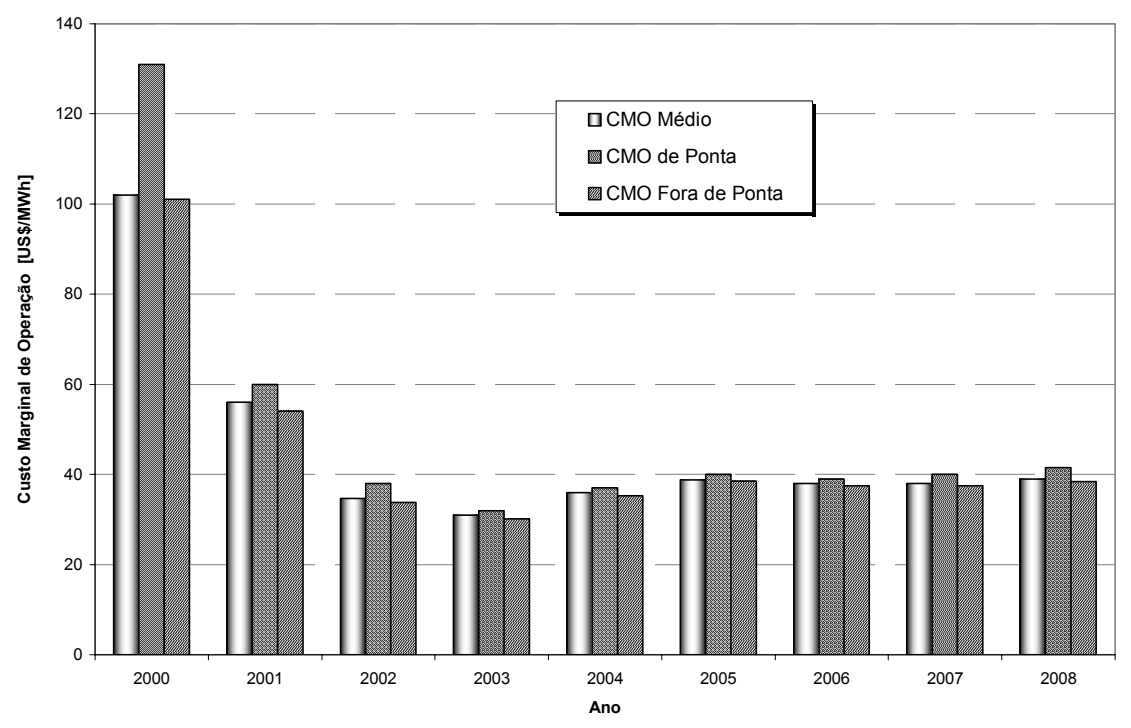

Figura 7.17 - Custos marginais de operação para todo o histórico de vazões.

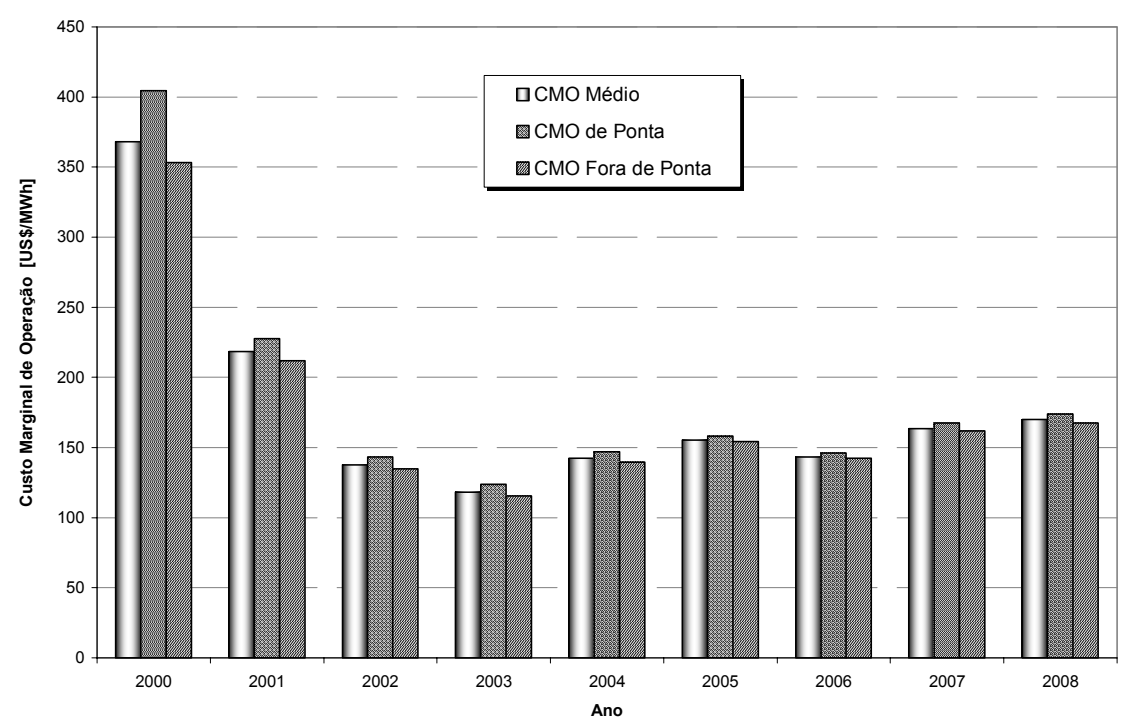

Figura 7.18 - Custos marginais de operação para os anos secos do histórico de vazões.

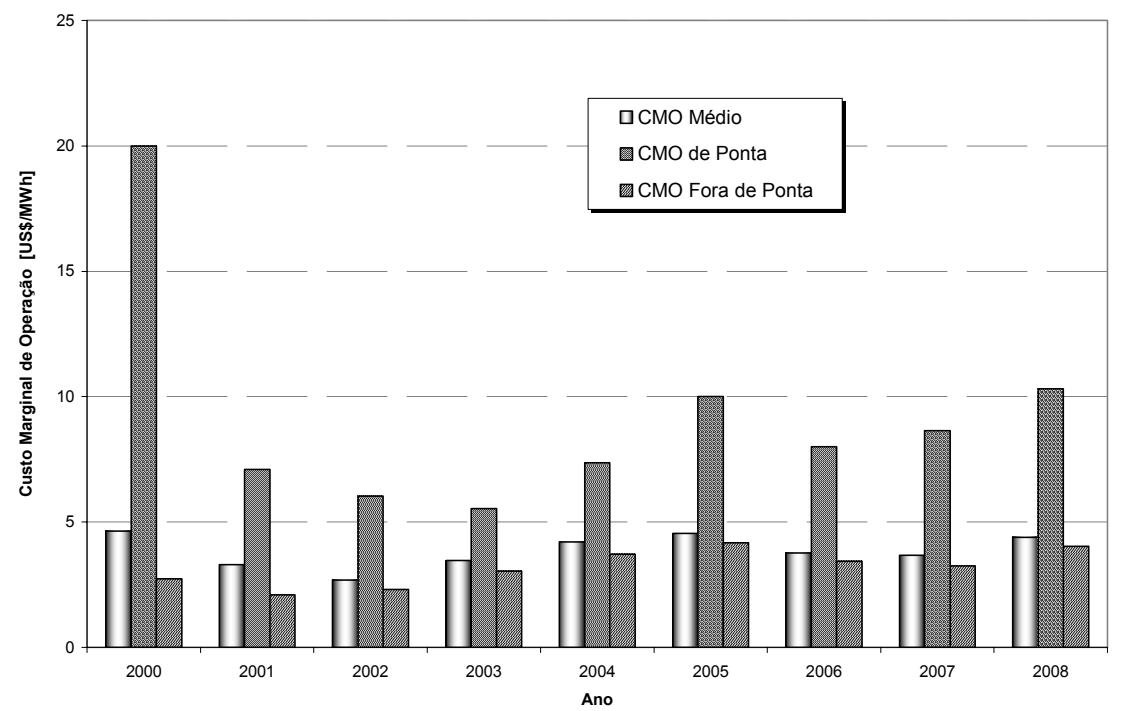

Figura 7.19 - Custos marginais de operação para os anos úmidos do histórico de vazões. 
Voltando à discussão sobre os valores de $r$, observa-se que para o histórico todo e para os anos secos, os custos marginais de ponta e fora de ponta são praticamente iguais, havendo diferenças significativas apenas para o ano de 2000. Já para os anos úmidos, as diferenças entre os custos de ponta e fora de ponta são mais significativas.

Na realidade, as diferenças entre $C M O_{P}$ e $C M O_{F P}$ decorrem da forma como o despacho em dois patamares é realizado, supondo-se duas cargas distintas a serem atendidas: uma no período fora de ponta e outra no período de ponta. Dependendo da relação entre as magnitudes das cargas de ponta e fora de ponta, e também das condições hidrológicas, os custos marginais $C M O_{P}$ e $C M O_{F P}$ podem variar bastante ou podem se manter praticamente constantes.

Por exemplo, em uma situação de hidrologia desfavorável, em que usinas termoelétricas estejam sendo despachadas mesmo fora de ponta, o acréscimo de carga do patamar de ponta pode simplesmente elevar a geração das térmicas já despachadas ou pode inclusive determinar o despacho de usinas térmicas mais caras. No primeiro caso, a relação entre $C M O_{P}$ e $C M O_{F P}$ é pequena, enquanto no segundo caso esta relação pode ser bem elevada. Supondo que $r$ possa refletir as condições de curto prazo, no primeiro caso tem-se $r$ praticamente unitário, enquanto no segundo caso $r$ pode chegar a possuir mais de um dígito.

Para os anos mais úmidos do histórico de vazões afluentes, Figura 7.19, observam-se diferenças significativas entre $C M O_{P}$ e $C M O_{F P}$. Nestes casos, como os custos marginais são relativamente baixos, praticamente não há térmicas despachadas. Assim, as diferenças decorrem apenas do valor mais elevado do despacho hidroelétrico na ponta em relação ao despacho hidroelétrico fora de ponta. Em outras palavras, o valor da água no patamar de ponta é sensivelmente maior que o valor da água no patamar fora de ponta.

De forma geral, conclui-se que os valores da energia na ponta e fora da ponta variam sensivelmente devido às condições conjunturais de operação. Supor que a Energia Firme na ponta terá um preço muito maior que a Energia Firme fora da ponta pode não ser realístico em grande parte do tempo. Por outro lado, supor preços iguais às energias nestes dois patamares pode desestimular a expansão da capacidade de ponta, além de não permitir as análises a que se presa esta sessão. Assim, para mostrar estes efeitos, supõem-se três valores de $r: r=1, r=2$ e $r=3$, os quais são utilizados nos estudos da próxima subsessão. 


\subsubsection{Expansão da Casa de Força}

A expansão da casa de força devido aos benefícios proporcionados pelo fator de modulação pode ser compreendida analisando-se como a Receita Total Anual, $R_{T}$, e o Custo Total Anual, $C_{T}$, comportam-se em função de incrementos da capacidade instalada de ponta, $p_{\text {nom, } p}$.

Em outras palavras, assumindo que a capacidade de base da usina e as dimensões do reservatório já estejam calculadas, a capacidade instalada de ponta deve ser aumentada enquanto $\Delta R_{T}>\Delta C_{T}$. Enquanto o valor de $C_{T}$ depende somente das dimensões da usina, o valor de $R_{T}$ depende também do fator de modulação, $r$.

\section{- Fator de Modulação $r=1$}

A utilização do fator de modulação unitário significa que a Energia Firme será valorizada ao mesmo preço, tanto na base quanto na ponta. Intuitivamente, isto significa dizer que não há motivo para expandir a capacidade instalada além da de base.

Supondo, por exemplo, dois projetos para uma mesma usina, ambos com mesmo Benefício de Energia Firme, não há diferença nenhuma, sob o ponto de vista de benefício econômico, deixar um com a potência instalada de base e outro com $500 \mathrm{MW}$ adicionais de capacidade instalada, já que a energia gerada a uma potência maior terá o mesmo preço que a energia gerada a uma potência igual à de base.

Recorrendo-se ao Capítulo IV, pode-se escrever a equação da receita anual de Energia Firme, igual à receita total anual para este caso:

$$
R_{T}=R_{E F}=360 \cdot\left(P_{E F B} \cdot E_{B}+P_{E F P} \cdot E_{P}\right)
$$

Utilizando-se as Equações 4.3 e 4.5, apresentadas no início desta Seção, pode-se escrever o valor de $R_{T}$ em função somente do preço médio da Energia Firme, $P_{E F}$ em $R \$ / M W h$, do número de horas de ponta, $n_{h p}$ em horas, do benefício de Ponta Garantida, $B_{P G}$ em $M W$, e da razão $r$ entre os preços de ponta e fora de ponta:

$$
R_{T}=360 \cdot\left(\frac{24 \cdot P_{E F}}{n_{h p} \cdot(r-1)+24} \cdot\left(24 \cdot B_{E F}+(r-1) \cdot n_{h p} \cdot B_{P G}\right)\right)
$$

Para $r=1$, tem-se: $R_{T}=8.640 \cdot P_{E F} \cdot B_{E F}$, ou seja, $R_{T}$ independe de $B_{P G}$ e, portanto, aumentos de $r$ não ocasionam aumentos de receita. 


\section{- Fator de Modulação $r=2$}

A utilização do fator de modulação $r=2$ implica a valorização da energia gerada na ponta, $E_{P}$ em $M W h$, por um preço duas vezes maior que a energia gerada na base, $E_{B}$ também em $M W h$. Para o preço médio da Energia Firme igual a $40 U S \$ / M W h$, tem-se $P_{E F P}=71,11 U S \$ / M W h$ e $P_{E F B}=35,55 U S \$ / M W h$.

O estudo realizado para testar a elevação no valor de $r$ é o Emb37ParEF40M2BGHT, cujos resultados são mostrados na Tabela 7.18. Observa-se que as dimensões da usina são praticamente iguais às encontradas no estudo Emb37ParEF40M1BGHT, apresentado na Seção 5.1, incluindo a capacidade instalada de ponta nula.

Este fato mostra que valorizar a ponta a um preço igual ao dobro da energia de base não constitui um incentivo suficiente para expandir a barragem, tampouco a casa de força, dada a estrutura de custos utilizada. No entanto, utilizar $r=2$ implica uma receita total anual maior que para o caso em que $r=1$, já que o mesmo benefício energético está sendo valorizado de forma diferente. Realmente, comparando as sessões Balanço Econômico Anual da Tabela 7.16 e da Tabela 7.18, observa-se que a Receita Líquida Anual do caso com modulação é superior à Receita Líquida Anual do caso com $r=1$ em cerca de 9,5 milhões de dólares.

A não expansão da casa de força além da capacidade de base pode ser justificada analisando-se os números apresentados na Tabela 7.19. Nesta tabela, apresentam-se a potência de base da usina, $p_{n o m, b}=928,50 \mathrm{MW}$, vários valores de potência de ponta, $p_{\text {nom, }, p}$, e, conseqüentemente, vários valores de potência instalada total, $p_{\text {nom }}$. Para cada valor de capacidade de ponta, apresentam-se o custo e a receita total anual, $C_{T}$ e $R_{T}$, e suas respectivas variações incrementais, $\Delta C_{T}$ e $\Delta R_{T}$. Observa-se que para cada elevação da potência instalada de ponta, os custos associados são sempre maiores que os respectivos benefícios, ou seja, $\Delta C_{T}>\Delta R_{T}$ para quaisquer incrementos de $p_{n o m, p}$. Isto faz com que seja inviável expandir a casa de força da nova usina, uma vez que incrementos de potência instalada sempre proporcionam reduções da Receita Líquida Anual, tal como ilustrado na Figura 7.20. 
Tabela 7.18 - Resultado completo do estudo Emb37ParEF40M2BGHT.

\begin{tabular}{|c|c|c|c|c|c|}
\hline \multicolumn{6}{|c|}{ Benefícios Energéticos Sistêmicos } \\
\hline & \multirow{2}{*}{$\begin{array}{l}\text { Sistema de } \\
\text { Referência }\end{array}$} & \multicolumn{2}{|c|}{ Sistema Completo } & \multicolumn{2}{|c|}{ Benefício Sistêmico } \\
\hline & & Mot. Base & Mot. Complet & Mot. Base & Mot. Completa \\
\hline Energia Firme $[\mathrm{MW}]$ & $18.785,0$ & $19.465,8$ & $19.465,8$ & 680,8 & 680,8 \\
\hline Energia Secundária $[\overline{\mathrm{MW}}]$ & $3.976,1$ & $3.800,5$ & $3.800,5$ & $-175,6$ & $-175,6$ \\
\hline Geração Média [MW] & $22.761,1$ & $23.266,3$ & $23.266,3$ & 505,2 & 505,2 \\
\hline Ponta Garantida [MW] & $35.533,6$ & $36.452,5$ & $36.452,5$ & 919,1 & 919,1 \\
\hline \multicolumn{2}{|c|}{ Dimensões Ótimas da USD } & \multicolumn{4}{|c|}{ Benefícios Energéticos da USD } \\
\hline Volume Mínimo [hm³]: & $4.000,0$ & \multicolumn{3}{|c|}{ Motorização de Base } & Motorização Final \\
\hline Volume Máximo $\left[\mathrm{hm}^{3}\right]$ : & $10.896,0$ & \multicolumn{2}{|c|}{ Energia Firme $[\overline{\mathrm{MW}}]$} & 415,3 & 415,3 \\
\hline Área Inundada [km²]: & 312,0 & \multicolumn{2}{|c|}{ Energia Secundária $[\overline{\mathrm{MW}}]$} & 36,0 & 36,0 \\
\hline Queda Referência [m]: & 89,9 & \multicolumn{2}{|c|}{ Geração Média $[\overline{\mathrm{MW}}]$} & 451,4 & 451,4 \\
\hline Queda Projeto [m]: & 117,8 & \multicolumn{2}{|c|}{ Ponta Garantida [MW] } & 927,4 & 927,4 \\
\hline Vazão Ref. Base $\left[\mathrm{m}^{3} / \mathrm{s}\right]:$ & $1.183,6$ & \multicolumn{2}{|c|}{ Custos (Mot. Final) [ US\$ ] } & \multicolumn{2}{|c|}{ Receitas (Mot. Final) [ US\$ ] } \\
\hline Vazão Ref. Total [m³/s]: & $1.183,6$ & Aquisição Terra: & $54.261 .193,2$ & Energia Firme: & $244.766 .177,7$ \\
\hline Potência Base [MW]: & 928,5 & Construção: & $332.779 .846,1$ & Energia Sec.: & 0,0 \\
\hline Potência Total [MW]: & 928,5 & Gerador Base: & $261.751 .817,4$ & Ponta Garant.: & 0,0 \\
\hline Fator de Capacidade [\%]: & 44,7 & Gerador Ponta: & 0,0 & RECEITA Líc & DUIDA ANUAL \\
\hline Custo Instalação [\$/kW]: & 803,5 & JDC [\%]: & 15,4 & $R_{10}=15$ & \\
\hline Índice de Mérito [\$/MWh]: & 15,3 & O\&M Anual: & $4.232 .967,7$ & & \\
\hline & & Balanço Econôm & Anual [US\$] & & \\
\hline & & Moto & ção de Base & Motor & ização Final \\
\hline Receita Bruta Anı & [ US\$ ] & & $.766 .177,7$ & 244. & $766.177,7$ \\
\hline Custo Total Anu & US\$ ] & & $073.834,2$ & 91. & $073.834,2$ \\
\hline Receita Líquida Ar & [ US\$ ] & & $692.343,5$ & 153. & $692.343,5$ \\
\hline
\end{tabular}

Tabela 7.19 - Análise incremental da expansão da casa de força para $r=2$.

\begin{tabular}{|c|c|c|c|c|c|c|}
\hline $\begin{array}{l}p_{\text {nom }, b} \\
{[\mathrm{MW}]}\end{array}$ & $\begin{array}{l}p_{\text {nom }, p} \\
{[\mathrm{MW}]}\end{array}$ & $\begin{array}{l}p_{\text {nom }} \\
{[\mathrm{MW}]}\end{array}$ & $\begin{array}{c}C_{T} \\
{[\mathrm{US} \$]}\end{array}$ & $\begin{array}{c}\Delta C_{T} \\
{[\mathrm{US} \$]}\end{array}$ & $\begin{array}{c}R_{T} \\
{[\mathrm{US} \$]}\end{array}$ & $\begin{array}{c}\Delta R_{T} \\
{[\mathrm{US} \$]}\end{array}$ \\
\hline 928,5 & 0,0 & 928,5 & 91.073 .834 & - & 244.766 .178 & - \\
\hline 928,5 & 96,1 & $1.024,6$ & 94.590 .746 & 3.516 .912 & 246.259 .352 & 1.493 .174 \\
\hline 928,5 & 192,1 & $1.120,6$ & 98.729 .209 & 4.138 .463 & 249.981 .620 & 3.722 .268 \\
\hline 928,5 & 288,1 & $1.216,6$ & 103.142 .744 & 4.413 .534 & 253.662 .669 & 3.681 .049 \\
\hline 928,5 & 384,1 & $1.312,6$ & 107.745 .224 & 4.602 .480 & 257.343 .837 & 3.681 .168 \\
\hline 928,5 & 480,2 & $1.408,7$ & 112.493 .575 & 4.748 .351 & 261.023 .458 & 3.679 .620 \\
\hline 928,5 & 576,2 & $1.504,7$ & 117.361 .531 & 4.867 .956 & 264.703 .237 & 3.679 .780 \\
\hline 928,5 & 672,2 & $1.600,7$ & 122.331 .275 & 4.969 .744 & 268.622 .962 & 3.919 .724 \\
\hline 928,5 & 768,2 & $1.696,7$ & 127.389 .870 & 5.058 .596 & 272.308 .615 & 3.685 .653 \\
\hline 928,5 & 864,2 & $1.792,7$ & 132.527 .472 & 5.137 .602 & 275.992 .626 & 3.684 .011 \\
\hline
\end{tabular}




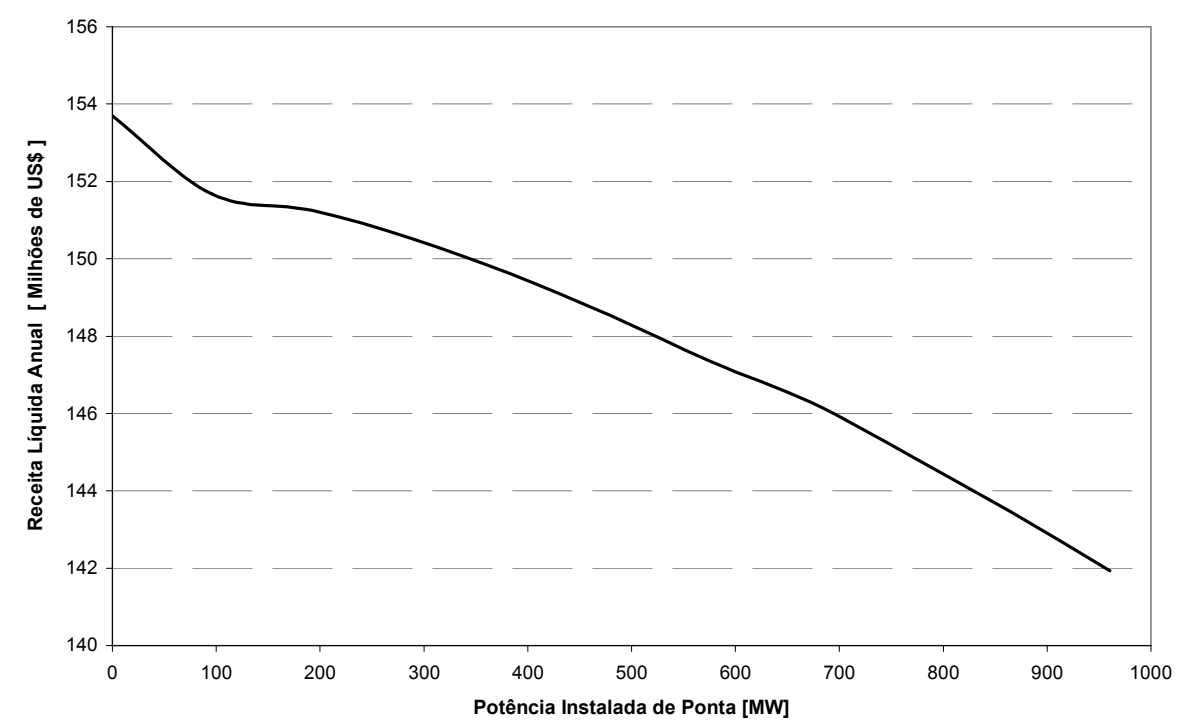

Figura 7.20 - Receita Líquida Anual em função da capacidade de ponta para $r=2$.

\section{- Fator de Modulação $r=3$}

Esta subseção desenvolve-se de forma praticamente idêntica à subseção anterior, exceto pela utilização do fator de modulação $r=3$, o que implica a valorização da energia gerada na ponta por um preço três vezes maior que a energia gerada na base. Para o preço médio da Energia Firme igual a $40 U S \$ / M W h$, tem-se $P_{E F P}=96,00 U S \$ / M W h$ e $P_{E F B}=32,00 U S \$ / M W h$;

O estudo realizado para testar a elevação no valor de $r$ é o Emb37ParEF40M3BGHT, cujos resultados são mostrados na Tabela 7.20. De forma geral, observa-se que as dimensões da usina são praticamente iguais às encontradas nos estudos anteriores (Tabela 7.16 e Tabela 7.18), exceto pela capacidade instalada de ponta, que neste caso é bem superior à capacidade instalada de base.

Este fato mostra que valorizar a ponta a um preço igual ao triplo da energia de base constitui um incentivo suficiente para expandir a casa de força ${ }^{41}$. Esta expansão da casa de força além da capacidade de base pode ser justificada analisando-se os números apresentados na Tabela 7.21, onde, a cada elevação da potência instalada de ponta, os custos associados são sempre menores que os respectivos benefícios. Em outras palavras, $\Delta C_{T}<\Delta R_{T}$ para quaisquer incrementos de $p_{n o m, p}$. Isto faz com que seja viável expandir a casa de força da nova usina, uma vez que incrementos de potência instalada sempre proporcionam ganhos de Receita Líquida Anual, ilustrado na Figura 7.21.

\footnotetext{
${ }^{41}$ Ressalta-se que este resultado depende da estrutura de custos utilizada.
} 
Obviamente, a expansão da casa de força não se justifica de forma ilimitada, havendo um balanço entre custos e receitas incrementais para $p_{\text {nom }}=6.000 \mathrm{MW}$. Este valor extremamente elevado não reflete a realidade de uma usina hidroelétrica, principalmente pela modelagem de custos simplificada adotada no trabalho. No entanto, ressalta-se que a partir dos resultados pode-se concluir que o fator de modulação na valorização da Energia Firme pode servir de sinalizador para a expansão da casa de força além da capacidade instalada de base. $\mathrm{O}$ valor do fator de modulação depende fortemente das condições de operação do sistema, as quais determinam as diferenças entre os custos marginais de operação para os patamares de ponta e fora de ponta.

Tabela 7.20 - Resultado completo do estudo Emb37ParEF40M3BGHT.

\begin{tabular}{|c|c|c|c|c|c|}
\hline \multicolumn{6}{|c|}{ Benefícios Energéticos Sistêmicos } \\
\hline & \multirow{2}{*}{$\begin{array}{l}\text { Sistema de } \\
\text { Referência }\end{array}$} & \multicolumn{2}{|c|}{ Sistema Completo } & \multicolumn{2}{|c|}{ Benefício Sistêmico } \\
\hline & & Mot. Base & Mot. Complet & Mot. Base & Mot. Completa \\
\hline Energia Firme $[\overline{\mathrm{MW}}]$ & $18.785,0$ & $19.465,8$ & $19.460,0$ & 680,8 & 675,0 \\
\hline Energia Secundária $[\overline{\mathrm{MW}}]$ & $3.976,1$ & $3.800,5$ & $3.852,7$ & $-175,6$ & $-123,4$ \\
\hline Geração Média [MW] & $22.761,1$ & $23.266,3$ & $23.312,7$ & 505,2 & 551,6 \\
\hline Ponta Garantida [MW] & $35.533,6$ & $36.423,9$ & $37.341,3$ & 890,3 & 1807,7 \\
\hline \multicolumn{2}{|c|}{ Dimensões Ótimas da USD } & \multicolumn{4}{|c|}{ Benefícios Energéticos da USD } \\
\hline Volume Mínimo [hm³]: & $4.000,0$ & \multirow[b]{2}{*}{ Energia Firme $[\overline{\mathrm{MW}}]$} & \multicolumn{2}{|c|}{ Motorização de Base } & Motorização Final \\
\hline Volume Máximo $\left[\mathrm{hm}^{3}\right]$ : & $10.896,0$ & & & 415,3 & 413,5 \\
\hline Área Inundada $\left[\mathrm{km}^{2}\right]$ : & 312,0 & \multicolumn{2}{|c|}{ Energia Secundária $[\overline{\mathrm{MW}}]$} & 36,0 & 85,3 \\
\hline Queda Referência [m]: & 89,9 & & 451,4 & 498,8 \\
\hline Queda Projeto [m]: & 117,6 & \multicolumn{2}{|c|}{$\begin{array}{l}\text { Geraçao IMledia [IVIVV] } \\
\text { Ponta Garantida [MW] }\end{array}$} & 927,4 & $1.883,0$ \\
\hline Vazão Ref. Base $\left[\mathrm{m}^{3} / \mathrm{s}\right]:$ & $1.183,6$ & \multicolumn{2}{|c|}{ Custos (Mot. Final) [ US\$ ] } & \multicolumn{2}{|c|}{ Receitas (Mot. Final) [ US\$ ] } \\
\hline Vazão Ref. Total [m³/s]: & $2.407,6$ & Aquisição Terra: & $54.261 .193,2$ & Energia Firme: & $316.786 .054,2$ \\
\hline Potência Base [MW]: & 928,5 & Construção: & $332.779 .846,1$ & Energia Sec.: & 0,0 \\
\hline Potência Total [MW]: & $1.888,8$ & Gerador Base: & $261.751 .817,4$ & Ponta Garant.: & 0,0 \\
\hline Fator de Capacidade [\%]: & 21,9 & Gerador Ponta: & $321.507 .301,8$ & \multirow{3}{*}{\multicolumn{2}{|c|}{$\begin{array}{c}\text { RECEITA LÍQUIDA ANUAL } \\
\text { RLQ }_{\text {= } 179.049 .733,7}\end{array}$}} \\
\hline Custo Instalação [\$/kW]: & 590,8 & JDC [\%]: & 15,4 & & \\
\hline Índice de Mérito [\$/MWh]: & 23,3 & O\&M Anual: & $7.861 .730,0$ & & \\
\hline \multicolumn{6}{|c|}{ Balanço Econômico Anual [US\$] } \\
\hline & & \multicolumn{2}{|c|}{ Motorização de Base } & Motor & ização Final \\
\hline Receita Bruta Anı & [ US\$ ] & & $339.644,6$ & 316. & $786.054,2$ \\
\hline Custo Total Anue & US\$ ] & & $073.834,2$ & 137. & $736.320,4$ \\
\hline Receita Líquida An & [ US\$ ] & & $265.810,4$ & 179. & $049.733,7$ \\
\hline
\end{tabular}


Tabela 7.21 - Análise incremental da expansão da casa de força para $r=3$.

\begin{tabular}{rrrrccc}
\hline $\begin{array}{l}p_{\text {nom }, b} \\
{[\mathrm{MW}]}\end{array}$ & $\begin{array}{c}p_{\text {nom }, p} \\
{[\mathrm{MW}]}\end{array}$ & \multicolumn{1}{c}{$\begin{array}{l}p_{\text {nот }} \\
{[\mathrm{MW}]}\end{array}$} & $\begin{array}{c}C_{T} \\
{[\mathrm{US} \$]}\end{array}$ & $\begin{array}{c}\Delta C_{T} \\
{[\mathrm{US} \$]}\end{array}$ & $\begin{array}{c}R_{T} \\
{[\mathrm{US} \$]}\end{array}$ & $\begin{array}{c}\Delta R_{T} \\
{[\mathrm{US} \$]}\end{array}$ \\
\hline 928,5 & 0,0 & 928,5 & 91.073 .834 & - & 252.339 .645 & - \\
928,5 & 96,1 & $1.024,6$ & 94.590 .746 & 3.516 .912 & 256.987 .650 & 4.648 .006 \\
928,5 & 192,1 & $1.120,6$ & 98.729 .209 & 4.138 .463 & 263.642 .996 & 6.655 .346 \\
928,5 & 288,1 & $1.216,6$ & 103.142 .744 & 4.413 .534 & 270.260 .076 & 6.617 .079 \\
928,5 & 384,1 & $1.312,6$ & 107.745 .224 & 4.602 .480 & 276.877 .370 & 6.617 .295 \\
928,5 & 480,2 & $1.408,7$ & 112.493 .575 & 4.748 .351 & 283.491 .880 & 6.614 .509 \\
928,5 & 576,2 & $1.504,7$ & 117.361 .531 & 4.867 .956 & 290.106 .676 & 6.614 .797 \\
928,5 & 672,2 & $1.600,7$ & 122.331 .275 & 4.969 .744 & 296.937 .423 & 6.830 .747 \\
928,5 & 768,2 & $1.696,7$ & 127.389 .870 & 5.058 .596 & 303.556 .276 & 6.618 .853 \\
928,5 & 864,2 & $1.792,7$ & 132.527 .472 & 5.137 .602 & 310.172 .173 & 6.615 .898 \\
\hline
\end{tabular}

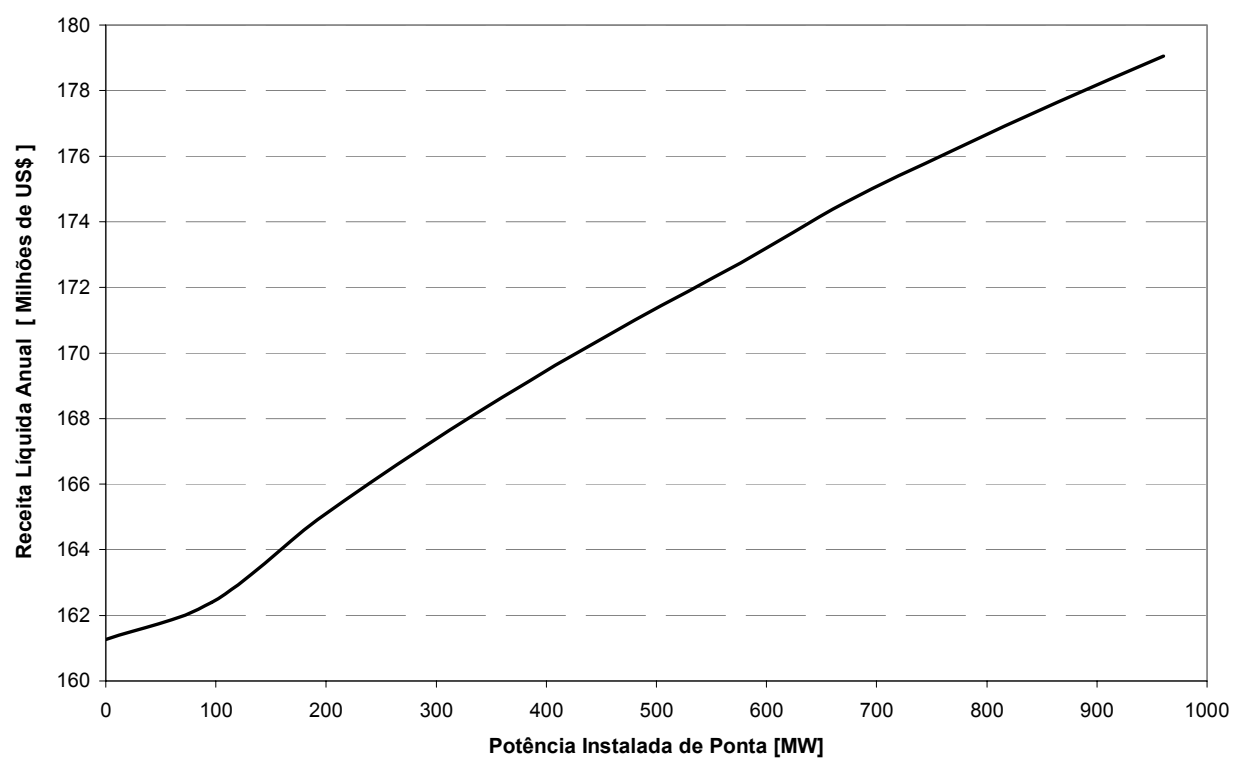

Figura 7.21 - Receita Líquida Anual em função da capacidade de ponta para $r=3$.

\subsection{Valorização da Energia Secundária}

A valorização da Energia Secundária trata da atribuição de um valor econômico à energia que a usina consegue, em média, gerar acima de sua Energia Firme. Como o nome indica, esta geração caracteriza-se como secundária, uma vez que sua disponibilidade varia sensivelmente ao longo do tempo.

Esta disponibilidade incerta implica um menor valor econômico atribuído à Energia Secundária, quando comparado ao valor da Energia Firme. Para estipular um "preço" à Energia Secundária, realizou-se novamente uma simulação com o modelo 
Newave [76], utilizando-se desta vez duas mil séries sintéticas de vazões afluentes. Para cada intervalo de simulação, determinou-se a geração total do subsistema Sudeste/Centro-Oeste e comparou-se o valor obtido com a Energia Assegurada deste subsistema. Calculou-se então o preço da Energia Secundária, $P_{E S}$ em $U S \$ / M W h$, como o valor médio do custo marginal de operação do subsistema Sudeste/Centro-Oeste para os meses em que havia Energia Secundária. Como resultado, obteve-se o valor esperado do custo marginal, dado que havia Energia Secundária, $P_{E S}=11,00 \mathrm{US} \$ \mathrm{MWh}$. Ressalta-se que este valor presta-se apenas aos estudos de dimensionamento realizados como testes do modelo proposto, devendo ser enfatizado que este preço atribuído à Energia Secundaria varia sensivelmente em função da relação entre a carga a ser atendida, as vazões afluentes e os volumes armazenados nos reservatórios. Assim, estudos de simulação com o modelo Newave realizados em condições um pouco distintas podem gerar sinalizações de preço de Energia Secundária bem diferentes.

Uma vez definido o valor a ser atribuído à Energia Secundária, realizam-se dois estudos de dimensionamento: Emb37ParEF40M2ESBGHT. No primeiro caso, valoriza-se a Energia Secundária, mas não se atribui nenhum benefício em função da modulação da Energia Firme. No segundo caso, além de valorizar a Energia Secundária, atribui-se à Energia Firme despachada na ponta, um preço igual ao dobro da Energia Firme de base. Os principais resultados encontrados são mostrados na Tabela 7.22 e na Tabela 7.23.

O primeiro fato a ser observado na Tabela 7.22 é a motorização de base igual à motorização final, ou seja, valorizar a Energia Secundária na ausência de incentivos proporcionados pela valorização modulada da Energia Firme não foi, neste caso, suficiente para expandir a casa de força.

Outro fato a ser observado é o sinal negativo da receita de Energia Secundária. Isto ocorre porque, conforme já mencionado, a inserção da usina de cabeceira reduz a Energia Secundária do Sistema de Referência em relação ao Sistema Completo. Logo, a atribuição de um preço à Energia Secundária faz com que o modelo interprete esta redução como uma perda de receita. Deve-se considerar que esta perda de receita é muito menor que o benefício econômico proporcionado pela Energia Firme, o que faz com que ainda assim seja vantajoso construir a usina. 
Tabela 7.22 - Resultado completo do estudo Emb37ParEF40M1ESBGHT.

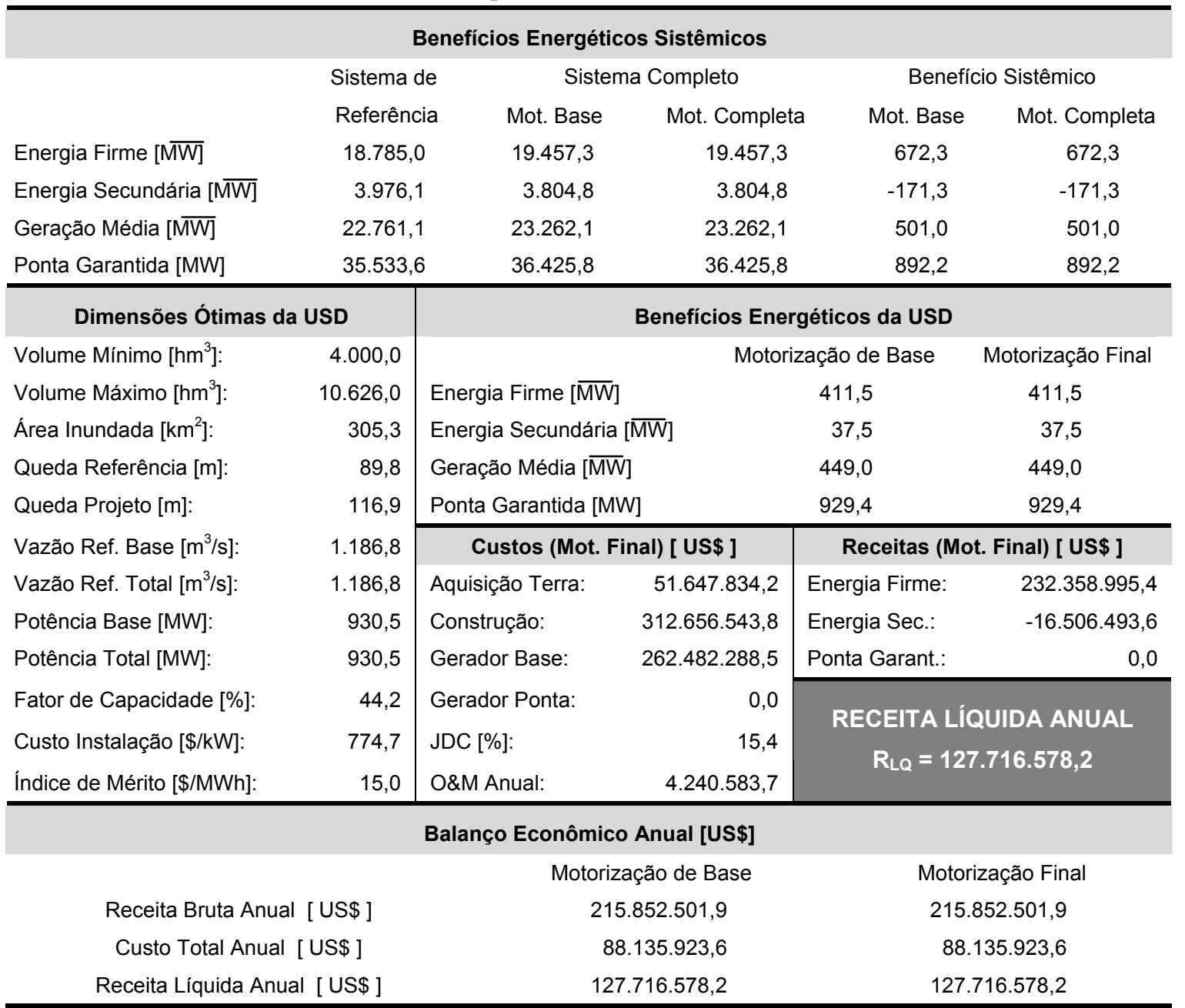

Comparando os resultados da Tabela 7.22 e da Tabela 7.16, página 278, constata-se que as dimensões ótimas da usina do estudo onde há valorização da Energia Secundária, Emb37ParEF40M1ESBGHT, são ligeiramente inferiores às da usina dimensionada com atribuição de preço apenas à Energia Firme. Esta diferença caracteriza um certo desestímulo causado pela redução de receita devido à valorização da Energia Secundária. De fato, na Tabela 7.16 tem-se $R_{L Q}=144.227 .326,3$ US\$, enquanto na Tabela 7.22 tem-se $R_{L Q}=127.716 .576,2$ US\$.

Observando os resultados apresentados na Tabela 7.23, verifica-se que a valorização conjunta da Energia Secundária e da modulação da Energia Firme com $r=2$ provoca, neste caso, a expansão da casa de força além da capacidade de base $\left(p_{n o m, b}=\right.$ $876,8 \mathrm{MW}$ e $\left.p_{\text {nom, }}=202,3 \mathrm{MW}\right)$. 
Tabela 7.23 - Resultado completo do estudo Emb37ParEF40M2ESBGHT.

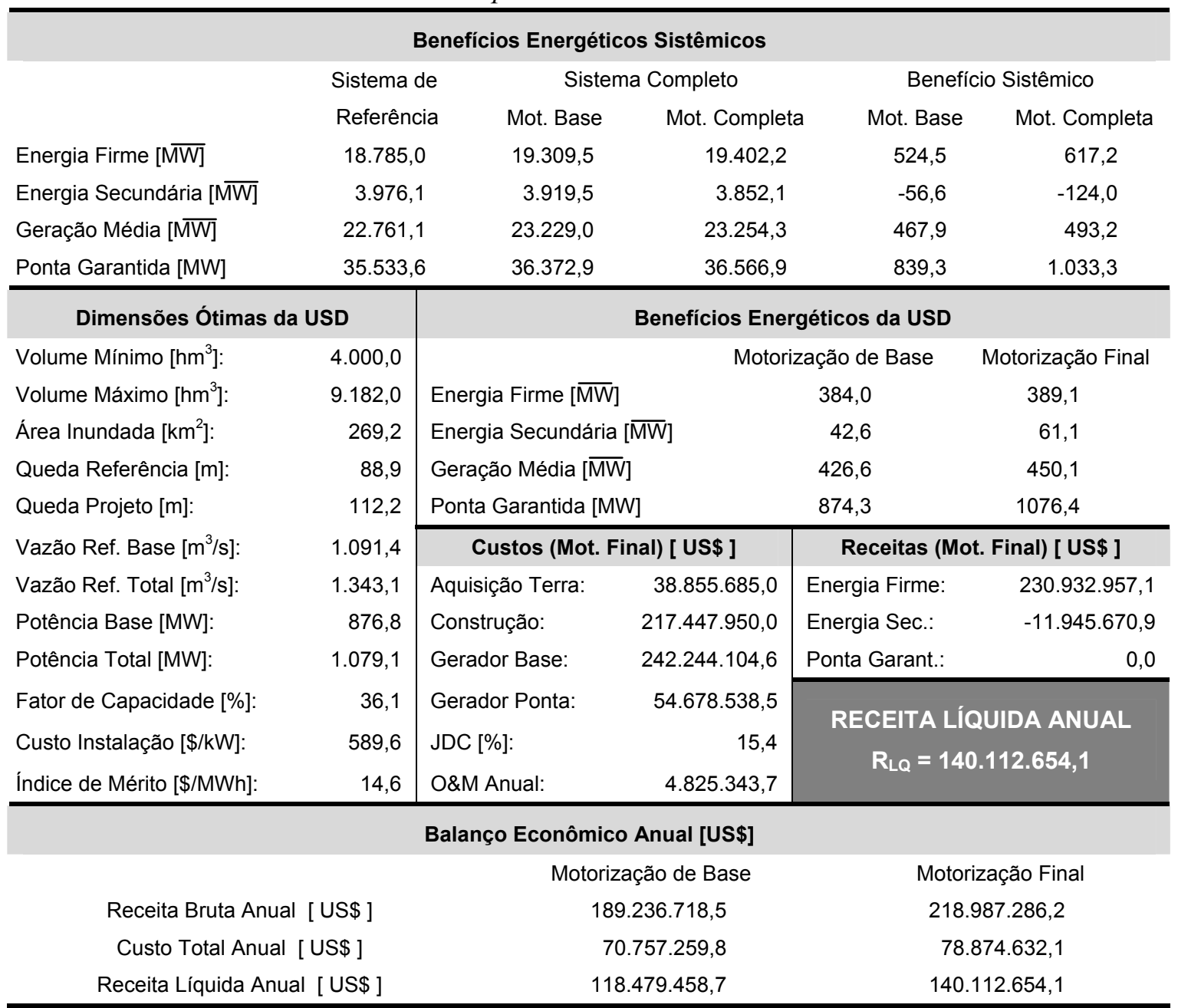

Também observa-se um fato curioso: a usina apresentada na Tabela 7.23 possui um reservatório menor e uma casa de força maior que a usina da Tabela 7.22. Tais relações explicam-se basicamente através do mecanismo de compensação:

- Por um lado, ao reduzir o volume da usina, o modelo reduz os custos de construção e de aquisição de terra, reduzindo o custo total anual em cerca de 17 milhões de US\$.

- Por outro lado, a valorização simultânea da Energia Firme em dois patamares e da Energia Secundária, faz com que o benefício atrelado a cada $M W$ instalado na casa de força seja bastante significativo.

A junção dos efeitos deste dois fatores faz com que um reservatório menor associado a uma usina mais motorizada seja mais lucrativo que um reservatório maior associado a uma casa de força com menos máquinas. De fato, na Tabela 7.22 tem-se $R_{L Q}=127.716 .576,2$ US\$, enquanto na Tabela 7.23 tem-se $R_{L Q}=140.112 .654,1$ US\$. 
Pode-se ainda associar mais um benefício à capacidade instalada: a valorização explícita da Ponta Garantida. O efeito de tal benefício é mostrado na próxima subseção.

\subsection{Valorização da Ponta Garantida}

A valorização da Ponta Garantida consiste em atribuir um valor econômico à potência que a usina consegue garantir em $95 \%$ do tempo. Conforme já mencionado, tal valorização visa incentivar a expansão da casa de força dos aproveitamentos, aumentando a capacidade de geração no patamar de ponta.

Para determinar o valor a ser atribuído a cada $M W$ instalado na casa de força, recorreu-se a estudos realizados pela Agência Nacional de Energia Elétrica [7] e realizaram-se vários testes de dimensionamento até encontrar um valor adequado do preço da Ponta Garantida, $P_{P G}$ em $U S \$ / M W$.ano. A idéia básica que norteou o processo foi atribuir um valor compatível simultaneamente com os estudos da ANEEL e com a estrutura de custos e receitas do modelo proposto. $\mathrm{O}$ valor adotado foi $P_{P G}=10.000,00$ US\$/MW.ano.

As análises da influência da valorização da Ponta Garantida foram baseadas em quatro estudos: Emb37ParEF40M1BGHT, Emb37ParEF40M1PGBGHT, Emb37ParEF40M2PGBGHT e Emb37ParEF40M2ESPGBGHT. A estratégia dos estudos é a adição progressiva de uma maior valorização aos benefícios energéticos. Primeiro, valoriza-se somente a Energia Firme com $r=1$; depois, adiciona-se a valorização da Ponta Garantida; em seguida, soma-se à valorização da Ponta Garantida a utilização de $r=2$ e, finalmente, adiciona-se ao terceiro caso a valorização da Energia Secundária. As principais características físicas da usina sob dimensionamento encontradas nos diferentes testes são mostradas na Tabela 7.24, enquanto os custos e receitas associados são mostrados na Tabela 7.25.

O primeiro fato a ser observado são os valores de volume mínimo, todos iguais ao limite mínimo de volume fornecido ao modelo, $4.000 \mathrm{hm}^{3}$. Isto mostra que independentemente da forma como os benefícios energéticos são valorizados, o modelo desenvolvido sinaliza que a usina de cabeceira deve valorizar o maior volume útil possível a fim de aumentar o benefício de Energia Firme. 
Tabela 7.24 - Principais características fisicas da usina sob dimensionamento em função da valorização da ponta garantida.

\begin{tabular}{lcccrr}
\multicolumn{1}{c}{ TESTE } & $\begin{array}{c}x_{\text {min }} \\
{\left[\mathrm{hm}^{3}\right]}\end{array}$ & $\begin{array}{c}x_{\text {máx }} \\
{\left[\mathrm{hm}^{3}\right]}\end{array}$ & $\begin{array}{c}p_{\text {nom, }} \\
{[\mathrm{MW}]}\end{array}$ & $\begin{array}{r}p_{\text {nom, } p} \\
{[\mathrm{MW}]}\end{array}$ & \multicolumn{1}{c}{$\begin{array}{c}p_{\text {nom }} \\
{[\mathrm{MW}]}\end{array}$} \\
\hline 1. Emb37ParEF40M1BGHT & $4.000,0$ & $10.892,5$ & 928,6 & 0,0 & 928,6 \\
2. Emb37ParEF40M1PGBGHT & $4.000,0$ & $10.626,1$ & 926,5 & 0,0 & 926,5 \\
3. Emb37ParEF40M2PGBGHT & $4.000,0$ & $11.166,5$ & 936,0 & 297,0 & $1.233,0$ \\
4. Emb37ParEF40M2ESPGBGHT & $4.000,0$ & $9.201,3$ & 877,1 & 524,9 & $1.402,0$ \\
\hline
\end{tabular}

Tabela 7.25 - Custos e receitas em função da valorização da ponta garantida.

\begin{tabular}{lccc}
\hline \multicolumn{1}{c}{ TESTE } & \multicolumn{1}{c}{$C_{T}$} & $R_{T}$ & $R_{L Q}$ \\
& [ US\$/ano ] & [ US $\$$ /ano ] & [ US $\$$ /ano ] \\
\hline 1. Emb37ParEF40M1BGHT & $91.035 .000,6$ & $235.262 .624,1$ & $144.227 .623,5$ \\
2. Emb37ParEF40M1PGBGHT & $88.136 .223,5$ & $241.653 .369,5$ & $153.517 .146,1$ \\
3. Emb37ParEF40M2PGBGHT & $107.057 .801,9$ & $271.052 .828,6$ & $163.995 .026,7$ \\
4. Emb37ParEF40M2ESPGBGHT & $94.633 .730,2$ & $246.873 .148,3$ & $152.239 .418,1$ \\
\hline
\end{tabular}

Analisando os valores de volume máximo, $x_{\text {máx }}$ em $\mathrm{hm}^{3}$, observa-se que do teste 1 para o teste 2 e do teste 3 para o teste 4 há reduções de volume máximo, enquanto do teste 2 para o teste 3 há uma elevação de $x_{\text {máx }}$. A pequena redução de volume do teste 1 para o teste 2 deve-se a uma redução de custos conseguida pela redução do reservatório, combinada com um ganho de receita ocasionado pela valorização da ponta garantida. Esta combinação fez com que a Receita Líquida Anual proporcionada pelo empreendimento passasse de US\$144.227.623,5 para US\$153.517.146,1.

Do teste 2 para o teste 3 , o valor de $x_{\text {máx }}$ eleva-se. Tal elevação deve-se ao incentivo significativo proporcionado pela valorização conjunta da Ponta Garantida e da Energia Firme em dois patamares com $r=2$. Neste caso, cada $\mathrm{hm}^{3}$ adicionado ao reservatório proporciona ganhos de Energia Firme, que se traduzem em elevações da Potência Instalada de Base, $p_{n o m, b}$, que por sua vez são valorizadas tanto pela modulação quanto pela maior Potência Garantida. Adicionalmente, cada $M W$ instalado como Potência Instalada de Ponta, $p_{n o m, p}$, faz com que a Ponta Garantida se eleve, elevando o benefício de Energia Firme $(r=2)$ e o benefício de Ponta Garantida. Neste caso, obtémse a maior Receita Líquida Anual dos quatro estudos, $R_{L Q}=U S \$ 163.995 .026,7$.

Finalmente, no teste 4 observa-se uma redução de $x_{\text {máx }}$ e de receita em relação ao teste 3. Tal fato deve-se à valorização da Energia Secundária que, conforme mencionado anteriormente, é vista sistematicamente como uma perda de receita, já que a introdução da nova usina reduz este benefício energético. Para minimizar esta perda, expande-se a casa de força, chegando-se a $p_{n o m, p}=524,9 \mathrm{MW}$. Neste caso, cada $M W$ 
adicionado à usina proporciona elevações de receita de Energia Firme $(r=2)$, Energia Secundária e Ponta Garantida.

De forma geral, constata-se que as dimensões da usina são bem sensíveis ao Mecanismo de Valorização da Energia adotado. Dependendo dos benefícios atribuídos a cada um dos benefícios energéticos, pode-se incentivar ou desestimular a expansão do reservatório, bem como a expansão da casa de força, dimensionando-se usinas diferentes, com receitas líquidas anuais também diferentes. Tal fato reforça a importância de um planejador eficiente que proporcione sinalizações corretas de preço, não somente quanto aos seus valores, tal como já comentado, mas também quanto a quais benefícios energéticos devem ou não ser valorizados.

\subsection{Adoção de Benefícios Locais}

A adoção dos chamados Benefícios Locais considera os benefícios energéticos proporcionados pela usina sob dimensionamento como sendo somente os Benefícios de Energia Firme, Energia Secundária e Ponta Garantida da própria usina, desconsiderando-se os ganhos sistêmicos.

Esta situação tem por objetivo especular o que aconteceria com as dimensões da nova usina, caso fossem-lhe atribuídos somente seus próprios benefícios. Para tanto, comparam-se os resultados de dez estudos de dimensionamento: cinco considerando Benefícios Locais e cinco considerando Benefícios Globais. Os testes realizados são mostrados na Tabela 7.26, e os principais resultados encontrados são mostrados na Tabela 7.27 e na Tabela 7.28.

Tabela 7.26 - Definição dos testes utilizados na comparação dos benefícios local e global.

\begin{tabular}{c|l|l}
\hline \multirow{2}{*}{ TESTE } & $\begin{array}{c}\text { Beneficio Local }- \text { BL } \\
\text { Nome do Teste }\end{array}$ & $\begin{array}{c}\text { Beneficio Global }- \text { BG } \\
\text { Nome do Teste }\end{array}$ \\
\hline 1 & Emb37ParEF40M1BLHT & Emb37ParEF40M1BGHT \\
2 & Emb37ParEF40M2BLHT & Emb37ParEF40M2BGHT \\
3 & Emb37ParEF40M2ESBLHT & Emb37ParEF40M2ESBGHT \\
4 & Emb37ParEF40M2PGBLHT & Emb37ParEF40M2PGBGHT \\
5 & Emb37ParEF40M2ESPGBLHT & Emb37ParEF40M2ESPGBGHT \\
\hline
\end{tabular}


Tabela 7.27 - Comparação das características fisicas da usina sob dimensionamento em função dos beneficios locais e globais.

\begin{tabular}{c|cccc|rrrr}
\hline \multirow{3}{*}{ TESTE } & \multicolumn{4}{|c|}{ Beneficio Local - BL } & \multicolumn{4}{c}{ Beneficio Global-BG } \\
& $\begin{array}{c}x_{\min } \\
{\left[\mathrm{hm}^{3}\right]}\end{array}$ & $\begin{array}{c}x_{\max } \\
{\left[\mathrm{hm}^{3}\right]}\end{array}$ & $\begin{array}{c}p_{\text {nom }, b} \\
{[\mathrm{MW}]}\end{array}$ & $\begin{array}{c}p_{\text {nom }} \\
{[\mathrm{MW}]}\end{array}$ & $\begin{array}{c}x_{\min } \\
{\left[\mathrm{hm}^{3}\right]}\end{array}$ & $\begin{array}{r}x_{\max } \\
{\left[\mathrm{hm}^{3}\right]}\end{array}$ & $\begin{array}{c}p_{\text {nom }, b} \\
{[\mathrm{MW}]}\end{array}$ & $p_{\text {nom }}$ \\
& {$[\mathrm{MW}]$} \\
\hline 1 & $4.000,0$ & $6.458,0$ & 825,9 & 825,9 & $4.000,0$ & $10.892,5$ & 928,6 & 928,6 \\
2 & $4.000,0$ & $6.430,0$ & 825,2 & 878,0 & $4.000,0$ & $10.896,0$ & 928,5 & 927,4 \\
3 & $4.000,0$ & $6.477,4$ & 827,5 & $1.053,0$ & $4.000,0$ & $9.182,0$ & 876,8 & $1.079,1$ \\
4 & $4.000,0$ & $6.712,1$ & 831,9 & $1.159,0$ & $4.000,0$ & $11.166,5$ & 936,0 & $1.233,0$ \\
5 & $4.390,1$ & $6.777,2$ & 841,3 & $1.352,0$ & $4.000,0$ & $9.201,3$ & 877,1 & $1.402,0$ \\
\hline
\end{tabular}

Tabela 7.28 - Comparação das Receitas Líquidas Anuais em função dos beneficios locais e globais.

\begin{tabular}{c|c|c}
\hline \multirow{2}{*}{ TESTE } & $\begin{array}{c}\text { Beneficio Local }- \text { BL } \\
\mathrm{R}_{\mathrm{L}}[\mathrm{US} \$]\end{array}$ & $\begin{array}{c}\text { Beneficio Global }-B G \\
\mathrm{R}_{\mathrm{LQ}}[\mathrm{US} \$]\end{array}$ \\
\hline 1 & $66.651 .016,1$ & $144.227 .326,3$ \\
2 & $85.746 .400,9$ & $153.761 .742,0$ \\
3 & $92.436 .563,1$ & $140.112 .654,1$ \\
4 & $95.649 .442,3$ & $163.995 .026,7$ \\
5 & $104.212 .199,9$ & $152.239 .418,1$ \\
\hline
\end{tabular}

Observando a Tabela 7.27 e a Figura 7.22, constata-se que a adoção dos Benefícios Locais produz usinas bem menores que a adoção dos Benefícios Globais. Por exemplo, o máximo $x_{\text {máx }}$ obtido com os Benefícios Locais é $6.777,2 \mathrm{hm}^{3}$, ao passo que o mínimo $x_{\text {máx }}$ obtido com os Benefícios Globais é 9.182,0 $\mathrm{hm}^{3}$. Estas dimensões acabam refletindo também na potência instalada de base, cujos valores são mostrados na mesma tabela. Esta redução das dimensões da nova usina ocorre porque os benefícios energéticos locais são sensivelmente inferiores aos benefícios energéticos globais. Por exemplo, para o teste 1 com Benefício Global, o ganho sistêmico de Energia Firme é 680,8 $\overline{M W}$, enquanto a Energia Firme da usina é 415,3 $\overline{M W}$ (Tabela 7.16, página 278). Conseqüentemente, as "receitas locais" também são menores, o que inibe a construção de um grande reservatório e de uma grande casa de força, uma vez que os custos associados facilmente superam os respectivos benefícios. Em outras palavras, a Receita Líquida Anual obtida quando consideram-se Benefícios Locais é inferior à obtida com os Benefícios Globais, tal como ilustrado na Tabela 7.28 e na Figura 7.23. 


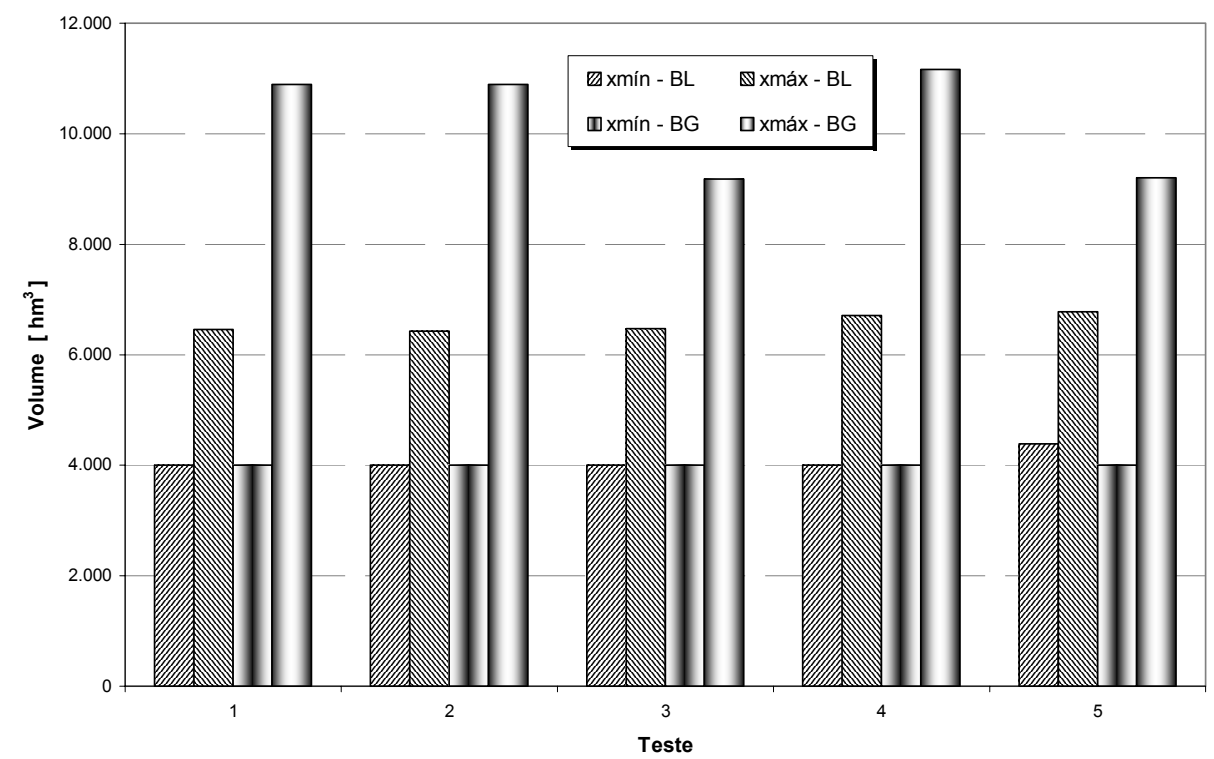

Figura 7.22 - Comparação das características físicas da usina sob dimensionamento em função dos beneficios serem locais ou globais.

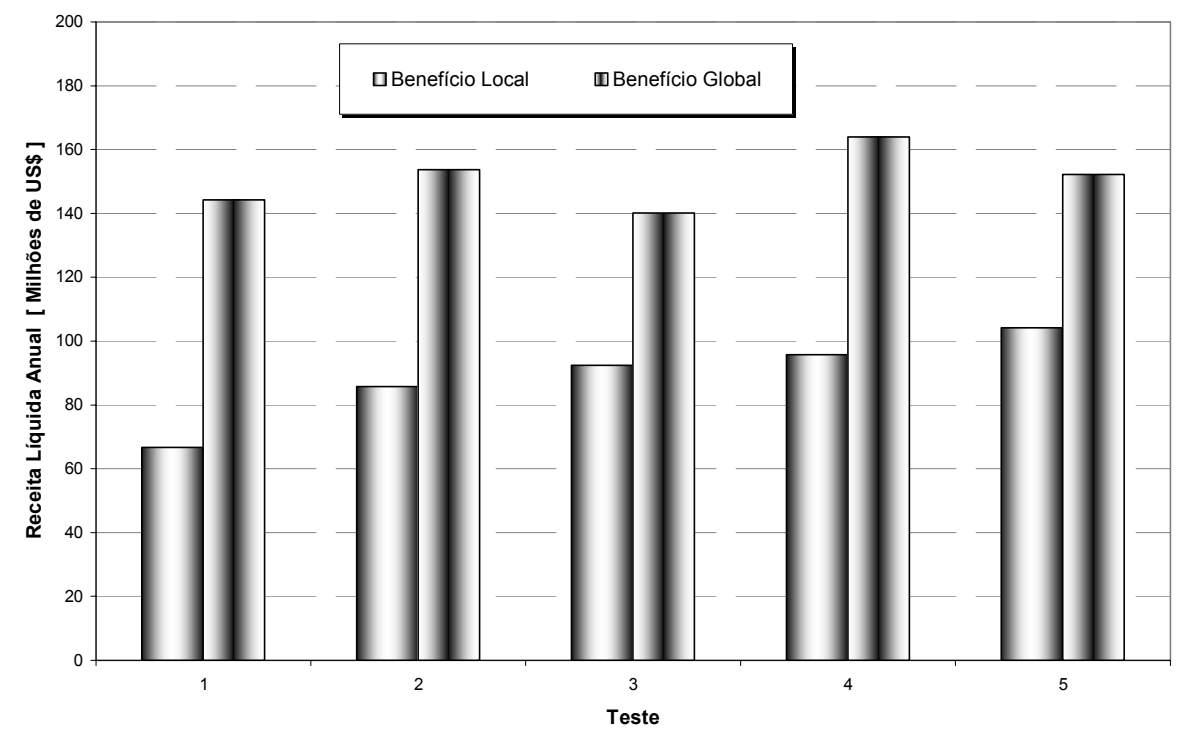

Figura 7.23 - Comparação da Receita Líquida Anual da usina sob dimensionamento em função dos beneficios serem locais ou globais.

Ainda referindo-se à Tabela 7.28 e à Figura 7.23, observa-se que para os Benefícios Locais, a Receita Líquida Anual é sempre crescente em função da adição da valorização da Energia Firme em dois patamares com $r=2$ (teste 1 para teste 2), da valorização da Energia Secundária (teste 2 para teste 3 ) e da valorização da Potência Garantida (teste 3 para teste 4). No entanto, para os Benefícios Globais, toda vez que a Energia Secundária passa a ser valorizada (teste 2 para teste 3 e teste 4 para teste 5), observa-se uma redução de Receita Líquida Anual. Esta diferença de comportamento observada nas receitas deve-se à diferença entre as Energias Secundárias sistêmica e 
local: para o sistema, a construção da nova usina implica redução da Energia Secundária, enquanto para a usina, sua construção implica uma Energia Secundária que até então não existia. Por exemplo, recorrendo novamente ao estudo Emb37ParEF40M1BGHT, Tabela 7.16 - página 278, enquanto o Benefício Global de Energia Secundária é $-175,6 \overline{M W}$, o respectivo Benefício Local é $36,1 \overline{M W}$.

Comparando os valores de volume mínimo, observa-se que em praticamente todos os casos tem-se $x_{\min }=4000,0 \mathrm{hm}^{3}$, o menor valor permitido. Conforme já observado, isto significa que o modelo interpreta que a usina de cabeceira deve possuir o maior volume útil possível a fim de aumentar o benefício de Energia Firme. Entretanto, para o Teste 5 com Benefícios Locais, tem-se $x_{\min }=4.390,1 \mathrm{hm}^{3}$. Isto mostra que, quando os benefícios são locais e todos os incentivos são dados à casa de força, o modelo interpreta que é mais vantajoso elevar o volume mínimo e garantir maior Potência Garantida e maior Energia Secundária à usina, a reduzir seu volume mínimo e possuir uma maior Energia Firme.

Este comportamento no qual prevalecem os benefícios próprios da usina sob dimensionamento em detrimento dos benefícios sistêmicos, incentivado pela forma de valorização dos benefícios energéticos, proporciona grandes perdas energéticas sistêmicas, tal como ilustrado na Tabela 7.29. Nesta tabela, mostram-se os benefícios energéticos sistêmicos para cada um dos testes. Por exemplo, o benefício sistêmico de Energia Firme é sempre cerca de 50\% menor quando o modelo de dimensionamento considera somente os Benefícios Locais na valorização da energia gerada. Também são observadas perdas sensíveis de Ponta Garantida e menores reduções de Energia Secundária.

Tabela 7.29 - Comparação dos beneficios energéticos sistêmicos em função da consideração de beneficios locais e globais.

\begin{tabular}{c|ccc|ccc}
\hline \multirow{3}{*}{ TESTE } & \multicolumn{3}{|c|}{ Beneficio Local - BL } & \multicolumn{3}{c}{ Beneficio Global-BG } \\
& $B_{E F}$ & $B_{E S}$ & $B_{P G}$ & $B_{E F}$ & $B_{E S}$ & $B_{P G}$ \\
& {$[\overline{M W}]$} & {$[\overline{M W}]$} & {$[\mathrm{MW}]$} & {$[\overline{M W}]$} & {$[\overline{M W}]$} & {$[\mathrm{MW}]$} \\
\hline 1 & 391,9 & 18,3 & 791,0 & 680,8 & $-175,6$ & 919,1 \\
2 & 392,0 & 24,5 & 841,7 & 675,0 & $-123,0$ & 927,4 \\
3 & 395,5 & 39,0 & $1.009,2$ & 617,2 & $-124,0$ & $1.033,3$ \\
4 & 409,0 & 36,9 & $1.110,1$ & 688,3 & $-149,5$ & $1.182,1$ \\
5 & 400,5 & 52,3 & $1.295,4$ & 617,8 & $-109,6$ & $1.341,8$ \\
\hline
\end{tabular}


Resumindo, a adoção dos Benefícios Locais determina aproveitamentos menores que a adoção dos Benefícios Globais. Em função das menores dimensões, os benefícios energéticos sistêmicos acabam sendo bem menores que os que poderiam ser conseguidos caso a nova usina se apropriasse dos benefícios por ela proporcionados ao restante do sistema.

\subsection{Adoção da Regra de Operação Baseada em Otimização}

A adoção da Regra de Operação Baseada em Otimização (Roo) é realizada alterando-se o algoritmo de simulação para determinação dos benefícios energéticos. Ao invés de assumir que os reservatórios são esvaziados e enchidos paralelamente, tal como havia sido feito até o momento, passa-se a considerar a operação dos reservatórios através de uma regra que, conforme já explicado no Capítulo VI, esvazia prioritariamente os reservatórios de cabeceira durante o período seco, e enche prioritariamente os reservatórios de jusante durante o período úmido.

Para avaliar os impactos da regra de operação no processo de dimensionamento, são realizados dez estudos, listados na Tabela 7.30. Os principais resultados encontrados são mostrados na Tabela 7.31 e na Tabela 7.32.

Tabela 7.30 - Definição dos testes utilizados na comparação das regras de operação.

\begin{tabular}{c|c|c}
\hline TESTE & $\begin{array}{c}\text { Regra de Operação com Otimização - Roo } \\
\text { Nome do Teste }\end{array}$ & $\begin{array}{c}\text { Regra de Operação Paralela - Par } \\
\text { Nome do Teste }\end{array}$ \\
\hline 1 & Emb37RooEF40M1BGHT & Emb37ParEF40M1BGHT \\
2 & Emb37RooEF40M2BGHT & Emb37ParEF40M2BGHT \\
3 & Emb37RooEF40M2ESBGHT & Emb37ParEF40M2ESBGHT \\
4 & Emb37RooEF40M2PGBGHT & Emb37ParEF40M2PGBGHT \\
5 & Emb37RooEF40M2ESPGBGHT & Emb37ParEF40M2ESPGBGHT \\
\hline
\end{tabular}

Tabela 7.31 - Comparação das características físicas da usina sob dimensionamento em função das regras de operação.

\begin{tabular}{|c|c|c|c|c|c|c|c|c|}
\hline \multirow[b]{2}{*}{ TESTE } & \multicolumn{4}{|c|}{ Regra de Operação com Otimização - Roo } & \multicolumn{4}{|c|}{ Regra de Operação Paralela - Par } \\
\hline & $\begin{array}{c}x_{\min } \\
{\left[\mathrm{hm}^{3}\right]}\end{array}$ & $\begin{array}{c}x_{\max } \\
{\left[\mathrm{hm}^{3}\right]}\end{array}$ & $\begin{array}{l}p_{\text {nom }, b} \\
{[\mathrm{MW}]}\end{array}$ & $\begin{array}{l}p_{\text {nom }} \\
{[\mathrm{MW}]}\end{array}$ & $\begin{array}{c}x_{\min } \\
{\left[\mathrm{hm}^{3}\right]}\end{array}$ & $\begin{array}{c}x_{\text {máx }} \\
{\left[\mathrm{hm}^{3}\right]}\end{array}$ & $\begin{array}{r}p_{\text {nom }, b} \\
{[\mathrm{MW}]}\end{array}$ & $\begin{array}{l}p_{\text {nom }} \\
{[\mathrm{MW}]}\end{array}$ \\
\hline 1 & $4.000,0$ & $11.042,0$ & 987,3 & 987,3 & $4.000,0$ & $10.892,5$ & 928,6 & 928,6 \\
\hline 2 & $4.000,0$ & $11.042,0$ & 987,3 & 987,3 & $4.000,0$ & $10.896,0$ & 928,5 & 928,5 \\
\hline 3 & $4.000,0$ & $9.371,6$ & 872,3 & 1023,0 & $4.000,0$ & $9.182,0$ & 876,8 & $1.079,1$ \\
\hline 4 & $4.000,0$ & $11.254,1$ & 987,5 & 1186,5 & $4.000,0$ & $11.166,5$ & 936,0 & $1.233,0$ \\
\hline 5 & $4.000,0$ & $10.205,7$ & 988,5 & 1566,2 & $4.000,0$ & $9.201,3$ & 877,1 & $1.402,0$ \\
\hline
\end{tabular}


Tabela 7.32 - Comparação das Receitas Líquidas Anuais em função das regras de operação.

\begin{tabular}{c|c|c}
\hline \multirow{2}{*}{ TESTE } & $\begin{array}{c}\text { Regra com Otimização-Roo } \\
\mathrm{R}_{\mathrm{LQ}}[\mathrm{US} \$]\end{array}$ & $\begin{array}{c}\text { Regra Paralela }- \text { Par } \\
\mathrm{R}_{\mathrm{LQ}}[\mathrm{US} \$]\end{array}$ \\
\hline 1 & $148.489 .490,1$ & $144.227 .326,3$ \\
2 & $157.693 .673,3$ & $153.692 .343,5$ \\
3 & $144.832 .032,3$ & $140.112 .654,1$ \\
4 & $166.863 .963,0$ & $163.995 .026,7$ \\
5 & $156.866 .331,1$ & $152.239 .418,1$ \\
\hline
\end{tabular}

O primeiro fato a ser observado na Tabela 7.31 são os volumes mínimos todos iguais ao menor valor que pode ser atribuído a esta variável, $4.000 \mathrm{hm}^{3}$. Conforme já citado várias vezes, o modelo de dimensionamento entende que a usina de cabeceira deve possuir o maior volume útil possível, a fim de valorizar a água de seu reservatório nas usinas de jusante, elevando o benefício sistêmico de Energia Firme. Para tanto, uma vez definido o volume máximo, o volume mínimo é reduzido ao seu limite inferior.

Comparando os valores de volume máximo, observa-se que a Regra Baseada em Otimização sempre determina reservatórios relativamente maiores que a Regra Paralela. Em um caso extremo, para o teste 5, a diferença entre os volumes máximos encontrados pelas duas regras é superior a $1.000 \mathrm{hm}^{3}$. Tal diferença justifica-se pela forma como a usina de cabeceira é esvaziada quando operada com a Roo. A prioridade de esvaziamento da usina de cabeceira faz com que esta usina seja esvaziada enquanto as usinas de jusante ainda encontram-se relativamente cheias, com quedas líquidas relativamente elevadas. Assim, o volume da usina de cabeceira passa pelas usinas de jusante enquanto estas apresentam produtividades maiores, permitindo que suas gerações sejam superiores às observadas quando o esvaziamento ocorre de acordo com a Regra Paralela.

Desta forma, pode-se dizer que a Regra Baseada em Otimização associa, a cada $\mathrm{hm}^{3}$ turbinado pela usina sob dimensionamento, um valor energético maior que o obtido com a Regra Paralela. Este maior valor energético determina, por sua vez, maiores receitas de Energia Firme, justificando a expansão do reservatório.

A maior valorização da Energia Firme pode ser constatada pelos pequenos ganhos de Receita Líquida Anual proporcionados pela Roo em relação a Par, mostrados na Tabela 7.32. Os valores apresentados mostram que mesmo investindo mais na construção do reservatório, a operação com a Regra Baseada em Otimização ainda 
consegue ganhos de receita maiores que os custos associados, garantindo Receitas Líquidas Anuais ligeiramente maiores que a Regra Paralela.

Os ganhos de receita só são obtidos porque os benefícios energéticos sistêmicos, Tabela 7.33, são de fato maiores quando o sistema é operado com a Regra Baseada em Otimização. Observam-se valores de Energia Firme sempre maiores para os casos em que a Roo é utilizada.

Tabela 7.33 - Comparação dos beneficios energéticos sistêmicos em função das regras de operação.

\begin{tabular}{c|ccc|ccc}
\hline \multirow{3}{*}{ TESTE } & \multicolumn{3}{|c|}{ Regra com Otimização-Roo } & \multicolumn{3}{|c}{ Regra Paralela-Par } \\
& $B_{E F}$ & $B_{E S}$ & $B_{P G}$ & $B_{E F}$ & $B_{E S}$ & $B_{P G}$ \\
& {$[\overline{M W}]$} & {$[\overline{M W}]$} & {$[\mathrm{MW}]$} & {$[\overline{M W}]$} & {$[\overline{M W}]$} & {$[\mathrm{MW}]$} \\
\hline 1 & 707,5 & -134.2 & 947.2 & 680,8 & $-175,6$ & 919,1 \\
2 & 707,5 & -134.2 & 947.2 & 675,0 & $-123,0$ & 927,4 \\
3 & 629,6 & -84.7 & 980.5 & 617,2 & $-124,0$ & $1.033,3$ \\
4 & 702,8 & -109.7 & 1138.4 & 688,3 & $-149,5$ & $1.182,1$ \\
5 & 667,2 & -78.7 & 1501.9 & 617,8 & $-109,6$ & $1.341,8$ \\
\hline
\end{tabular}

Concluindo, o algoritmo de simulação e, em particular, a política de operação adotada nos estudos de dimensionamento podem alterar de forma sensível as dimensões da nova usina, com conseqüentes alterações nos benefícios energéticos e econômicos esperados. Ressalta-se a importância dos estudos serem feitos com as políticas que de fato serão utilizadas na operação da usina, uma vez que modelos diferentes podem fazer com que os benefícios energéticos e econômicos vislumbrados durante a fase de projeto jamais possam ser alcançados. De forma oposta, a eficiência operacional esperada de uma usina ao longo de sua vida útil pode jamais ser atingida se seu projeto não foi realizado contemplando suas situações de operação.

\subsection{Alteração do Histórico de Vazões Afluentes}

A alteração do histórico de vazões traduz-se basicamente na alteração do conjunto de dados de vazão natural afluente utilizado nos estudos de dimensionamento. Ao invés de utilizar todo o histórico de vazões disponível, de janeiro de 1931 a dezembro de 1994 (Histórico Total), utilizou-se o conjunto de vazões referentes ao período de janeiro de 1960 a dezembro de 1994 (Histórico Parcial). 
Para avaliar o impacto da utilização de um conjunto diferente de vazões afluentes durante o processo de dimensionamento, comparam-se os resultados dos dez testes ilustrados na Tabela 7.34. Cada par de testes de 1 a 5 é realizado nas mesmas condições, exceto única e exclusivamente pelo conjunto de vazões utilizado. Os principais resultados encontrados são mostrados na Tabela 7.35 e na Tabela 7.36.

Tabela 7.34 - Definição dos testes utilizados na comparação dos históricos de vazão.

\begin{tabular}{c|l|l}
\hline \multirow{2}{*}{ TESTE } & $\begin{array}{c}\text { Histórico Parcial }-H P \\
\text { Nome do Teste }\end{array}$ & $\begin{array}{c}\text { Histórico Total }- \text { HT } \\
\text { Nome do Teste }\end{array}$ \\
\hline 1 & Emb37ParEF40M1BGHP & Emb37ParEF40M1BGHT \\
2 & Emb37ParEF40M2BGHP & Emb37ParEF40M2BGHT \\
3 & Emb37ParEF40M2ESBGHP & Emb37ParEF40M2ESBGHT \\
4 & Emb37ParEF40M2PGBGHP & Emb37ParEF40M2PGBGHT \\
5 & Emb37ParEF40M2ESPGBGHP & Emb37ParEF40M2ESPGBGHT \\
\hline
\end{tabular}

Tabela 7.35 - Comparação das características fisicas da usina sob dimensionamento em função do histórico de vazão natural afluente.

\begin{tabular}{|c|c|c|c|c|c|c|c|c|}
\hline \multirow[b]{2}{*}{ TESTE } & \multicolumn{4}{|c|}{ Histórico Parcial - HP } & \multicolumn{4}{|c|}{ Histórico Total - HT } \\
\hline & $\begin{array}{c}x_{\min } \\
{\left[\mathrm{hm}^{3}\right]}\end{array}$ & $\begin{array}{c}x_{m a ́ x} \\
{\left[\mathrm{hm}^{3}\right]}\end{array}$ & $\begin{array}{c}p_{n o m, b} \\
{[\mathrm{MW}]}\end{array}$ & $\begin{array}{l}p_{\text {nom }} \\
{[\mathrm{MW}]}\end{array}$ & $\begin{array}{c}x_{\min } \\
{\left[\mathrm{hm}^{3}\right]}\end{array}$ & $\begin{array}{c}x_{\operatorname{máx}} \\
{\left[\mathrm{hm}^{3}\right]}\end{array}$ & $\begin{array}{c}p_{n o m, b} \\
{[\mathrm{MW}]}\end{array}$ & $\begin{array}{l}p_{\text {nom }} \\
{[\mathrm{MW}]}\end{array}$ \\
\hline 1 & $4.000,0$ & $14.438,8$ & 964,1 & 964,1 & $4.000,0$ & $10.892,5$ & 928,6 & 928,6 \\
\hline 2 & $4.000,0$ & $12.692,6$ & $1.013,7$ & $1.060,0$ & $4.000,0$ & $10.896,0$ & 928,5 & 928,5 \\
\hline 3 & $4.000,0$ & $11.089,2$ & $1.053,6$ & $1.091,0$ & $4.000,0$ & $9.182,0$ & 876,8 & $1.079,1$ \\
\hline 4 & $4.000,0$ & $12.662,9$ & $1.014,5$ & $1.128,0$ & $4.000,0$ & $11.166,5$ & 936,0 & $1.233,0$ \\
\hline 5 & $4.000,0$ & $11.108,8$ & $1.053,1$ & $1.599,0$ & $4.000,0$ & $9.201,3$ & 877,1 & $1.402,0$ \\
\hline
\end{tabular}

Tabela 7.36 - Comparação dos benefícios energéticos sistêmicos em função dos históricos de vazão natural afluente.

\begin{tabular}{c|ccc|ccc}
\hline \multirow{3}{*}{ TESTE } & \multicolumn{3}{|c|}{ Histórico Parcial-HP } & \multicolumn{3}{c}{ Histórico Total $-H T$} \\
& $B_{E F}$ & $B_{E S}$ & $B_{P G}$ & $B_{E F}$ & $B_{E S}$ & $B_{P G}$ \\
& {$[\overline{M W}]$} & {$[\overline{M W}]$} & {$[\mathrm{MW}]$} & {$[\overline{M W}]$} & {$[\overline{M W}]$} & {$[\mathrm{MW}]$} \\
\hline 1 & 671,6 & $-142,3$ & 921,4 & 680,8 & $-175,6$ & 919,1 \\
2 & 662,0 & $-85,4$ & $1.013,3$ & 675,0 & $-123,0$ & $1.807,7$ \\
3 & 589,8 & $-40,4$ & $1.043,2$ & 617,2 & $-124,0$ & $1.033,3$ \\
4 & 660,0 & $-75,9$ & $1.078,1$ & 688,3 & $-149,5$ & $1.182,1$ \\
5 & 583,7 & $-9,1$ & $1.527,2$ & 617,8 & $-109,6$ & $1.341,8$ \\
\hline
\end{tabular}

O primeiro fato a ser observado são os valores de mínimo, todos iguais ao menor valor permitido nos testes, $4.000 \mathrm{hm}^{3}$. Conforme já mencionado outras vezes, o modelo entende que o reservatório da usina de cabeceira deve apresentar o maior volume útil possível, a fim de garantir um maior volume de água a ser turbinado ao longo do Período Crítico, além de permitir uma melhor regularização das vazões naturais. 
Observando os valores de volume máximo, nota-se que em todos os testes, o reservatório da usina dimensionada utilizando-se o Histórico Parcial é sempre maior que o reservatório determinado através do Histórico Total. Fato semelhante ocorre com a potência instalada de base.

Para entender melhor estas alterações, recorre-se à Figura 7.24 e à Figura 7.25, onde são mostradas, respectivamente, as seqüências de vazões dos dois Períodos Críticos e suas principais características.

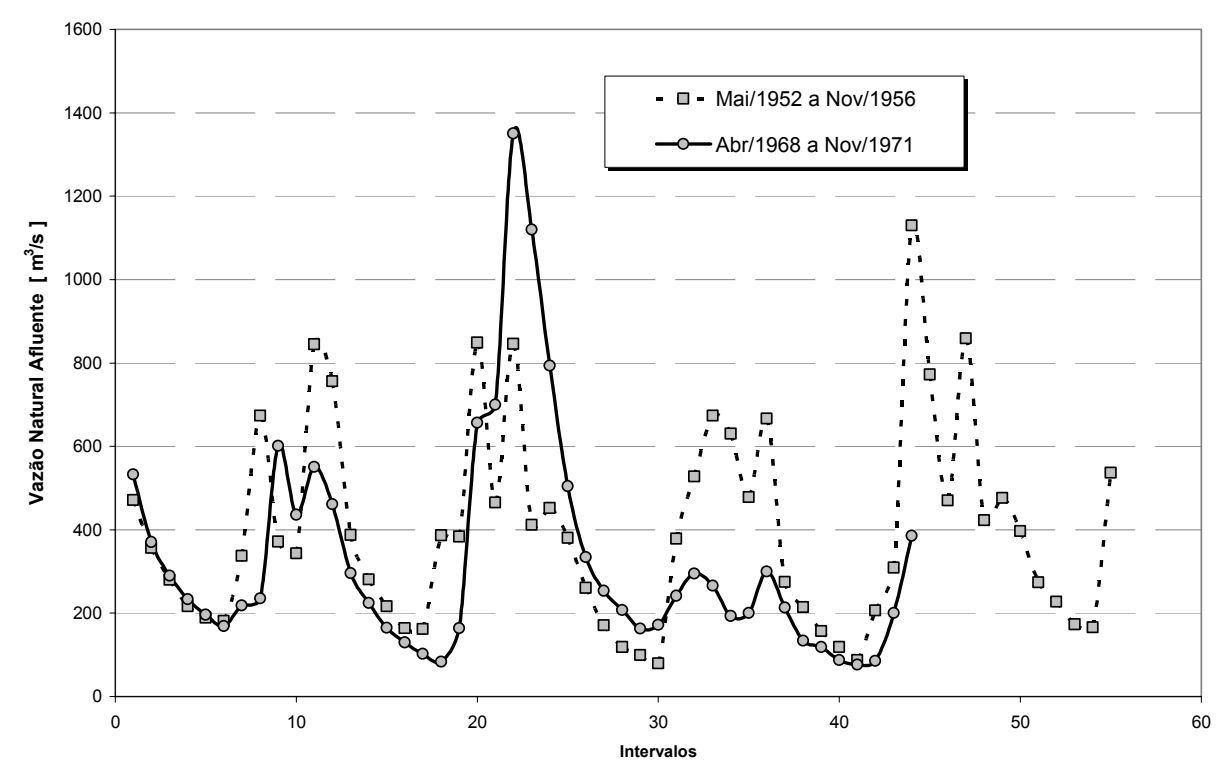

Figura 7.24 - Seqüências de vazões naturais afluentes para os Periodos Críticos dos dois históricos de vazão.

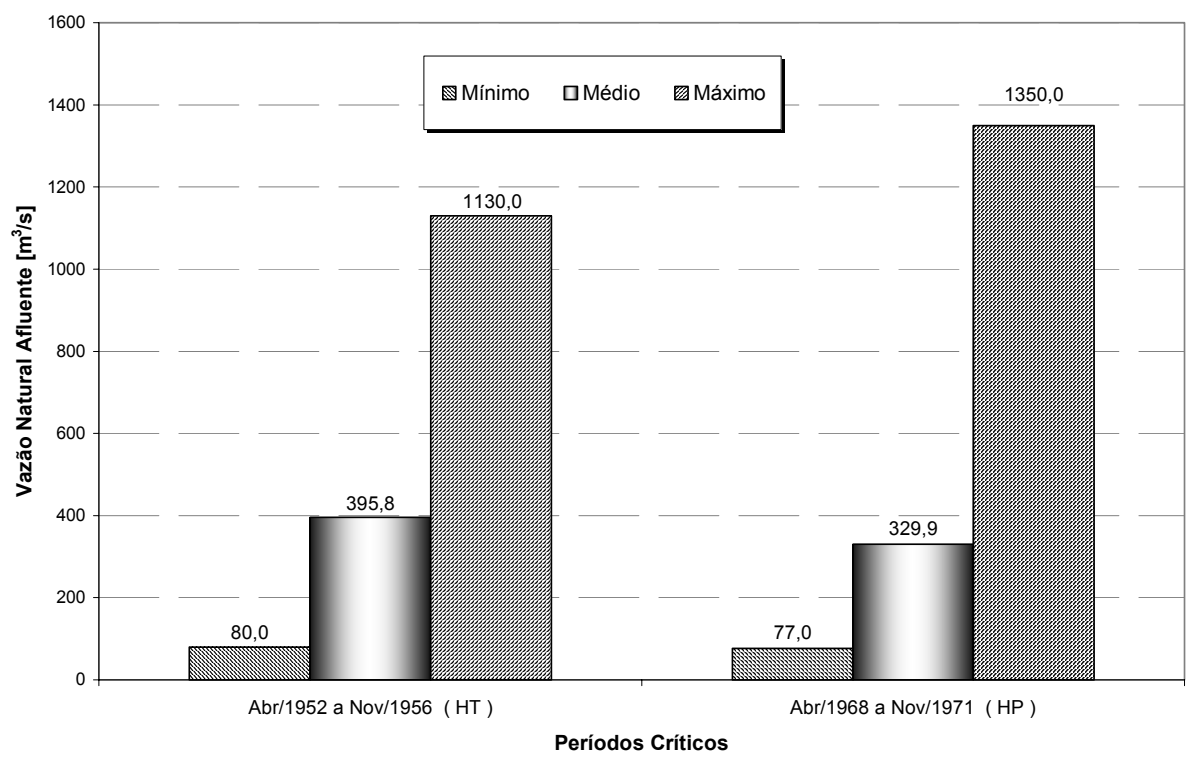

Figura 7.25 - Comparação das vazões naturais afluentes mínima, média e máxima durante os Periodos Críticos dos dois históricos de vazão. 
Baseando-se nos valores de vazão, nota-se que o Período Crítico do Histórico Parcial apresenta um grande pico de vazão, de $1.350,0 \mathrm{~m}^{3} / \mathrm{s}$. Este pico elevado de vazão faz com que a usina necessite de um grande reservatório para amortecê-lo, o que determina os valores de volume máximo observados na Tabela 7.35.

Por outro lado, a metodologia de dimensionamento adotada prevê que não pode haver vazão vertida ao longo do Período Crítico, de forma que capacidade instalada de base tenha que ser equivalente à máxima vazão a ser turbinada ao longo do Período Crítico. Esta metodologia faz com que a capacidade instalada de base seja sempre maior para o Histórico Parcial, uma vez que a vazão máxima do Período Crítico a ele associado é maior que a vazão máxima associada ao Período Crítico do Histórico Total. Assim, o Histórico Parcial determina reservatório e casa de força maiores para a usina sob dimensionamento.

Observando a Tabela 7.37, observa-se que a usina maior, dimensionada com base no Histórico Parcial, não apresenta Receitas Líquidas Anuais maiores que a usina determinada com base no Histórico Total. Aliás, ocorre justamente o contrário: para todos os casos, a usina determinada com o Histórico Total apresentou $R_{L Q}$ maior que a usina determinada com o Histórico Parcial.

Tabela 7.37 - Comparação das Receitas Líquidas Anuais em função do histórico de vazão natural afluente.

\begin{tabular}{c|c|c}
\hline \multirow{2}{*}{ TESTE } & $\begin{array}{c}\text { Histórico Parcial }-H P \\
\mathrm{R}_{\mathrm{LQ}}[\mathrm{US} \$]\end{array}$ & $\begin{array}{c}\text { Histórico Total }-H T \\
\mathrm{R}_{\mathrm{LQ}}[\mathrm{US} \$]\end{array}$ \\
\hline 1 & $112.507 .662,8$ & $144.227 .326,3$ \\
2 & $123.378 .628,7$ & $153.692 .343,5$ \\
3 & $117.471 .868,4$ & $140.112 .654,1$ \\
4 & $134.281 .824,8$ & $163.995 .026,7$ \\
5 & $130.169 .363,8$ & $152.239 .418,1$ \\
\hline
\end{tabular}

Nestes casos, reduzir a $R_{L Q}$ significa elevar custos sem a correspondente elevação de receitas na mesma proporção. Analisando a Tabela 7.36, conclui-se que as usinas maiores determinadas pelo Histórico Parcial não proporcionam maiores ganhos de Energia Firme, o que significa dizer que o reservatório e a casa de força maiores não geram mais energia ao longo do Período Crítico. De fato, observando as características hidrológicas dos dois Períodos Críticos, Figura 7.25, observa-se que o Histórico Parcial determina o maior valor de vazão máxima e, ao mesmo tempo, uma vazão média cerca de $20 \%$ inferior à determinada pelo Histórico Total. Em função destas características, a 
usina sob dimensionamento sempre apresenta uma menor Energia Firme quando os testes utilizam o Histórico Parcial de vazões, já que a Energia Firme corresponde justamente à geração média obtida ao longo do Período Crítico.

A constatação destas diferenças permite concluir que o conjunto de vazões utilizado nos testes altera de forma sensível as dimensões da usina sob dimensionamento. Na realidade, esta alteração ocorre de forma indireta: para diferentes conjuntos de vazão utilizados nos estudos de simulação têm-se diferentes vazões ao longo do Período Crítico, o que acaba determinando reservatórios sensivelmente distintos. As alterações de dimensão são proporcionadas pelos próprios valores de vazão e também pela forma como estes valores distribuem-se ao longo do tempo. Observouse, por exemplo, que um Período Crítico composto por um grande pico de vazão associado a vazões médias pequenas acaba proporcionando uma Receita Líquida Anual reduzida, pois se exige um grande reservatório e uma grande casa de máquinas, sem haver aumentos de Energia Firme.

Os resultados observados também sinalizam que os métodos de dimensionamento não devem ser baseados em um único conjunto de vazões afluentes, uma vez que este conjunto determina de forma imperativa as características do novo empreendimento. Uma vez construída a usina, seqüências de vazões semelhantes às de projeto podem nunca ser observadas novamente, fazendo com que os benefícios esperados não se verifiquem.

\subsection{Alteração do Sistema Completo}

A alteração do Sistema Completo dimensiona a usina de Emborcação supondo que a mesma esteja sendo inserida em um sistema diferente do utilizado até o momento. Para efeito de avaliação, ao invés de inseri-la em um sistema composto por 36 usinas, realiza-se a inserção de Emborcação em um sistema reduzido, composto apenas pelas usinas de Itumbiara, São Simão e Ilha Solteira.

Os testes utilizados para avaliar e comparar o impacto da adoção de um Sistema Completo diferenciado são mostrados na Tabela 7.38. Cada par de testes de 1 a 5 é realizado nas mesmas condições, exceto pelo Sistema Completo que ora é constituído por 4 e ora por 37 usinas. Os principais resultados são apresentados na Tabela 7.39, na Tabela 7.40 e na Tabela 7.41 . 
Tabela 7.38 - Definição dos testes utilizados na comparação do Sistema de Referência.

\begin{tabular}{c|c|c}
\hline \multirow{2}{*}{ TESTE } & $\begin{array}{c}\text { Sistema Completo com 4 Usinas } \\
\text { Nome do Teste }\end{array}$ & $\begin{array}{c}\text { Sistema Completo com 37 Usinas } \\
\text { Nome do Teste }\end{array}$ \\
\hline 1 & Emb4ParEF40M1BGHT & Emb37ParEF40M1BGHT \\
2 & Emb4ParEF40M2BGHT & Emb37ParEF40M2BGHT \\
3 & Emb4ParEF40M2ESBGHT & Emb37ParEF40M2ESBGHT \\
4 & Emb4ParEF40M2PGBGHT & Emb37ParEF40M2PGBGHT \\
5 & Emb4ParEF40M2ESPGBGHT & Emb37ParEF40M2ESPGBGHT \\
\hline
\end{tabular}

Tabela 7.39 - Comparação das características fisicas da usina sob dimensionamento em função do Sistema de Referência.

\begin{tabular}{c|cccc|crcr}
\hline \multirow{3}{*}{ TESTE } & \multicolumn{3}{|c|}{ Sistema Completo com 4 Usinas } & \multicolumn{4}{c}{ Sistema Completo com 37 Usinas } \\
& $x_{\text {min }}$ & $x_{\text {máx }}$ & $p_{\text {nom, } b}$ & $p_{\text {nom }}$ & $x_{\text {min }}$ & $x_{\text {máx }}$ & $p_{\text {nom, } b}$ & $p_{\text {nom }}$ \\
& {$\left[\mathrm{hm}^{3}\right]$} & {$\left[\mathrm{hm}^{3}\right]$} & {$[\mathrm{MW}]$} & {$[\mathrm{MW}]$} & {$\left[\mathrm{hm}^{3}\right]$} & {$\left[\mathrm{hm}^{3}\right]$} & {$[\mathrm{MW}]$} & {$[\mathrm{MW}]$} \\
\hline 1 & $4.000,0$ & $15.168,3$ & 719,5 & 719,5 & $4.000,0$ & $10.892,5$ & 928,6 & 928,6 \\
2 & $4.000,0$ & $14.693,5$ & 609,6 & 652,0 & $4.000,0$ & $10.896,0$ & 928,5 & 928,5 \\
3 & $4.000,0$ & $11.977,8$ & 490,9 & 952,1 & $4.000,0$ & $9.182,0$ & 876,8 & $1.079,1$ \\
4 & $4.000,0$ & $14.609,1$ & 606,1 & 679,9 & $4.000,0$ & $11.166,5$ & 936,0 & $1.233,0$ \\
5 & $4.000,0$ & $12.106,9$ & 496,7 & $1.260,0$ & $4.000,0$ & $9.201,3$ & 877,1 & $1.402,0$ \\
\hline
\end{tabular}

Mais uma vez, repete-se a determinação do volume mínimo sempre igual ao menor valor que pode ser atribuído a esta variável, $4.000 \mathrm{hm}^{3}$. Isto mostra que independentemente do número de usinas a jusante, o modelo de dimensionamento entende que a usina de cabeceira deve possuir o maior volume útil possível, a fim de valorizar a água de seu reservatório, elevando o benefício sistêmico de Energia Firme. Para tanto, uma vez definido o volume máximo, o volume mínimo é reduzido ao seu limite inferior.

Observando os valores de volume máximo, $x_{\text {máx }} \mathrm{em} \mathrm{hm}^{3}$, e de potência instalada de base, $p_{n o m, b}$ em $M W$, observa-se que o Sistema de Referência composto por 4 usinas determina um reservatório maior e uma casa de força menor que o Sistema de Referência composto por 37 usinas. Para entender esta relação, primeiro deve-se observar que os Períodos Críticos dos dois sistemas são diferentes. Enquanto o Período Crítico para o sistema composto por 37 usinas estende-se de maio de 1952 a novembro de 1955, o Período Crítico para o sistema composto por 4 usinas estende-se de maio de 1970 a novembro de 1971. A implicação destes períodos diferenciados é bem sensível, traduzindo-se em diferentes conjuntos de vazões afluentes. 


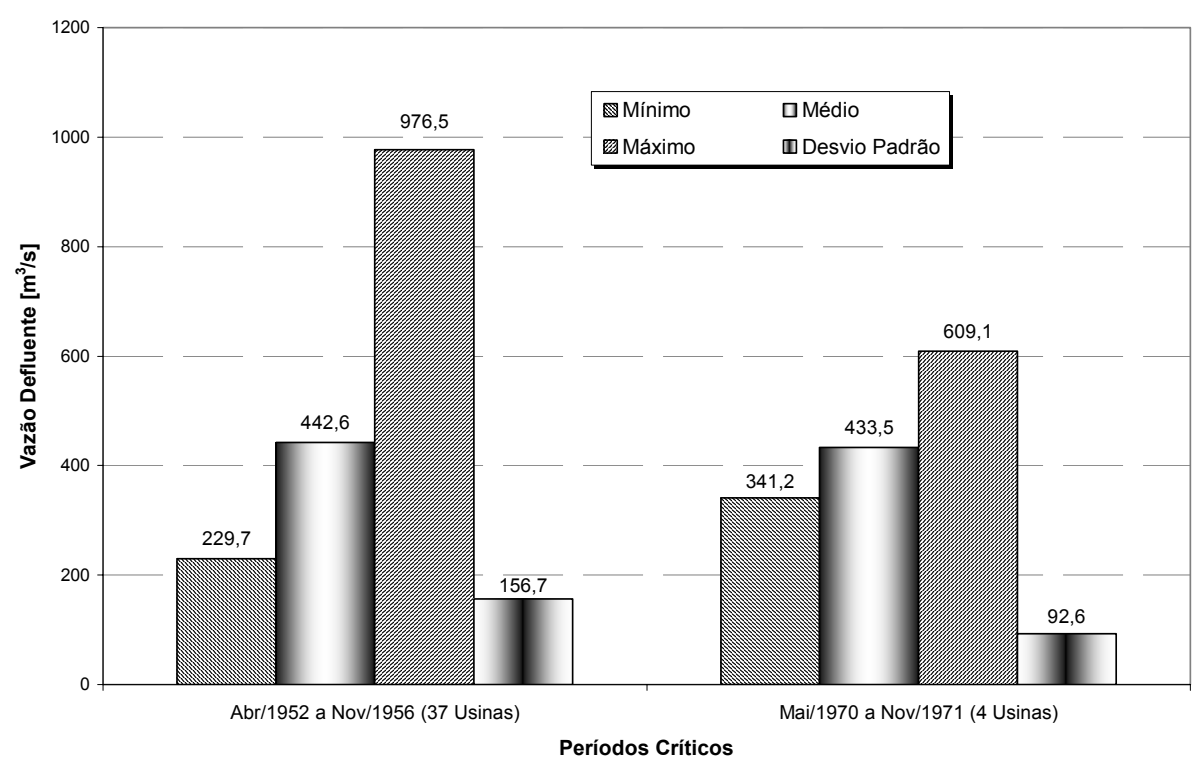

Figura 7.26 - Comparação das vazões defluentes mínima, média e máxima durante os Periodos Críticos dos dois Sistemas Completos.

Para mostrar as diferenças nos conjuntos de vazão, apresentam-se na Figura 7.26 os valores mínimo, médio e máximo de vazão afluente a Emborcação nos dois Períodos Críticos mencionados, bem como os respectivos desvios-padrão. Observando os valores apresentados, constata-se que as vazões do período de maio de 1970 a novembro de 1971 são bem mais uniformes que as vazões de maio de 1952 a novembro de 1956. Esta maior uniformidade é caracterizada por valores mínimo e máximo próximos à média, ou mesmo pelo próprio valor de desvio padrão.

O fato do período de maio de 1970 a novembro de 1971 apresentar uma vazão máxima menor que o período de maio de 1952 a novembro de 1955 acaba determinando uma casa de força menor para a usina dimensionada com o Sistema Completo com 4 usinas, já que a potência de base é justamente aquela que faz com que não haja vazão vertida ao longo do Período Crítico. Reduzindo-se a potência de base, reduz-se o custo da casa de força e o custo de operação e manutenção, liberando recursos a serem empregados na construção de um reservatório maior.

Constata-se assim que alterar o Sistema de Referência acaba determinando uma alteração no Período Crítico, que por sua vez altera o conjunto de vazões utilizado no dimensionamento das características de base, modificando a estrutura de custos do empreendimento e as dimensões ótimas finais. 
Tabela 7.40 - Comparação das Receitas Líquidas Anuais em função do Sistema de Referência.

\begin{tabular}{c|c|c}
\hline \multirow{2}{*}{ TESTE } & $\begin{array}{c}\text { Sistema com 4 Usinas } \\
\mathrm{R}_{\mathrm{LQ}}[\mathrm{US} \$]\end{array}$ & $\begin{array}{c}\text { Sistema com 37 Usinas } \\
\mathrm{R}_{\mathrm{LQ}}[\mathrm{US} \$]\end{array}$ \\
\hline 1 & $129.703 .685,0$ & $144.227 .326,3$ \\
2 & $129.223 .643,7$ & $153.692 .343,5$ \\
3 & $108.065 .588,4$ & $140.112 .654,1$ \\
4 & $135.846 .207,0$ & $163.995 .026,7$ \\
5 & $118.454 .492,0$ & $152.239 .418,1$ \\
\hline
\end{tabular}

Tabela 7.41 - Comparação dos benefícios energéticos sistêmicos em função do Sistema de Referência.

\begin{tabular}{c|ccc|ccc}
\hline \multirow{2}{*}{ TESTE } & \multicolumn{3}{|c|}{ Sistema Completo com 4 Usinas } & \multicolumn{3}{|c}{ Sistema } \\
& $B_{E F}$ & $B_{E S}$ & $B_{P G}$ & $B_{E F}$ & $B_{E S}$ & $B_{P G}$ \\
& {$[\overline{M W}]$} & {$[\overline{M W}]$} & {$[\mathrm{MW}]$} & {$[\overline{M W}]$} & {$[\overline{M W}]$} & {$[\mathrm{MW}]$} \\
\hline 1 & 791,4 & $-298,5$ & 689,4 & 680,8 & $-175,6$ & 919,1 \\
2 & 766,2 & $-294,3$ & 626,0 & 675,0 & $-123,0$ & $1.807,7$ \\
3 & 603,4 & $-113,0$ & 913,2 & 617,2 & $-124,0$ & $1.033,3$ \\
4 & 760,9 & $-283,9$ & 651,9 & 688,3 & $-149,5$ & $1.182,1$ \\
5 & 606,6 & $-85,2$ & $1.207,7$ & 617,8 & $-109,6$ & $1.341,8$ \\
\hline
\end{tabular}

Estas alterações nas dimensões ótimas dificultam a comparação em termos de benefícios energéticos e econômicos. Por exemplo, pela Tabela 7.40 nota-se que todos os valores de Receita Líquida Anual são maiores para os casos em que o Sistema Completo é composto por 37 usinas. Entretanto, pelos apresentados na Tabela 7.41, há variações sensíveis nos benefícios sistêmicos, ora apresentando maior ganho de Energia Firme para o Sistema Completo com 4 Usinas, ora para o Sistema Completo com 37 Usinas.

Ainda que os dois Sistemas Completos utilizados sejam excessivamente diferentes, as diferenças nas dimensões encontradas para a usina sob dimensionamento reforçam mais uma vez a necessidade de um planejamento cuidadoso, capaz de visualizar adequadamente o sistema no qual a nova usina será inserida. Desvios entre as situações planejada e verificada podem significar dimensões não ótimas para a usina, no sentido dos ganhos energéticos e econômicos verificados serem sensivelmente diferentes dos respectivos ganhos esperados. 


\subsection{Alteração da Usina Sob Dimensionamento}

A alteração da usina sob dimensionamento realiza os estudos supondo que o novo empreendimento a ser construído é a usina de Porto Primavera, localizada no rio Paraná. Esta alteração tem o objetivo de determinar como o modelo se comporta quando a usina sob dimensionamento não é uma usina de cabeceira, como Emborcação, mas sim uma usina localizada quase que a jusante de todo sistema (vide Figura 7.1).

Para realizar os estudos comparam-se os resultados dos dez testes ilustrados na Tabela 7.42. Cada par de testes é realizado nas mesmas condições, exceto somente pela usina sob dimensionamento. Os resultados encontrados são mostrados na Tabela 7.43 e na Tabela 7.44 .

Tabela 7.42 - Definição dos testes utilizados na comparação das usinas sob dimensionamento.

\begin{tabular}{c|l|l}
\hline TESTE & \multicolumn{1}{|c|}{$\begin{array}{c}\text { Porto Primavera }- \text { Pri } \\
\text { Nome do Teste }\end{array}$} & $\begin{array}{c}\text { Emborcação }- \text { Emb } \\
\text { Nome do Teste }\end{array}$ \\
\hline 1 & Pri37ParEF40M1BGHT & Emb37ParEF40M1BGHT \\
2 & Pri37ParEF40M2BGHT & Emb37ParEF40M2BGHT \\
3 & Pri37ParEF40M2ESBGHT & Emb37ParEF40M2ESBGHT \\
4 & Pri37ParEF40M2PGBGHT & Emb37ParEF40M2PGBGHT \\
5 & Pri37ParEF40M2ESPGBGHT & Emb37ParEF40M2ESPGBGHT \\
\hline
\end{tabular}

Tabela 7.43 - Comparação das características físicas da usina sob dimensionamento em função do Sistema de Referência.

\begin{tabular}{c|cccc|crcr}
\hline \multirow{3}{*}{ TESTE } & \multicolumn{4}{|c|}{ Porto Primavera-Pri } & \multicolumn{4}{c}{ Emborcação - Emb } \\
& $x_{\text {min }}$ & $x_{\text {máx }}$ & $p_{\text {nom }, b}$ & $p_{\text {nom }}$ & $x_{\text {min }}$ & $x_{\text {máx }}$ & $p_{\text {nom, } b}$ & $p_{\text {nom }}$ \\
& {$\left[\mathrm{hm}^{3}\right]$} & {$\left[\mathrm{hm}^{3}\right]$} & {$[\mathrm{MW}]$} & {$[\mathrm{MW}]$} & {$\left[\mathrm{hm}^{3}\right]$} & {$\left[\mathrm{hm}^{3}\right]$} & {$[\mathrm{MW}]$} & {$[\mathrm{MW}]$} \\
\hline 1 & $13.439,9$ & $14.107,1$ & $1.174,1$ & $1.174,1$ & $4.000,0$ & $10.892,5$ & 928,6 & 928,6 \\
2 & $13.541,3$ & $14.795,9$ & $1.196,2$ & $1.273,0$ & $4.000,0$ & $10.896,0$ & 928,5 & 928,5 \\
3 & $13.623,0$ & $14.852,4$ & $1.197,4$ & $1.744,0$ & $4.000,0$ & $9.182,0$ & 876,8 & $1.079,1$ \\
4 & $13.522,8$ & $14.779,8$ & $1.195,6$ & $1.419,0$ & $4.000,0$ & $11.166,5$ & 936,0 & $1.233,0$ \\
5 & $14.409,4$ & $15.520,6$ & $1.216,1$ & $2.140,0$ & $4.000,0$ & $9.201,3$ & 877,1 & $1.402,0$ \\
\hline
\end{tabular}

Tabela 7.44 - Comparação dos beneficios energéticos sistêmicos em função da usina sob dimensionamento.

\begin{tabular}{c|rrr|rrr}
\hline \multirow{2}{*}{ TESTE } & \multicolumn{3}{|c|}{ Porto Primavera - Pri } & \multicolumn{3}{c}{ Emborcação-Emb } \\
& $B_{E F}$ & $B_{E S}$ & $B_{P G}$ & $B_{E F}$ & $B_{E S}$ & $B_{P G}$ \\
& {$[\overline{M W}]$} & {$[\overline{M W}]$} & {$[\mathrm{MW}]$} & {$[\overline{M W}]$} & {$[\overline{M W}]$} & {$[\mathrm{MW}]$} \\
\hline 1 & 873,4 & 12,7 & 995,1 & 680,8 & $-175,6$ & 919,1 \\
2 & 886,8 & 45,4 & $1.119,5$ & 675,0 & $-123,0$ & $1.807,7$ \\
3 & 866,8 & 175,4 & $1.667,1$ & 617,2 & $-124,0$ & $1.033,3$ \\
4 & 882,4 & 90,7 & $1.279,1$ & 688,3 & $-149,5$ & $1.182,1$ \\
5 & 879,0 & 212,7 & $2.044,8$ & 617,8 & $-109,6$ & $1.341,8$ \\
\hline
\end{tabular}


Observando os valores de volume mínimo apresentados na Tabela 7.43, nota-se uma sensível diferença entre os valores de Emborcação e de Porto Primavera. Enquanto para Emborcação os volumes mínimos são sempre iguais aos menores valores permitidos pelo modelo para esta usina, $4.000 \mathrm{hm}^{3}$, para Porto Primavera os volumes mínimos encontrados são sempre superiores a $10.000 \mathrm{hm}^{3}$, o limite inferior de volume mínimo para este caso.

Isto mostra que o modelo de dimensionamento entende que uma usina de jusante tem mais a ganhar mantendo-se em cotas elevadas e gerando energia com produtividade maior. Dados os grandes volumes de água turbinados, qualquer redução de queda traduz-se em grandes perdas energéticas. Por outro lado, o modelo também entende que uma usina de cabeceira, cujos volumes turbinados são relativamente pequenos, deve desempenhar o papel de reguladora dos recursos hídricos e, uma vez especificado o seu volume máximo, deve possuir o menor volume mínimo possível.

Analisando as diferenças entre os volume máximos e mínimos (volumes úteis) das duas usinas, reforça-se o papel desempenhado por cada uma descrito no parágrafo anterior. A usina de Emborcação possui volumes úteis maiores para poder realizar a regularização das vazões afluentes, ao passo que Porto Primavera apresenta-se quase como usina a fio d'água. Na realidade, as vazões de Porto Primavera já encontram-se regularizadas pelas usinas de montante, restando-lhe o papel de turbinar estas vazões a cotas elevadas, sem grande variações da quantidade de água armazenada em seu reservatório.

Observando a Tabela 7.44, nota-se outra diferença relevante entre os dimensionamentos de uma usina de cabeceira e uma usina de jusante. Enquanto a inserção de Emborcação promove uma redução do benefício sistêmico de Energia Secundária, a inserção de Porto Primavera faz com que este benefício eleve-se. Tal fato pode ser justificado pelos benefícios de regularização proporcionados por Emborcação e pela quase ausência de benefícios desta natureza associados a Porto Primavera.

Como conseqüência da elevação do benefício sistêmico de Energia Secundária, a valorização deste benefício não representa um desestímulo à expansão da usina, tal como ocorria com Emborcação. Por exemplo, ao passar do teste 2 para o teste 3, e do teste 4 para o teste 5 , enquanto observam-se reduções de volume máximo para Emborcação, observam-se elevações no tamanho do reservatório de Porto Primavera. 
Resumindo, o dimensionamento de uma usina de cabeceira e de uma usina de jusante determina características bem distintas para estas usinas. Enquanto a usina de cabeceira proporciona maior regularização do sistema deve ser dimensionada para possuir o maior volume útil possível, a usina de jusante deve ser dimensionada praticamente como usina a fio d'água, evitando reduções de queda líquida com conseqüente perda de produtividade. Os testes realizados mostram que o modelo desenvolvido captou estas características de forma bem eficiente. 


\section{Capítulo VIII}

Conclusões

No presente trabalho desenvolveu-se uma metodologia flexível e automática de dimensionamento de usinas hidroelétricas. Esta metodologia foi implementada computacionalmente e aplicada a vários estudos de caso para verificar sua consistência e robustez. Posteriormente, vários testes de análise de sensibilidade foram realizados para mostrar como as hipóteses que fundamentam os estudos de dimensionamento podem alterar as dimensões ótimas da nova usina.

Para organizar o texto deste capítulo, primeiro apresentam-se comentários sobre as contribuições relativas ao Modelo de Dimensionamento. Em seguida, comentam-se as contribuições proporcionadas pela análise dos resultados fornecidos pelos estudos de caso realizados. Também são apresentadas algumas contribuições sob o ponto de vista do ensino e, finalmente, apresentam-se perspectivas para o desenvolvimento de futuros trabalhos.

\section{- O Modelo de Dimensionamento}

A partir dos resultados apresentados, pode-se concluir que o modelo de dimensionamento desenvolvido representou uma contribuição no sentido de caracterizar-se por ser automático, flexível e eficiente.

A primeira das características, o automatismo do modelo, deve ser entendida no sentido de que os valores ótimos das dimensões da usina sob dimensionamento foram sempre frutos de um processo de otimização que dispensa intervenções manuais ao longo de sua execução. Esta característica foi conseguida graças à técnica de otimização utilizada e à forma como o modelo foi desenvolvido.

A técnica de otimização evolucionária contribuiu para o automatismo do modelo, à medida que sua aplicação não requereu uma função analítica explícita. Assim, os algoritmos computacionais necessários para calcular a receita líquida 
proporcionada pela construção da nova usina hidroelétrica puderam ser aplicados de forma direta, resultando única e exclusivamente em um número (a própria receita líquida anual da usina) utilizado como aptidão do indivíduo do AG. Do mais, o próprio AG encarregou-se do processo evolutivo, produzindo indivíduos cada vez mais aptos em busca da solução ótima.

Quanto à forma de desenvolvimento do modelo de dimensionamento, destaca-se que todos os algoritmos foram concebidos e implementados especificamente para este trabalho, seguindo-se o paradigma de orientação por objetos e realizando-se as implementações em linguagem $\mathrm{C}++$. Dentre estes algoritmos, destacam-se o modelo de otimização evolucionária, o algoritmo de simulação da operação energética das usinas hidroelétricas, o mecanismo de valorização da energia gerada pelas usinas, o modelo de estimativa de custos e o modelo de fluxo de caixa. A implementação computacional destes algoritmos contribuiu para o automatismo, uma vez que todos os dados, processos e resultados puderam ser personalizados para que os diferentes modelos trabalhassem juntos, com comunicação a baixo custo computacional e com total controle sobre todos os processos. Caso fossem utilizadas ferramentas prontas, haveria dificuldades em colocá-las para trabalhar juntas, o custo computacional poderia ser proibitivo, além de poder haver prejuízos a outras características da metodologia (impossibilidade de alteração da regra de operação das usinas, por exemplo).

A segunda das características, a flexibilidade, pode ser entendida como a possibilidade de realização de estudos de dimensionamento em diferentes "condições" de operação, além da facilidade de configurar estas condições sem manipulações de código computacional, bastando que fossem alterados alguns valores dos conjuntos de dados.

Os estudos de casos apresentados no Capítulo VII demonstram claramente a flexibilidade do modelo, empregando-o para avaliar como alterações de parâmetros e suposições iniciais podem influenciar as dimensões ótimas da usina sob dimensionamento. De forma geral, os testes apresentados e seus resultados mostraram a execução do modelo de dimensionamento utilizando-se diferentes formas de valorização dos benefícios energéticos (diferentes hipóteses sobre as valorizações das Energias Firme e Secundária, além da Ponta Garantida), comparação dos efeitos de consideração dos benefícios locais e globais, adoção de regras distintas de operação do sistema hidroelétrico, consideração de diferentes conjuntos de vazão natural afluente, 
suposição da inserção da nova usina em sistemas existentes distintos, e mesmo a escolha de usinas sob dimensionamento com diferentes posições relativas dentro de suas cascatas (comparação do dimensionamento de uma usina de cabeceira e de uma usina de jusante, por exemplo).

A terceira das características citadas é a eficiência do modelo. Neste caso, tratase de uma análise comparativa entre os resultados conseguidos pelo modelo de dimensionamento e pelo modelo de Busca Exaustiva. Os testes apresentados no Capítulo VII para determinação dos parâmetros do Algoritmo Genético mostraram que mesmo uma discretização relativamente fina aplicada à Busca Exaustiva (divisão de cada variável de decisão em cinqüenta intervalos) proporcionou resultados que sempre eram suplantados pelas soluções conseguidas com o Algoritmo Genético. Ressalta-se ainda a grande diferença observada nos tempos computacionais: enquanto o tempo máximo de execução do Algoritmo Genético foi pouco inferior a cinco horas, a Busca Exaustiva sempre gastou mais de noventa horas para ser executada.

Assim, sob o ponto de vista metodológico, conclui-se que o trabalho alcançou os objetivos pretendidos com êxito, contribuindo para o desenvolvimento de uma ferramenta automática, flexível e eficiente para o dimensionamento de usinas hidroelétricas.

\section{- Resultados dos Estudos de Caso}

Na Seção 5 do Capítulo VII foram apresentados vários estudos de caso com o intuito de mostrar a consistência do modelo proposto e também para contribuir no entendimento da forma como alguns dos diversos parâmetros dos estudos de dimensionamento podem alterar as dimensões ótimas da nova usina.

Os resultados encontrados permitem que seja elaborada uma lista com várias conclusões pontuais já observadas durante os estudos:

1. O volume mínimo de uma usina de cabeceira tende quase sempre a ser o menor valor permitido para esta variável, uma vez que quanto maior o volume útil, maiores são os ganhos com a regularização das vazões afluentes e também com a energia gerada pela água armazenada durante o esvaziamento da usina ao longo do Período Crítico.

2. O ganho de regularização proporcionado pela construção de uma usina de cabeceira traduz-se em elevação da Geração Média sistêmica a uma taxa 
superior à Geração Média da própria usina, além de haver redução de Energia Secundária sistêmica.

3. Os ganhos sistêmicos de Energia Firme proporcionados pela construção de uma usina de cabeceira chegam a ser bem superiores à Energia Firme da própria usina.

4. Variações do preço médio da Energia Firme têm forte impacto sobre as dimensões do reservatório e da usina de forma geral, de modo que quanto maior é o preço atribuído à energia, maiores são os valores de volume máximo e potência instalada.

5. A ausência de efeitos de modulação da Energia Firme, de valorização da Energia Secundária e de Ponta Garantida determina usinas hidroelétricas dimensionadas com capacidades instaladas totais iguais às suas potências instaladas de base.

6. A consideração do despacho de Energia Firme em dois patamares com o preço da energia despachada na ponta superior ao preço da energia despachada fora de ponta sempre implica ganhos de receita em relação ao caso em que não há sinalizações diferenciadas de preço. No entanto, estes ganhos de receita só conseguem determinar a expansão da casa de força em situações extremas, em que as diferenças de preço são bem significativas.

7. A valorização do benefício sistêmico de Energia Secundária quando uma usina de cabeceira está sendo dimensionada acaba traduzindo-se inicialmente em uma perda de receita, uma vez que esta usina reduz este benefício energético. No entanto, quando análises incrementais são realizadas para determinar a viabilidade de expansão da casa de força, aumentos de potência instalada da usina aumentam sua Energia Secundária, o que acaba justificando a expansão da casa de força pela redução da perda inicial de receita.

8. A adoção simultânea de modulação de Energia Firme e valorização de Energia Secundária proporciona expansões da casa de força além da potência de base. A adição da valorização da Ponta Garantida proporciona expansões ainda maiores.

9. A adoção de Benefícios Locais determina a construção de uma usina hidroelétrica significativamente menor que a determinada pela adoção dos Benefícios Globais. Além de receitas proporcionadas relativamente 
pequenas, observam-se também ganhos energéticos sistêmicos bem menores no caso dos Benefícios Locais, caracterizando-se assim, de certa forma, uma exploração ineficiente dos recursos naturais.

10. Alterações na regra de operação utilizada nos estudos de simulação mostram que o melhor aproveitamento dos recursos naturais realizado pela Regra Baseada em Otimização, Roo, tem sensíveis implicações sobre as dimensões ótimas da nova usina. Nos casos apresentados, a Roo sempre determinou reservatórios maiores que a Regra Paralela, Par, encontrando-se, inclusive, diferenças da ordem de $1.000 \mathrm{hm}^{3}$. Os custos maiores associados às usinas dimensionadas pela Roo (maiores reservatórios e casas de força) foram compensados pelos também maiores benefícios energéticos sistêmicos, de forma que as Receitas Líquidas Anuais obtidas com esta regra foram sempre mais elevadas do que as determinadas pela Regra Paralela.

11. O conjunto de vazões afluentes utilizado nos estudos determina usinas hidroelétricas sensivelmente diferentes, tanto no que se refere ao tamanho do reservatório, quanto no que se refere à capacidade instalada da usina e aos próprios benefícios energéticos.

12. A alteração do Sistema Completo utilizado nos estudos também determina dimensões bem distintas à nova usina, em parte pela alteração do Período Crítico e, conseqüentemente, pela alteração das vazões afluentes que determinam os benefícios energéticos e a potência instalada de base.

13. Finalmente, constata-se que o modelo de dimensionamento entende que uma usina de jusante deve se comportar praticamente como usina a fio d'água, possuindo volume mínimo bem próximo ao volume máximo. Quanto aos ganhos energéticos, a construção de uma usina de jusante determina elevações sistêmicas de Energias Firme e Secundária (para a usina de montante havia redução de Energia Secundária), além de Ponta Garantida.

De forma geral, baseando-se nas conclusões pontuais listadas, conclui-se que os impactos provocados pelas análises de sensibilidade devem contribuir para alertar os órgãos responsáveis pelo planejamento e pela regulamentação do Setor Elétrico em diversos sentidos.

No que se refere às questões de planejamento, destaca-se que a ausência de um planejador centralizado eficiente pode determinar a realização de estudos com sistemas 
de referência equivocados, utilização de séries de vazões afluentes não prováveis (ou não representativas) ou mesmo sinalizações de preços de longo prazo que não possam ser concretizadas. Como estes parâmetros influenciam de forma sensível as dimensões dos novos aproveitamentos, suas sinalizações inadequadas podem promover a construção de usinas cujos benefícios esperados jamais sejam alcançados.

Por outro lado, no que se refere às questões de regulamentação, destaca-se a importância de haver regras específicas para a apropriação dos benefícios energéticos sistêmicos pelo proprietário de um novo empreendimento, para remuneração da Ponta Garantida e da Energia Secundária, ou mesmo para possíveis determinações de adoção de políticas de operação diferenciadas para os reservatórios. Estas regras, conforme observado nas conclusões pontuais, provocam sinalizações para os modelos de dimensionamento que alteram de forma sensível as dimensões dos novos empreendimentos.

Assim, sob o ponto de vista dos estudos realizados, conclui-se que as diferentes condições de realização dos testes contribuíram para proporcionar uma visão relativamente detalhada das implicações dos parâmetros do modelo sobre as próprias características da usina sob dimensionamento. Ressalta-se que a análise dos estudos possibilitou a identificação de algumas funções importantes dos órgãos de planejamento e de regulamentação, no sentido de implementarem regras claras sobre os parâmetros aos quais as dimensões ótimas são sensíveis.

Ressalta-se ainda que a utilização dos Algoritmos Genéticos para sistematizar a problemática de dimensionamento foi um dos aspectos mais relevantes da tese, o que contribuiu para a varredura organizada de uma ampla gama de situações de dimensionamento, com análises de sensibilidade não disponíveis na literatura.

\section{- Contribuições Didáticas}

A forma como o trabalho foi organizado, enfatizando conceitos básicos referentes à modelagem das usinas hidroelétricas e à operação de sistemas hidrotérmicos de potência, inclusive com exemplos numéricos, pode ser entendida como uma contribuição adicional, à medida que alguns capítulos da tese podem ser utilizados como referência bibliográfica para cursos de graduação e pós-graduação na área de Planejamento da Operação de Sistemas de Geração de Energia. 


\section{- Desenvolvimentos Futuros}

Os desenvolvimentos futuros listados nesta seção podem ser vistos como aprimoramentos a serem incorporados à metodologia desenvolvida e à ferramenta computacional implementada neste trabalho.

Sob o ponto de vista computacional, o software desenvolvido pode se tornar bem mais amigável que em seu estado atual através da implementação de uma interface gráfica para o modelo. Esta interface deve ser capaz de gerenciar um banco de dados com todas as informações necessárias aos estudos, bem como promover $\mathrm{o}$ acompanhamento dos processos de execução e conter ainda ferramentas para análise de resultados.

Sob o ponto de vista metodológico, há basicamente quatro aprimoramentos iniciais que poderiam ser incorporados ao modelo:

- Uma evolução natural do modelo existente é sua aplicação ao dimensionamento simultâneo de mais de uma usina hidroelétrica. Alterações de modelagem seriam realizadas, possibilitando que seja dado tratamento integrado ao dimensionamento de várias usinas, de forma que o modelo possa automaticamente determinar a melhor divisão de quedas de um rio ou mesmo de uma cascata. Esta abordagem teria basicamente dois grandes obstáculos a serem suplantados: (i) seriam necessárias inovações de modelagem para que os indivíduos do Algoritmo Genético passassem a representar, além das características das usinas, a composição de cada divisão de quedas ou cascata; (ii) a eficiência numérica do modelo teria que ser buscada de forma exaustiva, de forma que os tempos computacionais não o inviabilizassem, já que o problema passaria a ser combinatório, não-linear e sem uma função analítica explícita.

- Um dos resultados marcantes que pôde ser visualizado a partir das análises de sensibilidade foi a forte dependência das dimensões ótimas da usina sob dimensionamento em relação aos conjuntos de vazões utilizados. Esta dependência poderia ser melhor tratada se fosse incorporada à atual metodologia alguma consideração probabilística ao conjunto de vazões. 
- Um dos aspectos que tem marcado a implementação de novos projetos hidroelétricos é a questão do licenciamento ambiental. Assim, seria interessante se a ferramenta de dimensionamento pudesse tratar as questões ambientais de alguma forma, fornecendo ao final do processamento um conjunto de soluções eficientes, representativas de um compromisso entre mínima relação custo/benefício e mínimo impacto ambiental. Ressalta-se que os Algoritmos Genéticos têm sido utilizados em otimização multi-objetivo para gerar o próprio conjunto de soluções eficientes.

- O modelo de custos utilizado foi relativamente simples devido à ausência de dados de grandes aproveitamentos. Melhorias na modelagem utilizada, principalmente pelo estudo de formas precisas de considerar os gastos com provisão da casa de força, contribuiriam para a efetiva utilização da metodologia proposta em casos práticos. 


\section{Anexos}



Anexo A

Dados de Algumas

Usinas Hidroelétricas 



\section{Emborcação}

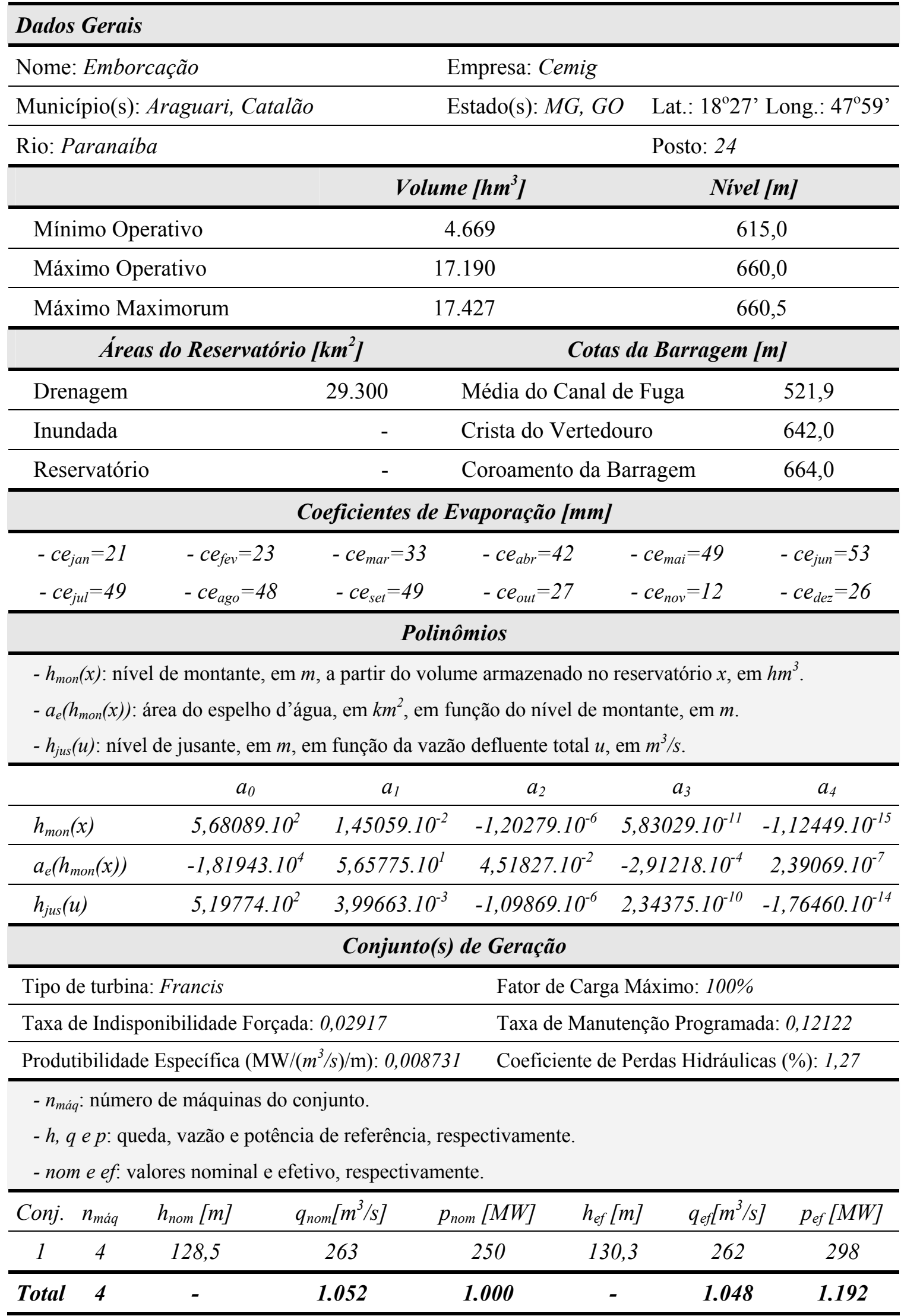




\section{Itumbiara}

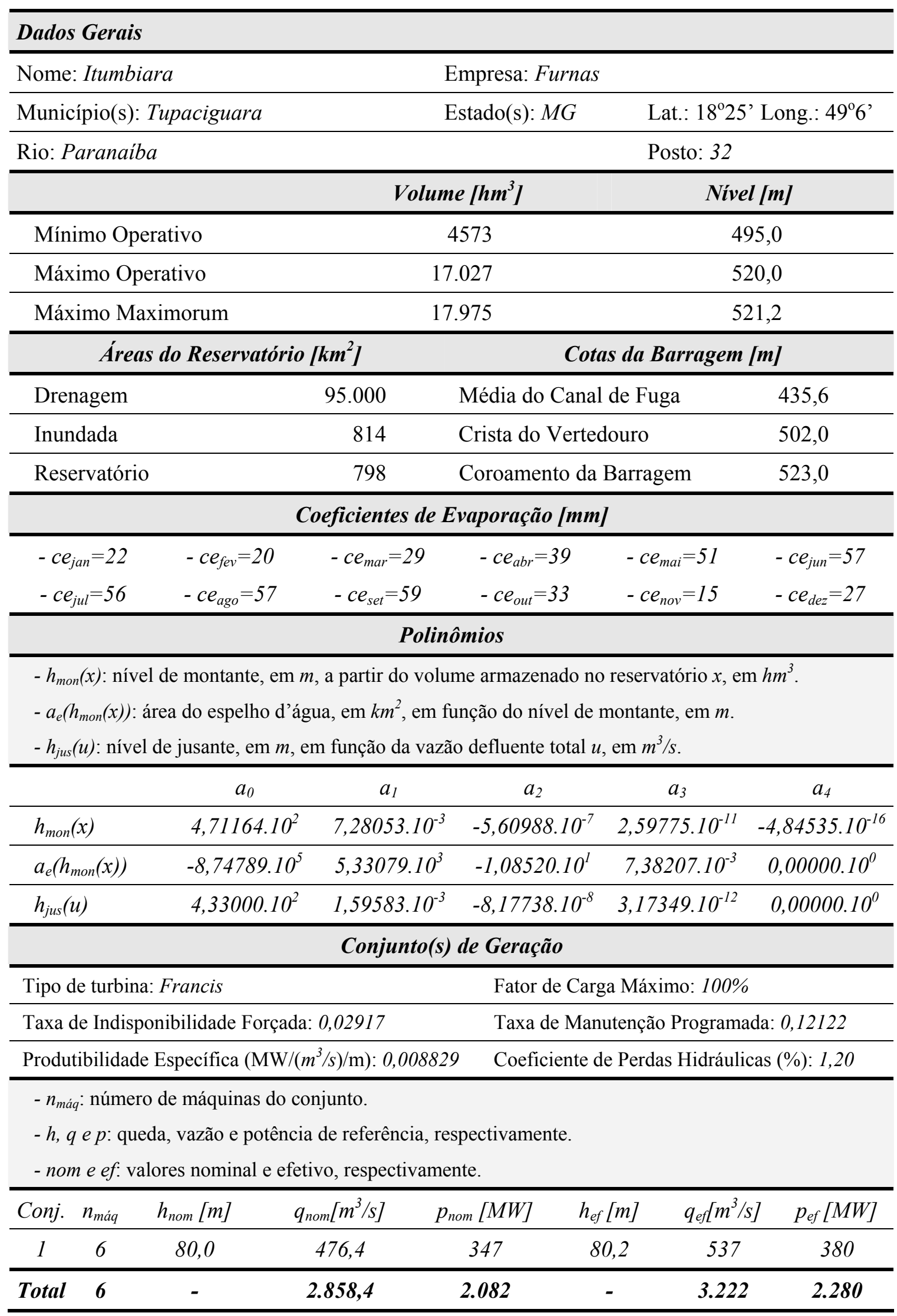




\section{São Simão}

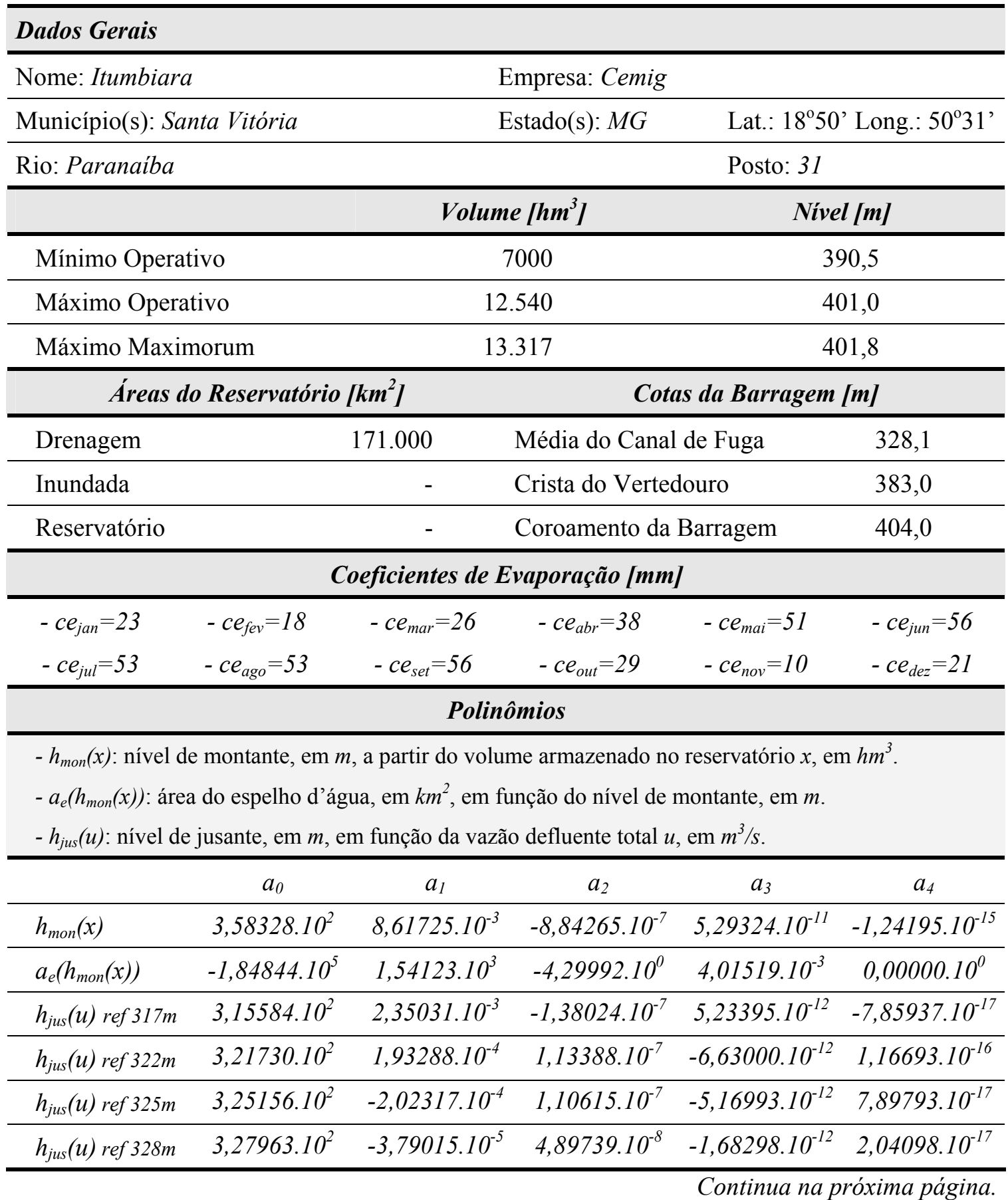




\section{Conjunto(s) de Geração}

\begin{tabular}{|c|c|c|c|c|c|c|c|}
\hline \multicolumn{4}{|c|}{ Tipo de turbina: Francis } & \multicolumn{4}{|c|}{ Fator de Carga Máximo: 100\% } \\
\hline \multicolumn{4}{|c|}{ Taxa de Indisponibilidade Forçada: 0,02917 } & & \multicolumn{3}{|c|}{ Taxa de Manutenção Programada: 0,12122 } \\
\hline \multicolumn{4}{|c|}{ Produtibilidade Específica $\left(\mathrm{MW} /\left(\mathrm{m}^{3} / \mathrm{s}\right) / \mathrm{m}\right): 0,009025$} & \multicolumn{4}{|c|}{ Coeficiente de Perdas Hidráulicas (\%): 0,62 } \\
\hline \multicolumn{8}{|c|}{$\begin{array}{l}\text { - } n_{\text {máq }} \text { número de máquinas do conjunto. } \\
\text { - } h \text {, q e p: queda, vazão e potência de referência, respectivamente. } \\
\text { - nom e ef: valores nominal e efetivo, respectivamente. }\end{array}$} \\
\hline Conj. & $n_{\text {máq }}$ & $h_{\text {nom }}[\mathrm{m}]$ & $q_{\text {nom }}\left[\mathrm{m}^{3} / \mathrm{s}\right]$ & $p_{\text {nom }}[M W]$ & $h_{e f}[m]$ & $q_{e f}\left[\mathrm{~m}^{3} / \mathrm{s}\right]$ & $p_{e f}[M W]$ \\
\hline 1 & 6 & 72,9 & 420 & 268 & 70,9 & 437 & 280 \\
\hline Total & 6 & - & 2.520 & 1608 & - & 2.622 & 1.680 \\
\hline
\end{tabular}




\section{Porto Primavera}

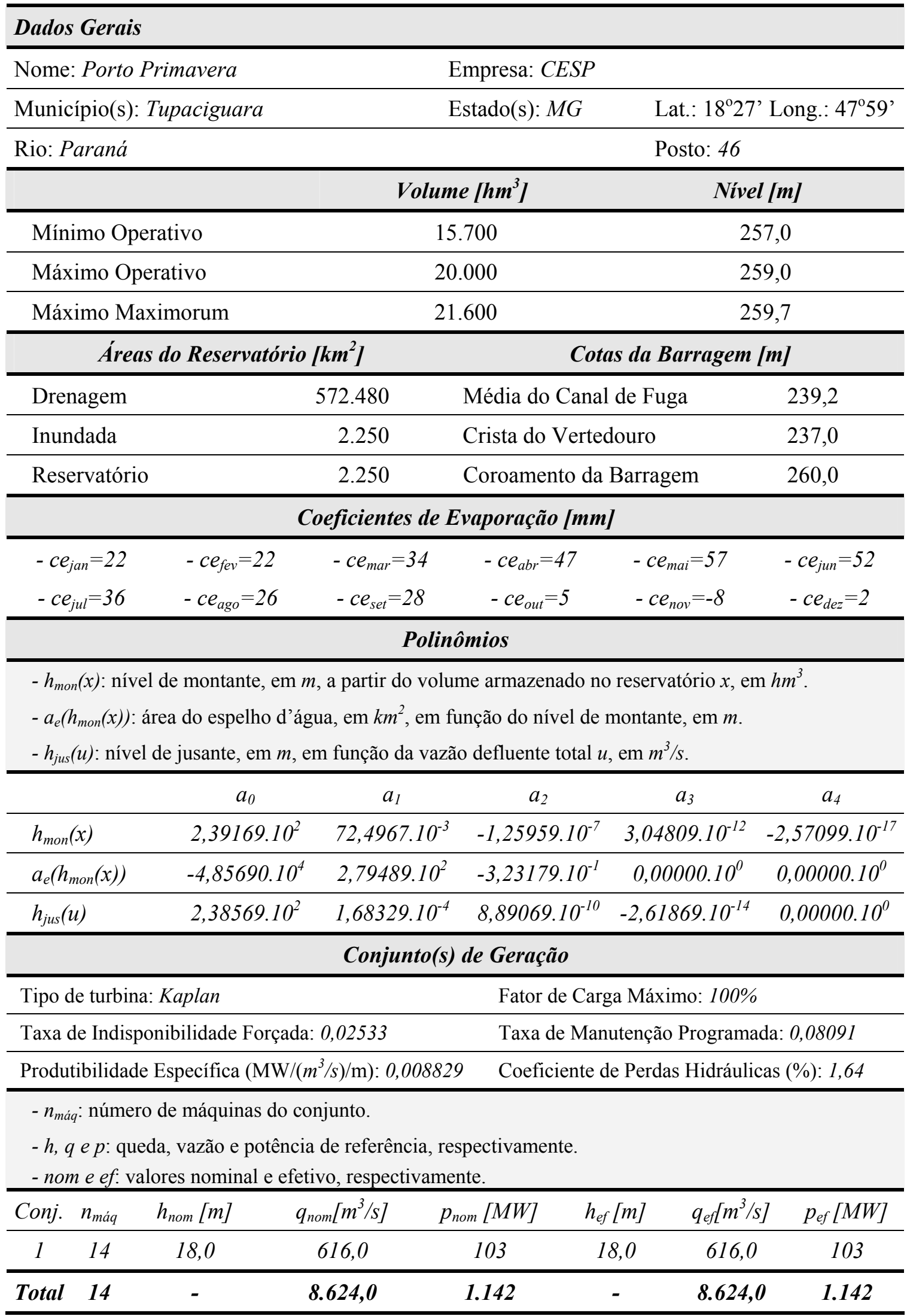



Anexo B

Ajuste de Curvas 



\section{Introdução}

A técnica de ajuste de curvas aqui apresentada pode ser dividida em duas partes: na primeira, é necessário que sejam encontrados pontos que melhor caracterizem a relação entre os dados, os centróides ou centros de agrupamento; na segunda, cria-se uma base de conhecimento Fuzzy que utiliza os centróides para determinar a curva ajustada.

A apresentação da metodologia será feita através de um exemplo, onde pretendese ajustar uma função sobre a nuvem de 660 pontos mostrada na Figura A.1.

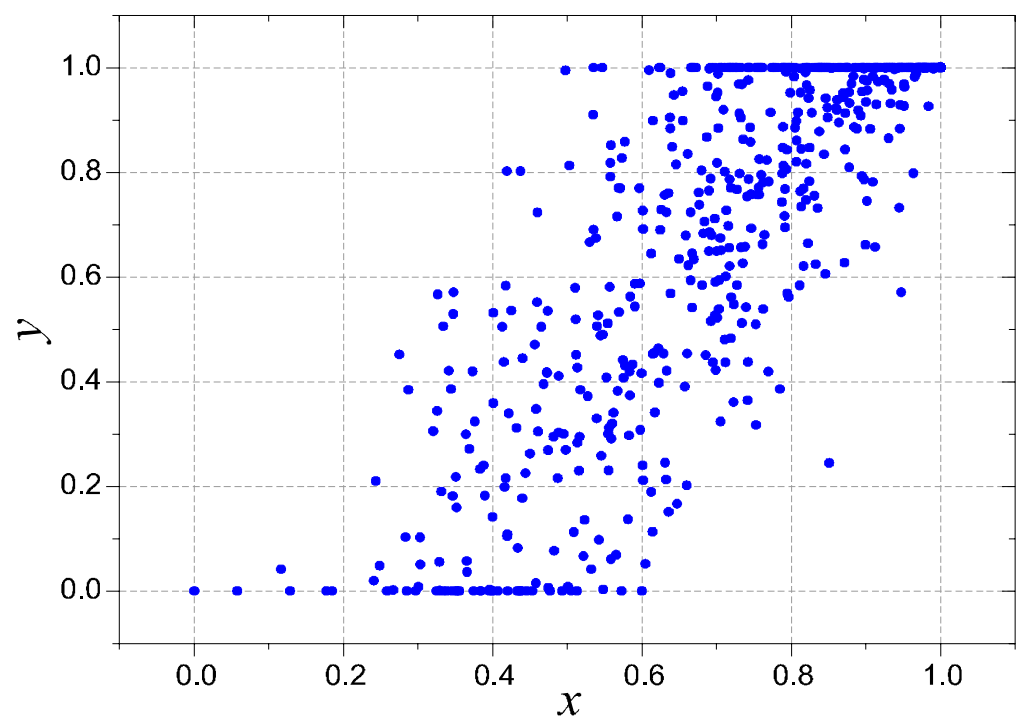

Figura A.1 - Nuvem de pontos do exemplo.

Conforme já mencionado, inicialmente deve-se determinar os centróides, ou centros de agrupamentos.

\section{Determinação dos centróides}

Dado um conjunto $X$ de dados ou objetos, o problema de agrupamento consiste, como o próprio nome sugere, em identificar subconjuntos naturais em que o conjunto principal pode ser dividido. Como os dados são normalmente números, eles não possuem nenhuma identificação que permita classificá-los diretamente em um subconjunto; é necessário que as características a eles associadas sejam extraídas de alguma maneira.

No caso do ajuste de curvas, uma técnica eficiente para determinar os centróides é o Método da Montanha [119, 120]. Este método pode ser aplicado ao ajuste de relações entre pontos de espaços de quaisquer dimensões, embora no exemplo considere-se apenas o $R^{2}$.

O primeiro passo consiste na discretização do espaço $R^{2}$ a partir da criação de 
uma grade sobre o conjunto de dados. A interseção de duas linhas de grade é chamada de nó e é denotada por $N_{i j}$, para a interseção da linha vertical $i$ com a linha horizontal $j$. O conjunto dos pontos $N_{i j}$ forma o conjunto de candidatos a centróides e quanto mais fina for a grade, melhor será a aproximação do centróide. Para a execução do exemplo adotou-se uma grade de 100×100 com linhas eqüidistantes; a eqüidistância não é uma obrigatoriedade do Método da Montanha e, dependendo do conjunto de dados, pode-se adotar um mapeamento diferenciado em determinadas regiões do plano $R^{2}$.

Depois de construída a grade, deve-se construir a função montanha, denotada por $M$ e definida sobre cada nó $N_{i j}=\left(n_{x i}, n_{y j}\right)$. Esta construção é feita de forma que cada ponto $p_{k}=\left(x_{k}, y_{k}\right), k=1, \ldots, n$, da nuvem de pontos adicione um valor à função montanha no nó $N_{i j}, M\left(N_{i j}\right)$, fazendo com que esta quantidade adicionada seja maior a medida que o ponto se localizar mais próximo do nó. Sendo $d\left(p_{k}, N_{i j}\right)$ o quadrado da distância euclidiana do ponto $p_{k}$ ao nó $N_{i j}$ e $\alpha$ uma constante positiva, a função montanha pode ser definida da seguinte forma:

$$
\begin{aligned}
& M\left(N_{i j}\right)=\sum_{k=1}^{n} e^{-\alpha \cdot d\left(p_{k}, N_{i j}\right)} \\
& d\left(p_{k}, N_{i j}\right)=\left(n_{x i}-x_{k}\right)^{2}+\left(n_{y j}-y_{k}\right)^{2}
\end{aligned}
$$

Como $d\left(p_{k}, N_{i j}\right)$ e $\alpha$ são números positivos, a função exponencial do somatório sempre estará elevada a um número negativo. A forma de uma função exponencial com expoente sempre negativo é a função em forma de sino da Figura A.2, onde são mostradas várias curvas, com diferentes valores de $\alpha$.

Pela Equação A.1 e pela Figura A.2 pode-se observar que o máximo valor adicionado à função montanha é 1 e este ocorre quando o ponto $p_{k}$ coincide com o nó $N_{i j}$ (neste caso a distância é nula!). Por outro lado, pontos distantes do nó $N_{i j}$ adicionam um valor muito pequeno à $M$ e quanto maior o valor de $\alpha$, menor será esta quantidade adicionada. Assim, se a distância de um ponto $p_{k}$ a um nó $N_{i j}$ for, por exemplo, 1, a quantidade adicionada à $M$ será 0,007 se $\alpha=5$ ou será 0,607 se $\alpha=0,5$. Quanto maior o valor de $\alpha$, menos “importantes" serão os pontos mais distantes ao nó $N_{i j}$; o que permite denotar a constante $\alpha$ como uma constante de seletividade. 


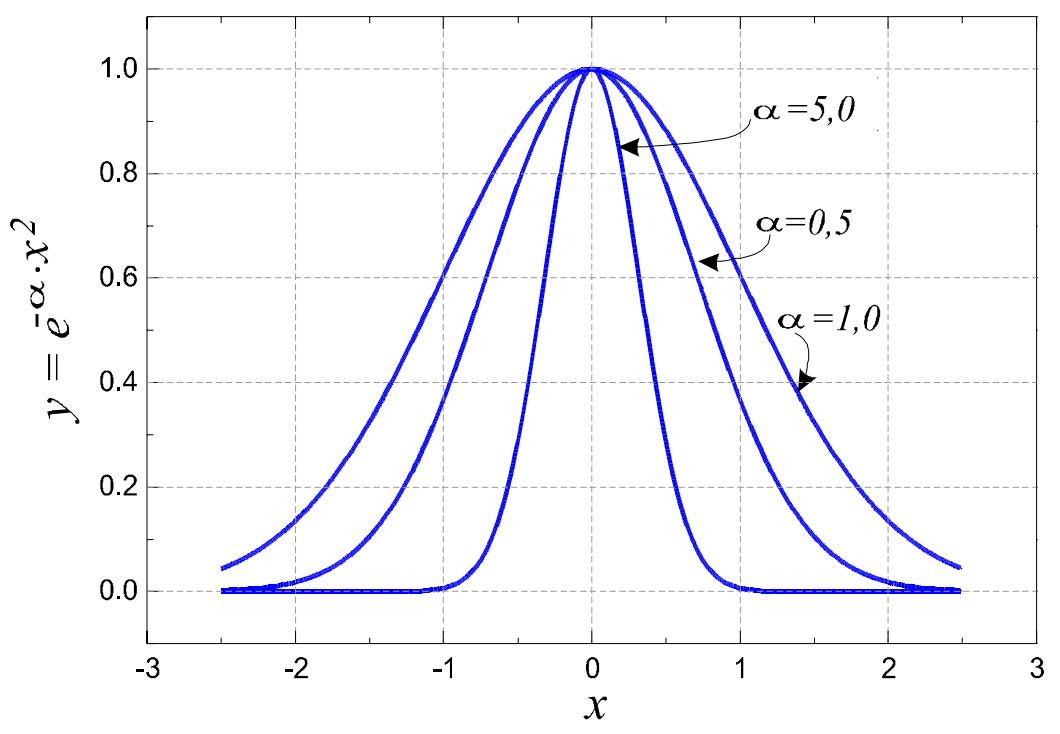

Figura A.2 - Função em forma de sino.

A função montanha pode ser interpretada como uma função densidade, possuindo valores maiores para os nós que encontram-se envolvidos por uma grande quantidade de pontos. Este comportamento pode ser observado na Figura A.3, onde tem-se a função montanha para a nuvem de pontos da Figura A.1, adotando-se $\alpha=5$.

Intuitivamente, o nó $N^{*}$ para o qual a função montanha atinge seu valor máximo, $M^{*}$, é o ponto que melhor identifica a relação entre as variáveis $x$ e $y$, e este será o primeiro centróide. Pela Figura A.3 tem-se:

$$
N^{*}=(0,87 ; 0,95) \text { e } M^{*}=204,66
$$

Devido ao próprio modo de construção da função, um pico normalmente estará cercado por nós que também possuem valores elevados da função montanha. Para encontrar o próximo centróide deve-se primeiro eliminar o efeito do centróide já determinado e dos nós de sua vizinhança. Isso é feito subtraindo-se uma quantidade da função montanha de cada nó, de forma que quanto mais próximo o nó estiver do nó $N^{*}$, maior será a quantidade subtraída. Isso é conseguido pela Equação A.3, onde $\beta$ é uma constante positiva. Forma-se assim uma função montanha revisada, definida sobre todos os nós:

$$
\hat{M}\left(N_{i j}\right)=M\left(N_{i j}\right)-M^{*} \cdot \sum_{k=1}^{n} e^{-\beta \cdot d\left(N^{*}, N_{i j}\right)}
$$




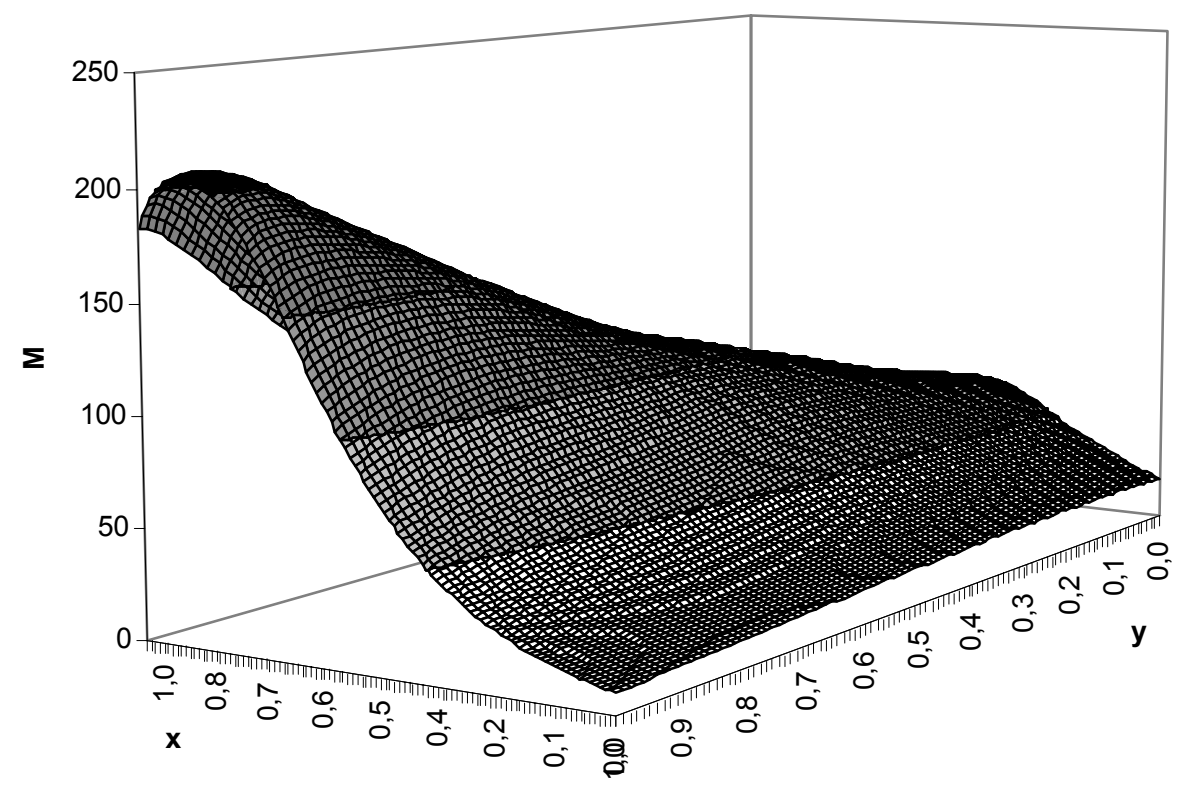

Figura A.3 - Função montanha para a nuvem de pontos da Figura A.1.

A função montanha revisada para a nuvem de pontos da Figura A.1 é mostrada na Figura A.4, adotando-se $\beta=3$. Note que o nó correspondente ao pico da montanha da Figura A.3 corresponde a um zero na função revisada, e que sua vizinhança agora é um vale.

A Figura A.5 também apresenta a função montanha revisada, porém com $\beta=8$. Note que a constante $\beta$ tem um efeito semelhante à constante $\alpha$ da função montanha. Neste caso, quanto maior o valor de $\beta$, menor será a vizinhança de nós a ser afetada pela destruição da montanha.

Encontrando-se o nó correspondente ao pico desta nova função (considera-se a montanha revisada da Figura A.4) tem-se o segundo centróide. Repetindo o processo até que o pico da função revisada atinja um valor inferior a uma constante preestabelecida, tem-se um conjunto de $m$ centróides. No caso do exemplo, os centróides são mostrados na Tabela A.1. É importante observar que o valor de $m$ é determinado automaticamente pelo método. 


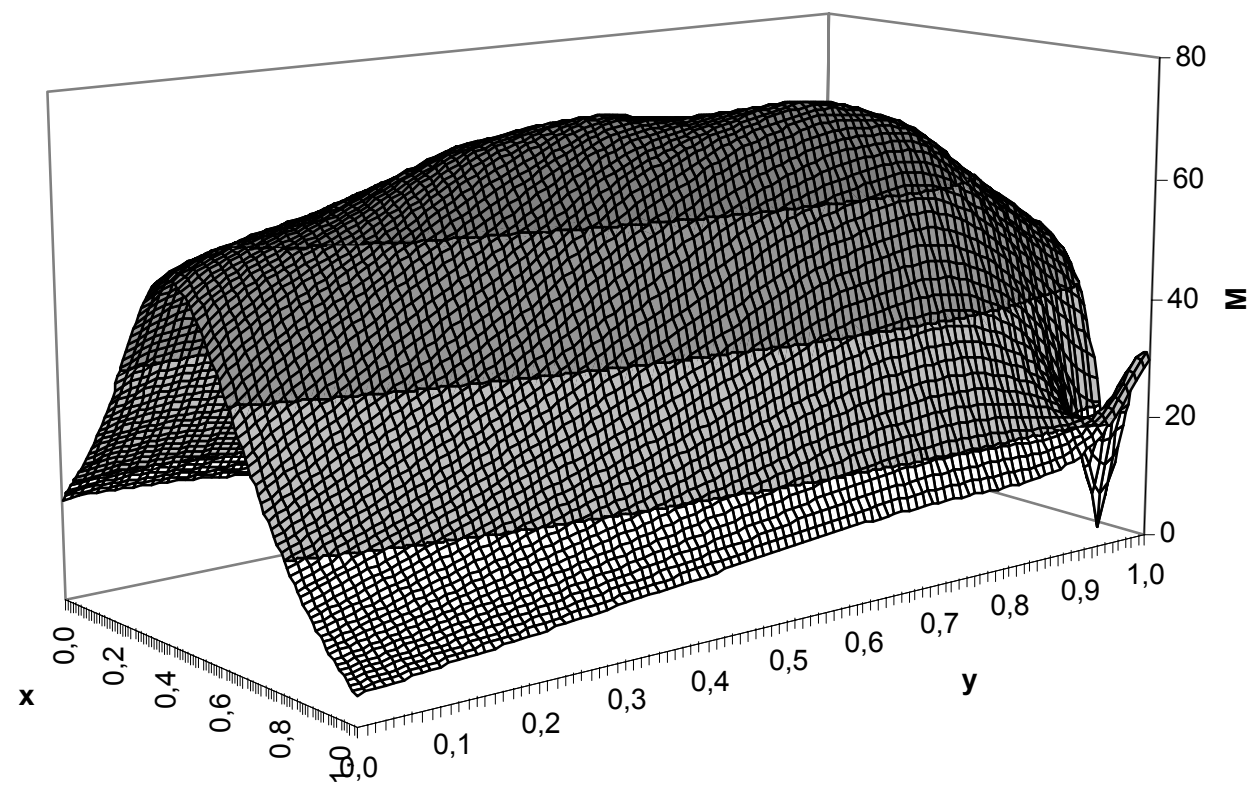

Figura A.4 - Função montanha revisada para a nuvem de pontos da Figura A.1 - $\beta=3$.

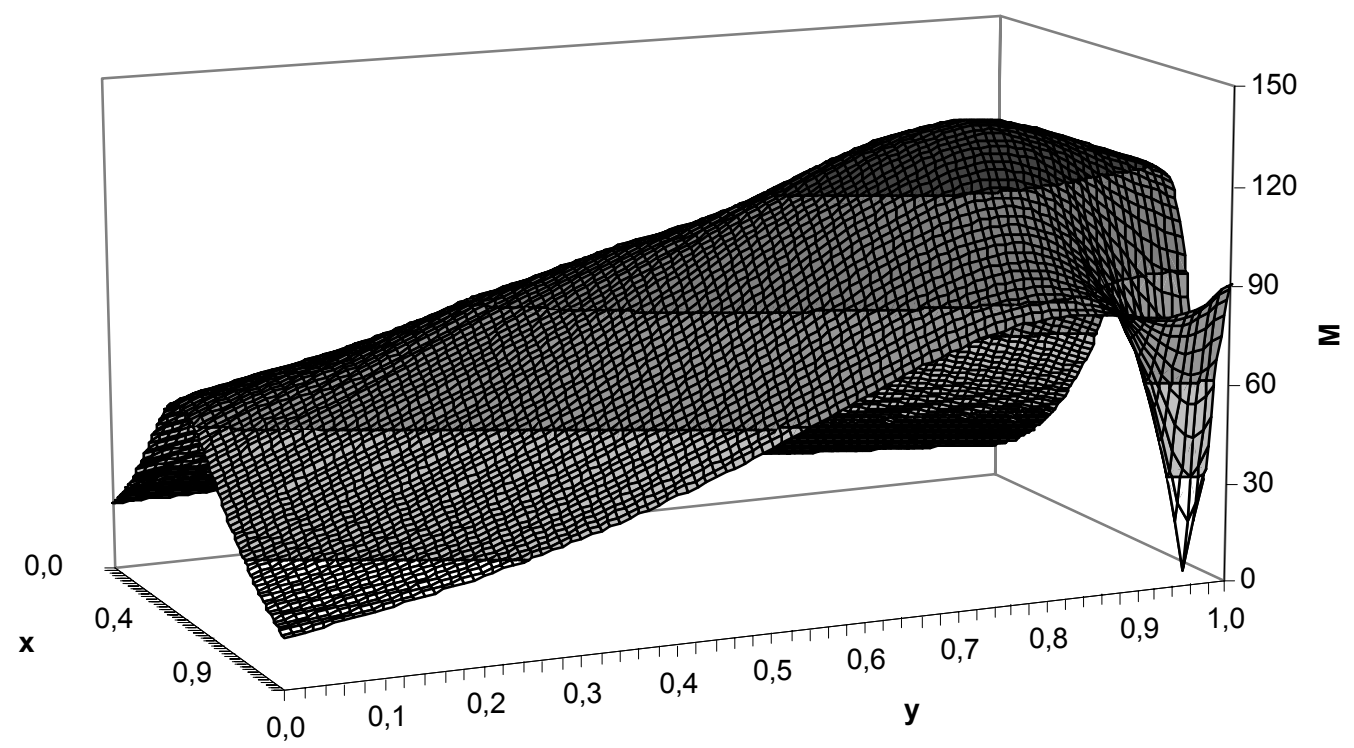

Figura A.5 - Função montanha revisada para a nuvem de pontos da Figura A.1 - $\beta=8$. 
Tabela A.1 - Centróides determinados pelo método da montanha.

\begin{tabular}{ccc}
\hline$i$ & $x_{i}^{*}$ & $y_{i}^{*}$ \\
\hline 1 & 0,87 & 0,95 \\
\hline 2 & 0,56 & 0,45 \\
\hline 3 & 0,72 & 0,81 \\
\hline 4 & 0,38 & 0,02 \\
\hline 5 & 0,00 & 0,00 \\
\hline
\end{tabular}

Existe outra característica deste método de agrupamento que é muito interessante: a interatividade. Se a curva a ser ajustada for obrigada a passar por determinados pontos, o usuário pode fazer com que estes pontos façam parte conjunto de centróides. Este ajuste forçado deve ser feito durante o processo iterativo, de modo que as influências destes pontos possam ser retratadas na função montanha.

A partir do conjunto de centróides constrói-se uma base de conhecimento Fuzzy, tal como mostrado a seguir.

\section{Base de Conhecimento Fuzzy}

A Base de Conhecimento Fuzzy é constituída por um conjunto de regras antecedenteconseqüente que relaciona os elementos de dois espaços $U$ e $V$, de forma a estabelecer a seguinte relação entre suas variáveis [91]:

\section{IF $U$ está próximo de $x^{*}$ ENTÃO $V$ está próximo de $y^{*}$}

na qual $x^{*}$ e $y^{*}$ são elementos que caracterizam os espaços $U$ e $V$.

Dada uma entrada $x$, a saída $y$ pode ser determinada através de um método simples de raciocínio difuso:

$$
y=\frac{\sum_{i=1}^{m} \tau_{i} \cdot y_{i}^{*}}{\sum_{i=1}^{m} \tau_{i}}
$$

e:

$$
\tau_{i}=\exp \left(-\rho \cdot\left(\frac{x-x_{i}^{*}}{\sigma_{i}}\right)^{2}\right) i=1, \ldots, m
$$


sendo:

- $\quad x_{i}^{*}$ a abcissa do $i$-ézimo ponto que caracteriza a relação entre $U$ e $V$;

- $y_{i}^{*}$ a ordenada correspondente a $x_{i}^{*}$;

- $\quad m$ o número de pontos característicos;

- $\rho$ uma constante positiva;

- $x$ a abcissa para a qual deseja-se determinar $y$;

- $\sigma_{\mathrm{i}} \mathrm{o}$ desvio padrão, estimado por:

$$
\sigma_{i}=\sqrt{\frac{1}{2 \cdot \beta}}
$$

Analisando a Equação A.5, constata-se que as funções $\tau_{i}$ são funções de pertinência, cujos valores medem o grau de pertinência da variável $x$ ao centróide cuja

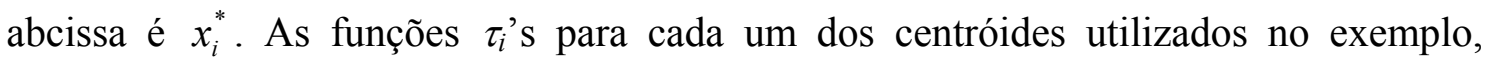
Tabela A.3, são mostradas na Figura A.6.

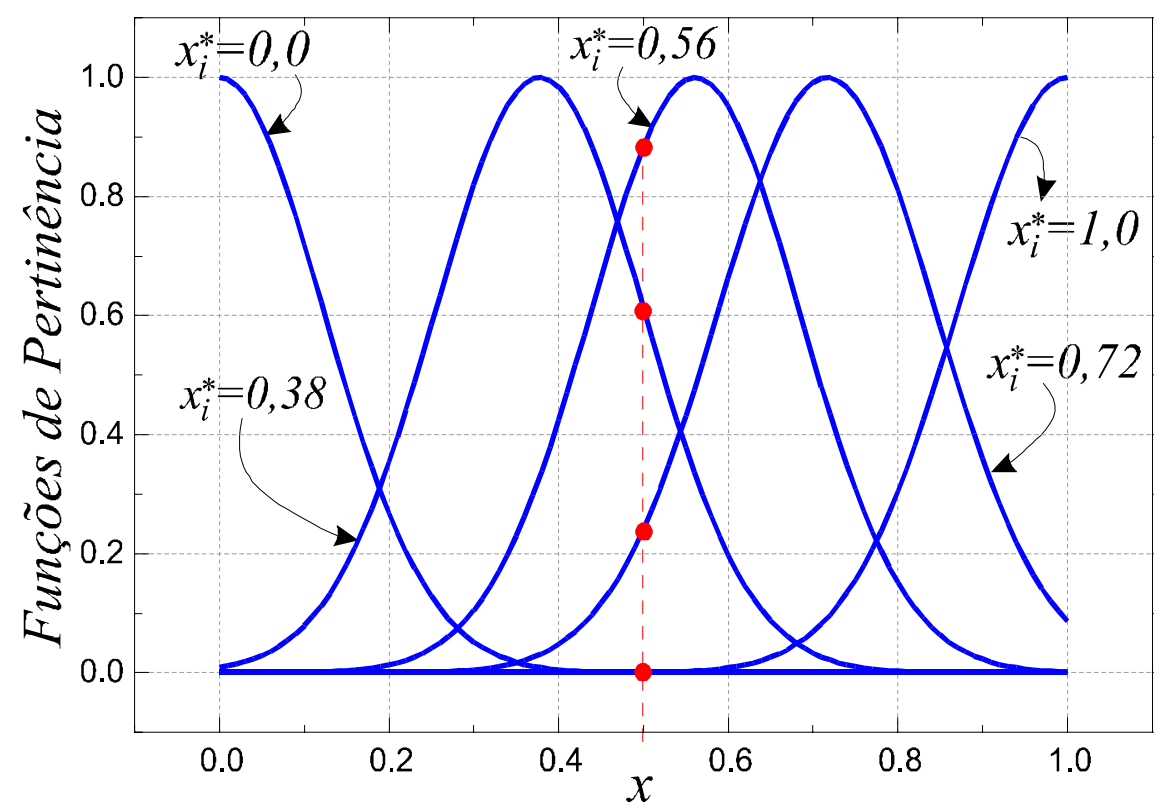

Figura A.6 - Funções de pertinência representadas por $\tau_{\mathrm{i}}$.

Dado um valor qualquer de $x, x=0,5$, por exemplo. A função $\tau_{i}$ deve ser calculada para cada um dos centróides; os valores encontrados para $\rho=5$ são mostrados na Tabela A.2. Por esta tabela observa-se que os valores de $\tau_{i}$ são maiores a medida que $x$ está próximo de $x_{i}^{*}$. 
Tabela A.2 - Valores das funções $\tau_{\mathrm{i}}$ para $x=0,5$.

\begin{tabular}{ccc}
\hline$i$ & $x_{i}^{*}$ & $\tau_{i}$ \\
\hline 1 & 0,87 & 0,001 \\
\hline 2 & 0,56 & 0,883 \\
\hline 3 & 0,72 & 0,241 \\
\hline 4 & 0,38 & 0,614 \\
\hline 5 & 0,00 & 0,000 \\
\hline
\end{tabular}

Voltando à Equação A.4 e observando os valores da Tabela A.2, nota-se que os valores da função de pertinência ponderam o quanto o valor $y_{i}^{*}$ irá influenciar na determinação do valor de $y$. Quanto mais próximo $x$ estiver de $x_{i}^{*}$, maior será a influência de $y_{i}^{*}$ sobre y. Daí a idéia de centros de agrupamento!

É interessante notar ainda que $x$ não pertence a nenhum grupo, mas sim sofre influência de todos. Conforme já mencionado no parágrafo anterior, a influência dependerá da “distância” entre $x$ e $x_{i}^{*}$.

Os centróides determinados pelo método da montanha são estimadores iniciais para os pontos que irão formar a Base de Conhecimento Fuzzy. Aplicando-se uma técnica de aprendizagem - algoritmo de retro-propagação - ao conjunto de centróides e às estimativas do desvio padrão, obtém-se os pontos que irão de fato construir a regra, mostrados na Tabela A.3.

Tabela A.3 - Conjunto de pontos característicos obtido para a nuvem de pontos do exemplo.

\begin{tabular}{cccc}
\hline$i$ & $x_{i}^{*}$ & $y_{i}^{*}$ & $\sigma_{i}$ \\
\hline 1 & 1,00 & 1,00 & 0,41 \\
\hline 2 & 0,56 & 0,45 & 0,39 \\
\hline 3 & 0,72 & 0,81 & 0,40 \\
\hline 4 & 0,38 & 0,02 & 0,39 \\
\hline 5 & 0.00 & 0.00 & 0,39 \\
\hline
\end{tabular}

Para $\alpha=5, \beta=3$ e $\rho=10$, a curva ajustada fica igual à mostrada na Figura A.7, onde também são indicados os centróides. 


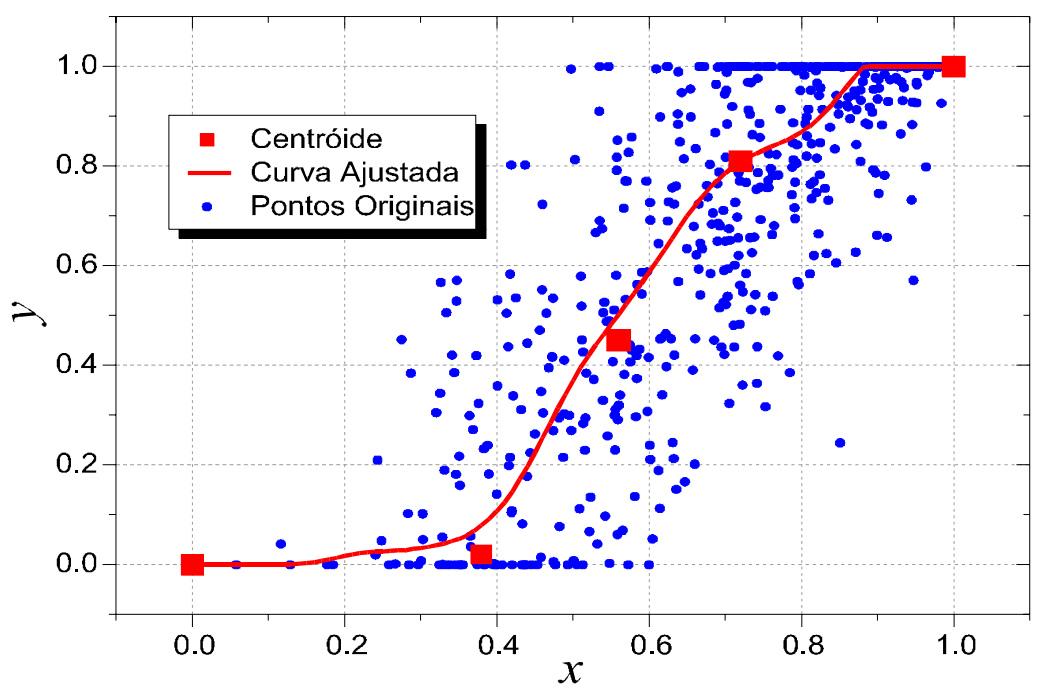

Figura A.7 - Curva ajustada para os pontos do exemplo. 

Anexo C

Busca Exaustiva 



\section{Introdução}

O processo de Busca Exaustiva resume-se a uma exploração uniforme do conjunto de possíveis valores das variáveis de entrada do modelo, calculando-se, a cada iteração, o valor da função objetivo. O maior valor da função objetivo encontrado durante todo o processo de busca, bem como os valores das variáveis que o originaram são armazenados, para que ao final do processo eles possam ser apresentados como solução ótima do problema.

O algoritmo deste método de busca pode ser resumido pela seqüência de passos mostrada abaixo. Na Figura A.8 tem-se uma ilustração da busca exaustiva.

\section{- Passo inicial:}

- Define-se o valor ótimo da função objetivo, $f^{*}$, e o conjunto de valores ótimos das variáveis, $x^{*}$.

- Define-se o número de variáveis, $n_{v a r}$.

- Para cada variável $x_{i}, 1 \leq i \leq n_{\text {var }}$, faz-se:

- Definem-se os seus valores mínimo e máximo, $\left[\min _{i}, \max _{i}\right]$.

- Define-se o número de pontos nos quais ela será avaliada, $n_{i}$.

- Define-se o comprimento do passo de cada variável, $p_{i}$, da seguinte forma:

$$
p_{i}=\frac{\max _{i}-\min _{i}}{n_{i}-1}
$$

- Atribui-se o valor inicial à variável: $x_{i}=\min _{i}$.

- Define-se o contador do número de iterações, $k=0$.

- Define-se o número máximo de iterações, $k_{\text {máx }}$ :

$$
k_{\text {max }}=\prod_{i=1}^{n_{\text {var }}} n_{i}
$$

\section{- Laço principal:}

- Enquanto $k<k_{\text {máx }}$, faz-se:

- Inicia-se a variável ativa $j=1$;

- Enquanto as variáveis não estiverem ajustadas:

1. Faz-se $x_{j}=x_{j}+p_{j}$;

2. Se $x_{j}>\max _{j}$ :

$$
\text { Faz-se: } x_{j}=\min _{j} \text { e } j=j+1 \text {; }
$$




\section{Retorna-se ao item 1.}

3. Caso contrário, consideram-se as variáveis ajustadas.

- Avalia-se a função objetivo $f\left(x_{1}, x_{2}, \ldots, x_{\text {nvar }}\right)=f(x)$.

- $\quad$ Se $k=1$ ou se $f(x)>f\left(x^{*}\right)$ :

Armazena-se o valor de $f(x)$ e de $x$ como solução ótima:

$$
f^{*}(x)=f(x) \text { e } x^{*}=x
$$

- Terminado o laço:

- O ótimo do problema corresponde a $f^{*}$ e $x^{*} \rightarrow$ FIM.

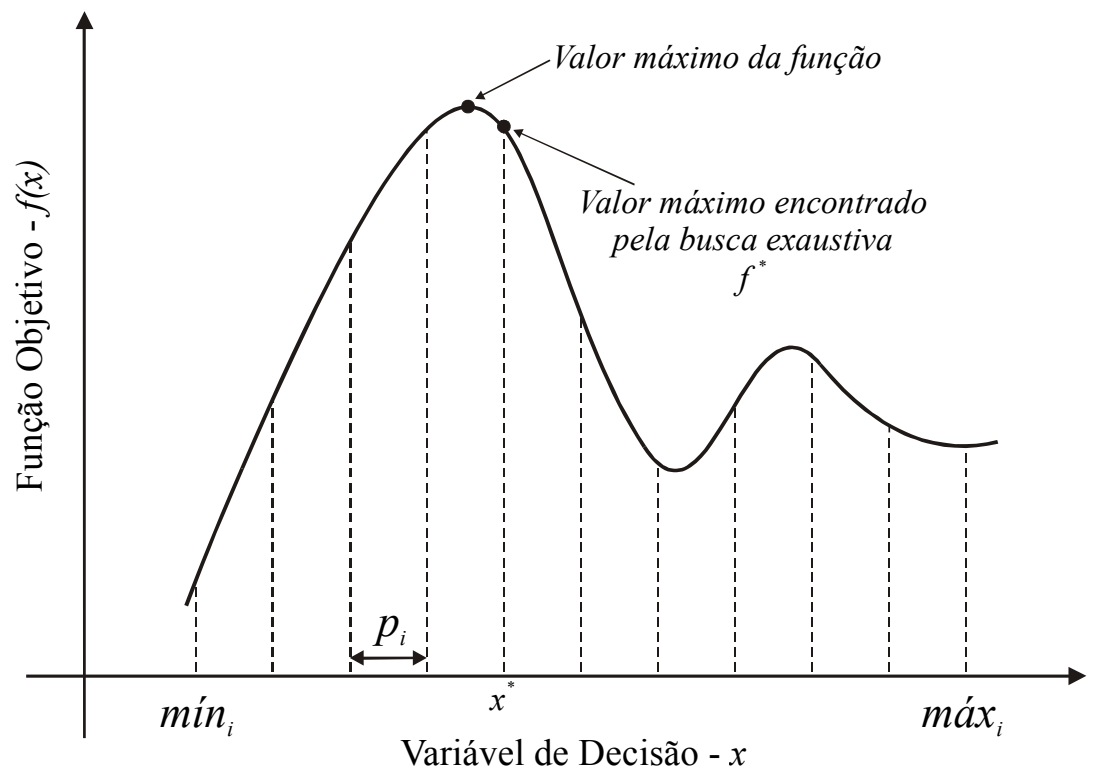

Figura A.8 - Visualização da busca exaustiva.

Este método possui como vantagem sua elevada robustez, sendo capaz de encontrar o valor máximo de $f(x)$ mesmo em situações complexas em que há mínimos locais. No entanto, este método possui um custo computacional elevado, pois para cada variável são realizadas $n_{i}$ avaliações. Dependendo da complexidade do cálculo relacionado à avaliação da função objetivo e da precisão requerida para $x_{i}$, o processo de otimização pode tornar-se muito lento. 


\section{Referências Bibliográficas}

[1] Grupo de trabalho para estruturação do CCPE, Estruturação do Comitê Coordenador do Planejamento da Expansão dos Sistemas Elétricos - CCPE. Brasília, DF, 1999, pp. 40.

[2] Comissão de Análise do Sistema Hidrotérmico de Energia Elétrica, $O$ desequilibrio entre oferta e demanda de energia elétrica. Brasília, DF, 2001, pp. 16.

[3] Secretaria de Energia - SEN, Centrais Elétricas Brasileiras S/A - Eletrobrás, Agência Nacional de Energia Elétrica - ANEEL, Proposta de estruturação do Comitê Coordenador do Planejamento da Expansão dos Sistemas Elétricos CCPE. Brasília, DF, 1999, pp. 9.

[4] A.S.M.E., The American Society of Mechanical Engineers, A national historic mechanical engineering landmark. Argonne, CA, 1979, pp. 16.

[5] T. Ackermann, D. P. Loucks, et al. "Real-time modeling for navigation and hydropower in the river Mosel". Journal of Water Resources Planning and Management, 2000: p. 298-303.

[6] J. C. R. Albuquerque \& M. A. P. Carvalho, Dimensionamento energéticoeconômico de usinas hidroelétricas no sistema brasileiro. In: Jornada de Países de Língua Oficial Portuguesa. Vol. 2. Rio de Janeiro, RJ, 1987.

[7] ANEEL, Agência Nacional de Energia Elétrica, Analysis of the Wholesale Energy Market rules. Brasília, DF, 2000, pp. 45.

[8] ANEEL, Agência Nacional de Energia Elétrica, Atlas de energia elétrica do Brasil. Brasília, DF, 2002, pp. 153.

[9] Army, Department of the Army, Corps of Engineers, Engineering and designing hydropower. N. 1110-2-1701. Washington, D.C., USA, 1985.

[10] N. V. Arvanitidis \& J. Rosing. "Composite representation of multiple reservoir hydroelectric power system". IEEE Transactions on PAS, 1970. 89(2): p. 319326.

[11] N. V. Arvanitidis \& J. Rosing. "Optimal operation of multiple reservoir system using a composite representation". IEEE Transactions on PAS, 1970. 89(2): p. 327-335.

[12] J. L. C. Ayres, S. L. R. A. Ferrão \& N. L. P. Silva, Estudo de divisão de queda 
do alto Tocantins. In: VII SNPTEE - Simpósio Nacional de Produção e Transmissão de Energia Elétrica. Brasília, DF, 1984.

[13] S. V. Bajay, Planejamento da expansão de sistemas hidrotérmicos de potência: o estado da arte, a prática do setor elétrico brasileiro e novas tendências. In: III CLAGTEE - Congresso Latino Americano Geração e Transmissão de Energia Elétrica. Vol. 1, pp.56-61. Campos do Jordão, SP, 1997.

[14] M. S. Bazaraa \& J. J. Jarvis, Linear programming and network flows. New York: Wiley, pp. x, 565, 1977.

[15] M. S. Bazaraa, C. M. Shetty \& H. D. Sherali, Nonlinear Programming: Theory and Algorithms: John Wiley \& Sons, pp. 656, 1993.

[16] R. Bettega \& F. Ramos. "O impacto da comercialização no mercado spot de energia na análise de viabilidade de hidrelétricas". Revista Brasileira de Recursos Hídricos, 2001. 6(1): p. 43-70.

[17] B. Bower, M. M. Hufschmidt \& M. M. Reedy, "Operating procedures: their role in the design of water resources systems by simulation analyses," in Design of water resources systems, A. Maass, A. Maass, A. Maass, A. Maass \& A. Maass, Eds. Cambridge, MA: Harvard University Press, 1962.

[18] L. M. M. Cabral \& P. B. B. Cachapuz, A Eletrobrás e a operação dos sistemas elétricos interligados brasileiros. Rio de Janeiro, RJ, pp. 25, 2000.

[19] A. A. F. M. Carneiro, Contribuição ao planejamento da operação energética de sistemas hidrotérmicos de potência. Tese de Doutorado. Faculdade de Engenharia Elétrica e Computação, Universidade Estadual de Campinas, Campinas, SP, pp. 131, 1991.

[20] A. A. F. M. Carneiro \& M. Kadowaki, Operação simulada de sistemas hidroelétricos com regras por redes neurais. In: XIV SNPTEE - Simpósio Nacional de Produção e Transmissão de Energia Elétrica. Vol. CD-ROM, pp.Grupo 10, No. GOP 004, Tema 5. Belém, PA, 1998.

[21] A. A. F. M. Carneiro, P. T. Leite, et al., Optimal energy operation of hydrothermal power systems using artificial intelligence techniques. In: VI SEPOPE - Symposium of Specialists in Electric Operational and Expansion Planning. Vol. CD-ROM. Salvador, BA, 1998.

[22] A. A. F. M. Carneiro \& D. Silva Filho, Análise do desempenho da operação a reservatório para a usina hidroelétrica de Itaipu. In: III CLAGTEE - Congresso Latino-Americano Geração e Transmissão de Energia Elétrica. Vol. 1, pp.253258. Campos do Jordão, SP, 1997.

[23] A. A. F. M. Carneiro \& D. Silva Filho, Fuzzy logic applied to operation rules for large hydrothermal power systems. In: International Conference on Power System Technology POWERCON'98. Vol. 2, pp.918-922. Beijing, China, 1998.

[24] A. A. F. M. Carneiro \& D. Silva Filho, Regras otimizadas de operação de sistemas hidroelétricos obtidas por lógica fuzzy. In: XII CBA - Congresso 
Brasileiro de Automática. Vol. CD-ROM, pp.1351-1356. Uberlândia, MG, 1998.

[25] A. A. F. M. Carneiro \& D. Silva Filho, Um procedimento computacional para análise do comportamento ótimo de um grande sistema hidroelétrico. In: XVIII CILAMCE - Congresso Ibero Latino-Americano de Métodos Computacionais para Engenharia. Vol. III, pp.1515-1522. Brasília, DF, 1997.

[26] A. A. F. M. Carneiro, D. Silva Filho, et al., Genetic algorithms applied to hydrothermal system scheduling. In: International Conference on Power System Technology POWERCON'98. Vol. 1, pp.547-551. Beijing, China, 1998.

[27] A. A. F. M. Carneiro \& S. Soares, Reservoir operation rules for hydroelectric power system optimization. In: IEEE/NTUA Athens Power Tech Conference: "Planning, Operation and Control of Today's Electric Power Systems", pp.965969. Athens, Greece, 1993.

[28] A. A. F. M. Carneiro, S. Soares \& P. S. Bond. "A large scale application of an optimal deterministic hydrothermal scheduling algorithm". IEEE Transactions on Power Systems, 1990. 5(1): p. 204-211.

[29] M. F. Carvalho \& S. Soares. "An efficient hydrothermal scheduling algorithm". IEEE Transactions on Power Systems, 1987. PWRS-2(3): p. 537-542.

[30] R. Castro, J. L. Juhas, et al., Atendimento à demanda de ponta: questão conjuntural ou estrutural? In: XIV SNPTEE - Seminário Nacional de Produção e Transmissão de Energia Elétrica. Vol. CD-ROM. Belém, PA, 1997.

[31] CEEE-RS,, Companhia Estadual de Energia Elétrica do Rio Grande do Sul, http://www.ceee.com.br, 23/12/2001.

[32] CESP, Companhia Energética de São Paulo, Aproveitamento hidroelétrico do rio Ribeira: estudos de inventário das usinas de Divisa, Tijuco, Itaoca, Funil e Batatal. São Paulo, SP, 1988.

[33] CESP, Companhia Energética de São Paulo, Aproveitamento hidroelétrico do rio Ribeira: estudos de inventário das usinas de Itaoca, Funil e Batatal. São Paulo, SP, 1991.

[34] CESP, Companhia Energética de São Paulo, Aproveitamento hidroelétrico do rio Ribeira: estudos de viabilidade da usina de Itaoca. N. 029. São Paulo, SP, 1994, pp. 318.

[35] M. A. Cicogna, Modelo de planejamento da operação energética de sistemas hidrotérmicos a usinas individualizadas orientado por objetos. Dissertação de Mestrado. Faculdade de Engenharia Elétrica e Computação, Universidade Estadual de Campinas, Campinas, SP, pp. 217, 1999.

[36] E. F. Cook, Man, energy, society. San Francisco: W. H. Freeman, pp. xi, 478, 1976.

[37] J. M. Damázio, F. S. Costa \& F. P. Neves, Dimensionamento energético de 
aproveitamento hidroelétrico a nível de inventário. In: XV SNPTEE - Seminário Nacional de Produção e Transmissão de Energia Elétrica. Vol. CD-ROM. Foz do Iguaçu, PR, 1999.

[38] C. Darwin, The origin of species. London and New York,: J. M. Dent \& sons ltd.; E. P. Dutton \& co. inc., pp. xxiv, 488, 1939.

[39] D. Dasgupta \& Z. Michalewicz, Evolutionary algorithms in engineering applications. Berlin New York: Springer, pp. xxi, 554, 1997.

[40] D. M. Dumych, Waterpower at Niagara, http://home.earthlink.net/ dumych, 20/12/2001.

[41] E.I.A., Energy Information Administration, U. S. Department of Energy, World carbon dioxide emissions from the consumption and flaring of fossil fuels 19802000, http://www.eia.doe.gov, 04/01/2003.

[42] E.I.A., Energy Information Administration, U. S. Department of Energy, World electricity installed capacity by Type on January 1, 2000, http://www.eia.doe.gov, 04/01/2003.

[43] E.I.A., Energy Information Administration, U. S. Department of Energy, World per capita total primary energy consumption 1980-2000, http://www.eia.doe.gov, 04/01/2003.

[44] E.I.A., Energy Information Administration, U. S. Department of Energy, World population 1980-2000, http://www.eia.doe.gov, 04/01/2003.

[45] E.I.A., Energy Information Administration, U. S. Department of Energy, World production of primary energy by selected country groups 1990-2000, http://www.eia.doe.gov, 04/01/2003.

[46] E.I.A., Energy Information Administration, U. S. Department of Energy, World total primary energy consumption 1980-2000, http://www.eia.doe.gov, 04/01/2003.

[47] Eletrobrás, Centro da Memória da Eletricidade do Brasil, Banco de Imagens de Usinas de Energia Elétrica 1883-1999. Rio de Janeiro, RJ, 2000.

[48] Eletrobrás, GTPE/GCPS - Grupo de Trabalho para Estudos de Planejamento Energético e Grupo Coordenador para Estudos de Critérios de Planejamento Energético, Boletim de Planejamento de Engenharia. Rio de Janeiro, RJ.

[49] Eletrobrás, Centro da Memória da Eletricidade do Brasil, Caminhos da modernização 1850-1998. Rio de Janeiro, RJ, 2000.

[50] Eletrobrás, Centro da Memória da Eletricidade do Brasil, http://www.memoria.eletrobras.gov.br, 12/12/2001.

[51] Eletrobrás, Diretoria de Planejamento e Engenharia, Dimensionamento de características energéticas de aproveitamentos hidroelétricos. Rio de Janeiro, RJ, 1980. 
[52] Eletrobrás, Diretoria de Planejamento e Engenharia, Manual de instruções para estudos de viabilidade de aproveitamentos hidroelétricos - SINV. N. CD-ROM. Rio de Janeiro, RJ, 1997.

[53] Eletrobrás, Manual de metodologia do OPUS - Modelo de simulação a usinas individualizadas, v. 3.0. Rio de Janeiro, RJ, 1992, pp. 35.

[54] Eletrobrás, Grupo Coordenador do Planejamento do Sistema Elétrico - GCPS, Metodologia para dimensionamento da potência instalada em usinas hidroelétricas. Rio de Janeiro, RJ, 1982.

[55] Eletrobrás, Comissão de Integração Elétrica Regional - CIER, Metodologia para dimensionamento de usinas hidroelétricas a nível de viabilidade. Rio de Janeiro, RJ, 1983.

[56] Eletrobrás, Plano 2015 - Projeto I - Metodologia e processo de planejamento da expansão do setor elétrico brasileiro. Rio de Janeiro, RJ, 1992.

[57] Eletrobrás, Comitê Coordenador do Planejamento dos Sistemas Elétricos, Plano decenal de expansão 2001/2010. Rio de Janeiro, RJ, 2002, pp. 290.

[58] Eletrobrás, Centrais Elétricas Brasileiras S.A., SINV 3.0 - Programa de Estudos Energéticos,

http://www.eletrobras.gov.br/downloads/atuacao/recursos/sinv3.0.zip, 26/12/2001.

[59] L. A. M. Fortunato, T. A. Araripe Neto, et al., Introdução ao planejamento da expansão e operação de sistemas de produção de energia elétrica. Rio de Janeiro, RJ: EDUFF Editora Universitária, pp. 232, 1990.

[60] M. Gen \& R. Cheng, Genetic algorithms and engineering optimization. New York: Wiley, pp. xvi, 495, 2000.

[61] D. E. Goldberg, Genetic algorithms in search, optimization, and machine learning. Reading, Mass.: Addison-Wesley Pub. Co., pp. xiii, 412, 1989.

[62] J. Goldemberg, Energia, Meio Ambiente \& Desenvolvimento. São Paulo, SP: Editora da Universidade de São Paulo, pp. 240, 1998.

[63] R. L. Haupt \& S. E. Haupt, Practical genetic algorithms. New York: Wiley, pp. xiv, 177, 1998.

[64] C. S. Horstmann, Mastering $C++$ : an introduction to $C++$ and object-oriented programming for $C$ and Pascal programmers, 2nd ed. New York: John Wiley \& Sons, pp. xii, 292, 1996.

[65] C. S. Horstmann, Practical object-oriented development in C++ and Java. New York: Wiley Computer Pub., pp. xiii, 562, 1997.

[66] Ilumina," Instituto de Desenvolvimento Estratégico do Setor Elétrico, http://www.ilumina.org.br, 26/12/2001. 
[67] S. A. Johnson, J. R. Stedinger \& K. Staschus. "Heuristic operating policies for reservoir system simulation". Water Resources Research, 1991. 27(5): p. 673685.

[68] B. Kucinski, Jornalismo Econômico, vol. 1. São Paulo, SP: EDUSP - Editora da Universidade de São Paulo, pp. 240, 1996.

[69] D. P. Loucks, J. R. Stedinger \& D. A. Haith, Water resource systems planning and analysis. Englewood Cliffs, N.J.: Prentice-Hall, pp. xv, 559, 1981.

[70] J. R. Lund. "Derived power production and energy drawdown rules for reservoirs". Journal of Water Resources Planning and Management, 2000(March/April): p. 108-111.

[71] C. Lyra, H. Tavares \& S. Soares. "Modelling and optimization of hydrothermal generation scheduling". IEEE Transactions on Power Apparatus and Systems, 1984. PAS-103(8): p. 2126-2133.

[72] R. A. Macêdo, D. Silva Filho \& D. V. Coury, Algoritmos Genéticos aplicados à estimação de componentes harmônicos em sistemas elétricos de potência. In: XIV CBA - Congresso Brasileiro de Automática. Vol. CD-ROM. Natal, RN, 2002.

[73] R. A. Macêdo, D. Silva Filho, et al., An evolutionary optimization approach to track voltage and current harmonics in electrical power systems. In: IEEE PES General Meeting 2003. Vol. CD-ROM. Toronto, Canadá, 2003.

[74] R. A. Macêdo, D. Silva Filho, et al. "Genetic algorithm approach to track voltage and current harmonics in electrical power systems". International Journal of Intelligent and Fuzzy Systems, 2002. 13(2-4): p. 167-175.

[75] R. A. Macêdo, D. Silva Filho, et al., Uma nova abordagem para a estimação das componentes harmônicas em sistemas elétricos de potência baseada em algoritmos genéticos. In: XVII SNPTEE - Seminário Nacional de Produção e Transmissão de Energia Elétrica. Vol. CD-ROM. Uberlândia, MG, 2003.

[76] M. E. P. Maceira, A. P. C. Costa \& A. L. M. Marcato, CEPEL - Centro de Pesquisa de Engenharia Elétrica, Programação dinâmica dual estocástica aplicada ao planejamento da operação energética de sistemas hidrotérmicos com representação do processo estocástico de afluências por modelos autoregressivos periódicos - NEWAVE - Especificação funcional. N. 349/99. Rio de Janeiro, RJ, 1999.

[77] L. Martinez, Politicas de controle malha fechada e malha aberta no planejamento da operação energética de sistemas hidrotérmicos. Tese de Doutorado. Faculdade de Engenharia Elétrica e Computação, Universidade Estadual de Campinas, Campinas, SP, pp. 166, 2001.

[78] L. W. Mays, Water resources engineering, 1st ed. New York: J. Wiley \& Sons, pp. xv, 761, 2001.

[79] Z. Michalewicz, Evolutionary Computation: Practical Issues. In: IEEE 
International Conference on Evolutionary Computation. Vol. CD_ROM, pp.3035. Nagoya, Japan, 1996.

[80] Z. Michalewicz, Genetic algorithms + data structures $=$ evolution programs, 2nd, extended ed. Berlin ; New York: Springer-Verlag, pp. xvi, 340, 1994.

[81] MMA, Ministério do Meio Ambiente, Licenciamento Ambiental, http://www.mma.gov.br/port/sqa/progestao/energia/texto_licenciamento.html, $22 / 12 / 2001$.

[82] MNE, Ministério de Minas e Energia, Avaliação da metodologia de cálculo de energia assegurada de usinas hidroelétricas. Brasília, DF, 2002, pp. 35.

[83] B. R. Munson, D. F. Young \& T. H. Okiishi, Fundamentals of fluid mechanics, 3rd ed. New York: Wiley, pp. xvii, 877, 1998.

[84] G. G. Oliveira \& S. Soares. "A second-order newtwork flow algorithm for hydrothermal scheduling". IEEE Transactions on Power Systems, 1995. 10(3): p. 1635-1641.

[85] R. Oliveira \& D. P. Loucks. "Operating rules for multireservoir systems". Water Resources Research, 1997. 33(4): p. 839-852.

[86] ONS, Operador Nacional do Sistema Elétrico, Evaporações líquidas nas usinas hidroelétricas. N. RE 3/159/2001. Rio de Janeiro, RJ, 2001, pp. 80.

[87] ONS, Operador Nacional do Sistema Elétrico, Operação do Sistema Interligado Nacional - Dados Relevantes de 2000. Rio de Janeiro, RJ, 2001, pp. 61.

[88] ONS, Operador Nacional do Sistema Elétrico, Operação do Sistema Interligado Nacional - Dados Relevantes de 2001. Rio de Janeiro, RJ, 2002, pp. 67.

[89] ONS, Operador Nacional do Sistema Elétrico, Procedimentos de Rede, Submódulo 18.2: Modelos computacionais. N. Submódulo 18.2 - Modelos computacionais. Rio de Janeiro, RJ, 2001, pp. 26.

[90] ONS, Operador Nacional do Sistema Elétrico, Procedimentos de Rede, Submódulo 7.1: Planejamento da Operação Energética. N. Submódulo 7.1 Planejamento da Operação Energética. Rio de Janeiro, RJ, 2001, pp. 7.

[91] W. Pedrycz \& F. Gomide, An introduction to fuzzy sets : analysis and design. Cambridge, Mass.: MIT Press, pp. xxiv, 465, 1998.

[92] M. V. F. Pereira, CEPEL - Centro de Pesquisas de Energia Elétrica, Metodologias probabilísticas de cálculo de garantia de suprimento. Rio de Janeiro - RJ, 1987.

[93] M. V. F. Pereira \& L. M. V. G. Pinto. "Stochastic optimization of a multireservoir hydroelectric system: a decomposition approach". Water Resources Research, 1985. 21(6): p. 779-792.

[94] D. Quagliarella, Genetic algorithms and evolution strategy in engineering and 
computer science : recent advances and industrial applications. Chichester ; New York: John Wiley \& Sons, pp. x, 391, 1998.

[95] C. ReVelle, E. Joares \& W. Kirby. "The linear decision rule in reservoir management and design, 1, Development of the stochastic model". Water Resources Research, 1969. 5(4): p. 767-777.

[96] L. F. P. G. Sarkis, D. Silva Filho, et al., Algoritmo genético na otimização de roteiros de coleta de resíduos de serviços de saúde - estudo de caso. In: XXII Congresso Brasileiro de Engenharia Sanitária e Ambiental. Joinville, SC, 2003.

[97] D. Silva Filho, R. Ballini, et al., Interpretação lingüística da operação ótima de uma usina hidroelétrica através de redes neurais nebulosas adaptáveis. In: XIII CBA - Congresso Brasileiro de Automática. Vol. CD-ROM, pp.1574-1579. Florianópolis, SC, 2000.

[98] D. Silva Filho, R. Ballini, et al. "Interpretação lingüística da operação ótima de uma usina hidroelétrica através de redes neurais nebulosas adaptáveis". Revista Controle \& Automação, 2003. 14(3): p. 321-329.

[99] D. Silva Filho \& A. A. F. M. Carneiro, Cálculo dos parâmetros de dimensionamento de usinas hidroelétricas em função de diferentes políticas de operação. In: I Oficina da Pós-Graduação do Departamento de Engenharia Elétrica da Escola de Engenharia de São Carlos - USP. Vol. CD-ROM. São Carlos, SP, 2000.

[100] D. Silva Filho \& A. A. F. M. Carneiro, Modelo de Otimização Evolutivo para Dimensionamento de Usinas Hidroelétricas. In: XIV CBA - Congresso Brasileiro de Automática. Vol. CD-ROM. Natal, RN, 2002.

[101] D. Silva Filho \& A. A. F. M. Carneiro, Regras otimizadas de operação de sistemas hidroelétricos obtidas por Lógica Fuzzy. In: XII CBA - Congresso Brasileiro de Automática. Vol. 4, pp.1351-1356. Uberlândia, MG, 1998.

[102] D. Silva Filho \& A. A. F. M. Carneiro, Sistema de apoio à decisão para simulação da operação de sistemas hidroelétricos de geração. In: XX CILAMCE - Congresso Ibero Latino-Americano de Métodos Computacionais em Engenharia. Vol. CD-ROM. São Paulo, SP, 1999.

[103] D. Silva Filho, A. A. F. M. Carneiro \& A. F. R. Araújo, A digital neural simulator for the energetic operation of hydroelectric power systems. In: Third International Conference on Digital Power System Simulators ICDS'99. Vol. 1, pp.1-5. Vasteras, Sweden, 1999.

[104] D. Silva Filho, A. A. F. M. Carneiro \& A. F. R. Araújo, Redes RBF aplicadas à simulação da operação de usinas hidroelétricas. In: IV Congresso Brasileiro de Redes Neurais. Vol. CD-ROM, pp.275-280. São José dos Campos, SP, 1999.

[105] D. Silva Filho, A. A. F. M. Carneiro, et al., Influência das regras de operação sobre parâmetros de dimensionamento de usinas hidroelétricas. In: VII SEPOPE - Symposium of Specialists in Electric Operational and Expansion Planning. Vol. CD-ROM. Curitiba, PR, 2000. 
[106] D. Silva Filho, D. P. Loucks \& A. A. F. M. Carneiro, The optimal expansion of the Brazilian Hydropower Capacity depends on the system operation policies. In: 2001 Engineering Graduate Research Symposium Cornell University. Vol. 1, pp.11-12. Ithaca, NY USA, 2001.

[107] A. K. Sinha \& C. H. Bischof. "Application of automatic differentiation to reservoir design models". Journal of Water Resources Planning and Management, 1998. May/June: p. 162-167.

[108] A. K. Sinha, B. V. Rao \& C. H. Bischof. "Nonlinear optimization model for screening multipurpose reservoir systems". Journal of Water Resources Planning and Management, 1999. July/August: p. 229-233.

[109] A. K. Sinha, B. V. Rao \& U. Lall. "Yield model for screening multipurpose reservoir systems". Journal of Water Resources Planning and Management, 1999. November/December: p. 325-332.

[110] S. Soares. "Planejamento da operação de sistemas hidrotérmicos". Revista SBA - Controle e Automação, 1987. 1(2): p. 122-131.

[111] S. Soares, A. A. F. M. Carneiro, et al., Otimização da operação energética das usinas do rio Paranapanema. In: I Congresso de Inovação Tecnológica em Energia Elétrica - Citenel. Vol. CD-ROM. Brasília, DF, 2001.

[112] S. Soares, C. Lyra \& H. Tavares. "Optimal generation scheduling of hydrothermal power systems". IEEE Transactions on Power Apparatus and Systems, 1980. PAS-99: p. 1107-1115.

[113] J. D. V. Sobrinho, Matemática Financeira, vol. 1, 7 ed. São Paulo, SP: Editora Atlas S.A., pp. 409, 2000.

[114] J. R. Stedinger, B. F. Sule \& D. Pei. "Multiple reservoir system screening models". Water Resources Research, 1983. 19(6): p. 1383-1393.

[115] B. Stroustrup, The C++ programming language, Special ed. Boston: AddisonWesley, pp. x, 1019, 2000.

[116] M. K. Tolba, Saving our planet : challenges and hopes, 1st ed. London ; New York: Chapman \& Hall, pp. ix, 287, 1992.

[117] U.N.D.P., United Nations, United Nations Development Programm, Human Development Indicators, http://www.br.undp.org, 17/12/2001.

[118] V. P. P. B. Vieira, L. S. Diniz, et al., Sistemas Inteligentes. Porto Alegre - RS: Editora da Universidade - UFRS, pp. 246, 1999.

[119] R. R. Yager \& D. P. Filev. "Approximate clustering via the Mountain Method". IEEE Transactions on Systems, Man and Cybernetics, 1994. 24: p. 1279-1284.

[120] R. R. Yager \& D. P. Filev, Essentials of fuzzy modeling and control. New York: J. Wiley, pp. xvi, 388, 1994. 
[121] S. Yakowitz. "Dynamic programming applications in water resources". Water Resources Research, 1982. 18(4): p. 673-696.

[122] W. W.-G. Yeh. "Reservoir management and operation models: a state-of-the-art review". Water Resources Research, 1985. 21(12): p. 1797-1818.

[123] M. Zeleny, Multiple criteria decision making. New York: McGraw-Hill, pp. xxii, 563, 1981. 